UNIVERSIDADE dE SÃo PAULO

FACULDADE DE ARQUITETURA E URBANISMO

CURSO DE PÓS-GRADUAÇÃO EM ARQUITETURA E URBANISMO

curso de doutorado

Área de Concentração: Planejamento Urbano e Regional

Linha de Pesquisa: Políticas Públicas Urbanas

Orientador

PROF. DR. EDUARDO ALBERTO CUSCE NOBRE

tese de doutoramento

GRANDES PROJETOS URBANOS E A TRANSFORMAÇÃO DA FORMA URBANA NA CIDADE CONTEMPORÂNEA

Operação Urbana Orla Ferroviária de Suzano

ELVIS JOSÉ VIEIRA

2012 

ELVIS JOSÉ VIEIRA

\section{GRANDES PROJETOS URBANOS E A TRANSFORMAÇÃO DA FORMA URBANA NA CIDADE CONTEMPORÂNEA: Operação Urbana Orla Ferroviária de Suzano}

Tese apresentada à Faculdade de Arquitetura e Urbanismo da Universidade de São Paulo para obtenção do título de Doutor em Arquitetura e Urbanismo

Área de Concentração:

Planejamento Urbano e Regional

Orientador:

Prof. Dr. Eduardo Alberto Cusce Nobre 

AUTORIZO A REPRODUÇÃO E DIVULGAÇÃO TOTAL OU PARCIAL DESTE TRABALHO,POR QUALQUER MEIO CONVENCIONAL OU ELETRÔNICO, PARA FINS DE ESTUDO E PESQUISA,DESDE QUE CITADA A FONTE.

EXEMPLAR REVISADO E ALTERADO EM RELAÇÃO À VERSÃO ORIGINAL, SOB RESPONSABILIDADE DO AUTOR E ANUÊNCIA DO ORIENTADOR.

Vieira, Elvis José

V658gGrandes projetos urbanos e a transformação da forma urbana na cidade contemporânea: Operação Urbana Orla Ferroviária de Suzano/Elvis José Vieira - São Paulo, 2012.

370 p.: il.

Tese (Doutorado - Área de Concentração: Planejamento Urbano e Regional) - FAUUSP.

Orientador: Eduardo Alberto Cusce Nobre

1. Operações urbanas - Suzano (SP) 2. Política urbana

3. Renovação urbana 4. Morfologia urbana I.Título

CDU 711.51:332.72(816.12) 

A Lucimara Vieira, que desde o início me apoiou das suas diversas maneiras: companheira, amorosa e compreensiva... 

Concluir um trabalho desta envergadura não trata de tarefa fácil tão pouco é possível sua elaboração sem a ajuda e compreensão de muitas pessoas queridas, às quais a participação de cada uma de forma direta ou indireta, perceptível ou não, são colocadas sempre como importantes contribuições para as reflexões levadas a cabo nesta tese, e são a elas que quero aqui deixar meus mais sinceros agradecimentos.

Em primeiro lugar quero agradecer ao Professor Dr. Eduardo Alberto Cusce Nobre, que na figura de orientador soube "dosar e podar" meus voos sobre a tese e os estudos de caso, levando o trabalho sempre por caminhos coesos e estimulantes à qualidade exigida, ensinando-me sempre o valor dos Grandes Projetos Urbanos e compreendendo minhas múltiplas atividades profissionais e docentes.

Aos Professores Dr. Jorge Bassani (FAUUSP) e Pedro Manuel Rivaben de Sales (Escola da Cidade) que em muito contribuíram no encaminhamento do trabalho a partir da Banca de Qualificação.

Aos Professores Dr. Adilson Costa Macedo, Dra. Maria Luiza Correa e Dr. Francisco Spadoni, pelas importantes contribuições ao desenvolvimento do trabalho a partir das disciplinas cursadas.

À Marcelo de Souza Candido (prefeito da cidade de Suzano - 2005 a 2012) por acreditar em minhas convicções urbanísticas e aceitar minhas propostas nem sempre consolidadas pela politica, mas com olhares técnicos e acadêmicos possíveis de reflexão e contribuição para uma cidade mais justa e igualitária. Sua generosidade e confiança me possibilitou ver e vivenciar as diversas esferas do poder público e suas interferências para a consolidação dos Grandes Projetos Urbanos.

À Secretaria Municipal de Politica Urbana, que na pessoa de Miguel Reis Afonso, me deu a oportunidade de colocar em prática os sonhos e desejos como arquiteto e urbanista. Da mesma forma, a todos os funcionários que contribuíram direta ou indiretamente com nossos conceitos e forma de ver a arquitetura e o urbanismo contemporâneo, sob a ótica do poder público.

À Faculdade de Arquitetura e Urbanismo das Universidades Braz Cubas e Mogi das Cruzes que me servem de instrumento de transmissão de meus conceitos e convicções sobre os Grandes Projetos Urbanos. Em especial, aos professores destas faculdades: José Francisco Xavier Magalhães (coordenador FAUUBC) e Cristina Ragaini (gestora FAUUMC) pelo apoio e compreensão na redução da carga horária, Carlos Costa Ferreira, Suzel Márcia Maciel, Erineuda Clementino Ventura (meus eternos professores), Fabiola de Almeida Rodrigues, Ricardo Hawiu Lu, Angelo Salvador Filardo Jr., Julio Strelec (professores e amigos), no qual agradeço a cada instante de discussão sobre o tema da pesquisa. 
Aos alunos pesquisadores da Iniciação Cientifica: Rafael Verissimo (FAUUMC), Gabriela Ito, Laura Yamamoto, Tatiana Ashino, Ana Tamie Deno (FAUUBC) pelas descobertas e confirmações de minhas convicções. Da mesma forma, aos meus alunos da disciplina de Projeto de Urbanismo pela oportunidade de discutirmos juntos a importância dos Grandes Projetos Urbanos para a Cidade Contemporânea e seus resultados alcançados, em especial a turma do $8^{\circ}$ semestre de 2011 (FAUUMC) e $7^{\circ}$ e $8^{\circ}$ semestre de 2011 e 2012 (FAUUBC), sintam-se todos agradecidos.

Aos arquitetos e amigos: Ricardo Lu (China) pela convivência e grande ajuda nas diagramações desde o projeto de pesquisa até a conclusão deste trabalho, Cristian Baccelli (primo) que soube ouvir por horas os estudos realizados durante a pesquisa, Marcelo Suzuki pelas poucas, mas fundamentais observações sobre o trabalho, Marcos Boldarini pelas pequenas, mas importantes reflexões sobre o tema, e grande amizade. Douglas e Andressa que souberam dividir os finais de semana entre o entretenimento e as leituras acadêmicas.

À Isa e Dinah da Secretaria e Maria José da Biblioteca da FAU Maranhão, grande apoio institucional.

Por fim, minha família, a base e estímulo deste caminho percorrido, à compreensão das diversas ausências e finais de semana dedicados à tese. Lucimara, esposa que sempre esteve ao meu lado e por muitas vezes a estrutura para me manter no caminho. Carlos Eduardo (Dudu) e Pedro Henrique (um presente), estímulo e esforço de me tornar exemplo a ser seguido: "Nunca pare de buscar o conhecimento... Um bem que ninguém jamais o tirará". 


\section{RESUMO}

A hipótese que conduz o trabalho atribui aos Grandes Projetos Urbanos à condição de ferramenta de transformação da forma urbana sob a ótica das intervenções sobre o tecido urbano degradado ou ociosos capaz de regenerar partes deste tecido e provocar a reabilitação de sua paisagem e dinâmica social e econômica. Como meio de investigação sobre a cidade contemporânea, a primeira parte da tese é dedicada ao estudo e análise da forma urbana e seus pesquisadores, no qual cada um apresenta suas teorias e resultados sobre o tecido urbano que se transforma a cada instante. É certo que os Grandes Projetos Urbanos tiveram maior influência nos países europeus motivados por diversos fatores (naturais ou não) que obrigaram as cidades a repensar suas estruturas urbanas e definir, rapidamente, estratégias de reconstrução de forma eficiente, assim na segunda parte da tese os "estudos de caso" são colocados como objetos de estudo e análise da forma urbana a partir da compreensão e entendimento das causas e consequências com que levaram cada cidade estudada a iniciar 0 processo de transformação da forma urbana, da mesma forma com que utilizaram de estratégias econômicas e sociais capaz de regenerar o tecido urbano e revigorar a dinâmica da cidade, sendo eleitos quatro Grandes Projetos Urbanos: 22@ BCN e La Sagrera-San Andreu em Barcelona - Espanha, ZAC Paris Rive Gauche em Paris França, Spina 2 - Porta Susa em Torino - Itália, que se relacionam de forma direta ou indireta com o objeto de estudo: Operação Urbana Orla Ferroviária de Suzano, colocado em discussão na terceira parte da tese, confirmando a necessária condição com que as cidades americanas, e em especial as latinas e central, se posicionam quanto as hoje configuradas "Cidades Globais", e que em muitas vezes perderam ao longo do tempo sua dinâmica urbana em detrimento ora da falta do planejamento urbano ordenado ou pela degradação gradativa em função da transformação econômica e/ou tecnológica. $O$ caso de Suzano, cidade localizada na Região Metropolitana de São Paulo e distante cerca de $40 \mathrm{Km}$ do centro da capital, não pode ser tomada como exceção deste processo de "desmontagem das peças urbanas" que provocou a subutilização dos espaços antes ocupados pelos serviços de manobra e depósito da rede ferroviária assim como a degradação dos espaços construídos provocados pela falta de uma politica pública que incentivasse novas experiências e o redesenho urbano neste trecho da cidade. Em resposta a estes fatores, o objeto de estudo é compreendido neste caso, como uma importante ferramenta de transformação da forma urbana com estratégias que garantam sua sustentabilidade e desenvolvimento urbano compatíveis com as atuais tecnologias. O trabalho defende que os Grandes Projetos Urbanos quando se tornam objetos de redesenho do tecido tendem a transformar a Forma Urbana incorporando critérios além daqueles funcionais e específicos da paisagem, mas também com uma intensa relação com sua vizinhança e entorno próximo. Nesta condição, tendem a desempenhar um papel relevante na qualidade espacial da cidade contemporânea provocando a regeneração tanto dos espaços não construídos (vazios urbanos) como os construídos (edifícios), num convívio mútuo entre as formas urbanas existentes e as propostas pela intervenção. 

The hypothesis driving the work assigned to the Large Urban Projects tool condition transformation of urban form from the perspective of interventions into the urban fabric degraded or idle able to regenerate parts of this tissue and cause your landscape rehabilitation and social and economic dynamics. As a means of research on the contemporary city, the first part of the thesis is devoted to the study and analysis of urban form and its researchers, in which each presents his theories and findings on the urban fabric that transforms every moment. Admittedly the Large Urban Projects had more influence in European countries motivated by several factors (natural or not) that forced the city to rethink its urban structures and set quickly rebuilding strategies efficiently, so the second part of the thesis "case studies" are placed as objects of study and analysis of urban form from the comprehension and understanding of the causes and consequences with each city studied that led to begin the process of transformation of urban form, the same way they used strategies social and economic able to regenerate and invigorate the urban dynamics of the city, being elected four Large Urban Projects: 22 @ BCN and La Sagrera-San Andreu in Barcelona - Spain, ZAC Paris Rive Gauche in Paris - France, Spina 2 - Porta Susa in Torino - Italy, which relate directly or indirectly to the subject of study: Urban Train Operation Orla Suzano, put in discussion in the third part of the thesis, confirming that the necessary condition to American cities, and especially Latin and Central stand today as the configured "Global Cities", and that in many times lost over time its urban dynamics over prays the lack of urban planning for orderly or gradual degradation due to the economic transformation and / or technological.The case of Suzano, a town in the Metropolitan Region of São Paulo and distant about $40 \mathrm{~km}$ from the city center, cannot be taken as an exception in this process of "dismantling of urban pieces" that led to the underutilization of the space once occupied by services maneuver and tank rail network as well as the degradation of built spaces caused by the lack of a public policy that encourages new experiences and urban redesign this part of town. In response to these factors, the study object is understood in this case as an important tool for transformation of urban form with strategies that ensure their sustainability and urban development compatible with existing technologies. The paper argues that the Large Urban Projects when they become objects redesign tissue tend to make Urban Form incorporating criteria beyond that functional and specific landscape, but also with an intense relationship with his neighborhood and near surroundings. In this condition, tend to play a role in spatial quality of the contemporary city causing regeneration of both spaces not built (urban voids) as built (buildings), a mutual interaction between the existing urban form and the proposed intervention. 

La hipótesis que impulsa el trabajo concede a los Grandes Proyectos Urbanos la condición de la herramienta de procesamiento de la forma urbana desde la perspectiva de las intervencionessobre el tejido urbano degradadoo ralentí capaz de regenerar partes de este tejidoy hacer que la rehabilitación de su paisajey la dinámica social y económica. Como una forma de investigación sobre la ciudad contemporánea, la primera parte de la tesis está dedicada al estudio y análisis de la forma urbana y sus investigadores,en el que cada uno presenta sus teorías y hallazgos en el tejido urbano que transforma cada momento. Es cierto que los Grandes Proyectos Urbanos tuvieron más influencia en los países europeos motivados por varios factores (naturales o no) que obligó a la ciudad a repensar sus estructuras urbanas y establecer estrategias de forma rápida reconstrucción de manera eficiente,por lo que la segunda parte de los "estudios de caso" tesis se colocan como objeto de estudio y análisis de la forma urbana de la comprensión y el entendimiento de las causas y consecuencias con cada ciudad estudiada que llevó a iniciar el proceso de transformación de la forma urbana,la misma que la utilizada para las estrategias económicas y sociales capaces de regenerar y revitalizar la dinámica urbana de la ciudad, siendo elegidos cuatro Grandes Proyectos Urbanos:22 @ BCN y La Sagrera-San Andreu en Barcelona - España, ZAC Paris Rive Gauche en París - Francia, Spina 2 - Porta Susa, en Turín - Italia, que se relacionan directa o indirectamente con el tema de estudio:Operación Urbana Orla Ferroviaria Suzano, puesto en discusión en la tercera parte de la tesis, lo que confirma que la condición necesaria para las ciudades de América Latina, y en especial Centroamérica y soporte hoy como los configurados "Ciudades Globales", y a menudo se pierde en el tiempo a través de sus dinámicas urbanas reza la falta de planificación urbana para la degradación ordenada o gradual debido a la transformación económica y / o tecnológico.El caso de Suzano, una ciudad en la Región Metropolitana de São Paulo y distante a unos $40 \mathrm{~km}$ del centro de la ciudad,no puede ser tomado como una excepción en este proceso de "desmantelamiento de las piezas urbanas" que llevaron a la subutilización del espacio una vez que los servicios y maniobras depósito de los ferrocarriles, así como la degradación de los espacios construidos causados por la falta de una política pública que estimule nuevas experiencias urbano y rediseñar esta parte de la ciudad.En respuesta a estos factores, el objeto de estudio es entendido en este caso como una importante herramienta para la transformación de la forma urbana con estrategias que aseguren su sostenibilidad y el desarrollo urbano compatible con las tecnologías existentes. El trabajo sostiene que los grandes proyectos urbanos cuando se convierten en tejido objetos rediseño tienden a poner la Forma Urbana incorporando criterios más allá de los paisajes funcionales y específicos, pero también con una intensa relación con su barrio y sus alrededores cercanos. En esta condición, tienden a jugar un papel en la calidad espacial de la ciudad contemporánea que causa la regeneración de ambos espacios no construidos (vacíos urbanos) como construido (edificios), una interacción mutua entre la forma urbana existente y la intervención propuesta. 

L'hypothèse de conduire les travaux confiés à la transformation des grands projets urbains état de l'outillage de la forme urbaine du point de vue des interventions dans le tissu urbain dégradé ou ralenti en mesure de régénérer des parties de ce tissu et causer la réhabilitation du paysage et de la dynamique sociale et économique. Comme un moyen de recherche sur la ville contemporaine, la première partie de la thèse est consacrée à l'étude et à l'analyse de la forme urbaine et de ses chercheurs, dans lequel chacun présente ses théories et résultats sur le tissu urbain qui transforme chaque instant. II est vrai que les grands projets urbains ont plus d'influence dans les pays européens motivés par plusieurs facteurs (naturels ou non) qui ont forcé la ville à repenser ses structures urbaines et définir rapidement des stratégies de reconstruction de manière efficace, de sorte que la deuxième partie des «études de cas» les thèses sont placés comme des objets d'étude et d'analyse de la forme urbaine de la compréhension et de la compréhension des causes et des conséquences de chaque ville étudiée qui a conduit à entamer le processus de transformation de la forme urbaine, la semblable à celle utilisée pour les stratégies économiques et sociales capables de se régénérer et tonifier la dynamique urbaine de la ville, étant élu quatre Grands Projets Urbains: 22 @ BCN et de La Sagrera-San Andreu à Barcelone - Espagne, ZAC Paris Rive Gauche à Paris - France, Spina 2 - Porta Susa à Turin - Italie, qui se rapportent directement ou indirectement à l'objet d'étude: Urban train Opération Orla Suzano, mis en discussion dans la troisième partie de la thèse, ce qui confirme que la condition nécessaire de villes américaines, et en particulier Latine et Centrale position aujourd'hui comme les «villes globales configurées", et que, dans de nombreuses fois perdu au fil du temps ses dynamiques urbaines au cours prie le manque de planification urbaine de la dégradation progressive ordonnée ou en raison de la transformation économique et / ou technologique. Le cas de Suzano, une ville située dans la région métropolitaine de São Paulo et distante d'environ $40 \mathrm{~km}$ du centre-ville, ne peut pas être considérée comme une exception dans ce processus de "démontage de pièces urbaines» qui ont conduit à la sous-utilisation de l'espace autrefois occupé par les services de manœuvre et le réseau ferroviaire réservoir ainsi que la dégradation des espaces bâtis causés par le manque d'une politique publique qui favorise de nouvelles expériences et de redéfinition urbaine de cette partie de la ville. En réponse à ces facteurs, l'objet d'étude est entendu dans ce cas comme un outil important pour la transformation de la forme urbaine avec des stratégies qui assurent leur pérennité et le développement urbain compatible avec les technologies existantes. Le document fait valoir que les Grands Projets Urbains quand ils deviennent des tissus refonte objets ont tendance à faire la forme urbaine intégrant des critères au-delà de ceux paysage fonctionnel et spécifique, mais aussi avec une relation intense avec son quartier et ses environs proches. Dans cette condition, ont tendance à jouer un rôle dans la qualité spatiale de la ville contemporaine provoquant la régénération des deux espaces non bâtis (vides urbains) tel que construit (bâtiments), une interaction mutuelle entre la forme urbaine existante et l'intervention proposée. 

L'ipotesi guida del lavoro assegnato al grande trasformazione urbana condizione dello strumento Progetti della forma urbana dal punto di vista degli interventi nel tessuto urbano degradato o minimo in grado di rigenerare parti di questo tessuto e causare il ripristino del paesaggio e le dinamiche sociali ed economiche. Come mezzo di ricerca sulla città contemporanea, la prima parte della tesi è dedicata allo studio e l'analisi della forma urbana e dei suoi ricercatori, in cui ciascuno presenta le sue teorie e conclusioni in merito al tessuto urbano che trasforma ogni momento. È vero che i grandi progetti urbani avuto più influenza nei paesi europei motivati da diversi fattori (naturali e non) che hanno costretto la città a ripensare le proprie strutture urbane e impostare strategie di rapida ricostruzione in modo efficiente, così la seconda parte dei "casi di studio" tesi vengono inseriti come oggetti di studio e di analisi della forma urbana dalla comprensione e la comprensione delle cause e delle conseguenze di ogni città che ha portato studiato per iniziare il processo di trasformazione della forma urbana, la simile a quella utilizzata per le strategie economiche e sociali in grado di rigenerare e rinvigorire le dinamiche urbane della città, essendo eletti quattro Grandi Progetti Urbani: 22 @ BCN e La Sagrera-San Andreu a Barcellona - Spagna, ZAC Paris Rive Gauche a Parigi - Francia, Spina 2 Porta Susa a Torino - Italia, che si riferiscono direttamente o indirettamente oggetto di studio: Urbano di Treni di Orla Suzano, messo in discussione nella terza parte della tesi, a conferma che la condizione necessaria per città americane, e soprattutto latina $e$ centrale posizione oggi come configurati "Global Cities", e che in molte volte ha perso nel corso del tempo le sue dinamiche urbane prega sopra la mancanza di pianificazione urbana per la degradazione ordinata o graduale a causa della trasformazione economica e / o tecnologiche. II caso di Suzano, una città nella regione metropolitana di São Paulo e distante circa $40 \mathrm{~km}$ dal centro della città, non può essere preso come eccezione in questo processo di "smantellamento di pezzi urbani" che hanno portato alla sottoutilizzazione dello spazio un tempo occupato dai servizi manovra e la rete ferroviaria del serbatoio e il degrado degli spazi costruiti causati dalla mancanza di una politica pubblica che incoraggia nuove esperienze e ridisegno urbano questa parte della città. In risposta a questi fattori, l'oggetto di studio è intesa in questo caso come un importante strumento per la trasformazione della forma urbana con strategie che garantiscano la sostenibilità e lo sviluppo urbano compatibile con le tecnologie esistenti. II documento sostiene che i Grandi Progetti Urbani quando diventano oggetti riprogettazione dei tessuti tendono a rendere forma urbana introdurre criteri di là di quelli paesaggio funzionale e specifico, ma anche con un rapporto intenso con il suo quartiere e dintorni vicino. In questa condizione, tendono ad avere un ruolo nella qualità spaziale della città contemporanea causando la rigenerazione di entrambi gli spazi non costruiti (vuoti urbani) da incasso (edifici), una mutua interazione tra la forma urbana esistente e l'intervento proposto. 



\section{LISTA DE IMAGENS}

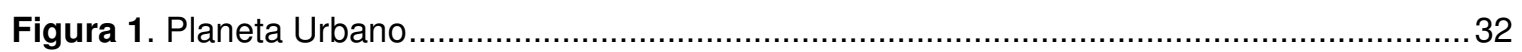

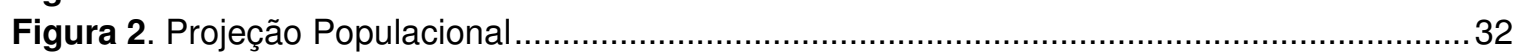

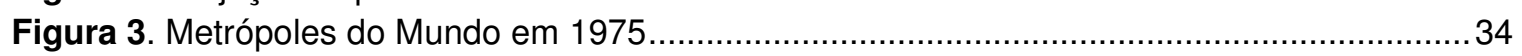

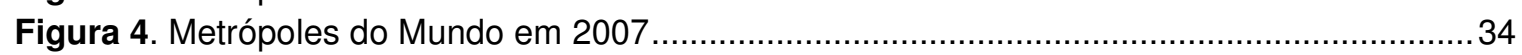

Figura 5. Projeção das Metrópoles do Mundo em 2025 ............................................................ 34

Figura 6. Vista aérea de Canary Wharf - Docklands - Londres ................................................. 36

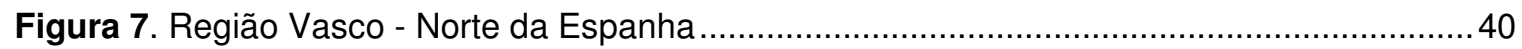

Figura 8. Vistas de Bilbao antes das intervenções urbanas em Bilbao-Ría 2000 ........................ 40

Figura 9. Vista de Bilbao e as obras de intervenção Bilbao-Ría 2000 ......................................40

Figura 10. Vista de Dubai - Emirados Arabes, e suas obras faraônicas ........................................46

Figura 11. Potsdamer Platz - Berlim - Alemanha - projeto urbano de Renzo Piano ....................... 48

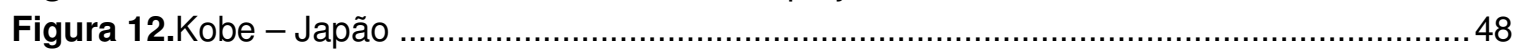

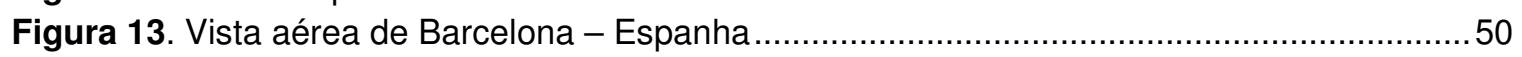

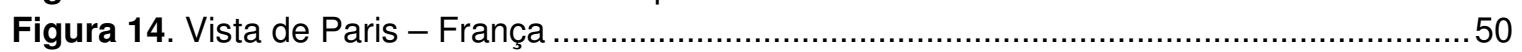

Figura 15. Vista de Torino: em primeiro plano Museu da Televisão e ao fundo os Alpes Suiços 52

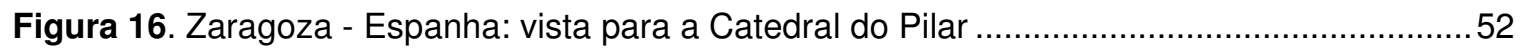

Figura 17. Vista para o Centro Administrativo de Bobigny - França ............................................52

Figura 18. Folha de rosto da Encyclopédie Méthodique - Arquitecture de Quatremère de Quincy

Figura 19. Plano de Bolonha, 1965

Figura 20. Plano para o Centro de Bolonha, 1969 - acima: estudo de expansão da cidade e foto

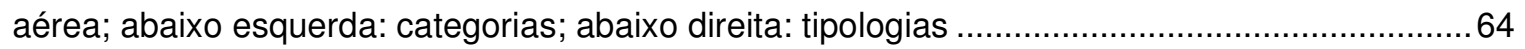

Figura 21. Plano que Camillo Sitte elaborou para Marienberg, em 1903 ...................................68

Figura 22. Sitte e a Ringstrasse - acima: Rinstrasse-residenzplatz; esquerda:Ringstrasse-Viena

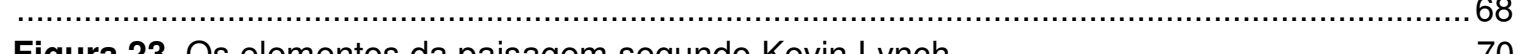

Figura 23. Os elementos da paisagem segundo Kevin Lynch ................................................

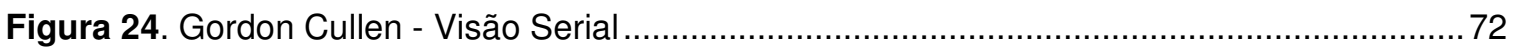

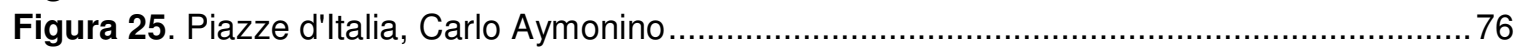

Figura 26. O movimento segundo Raymond Unwin Buttstedt: mapa e seqüência de uma das

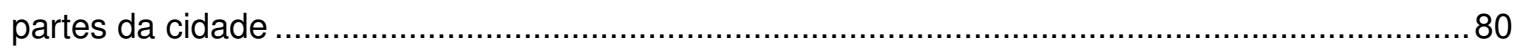

Figura 27. A análise da morfologia urbana no estudo da evolução de um quarteirão de Versalles,

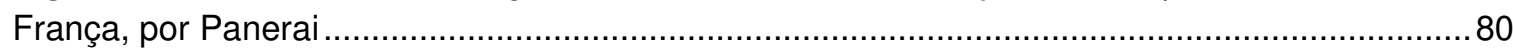

Figura 28. Plantas figura-fundo destacando malha viária (a), espaço privado (b), perfil fundiário

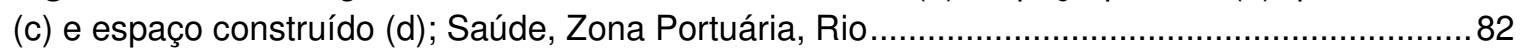

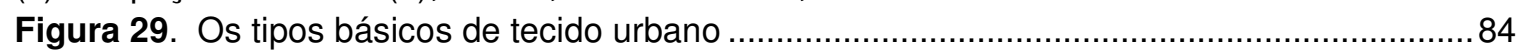

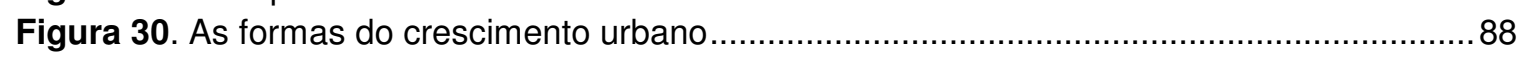

Figura 31. Projetos Urbanos propostos por Solà-Morales a partir do conceito das "coisas

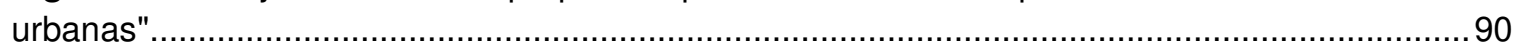

Figura 32. Torre Agbar em Barcelona e Museu du Quai Branly em Paris (esquerda detalhe da fachada do Museu), projetos do arquiteto Jean Nouvel..............................................................92

Figura 33. Estudos volumétricos de composição de quadras abertas.........................................94

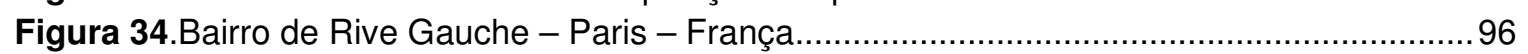

Figura 35. Diagrama dos Eixos de Investigação da Forma Urbana......................................... 102

Figura 36. Cidade de Barcino no século IV protegida pelas 78 torres, à direita: foto-inserção da

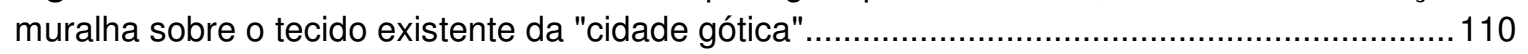

Figura 37. Vista de Arrabal - Barcelona em princípios do século XVII......................................110

Figura 38. Esquema de Expansão de Miguel Garriga y Roca, 1858 .......................................112

Figura 39. Projeto vencedor do concurso: arquiteto Antonio Rovira e Trias.............................112

Figura 40. Segundo e terceiro colocados: engenheiro Francesco Soler i Glòeria e projeto do engenheiro Josep Fontseré i Mestres, consecutivamente. 
Figura 41. Mapa do Eixample de Barcelona de Ildefonso Cerdà, 1859 .................................. 114

Figura 42. Vista aérea do Eixample de Cerdà ................................................................ 116

Figura 43. A diversidade tipológica sob a malha regular do Desenho das Esquinas do Plano de

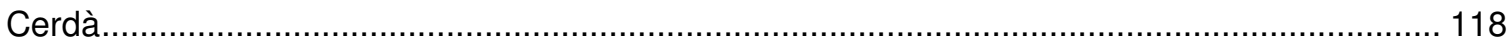

Figura 44. Possibilidades de ocupação sobre las manzanas no Plano de Cerdà....................... 120

Figura 45. Ocupação das manzanas atualmente no Eixample de Cerdà ................................. 120

Figura 46. Plano Urbanístico da Exposição Internacional de Barcelona 1929, montanha de

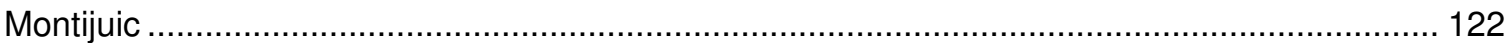

Figura 47. Vista atual da área da Exposição Internacional de Barcelona ................................. 122

Figura 48. Reabilitação e criação de espaços públicos na Cidade Velha (acupuntura urbana) 124

Figura 49. A frente costeira, em 1987, com instalações obsoletas, os containers do Porto nas praias e esgotos que escoam para o mar. Vista do mesmo local, transformada em 1992 ........... 126

Figura 50. Área do Fórum de las Culturas 2004, antes e depois das intervenções urbanas..... 126

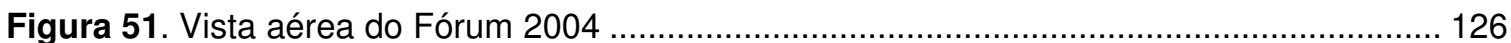

Figura 52. Distrito de El Poblenou em 1922 e 1928 ........................................................ 128

Figura 53. Gráfico da ampliação de densidade construtiva, elaborado a partir das informações do

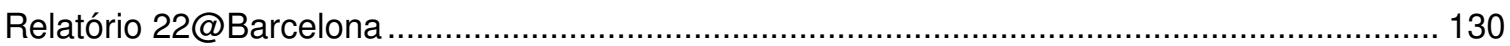

Figura 54. Barcelona 1976 | Distrito de Poblenou ...................................................................... 132

Figura 55. Barcelona 1987 | Pré-Olimpíadas 92, imagem da área hoje conhecida como

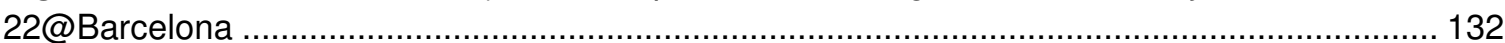

Figura 56. Barcelona 2011 | Projeto 22@BCN, Planos Especiais de Reforma Interior (PERI) . 132

Figura 57. A continuação da Diagonal como uma conexão urbana com Poblenou ..................... 134

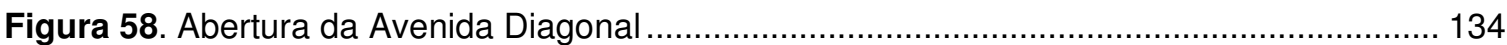

Figura 59. Maquete volumétrica do Projeto 22@BCN, em primeiro plano Torre Agbar ............ 134

Figura 60. Vistas da área do Projeto 22@BCN, mudança do cenário urbano de Poblenou...... 136

Figura 61. Vistas da Torre Agbar: diurna e noturna, uma nova paisagem do distrito de Poblenou

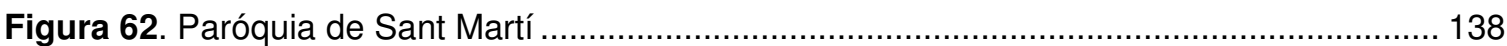

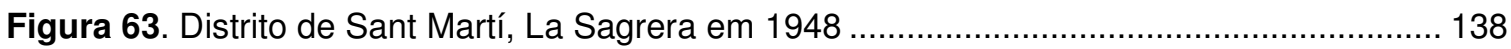

Figura 64. Sobreposição do Plano Cerdà com Cartografia atual de Barcelona .......................... 140

Figura 65. Mapa das novas conexões de transporte de massa ............................................... 140

Figura 66. Contexto dos Projetos Urbanos e sua inter-relação entre as propostas e o tecido

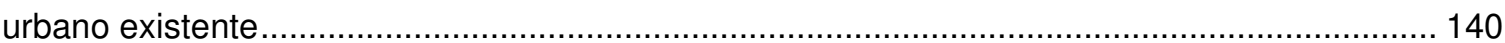

Figura 67. Infraestruturas propostas pelo Projeto La Sagrera | 1) suburbano; 2) metrô; 3) alta

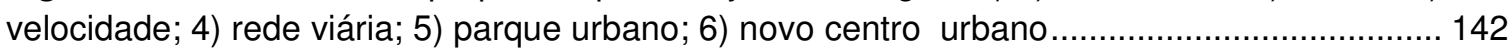

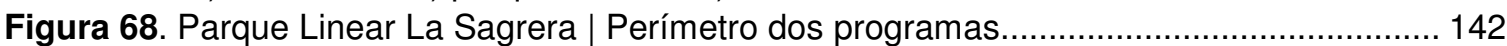

Figura 69. Carta de Uso do solo proposto no Projeto La Sagrera............................................. 146

Figura 70. Estação Intermodal La Sagrera, edifício semi enterrado que garante a conexão entre Sagrera e o Parque Sant Martí .............................................................................................. 146

Figura 71. Estado atual da área de intervenção em Sagrera: 2005 e 2009 ................................ 146

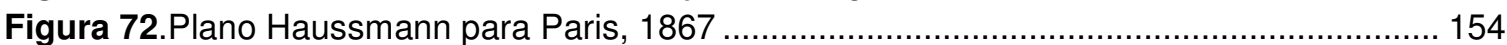

Figura 73.Crescimento de Paris intramuros ao longo dos séculos.......................................... 154

Figura 74.Evolução Demográfica de Paris............................................................................ 158

Figura 75.Plano Voisin propostos por Le Corbusier: acima esquerda - Plan Voisin em 1925; acima direita - Plan Voisin em 1937; abaixo - maquete física .................................................. 158

Figura 76. Centro Cultural Georges Pompidou (1977), Parque La Villette (1982), Instituto do

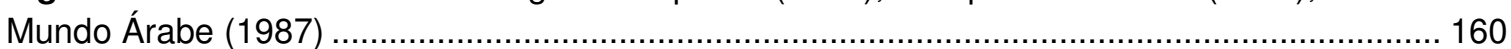

Figura 77.Villes Nouvelles em Ile-de-France - em roxo: Sénart, Saint-Quentin en Yvelines, Evry,

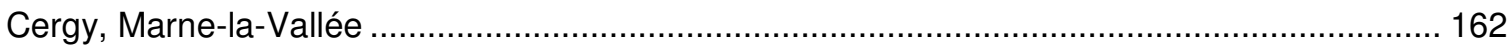

Figura 78.Propostas para o Plano Le Grand Pari - na seqüência: equipe Lin, Christian de Portzamparc, Jean Nouvel, MVRDV, Richard Rogers, Antoine Grumbach, 2010 ..................... 166

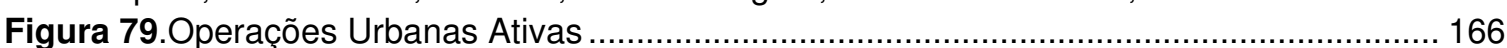


Figura 80.Bilblioteca Nacional da França - arquiteto Dominique Perrault.................................. 168

Figura 81.Proposta de Intervenção para a ZAC Rive Gauche, autoria de Jean Nouvel..............170

Figura 82. Implantação para ZAC Rive Gauche, de autoria de jean Nouvel ..............................170

Figura 83.ZAC Rive Gauche: setorização das áreas de intervenção ........................................ 172

Figura 84.Vista da Biblioteca Nacional da França a partir da Torre Eiffel..................................172

Figura 85.Biblioteca Nacional da França, Estação Ferroviária Austerlitz e Hospital Pitie-

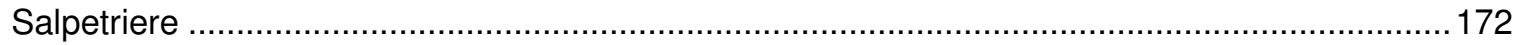

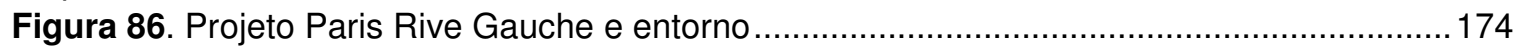

Figura 87. Elementos urbanos e arquitetônicos referenciais no PRG: rio sena e suas atividades fluviais, Biblioteca Nacional da França, Ministério da Economia, Indústria e Emprego ..............176

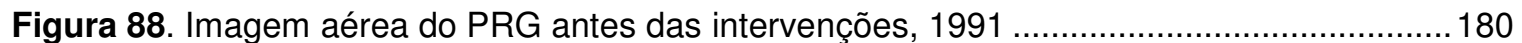

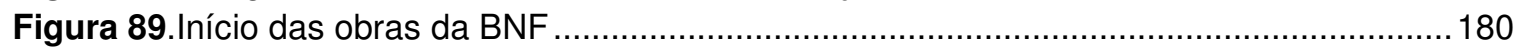

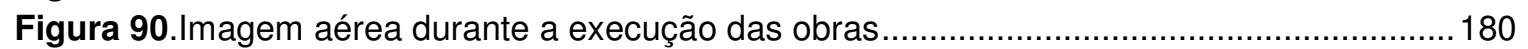

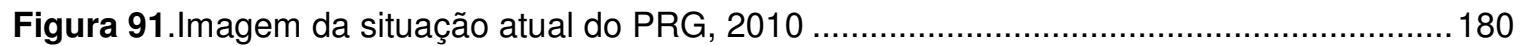

Figura 92. Imagens do bairro de Rive Gauche após as intervenções urbanas, 2011 ................ 182

Figura 93. Cidade Barroca (século XVII) protegida pelas muralhas e implantada na junção entre

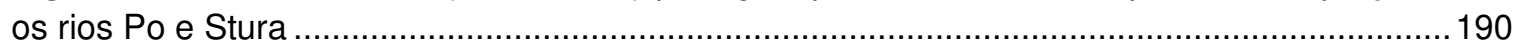

Figura 94. Cidade Burquesa (final século XIX) a cidade se desenvolve além das muralhas com a chegada da rede ferroviária (Porta Nuova) e as primeiras indústrias (Manifattura Tabacchi)..... 190 Figura 95. Cidade Industrial (anos vinte do século XX) com o advento da ferrovia a cidade amplia seu parque industrial, mudando radicalmente sua localização geográfica, onde antes era os rios, agora a ferrovia determina a implantação das indústrias ......................................................... 192

Figura 96. Indústria Manifattura Tabacchi, uma das primeiras indústrias de Torino junto ao rio Po 192

Figura 97. Grande crescimento territorial pós II Guerra Mundial com desenvolvimento de uma infraestrutura urbana em grelha ....................................................................................... 194 Figura 98. A cidade atualmente num processo de reabilitação urbana desencadeada em 1995, agora caracterizada como uma cidade funcional, marcados por três questões: eixo rio Po, Spina Centrale e Corso Marche, além das linhas de metrô 1 e 2 (laranja e violeta) ............................... 194

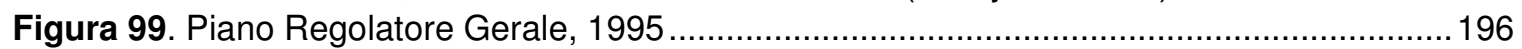

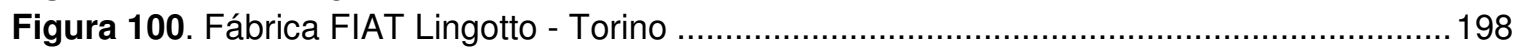

Figura 101. Exposição Internacional do Trabalho, 1961 em celebração ao centenário da

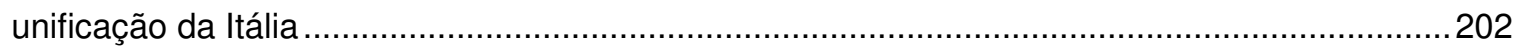

Figura 102. Palavela de Torino, antiga estrutura da Exposição de 61 readequadoa para as

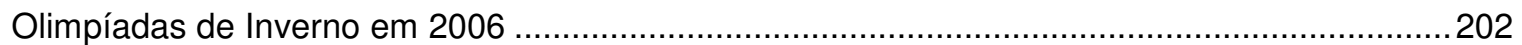

Figura 103. Implantação do Grande Projeto Urbano Spina Centrale e Passante Ferroviário ....204

Figura 104. Vista do Eixo da Spina Centrale em obras, 2005 ..................................................204

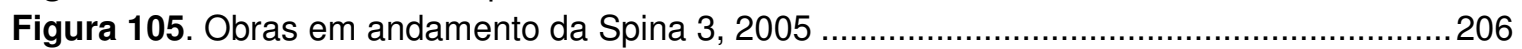

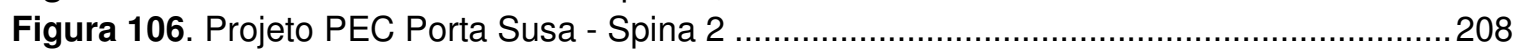

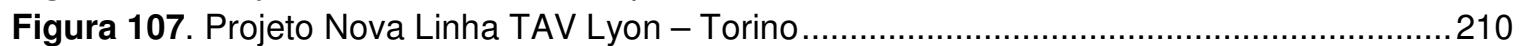

Figura 108. Vista da Área de Intervenção Spina 2 - Porta Susa, entre os bairros Centro Crocetta, San Paolo - Cenisia - Pozzo Strada - Cit Turin - Borgata Lesna, e San Donato - Capitol

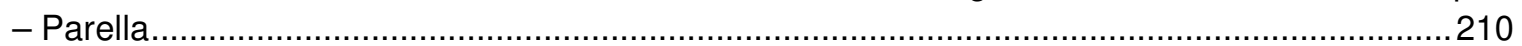

Figura 109. Início das obras da Estação Porta Susa - Spina 2 ..............................................212

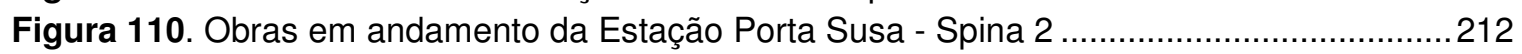

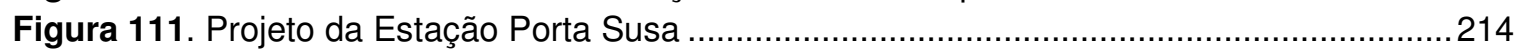

Figura 112. Corte Transversal sobre a Estação Porta Susa e Avenida Spina Centrale ..............214

Figura 113. Maquete volumétrica da Nova Estação Porta Susa...............................................214

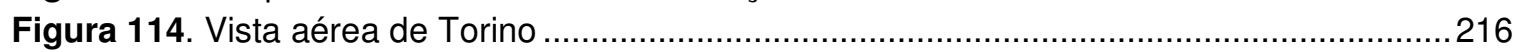

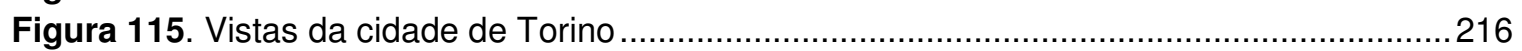

Figura 116. Implantação da Nova Estação Porta Susa na malha urbana existente ....................218

Figura 117.Croquis da implantação da Estação Porta Susa.....................................................218 
Figura 118. Estação Porta Susa parcialmente em funcionamento......................................... 218

Figura 119. Obras da Novas Estação Porta Susa - Spina 2 ………................................... 220

Figura 120. Montagem da Cobertura Metálica da Nova Estação Ferroviária............................. 220

Figura 121.Esquema de Demarcação fixada pelo Tratado de Tordesilhas, 1494 ...................... 228

Figura 122. Esquerda: Vila Sant'anna a partir de 1610. Direita: Vila de Sant'anna em 1653 .... 234

Figura 123. Esquerda: Vila Sant'anna em 1832. Direita: Vila sant'anna em 1857 ..................... 234

Figura 124. Esquerda: Mogi das Cruzes em 1898. Direita: Mogi das Cruzes em 1949, emancipação político-administrativo de Suzano............................................................... 236

Figura 125. Esquerda: Mogi das Cruzes em 1954. Direita: Mogi das Cruzes em 1964 ............. 236

Figura 126. Esquerda: Mogi das Cruzes em 1970. Direita: Configuração atual das cidades

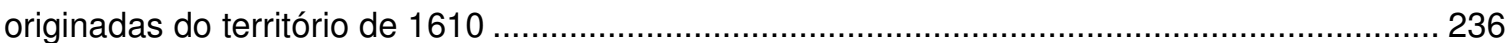

Figura 127. Mapa de Suzano em meados do século XVII com a localização da "Estrada Real do Guaió", segundo descrição de Suami Azevedo quanto a sua localização entre os rios Taiaçupeba (direita) e Guaió (esquerda), estrada de ligação entre a Vila de Sant'anna, o Litoral e a Vila São

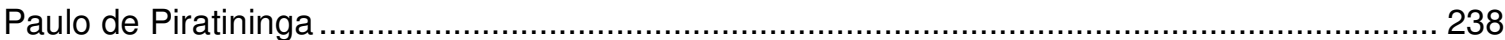

Figura 128.Formação do núcleo do Baruel do final do século XIX, composição espacial

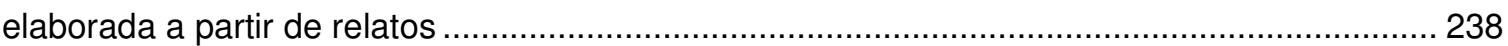

Figura 129. Capela do Baruel atualmente, preservada pela PMS e a família Bianchi ................ 240

Figura 130.Mapa da rede ferroviária de carga - SR4 - São Paulo ........................................... 242

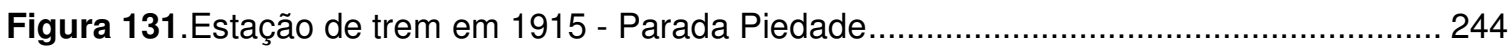

Figura 132.A estação em 1948: inaugurada em 6 de novembro de 1875.................................. 244

Figura 133.0 casarão de Antonio Marques Figueira - $1^{\text {a }}$ casa do novo núcleo da cidade. Esquerda: casarão em 1952. Direita: imóvel atualmente preservado ...................................... 244

Figura 134. Vila da Concórdia, desenho de João Romariz, o primeiro traçado urbano da cidade,

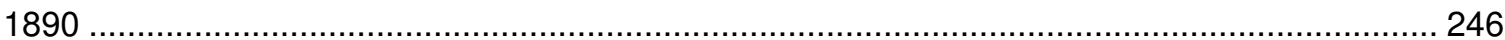

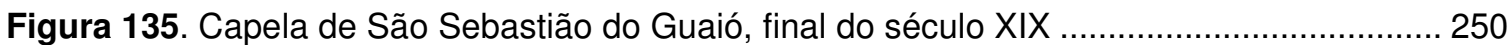

Figura 136. Igreja Matriz São Sebastião nos dias atuais.................................................... 250

Figura 137.Suzano em 1935: o distrito tinha a maior arrecadação entre outros bairros que pertenciam a Mogi das Cruzes. Nota-se um número limitado de ruas, ainda em terra, das quais as existentes até hoje como Gal. Francisco Glicério, Benjamin Constant, Marechal Deodoro, Major Pinheiro Fróes, Monsenhor Nuno, Prudente de Moraes, onde a ocupação se limitava ao

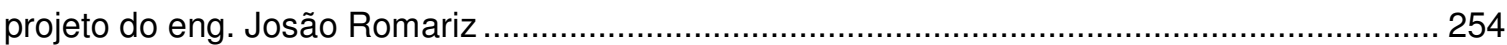

Figura 138.Suzano em 1952: emancipada, independente de Mogi das Cruzes ......................... 254

Figura 139.Inauguração do Paço Municipal na Rua Campos Sales - 1952 .............................. 258

Figura 140. Comparação entre a proposta da Vila de Concórdia, proposta de João Romariz (1890) e o Centro Urbano atual de Suzano (2012) ................................................................... 262

Figura 141. Tintura e Estamparia de Tecidos Suzano, uma das primeiras indústrias da cidade

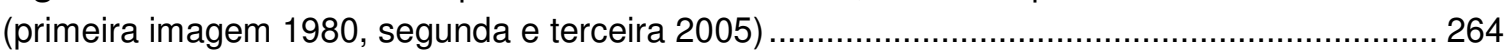

Figura 142. Foto aéreo da região central de Suzano na década de 1970 ................................. 266

Figura 143. Principais referências urbanas de Suzano na década de 1970 .............................. 268

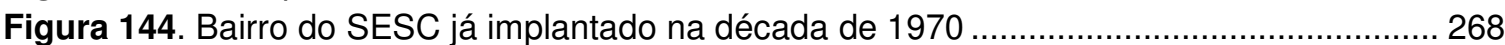

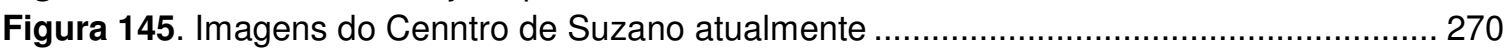

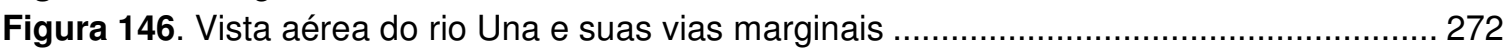

Figura 147. Suzano e sua inserção urbana na Região Metropolitana de São Paulo .................. 274

Figura 148. Suzano e sua inserção urbana na Região do Alto Tietê ......................................... 274

Figura 149. Imagens do Centro Urbano de Suzano em 2005 ................................................ 278

Figura 150. Vista para a Represa de Taiçupeba: em primeiro palno a cidade de Suzano, ao

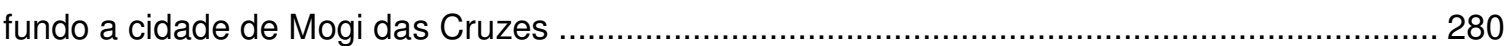

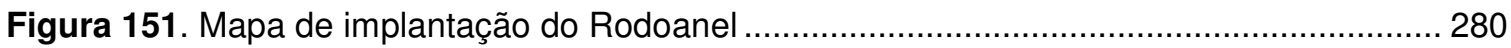

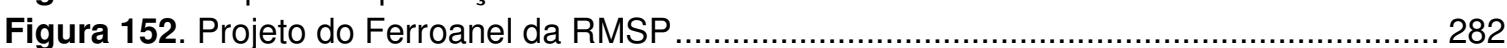

Figura 153.Articulação Arquitetônica e Urbanística do Estudo de Pré-viabilidade Técnica, Econômica e Ambiental do Hidroanel Metropolitano de São Paulo ............................................. 282 
Figura 154.Parque Várzeas do Tietê com $107 \mathrm{~km}^{2}$ de área verde e 33 núcleos com

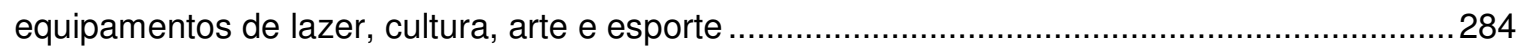
Figura 155. Obras previstas para a Copa 2014, entre elas a Perimetral da Copa | Trecho Suzano

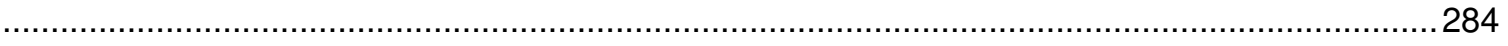

Figura 156. Terminal Urbano Ver. José Diniz, projeto do arquiteto João Valente, 2005 ............286

Figura 157. Praça Cidade das Flores, projeto do arquiteto Marcos Boldarini e equipe, 2005....286 Figura 158. Mapa das três regiões de Suzano: Boa Vista (norte), Centro e Palmeiras (sul) .....288 Figura 159. Planos e Grandes Projetos Urbanos previstos para a cidade de Suzano desde 2005 294

Figura 160. Vista da Área de Intervenção da Operação Urbana Orla Ferroviária. Em 2005 esta região da cidade se encontrava com seu conjunto edilício degradado, diversos vazios urbanos e áreas subutilizadas como o pátio de manobras e depósito de dormentes da CPTM e o terreno do "Terminal de Ônibus", área totalmente degradada urbana e fisicamente .....................................300 Figura 161. Pátio de Manobras e Depósito de Dormentes da Companhia Paulista de Trens Metropolitanos - CPTM, área desativada e subutilizada (terrain vague) …….............................302

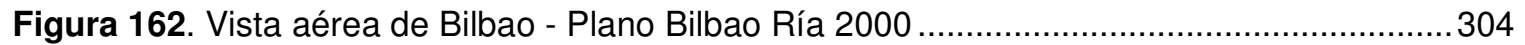

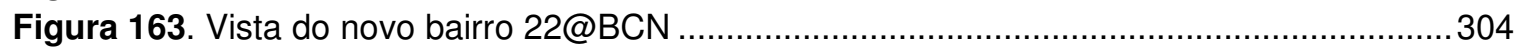

Figura 164. imagem aérea da área central de Suzano e o eixo ferroviário ................................306 Figura 165. Mapa de Suzano com suas estruturas urbanas de ferrovias de trasnporte de passageiros (leste-oeste) e cargas (norte-sul) e os principais rios da cidade como Tietê (norte), Guaió (oeste) e Taiaçupeba (leste), assim como sua represa .................................................308

Figura 166. Casa do Engenheiro Josquim Augusto Suzano Brandão, atualmente demolida para dar lugar a nova estação ferroviária ........................................................................... 310 Figura 167.Perímetro das intervenções urbannas da Operação Urbana Orla Ferroviária de

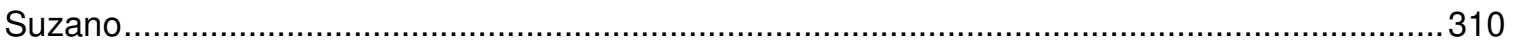

Figura 168. Vista aérea do centro comercial de Suzano. Observa-se que a única área livre verde ainda presente é a Praça João Pessoa, prevista desde 1890 pelo eng. Romariz .......................312 Figura 169. Morfologia Urbana de Suzano onde a primeira ocupação (final do século XIX) manteve-se intacta com suas quadras regulares (1 hectare). Com o passar dos anos, sua expansão se deu sem qualquer planejamento onde os bairros eram implantados sem a mesma lógica da malha regular em xadrez, resultando em uma grande diversidade de formas

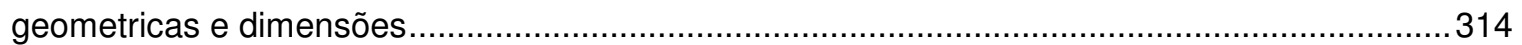

Figura 170. VIsta para o centro comercial, o eixo ferroviário e os bairros a norte da linha férrea 316

Figura 171. Diagramas Urbanos no perímetro da Operação Urbana Orla Ferroviária: pedonal,

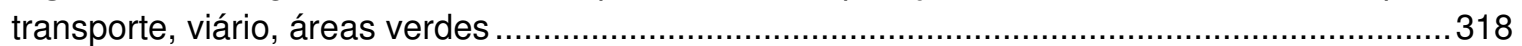
Figura 172. Digrama urbano: equipamentos públicos e espaços construídos existentes ...........324 Figura 173. Perímetro da AIU - Área de Intervenção Urbana - Operação Urbana Orla Ferroviária 324

Figura 174. Projetos e obras da Operação Urbana Orla Ferroviária - AIU: 1. Terminal urbano norte, 2. Shopping Popular, 3. Nova Estação Ferroviária, 4. Restaurante Popular, 5. Nova Praça

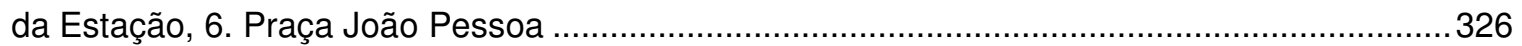
Figura 175. Nova Estação de Suzano, projeto do escritório JBMC Arquitetura e Urbanismo, 2010 326

Figura 176. Estudos volumétricos das novas formas urbanas sobre os espaços construídos da Operação Urbana Orla Ferroviária. Propostas apresentadas pelo Grupo de Pesqsuisa da

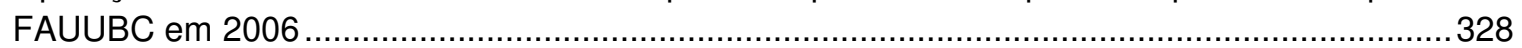
Figura 177. Vista da área da Operação Urbana Orla Ferroviária em 2005 e proposta de

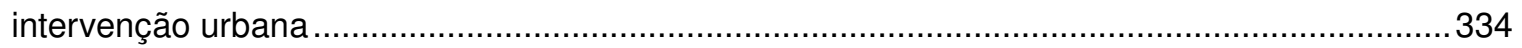
Figura 178. Nova Estação Ferroviária de Suzano, projeto do escritório JBMC Arquitetura e

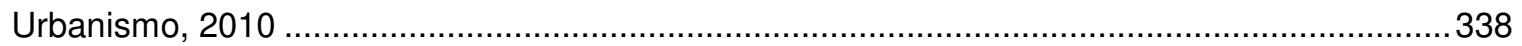
Figura 179. Projeto da Praça da Estação, de autoria da equipe técnica da PMS, 2010 ............338 
Figura 180. Projeto do Shopping Popular, de autoria da equipe técnica da PMS, 2010 338

Figura 181. Evolução das intervenções urbanas previstass na Operação Urbana Orla Ferroviária e sua transformação da Forma Urbana: 1. situação encontrada em 2005; 2. construção do terminal urbano norte; 3 . desapropriação e demolição de edifícios e espaços ociosos para a construção da nova estação ferroviária e equipamentos públicos; 4. Desapropriação de faixa edificada para a duplicação da av. dr. Prudente de Moraes; 5 . área resultante da demolição da faixa edificada; 6 . construção de novos equipamentos públicos e parque central; 7 . alteração da forma urbana nas quadras lindeiras num período de 10 anos; 8 . alteração da forma urbana num período de 30 anos 340

Figura 182. Transformação do tecido e sua forma urbana a partir dos Grandes Projetos Urbanos em Barcelona, Paris e Torino 350

Figura 183. Situação atual da área de intervenção da Operação Urbana Orla Ferroviária ........ 354 Figura 184. Vista do canteiro de obras da construção da Nova Estação Ferroviária de Suzano, 2012 356 
Grandes Projetos Urbanos e as Novas Formas Urbanas na Cidade

PARTE I

ANÁLISE DA CIDADE CONTEMPORÂNEA

Capítulo 1

Morfologia Urbana como Método de Análise da Cidade Contemporânea 59

1.1 Morfologia Urbana | Pressupostos 61

1.2 Italianos, franceses, entre outras referências ...................................................... 73

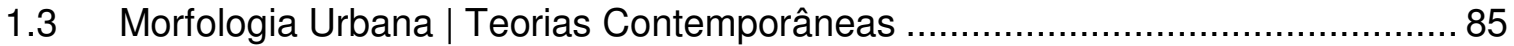

1.4 Morfologia Urbana como Método de Análise ................................................. 100

PARTE II

GRANDES PROJETOS URBANOS NA CIDADE CONTEMPORÂNEA 105

Capítulo 2

Barcelona | Espanha 107

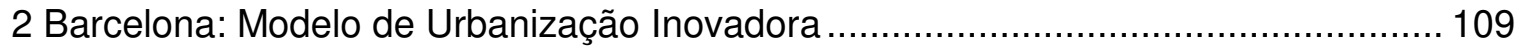

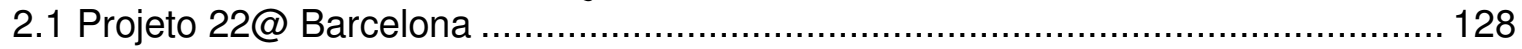

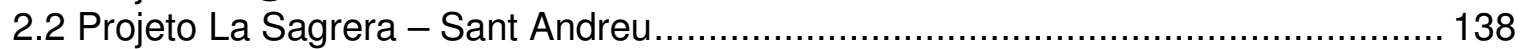

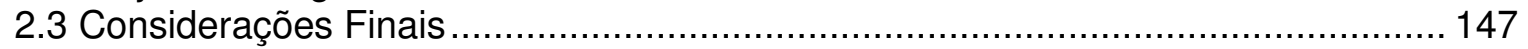

Capítulo 3

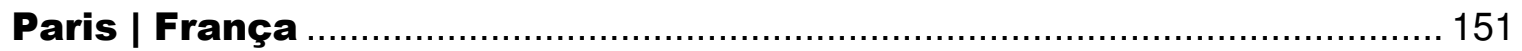

3 Paris: Intervenções Urbanas e a Homogeneidade do Tecido Urbano ................ 153

3.1 As ZACs parisiense e os Grandes Projetos Urbanos para Paris ........................... 161

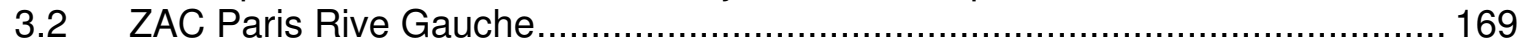

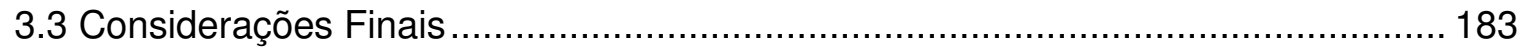

Capítulo 4

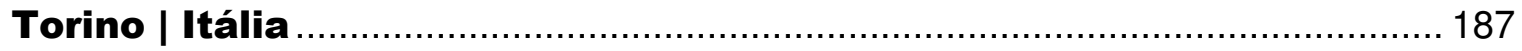

4 Torino: Transformação Contínua sobre um Tecido Existente ................................... 189

4.1 Grandes Eventos Internacionais e as transformações da Forma Urbana ............... 199

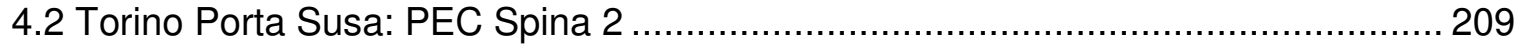

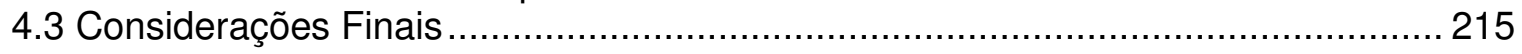

PARTE III

SUZANO E A CONSTRUÇÃO DE UM NOVO TERRITÓRIO ........................ 223

Capítulo 5

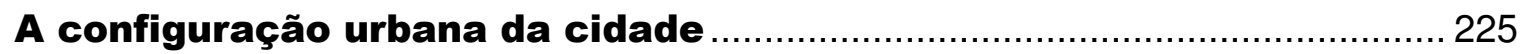

5.1 A consolidação do primeiro núcleo | Baruel .................................................... 227

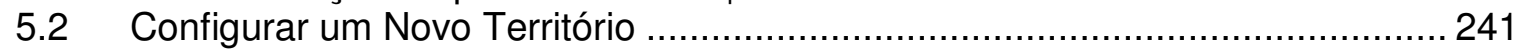


Capítulo 6

Inserção Urbana e Infraestrutura da Cidade: a construção de um novo

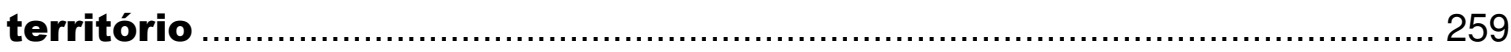

6.1 A consolidação do novo território às margens da linha férrea .............................2.261

6.2 Inserção e Infraestrutura Urbana: Suzano e a RMSP ......................................... 273

6.3 Estratégias Urbanas e o Desenho da Cidade.................................................. 279

Capítulo 7

OPERAÇÃO URBANA ORLA FERROVIÁRIA: contextualização do

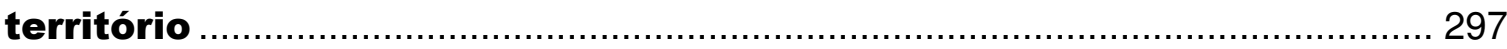

7.1 Operação Urbana Orla Ferroviária: contextualização e estratégias urbanas .......... 299

7.2 Limites e Fronteiras: definições das Bordas Urbanas......................................... 307

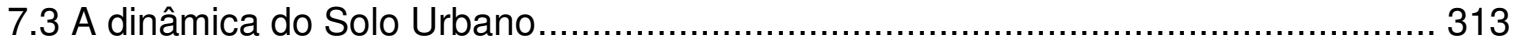

7.4 Fluxos, Fixos e os Vazios Urbanos na Cidade ................................................. 317

Capítulo 8

OPERAÇÃO URBANA ORLA FERROVIÁRIA: oportunidade de

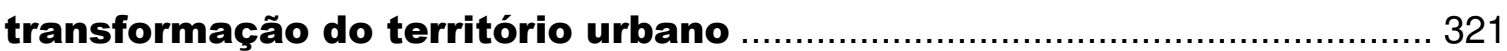

8.1 A transformação da morfologia urbana ............................................................ 323

8.2 LABORATÓRIO URBANO: mais de meia década de experiências sobre o solo urbano

PARTE IV

CONSIDERAÇÕES FINAIS 343

Capítulo 9

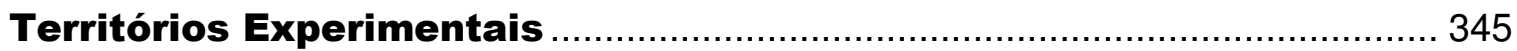

9.1 A Construção de Novas Formas Urbanas na Cidade Contemporânea .............. 347

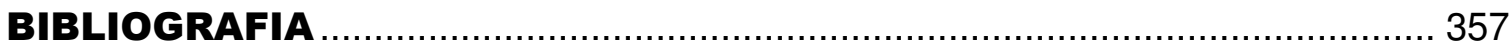




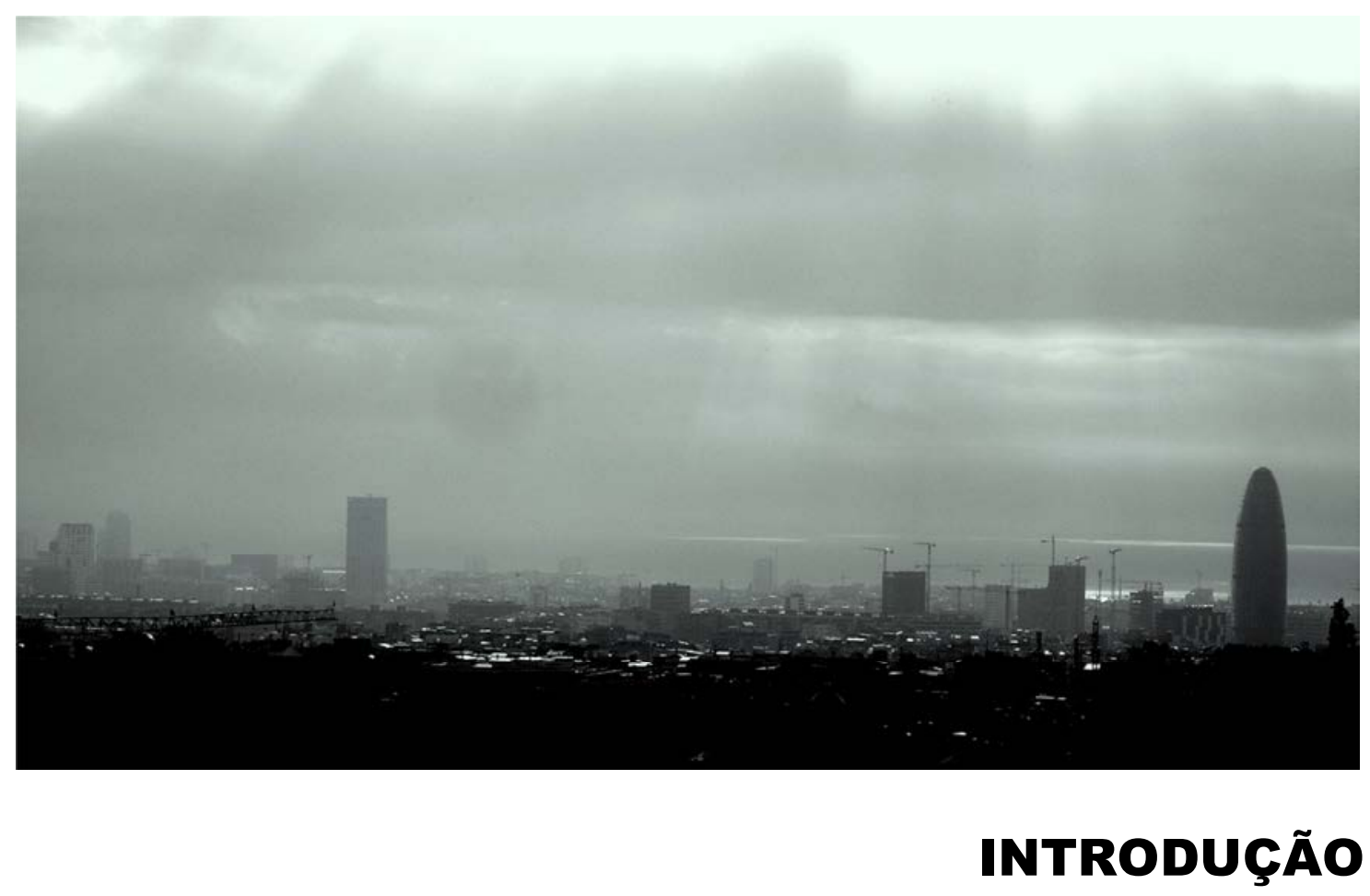





\section{Grandes Projetos Urbanos e as Novas Formas Urbanas na Cidade Contemporânea}

As cidades se desenvolvem constantemente, por mais que sua estrutura urbana se mantenha "estática" durante o passar dos anos, sua forma (urbana) se altera através das construções e reconstrução da cidade com novos investimentos que configuram a paisagem criando novos cenários urbanos a cada momento.

Estas transformações acontecem muitas vezes de forma gratuita ou descontrolada, lenta ou ligeira, gradual ou completa; e sua necessidade se dá por diversos motivos como a renovação de espaços urbanos degradados, subutilizados, áreas abandonadas ou em processo de transformação. Na maioria dos casos, estas transformações são provocadas pela necessidade de atender a interesses públicos ou privados que visam um retorno rápido aos altos investimentos sobre a cidade.

As últimas duas décadas do século $X X$ se consolidaram como os "tempos de transformação" do tecido urbano e a possibilidade de especulações e experiências sobre novas formas urbanas que se adequassem as então condições e dinâmicas exigidas pela Cidade Contemporânea, agora, organismos resultantes de uma mistura única do previsto e do não planejado, de recursos que foram intencionalmente projetados pelo governo e outros que surgiram organicamente, ao logo do tempo, a partir de escolhas e decisões feitas por seus "gerentes públicos".

A II Guerra Mundial também contribuiu para a esta revisão urbana necessária. As cidades afetadas pela "destruição" e "ataques" viram seu tecido urbano se desmontar e ser abandonado gradativamente. Por outro lado, a partir da década de 70 estas mesmas cidades viram nos territórios atingidos a possibilidade da transformação destes espaços para atender a uma "nova sociedade"; esta revolução influenciaria de forma decisiva a consolidação de um "novo urbanismo" para as cidades e seus habitantes.

Mais recentemente a mudança na economia mundial provocou o abandono de grandes áreas portuárias, industriais e de transformação que já não cumpriam a função dentro da lógica econômica terciaria das cidades.

Assim, conforme Su Dan:

“...a emergência e o desenvolvimento das principais funções das cidades está relacionado ao seu beneficio econômico: aumentando a escala potencial do mercado local; larga escala no mercado local pode reduzir o custo de produção; custo para importar material bruto e componentes para a região local pode ser muito reduzido se forem proporcionados serviços públicos e utilitários; acumulação de configuração vocacional e mecanismos de acordos; diretores talentosos e grupos de empresários na cidade; condições superiores disponíveis na metrópole por organizações financeiras e comerciais; a centralização da cidade pode prover grande variedade de instalações para recreação, atividades sociais, educação etc e em bases regulares; circuitos de negócios preferem estar centralizados na cidade para operação e direção mais eficiente; e centralização geográfica inspira a iniciativa para reforma" (DAN 2003, p 24). 

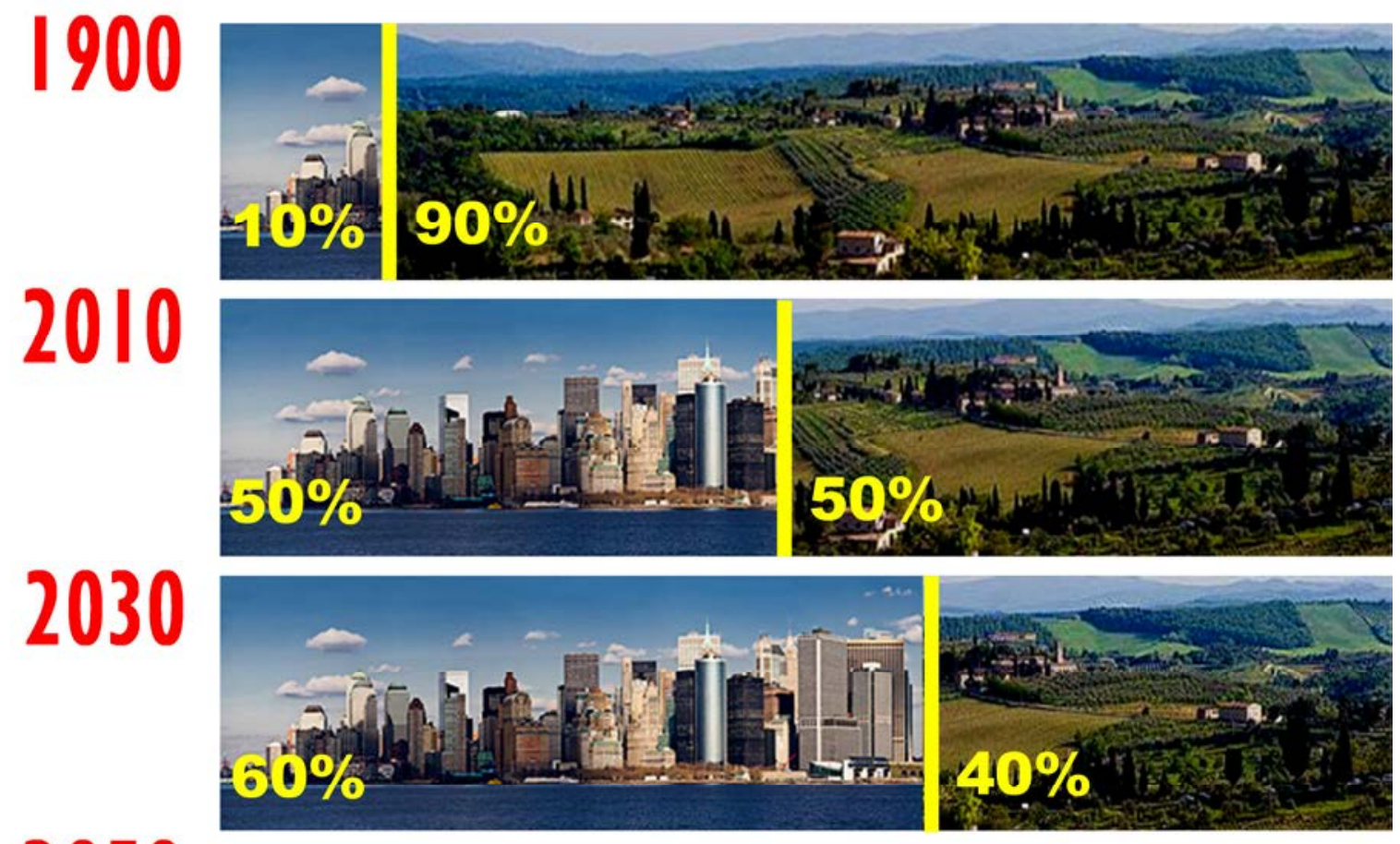

2050
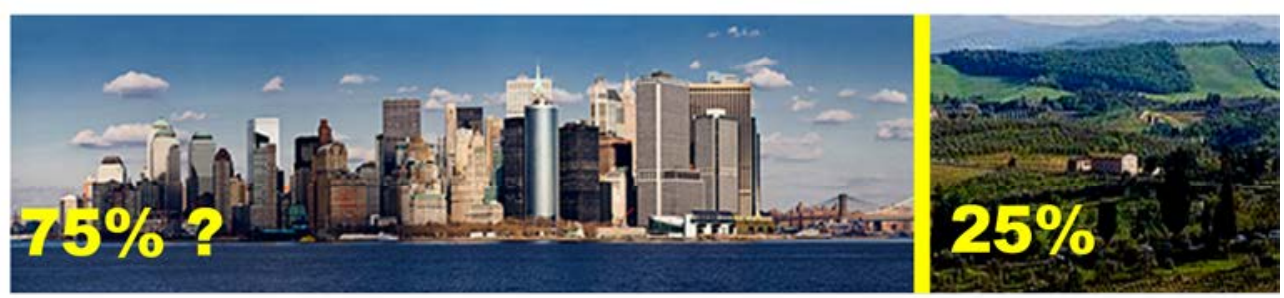

Figura 1. Planeta Urbano

Fonte: conferência urban age américa do sul, 2008

Organização: Elvis Vieira, 2010

Figura 2. Projeção Populacional

Fonte: Agência de Referência Populacional e ONU

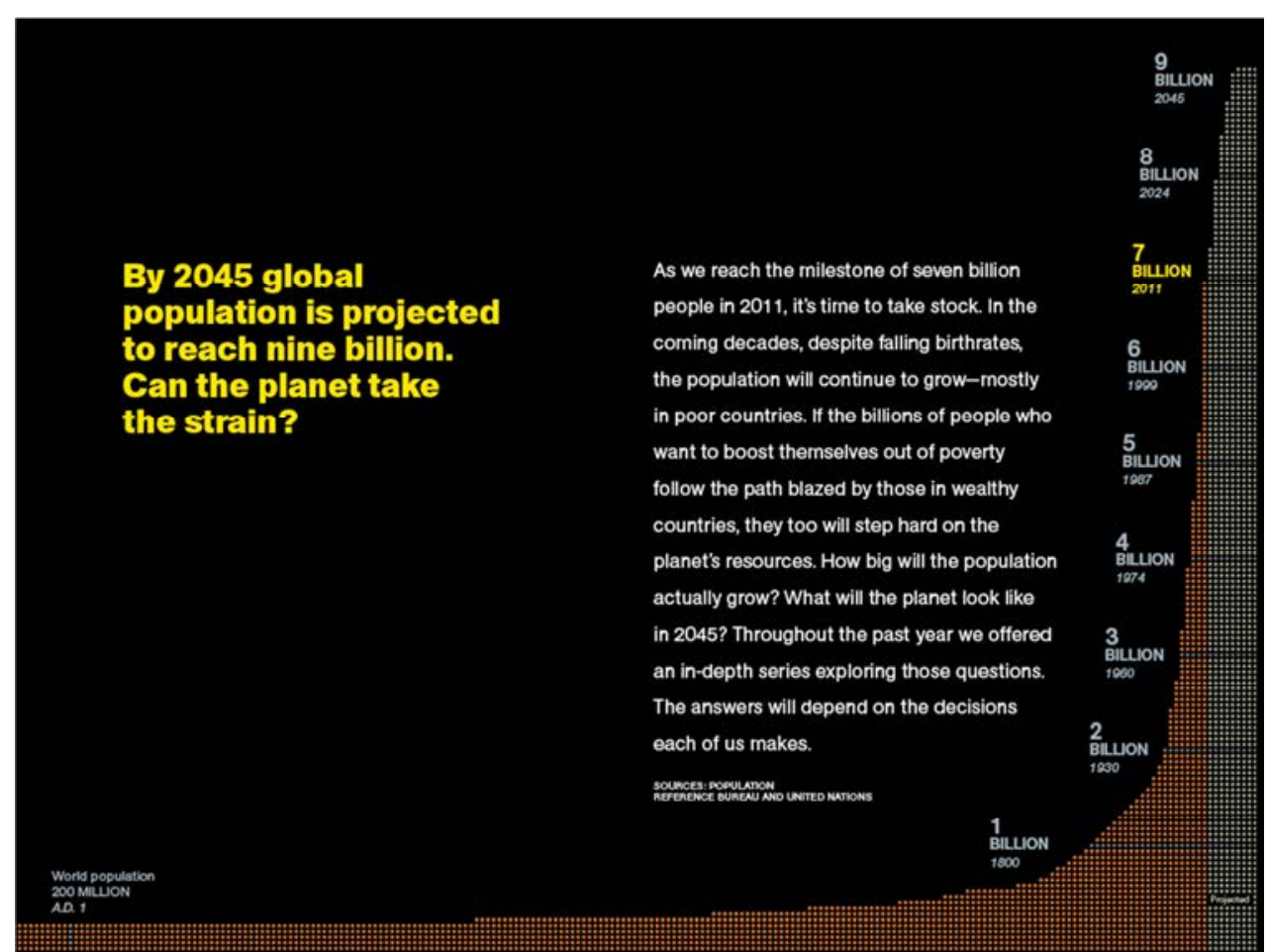


Neste panorama, um número considerável de arquitetos responderia as ansiedades desta "sociedade moderna", tendo em comum, à primeira vista, a ideia-força de empreender o que foi uma verdadeira revolução arquitetônica.

"Assim se passou de uma arquitetura reservada às realizações únicas e excepcionais à arquitetura aplicada à solução das necessidades desse novo cliente coletivo constituído basicamente dos trabalhadores nas indústrias e escritórios"(KOPP 1990, p 16).

Neste momento, um grande número de cidades tinham seu tecido urbano redesenhados, sob o olhar da renovação urbana e de estratégias capazes de criar uma nova vocação para elas, e formas urbanas mais compatíveis à vida contemporânea.

Este fenômeno também é defendido como capaz de gerar a transformação da cidade a partir de intervenções pontuais sobre o tecido degradado, onde "o desenho urbano vai continuar as regras tradicionais de composição do espaço e de relacionamento das suas partes, ou 'elementos morfológicos'”'(LAMAS 1992, p 203).

Com isto, assistimos a uma "mudança de paradigma" nas intervenções urbanas realizadas a partir da década de 1970, tendo como estratégia a renovação do tecido urbano e a reconstrução de trechos desta cidade agora ociosa, destruída ou abandonada, agora na busca, de uma cidade contínua e contemporânea, atendendo às necessidades tecnológicas do último século e as novas condições das recentes cidades globais. Neste ponto, apesar desta tese não tratar especificamente sobre tal efeito, cabe resaltar as ligeiras e recentes mudanças com que as cidades vêm passando desde 0 início deste século.

Diversos autores e pesquisadores já advertiam sobre o crescimento das cidades e, sobretudo na inversão no uso do solo. Nas últimas décadas, tem-se observado um constante crescimento demográfico nas cidades e o surgimento a cada período de Grandes Metrópoles Mundiais, que do ponto de vista urbanístico, estas transformações resultam em uma série de problemas comuns para todas as cidades.

Em seu texto intitulado "Cidades $2010+25$ ", Carlos Leite aponta:

"Há 100 anos (1900), apenas 10\% da população mundial vivia em cidades. Atualmente, somos mais de 50\%, e até 2050, seremos mais de $75 \%$ "(LEITE 2010).

O autor defende o conceito de que hoje já somos um "Planeta Urbano", visto que mais de $50 \%$ da população vive no meio urbano de suas cidades. Segundo dados da ONU a cada momento estão mais constantes o número de países com crescimento urbano superior de 40 a 50 pessoas/hora, mais especificamente os países em desenvolvimento como Lagos e Kinshasa (África), Delhi, Karachi, Mumbai (Emirados Árabes), Shangai, Dhaka (Ásia) que apresentam tais índices projetados para 2015(ONU, 2008). Reflexo deste efeito está na marca alcançada em 2011 de 7 bilhões de habitantes no planeta, 0 crescimento populacional global chega a marcas de bilhões de pessoas em períodos cada vez mais curtos, tendo previsto para 2024 - 8 bilhões e antes de meados do século XXI (2045) chegando a 9 bilhões de habitantes (vide fig. 2, pag. 32). 
Figura 3. Metrópoles do Mundo em 1975

Fonte: United Nations, Department of Economic e Social Affairs, Population Division (2008). World Urbanization Prospects. The 2007 Revision.

Highlights. (United Nations Working Paper No. ESA/P/WP/205).

Organização: Elvis Vieira, 2010
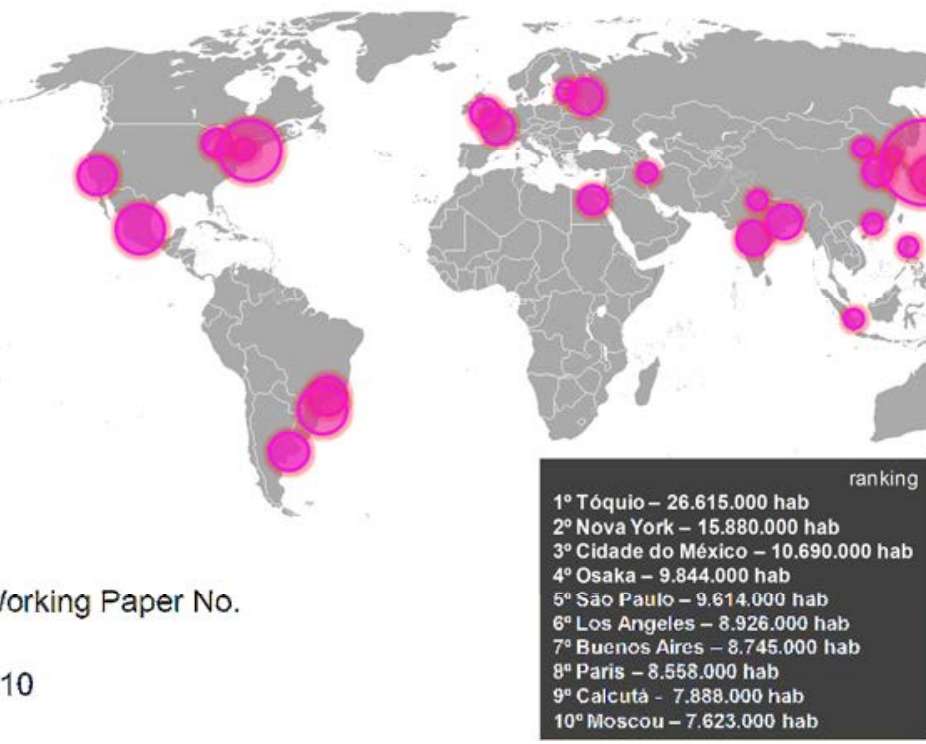

Figura 4. Metrópoles do Mundo em 2007

Fonte: United Nations, Department of Economic e Social Affairs, Population Division (2008). World Urbanization Prospects. The 2007 Revision. Highlights. (United Nations Working Paper No. ESA/PNWP/205).

Organização: Elvis Vieira, 2010
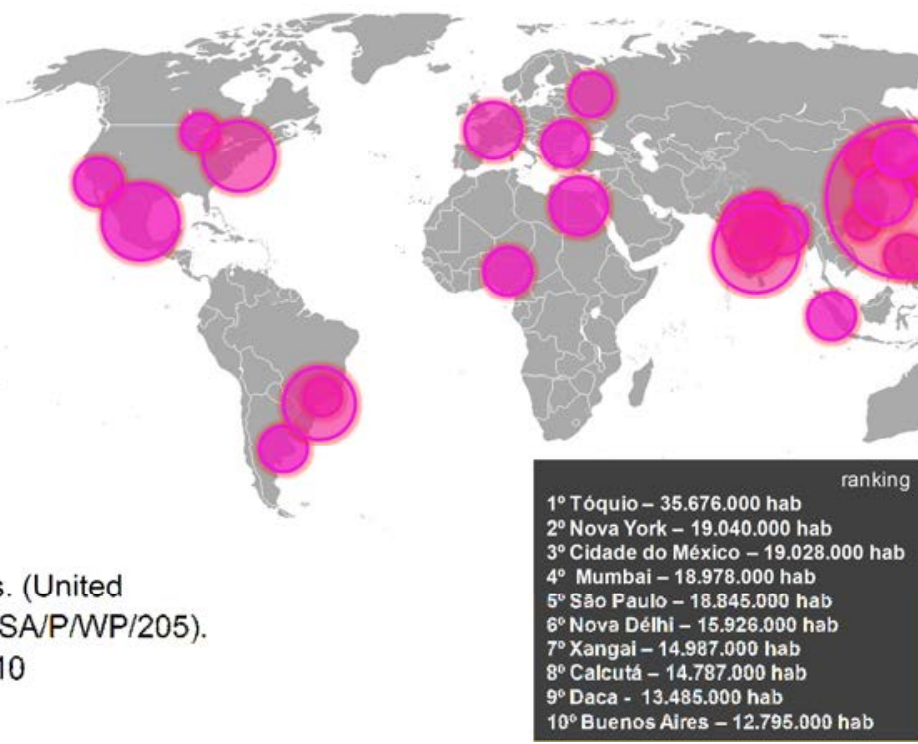

Figura 5. Projeção das Metrópoles do Mundo em 2025

Fonte: United Nations, Department of Economic e Social Affairs, Population Division (2008). World Urbanization Prospects. The 2007 Revision. Highlights. (United Nations Working Paper No. ESA/P/WP/205).

Organização: Elvis Vieira, 2010
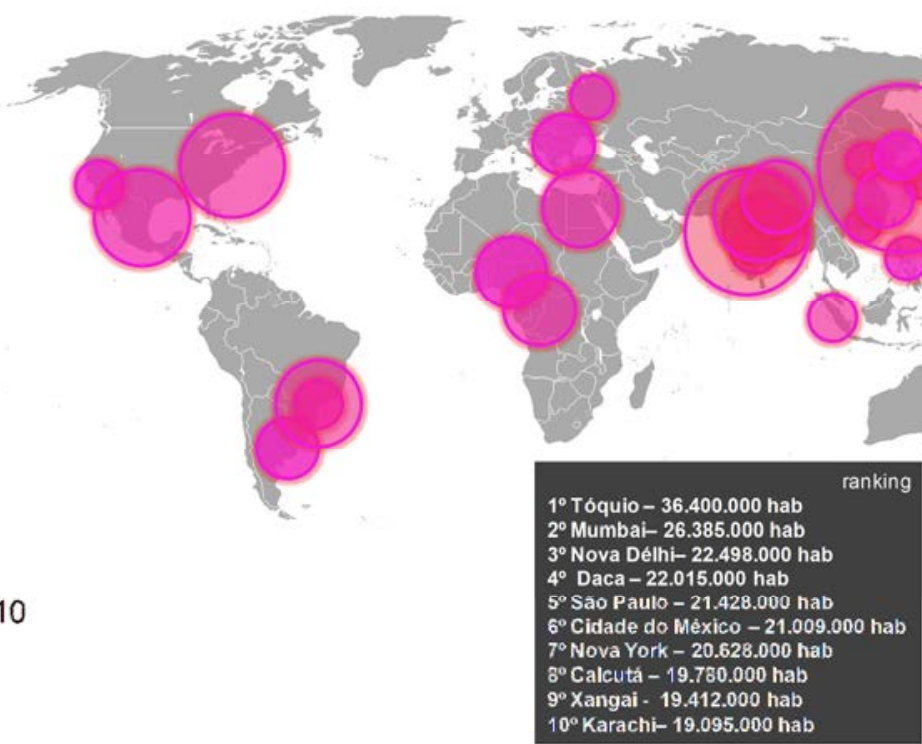
Da mesma forma, este "inchaço urbano" resulta no surgimento de Megacidades localizadas em novos endereços. Enquanto que em 1975 tínhamos as maiores metrópoles localizadas na Ásia (Japão), América do Norte (Nova lorque) e América Central (Cidade do México) como as principais metrópoles mundiais; passados pouco mais de três décadas (2007), as três primeiras metrópoles permanecem no ranking, enquanto que Mumbai surge em 40 lugar como uma das mais importantes. Já nas projeções previstas para 2025, este panorama se altera tendo os países do Oriente Médio como as mais significativas (ONU, 2008). ${ }^{1}$

Como enunciado por Leite (2012), "as cidades se reinventam, não são fossilizadas":

"...o século 19 foi dos impérios, o século 20, das nações, o século 21 é das cidades. As megacidades são o futuro do Planeta Urbano"(LEITE 2012, p 14).

Podemos então afirmar que num período cada vez mais curto as cidades estão se expandindo em escala e tamanho, em densidade e infraestruturas necessárias. Novas cidades e centros urbanos passaram a ocupar áreas rurais e exigir a cada instante novas formas urbanas de ocupação sobre um território cada vez mais denso e ocupado.

Como estratégia para reconfigurar a dimensão urbana e o desenvolvimento de áreas ociosas, deterioradas e abandonadas pelo simples fato da movimentação "espontânea" dos centros urbanos ou da mudança de um modelo econômico, a resposta a estas migrações para o meio rural, a ampliação demográfica na maioria das cidades e a procura por territórios que proporcionem negócios privados e atividades diversas à escala da cidade contemporânea, os Grandes Projetos Urbanos (GPUs), também reconhecidos como Grandes Intervenções Urbanas ou Megaprojetos, ${ }^{2}$ configuram numa importante ferramenta de desenvolvimento urbano e gestão do solo sobre um tecido urbano já consolidado e que por diversos motivos perderam sua dinâmica urbana e 0 interesse da iniciativa privada (investidores do mercado imobiliário).

"Sempre polêmicos, tais projetos contam com um potencial para o debate sobre a cidade como um todo a partir das questões facilmente compreendidas pela população sob impacto imediato de suas implementações" (ULTRAMARI e REZENDE 2007, p 8).

Se levarmos em consideração que a implementação dos Grandes Projetos Urbanos tem-se por premissa: 1) a revalorização cênica do patrimônio arquitetônico; 2) a valorização de trechos do tecido urbano degradado e/ou ociosos; 3) a possibilitadade de reabilitação do território e da economia defasada; podemos remontar estes fatores às intervenções de meados do século XIX, como Paris de Haussmann, com obras iniciadas em 1852, à Viena de Franz Josep, que a partir de 1857, cede às pressões liberais para que se derrubem as muralhas entre a área central e a periferia e, à Barcelona de Ildefonso Cerdà numa lógica de crescimento continuo a partir da lógica da quadra urbana (Manzana), em 1858.

1. Em 1975 a cidade de Mumbai não era considerada Metrópole, não aparecendo no ranking das 10 Metrópoles Mundiais. Em 2025, a ONU classifica as cinco principais metrópoles como: Tóquio, Mumbai, Nova Délhi, Dakar, São Paulo, consecutivamente.

2. Em inglês, a terminologia mais utilizada é a de Megaproject ou, conforme se tem visto mais recentemente na literatura especializada, Large Scale Urban Projects ou Large Scale Urban Interventions. Em espanhol, são comuns os termos Grandes Proyectos Urbanos e Macroproyectos Urbanos. 
Na América, o movimento iniciado nos Estados Unidos na última década do século XIX, City Beautiful, em resposta à rápida urbanização, tinha como principais defensores membros das classes ricas que se propunham, pela reforma urbana, "a 'corrigir' os desvios sociais de seu país" (ULTRAMARI e REZENDE 2007).

Destes casos exemplares, podemos dizer que suas intervenções tinham como papel revelador a capacidade de constituir-se em ícones emblemáticos do poder, sucesso, beleza, modernidade e desenvolvimento em função de suas Grandes Intervenções.

De certo modo, as intervenções colocadas em prática apartir do segundo meados do século XX possuem outra tônica. Em resumo, são tidos não somente como Projetos Urbanos, mas como Projetos Estratégicos em busca de soluções que possibilitem a transformação do tecido urbano física e economicamente.

Vicente del Rio, pesquisador e professor em Desenho Urbano, em seu livro Introdução ao Desenho Urbano (1990), torna-se importante fonte de pesquisa por se tratar das análises e métodos sobre a leitura da cidade. Da mesma forma, o mesmo autor nos apresenta um panorama destes projetos em desenvolvimento como a revitalização do bairro histórico de Fells Point, Baltimore - EUA, numa forma de enfrentar a decadência econômica e física vigente.

Segundo del Rio:

"O sucesso deste plano, comprovando a possibilidade da dinamização da economia local através da recuperação estrutural da área central, abriu caminho para uma série de outros programas e projetos de renovação e revitalização de caráter geral em Baltimore. Ainda em meados dos anos 60, a Prefeitura iniciou 0 programa de renovação da Área Portuária interior (inner harbor), experiência exemplar em todo o mundo" (del RIO 1990, p 146).

Figura 6. Vista aérea de Canary Wharf - Docklands - Londres

Fonte:

www.bbc.co.uk

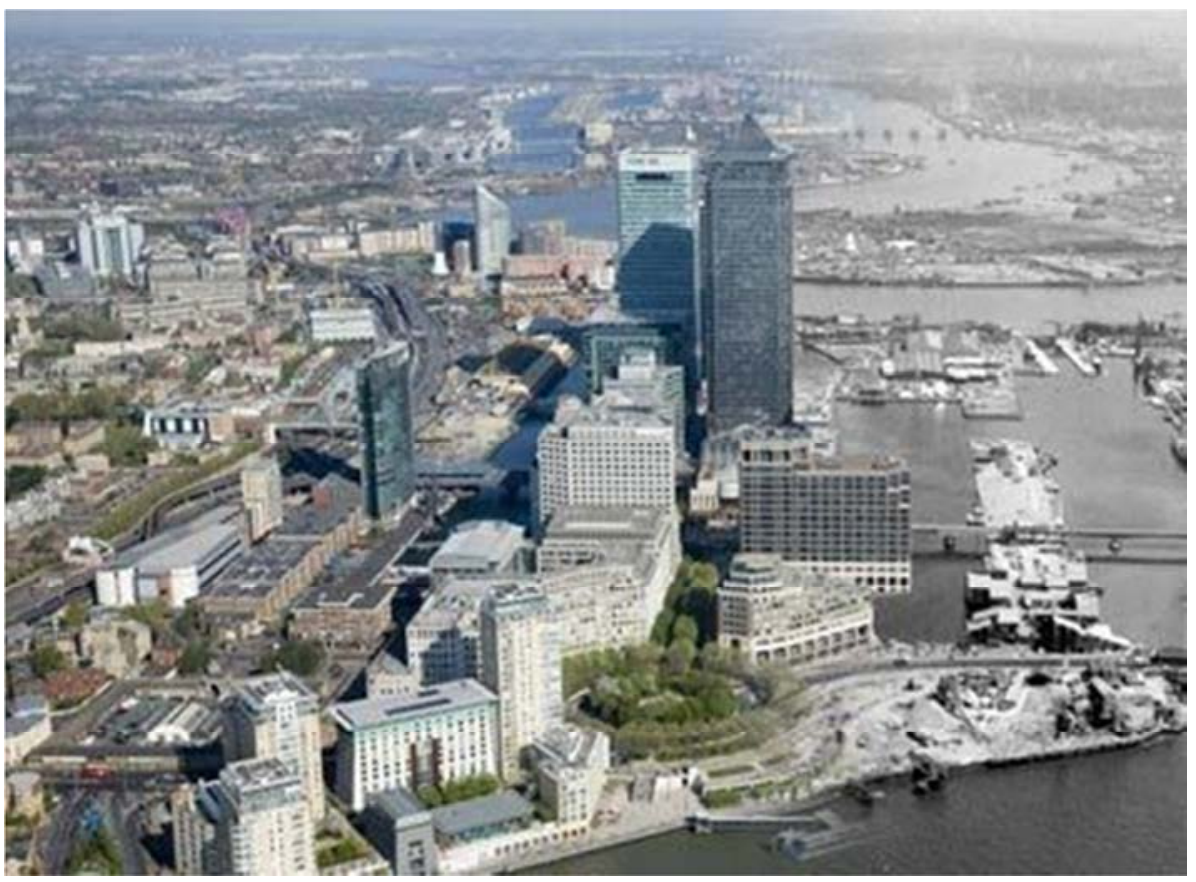


Outros casos clássicos podem aqui ser elencados como Projetos Urbanos Estratégicos, alguns com a intenção de Recuperação de Centros Históricos tendo suas intervenções aplicadas como Acupuntura Urbana junto ao tecido degradado; é o caso de Paris e Barcelona que entre as décadas de 70 e 90 implantaram no "coração histórico das cidades" equipamentos de cultura e educação como estratégia de renovação direta e indireta de seu tecido urbano. Tanto o Centro Cultural Georges Pompidou em Paris (1977) como o MACBA - Museu de Arte Contemporânea de Barcelona (1990) tinham como função a regeneração urbana, defendida por Solà-Morales, traduzindo em uma intervenção que, "em virtude dos seus limites intrínsecos e organização é capaz de aumentar o tecido da cidade de tal forma que serve simultaneamente como uma ferramenta para reestruturar e também para enriquecer contexto imediato"(SOLÀMORALES 2008, p 7-8). ${ }^{3}$

Após a década de 1980, um grande conjunto de cidades que até este momento se coloca como "produtores ou prestadores de serviços", numa rede de cidades geograficamente importantes para o comércio fluvial de mercadorias, assistem a degradação de seus territórios em detrimento da mudança econômica global, observando a partir disto "que as modificações no paradigma de desenvolvimento têm causado uma série de consequências na estruturação territorial das cidades e regiões" (NOBRE 2000, p 91).

Ainda segundo Nobre:

"A transferência das atividades manufatureiras, o crescimento do fluxo de investimentos e informações em nível mundial, possibilitados pelo novo paradigma tecnológico, tem ocasionado a decadência e a ascensão de diferentes regiões do mundo"(2000 p 91).

Em sua maioria, as cidades portuárias foram as que mais se degradaram devido a este fator mundial de transformação econômica, como Nova lorque, Buenos Aires e Santos nas Américas do Norte e Sul, sucessivamente, Tóquio e Kobe na Ásia e, Londres, Barcelona, Bilbao na Europa.

Poderíamos então apontar inúmeros conjuntos de intervenções bem sucedidas ou não, utilizando-se de estratégias diversas para alcançar seus objetivos e com resultados também adversos. Intervenções como as colocadas em prática em Londres, na região portuária a leste do centro da capital inglesa. Durante muitos anos este foi um dos maiores portos do mundo, caindo em decadência à medida que a tecnologia portuária se transformava. "O processo de obsolescência se arrastou de 1960 a 1980, com o encerramento das atividades portuárias, que deixou para trás a perda de algo em torno de 100 mil postos de trabalho" (NOBRE in ZANETTI 2005, p 48).

Os projetos urbanos se concentraram em criar programas de habitação de diversos custos, uma rede de transporte, manter certas potencialidades do lugar, e criar um novo centro financeiro na Zona Empresarial, chamada Canary Wharf, que se converteu no

3. Tradução do autor, 2012

En virtud de sus límites y organización intrínseca, es capaz de aumentar el tejido de la ciudad de tal forma que sirve al mismo tiempo como instrumento para reestructurar y también para enriquecer el contexto inmediato. 
"motor" da renovação urbana da cidade atual. Em síntese, o Grande Projeto Urbano para Docklands buscava a consolidação de uma Nova Centralidade para Londres.

Para que isto se realizasse em médio prazo, o governo dá à corporação (LDDC London Docklands Development Corporation) poderes como a compra compulsória (boa parte das terras eram particulares e evitavam a especulação imobiliária), o controle do desenvolvimento urbano da área de intervenção (responsabilidade de aprovação dos projetos - taxas de ocupação, índices de elevação etc.), além de firmar acordos de parceria de iniciativa pública e privada. ${ }^{4}$

Esta afirmação fica clara na publicação de Peter Hall:

“... o processo de urbanização fora dos limites da cidade, especialmente o dirigido pelo próprio mercado, foi mais geral e evidente em Londres e Nova lorque (...). E, de todas as grandes capitais, Londres foi, em certos aspectos importantes - o transporte público, as hipotecas baratas e a longo prazo, as relações entre empresas privadas e as grandes construções estatais - a cidade mais interessante, mais vital e com uma problemática mais evidente(...)"(HALL 1996, p 59). ${ }^{5}$

Da mesma forma Nobre afirma:

"Em função do tamanho das Docklands e da sua complexidade e diversidade, o $\angle D D C$ dividiu a área em três grandes áreas, estabelecendo diferentes estratégias para cada uma delas: Wapping and Limehouse e Surrey Docks, a oeste; no centro a Ilhas dos Cães (Isle of Dogs) e no extremo leste, Royal Docks" (NOBRE 2000, p 110).

Apesar das diversas estratégias utilizadas naquele momento para a consolidação dos projetos, levando muitas vezes a considerar a área de intervenção como um "laboratório urbano" para os grandes escritórios e arquitetos - Richard Rogers (Millenium Dome), Norman Foster (estação em Canary Wharf, City Hall), entre outros. Por outro lado, no que trata das Novas Formas Urbanas, os resultados alcançados em Docklands foram "desastrosos" tanto na paisagem da cidade como na expulsão de uma camada social de baixa renda junto a área renovada, gerando o que seria um dos primeiros processos de "Gentrificação" reconhecido.

Já a cidade de Bilbao, localizada ao norte da Espanha, durante todo século XIX teve sua economia centrada na indústria voltada à produção de navios para toda Espanha e boa parte da Europa. Devido sua localização privilegiada com modernos estaleiros em sua zona portuária. ${ }^{6}$

\footnotetext{
4. Estes novos instrumentos e gestão urbana sobre a intervenção fez do Plano de Renovação em Docklands um dos primeiros a colocar em prática tais propostas com recursos públicos e privados numa mesma proposta.

5 . Tradução do autor, 2012

El proceso de urbanización fuera de los límites de la ciudad, especialmente el dirigido por el propio mercado, fue más general y evidente en Londres y New York (...) Y, de todas las grandes capitales, Londres fue, en ciertos aspectos importantes - el transporte público, las hipotecas baratas y a largo plazo, las relaciones entre empresas privadas y las grandes construcciones estatales - la ciudad más interesante, más vital y con una problemática más evidente (...).

6. Paulo Julio Valentino Bruna e Lucio Gomes Machado. Disciplina: AUH5849 - Teoria e Prática da Arquitetura Contemporânea. FAU, Faculdade de Arquitetura e Urbanismo, 2005.
} 
Devido ao declínio industrial após a segunda metade do século XX Bilbao decide elaborar um plano de revitalização na busca de reprimir a crise existente, melhorar a cidade para seus habitantes e determinar uma visão de futuro para a cidade.

Para que estes objetivos fossem alcançados nos prazos pretendidos, dois planos estratégicos foram desenvolvidos na intenção de sanar os "conflitos" encontrados nas estruturas físicas da cidade e explorar os "potenciais" do território (geográficos e morfológicos). ${ }^{7}$ O primeiro de caráter metropolitano (Bilbao Metrópole 30 ) como forma de sanar as deficiências de acessibilidade e conexão da Região Vasco com as demais da Espanha, como a Catalunha (TAV Bilbao - Barcelona), o novo aeroporto e uma rede rodoviária entre a cidade e a região. Enquanto que o segundo plano, já de caráter territorial (Bilbao Ría 2000) se encarregou de recuperar zonas e áreas industriais desativadas, entre as quais se destaca a recuperação da zona de Abandoibarra, considerado como a intervenção mais emblemática tendo como "projeto motor" o Museu Guggenheim, projeto do arquiteto norte-americano Frank O. Gehry, inaugurado em 1997, e o Palácio do Congresso e da Música Euskalduna, obra de Federico Soriano y Dolores Palacio, inaugurado em 1999, que "representa a consolidação da atividade musical e da atividade do congresso que tem caracterizado o papel de Bilbao como um centro de intensa atividade comercial e turística..."(BILBAO RÍA 2000 s.d.) ${ }^{8}$

"Juntamente com isso, Bilbao conta com diferentes enclaves já existentes ou em processo de regeneração que atraem atividades empresariais de alta tecnologia e inovadoras, como podem ser o Parque Tecnológico de Zamudio e a zona de Abandoibarra".

"Um elemento diferencial de todo este processo tem sido o impulso as parcerias público-privada, uma nova forma de tomar as lideranças e promover a participação e entusiasmo dos cidadãos no futuro da sua cidade. Tudo isto sem perder de vista uma das características básicas da sincronia bilbaína: sua vocação solidaria e seu projeto de comunidade não excludente"(ASSOCIACIÓN BILBAO METROPOLI-30 2009, p 10). ${ }^{9}$

7 . Os termos "conflitos e potenciais" são utilizados nas análises físicas e morfológicas como método para a definição e reflexão sobre o objeto de estudo na disciplina de Projeto de Urbanismo nas FAUUBC e FAUUMC, no qual serão desenvolvidos no Capítulo Análise da Cidade Contemporânea.

8 . Tradução do autor, 2012

Representa la consolidación de la actividad musical y de la actividad de congresos que han caracterizado el papel de Bilbao como polo de un intenso turismo comercial y de negocios

9 . Tradução do autor, 2012

Junto a esto, cuenta Bilbao con diferentes enclaves ya existentes o en proceso de regeneración que atraen actividades empresariales de alta tecnología e innovadoras, como pueden ser el Parque Tecnológico de Zamudio y la zona de Abandoibarra.

Un elemento diferencial de todo este proceso ha sido el impulso de la colaboración público-privada, un nuevo modo de asumir liderazgos y fomentar la participación e ilusión de los ciudadanos en el futuro de su ciudad. Todo ello sin perder de vista una de las características básicas de la idiosincrasia bilbaína: su vocación solidaria y su proyecto de comunidad no excluyente. 


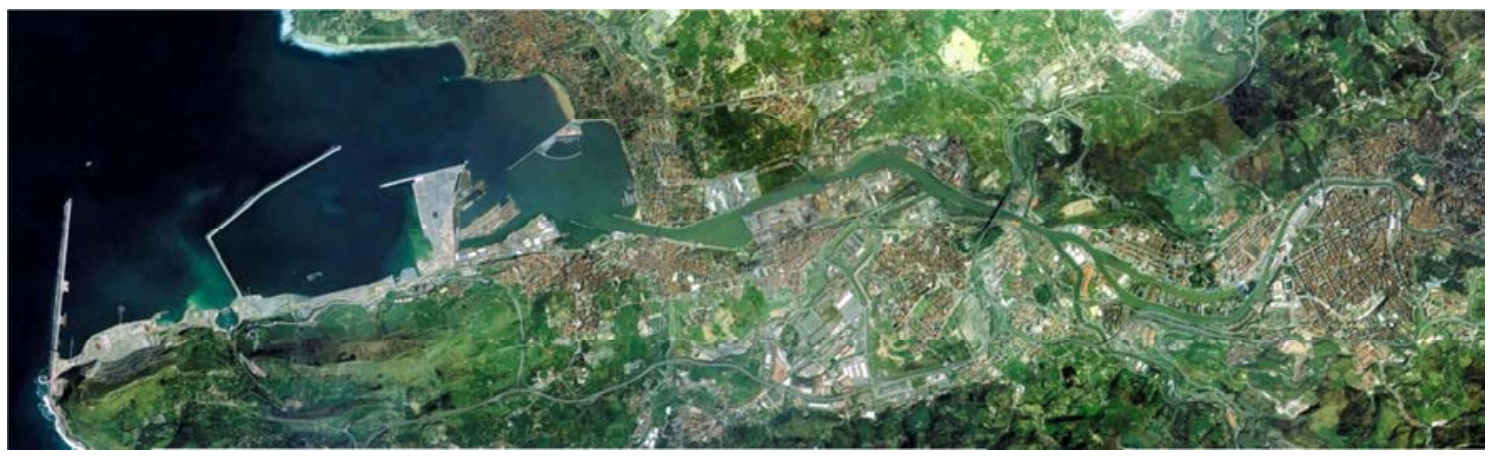

Figura 7. Região Vasco - Norte da Espanha

Fonte: Google maps, 2010
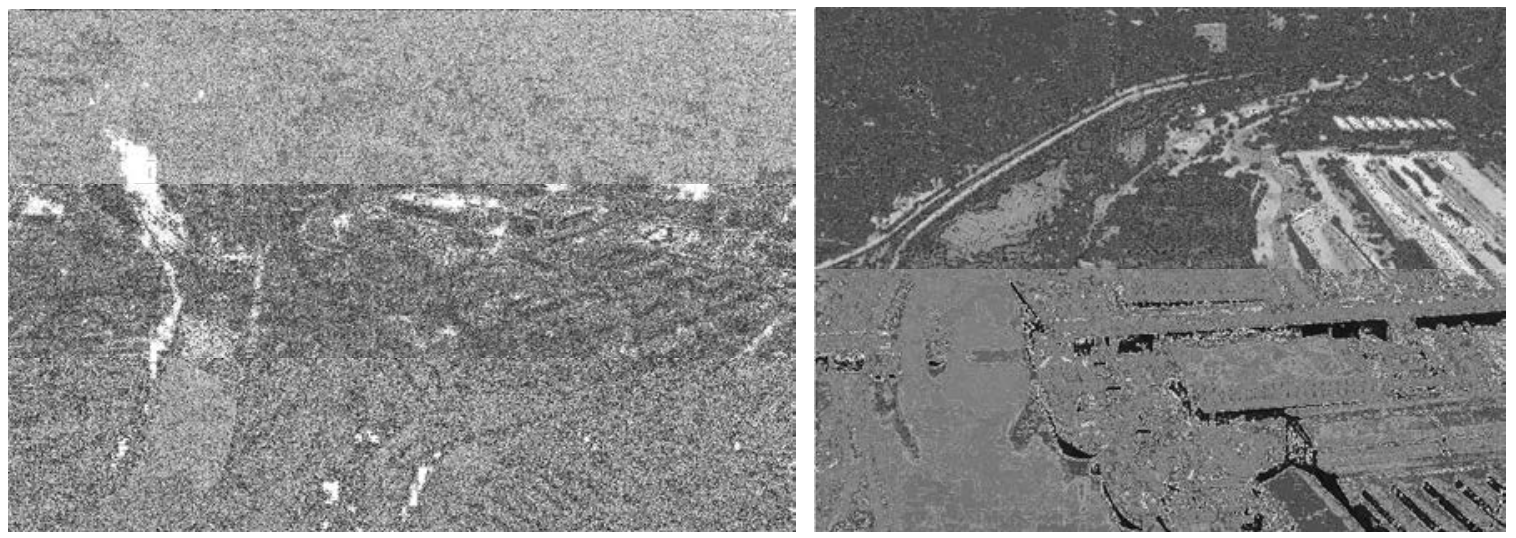

Figura 8. Vistas de Bilbao antes das intervenções urbanas em Bilbao-Ría 2000

Fonte: Bilbao-Ría 2000

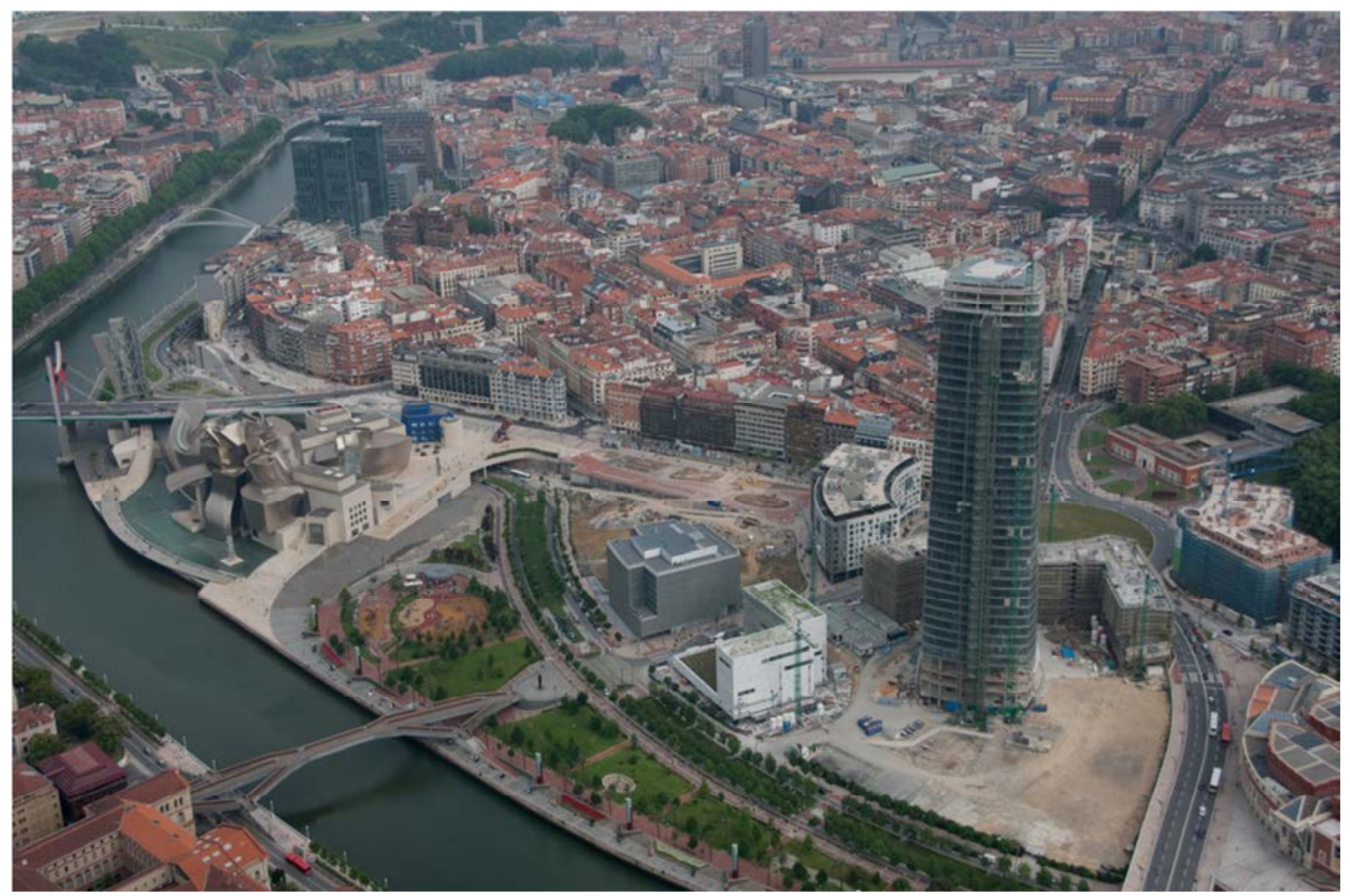

Figura 9. Vista de Bilbao e as obras de intervenção Bilbao-Ría 2000

Fonte: Elvis Viiera, 2009 
Apesar da grande distinção e escala dos dois planos, eles deveriam trabalhar juntos de forma a compartilhar seu objetivo final de melhorar a competitividade internacional de Bilbao, definindo a revitalização da cidade e a melhoria da qualidade de vida de seus habitantes.

Entre os resultados alcançados até hoje estão uma grande diversidade de projetos e obras tanto públicas como privadas, que vai muito além do Museu Guggenheim, redesenhando trechos da cidade com Novas Formas Urbanas Contemporâneas capazes de reverter a situação econômica e física do desenho da cidade, com ruas, pontes, áreas verdes e paisagens "renovadas", inserindo a cidade no roteiro turístico de milhares de pessoas. ${ }^{10}$

Podemos dizer que algumas cidades possuem seu crescimento contínuo no tempo, de forma ordenada ou não, mas que possuem a capacidade de se transformar e regenerar para atender as especificidades e diversidade exigida pela Globalização. Neste raciocínio, poderíamos apontar uma infinidade de cidades que se inseriam na condição de "Cidades Globalizadas", como São Paulo, Nova lorque, Londres, Tóquio, Shangai, e até mesmo Mumbai que "fazparte de um circuito global de incorporação imobiliária, que inclui empresas provenientes de cidades tão diversas quanto Londres e Bogotá" (SASSEN s.d.).

Atualmente as cidades passam por um processo de revisão das teorias urbanísticas, em que o conceito do "Novo Urbanismo", a partir da publicação da Carta do Novo Urbanismo em 1996 nos Estados Unidos, abre a possibilidade de repensar a cidade como espaço interativo entre os cenários possíveis e a escala humana, tendo como intenção, entre outros princípios:

“... organizar sistemas regionais articulando áreas urbanizadas centrais com as cidades menores em setores bem delimitados do território, evitando a ocupação dispersa; valorizar a acessibilidade por transportes coletivos, e retomar os tipos do urbanismo tradicional relativos ao arranjo das quadras e da arquitetura..." (MACEDO, 2010).

Enquanto isto, a Europa redesenha partes do tecido urbano de suas cidades, sob o olhar da renovação urbana e de estratégias capazes de criar uma nova vocação para elas, com formas urbanas mais compatíveis à vida contemporânea.

Ao buscarmos compreender as razões com que estes "novos paradigmas" influenciaram diretamente sobre o desenho da cidade contemporânea. Deparamo-nos com um conjunto de teorias e estudiosos que defendem a importância dos Grandes Projetos Urbanos como um caminho para se "ajustar o solo urbano" de forma mais ampla e igualitária.

10 . Bilbao Ría 2000, criada como uma "sociedade gestora" em 1992 para recuperar zonas degradadas e subutilizadas próximas ao centro histórico da cidade, melhorando a malha urbana e executando ações integradas ao urbanismo, transporte e meio ambiente. Para isto, o arquiteto Cesar Pelli foi incumbido de desenvolver o plano de forma a ser aplicado gradualmente em conjunto com os edifícios mais emblemáticos, que em sua maioria seriam desenvolvidos por arquitetos reconhecidos internacionalmente. Constrói-se o Museu Guggenheim e o Palácio Euskalduna. Estes edifícios qualificaram o lugar, dotando a área de equipamentos públicos com maior caráter social e cultural a Abandoibarra. Mais tarde se investe na urbanização do local, ação esta a cargo das entidades públicas, os demais edifícios como escritórios, hotéis, residenciais e comerciais chegam pela iniciativa privada, que adquirem os terrenos e constroem seus projetos tendo como referência o plano original de Pelli, quanto ao uso e ocupação do solo, como os critérios de desenho arquitetônico. 
Apesar de sempre polêmicos, tais projetos devem contar com um potencial para o debate sobre as cidades como ferramenta no qual os diversos agentes (públicos e privados) possam estar envolvidos e atuar sobre uma única base: apropriar-se de territórios degradados ou ociosos, em uma estratégia afinada que tende a buscar um equilíbrio entre o objeto de intervenção e seu entorno (local, regional, global), reconhecendo suas oportunidades nas áreas de Nova Centralidade em uma infraestrutura urbana em rede (acessos, mobilidade, espaços públicos e edificados, vazios urbanos).

Da mesma forma, como defende Manuel de Solà-Morales, os Grandes Projetos Urbanos também necessitam de uma "precisão através do exercício disciplinado e a sensibilidade mediante o aprender a olhar, para entender como a cidade funciona $e$ como as pessoas fazem uso dela" (SOLÀ-MORALES 2008, p 14). ${ }^{11}$

Ainda em Jordi Borja:

"A cidade é algo que deve realizar-se lentamente, discutindo e melhorando a cada projeto, concordando cada intervenção, permitindo que a mesma dinâmica da cidade vá evoluindo"(BORJA e MUXÍ 2004, p 212). ${ }^{12}$

Portanto, não é de se estranhar que a maioria dos Grandes Projetos Urbanos possuem (e devem ter) cronogramas de aplicabilidade a meio e a longo prazo, adequando-se as interferências pré-existentes e as devidas escalas de intervenção, como sua constante avaliação em busca da minimização nos impactos e riscos de gentrificação.

Estas últimas intervenções demonstraram que a necessidade da realização de grandes intervenções sobre o tecido existente é fundamental para a garantia de uma cidade contínua e contemporânea, atendendo as necessidades tecnológicas destes últimos dois séculos.

Como já elucidado, José Lamas chama este fenômeno de "Novo Urbanismo", capaz de gerar a transformação da cidade a partir de intervenções pontuais sobre o tecido degradado. Todavia, "o desenho urbano vai continuar as regras tradicionais de composição do espaço e de relacionamento das suas partes, ou 'elementos morfológicos.." (LAMAS 1992, p 203).

A partir do exposto acima, cabe as perguntas: Como desenhamos nossas cidades? $O$ que podemos abstrair da arquitetura e urbanismo do Movimento Moderno, vinculado às soluções dos problemas urbanísticos atuais? Os problemas de habitação econômica e os equipamentos públicos, por exemplo, ainda permanecem como as raízes dos problemas urbanísticos e sociais na maioria das cidades? E por fim, as soluções arquitetônicas e urbanísticas propostas a partir do último quarto do século XX e início do novo milênio respondem a uma forma urbana harmônica entre o desenho pré-existente e o novo tecido urbano contemporâneo?

11. Tradução do autor, 2012

Precisión a través del ejercicio disciplinado y la sensibilidad mediante el aprender a mirar, a captar cómo funciona la ciudad y cómo las personas hacen uso de ella.

12 . Tradução do autor, 2012

La ciudad es algo que debe realizarse lentamente, discutiendo y mejorando cada proyecto, pactando cada intervención, dejando que la misma dinámica de la ciudad vaya evolucionando. 
Todas estas questões devem ser compreendidas como soluções propostas e encontradas muitas vezes como objetos isolados no território das cidades. Outro fator relevante, é que na prática, tanto a arquitetura como o urbanismo, entre os dois séculos, discorrem por caminhos suficientemente distantes entre si.

Enquanto que na arquitetura, se teve um esforço maior no âmbito construtivo e formalista do que propriamente morfológico, desconsiderando por muitas vezes sua configuração na paisagem existente, já no urbanismo, exageradamente regulamentarista e desprovido de conceitos e mecanismos, sempre procurou estabelecer uma ponte entre o edifício e a configuração da cidade.

Entre os anos 70 e 80, se desencadearam várias crises de ordem econômica e social que provocaram importantes repercussões sobre o desenvolvimento das cidades. Numa breve retrospectiva conseguimos esboçar desde o final do século $X X$, estes processos de crises como que introduzindo modificações significativas sobre os modelos e as formas de afrontar o crescimento desordenado das cidades, em particular as áreas periféricas às regiões centrais, eixos e pátios ferroviários ociosos, e territórios que sofreram com os desastres naturais ou causados pelo homem, como a Segunda Grande Guerra.

O que se observa desde então, é o crescimento incontrolável sobre uma morfologia urbana nem sempre coerente, no perímetro das cidades, até como uma busca de garantir e valorizar as "ruínas", ${ }^{13}$ ou garantir o patrimônio construído nas áreas centrais que resistiram aos ataques ou desastres, além de estarem em sua maioria, vulneráveis a futuros ataques ou a demolições gratuitas das construções remanescentes.

Assim inicia-se um processo de redesenho destas cidades manifestando-se espacialmente através das intervenções de peças concretas sobre o "mosaico urbano": primeiro sobre os tecidos periféricos, e em segundo, sobre as áreas centrais devastadas e áreas ociosas.

Durante a transição entre o conservadorismo e o liberalismo, surgiram iniciativas de política urbanística que tinham a intenção de amenizar os impactos provocados pelas recessões econômicas e valorizar as peças particulares do "urban puzzle". Neste sentido, a construção de centros de arte, desenhados com uma "alta arquitetura", precedidos de vastos concursos internacionais, constituem numa iniciativa que busca reverter os impactos econômicos e sociais que se desencadearam nas cidades por conta das trocas e experiências sobre o novo modo produtivo econômico. Por outro lado, estas ações se transformaram em excelentes iniciativas de novas "tendências do urbanismo contemporâneo" que, às vezes refletidos em bons resultados e outras em soluções incompletas ou pontuais, já que pretendiam instalar-se como propostas urbanísticas que influenciassem a produção arquitetônica do espaço construído.

A segunda metade do século XX, desde a II Guerra Mundial, houve a produção de uma autentica revolução urbana. A revolução pós-industrial, baseada na multiplicação da capacidade produtiva do cidadão apoiado pela automatização e a informatização dos processos produtivos, gerou uma suposta reorganização da superfície urbana

13. Apesar da estratégia da II Guerra Mundial ser o ataque aos edifícios governamentais para destruir o governo da cidade ou estado, e grandes edifícios destinados ao abrigo e guarda dos alimentos, para enfraquecer os civis, por muitas vezes os ataques acabavam atingindo as áreas centrais e importantes patrimônios das cidades. 
construída. ${ }^{14}$ Este é um processo que está se produzindo em todo o mundo, tanto nos países em desenvolvimento, como nos já desenvolvidos economicamente.

No entanto, todo este processo de transformação pouco considerou os resultados em que a paisagem urbana chegaria tão pouco discutiu as possibilidades e as novas formas urbanas compatíveis à cidade contemporânea, gerando em muitos casos espaços desconectados entre si e um cenário interrompido entre o espaço construído existente, o novo proposto e o espaço livre gerado a partir da intervenção.

Por outro lado, as cidades se viram obrigadas a desenhar novas estratégias de intervenções urbanas que resultassem na transformação do espaço não construído e o controle do novo conjunto edilício do entorno próximo de forma harmônica, produzindo novas morfologias e uma configuração de espaços (vazios ou não) capaz em atender a dinâmica urbana, social e econômica da cidade contemporânea.

Junto a isto, as autoridades públicas iniciaram um processo de rever sua "vocação urbana" e reanalisar as estratégias econômicas e produtivas para garantir a sustentabilidade, na busca de uma nova "habilidade" urbana para a cidade.

Como ilustração, dois exemplos deste fato adotado pelas cidades devem ser levados em consideração: Bilbao que até a II Guerra Mundial era considerada como uma das mais importantes produtoras naval para toda a Europa, gerando uma mão de obra especializada e uma morfologia urbana "modelada" a este fim, em qual tecido urbano junto ao eixo do rio Nervión instalaram-se os principais estaleiros da cidade (se não da Europa), mas que foi perdendo ao longo dos anos sua dinâmica econômica resultando em espaços degradados e ociosos junto a orla deste rio. Apesar de sua valiosa localização geográfica, o governo coloca como uma das estratégias da requalificação do centro da cidade a implantação do Museu Guggenheim afirmando a potencialidade da cidade através do turismo cultural. Sob outra ótica, Dubai inverte sua lógica econômica até então gerada com a extração do petróleo, para o turismo de alta renda, atraindo um número enorme de turistas para a cidade, empresários e investidores em busca da realização de novos investimentos imobiliários.

Em contrapartida, muitas das intervenções colocadas em prática desde a década de 70 contribuiu para a consolidação de novas formas urbanas e a discussão sobre o desenho urbano contemporâneo, ajustando as necessárias transformações do espaço construído e não construído, as possibilidades de se explorar as mais avançadas tecnologias da construção e a organização de uma cultura urbana gerada a partir dos novos conceitos sociais, econômicos e de apropriação do espaço.

A apropriação desta morfologia urbana contemporânea garantiu a ampliação da dinâmica do espaço público, a renovação do tecido urbano degradado, e a garantia de valorização do patrimônio construído, apontando "tendências" da nova ocupação do solo urbano sobre o tecido existente e a consolidação de Novas Formas Urbanas.

14. As transformações no processo produtivo geraram também uma reorganização do espaço construído para adaptarse ao novo método de produção das indústrias do século XX, onde as plantas já não necessariamente justificam-se com enormes espaços e áreas de estoques, gerando espaços subutilizados em áreas centrais e nobres da cidade. 
Assim, como defendido por Lynch:

"A cidade não é apenas um objeto percebido (e talvez desfrutado) por milhões de pessoas de classes sociais e características extremamente diversas, mas também o produto de muitos construtores que, por razões próprias, nunca deixam de modificar sua estrutura" (LYNCH 2010, p 02).

A imagem da cidade é percebida, num primeiro instante, pela leitura dos cenários apresentados a quem as visita, utiliza dos espaços livres, trabalha ou habita.

Ainda em Lynch, o mesmo aponta:

"Se, em linhas gerais, ela pode ser estável por algum tempo, por outro lado está sempre se modificando nos detalhes"(2010 p 02).

Assim, a cidade obriga a cada instante estarmos atentos às transformações da paisagem urbana, as "mutações arquitetônicas" com que o desenho da cidade provoca na suas mais diversas formas.

Cidades como Berlim e Kobe, que sofreram bruscos ataques durante a II Guerra Mundial, perdendo importantes parcelas do tecido urbano em detrimento dos bombardeios, viram-se obrigadas a reconstruir bairros inteiros, centros administrativos, ou áreas portuárias destruídas pelos ataques aéreos. É evidente que as transformações tecnológicas a partir da segunda metade do século XX causaram o "engessamento" econômico e financeiro de diversas cidades que dependiam de determinados setores econômicos confirmando ainda mais a necessidade de se rever tanto sua "vocação" como a forma de tratar o desenho de sua malha urbana.

Por outro lado há cidades que se transformam continuamente como um "organismo vivo", um rizoma urbano capaz de se renovar a cada instante e instigar a mutação da paisagem como um elemento organizador passível de abstrair a forma do conjunto edilício a favor da constituição de novas formas urbanas contemporâneas.

Paris e Barcelona se enquadram como estas cidades que necessitam da renovação constante de seu tecido, tanto através do espaço construído como o não construído, tanto pelo controle de sua densidade urbana como a criação de nova centralidade capaz de suportar, numa escala urbana local, as necessidades sociais e econômicas de determinados setores da cidade.

Os Grandes Planos propostos por Haussmann e Cerdà para Paris e Barcelona, consecutivamente, foram capazes de gerar uma nova paisagem para estas cidades e influenciar por décadas, diversos urbanistas e governantes de muitas cidades europeias e até mesmo em outros continentes.

Estas cidades possuem, de maneira geral, a capacidade de explorar as imagens num primeiro instante heterogêneas, mas que no conjunto contribuem para a constante mutação urbana. "Em vez de uma única imagem abrangente para todo o ambiente, parecia haver grupos de imagens que mais ou menos se sobrepunham e se interrelacionavam" (LYNCH 2010, p 95). 


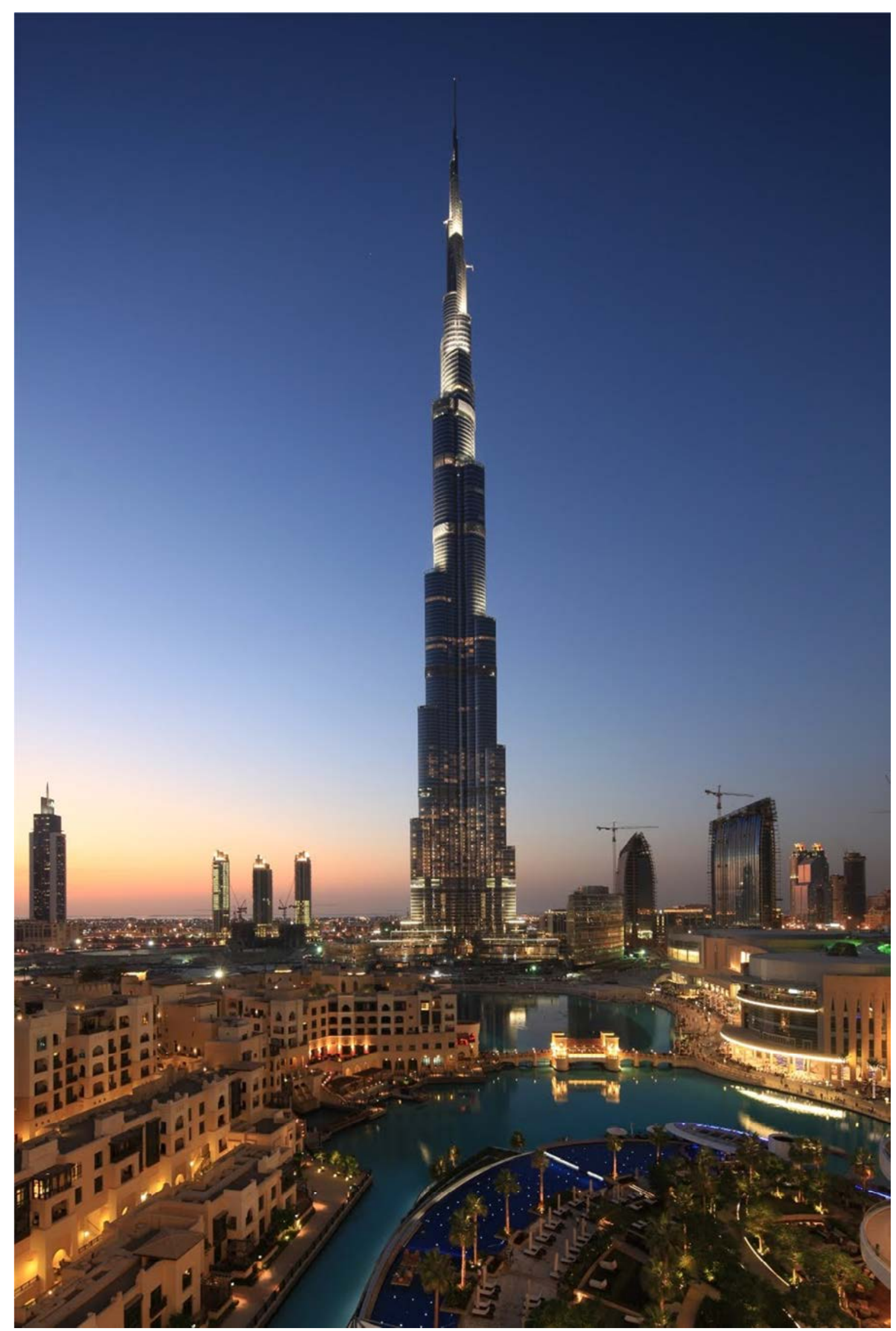

Figura 10. Vista de Dubai - Emirados Arabes, e suas obras faraônicas

Fonte: www.bubai.ae 
A composição de imagens e a transposição de cenários fazem com que ela se transforme a cada momento, a cada esquina, sob o olhar do observador ou numa veloz captura de quem esta no automóvel, ônibus ou trem. Assim, como explicitado por Lynch, estas imagens:

“(...) organizavam-se numa série de níveis aproximadamente segundo a escala da área em questão, de tal modo que, quando necessário, o observador passasse por uma imagem da rua a uma do bairro, da cidade ou da região metropolitana" (2010 p 95).

É certo que as intervenções realizadas no século XIX nestas duas cidades alteraram rapidamente sua imagem, criando símbolos identificáveis e importantes referências urbanas, e porque não afirmar, mundiais; Torre Eiffel, Teatro Ópera ou Arco do Triunfo em Paris, possuem o mesmo valor como a Sagrada Família, Casa Milá ou o Bairro Gótico em Barcelona. No entanto, o que mais surpreende é a transformação do desenho urbano propostos para estas duas cidades criando, no caso de Paris uma cidade onde a imagem mais homogênea do tecido possibilitasse o aumento da qualidade formal urbana enquanto que Barcelona recebe uma configuração urbana homogênea e contínua em sua expansão, mas com a possibilidade de uma ocupação pensada bidimensionalmente que regulasse o aumento do perímetro da cidade e futura modificação da forma de ocupação dos quarteirões.

Nota-se que estas cidades estão fadadas a constantes planos que acompanhem as transformações urbanas, como o Plano para a Grande Paris, proposto pelo então Presidente da França (2007-2012), Nicolas Sarkozy, convidando 10 famosos arquitetos para prepararem propostas para a Paris do século $21 .{ }^{15}$ Os arquitetos deveriam propor uma metrópole europeia para 2030, que passaria a ser o primeiro centro urbano a respeitar o protocolo de Kyoto; ou como no caso de Barcelona que a cada instante os Planos Urbanos e Projetos se sobressaem ao Plano de Cerdà - o Plano para os Jogos Olímpicos de 92, 22@ BCN ou Fórum 2004 revendo a cada proposta a imagem da cidade e possibilitando a criação de novos cenários para a cidade.

Outras cidades como Torino na Itália, Zaragoza na Espanha ou Bobigny na França tomaram como estratégia de renovação de seu tecido urbano desenhar trechos da cidade gerando uma nova dinâmica econômica, atraindo em sua maioria investimentos do poder privado e a transformação da paisagem melhorando a qualidade espacial, social e econômica de seus habitantes. ${ }^{16}$ Assim como bairros subutilizados que se degradaram por conta das transformações tecnológicas ou o abandono de parcela do território da cidade composto por terrenos que abrigaram grandes áreas industriais, espaços ferroviários e portuários.

15 . Entre os convidados o britânico Richard Rogers, os italianos Bernardo Secchi e Paola Vigano, o alemão Fin Geipel, os holandeses de MVRDV (Winy Maas, Jacob Van Rijs e Nathalie de Vries) e os franceses Jean Nouvel, Christian de Portzamparc, Antoine Grumbach, Roland Castro, Djamel Kouche e Yves Liot.

16. Das três cidades apontadas, a intervenção em Bobigny não utilizou de investimentos privados para a consolidação das propostas. 


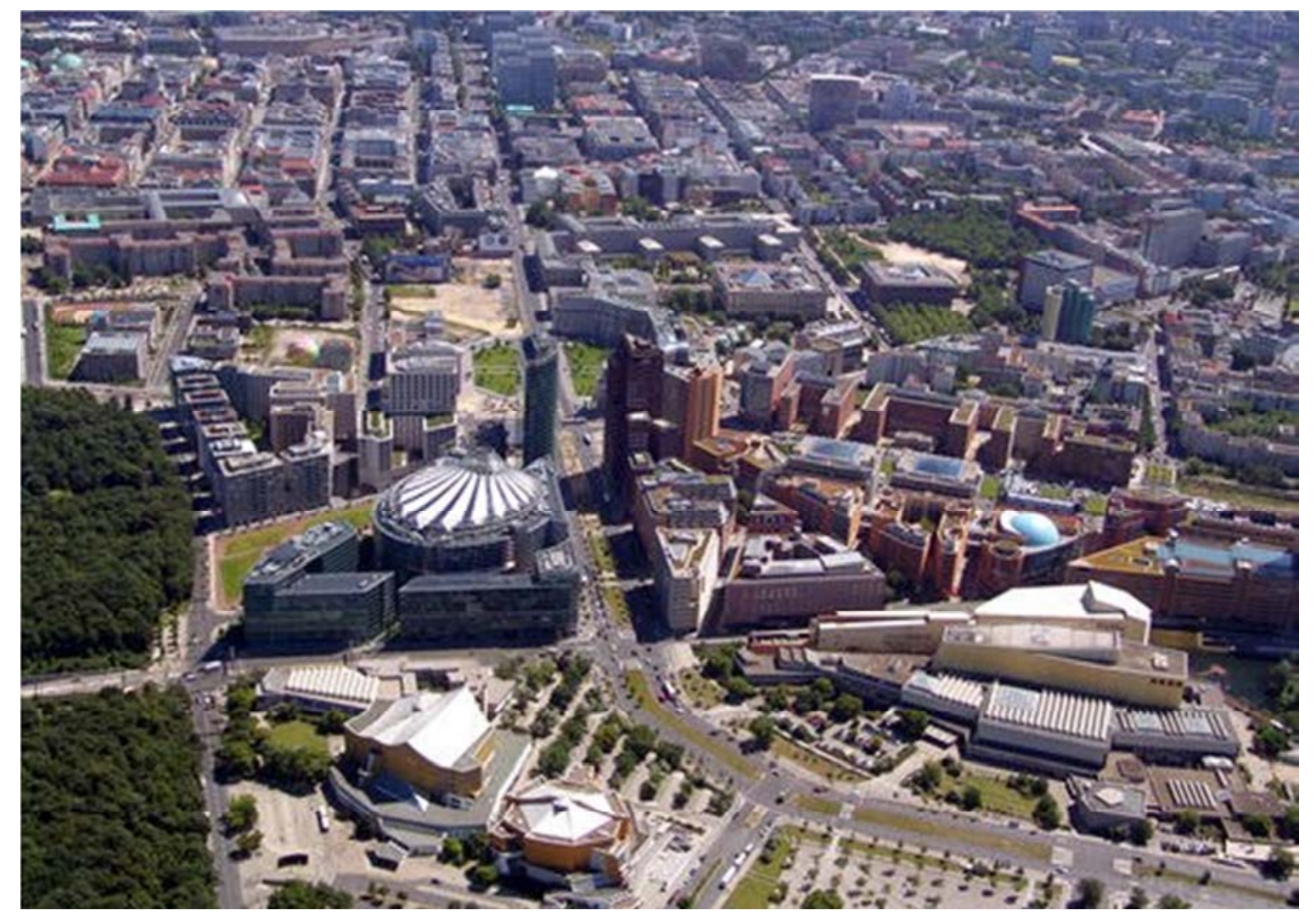

Figura 11. Potsdamer Platz - Berlim - Alemanha - projeto urbano de Renzo Piano Fonte: Renzo Piano Building Workshop

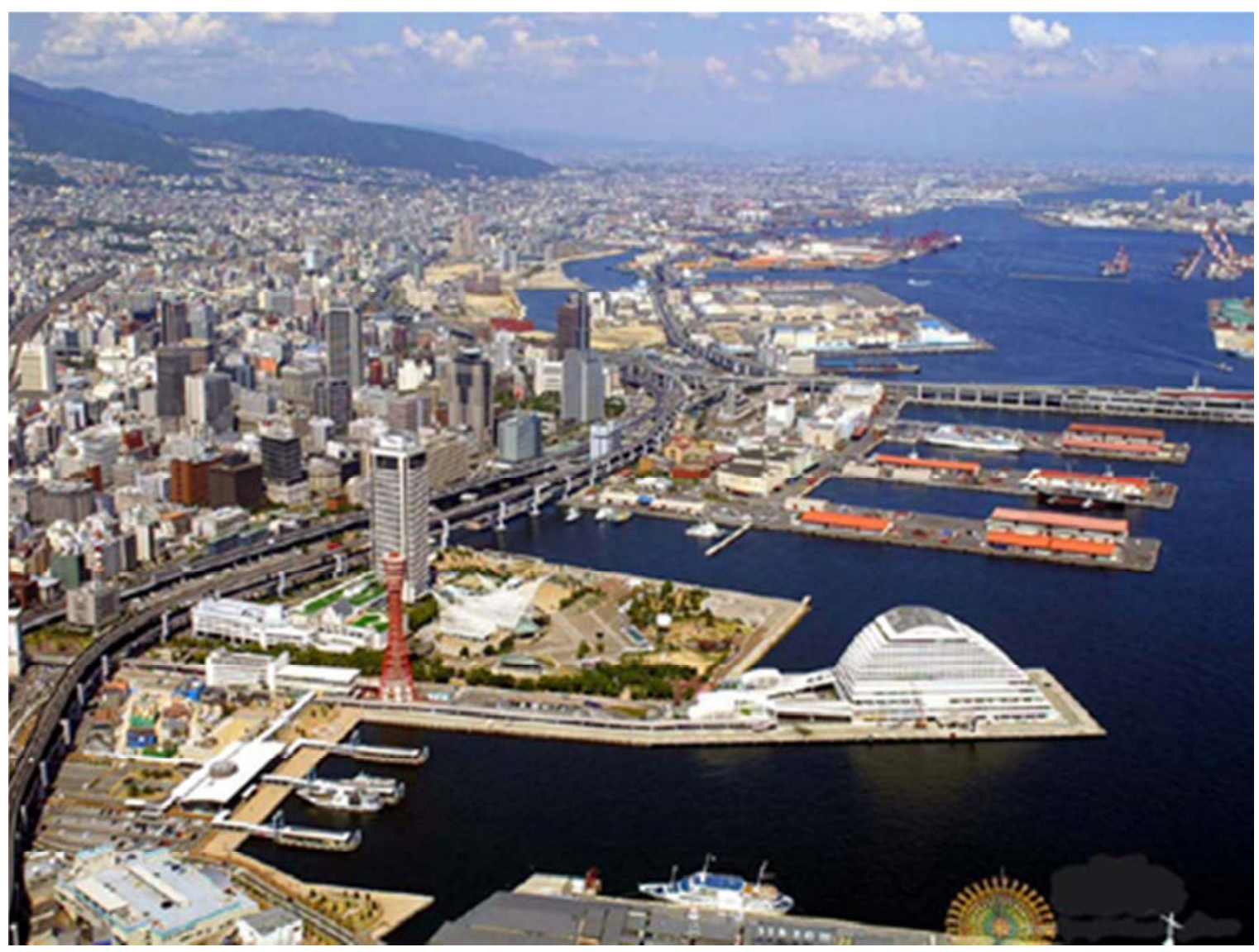

Figura 12. Kobe - Japão

Fonte: cidade de Kobe 
Neste sentido, o $13^{\circ}$ Distrito recebeu uma operação urbana com capacidade de criar um polo urbano misto ampliando a densidade fixa e flutuante deste setor da cidade, além da ligação com o rio Sena e os demais distritos, assim como a proposta de dar à cidade a possibilidade de se construir um cenário urbano compatível às atividades contemporâneas da cidade. ${ }^{17}$

Dubai nos Emirados Árabes, por outro lado, adotou estratégias de gestão e de construção da paisagem como instrumento de atração ao turística de alto padrão, colocando a imagem da cidade em todo o circuito das cidades mais visitadas do mundo. Mas toda esta estratégia tem seu preço, em que a paisagem construída ainda mantém uma linguagem heterogênea, resultando num desenho urbano complexo e ao mesmo tempo conflituoso visualmente, em que cada edifício compete entre si na busca de sobressair na paisagem, mas sem qualquer preocupação com a composição dos cenários urbanos.

No entanto, estas intervenções levam a alguns questionamentos ligados diretamente a concepção e construção dos cenários urbanos e a imagem da cidade.

"A arquitetura deve ser concebida como uma configuração de lugares intermediários claramente definidos. Isso não implica uma transição continua ou um adiamento sine die no que diz respeito a lugar e ocasião. Pelo contrário, subentende um afastamento do conceito contemporâneo (vamos chamá-lo de moléstia) de continuidade espacial e a tendência para apagar toda e qualquer articulação entre espaços, isto é, entre exterior e interior, entre um espaço e outro (entre uma realidade e outra). Em vez disso, a transição deve ser articulada por meio de lugares intermediários definidos que introduzem à percepção simultânea do que é significativo de uma lado e do outro. Nesse sentido, um espaço intermediário fornece o terreno comum onde as polaridades conflitantes podem tornar-se de novo fenômenos gêmeos." (Aldo van Eyck in VENTURI 1995, p 111).

A presença destes Grandes Projetos Urbanos (GPU) torna-se elemento fundamental para uma leitura analítica sobre o desenho da cidade contemporânea, sua nova configuração urbana e em especial os resultados sobre a paisagem, tendo como resultado, segundo nossas pesquisas, os seguintes fatores:

1. Os GPUs utilizam, em sua maioria, a estratégia econômica e financeira como elemento chave para sua consolidação e sucesso global;

2. De maneira geral, os GPUs são desenhados desassociados dos projetos arquitetônicos, perdendo o controle da forma urbana proposta pelos responsáveis urbanísticos;

3. Em detrimento de se criar um plano urbanístico que garanta a sustentabilidade econômica à área de intervenção, a construção das formas urbanas (imagem da cidade) ficam à mercê da especulação imobiliária que, em sua maioria, tem como visão unitária uma maior exploração do solo ao menor preço;

17 . Entende-se que a proposta da Biblioteca Nacional de Paris, projeto do arquiteto Dominique Perrault, foi o ator principal da transformação desta paisagem. 
Figura 13. Vista aérea de Barcelona - Espanha

fonte: Elvis Vieira, 2009

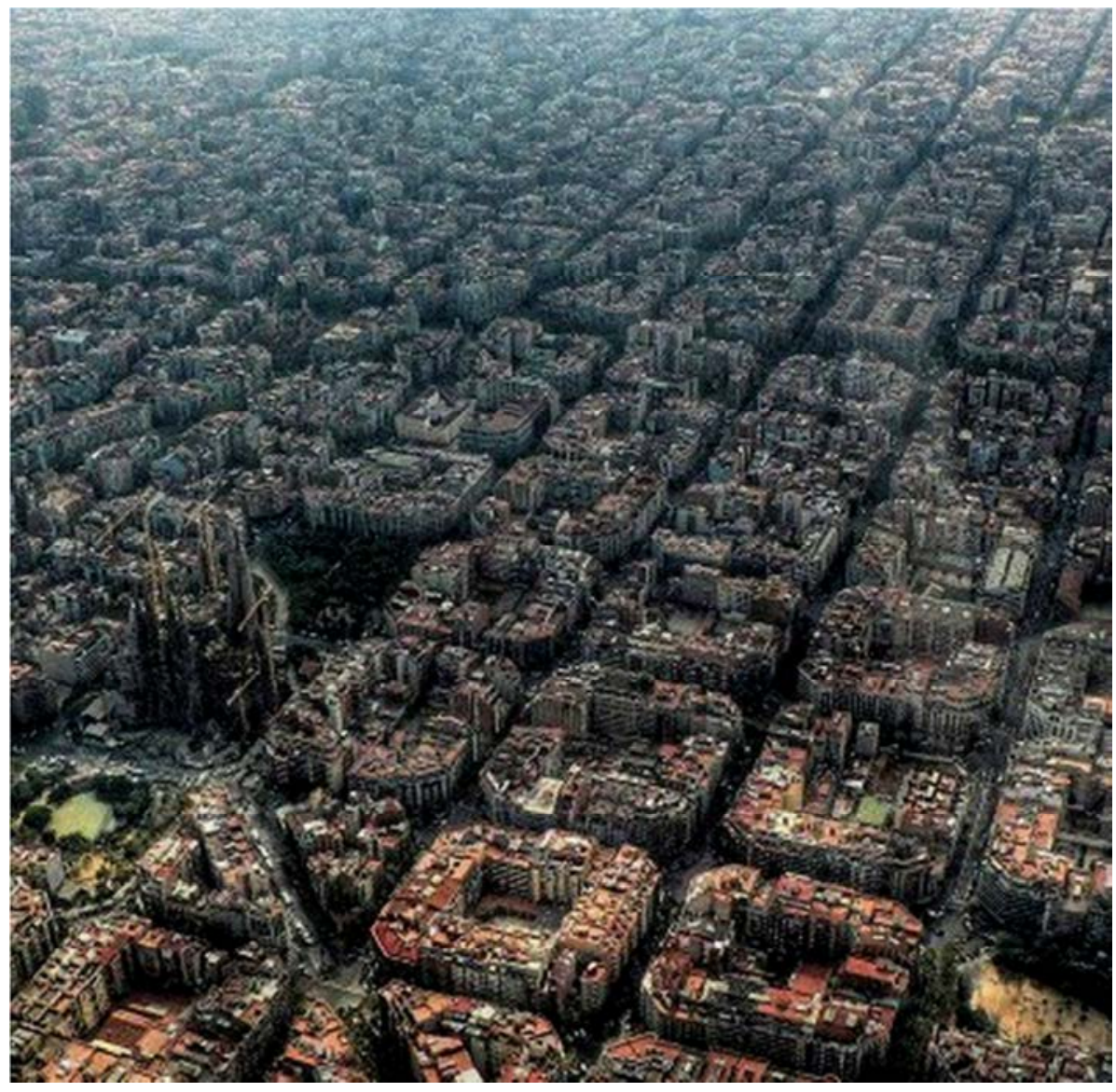

Figura 14. Vista de Paris - França Fonte: Cidade de Paris

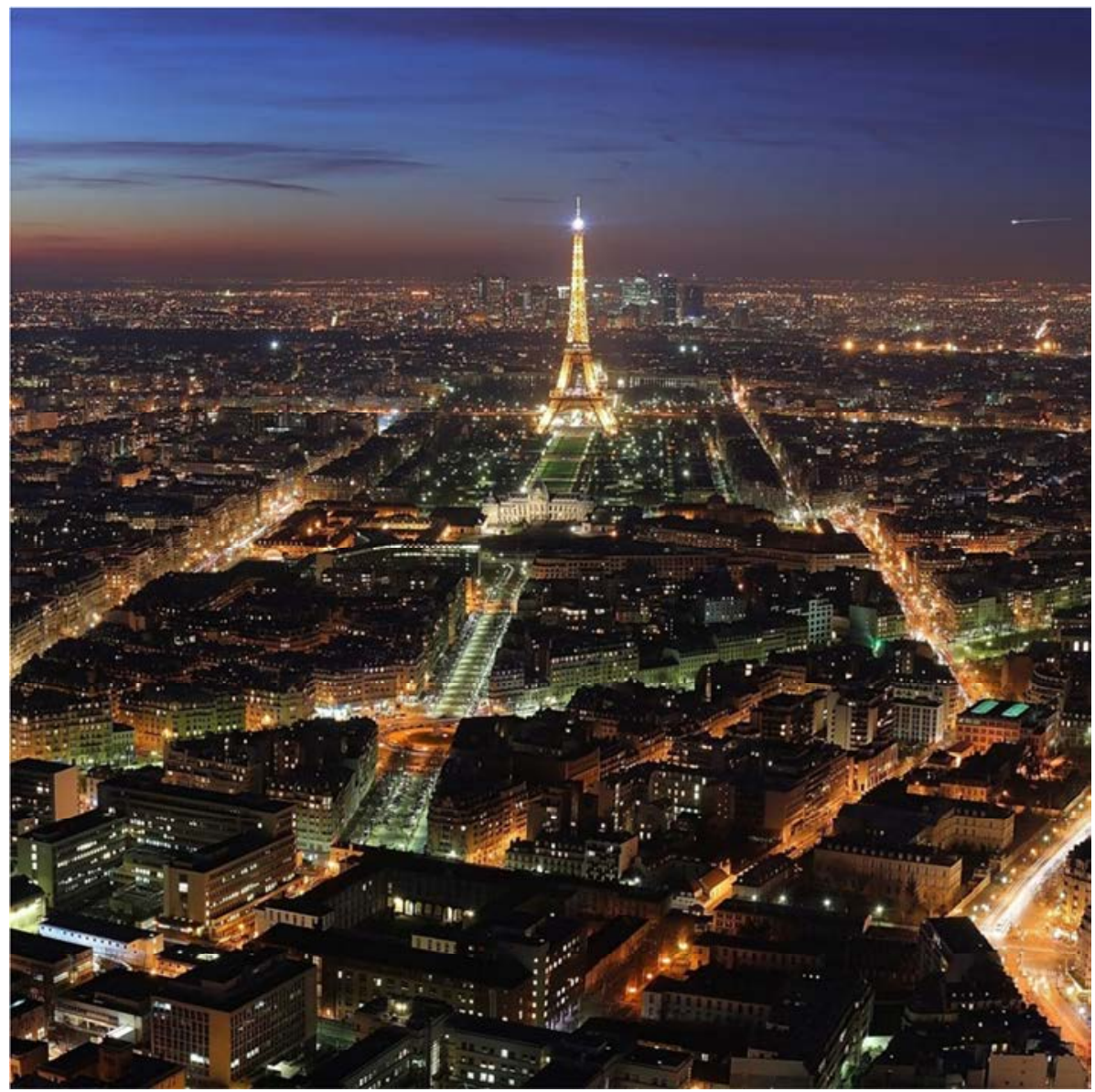


4. As intervenções ligadas aos grandes eventos e exposições exploram a construção de um cenário lúdico capaz de atrair a curiosidade e "admiração" de seus visitantes, mas que resultam após a realização destes, num "cenário desconexo" da cidade existente ou num conjunto de edificações heterogêneas sem comunicação na paisagem.

A partir destes fatos, podemos afirmar que, mesmo de forma preliminar, os Grandes Projetos Urbanos que vislumbram melhorar a qualidade de vida de seus habitantes e determinar uma nova visão para o futuro da cidade, mesmo que os investimentos sejam providos não somente de organismos públicos, mas numa parceria mútua com o poder privado para garantir sua aplicabilidade ao longo dos anos e tendo como estratégia as diversas escalas possíveis de intervenção, caracterizado por uma concepção global, uma ação integral e coordenada, alcançam resultados mais concretos e coerentes em relação ao desenho da cidade, favorecido muitas vezes, pela experiência de ensaiar Novas Formas Urbanas.

É neste espírito que a tese se estrutura: o tema do presente doutorado é a relação entre os Grandes Projetos Urbanos e a Forma Urbana Contemporânea. Os Grandes Projetos Urbanos sob a ótica de entendê-los como ferramentas em busca da transformação de trechos da cidade e de seu tecido urbano degradado e/ou ociosos, no mesmo caminho e raciocínio, possibilitando identificar os nexos históricos e as mudanças das bases socioeconômicas e tecnológicas, com a finalidade (no caso dos projetos) de compreender a atual situação que em sua maioria as cidades pós-fordistas passam e os resultados espaciais alcançados apartir da leitura da Morfologia Urbana Contemporânea.

Cada cidade a ser estudada deverá ser entendida, inicialmente como objetos empíricos analisados individualmente na intenção de compreender os fatores que levaram as transformações urbanas, ${ }^{18}$ as propostas de intervenções urbanas, a aplicabilidade e os resultados alcançados com o novo desenho urbano proposto. Num segundo momento estes objetos deverão ser classificados e agrupados de forma a confrontá-los e compreendê-los num mesmo "nível de intervenção".

Por fim, esta pesquisa se coloca como elemento de análise dos resultados físicos alcançados após as intervenções urbanas nas cidades estudadas. A construção de "Novas Formas Urbanas" para resultar na qualidade de vida aos habitantes e usuários destes espaços, sejam eles públicos privados ou de uso controlado.

18. Estas transformações podem ser provenientes de diversos fatores, como econômicos, sociais, planejamento urbano inadequado, destruição devido a II Guerra Mundial ou a necessidade de atualizar seu tecido em função das novas tecnologias. 


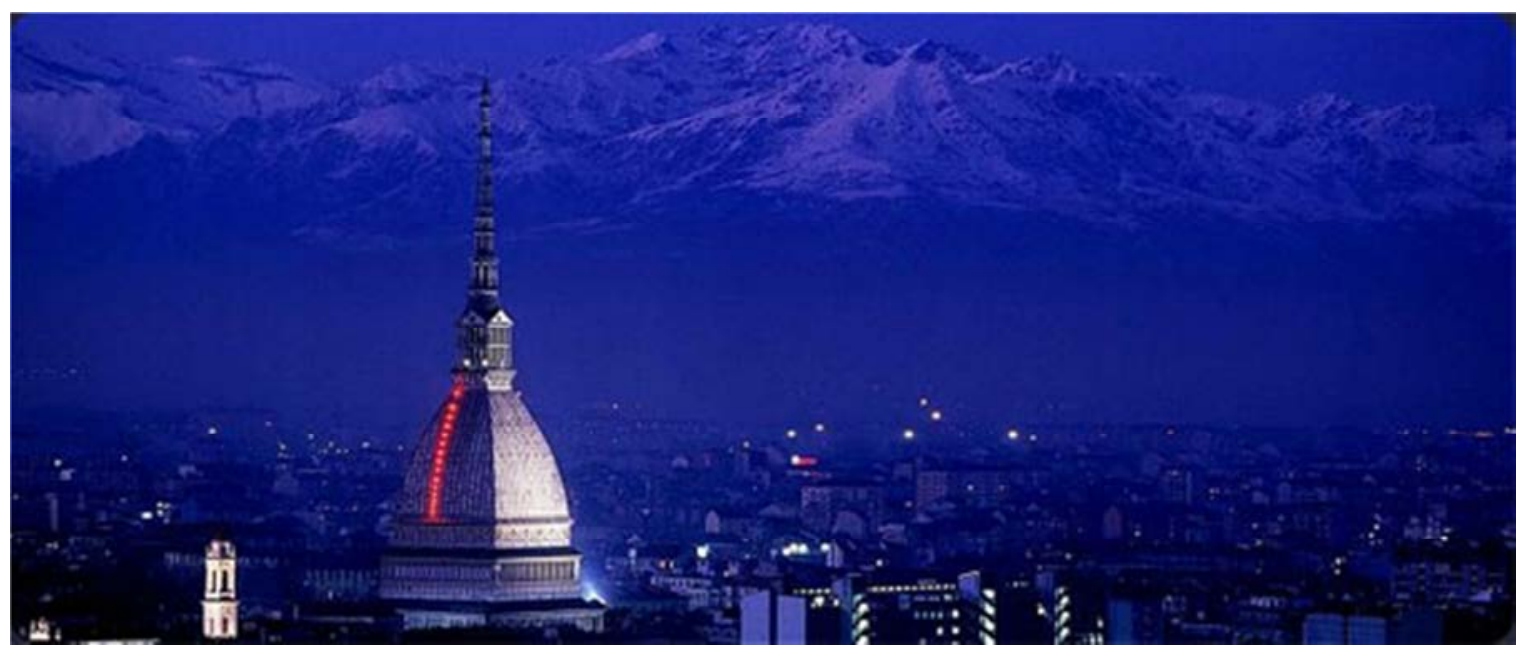

Figura 15. Vista de Torino: em primeiro plano Museu da Televisão e ao fundo os Alpes Suiços Fonte: Città di Torino

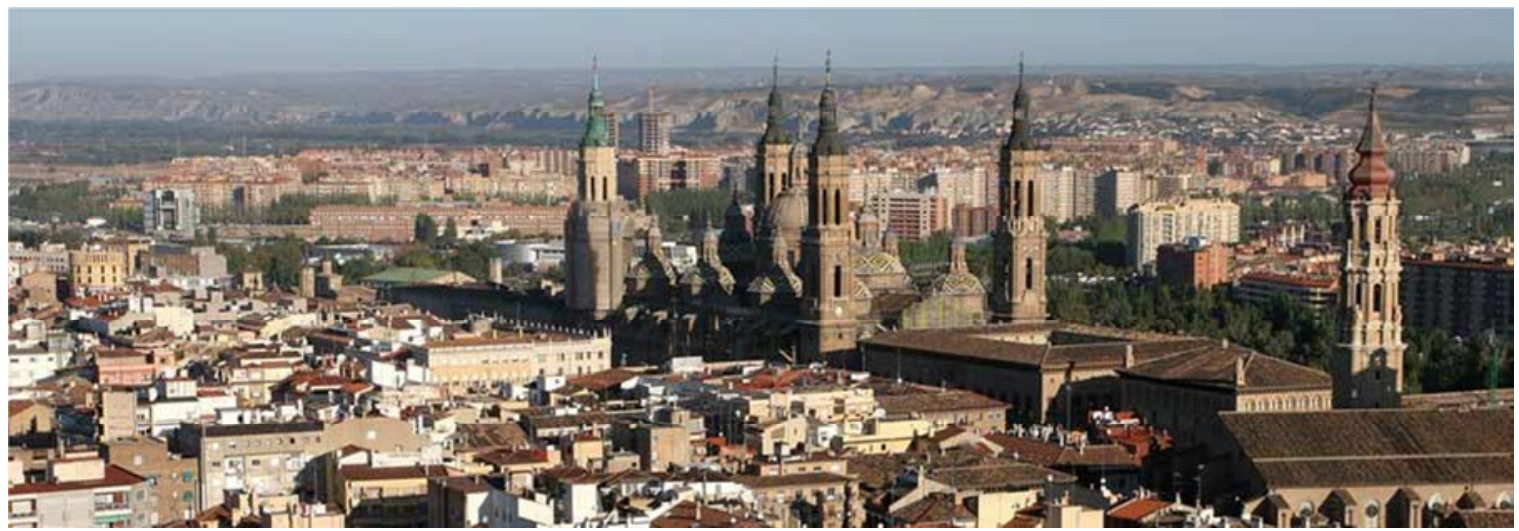

Figura 16. Zaragoza - Espanha: vista para a Catedral do Pilar

Foto: Elvis Vieira, 2009

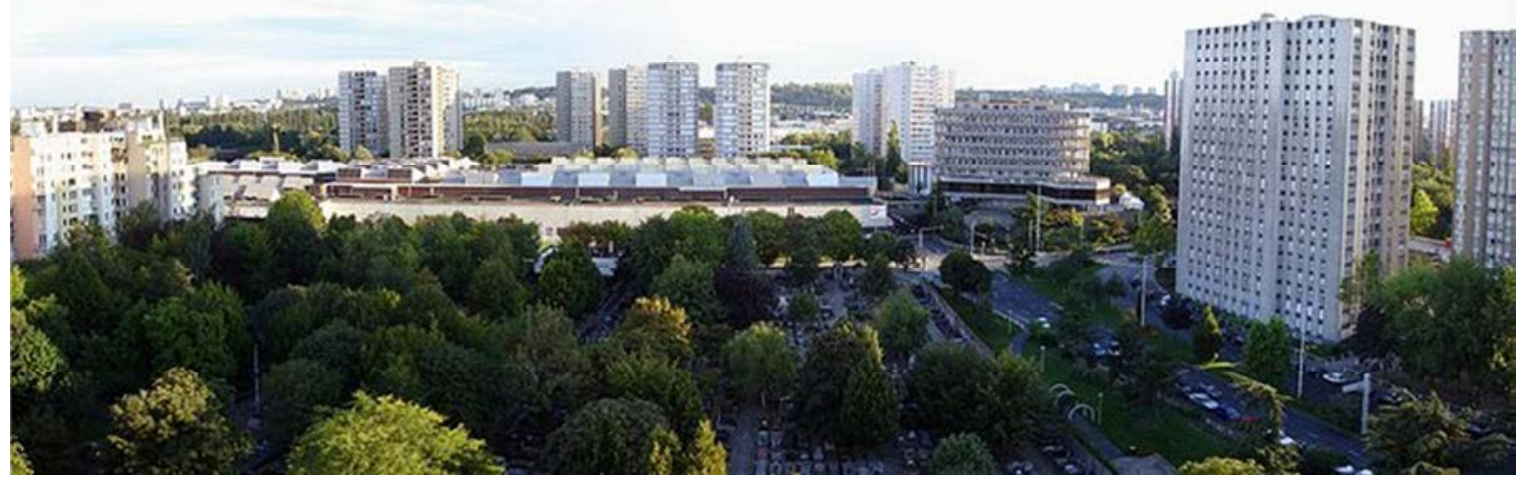

Figura 17. Vista para o Centro Administrativo de Bobigny - França

Foto: Elvis Vieira, 2006 
O objetivo do trabalho foi reunir, analisar e averiguar a partir de dados concretos e pesquisa em campo, como "Construção de Repertório Urbano", que sirvam de exemplos e instrumentos de avaliação e subsídios, da mesma forma que indicar possibilidades para a reflexão e aplicabilidade (com sua devida escala e similaridade) sobre o objeto de estudo - Operação Urbana Orla Ferroviária de Suzano, que desde 2005 é colocada em prática pelo poder público como forma de requalificar e reabilitar um conjunto de espaços públicos e privados, construídos ou vazios, sob uma nova ordem, a possibilidade de reorganizar o tecido urbano degradado e ocioso desde a década de 1980. Território privilegiado urbanística e economicamente por tratar-se de uma das "Portas de Entrada"; é por este eixo que se chega ou saí da cidade, é esta "porta" que conecta a cidade as demais da Região do Alto Tietê e com a capital paulista (São Paulo). Ao mesmo tempo, este território ainda concentra um significativo número de comércio e prestadores de serviços que atraem diariamente consumidores e compradores de toda a região, impulsionando ainda mais a economia da cidade.

Tendo em vista o caráter processual do objeto de estudo como ambiente constantemente mutável, suas transformações em períodos temporais nem sempre concomitante as intervenções urbanas, e entendendo que o "abandono" das estruturas existentes e os grandes equipamentos de mobilidade urbana (local, regional e metropolitano) contribuíram para o declínio econômico deste trecho da cidade, em especial as primeiras quadras próximo à estação ferroviária e ao "terminal urbano", gerando vazios urbanos e mesmo construídos sem qualquer valor paisagístico, tão pouco de mercado, configurando este território num eixo linear desconexo da dinâmica econômica do centro urbano e expulsando gradativamente o interesse por moradias e investidores privados, influenciando significativamente no funcionamento da cidade e seus atributos funcionais do lugar.

Tal objetivo foi motivado pelahipótese que atribui aos Grandes Projetos Urbanos o caráter de "peças urbanas" (MONTANER 2008) capaz de regenerar o tecido urbano e trazer soluções morfológicas mais adequadas aos problemas encontrados nas cidades contemporâneas. Como delineado por Pedro Sales:

“(...) o tema dos projetos de transformação de antigas áreas portuárias, bem como ferroviárias e industriais, tornadas obsoletas ou subutilizadas pelos processos de inovações nas tecnologias de transporte ou de produção, têm sido, desde pelo menos os meados da década de 80 uma das principais pautas do urbanismo contemporâneo. (...) o esvaziamento dessas áreas, (...), iria propiciar verdadeiras 'oportunidades' para a atualização e revalorização da cidade contemporânea” (SALES 1999, p 3 - grifo nosso).

Assim a tese que se defende consolida-se na averiguação e confirmação da importância dos Grandes Projetos Urbanos como instrumentos de desenho urbano capaz de regenerar o tecido urbano ocioso e degradado, transformando sua forma urbana e reconstruindo trechos da cidade sob uma nova dinâmica urbana, econômica e social, gerando espaços mais qualificados e integrados a nova cultura urbana, cidades mais justas, igualitárias e, agora, na escala do homem, onde o espaço público recebe maior potencial em função de sua imponência junto ao desafio que se coloca nas últimas décadas as cidades contemporâneas. 
Esta hipótese é reforçada pelas análises dos GPUs selecionados para construir o arcabouço teórico desta tese, levando em consideração não somente a apresentação dos conceitos e propostas urbanas colocadas em pauta pelos autores e/ou entidades responsáveis (públicas e privadas), mas sua aplicabilidade durante a consolidação das obras e o processo de "ajustes" ao tecido urbano existente e suas estruturas urbanas. Esta investigação procura, a partir dos estudos e análises dos Grandes Projetos Urbanos e a leitura do território (in loco) das áreas de estudo, averiguar as interferências sobre o espaço proposto e suas consequências urbanas (formas urbanas), econômicas e sociais (gentrificação).

Sob este aspecto, no que diz respeito aos objetos selecionados como "estudos de caso", levamos em consideração a contribuição destes objetos à hipótese levantada, no qual os GPUs apontados deveriam fornecer um conjunto de elementos que subsidiasse a análise final do "objeto de estudo" e promovesse as reflexões sobre o tema levantado - Novas Formas Urbanas na Cidade Contemporânea. Nisto, foram eleitos três cidades como referência e quatro Grandes Projetos Urbanos como elementos de análise direta: 1) Barcelona - Projeto 22@ BCN e La Sagrera, no qual cada projeto possui suas particularidades e estratégias desenhadas para a regeneração do território degradado e ocioso, ora pela regeneração do tecido urbano apartir da reorganização de sua dinâmica econômica e social, ora pelas possibilidades das "costuras" e rompimento das fraturas urbanas existentes entre dois bairros da cidade; 2) Paris - ZAC Paris Rive Gauche,

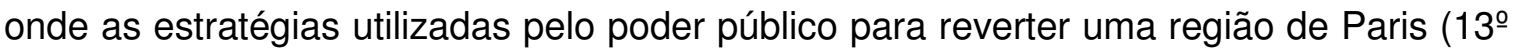
distrito) até então considerada como a "desordem urbana" posta pela degradação urbana, violência e "descaso social"; 3) Torino - PEC Spina 2 - Porta Susa, numa proposta de reconversão de um grande eixo ferroviário desativado com a consolidação de uma Nova Centralidade junto ao centro histórico da cidade. As três cidades foram acompanhadas desde 2005 através das continuas visitas "in loco" com o intuito de melhor compreender a execução dos projetos e os resultados alcançados entre a proposta e a cidade real.

A pesquisa desenvolvida na tese (estudos de caso) e motivada pela hipótese deu-se, em grande parte pela observação destes GPUs, mas também as questões, conceitos, teorias e enfrentamentos no trabalho cotidiano, profissional e acadêmico.

Como acadêmico, deve-se destacar a relevância das disciplinas cursadas durante os dois semestres de 2010, contribuindo para as primeiras reflexões sobre o tema da tese e sua hipótese (AUP 5846 Projeto de Arquitetura Urbana e AUP 5827 - O Projeto como Pesquisa Contemporânea em Arquitetura), possibilitando construir um método de estudo e análise da produção arquitetônica e seus resultados sobre o desenho da cidade. A participação nos seminários e congressos, assim como os artigos publicados em web sites e revistas especializadas, provocaram a cada momento abrir as discussões e análises sobre o tema da tese: I ENANPARC - Encontro Nacional da Associação de Pesquisa e Pós-graduação em Arquitetura e Urbanismo (Rio de Janeiro, 2010), IX Seminario de Investigación Urbana y Regional (Bogotá - Colômbia, 2010), PNUM - Rede Portuguesa de Morfologia Urbana (Lisboa - Portugal, 2012); e os artigos publicados na revista virtual Contemporaneu (Grandes Projetos Urbanos e a Cidade Contemporânea, fev. 2011 e Barcelona e o Legado dos Grandes Projetos Urbanos, abr. 2011); eno web site ArchDaily (Arquitetura Vivenciada: O Sheraton Abandoibarra Hotel de Ricardo Legorreta, 2012). 
Paralelamente a pós-graduação e eventos (seminários e congressos), as atividades como docente nas Faculdades de Arquitetura e Urbanismo das Universidades Braz Cubas (desde 2000) e Mogi das Cruzes (desde 2005) nas disciplinas de Projeto de Urbanismo e na orientação de TFG (trabalho final de graduação), assim com o desenvolvimento e orientação no Programa de Iniciação Cientifica (FAUUMC - 20082011, FAUBC - 2011-2012) com o grupo de pesquisas sobre Grandes Projetos Urbanos na América Central e Latina trouxeram a tona novas indagações teóricas sobre o tema, motivando a elaboração de muitas análises desenvolvidas nesta tese.

Como arquiteto e urbanista, as experiências colocadas em prática desde 2005 na Prefeitura Municipal de Suzano - SP, inicialmente como Secretário Adjunto de Política Urbana (2005-2006) e posteriormente como Diretor de Projetos Públicos (2007 até o momento), em especial sobre as propostas dos Grandes Projetos Urbanos para a cidade, utilizados como "Laboratório Urbano", consolidaram conhecimentos e ensaios urbanos constituindo importante repertório para o percurso da investigação; e é destas experiências que se configura o "objeto de estudo", a Operação Urbana Orla Ferroviária, iniciada em 2005 com a assinatura do convênio entre o poder público municipal e o governo do estado em prol da requalificação do eixo ferroviário e áreas lindeiras da estação de trem.

O objeto foi estudado e analisado a partir de dados concretos e pesquisa em campo (neste momento como objeto empírico e livre dos "olhares" do gestor público) averiguando os resultados alcançados (mesmo que ainda não concluído) e suas interferências entre a Nova Forma Urbana e o tecido existente; da mesma forma com as transformações dos espaços construídos, ou privados, provocados pelas intervenções sobre o espaço não construído e os grandes equipamentos de transportes (local, regional, metropolitano), tanto em seu perímetro estudado como as áreas indiretas (entorno).

Neste raciocínio, a Primeira Parte: Análise da Cidade Contemporânea (Capítulo 1), procura construir um conjunto de conceitos, de forma empírica, sobre a morfologia urbana e a cidade contemporânea, no qual os estudos dos pesquisadores sobre a forma urbana, suas teorias e conceitos, configuram o arcabouço teórico para a consolidação de um suporte teórico, e prático, a partir da análise dos elementos morfológicos sobre os estudos de caso e posteriormente, o objeto de estudo. As indagações colocadas neste capítulo se estruturam sobre os teóricos e estudiosos da forma urbana e as experiências colocadas em prática na academia.

Como meio de construir as análises sobre as intervenções urbanas e suas interferências sobre a forma urbana, a Segunda Parte: Grandes Projetos Urbanos na Cidade Contemporânea (Capítulo 2 - Barcelona, Capítulo 3 - Paris, Capítulo 4 - Torino) toma como parâmetro a seleção e definição dos "projetos estudo de caso",obedecendo alguns critérios de ordem conceitual e prática, visando construir em função do processo de conhecimento e descobertas sobre os "objetos empíricos", ferramentas de análises para o objeto de estudo. Os GPUs selecionados, em sua essência, sejam como conceitos, partido urbanístico ou estratégia utilizada, consolidam as "confirmações" de nossa hipótese defendida nesta tese, da mesma forma que sua similaridade quanto à temática das intervenções ou estado das áreas de intervenção com o objeto de estudo, configuram importante objeto de "checagem" entre os objetos estudados e o de análise urbana. 
A Terceira Parte:Suzano e a Construção de um Novo Território Urbano (Capítulos 5, 6, $7,8)$ é dedicada ao estudo e análise do objeto de estudo - Operação Urbana Orla Ferroviária de Suzano e sua Área de Intervenção Urbana - AIU, aplicando os conceitos e métodos de análise da forma urbana, estabelecendo uma correlação entre as teorias estudadas (morfologia urbana) e estratégias urbanas (estudos de caso), consolidando um conjunto de elementos que interferem sobre a forma urbana como indutores da requalificação urbana da área em estudo. Da mesma forma, as análises estabelecidas sobre o objeto de estudo configura-se como "Laboratório Urbano" aplicável ao território real e agenciado pelo poder público, ainda que não concluída as intervenções urbanas previstas, mas com obras em andamento desde o início das propostas (2005), possibilitam a avaliação e consolidação de nossa tese e hipótese levada a cabo.

No que diz respeito às considerações finais desta tese, induzida pela hipótese apresentada, aQuarta Parte: Conclusões: territórios experimentais e a construção de novas formas urbanas (Capítulo 9)apresenta uma sistematização das idéias a partir da fundamentação, comprovação e conclusão de nossa hipótese, averiguando os resultados alcançados e sua relevância quanto ao tema abordado nesta tese. As conclusões refletem o caminho trilhado pelo pesquisador ao longo dos estudos e análises dos projetos-referência (estudo de caso) e o objeto de estudo - Operação Urbana Orla Ferroviária, como as experiências urbanas colocadas em prática (Laboratório Urbano) durante o período de implementação do Grande Projeto Urbano para Suzano, assim como os resultados alcançados até então, como gestor público coresponsável pelo desenvolvimento e acompanhamento das propostas das intervenções urbanas. 


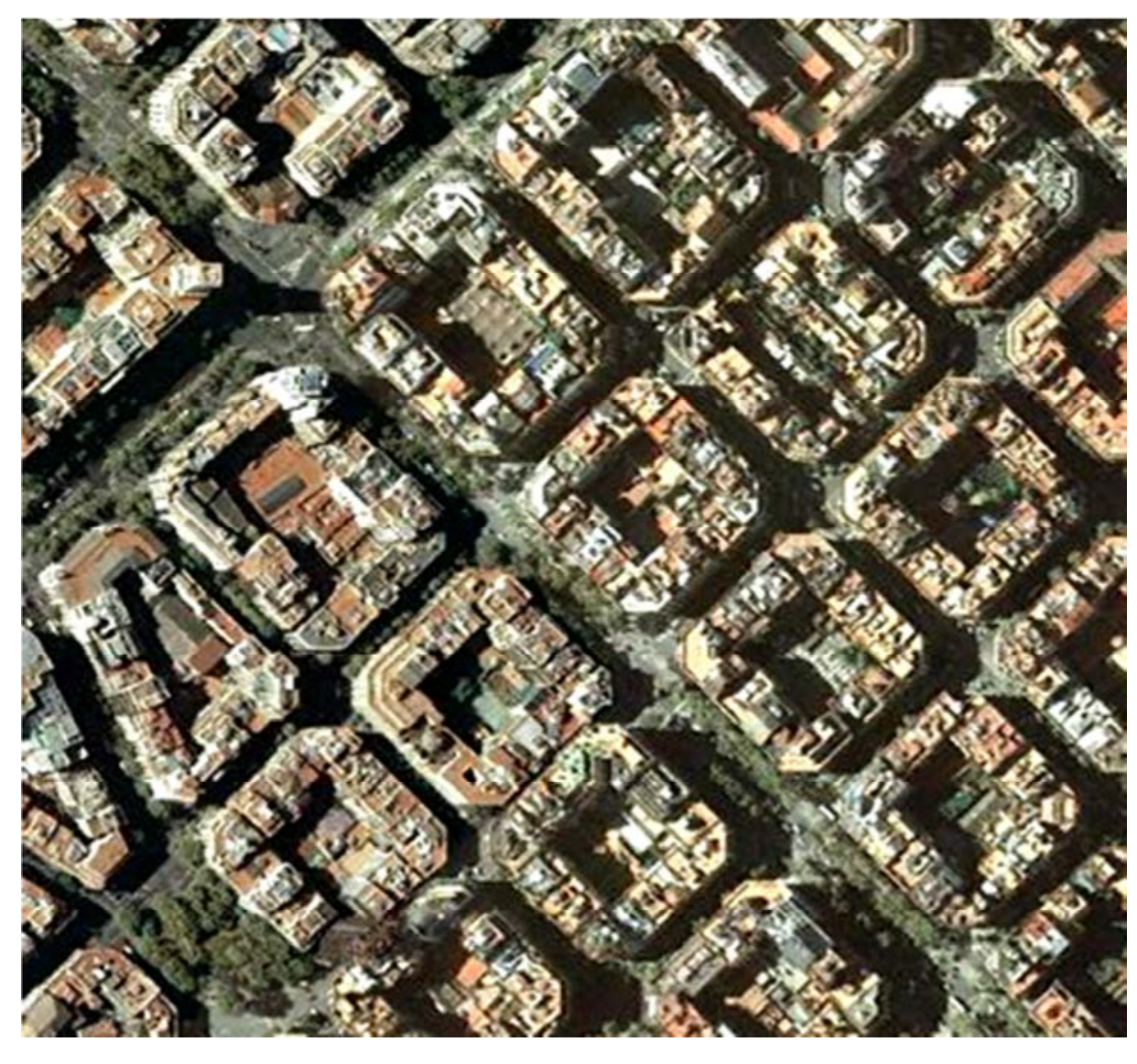

PARTE I

\section{ANÁLISE DA CIDADE CONTEMPORÂNEA}





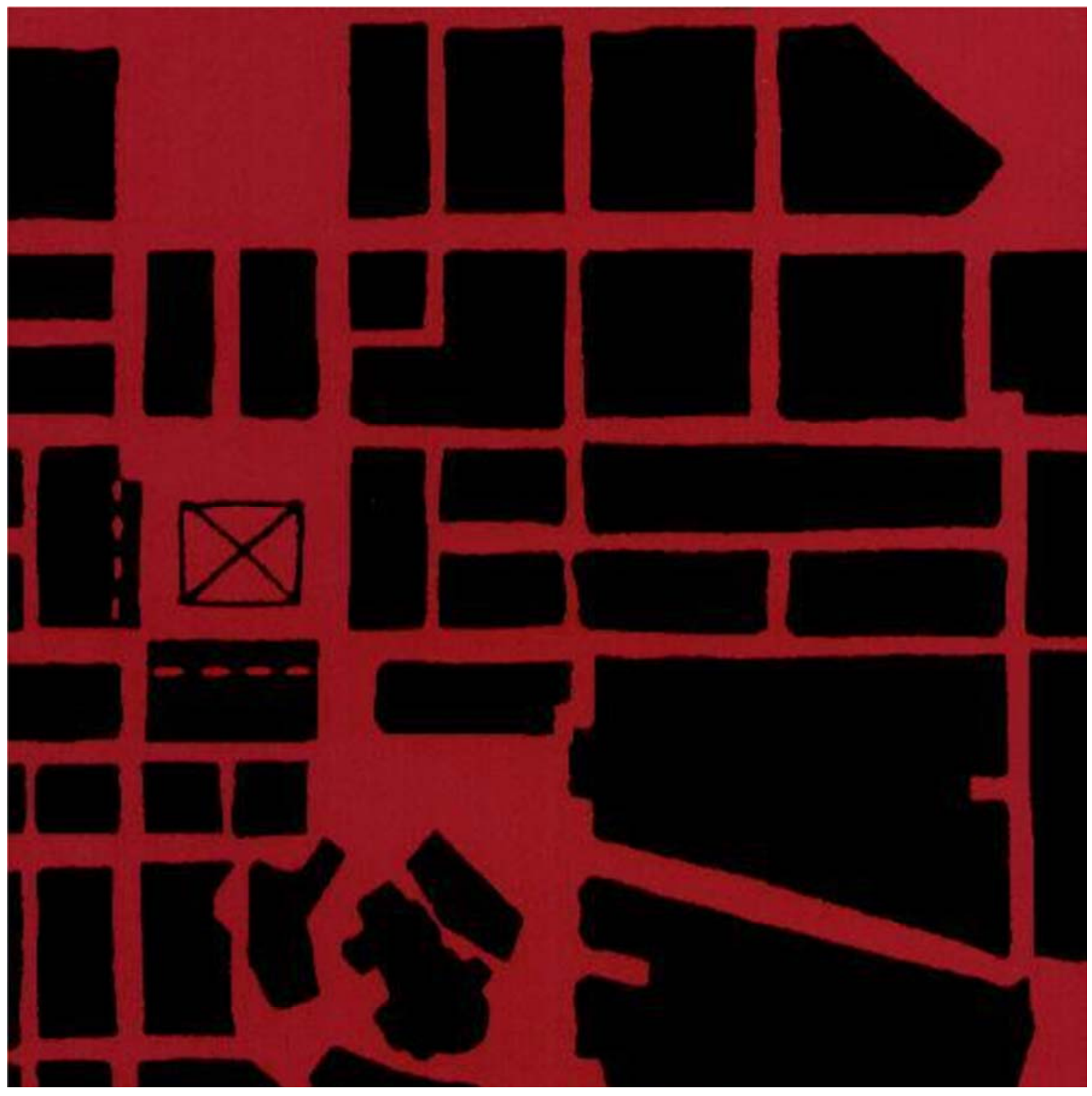

Capítulo 1 Morfologia Urbana como Método de Análise da Cidade Contemporânea 



\subsection{Morfologia Urbana | Pressupostos}

A morfologia urbana tem sido objeto de diferentes abordagens desenvolvidas por pesquisadores provenientes de diferentes disciplinas e com objetivos também adversos ao desenho da cidade e o resultado que os elementos urbanos podem causar sobre 0 tecido urbano e sua conformação paisagística. Aspectos de percepção visual ou possíveis leituras cartográficas, aparentemente mais técnicas, ou ainda em outrora a interpretação do desenvolvimento histórico de determinado território condiciona a uma enorme gama de olhares diversos e sugestivos a concepção de uma metodologia a ser aplicada na leitura e análise da forma e morfologia urbana de uma área de intervenção. $^{19}$

"As cidades vêm sofrendo bruscas transformações em detrimento de uma diversidade de influências, hábitos e comportamentos, redefinindo a forma de compreendê-la e concebê-la."(VIEIRA 2011)

A partir deste pressuposto podemos afiirmar que tais transformações vão gerar, em especial, a mudança de dois elementos urbanos: os espaços construídos (edifícios) e espaços não construídos (áreas livres, praças, sistema de viário etc); Por outro lado, a percepção, o reconhecimento, o sentido de direção e orientação espacial que o transeunte (pedestre) possui da cidade está diretamente relacionada à sua escala (escala humana) e o conjunto entre os dois espaços (construído e não-construído). Esta imagem do espaço urbano é fundamental na definição da relação que cada ser humano tem com o meio que o rodeia. Assim, o espaço urbano torna-se por excelência 0 "espaço de exercício do direito de cidadania", espaço em que vive cada dia, em que a cada instante é dominado por suas percepções e que cria e recria memórias de acordo com as imagens gravadas e guardadas no fundo de cada um.

"No ritmo de suas metamorfoses, a cidade é sempre o território da contingência absoluta. Não somente nela tudo é possível, mas, mais ainda, o possível está fundamentalmente ligado à emergência constante do casual. O que a cidade oferece a qualquer percepção é o próprio fato dessa relação indestrinçável, implícita, entre o tempo e a contingência. Na infinidade cotidiana de nossas apreensões e de nossas percepções, durante o mais corriqueiro dos deslocamentos ou do andar sem rumo pela cidade, o que pode simultaneamente ser ou não ser continua sendo o possível da visualização. Não se trata mais da abordagem 'sensível' da cidade, encenada por uma certa fenomenologia da vida urbana, mas de uma confrontação, feliz ou infeliz, com a irrupção da contingência." (JEUDY 2005, p 108)

Nisto, o espaço urbano apresenta-se como resultado de uma composição que se altera na medida em que é observada (sentida) no movimento de cada pessoa (a pé, bicicleta, automóvel, ônibus, trem, barco, avião...) percorrendo o olhar sobre o espaço "estático", porém podemos afirmar que o espaço, ou melhor, as formas urbanas, são mutantes à medida que são transformados, ora pela destruição (guerras, ataques), pelas catástrofes naturais (terremotos, maremotos), pela saturação do território (econômica, social), ora fruto de grandes intervenções urbanas, em busca de uma nova dinâmica urbana, social ou econômica das cidades. Em sua maioria, tais intervenções têm por

19 . Neste momento, a construção de uma metodologia para a leitura e análise do objeto de estudo será importante para garantir os resultados a serem alcançados e possibilitar uma melhor reflexão sobre as hipóteses levantadas nesta tese. 
pressuposto a renovação da "imagem da cidade", tendo como ferramenta a transformação de sua morfologia urbana.

Do ponto de vista urbanístico, a morfologia urbana ${ }^{20}$ pode ser definida como o estudo da forma urbana ou o estudo dos aspectos exteriores ao meio urbano, por meio do qual se coloca em evidência a paisagem e sua estrutura (LAMAS 1992, p 37). Em seu livro publicado no início dos anos 90, José Lamas propõe um novo olhar ao que ele denomina de Novo Urbanismo que deve ser estudado a partir da análise dos elementos morfológicos: "unidades ou partes físicas que, associadas e estruturadas, constituem a forma"(LAMAS 1992, p 46), os elementos que compõe a forma urbana, como: solo, edifícios, lote, quarteirão, fachadas, logradouros, traçado viário, praças, monumentos, vegetação, mobiliário devem ser estudados de forma articulada entre si e vinculados ao conjunto que definem "os lugares que constituem o espaço urbano" (LAMAS 1992, p 38).

Porém o termo "morfologia" deve ser atribuído aos geógrafos alemães e ingleses no primeiro quartel do século XIX. No âmbito da arquitetura e urbanismo, os estudos iniciam-se na Itália e França e, posteriormente, na Espanha na segunda metade do século passado, tendo neste campo seus "predecessores" aos estudos que hoje conhecemos como "urbanistas contemporâneos".

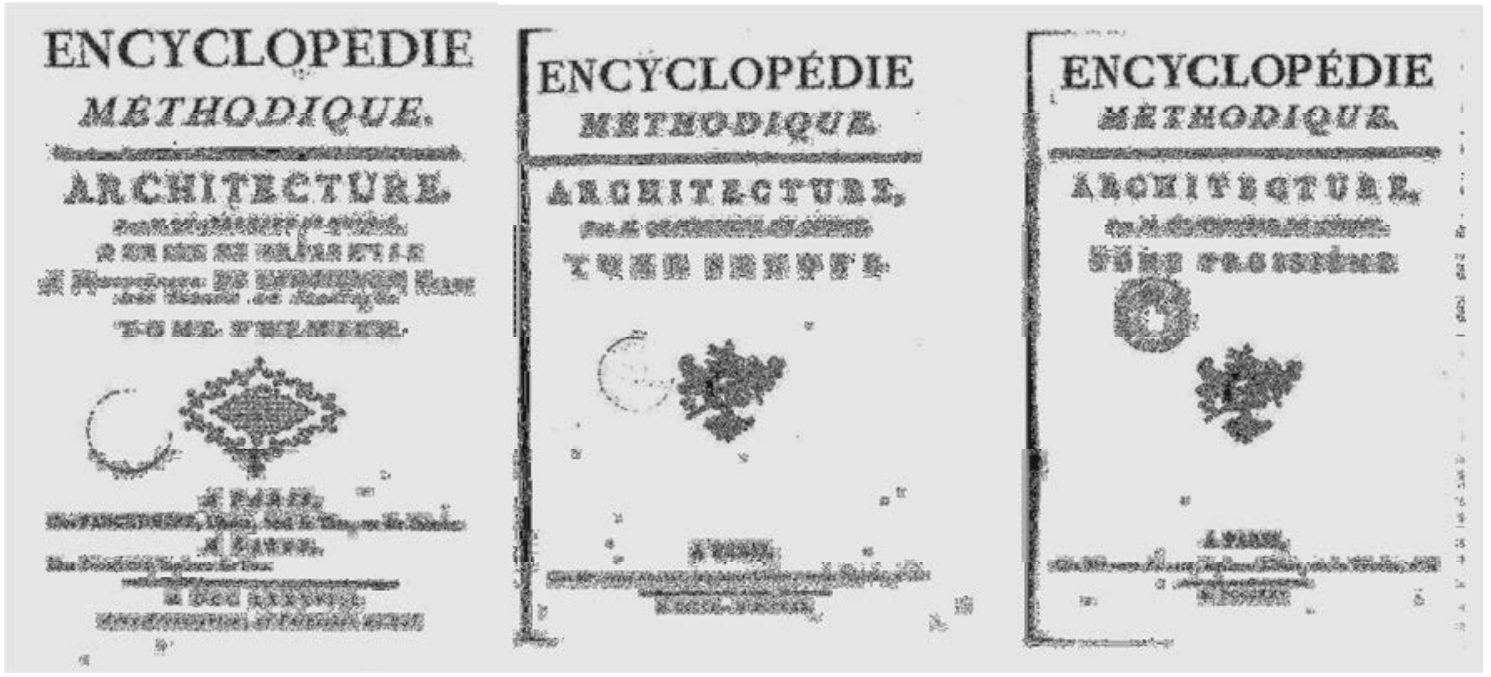

Figura 18. Folha de rosto da Encyclopédie Méthodique - Arquitecture de Quatremère de Quincy

Figura 19. Plano de Bolonha, 1965

Fonte: Comune di Bologna, 2010

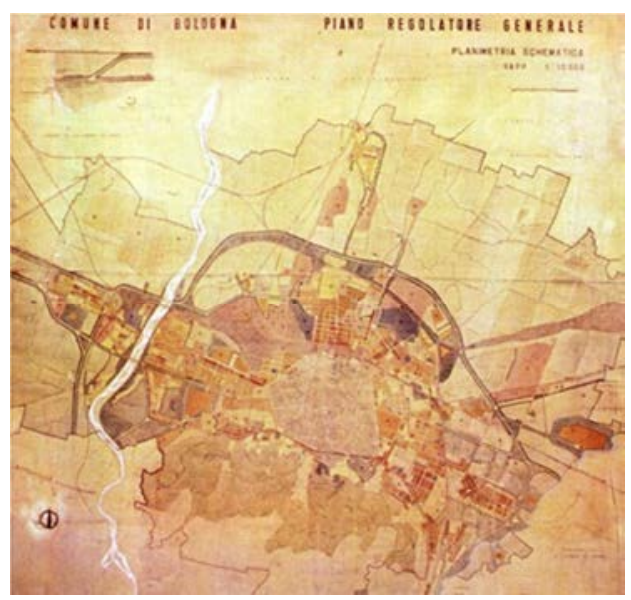

20. O termo "morfologia" vem do grego (morphé + lógos + ía) e significa "a ciência que estuda a forma" ou "a ciência que trata da forma". 
Segundo Solange Aragão (2006), o primeiro tratadista a formular teoricamente 0 conceito de tipo, foi Quatremère de Quincy, em Paris, no final do século XVIII:

“A palavra 'tipo' não representa tanto a imagem de uma coisa que deve ser imitada à perfeição, mas a idéia de um elemento que deve servir, por si mesmo, de regra a um determinado modelo (...). O modelo, entendido em termos de prática da arte, constitui um objeto que deve ser repetido de forma exata; por outro lado, o tipo é um objeto a partir do qual podem ser concebidas obras totalmente diferentes entre si. No modelo, tudo é dado e definido com precisão; no tipo, tudo é mais ou menos impreciso."(QUINCY in AYMONINO 1981, p 104$105)^{21}$

Neste momento, as análises das formas foram realizadas mediante a observação, a comparação, a descrição e a classificação dos elementos urbanos na história, como uma forma de compreender as leis que regulavam as construções da cidade, uma proposta de análise "morfotipológica".

Para Quincy, "a tipologia urbana garante a continuidade formal da estrutura urbana para a sua estabilidade em diferentes momentos da história, o que constutui em seu instrumento projetual capaz de contribuir na construção da cidade em qualquer escala"(FERRO 2010, p 20). ${ }^{22}$ Esta corrente de análise não é uma leitura puramente formal da cidade e sua arquitetura, podemos notar que a proposta de Quincy está relacionada diretamente sobre uma análise estrutural já que inclui distintos elementos da cidade (de permanência, de conformação, de espaços coletivos etc), seus diálogos e suas mudanças. Adeptos a mesma corrente, os trabalhos de Saverio Muratori e Gianfranco Cannigia, e Gian Luigi Maffei contribuem para o melhor entendimento destas análises a partir de seus estudos realizados que identificam o tipo e sua integração no tecido e no organismo urbano. Da mesma forma, as propostas para Bolonha (1955 e 1969) dos arquitetos Pier Luigi Cervelatti e Roberto Scannavini, consiste numa detalhada análise histórica e na definição das formas urbanas (morfologia) a partir da tipologia.

O Plano Urbanístico de Bolonha tinha por objetivo descentralizar as funções inadequadas irrelevantes ao contexto e criar um papel preeminente para o centro da cidade, num primeiro momento com o Plano Geral de Metas da Cidade, apontando para a "adesão dos municípios próximos, a fim de criar uma atração regional e cruzamento de tráfego com recursos de terra dos subúrbios"(COMUNE DI BOLOGNA s.d.), já o Plano para o Centro Histórico (1969) tinha como premissa a "recuperação, dentro da vida coletiva, de toda a cidade antiga como uma entidade completa de valores histórico, cultural, simbólico e ideal, caracterizado por funções claras"(COMUNE DI BOLOGNA s.d.).

21. Tradução do autor, 2011

La palabra "tipo" no representa a ninguno de la imagen de una cosa que debería ser imitado a la perfección, pero la idea de un elemento que debe ser utilizado por sí mismo, como una regla a un modelo en particular (...). El modelo, entendido en términos de la práctica artística, es un objeto que debe repetirse con exactitud, por otro lado, el tipo es un objeto de trabajo que puede ser diseñado completamente diferente. En el modelo, todo está determinado y definido con precisión, el tipo, todo lo que es más o menos inexacta.

22 . Tradução do autor, 2011

La tipología urbana garantiza la continuidad formal de la estructura urbana por su estabilidad en los distintos momentos de la historia, lo que la constituye en su instrumento proyectual capaz de aportar en la construcción de la ciudad a cualquier escala. 

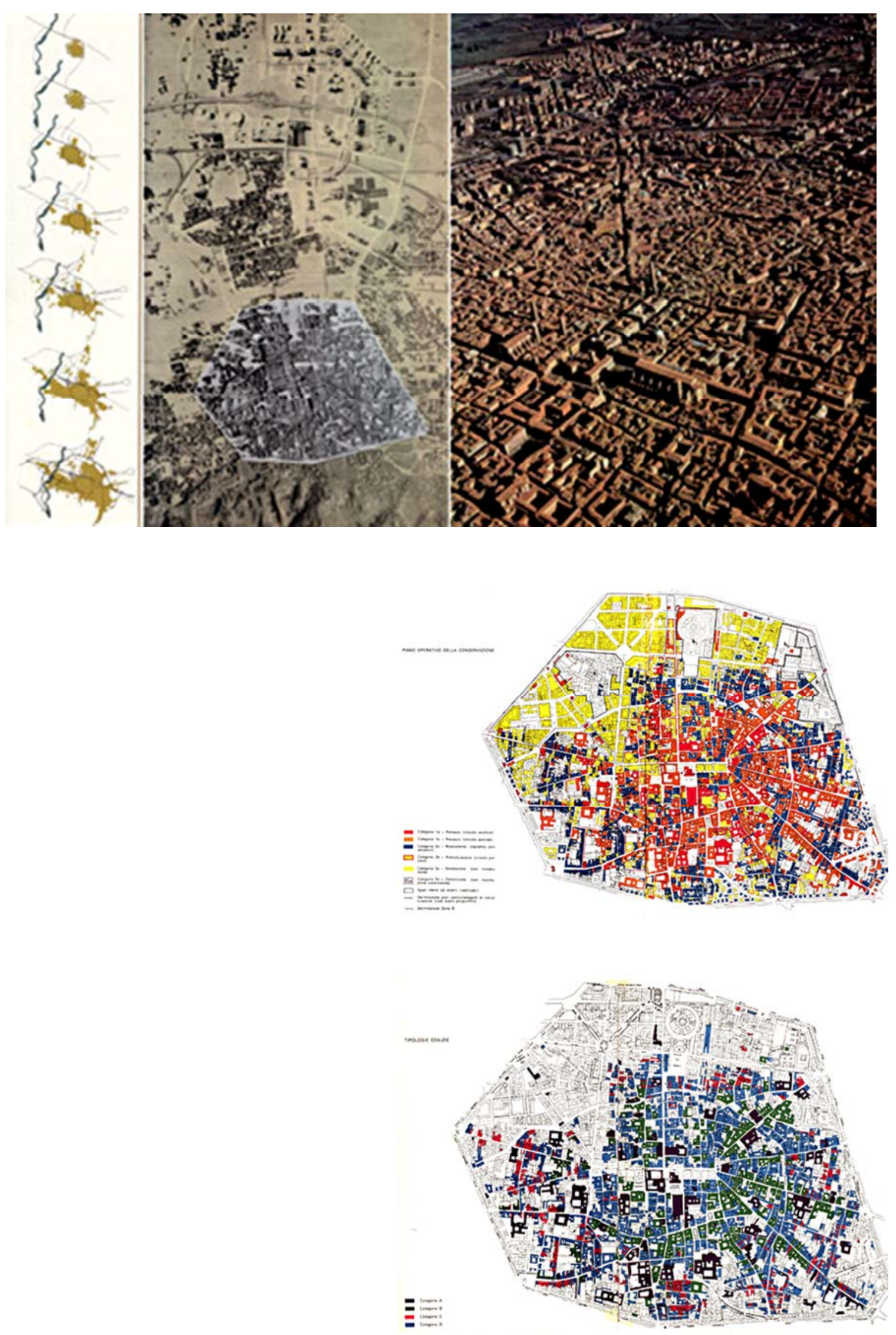

Figura 20. Plano para o Centro de Bolonha, 1969 - acima: estudo de expansão da cidade e foto aérea; abaixo esquerda: categorias; abaixo direita: tipologias

Fonte: Comune di Bologna, 2000 
Os dois planos urbanos resultaram em uma pesquisa detalhada dos valores históricos da cidade, o programa de conservação definiu o conceito de "tipologia", que pretendia ser a constância de formas e tipos de vidas concentradas em construções semelhantes e repetidas, constantes e rígidas em comparação com a função de cada conjunto edilício. Assim, o programa definiu quatro categorias tipológicas e classificando os edifícios históricos. ${ }^{23}$

Segundo Montaner (2007, p 95), a arquitetura italiana foi definida durante os anos 1920/1930 pela liderança de arquitetos procedentes de classes altas, que demonstravam especial preocupação social, militando em partidos de esquerda. Suas idéias predominantes valorizavam os mestres italianos dos anos 20 e 30 do século XX, atualizando a sua mensagem de modernidade; e defendiam a cidade como lugar do coletivo, expressão da sociedade livre, e patrimônio da cultura.

Como colocado por Antonucci:

"A enorme diversidade de correntes arquitetônicas na Itália ocorria tanto em função de diferenças culturais e urbanas quanto de distintas posições políticas" (2005, p 57-58).

No contexto romano destacou-se a arquitetura neo-realista (influência do cinema) corrente efêmera de arquitetura neopopular. No contexto do norte (Milão, Genova, Turim) destacou-se uma arquitetura mais elitista e delicada, com recuperação dos materiais e figurações do início do século XX: BBPR, ${ }^{24}$ Carlo Aymonino, Victorio Gregotti e Gae Aulenti e, mais tarde Aldo Rossi (MONTANER 2007, p.95).

Resultado do considerável número de estudiosos deste tema na Itália, em meados do século XX (1944), criou-se em Milão o MSA - Movimiento Studi per l'Architettura - que manteve relações com os CIAM e se converteu, junto com Casabella, no segundo catalisador do debate cultural no norte da Itália (MONTANER 2007, p 95).

Apesar da grande diversidade de estudos realizados entre os anos 20 e 40, em sua maioria todos ainda permaneciam sobre o campo dos estudos tipológicos de forma ainda isolados do contexto urbano, seus elementos de composição do desenho urbano e consequências sobre o espaço livre. Por outro lado, Saverio Muratori foi o primeiro a adotar o método da Morfologia Urbana como ferramenta de análise em seus estudos tipológicos do projeto urbano e arquitetônico. Segundo Montaner, "os objetivos dos estudos tipológicos eram reduzir a algumas categorias analíticas a variedade de formas existentes a partir da definição de critérios para sua identificação e classificação" (2007, p.141).

Denise Antonucci, aponta que Muratori em seus ensaios de 1944 a 1946, surgem conceitos de cidades comoorganismos vivos e como trabalhos de arte coletivos. A idéia de planejar novosedifícios como continuidade da cultura construtiva do lugar foi destacada, emseus textos dessa época. Surgia incipiente a idéia de 'história operante',formulada posteriormente em Veneza para onde foi chamado como catedrático em 1952.

Como contribuição para este tema, os estudos realizados em Veneza durante dez anos, empregando os conceitos fundamentais de tipo, tecido, organismo e história operante,

23. Naquele momento foram classificadas pelo autor quatro categorias, desde os grandes "contenitoris" aos edifícios privados.

24 . BBPR - Escritório de Gian Luigi Banfi, Ludovico Barbiano di Belgiojoso, Enrico Peressutti e Ernesto Nathan Rogers. 
será de grande valia na construção de uma metologia de análise da forma urbana. À frente do Istituto di Architettura di Venezia, Muratori realiza estudos do tecido urbano da cidade baseado no método tipológico. Deste estudo com levantamentos e análise precisa de amostras importantes do tecido urbano, o autor retira três lições fundamentais:

1. tipo não se caracteriza fora de sua aplicação concreta, isto é, fora do tecido construído;

2. o tecido urbano por sua vez não se caracteriza fora de seu quadro, isto é, fora do estudo do conjunto da estrutura urbana; e

3. o estudo da estrutura urbana não se concebe fora de sua dimensão histórica, pois sua realidade se funda no tempo por uma sucessão de reações e crescimentos a partir de um estado anterior.

Em nossos estudos, percebemos que se existe uma diferença entre "morfologia" e "tipologia", trata-se, sobretudo, de uma diferença de método. Na morfologia, selecionase um trecho do tecido urbano (ou fragmento) e procede-se à análise de todos os elementos que o compõem (o solo, os edifícios, os quarteirões, as fachadas etc), articulando-se entre si e vinculando-os ao conjunto que o definem. Já na tipologia, seleciona-se um elemento morfológico (um tipo de construção, de espaço livre ou de componente do espaço), investigando-se suas variações, hierarquias e sua relação com o contexto urbano, o período histórico e a sociedade que o produziu.

Outro componente que difere a "morfologia" da "tipologia" está relacionado à escala pelo qual cada um estuda: o primeiro vai se ateraos resultados apartir da escala urbana, estudando o próprio tecido e seus componentes, na tipologia a escala trabalhada é a do edifício (ou elemento selecionado), analisando os tipos edificatórios e seus elementos que o compõem em relação à cidade, como muros, pátios, jardins, entre outros.

Porém, existe uma terceira corrente no qual propõe que os estudos dos "tipos" sejam feitos concomitantemente à análise do tecido urbano, denominada "typo-morphology" (tipo-morfologia). O método empregado estabelece uma correspondência entre a tipologia e a morfologia, identificando-se os tipos edificatórios existentes e analisando-os em relação ao entorno.

Entender o significado dessa relação entre tipo arquitetônico e forma urbana é fundamental para compreender a estruturação urbana e subsidiar a metodologia do projeto arquitetônico e urbanístico. Neste sentido, a morfologia urbana tem sido objeto de diferentes abordagens desenvolvidas por autores também de diferentes perfis disciplinares. Em alguns casos prevalecem os aspectos da percepção visual, noutros as possíveis leituras mais técnicas, e noutros ainda, é a história que condiciona os olhares.

Isto posto, entendemos que para o enriquecimento da futura leitura da cidade e objetos de estudos (seja estudos de caso e/ou objeto de estudo desta tese), a referência de determinados autores que, juntamente com os precursores dos estudos da "tipologia" e "morfologia" urbana, nos seria enriquecedor para a construção de um repertório que nos possibilite tratar com maior propriedade a respeito dos estudos e pesquisadores contemporâneos sobre o tema. Num primeiro momento, entendemos que o estudo de autores consagrados como Sitte (1843-1903), Lynch (1918-1984), Cullen (1914-1994) nos fornecerá importante documento empírico e analítico sobre o tema estudado, no qual suas teorias e análises influenciaram estudiosos contemporâneos.

Os autores acima citados acentuam em sua obra a capacidade individual de percepção visual da cidade considerando não apenas o ponto de vista do habitante, de certa forma 
tratado por autores como Maurice Halbawacsh ${ }^{25}$ (1925) ou mais recentemente Pierre Jeudy $^{26}(2005)$ e que faz apelo à memória da vivência urbana de cada um, percorrendo a cidade através do olhar do cidadão e seus trajetos por novas descobertas.

Se desejássemos transpor para os tempos atuais as discussões colocadas pelos trêsautores acima, poderíamos dizer que não só se trata do "reconhecimento" da cidade como "qualidade urbanística", do ponto de vista formal, ou seja, o traçado urbano propriamente dito (traçados, descobertas, praças, cruzamentos, ritmo urbano etc), no qual com suas interpretações buscavam uma relação entre a percepção, 0 reconhecimento (no sentido de orientação espacial e a escala humana) e a medida padrão urbanística em todas as situações.

A imagem formada do espaço urbano é fundamental na definição da relação que cada ser humano tem com o meio que o rodeia. A concepção, como projeto, do espaço urbano deve contemplar o conjunto de fatores em que o desenho possa proporcionar como qualidade de vida, não somente a quem ocupa aquele território, mas a quem se utiliza daquele espaço como lugar, passagem ou área de vislumbração.

É sabido que as cidades passam por processos históricos, sociológicos e econômicos, que ao longo dos anos e dos séculos vão resultando em transformações significativas sobre a configuração espacial e, em sua consequência, na imagem da cidade. Enquanto imagem, o que nos interessa é justamente a construção destas através das novas formas urbanas geradas a partir dos Grandes Projetos Urbanos sobre o tecido da Cidade Contemporânea.

Como colocado anteriormente, fundamentar o arcabouço teórico sobre morfologia urbana perpassa por estudiosos como Camillo Sitte que escreveu a sua mais conhecida obra (A Construção das Cidades segundo seus Princípios Artísticos) com o objetivo de compreender e identificar as regras que estão presentes na forma das cidades, e em especial as cidades antigas, que expressam para o autor o elemento-chave para a discussão colocada em pauta em sua obra, em que a história da cidade torna-se um conjunto de camadas sociais, econômicas e urbanas que se acumulam entre si pelas sucessivas "intervenções" ao longo dos anos, décadas e séculos de existência do tecido urbano e sua morfologia.

Como posto por Kohlsdorf:

"Centrada nas áreas públicas, a proposta de Sitte remete a indagações ao atual contexto urbano e às práticas correntes de sua construção, vinculando reflexões teóricas e operacionalidade planejadora". (2005)

Esta obra do final dos anos 80 pode e deve ter uma leitura contemporânea, na medida em que essas regras, não só são as mesmas, mas também remete as condições e elementos urbanos existentes em nossas cidades após mais de trinta anos das reflexões de Camillo Sitte.

Como colocado pelo autor em seu texto "A presença de Camillo Sitte" (KOHLSDORF 2005), o contexto com que viveu Sitte foi especial porque marcou a origem do

25 . Maurice Halbwachs (1877 - 1945) foi um sociólogofrancês da escola Durkheimiana - França. Escreveu uma tese sobre o nível de vida dos operários, e sua obra mais célebre é o estudo do conceito de memória coletiva, que ele criou (Wikipédia, a enciclopédia livre, acessado em 19/07/2011).

26 . Henri-Pierre Jeudy é sociólogo do Centre National de la Recherche Scientifique - CNRS (Laboratório de Antropologia das Instituições e das Organizações Sociais - LAIOS) e professor de estética na Escola de Arquitetura de Paris-Villemin (http://www.estacaoliberdade.com.br/autores/jeudy.htm, acessado em 19/07/2011). 
planejamento urbano moderno. Nessa conjuntura o autor (SITTE) apontava diversos problemas de produção urbanística (KOHLSDORF 2005, p 5-6), como as deficiências dos planos urbanísticos, a ignorância do relevo do solo na concepção do projeto, a restrição dos elementos básicos do tecido urbano, a redução nas análises de trânsito e boa circulação de veículos, o zoneamento como legislação urbanística, entre outros elencados pelo pesquisador.

Como podemos verificar, a listagem revela o quanto afloravam, na época de Sitte, questões profissionais nas estratégias de organização espacial via planejamento urbano. Embora seja aqui impossível empreender discussões profundas, os fatos relatados nos levam a refletir sobre a incompatibilidade entre a argumentação higienista e a tecnológica, visto que as cidades em sua maioria tornavam-se a cada momento em "estruturas industriais", que necessitavam de novas configurações espaciais diferentes das preexistentes nas estruturas das cidades antigas.

No que diz respeito aos espaços urbanos das cidades, como ruas e praças, Sitte adverte:

"Apenas em nosso século matemático é que os conjuntos urbanos e a expansão das cidades se tornaram uma questão puramente técnica, (...) com isso, apenas um aspecto do problema é solucionado..." (SITTE 1992, p 15).

Para o autor, construir cidades segundo seus princípios artísticos significava fazê-las com arte, como aconteceu na maior parte da história das cidades, quando essa realização associava tecnologias disponíveis a referências expressivas e simbólicas (KOHLSDORF 2005).

Figura 21. Plano que Camillo Sitte elaborou para Marienberg, em 1903

Fonte: www.vitruvius.es, acessado em 18/10/11
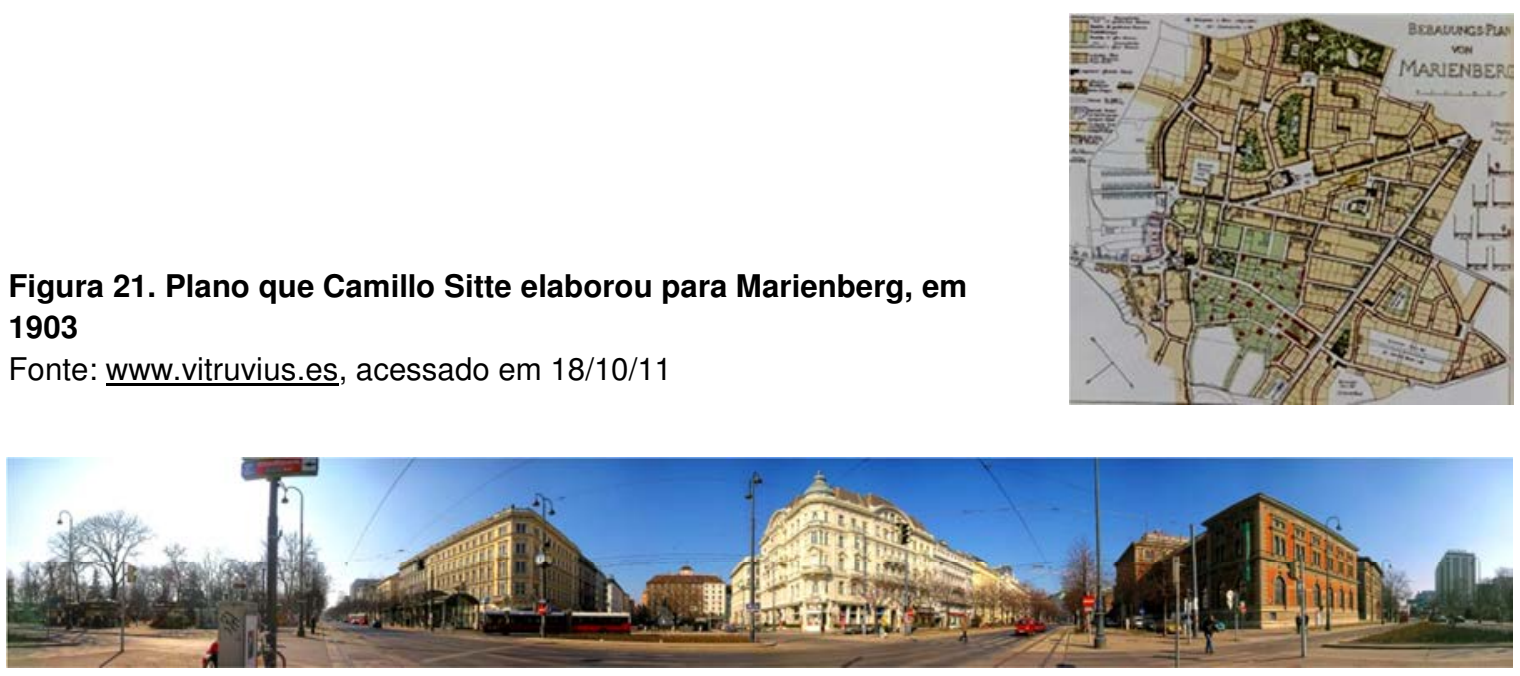

Figura 22. Sitte e a Ringstrasse - acima: Rinstrasseresidenzplatz; esquerda: Ringstrasse-Viena

Fonte: O Urbanismo, 1992

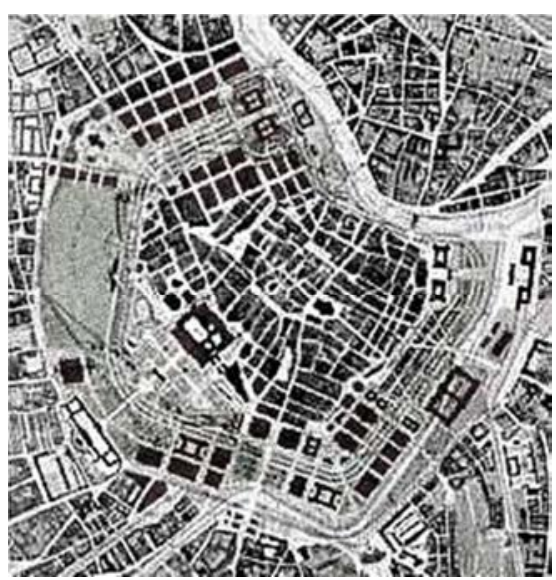


Por fim, cabe ressaltar as posturas de Camillo Sitte sobre as avaliações dos lugares existentes. Como método ao exercício projetual, o autor analisa o objeto urbano por duas abordagens: 1) a posição do observador cotidiano, fisicamente dentro do espaço considerado; 2) o ponto de vista do cientista ou do técnico, física e intelectualmente fora do espaço examinado.

Assim, podemos agora afirmar que as análises de Camillo Sitte não são meras descrições, mas descobertas de atributos fundamentais da configuração espacial, em que o mesmo propunha "aprender com a natureza e com os mestres" (1992), sem necessariamente imitá-los, mas entendendo seus processos e, anunciar em seus estudos da percepção espacial aplicados à projetação, a partir de 1940 e influenciando duas décadas depois, um conjunto de pesquisadores como, por exemplo, Kevin Lynch entre outros. ${ }^{27}$

Ao nos depararmos com a descrição de Kevin Lynch podemos considerar que sua obra trata de sistematização da percepção visual da cidade. A obra, publicada em 1960 sob o título "The Image of the City" ( $A$ imagem da Cidade), é o resultado de cinco anos de estudos em como as pessoas percebem e organizam informações aleatórias quando trafegam pelo espaço urbano. Tendo como objeto de estudo três cidades diferentes (Boston, Jersey City e Los Angeles), o autor analisou que as pessoas no geral, "entendem a cidade ao seu redor de maneira consistente e previsivel, formando mapas mentais" (LYNCH 2010) utilizando-se de cinco elementos que ele julga fundamentais para a leitura da cidade (vias, limites, bairros, pontos nodais, marcos).

"Florença é uma cidade dotada de poderosa personalidade, um lugar apreciado. A cidade tem uma história econômica, cultural e política de enormes proporções e que os indícios visuais desse passado explicam grande parte das inconfundíveis características. O centro da cidade tem características regionais: ruas extremamente estreitas e com calçamento de pedras, altos edifícios de estuque de pedra e de cor cinzento-amarelada, com venezianas, grades de ferro e entradas que lembram cavernas, encimadas pelos característicos beirais. Nessa área existem muitos pontos nodais, a área central está cheia de marcos. As pessoas desenvolvem ligação com essas formas claras e diferenciadas, tanto em decorrência do passado quanto de suas experiências"

(Kevin Lynch, 1960)

Para Kevin Lynch a percepção faz parte de um processo complexo em que a memória é um elemento essencial, assentado sobre a idéia que a legibilidade e a orientação são os pilares onde assenta a constituição da imagem da cidade, como imagem que cada um pode construir sobre o espaço a partir de sua experiência individual. É a partir deste pressuposto no qual cada indivíduo pode definir a identidade, a estrutura e o significado de cada elemento do lugar.

No processo de orientação, o elo estratégico torna-se a imagem ambiental, o quadro mental generalizado do espaço urbano e a necessidade de reconhecer e "padronizar" nosso ambiente. ${ }^{28}$

27 . Entre os pesquisadores influenciados por Camillo Sitte, podemos apontar Gary Winkel, Donald Appleyard, Terence Lee e outros.

28. Na obra é possível identificar três características sobre a imagem da cidade: Legibilidade, Estrutura e identidade, Imagibilidade. Da mesma forma, o autor expõe como ferramenta para a análise morfológica de cada território, 
Assim podemos dizer que a cidade é uma organização por sua natureza mutável e polivalente, um espaço com muitas funções, erguido num período relativamente rápido, onde as imagens se sobressaem a cada instante e informando o observador em cada ponto, limite ou marco. Existe, porém algumas funções fundamentais, que as formas da cidade podem expressar, e que o autor aponta como "qualidades da forma" em sua obra: singularidade, simplicidade, continuidade, predominância, clareza de ligação, diferenciação direcional, alcance visual, consciência do movimento,séries temporais, nomes e significados(LYNCH 2010).

Figura 23. Os elementos da paisagem segundo Kevin Lynch

Fonte: A Imagem da Cidade, 2010

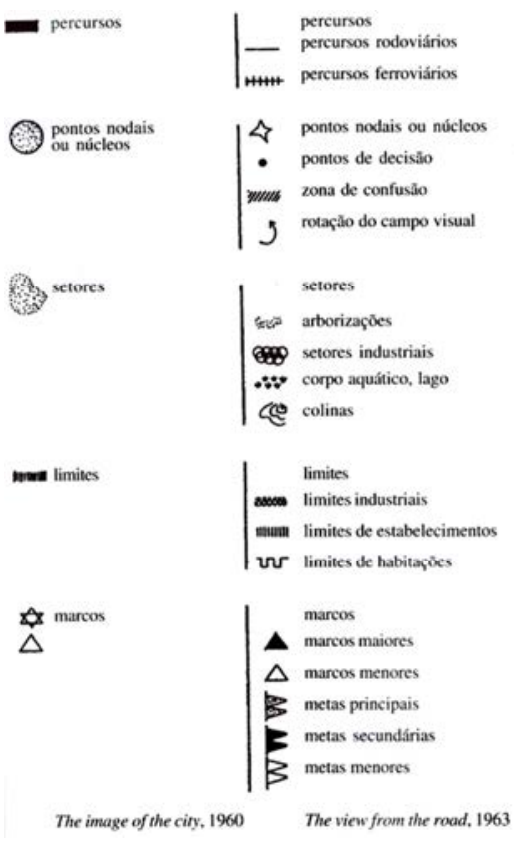

Estas qualidades podem ser compreendidas como artifícios, ou mecanismos, capazes de gerar uma análise mais apurada sobre o espaço urbano estudado, podendo assim, serem explorados ora independentes, ora inter-relacionados como um só "elemento", respondendo aos requisitos propostos por Lynch em sua obra.

Evidente que a forma de uma cidade não se apresenta ordenada, como modelo único e contínuo, nem tão pouco estático, para tanto, deve ser adaptável aos hábitos perceptivos de seus habitantes e usuários, aberta às mudanças de função e significado, receptivamente à formação de novas imagens.

Diferentemente dos demais pesquisadores, o conceito de paisagem urbana de Gordon Cullen tornou-se uma das propostas mais difundidas como instrumento de avaliação dos espaços urbanos. Isto se deu devido a sua simplicidade e objetividade em apontar as formas de comprender e analisar o espaço, intuitivamente ou não.

De acordo com o autor, "paisagem urbana é a arte de tornar coerente e organizado, visualmente, o emaranhado de edifícios, ruas e espaços que constituem o ambiente urbano" (CULLEN 1983). 
Cullen reconhece o princípio que distingue um edifício de um conjunto de edifícios, nãocomo resultante do fator puramente quantitativo, mas, sobretudo como um fatoqualitativo produtor de uma nova situação morfológica e social. Tais conjuntos e suas escalas (maiores ou menores) criam novos espaços que resultam da relação entre estes elementos, produzindo ruas, praças e vazios, cujo entendimento formal e social pode gerar situações diversificadas de apropriação do espaço e sua percepção.

Neste sentido cada conjunto depende da sua dimensão, do contexto social que produz e em que está envolvido. $O$ autor reconhece também as questões da percepção visual como base para qualquer observação e chama a memória do observador para sustentar que "a visão tem o poder de invocar as nossas reminiscências e experiências, com todo o seu corolário de emoções" (CULLEN 1983). Neste sentido propõe três campos de reflexão que têm relação com a descoberta, com a localização e com a especificidade de cada lugar.

O homem tem em todos os momentos a percepção da sua posição relativa, sente anecessidade de se identificar com o local em que se encontra, e esse sentido deidentificação, por outro lado, está ligado à percepção de todo o espaço circundante, no qual Cullen classifica três aspectos principais a considerar: Ótica, Local e Conteúdo.

No que podemos observar, todos os elementos citados pelo autor são essenciais e contribuem na leitura e interpretação da cidade e seus espaços urbanos, de reorganizar ou de tomar as medidas necessárias para suster a sua degradação e posterior reabilitação.

Ao procurarmos compreender a percepção que fazemos da morfologia urbana teremos certamente que "descobrir a cidade", compreender a natureza do seu traçado e submeter ao processo de percepção visual entre os diferentes aspectos da memória, não só individual, mas, sobretudo desta na sua relação com o mundo em que vivemos como artifício à memória do observador.

Assim, projetar formalmente um espaço deveria ser antes de mais nada balizar o terreno com referências, nas quais cada um pudesse assentar a sua percepção e descodificar o sentido, nas suas múltiplas possibilidades. Pretende-se desta forma, reunir estes elementos como uma espécie de "prontuário" onde se encontrassem reunidos como referencias ao traçado urbano e sua morfologia.

Como apontado por Roberto Sabatella Adam (2008), em suas conclusões no texto "Analisando o conceito de paisagem urbana de Gordon Cullen":

"O que há de mais precioso na proposta de Cullen é o estímulo que promove à percepção da cidade, pois esteja o sujeito no espaço que for e em qualquer velocidade de apreciação, pode fluir poéticas urbanas nem sempre valoradas. $A$ visão serial como instrumento faz surgir um novo observador mais atento às suas emoções e aos espaços urbanos, contudo não concita este observador, a ser um sujeito integral, pleno, ativo e transformador, que se constrói ao mesmo tempo em que age no mundo"(ADAM 2008, p 67).

A partir do exposto por Adam, pode-se dizer que a percepção da cidade e sua apropriação são um único processo. Memória do lugar, do contexto, da localização da percepção, mas, sobretudo memória que assente nas lembranças suscitadas pelas referências cujo caráter é essencial reconhecer. 

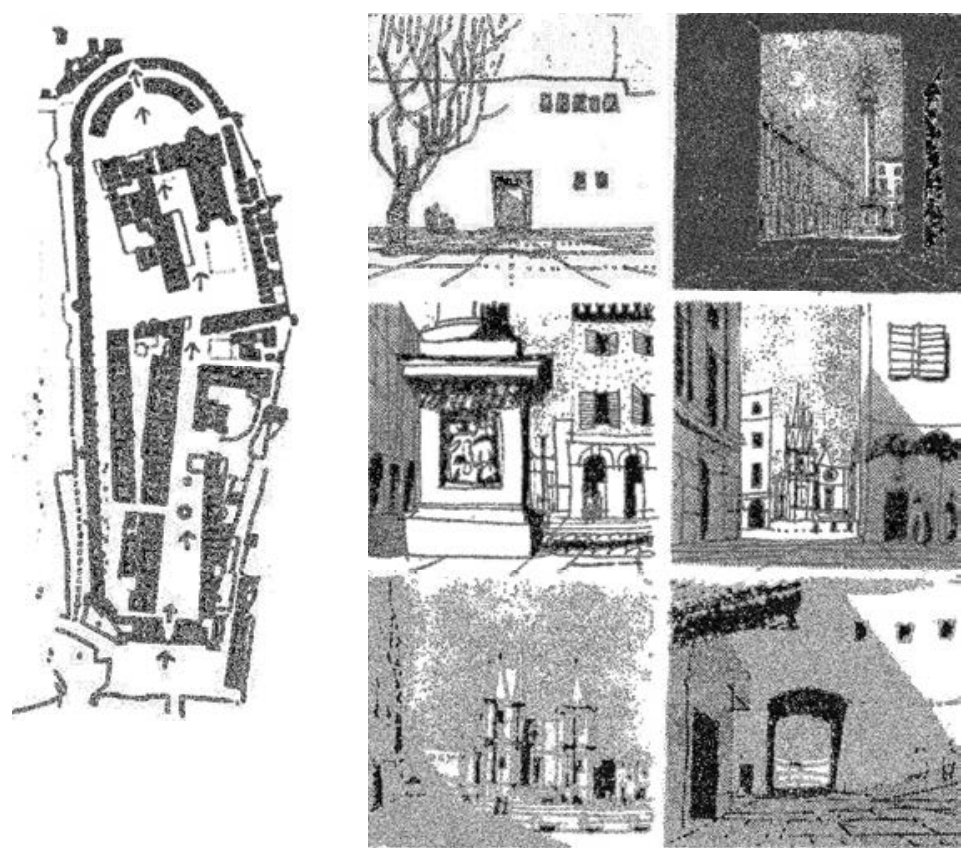

Figura 24. Gordon Cullen - Visão Serial

Fonte: Paisagem Urbana, 1983

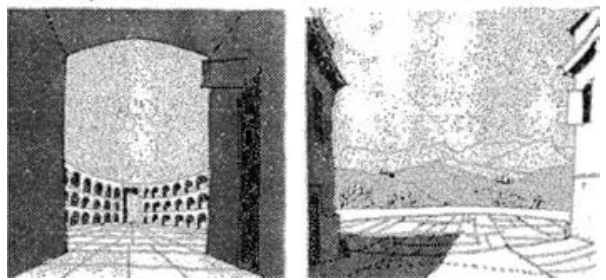

Por fim, nas pesquisas realizadas por estes três autores, Sitte, Lynch e Cullen, encontraram uma reflexão que nos permite entender que a imagem da cidade, a paisagem urbana ou os princípios artísticos do urbanismo, tem por base a percepção visual, condição de descoberta do "lugar".

Esta percepção pressupõe a idéia de percurso e descoberta: a relação entre o olhar, a memória e a referência espacial, que nos permite sentir a localização e que de certa forma significa a possibilidade de apropriação do espaço. 


\subsection{Italianos, franceses, entre outras referências}

A análise morfológica urbana foi utilizada ao longo da segunda metade do século XX em diferentes contextos, verificando assim, que alguns autores e pesquisadores, como também os críticos de arquitetura e urbanismo, se ativeram às formulações que determinados arquitetos desenvolveram sobre Tipologia e Morfologia Urbana. Observamos ao longo de nossa pesquisa, que muitas vezes um mesmo "agente urbano" desempenha papel de pesquisador, arquiteto e historiador, em sua maioria ligada não somente aos seus "conceitos", mas também às produções acadêmicas ou práticas.

Dois países europeus em especial, contribuíram em grande valia para estas análises tendo como ferramenta a Morfologia Urbana. Durante a primeira metade do século XX, os pesquisadores italianos e franceses se mostraram personagens fundamentais para a difusão deste tema, tanto em suas práticas profissionais como em suas pesquisas acadêmicas nas mais diversas escolas de arquitetura e urbanismo dos dois países.

Não cabe a esta tese elencar um rol de arquitetos, urbanistas, pesquisadores, historiadores, ou até mesmo geógrafos que analisaram a evolução das cidades partindo de seus princípios formadores e/ou considerando suas constantes transformações. No entanto, pretendemos mesmo que sinteticamente, recuperar o pensamento de alguns teóricos que utilizaram do conceito da morfologia urbana no estudo das cidades com resultados tangíveis das ações sociais e econômicas, e suas mutações sobre o tecido urbano.

Para Montaner (2007), a arquitetura italiana foi definida no início do século XX (anos 1920/30) procedente da alta classe de arquitetos que se dedicavam aos estudos sobre "mensagem de modernidade", com especial preocupação social, valorizando os setores populares (em resistência ao fascismo) e militando em partidos de esquerda, "definiam a cidade como lugar do coletivo, expressão da sociedade livre, e patrimônio da cultura" (ANTONUCCI 2005, p 57).

Durante este período os acadêmicos mantiveram nas universidades e instituições de ensino um campo favorável às discussões e descobertas sobre o tema em questão. Como apontado por Portoghesi, os racionalistas opuseram-se à "americanização" da tendência orgânica. "Os orgânicos não tiveram longa atuação, dado seu caráter polêmico" (PORTOGHESI 2002, p 72).

A grande diversidade de correntes arquitetônicas na Itália nos leva também ao leque diverso de pesquisadores, no qual poderíamos destacar inúmeros arquitetos que contribuíram para difundir a temática por todo o país, cada qual com suas análises, convicções e pontos de vista em relação à Tipologia e Morfologia Urbana. Para tanto entendemos que alguns personagens foram, e são fundamentais para a construção do arcabouço desta tese, esclarecendo que em momento algum pretendemos eleger uma colocação entre eles, mais ou menos importante, nem tão pouco avaliar sua contribuição.

Nisto, identificamos os pesquisadores que, a nosso ver, mais difundiram seus métodos e resultados alcançados durante suas análises. Como já citado no início deste capítulo, Saverio Muratori desenvolveu um conjunto de pesquisas e estudos, procedido do método tipológico que possibilitaram reduzir a algumas categorias analíticas a variedade de formas existentes até o momento. Sua contribuição, tanto profissional como acadêmica resultou numa reforma intelectual, que em conjunto com seus assistentes resultaram numa grande diversidade de experiências. 
"Ao longo dos anos desenvolveram seminários, com a participação de alunos interessados, em que cada assistente era responsável por certos tópicos. Mais tarde estas experiências continuaram em cursos livres entre 1965 e 1966, sob sua supervisão"(ANTONUCCI 2005, p 61).

Ao longo de sua trajetória, Muratori, adquiriu admiradores, mas também pesquisadores que discordavam de suas teorias, como por exemplo, Bruno Zevi que o considerava tradicionalista. Por outro lado, arquitetos como Pier Luigi Cervellati e Gianfranco Caniggia são adeptos de suas teorias dos “procedimentos/métodos tipológicos' em função do foco em tipos construtivos como raiz elementar da forma urbana"(MOUDON in ANTONUCCI 2005, p 63, grifo nosso).

Em 1965, o termo tipologia arquitetônica foi colocado em prática novamente por Giulio Carlo Argan. A interpretação histórica de Argan propiciava uma visão global da arte e arquitetura italiana.

Devido à sua clareza de critérios metodológicos (MONTANER 2007), diversos arquitetos e teóricos, influenciados por Argan, expressavam a cidade em termos de "tipologia $e$ morfologia e olhavam construções e cidades como teatros da memória" (ANTONUCCI 2005, p 65). Apesar de sua influência sobre alguns arquitetos italianos, por exemplo, Aldo Rossi e Giorgio Grassi, seu trabalho não foi suficientemente reconhecido.

Uma de suas principais produções teóricas, o livro Progetto e Destino, publicado em 1965 e traduzido para o português por Marcos Bagno em 2001, no qual podemos destacar o texto "Sobre o conceito de tipologia arquitetônica", suas concepções sobre cultura, arte e arquitetura e sua relação com a sociedade e a produção industrial são básicas para sustentar idéias de seus contemporâneos.

Argan em seu texto condiciona o nascimento do tipo "ao fato de já existir uma série de edifícios que têm entre si uma evidente analogia formal e funcional: em outros termos, quando um tipo se fixa na prática ou na teoria arquitetônicas ele já se existe, numa determinada condição histórica da cultura, como resposta a um conjunto de exigências ideológicas, religiosas ou práticas" (ARGAN 2001, p 66).

O autor vai deter suas teorias sobre a aceitação do tipo ao momento do juízo histórico, tendo o tipo como "ponto de partida do projeto ou ideação formal" (ARGAN 2001). Seu método consiste em apresentar a história como síntese da interpretação formalista.

Para Montaner, sua insistência na perda da qualidade conceitual da cultura contemporânea em função do pragmatismo e, sua defesa do trabalho artesanal frente à perda da dimensão artística que comporta a indústria, são idéias sintonizadas com a nostalgia e o idealismo historicista de arquitetos e urbanistas, ainda que também expressem uma crítica às leis da sociedade capitalista (2007, p 96).

"Todo arquiteto urbanista é, enfim, um reformador social, do mesmo modo como os arquitetos do Renascimento foram os reformadores do pensamento científico de seu tempo (...)" (ARGAN 2001, p 87).

A postura nostálgica de Argan influenciou Ernesto Nathan Rogers, editor da revista Casabella-Continuitá (1953 a 1964), conquistando discípulos que conciliavam com sua postura, Aldo Rossi, Gorgio Grassi, CarloAymonino, Manfredo Tafuri, Victorio Gregotti, Giancarlo De Carlo, ${ }^{29}$ no qual como afirma Montaner, passaram a escrever artigos de crítica arquitetônica em revistas, em especial Casabella-Continuitá, onde definiam os

29. Único pertencente ao Team X. 
conceitosdepré-existências ambientais, do papel crucial da história da arquitetura, dacentralidade da discussão sobre a tradição na cidade européia, da idéia de monumento, da responsabilidade do artista e do intelectual na sociedade moderna, assim como defendiam o dever de continuar os ensinamentos dos mestres do Movimento Moderno(MONTANER 2007, p 139).

Aldo Rossi (1931-1997) em seu livro "A Arquitetura da Cidade" apresenta o rigor e o interesse de seus escritos teóricos e o atrativo pessoal de sua linguagem arquitetônica. Propõe uma série de critérios metodológicos e influenciado pela Escola de Frankfurt, afirmando que não existe uma relação unívoca e linear entre as formas e as funções. "As formas não são diretamente o resultado das funções, vão muito além das estritas funções"(MONTANER 2007, p 99).

Para Rossi (2001), a "arquitetura é a expressão física de certos pensamentos e a tarefa do arquiteto é explicar estes pensamentos convertendo-os em realidade construída", desta forma, podemos observar na obra do arquiteto não somente o estudo da arquitetura em si, mas também os examina como fatos urbanos, representados por objetos físicos que fazem as cidades.

Como contribuição a esta tese, a obra de Rossi definida por dois elementos básicos da cidade: os monumentos e as áreas residenciais ${ }^{30}$ - podem ser tomados como "elementos que vão contribuir para o desenho do tecido urbano" e definir novas formas urbanas variáveis relacionadas no tempo e no espaço.

Pertencente a Nuova Tendenza, Carlo Aymonino (1926-2010) aponta a possibilidade de estabelecer uma relação entre as características morfológicas da cidade e as identidades tipológicas de alguns fatos edilícios. O autor desenvolve uma série de pesquisas e interesses projetuais no campo da Morfologia Urbana concentrando-se em elementos formadores: "praças, espaço coletivo por excelência, expressão máxima da dimensão cívica e pública das cidades, onde o monumental se encontra com 0 cotidiano" (del RIO 1990, p. 83).

Diferentemente de Aldo Rossi que irá se concentrar sobre os estudos tipológicos, tendo por referência as tipologias expressas por Quatremère de Quincy, Aymonino desenvolve seus estudos e pesquisas sobre objetos reais e contemporâneos. ${ }^{31}$ Em sua outra obra: El significado de las ciudades, publicado em meados dos anos 70, o autor apresenta a tese da passagem da referência de um monumento em si (isoladamente) para a cidade como monumento (ANTONUCCI 2005, p 72).

"O Capitólio, em Roma renova sua existência reforçando seu significado simbólico e urbano; o processo inverso também ocorre: grandes construções integradas na paisagem são elementos urbanos porque sua representação é validada pela experiência das cidades" (AYMONINO 1981).

Como análise urbana, Carlo Aymonino vai estudar as transformações urbanas através dos tempos como testemunhas físicas de condicionamentos sociais e econômicos. Estas pesquisas resultam na hierarquia dos elementos e suas inter-relações morfológicas, tendo a arquitetura, antes de tudo, um fenômeno urbano.

30 . Para Rossi, os monumentos são os elementos primários, edifícios e espaços públicos ou pertencentes à esfera pública, enquanto que as áreas residenciais são as habitações que crescem sempre por áreas e conforma o tecido básico da cidade.

31. Entende-se tal contemporaneidade as obras construídas durante o inicio do século XX - Movimento Moderno. 
Figura 25. Piazze d'Italia, Carlo Aymonino Fonte: El significado de las ciudades, 1981

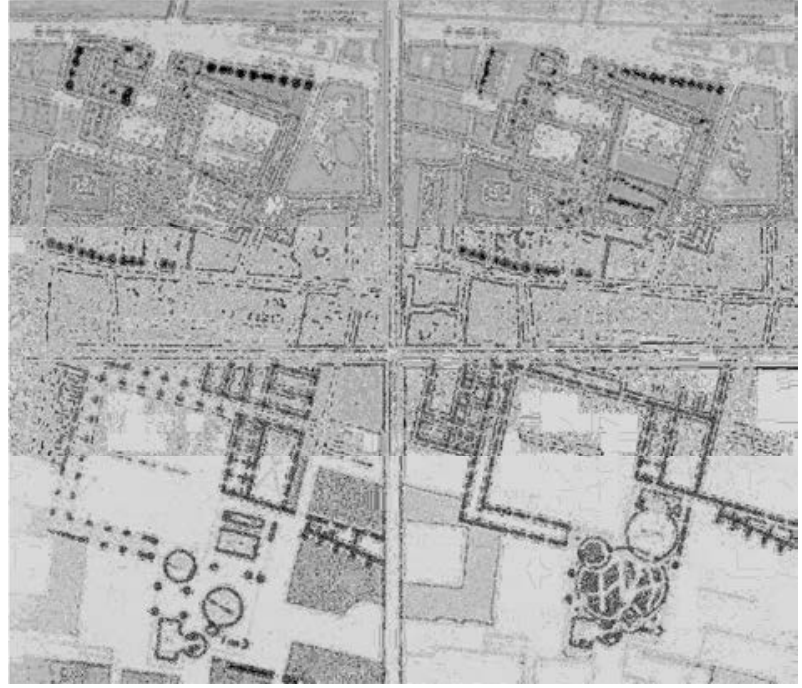

Para Aymonino a cidade possui um significado se for encontrada morfologicamente uma homogeneidade de representação arquitetônica, uma relação precisa entre a forma urbana e a escala dos edifícios (ANTONUCCI 2005, p 73).

Como intervenção urbana, o autor entende, mesmo que seja parcial, que estabeleça uma idéia geral; para isto estabelece duas condições: a primeira que assumem as formas urbanas como elementos historicamente precisos e catalogáveis segundo juízos de valores (história da arquitetura, ciência urbana); enquanto que a segunda que assumem as imagens urbanas, como elementos subjetivos, a precisar relativamente à história presente - nova projetação - com predominância da Morfologia Urbana (AYMONINO 1973, p 21).

Como Aymonino, acreditamos que as intervenções urbanísticas baseadas na análise de transformações urbanas ocorridas ao longo dos anos, ora gerando expansão do território urbano ora reconfiguração do tecido degradado, devem ser identificados seus agentes políticos, econômicos e sociais. As mesmas intervenções como significado da "nova imagem da cidade" devem representar a "atualização" do tecido urbano e sua dinâmica, mas também garantir a permanência da história do lugar e suas relações sociais.

Diferentemente dos italianos, os pesquisadores franceses possuem sua história mais recente. Na segunda metade do século XX, a França apresentava um crescimento demográfico e econômico característico do pós-guerra, resultando na produção em grande escala de habitações sociais. Apoiados nos princípios da Carta de Atenas construíam alojamentos de padrões mínimos (PANERAI 2006), resultando no geral em obras de má qualidade, tanto em sua concepção quanto execução. Assim, a França chega aos anos 80 com uma degradação urbana e social latente.

$\mathrm{Na}$ academia, a maioria dos profissionais atuantes no país e em especial em Paris, era influenciada pelos elementos formais do Movimento Moderno, no qual dominavam a Escola de Beaux Arts, convertendo-a no lugar do laissez-faire (deixar-fazer) absoluto. É perceptível a falta de reflexão teórica nas escolas e são comprovadas pela falta quase total de publicações.

"A cidade era ignorada na esfera do ensino assim como na das práticas urbanísticas, onde o problema da habitação só era entendido como expansão urbana para áreas cada vez mais longínquas"(ANTONUCCI 2005, p 75). 
Estes fatores culminaram na criação de uma nova escola, ainda no final dos anos 60 , que respondesse as tendências e problemáticas das cidades pós-guerra. Fundada pelo arquiteto Jean Castex e o sociólogo Jean-Charles Depaule, a Escola de Arquitetura de Versalhes surge como uma "reação à arquitetura modernista e sua conseqüente rejeição a história” (PANERAI 2006).

A nova escola francesa foi beneficiada por um grupo de pesquisadores e intelectuais sobre a vida urbana, que extrapolava a arquitetura: como por exemplo, o sociólogo Henri Lefèbvre e os historiadores da arquitetura Françoise Boudon e André Chastel, que naquele momento dedicaram suas pesquisas na evolução histórica dos arredores de Paris. Por outro lado, a figura dos professores Philippe Panerai e Jean Castex foi fundamental para o aprofundamento da sondagem das dimensões teóricas e metodológicas sobre a análise urbana, tendo como referência os trabalhos de Muratori, até então desconhecido na França.

Como contribuição a estas análises, segundo Antonucci (2005), uma série de estudos estavam sendo realizados entre os anos 70 e 80 , substituindo significativamente com as análises da forma urbana na França: Elementos de Análise Urbana (1980) - Philippe Panerai, Jean Castex e Jean-Charles Depaule; Leitura de uma Vila: Versailles (1977) Katherine Burlen, J. Castex, Patrick Celeste, Catherine Furet e Panerai; Morfologia Urbana e Tipologia Arquitetônica (1977) - Ahmet Gulgonen e François Laisney; e Le Creusot (1981) - Christian Devillers e B. Huet. ${ }^{32}$

Os estudos de Philippe Panerai, em particular na Análise Urbana, em muito contribui para nossas pesquisas detidas nesta tese. No livro Formes Urbaines: De l'ílot a la Barre, resultante de pesquisas realizadas entre 1974-75 e publicado pela Gustavo Gili em 1985, analisam o declínio da quadra (ílot - em francês) por meio de revisão de um século de intervenção urbanística examinando cinco exemplos paradigmáticos. ${ }^{33}$

Poderíamos aqui registrar outras obras de mesmo valor e importância na trajetória de Panerai ao longo de suas pesquisas a respeito da análise da forma urbana nas cidades, como por exemplo, os estudos realizados ainda na década de 70 (1975), em conjunto com Depaule e Marcelle Demorgon sobre os princípios de análise urbana, publicado em 1980 sob o título Urban Analysis Éléments(Elementos de Análise Urbana). Seus autores estabelecem que para compreender a cidade é necessário:

“... participar modestamente da elaboração de um conhecimento misturando, de modo impuro, a pesquisa histórica, a geografia, o trabalho cartográfico, a análise arquitetônica, a observação construtiva e dos modos de vida... Conhecer a forma das cidades, reconstituírem sua história, é também orientar uma forma de projetar"(PANERAI, DEPAULE e DEMORGON, in ANTONUCCI 2005, p 78-79). ${ }^{34}$

A obra dos autores procura estudar a forma urbana identificando sua organização e, os elementos de composição, como os mesmos descrevem abaixo:

32 . Ainda segundo Denise Antonucci, outros trabalhos do gênero tipo-morfológico devem ser incluídos: Antoine Grumbach e Jean Louis Cohen sobre Paris; Jean Castex sobre Versalhes; Philippe Bourdon sobre a cidade de Richelieu; Bruno Fortier sobre cartografia; Alain Boirie sobre parcelamento; David Mangin e Panerai sobre nova imagem do urbanismo francês.

33. Analisa-se a Paris de Haussman; as cidades-jardins inglesas; a expansão de Amesterdam de Berlage; os Siedlung de Ernest May - Frankfurt, e a Ville Radieuse de Le Corbusier.

34 . Tradução do autor, 2011

... Participer à l'élaboration d'un savoir modeste de mélange, donc impur, la recherche historique, la géographie, le travail cartographique, l'analyse architecturale, l'observation et des moyens constructifs de la vie ... Connaissant la forme des villes, de reconstruire son histoire, est aussi une manière directe à la conception. 
“A análise urbana permite... definir o lugar teórico do projeto"(1999).

Cabe afirmar que uma obra de Panerai em especial consideramos essencial para as análises e discussões do tema colocado neste capítulo e na tese como um todo. Traduzido por Francisco Leitão com revisão técnica de Sylvia Ficher (UNB) em 2006, Análise Urbana chega ao Brasil como um estimulante à contribuição à teoria e à prática do desenho urbano. ${ }^{35}$

$\mathrm{Na}$ apresentação da obra feita por Sylvia Ficher, fica claro a importante contribuição tanto ao academicismo como a prática do desenho urbano:

“... muito de minhas pesquisas foi influenciado pela perspectiva intelectual que seus estudos (Philippe Panerai) me proporcionaram" (Sylvia Ficher in PANERAI 2006, p 7 - grifo nosso).

Ainda em suas primordiais reflexões sobre a publicação, Ficher se deteve sobre a possibilidade de investigação com que a análise urbana nos fornece sobre a cidade:

"Como se vê, a análise urbana é uma atividade peripatética por excelência. Requer disposição para andar e observar, ou para se sentar em algum barzinho bebendo uma caipirinha, ir a alguma festa local, botar o carro na estrada e procurar os limites da mancha urbana, esmiuçar tanto o seu centro como os seus confins" (Sylvia Ficher in PANERAI 2006, p 7 ).

Por fim, confirma a qualidade e importância da contribuição do autor para os estudos urbanos:

"Além de um precioso manual de iniciação ao fenômeno 'cidade', trata-se de uma fonte de inspiração para novas pesquisas, para a ampliação do campo de investigação..., podem ser estudados de inúmeras maneiras, por infindáveis métodos e enfoques" (Sylvia Ficher in PANERAI 2006, p 8 ).

Afirmando a importância desta obra como ferramenta a compreensão do desenho da cidade e sua análise urbana, o autor não deixa de considerar as crises econômicas e urbanas, resultado disto se pôs sobre a urbanização da segunda metade do século XX no qual "mudou ainda mais radicalmente a paisagem; o volume das próprias edificações, seu modo de implantação, as técnicas utilizadas indicam uma ruptura" (PANERAI 2006, p 11).

Diferentemente da primeira edição, publicada em 1999 (Analyse Urbaine), o autor reve os textos suprimindo dois capítulos julgados excessivos por tratar-se do debate acadêmico francês. No entanto acrescentará um capítulo dedicado a Brasília. No mais, seus capítiulos introduzem a noção de "território' sobre o qual a paisagem se estabelece e de 'paisagem urbana' dela resultante" (PANERAI 2006, p 13 - grifo nosso), no qual coloca o trabalho e pesquisa sobre a visão da grande escala.

Como leitura da paisagem, o autor utiliza estudos de pesquisadores já consagrados como Camillo Sitte e Kevin Lynch, apropriando-se de seus métodos de análise (visual e sequencial), no qual a primeira trata dos percursos, pontos nodais ou núcleos, setor, limites, marcos, abstratído da obra de Lynch, enquanto a segunda se centraliza nos elementos que constituem a paisagem por meio de análise direta realizada no próprio

35. Os estudos sobre o desenho urbano já vinham sendo realizados por Nestor Goulart Reis Filhoem São Paulo a partir de 1970 e Vicente Del Rio no Rio de Janeiro desde a década de 1980. 
local. "A idéia consiste em isolar e reconhecer em sequência os 'quadros', que são como que disposições esquemáticas e codificadas da paisagem" (PANERAI 2006, p. 40), em que o autor defini um conjunto de dados e sobreposições que irão auxiliar na leitura da cidade (simetria/assimetria, definição lateral/definição central, abertura/fechamento, convexidade/concavidade). Tais dados gera novas análises e definições de outros parâmetros, direção ao ponto de fuga e fechamento da imagem.

Suas análises discorrerão sobre as diversas escalas e irão tratar dos elementos constitutivos da análise, no qual para esta tese torna-se de grande valia como contribuição para nossas hipóteses levantadas: os "Tecidos Urbanos" são estudados na escala intermediária, enquanto as "Tipologias"(PANERAI 2006) abre o debate entre 0 "saber arquitetônico e o saber urbano".

Para Panerai, o tecido urbano é constituído pela superposição ou imbricação de três conjuntos (2006, p 77-78): a rede de vias, os parcelamentos fundiários e as edificações.

"A análise do tecido urbano é feita pela identificação de cada um desses conjuntos e pelo estudo de sua lógica e de suas relações..." (PANERAI 2006).

Quanto às tipologias, o autor empregará as definições dos estudiosos italianos como Aymonino ou Durand, como idéia de análise da arquitetura em termos de elementos. Como método de análise Panerai utilizará as pesquisas desenvolvidas por Muratori e Aymonino. Assim, para o autor, "... um tipo é um objeto abstrato, construído pela análise, que reúne as propriedades essenciais de uma categoria de objetos reais e permite explicá-las com economia" (2006, p 127).

Devemos ressaltar ainda que os resultados alcançados pelos pesquisadores franceses, e em especial Philippe Panerai, possuem grande importância na "análise do cadastro urbano", que nas palavras de Solà-Morales (1997)é "enciclopédico e minucioso quanto à temática", em que a análise não se limita aos monumentos ou obras singulares, diferentemente da afirmação de Rossi em sua obra (A arquitetura da cidade), mas privilegiará as arquiteturas ordinárias, como colocado por Antonucci: “... que se concretizaram a partir dos parcelamentos do solo, das constantes tipológicas, constituindo-se em elementos de composição do agregado" (2005, p 79).

Assim, o autor conclui, numa forma de reorganizar as idéias colocadas até este momento em seu livro:

"Na cidade, o morador, o visitante ou o turista é também um ator", e ainda completa, "... a presença da história, a carga simbólica, as lembranças pessoais ou os fenômenos de moda fazem com que tal rua, tal praça ou tal lado de uma avenida tomem uma importância particular e que a cidade sem eles pareça diminuída" (PANERAI 2006, p 164).

No Brasil os estudos referentes à morfologia urbana foram explorados a partir de 1970 por Nestor Goulart Reis Filho sobre a evolução da tipologia residencial no Brasil, desde o Império até a década de 1940. Sua obra intitulada "Quadro da Arquitetura no Brasil" relacionava a arquitetura com as estruturas urbanas e com as condições de evolução social e cultural, assegurando as condições de uso e a produção da arquitetura sobre 0 lote, reconhecendo sua evolução como condição a se adaptar-se a nossa realidade. 

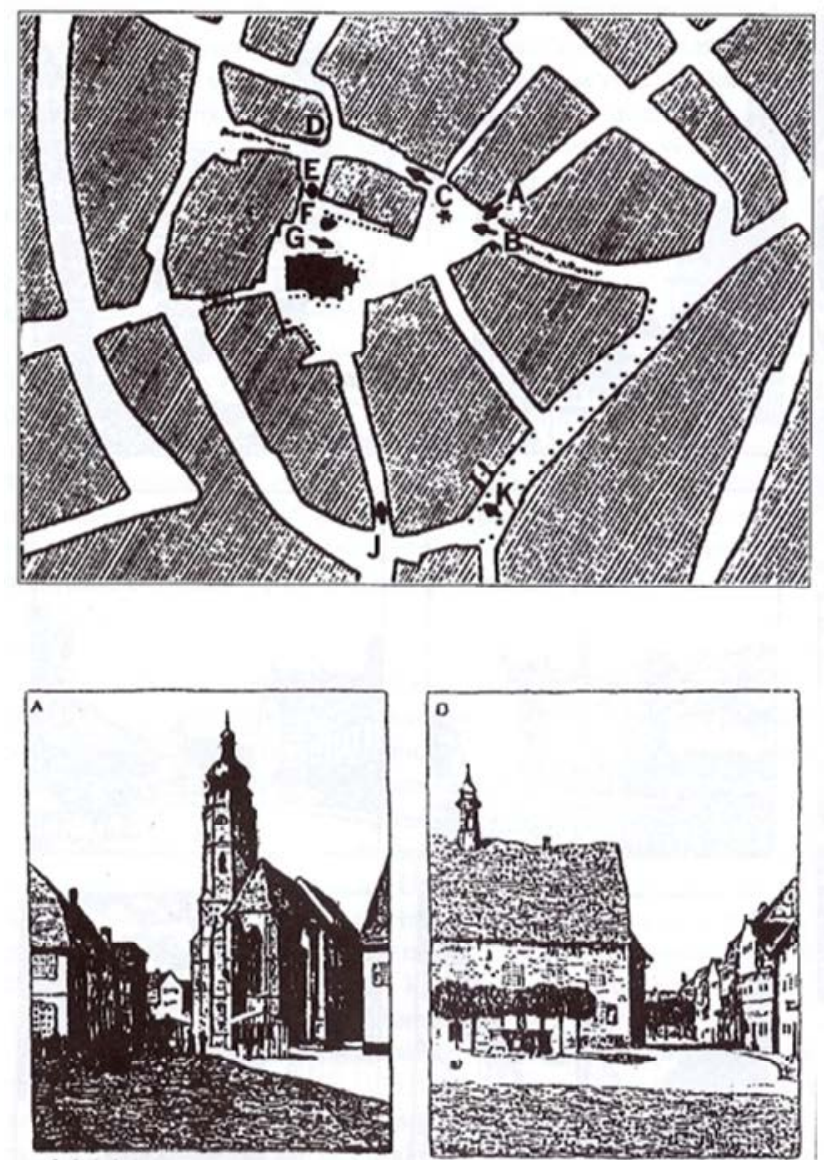
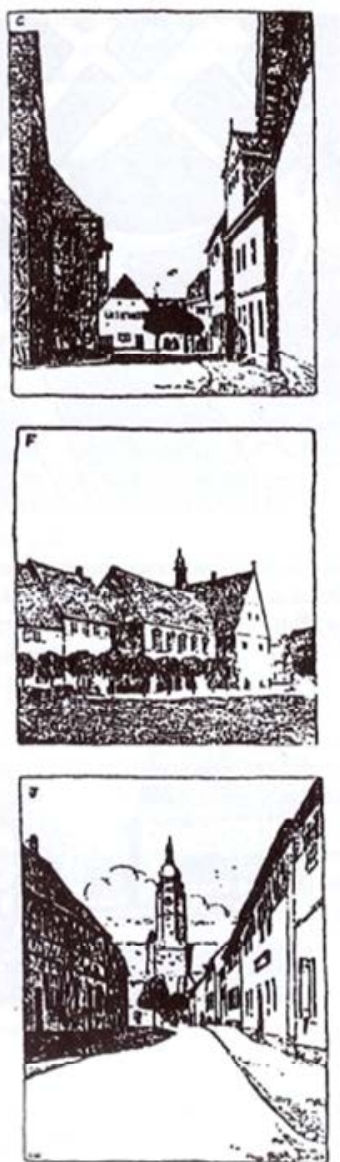
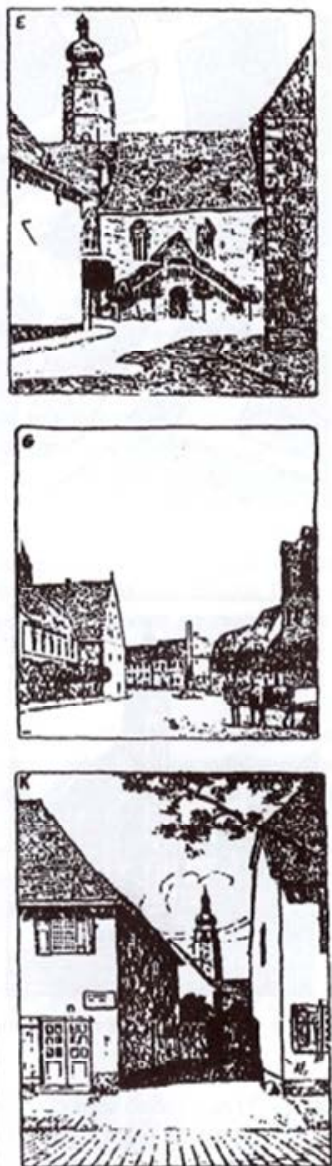

Figura 26. O movimento segundo Raymond Unwin Buttstedt: mapa e seqüência de uma das partes da cidade

Fonte: Raymond Unwin, Town planiing in pratice, 1900

Figura 27. A análise da morfologia urbana no estudo da evolução de um quarteirão de Versalles, França, por Panerai

Fonte: Desenho Urbano no processo de planejamento, 1990
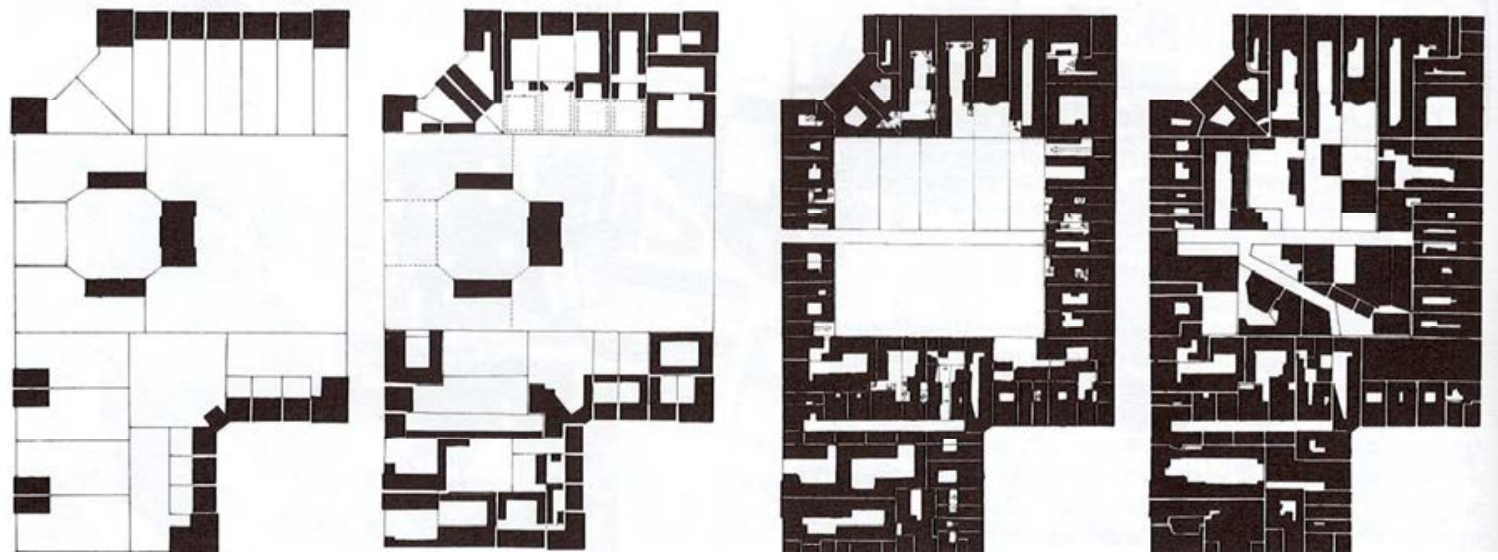
A obra reúne ensaios sobre os modelos de arquitetura urbana utilizados no Brasil e suas estruturas em que estão inseridos. Trata-se, essencialmente da análise da morfologia urbana sem pretensão de se "criar uma metodologia" capaz de subsidiar futuros estudos. No entanto sua obra torna-se uma importante referência para os pesquisadores sobre este tema.

Apesar de seus estudos referenciarem diretamente as cidades brasileiras, é notória a semelhança às análises propostas por Muratori na Itália:

"Tentando encarar os fenômenos arquitetônicos com a objetividade de uma abordagem científica, tínhamos necessidade de superar os limites das análises de problemas puramente formais, para relacionar a arquitetura com um quadro mais amplo, especialmente com as estruturas urbanas e com as condições de evolução social e cultural no Brasil (...)"(REIS FILHO 2006, p 9-10).

Segundo Aragão (2006), o sociólogo, arquiteto e historiador demonstra as relações entre a arquitetura e o tipo de lote em que está implantada:

"Não é difícil constatar que os lotes urbanos têm correspondido, em princípio, ao tipo de arquitetura que irão receber: os lotes medievo-renascentistas à arquitetura daqueles tempos, os lotes mais amplos do século XIX e início do século $X X$ às casas com jardins particulares e, finalmente, as superquadras à complexidade dos programas residenciais recomendados pelo urbanismo contemporâneo"(REIS FILHO 2006, p 16).

Apesar da extensa literatura com que o autor trata o tema em questão - tipologia, desde as análises e discussões sobre o lote urbano e a arquitetura no Brasil, passando pela descrição sobre a arquitetura brasileira no século XIX até suas conclusões a respeito do patrimônio da cultura, percebemos que sua pesquisa se detém sobre as transformações do espaço construído - as edificações - ou as alterações nas plantas. Poucas vezes, contudo, os estudos dos tipos serão aplicados aos espaços não construídos que compõem o tecido urbano e a cidade. No entanto, "o texto de Nestor Goulart demonstra que por meio do estudo dos tipos de habitação, relacionados ao lote e à estrutura urbana, pode-se caracterizar paisagens diversas, de épocas distintas"(ARAGÃO 2006, p 41).

No que diz respeito aos estudos relacionados aos elementos de análise da Morfologia Urbana, podemos afirmar que um dos pioneiros no Brasil foi Vicente del Rio. Como apontado por Miguel Pereira (1990), del Rio "procura seu próprio lugar neste contexto", contribuindo através de suas teorias e práticas para uma nova disciplina que fluía sobre a academia, a disciplina de Desenho Urbano.

Neste contexto, vale notar que a adesão a essa escala de projeto, torna-se crescente entre nós, a partir da década de 1990, sem que as bases dessa discussão estivessem presentes, tão pouco discutidos nas escolas de arquitetura daquela época.

Resultado de seu mestrado em Desenho Urbano (Oxford Polytechinic 1981) e com origem de uma tese, elaborada em 1989, para inscrição em concurso de professor titular em planejamento urbano na FAU/UFRJ, a publicação Introdução ao Desenho Urbano no processo de planejamento (1990) tornaou-se um importante instrumento e base para estudos e trabalhos no que tratam do Desenho Urbano, suas origens, definições, teorias e metodologias básicas. Segundo David Gosling - professor e diretor do Centro para Desenho Urbano, Universidade de Cincinnati, EUA, o livro de Vicente del Rio é altamente significativo no que condiz: 
“... um dos teóricos urbanos de ponta no Brasil e sua pesquisa em desenho urbano começou a cobrir o abismo entre o planejamento urbano e o projeto de arquitetura;... é apenas através de tão profundas investigações que estratégias racionais de ocupação territorial podem ser propostas de uma maneira lógica" (GOSLING in del RIO 1990, p 9).

Organizado em duas partes, em que são tratadas as origens e definições possíveis do Desenho Urbano, levando em consideração o contexto histórico no processo de planejamento urbano:

"Veremos como e porque surgiu o campo disciplinar a partir de todo um contexto crítico propício nos anos 60, quais as suas características básicas para tentar formar um corpo conceitual coerente em torno a uma definição de Desenho Urbano que responda ao contexto brasileiro"(del RIO 1990, p 12).

A obra ainda se deterá sobre o papel do Desenho Urbano no processo de Planejamento Urbano, propondo ainda uma metodologia possível de investigação em nosso contexto:

“... este enfoque parte de quatro categorias complementares às que o próprio Planejamento Urbano nos legou; são discutidos os conceitos e metodologias básicos das categorias de 'morfologia urbana', 'análise urbana', 'percepção ambiental' e 'comportamento ambiental'” (del RIO 1990, p 12).

Assim, como conceito del Rio propõem quatro temas para pesquisa da morfologia urbana (1990, p 83), expondo as lógicas evolutivas e estruturadoras da cidade, tendo como referência pesquisadores como Rossi, Castex, Panerai entre outros: Crescimento, Traçado e parcelamento, Tipologias dos elementos urbanos, Articulações.
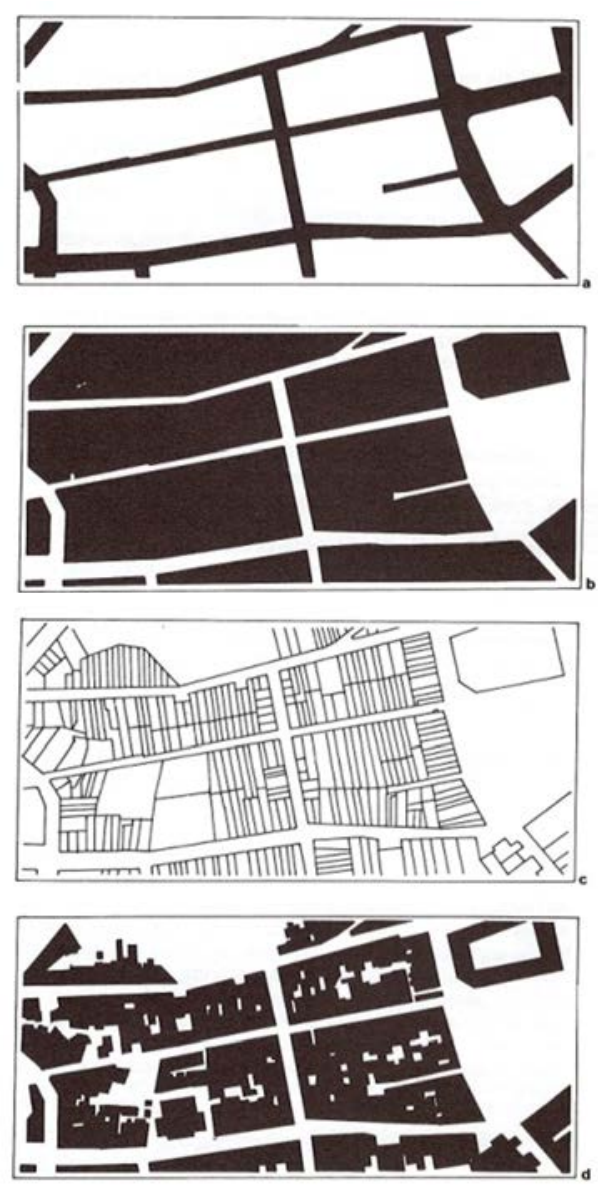

Figura 28. Plantas figura-fundo destacando malha viária (a), espaço privado (b), perfil fundiário (c) e espaço construído (d); Saúde, Zona Portuária, Rio

Fonte: Desenho Urbano no processo de planejamento, 1990 
Ainda segundo o autor, o Desenho Urbano "define-se pela criação do domínio público, que corresponde o espaço público, um 'constructo' físico e formal, assim por suas instituições publicas, um 'constructo' político e econômico..."(del RIO 1990).

Assim, a implantação do Desenho Urbano no Brasil deve buscar duas áreas básicas e fundamentais: a primeira de ordem administrativa governamental (em ambos os níveis de governo), mas principalmente o municipal no qual se detém maior domínio do desenho da cidade, enquanto que a segunda deveria ser de ordem acadêmica denunciando a importância da inserção do Desenho Urbano como disciplina nos cursos de graduação de Arquitetura e a criação do ensino da temática em cursos específicos de Pós-graduação, demonstrando já naquele momento a preocupação em difundir uma metodologia capaz de analisar e gerar propostas de intervenções urbanas em nossas cidades. Nisto, como "novos caminhos", Vicente del Rio finaliza:

“... na esperança de que nossa potencialidade criativa transforme a vida urbana e seu espaço em fontes de prazer e liberdade" (del RIO 1990, p 121).

Influenciados pelas teorias de Vicente del Rio, outros pesquisadores começam a demonstrar seu interesse pela análise da morfologia urbana. Ao final do século XX, novas pesquisas utilizando a metodologia sugerida pela morfologia urbana vieram a público nos encontros da ANPUR - Associação Nacional de Pós-Graduação e Pesquisa em Planejamento Urbano e Regional, em destaque para os trabalhos de Maria Elaine Kohlsdorf e Renato Cymbalista.

Como contribuição acadêmica, apesar de nos aprofundarmos mais à Faculdade de Arquitetura e Urbanismo de São Paulo - FAUUSP, as referências sobre Morfologia Urbana e Tipologia Arquitetônica são ainda escassas e em sua maioria vinculadas a área do Paisagismo. Em nossa área de interesse - Projeto Urbano - podemos destacar os trabalhos de Wakisaka (1991), Taralli (1993), Rivaben de Sales (1999), Lagreca de Sales (1999 e 2008), del Rio (1999), Reis (2002) e Antonucci (2005).

Em sua maioria, os autores citados acima vão estudar a morfologia urbana em seu conceito, essência e resultados sobre o tecido urbano em que os instrumentos se comportam perante os resultados das intervenções urbanas e como desenho urbano.

Wakisaka e Taralli têm como base de suas pesquisas as questões legislativas e suas aplicações sobre o desenho da cidade, enquanto que Antonucci, por sua vez, se deterá sobre as análises da forma urbana a partir da Legislação Urbanística capaz de transformar a paisagem da cidade:

"São ressaltados dois aspectos: de um lado a identificação da legislação que determina configurações espaciais; de outro, as tipologias de tecido urbano existentes e a relação das tipologias com as referidas configurações que lhe deram origem"(ANTONUCCI 2005, p 9 - grifo nosso).

Rivaben, Lagreca e Reis apresentam em suas pesquisas acadêmicas instrumentos e estratégias utilizadas no enfrentamento das transformações urbanas como contribuição aos projetos de intervenção em áreas de obsolescência, territórios privilegiados. Cada autor se utiliza de um objeto, ou mais objetos de estudo, para expor suas análises e conclusões: Reconversão Urbanística do Porto de Santos, no litoral do Estado de São Paulo (P. M. SALES 1999); o mesmo aparece na tese de Vicente del Rio, no qual tem como objeto a revitalização de área central no Rio Janeiro junto a Zona Portuária da capital carioca (del RIO 1999), Eixo Tamanduateí e a Linha Férrea (M. M. SALES 1999); ou mesmo os estudos: Projeto Recife-Olinda (M. M. SALES 2008) e, Transformações, 
formas e processos decrescimento na llha de Santa Catarina - Florianópolis (REIS 2002), que mesmo não tendo como referência intervenções paulistas são de grande importância para a contribuição desta tese.

Pelos trabalhos analisados, percebe-se nas abordagens nacionais a busca incessante de meios/instrumentos para entender, intervir e requalificar nossas cidades:requalificação de espaços; recriação de espaços coletivos; reformulação dospróprios processos de crescimento "desordenado" das cidades (ANTONUCCI 2005, p 101).

Recentemente estudos relacionados aos efeitos dos instrumentos urbanísticos e do zoneamento na configuração dos tipos de tecido urbano, as configurações imobiliárias e sua aplicação no planejamento de bairros, o arquiteto e professor Candido Malta Campos Filho publica em 2003 o livro Reinvente seu bairro. Neste livro, de caráter didático e linguagem acessível, apresenta a moradia como foco principal.

A principal contribuição desta obra se dá na incorporação das formações produtivas imobiliárias de cada tipologia em detrimento da formação do tecido urbano. Tal discussão é acompanhada de um conjunto de croqui do autor em busca de concretizar seus conceitos e defesas para o desenho da cidade.

Nota-se no decorrer da leitura da obra de Campos Filho, que as análises e propostas do autor são colocadas numa compreensão do desenho da cidade de forma tridimensional, resultando na espacialidade dos espaços da cidade de fácil compreensão da dinâmica de transformação urbana.

Figura 29. Os tipos básicos de tecido urbano Fonte: Reinvente seu bairro: caminhos para você participar do planejamento de sua cidade, 2003

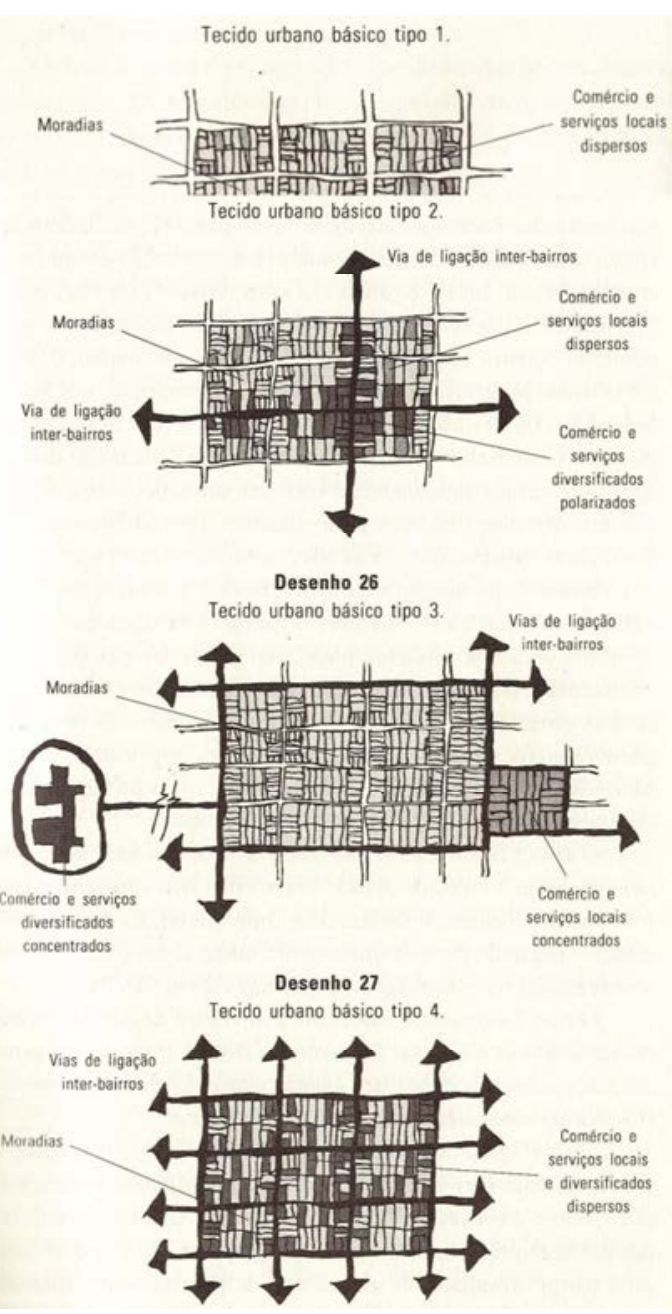




\subsection{Morfologia Urbana | Teorias Contemporâneas}

Ao tratarmos das teorias adotadas por pesquisadores contemporâneos, entendemos que a contribuição italiana, e mesmo a francesa, foi fundamental no sentido de unir as escolas de Morfologia Urbana existentes até o momento e, formatar o ISUF (International Seminar On Urban Form) ${ }^{36}$, ajudando a ampliar e difundir as pesquisas realizadas sobre a Morfologia Urbana em diversas partes do mundo.

Segundo Denise Antonucci (2005), apesar da suposta complexidade genealógica adotada pelo ISUF, com diferentes intenções e missões, além das diferenças culturais e linguísticas entre anglo-saxões e latinos, "os primeiros encontros do ISUF em Lausanne incrementaram a intensidade de trocas entre as escolas", numa rica e intensa sociabilidade entre as pesquisas realizadas, tendo como resultado "uma nova geração de pesquisadores em Morfologia Urbana", produzindo trabalhos comparativos nas três escolas.

Esta "aproximação" entre os diversos pesquisadores, segundo Moudon (1997), foi importante para identificar certas semelhanças entre as pesquisas realizadas até então, e reconhecendo, em seu nível mais elementar, a análise morfológica pode ser baseada em três principios (MOUDON 1997, p 7): ${ }^{37}$

1. Forma urbana é definida por três elementos físicos fundamentais: edifíciose respectivos espaços abertos, terrenos ou lotes, e as ruas;

2. Forma urbana pode ser entendida em diferentes níveis de resolução. Comumente, quatro são reconhecidos, o que corresponde à construção / lote, o bloco / rua, a cidade e a região;

3. Forma urbana só pode ser entendida historicamente desde os elementos de que é composta sofram uma transformação contínua e de reposição.

Então forma, solução e tempo, segundo Moudon constituem três componentes fundamentais da pesquisa em Morfologia Urbana. Está presente em todos os estudos, seja de geógrafos ou arquitetos, seja seu foco as cidades medievais, barrocas ou contemporâneas.

Neste sentido, podemos afirmar que os tecidos urbanos são grupos de edificações, espaços abertos, lotes e ruas, que forma um todo coeso ou porque foram construídos ao longo dos anos ou dentro dos mesmos parâmetros, possibilitando a criação de um processo de transformação do desenho da cidade e de sua forma urbana.

É a partir da segunda metade do século XX que os teóricos vão buscar respostas às propostas do Movimento Moderno, as posições dos CIAMs e à Carta de Atenas. A

36. ISUF tem por objetivo compartilhar as idéias, métodos e descobertas sobre a forma urbana. Com início de suas atividades em $1994 \mathrm{com}$ a união de cerca de 20 arquitetos, geógrafos, urbanistas e historiadores, representando quatro áreas de linguagem diferente, hoje conta com cerca de 600 membros individuais e institucionais de cerca de 50 países. Atualmente é presidido pelo Professor Michael Conzen (2013), Universidade de Chicago, EUA.

37 . Tradução do autor, 2011

1. Urban form is defined by three fundamental physical elements: buildings and their related open spaces, plots or lots, and streets;

2. Urban form can be understood at different levels of resolution. Commonly, four are recognized, corresponding to the building/lot, the street/block, the city, and the region;

3. Urban form can only be understood historically since the elements of which it is comprised undergo continuous transformation and replacement. 
rejeição a política da "tabula rasa", a necessidade de recuperar a tradição histórica, a obsolescência da separação das funções urbanas e as possibilidades de novos olhares sobre as cidades contemporâneas.

"A noçãode necessidade, central ao urbanismofuncionalista, que se baseia no conhecimentoobjetivo doprofissional, a quem se consideracapaz de definirquais são asnecessidades, aspiraçõese desejos doscidadãos semsua opinião, passa a ter do desejo,uma noção queé a vontadee o envolvimento ativodo sujeito" (SANCHEZ in FERRO 2010, p 17). ${ }^{38}$

A partir deste momento, a cidade começa a ser estudada com novos métodos, instrumentos e ferramentas, tendo como ponto de partida um conjunto de dados e fatores, desde aspectos como a arquitetura, a paisagem, a imagem, a sociedade, ou a habitabilidade.

Os arquitetos e urbanistas assim começam a trabalhar com métodos de análises que até então não eram levados a cabo, considerando a transformação do tecido urbano e as formas da construção, constituindo novas formas de análise urbana e formas de investigação sobre a cidade e definindo linhas de pensamentos baseados agora na revisão dos estudos e seus elementos, suas variáveis e limites segundo cada objeto e resultado obtido.

Assim, segundo Ferro:

"A análise morfológica permite identificar a forma urbana e sua relação com o tipo, mas a distância entre o tipo e a forma da estrutura da cidade tem sido motivo de discussão levando a um problema não resolvido"(2010, p.21). ${ }^{39}$

Desta forma, podemos destacar o trabalho realizado pelos pesquisadores catalães que analisam as relações entre a forma urbana e a transformação das cidades em função de aspectos históricos, sociais e econômicos.

Na Espanha, a década de 1950 é marcada com Regionalismo crítico em reação ao domínio do Movimento Moderno, liderado por J.M. Sostre e Oriol Bohigas, a fundação do Grupo R em Barcelona, provocou uma nova discussão da forma urbana e sua análise. Os diversos impulsos culturais que constituíram esteRegionalismo heterogêneo tendem a confirmar a natureza inevitavelmentehíbrida da cultura regional moderna(FRAMPTON 1997, p 383).

Em 1968, foi fundado o LUB - Laboratório de Urbanismo da Escola Técnica Superior de Arquitetura Universitat Politécnica de Catalunya, tendo com diretor o arquiteto e pesquisador Manuel de Solà-Morales i Rubió. Devido sua criação sob o período de transição entre o final franquista e a democrática, adquiriu importante status na discussão e compromissos com a recuperação urbanística de Barcelona.

38 . Tradução do autor, 2011

La noción de necesidad, central en el urbanismo funcionalista, que descansa en el conocimiento objetivo del profesional, a quien sien se considera capaz de definir lo que constituyen las necesidades, aspiraciones y deseos de los ciudadanos sin contar con su opinión, se sustituye por la de deseo, una noción que supone la voluntad y la implicación activa del sujeto.

39. Tradução do autor, 2011

El análisis morfológico permite identificar la forma urbana y sus relaciones con la tipología, sin embargo la distancia entre la tipología y la forma de la estructura de la ciudad ha sido motivo de discusión que lleva a una problemática no resuelta. 
De mesmo valor e importância, a Escola de Barcelona foi um elemento impulsor das discussões e criticas que afloravam, sob duas frentes inter-relacionadas: o discurso crítico elaborado pela Revista Bis (1974), e os esforços conjuntos no sentido de transformar a tessitura da cidade. Novamente a figura de Bohigas (Delegado de Urbanismo entre 1981-84), com a ajuda de antigos membros graduados da Escola de Arquitetura de Barcelona. ${ }^{40}$

"Dois fatores tornaram esse programa de reconstrução único: a intenção de restaurar a cidade sobre a base de um aterro gradual, e a determinação por parte da municipalidade de transformar o plano em realidade"(FRAMPTON 1997, p 410).

A forma analítica dos catalães apresenta um campo mais amplo que a estrita observação "tipomorfológica" dos seus precursores italianos e franceses, no qual, "sua originalidade está em buscar um estilo especifico de análise para projetar a cidade"(ANTONUCCI 2005, p 82 grifo nosso).

Neste panorama, é Solà-Morales que se torna figura proeminente na elaboração teórica da Escola Catalã, representados primeiramente pelo artigo publicado em 1969 - Sobre la Metodologia Urbanística. Passou a descartar esquemas urbanos ideais e formais, assim como o funcionalismo derivado do modernismo racionalista (ANTONUCCI 2005, p 82), e mais tarde, já no final da década de 1990, com o livro Las Formas de Crecimiento Urbano, com um "olhar ampliado" da proposta italiana de análise e observação, tendo o objeto de planejamento no processo de crescimento urbano (M. M. SALES 1999).

Resultado do programa do curso de mesmo nome do livro, de Urbanística I, inicialmente elaborado em 1971-72, propõe um olhar próprio e um estilo específico para a análise urbana.

O que Solà-Morales coloca em questão neste curso é a análise da cidade em que "o estudo do crescimento urbano se planejará como uma análise das relações entre as diferentes formas de crescimento (morfologia urbana) e as forças sociais que constituem o motor e o conteúdo" (SOLÀ-MORALES i RUBIÓ 1997, p 11). ${ }^{41}$

A visão do pesquisador esta diretamente relacionada ao trabalho contínuo do "planejador" ao "arquiteto", em que meios e fins não podem isolar-se. Proposta e programa não podem ser separados, porque existe uma relação dialética entre as formas e o conteúdo, os meios e os fins, que podem transformar substancialmente os esquemas iniciais(M. M. SALES 1999, p 13).

"Urbanismo não é um processo linear do geral para o particular, do objetivo ao instrumento: é um sistema duplo biunívoco, de interação em ambos os níveis"(SOLÀMORALES in M.M.SALES 1999, p 11).

Os estudos de Solà-Morales tinham como referência a estrutura física das cidades como hipótese metodológica para a ordenação do território, não se podendo entender 0 espaço apenas como hipótese das relações sociais:

40 . Entre os arquitetos estavam Frederico Correa, Manuel de Solà-Morales, Luis Domenech, Helio Piñon, Rafael Moneo e o filósofo Tomás Llorens.

41. Tradução do autor, 2011

El estudio del crecimiento urbano se planteará como un análisis de las relaciones entre las diferentes formas de crecimiento (morfología urbana) y las fuerzas sociales que constituyen el motor y el contenido. 
“... as formas urbanas e as formas do território importam como materialde análise e projeto, na medida em que são o resumo das leis próprias deconstrução do espaço, das atividades dos habitantes, e dos interesses emconflito que sua apropriação comporta"(SOLÀ-MORALES et ANTONUCCI 2005, p 83).

A metodologia analítica e operativa do autor enfatiza a idéia do "conhecimento da identidade do território" como possibilidade para a sua própria transformação, tendo como elemento-base a decomposição conceitual da forma urbana em três elementos essenciais que tem lugar nos processos de gestão que deram a forma: Parcelamento, Urbanização, Edificação $(\mathrm{P}+\mathrm{U}+\mathrm{E})$, estabelecendo uma nova compreensão da cidade (não mais o conceito ideal unitário) a partir de sua visão como "uma soma conflitiva de fragmentos reais", de uma cidade que se constrói e se consolida por meio de projetos (parciais) (ANTONUCCI 2005, p 84 grifo nosso).

"Estas três operações não são atos simultâneos nem encadeados sempre de igual maneira. Ao contrário, muitas das suas formas de combinar-se no espaço, se origina da riqueza morfológica das cidades" (SOLÀ-MORALES i RUBIÓ 1997, p 19). ${ }^{42}$

As diferentes maneiras de organizar as ruas, parcelas e edificações são formas de compreensão do parcelamento, urbanização e edificação, que em diferentes combinações dão lugar a diversas formas urbanas; a forma urbana é o resultado de idéias e projetos sobre a forma de urbanização.

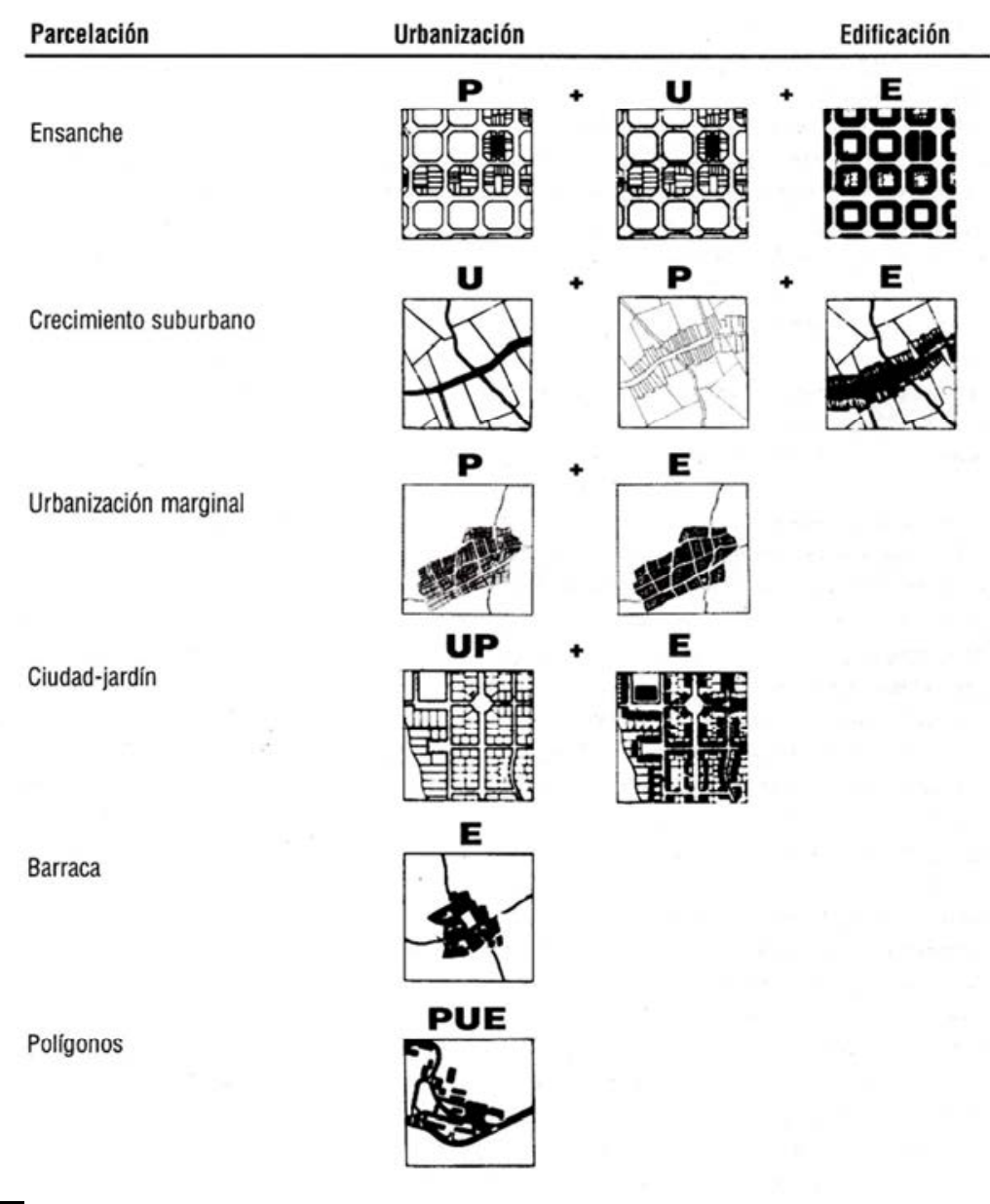

Figura 30. As formas do crescimento urbano

Fonte: Las formas de crecimiento urbano, 1997

42 . Tradução do autor, 2011

Estas tres operaciones no son actos simultáneos ni encadenados siempre de igual manera. Al contrario, de sus múltiples formas de combinarse en el espacio, se origina la riqueza morfológica de las ciudades. 
Solà-Morales (1997) afirma que "os resultados dos estudos da forma construída das cidades permitiram aprovar a eficácia do método morfológico".

Sob uma nova ótica, Manuel de Solà-Morales publica em 2008 o livro "De cosas urbanas", na qual se tem a lógica abstrata da cidade como "coisas urbanas", onde a urbanidade esta co-relacionada ao concreto, a riqueza latente e aos lugares urbanos.

Solà-Morales irá propor nesta obra a possibilidade de novos olhares sobre a cidade, estabelecendo a continuidade das diferenças e valores (tamanhos, escalas, pontos vitais, atributos adjetivos) aplicados sobre o método da Acumpuntura Urbana.

"A pele das cidades é feita de construções, texturas, contrastes. De ruas e espaços livres, de jardins e muros, de perfis e vazios" (M. d. SOLÀ-MORALES 2008, p 23). ${ }^{43}$

Para o autor a pele da cidade, instrumento do arquiteto urbanista, mostra experiências e sensações reais de trabalho, útil e substancial em si mesmo. "Intervir na pele da cidade tem, assim, certa analogia com a ação da acupuntura" (M. d. SOLÀ-MORALES 2008, p 25).

"Estou buscando em alguns dos meus trabalhos uma acupuntura urbana como proposta projetual concreta, e como abordagem metodológica para um urbanismo físico, até talvez fisiocrática" (M. d. SOLÀ-MORALES 2008, p 25). ${ }^{44}$

Solà-Morales propõe esta "nova leitura" a partir de três "Cosas Urbanas" (Coisas inventadas, Coisas sobrepostas, Coisas em conflito), traduzidas e exemplificadas em projetos urbanos realizados nas últimas duas décadas (1990-2010) interpretando os limites entre a arquitetura e o urbanismo cujos efeitos transcendem o âmbito físico de sua intervenção:

Novamente Solà-Morales propõem um novo olhar sobre a morfologia urbana e novas ferramentas de leitura e intervenção sobre o tecido urbano.

"Não basta misturar os usos e funções; às vezes concordar em congestionar os contatos materiais, as referências mentais, muitas ordens de urbanidade, outras tantas identidades" (M. d. SOLÀ-MORALES 2008, p 143). ${ }^{45}$

Neste sentido, para Solà-Morales (2008) o Projeto Urbano agora pode estar muito mais "ancorado" nas estratégias do que nas soluções materiais (edifícios), "com intenções acupunturais sobre a pele urbana para afetar o organismo inteiro (...), para confiar na troca da riqueza dos materiais na capacidade de construir a urbanidade contemporânea".

Com teorias semelhantes, Josep Maria Montaner propõe a leitura da cidade por meio do que ele defende ser "Sistemas" como capacidade de desenvolver formas que se adaptam melhor aocontexto contemporâneo.

43. Tradução do autor, 2011

La piel de las ciudades está hecha de construcciones, texturas, contrastes. De calles y espacios libres, de jardines y muros, de perfiles y vacios.

44. Tradução do autor, 2011

Ando buscando en algunos de mis trabajos una acupuntura urbana como propuesta proyectual concreta, y como actitud metodológica de un urbanismo físico, hasta fisiocrático quizá.

45 . Tradução do autor, 2011

No basta mezclar los usos y las funciones; a veces convendrá congestionar los contactos materiales, las referencias mentales, los muchos órdenes de urbanidad, otras tantas identidades. 
Figura 31. Projetos Urbanos propostos por Solà-Morales a partir do conceito das "coisas urbanas" Fonte: cosas urbanas, 2008

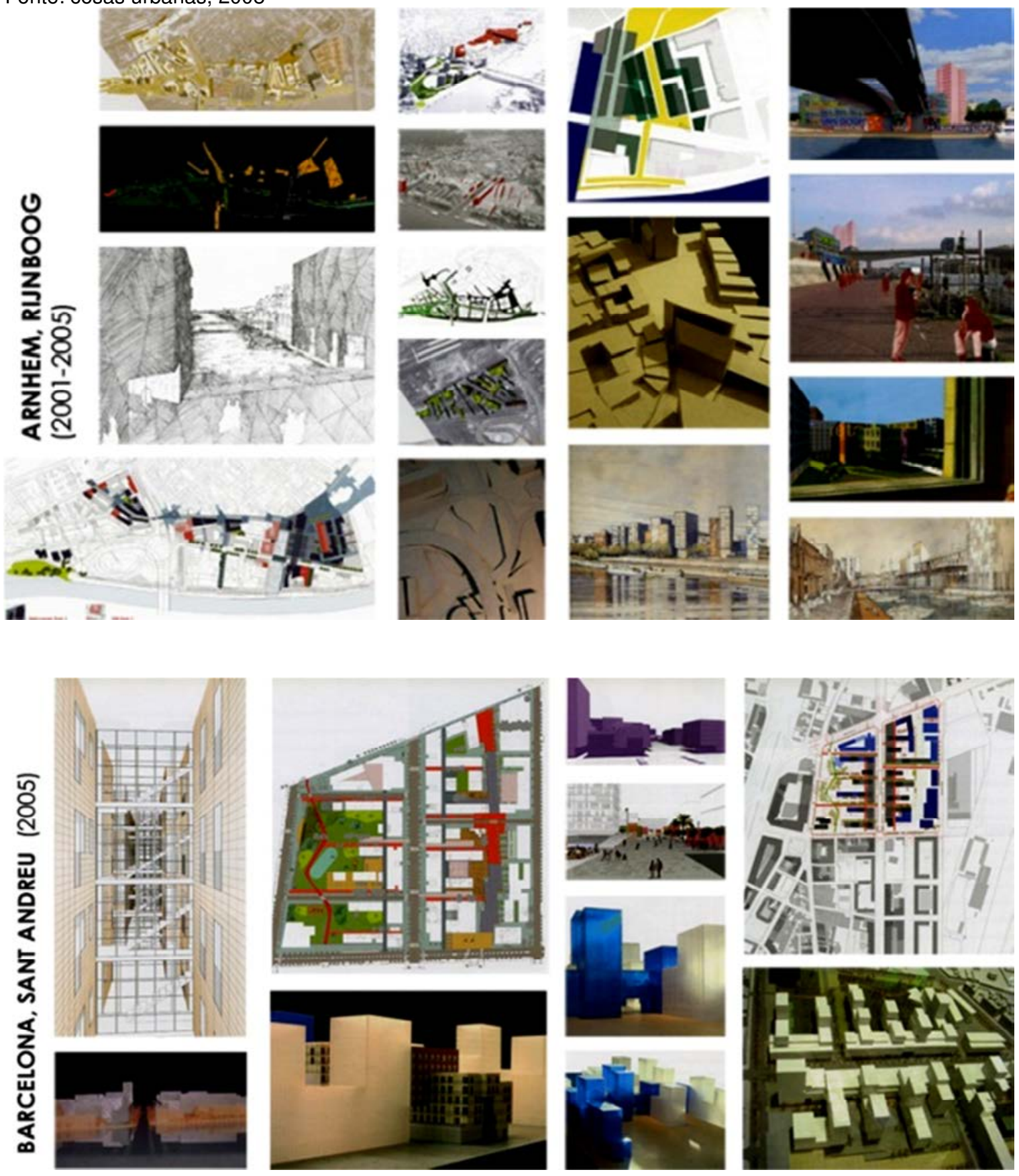


Publicado em 2008, o livro Sistemas Arquitectónicos Contemporáneos coloca em pauta uma nova visão da arquitetura contemporânea, desde princípios do século XX até as primeiras décadas do XXI, que parte da crise do objeto isolado, colocando principal ênfase nas relações entre os edifícios e os valores do espaço público que o definem.

"Entendo, portanto, que um sistema é um conjunto de partes heterogêneas (material ou não), de escalas distintas, que estão relacionados entre si (...). Cada parte do sistema está em função de outra; não existem partes isoladas..." (MONTANER 2008, p 11). ${ }^{46}$

Apesar da obra de Montaner tratar essencialmente da arquitetura e sua relação com o desenho da cidade, no que se refere esta tese, o texto Redes y nodos coloca em pauta a discussão da arquitetura (edifício) como transformador da imagem da cidade.

"A cidade, como criação humana, é um acúmulo de infraestruturas de redes sobrepostas: abastecimento de água e energia, saneamento, telecomunicações e circulação" (MONTANER 2008, p 201), ${ }^{47}$ o autor defende a existência de uma morfologia em rede, definidos entre a massa horizontal contrapostas às torres que emergem.

Ainda assim, Montaner identifica um conjunto de obras no que ele as relaciona ao "delírio da arquitetura como espetáculo", em obras puramente visuais, isoladas do contexto urbano e criadas para serem percebidas visualmente, mas dificilmente para ser vivida ou experimentada.

"No entanto, nas últimas obras do Nouvel o delírio da imaterialidade e energia tem levado a pura cenografia urbana, como na torre Agbar, em Barcelona (19952005), ou obras que são apenas um acúmulo de experiências visuais, como 0 Museu du Quai Branly, em Paris (1999-2006)" (MONTANER 2008, p 204 grifo nosso).

Assim como os catalães, a contribuição dos franceses para a análise da cidade contemporânea rendeu novos métodos e ferramentas que possibilitam a discussão e a reformulação do desenho da cidade "consolidada". É notória a presença de Panerai neste panorama tanto acadêmico quanto no exercício profissional de seus ateliês. No entanto é com a publicação do texto Ville áge III (A terceira era da cidade), de autoria de Christian de Portzamparc, originalmente em francês (1997), ${ }^{48}$ em que o arquiteto propõe um novo olhar e "classificação" entre a cidade tradicional, em contraposição a cidade contemporânea e uma terceira vertente sobre a cidade em que hoje vivemos.

Durante os anos 1960, Portzamparc começa a interessar-se pelo Urbanismo Moderno, pelo fato de que Paris estava sendo reconstruída, passando a ter um "cenário urbano" e uma planta de cidade moderna. Para ele, a cidade moderna era pura e limpa, totalmente integrada ao tempo, num reconhecimento mútuo entre o passado e a cidade atual.

\footnotetext{
46. Tradução do autor, 2011

Entiendo, por tanto, que un sistema es un conjunto de elementos heterogéneos (materiales o no), de distintas escalas, que están relacionados entre sí (...).Cada parte del sistema está en función de otra; no existen elementos aislado.

47 . Tradução do autor, 2011

La ciudad, como creación humana, es un cúmulo de redes infraestructurales superpuestas: abastecimiento de agua y energía, saneamiento, telecomunicaciones y circulación.

48. O texto foi traduzido por Denio Munia Benfatti, professor da FAUPUC - Campinas e publicado pela Revista Óculum \#9 ainda no mesmo ano.
} 

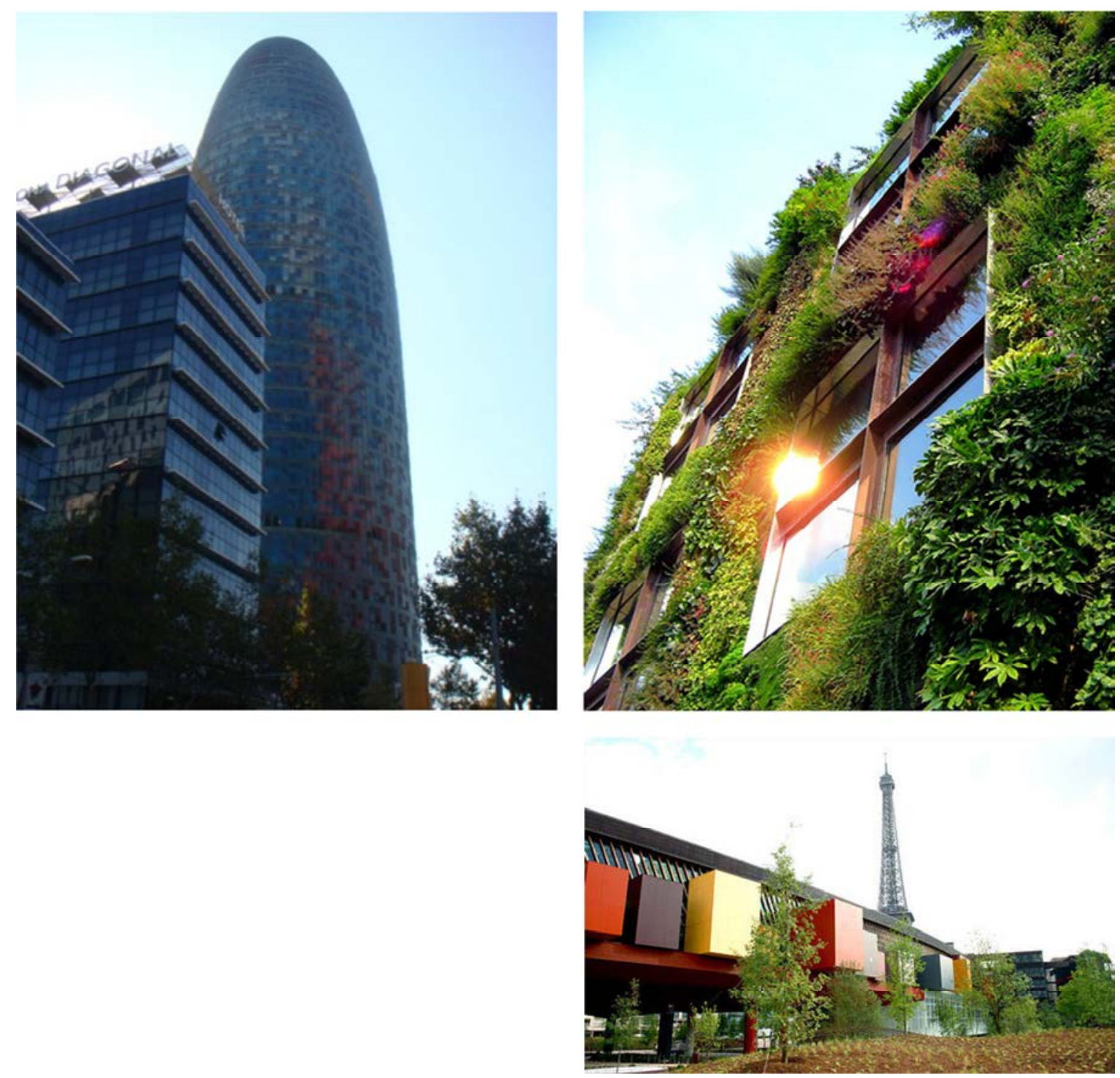

Figura 32. Torre Agbar em Barcelona e Museu du Quai Branly em Paris (direita detalhe da fachada do Museu), projetos do arquiteto Jean Nouvel

Fotos: Elvis Vieira, 2009 e 2011 
No entanto, Portzamparc sintia-se incomodado com os conceitos aplicados a cidade moderna onde deveria-se destruir boa parcela do tecido urbano das cidades "original" em detrimento da higienização urbana, ou em função do automóvel. ${ }^{49}$

Segundo Benfatti (1997), o urbanismo passava por um momento de reflexão e análise não apenas sobre os aspectos urbanísticos e sobre o ideário moderno, mas também sobre toda matéria sedimentada da cidade.

"Hoje estamos tateando o novo, e o vazio que acompanha esta busca facilita e reforça a tendência à regressão e a necessidade de apego rápido às tradições mais recentes" (BENFATTI 1997, p 31).

Ainda em Benfatti, o autor irá recorrer à idéia de que a cidade em seu sentido tradicional ganha de novo certa importância:

“... fala-se em um retorno à cidade, de uma redescoberta dos valores da cidade. Mas que valores são esses exatamente? De que cidade ou parte delas estamos falando? E para que situação específica estamos propondo esta volta a cidade?" (1997, p 31).

São sobre estas indagações que, segundo Benfatti, Christian de Portzamparc centraliza suas pesquisas sobre a cidade no que ele nomeia como a Terceira Era da Cidade (Ville âge III).

"Quando comecei a falar de uma 3a Era (Âge III), de uma 'terceira cidade' para designar nosso tempo, nossa época, foi com o intuito de tentar compreender o momento atual, de resistir ao risco do imobilismo, e também de resistir à tentação oposta de uma saída fácil"(PORTZAMPARC 1997, p 36).

Portzamparc trabalha sobre a idéia de uma cidade ( $3^{\text {a }}$ Era) composta por elementos urbanos e tecidos existentes de outras épocas ( $1^{\underline{a}}$ e $2^{\underline{a}}$ Eras) relacionando-as entre si e, ao mesmo tempo, colocando em cheque a forma com que as cidades se transformaram ao longo dos anos, em especial durante o Movimento Moderno.

"Enquanto a 1a Era é contida, compacta, fechada como uma concentração defensiva, uma proteção contra a imensidão, contra o informe, o desconhecido, a cidade da $2^{a}$ Era desenvolve o movimento de conquista territorial e 'arrazoamento' do planeta, que é o grande destino do ocidente. A lógica é de libertar-se do lugar, das amarras, da matéria e, dentro em pouco, do corpo físico" (PORTZAMPARC 1997, p 40).

Assim, o autor propõe a uma análise das cidades contemporâneas respeitando as heranças das outras Eras da Cidade, porém possibilitando a invenção de novas formas de ocupação, a cidade da era das metrópoles, das grandes acumulações, das redes imateriais, e ainda de uma "dupla herança contraditória", resultando no seguinte conceito: $3^{\underline{a}}$ Era $=1^{\underline{a}}$ Era $+2^{\underline{a}}$ Era $+X(X=a$ incógnita atual, os novos dados $)$.

49. Naquele momento Paris passava por uma nova proposta onde se previa a destruição de $65 \%$ da cidade original. 


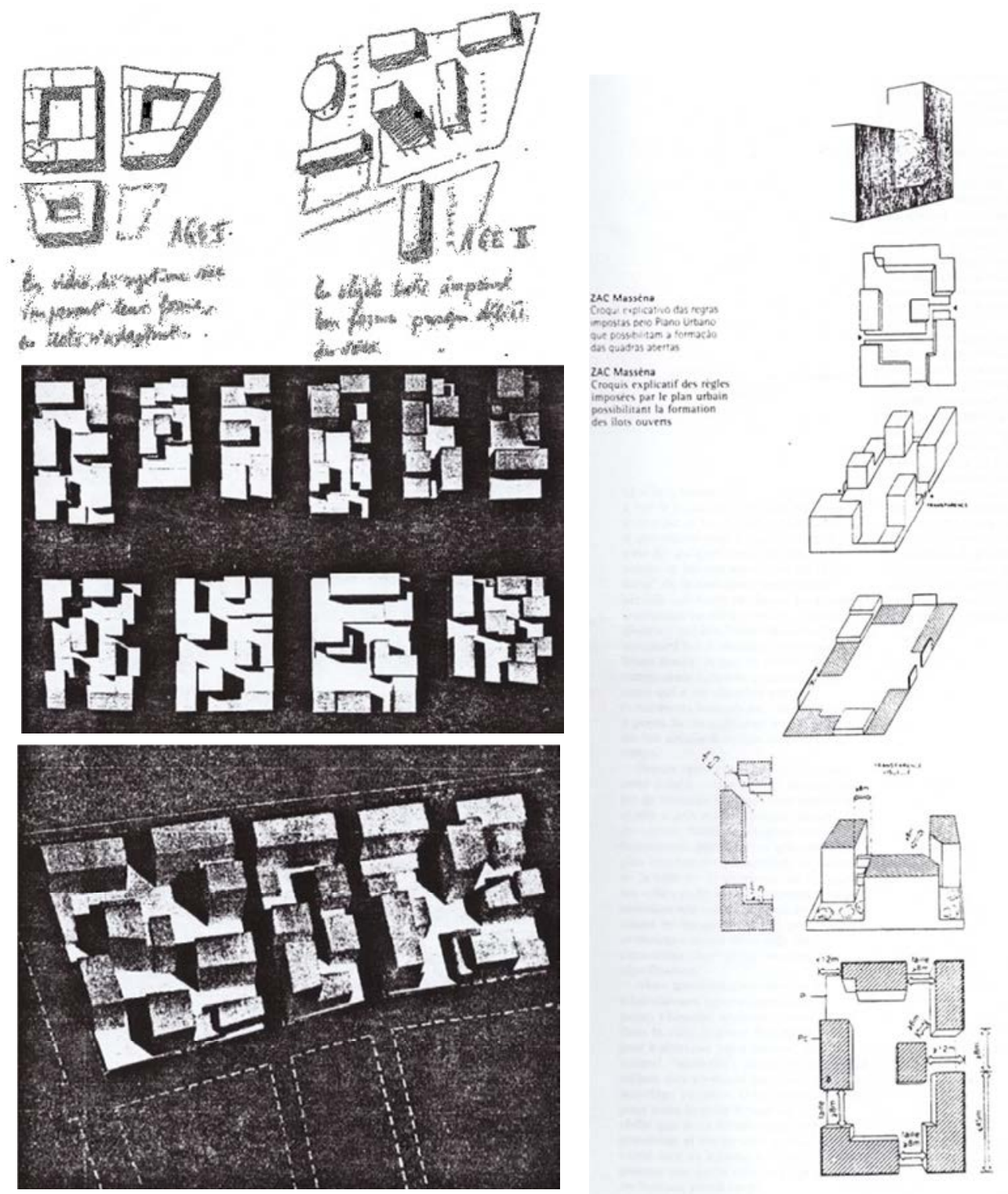

Figura 33. Estudos volumétricos de composição de quadras abertas Fonte: Revista Óculum \#9, 1997 
Apesar de Portzamparc não definir, tão pouco afirmar a uma "fórmula" de análise da cidade contemporânea, o mesmo possibilita a continua leitura de um tecido urbano em pleno desenvolvimento e transformação. Além disto, a leitura que o autor faz em suas pesquisas estão sempre compreendidas em uma "leitura tridimensional", onde a cidade, ou parte dela, é vista sobre três dimensões podendo-se medir suas conseqüências de forma mais concreta e segura.

A 3 $3^{\text {a }}$ Era (Âge III), segundo Portzamparc, é formada por arquipélagos de bairros que se costeiam, com uma diversidade de formas e condições resultantes de tecidos urbanos originais de sua formação, da sobreposição de intervenções recentes ou não, de áreas subutilizadas e/ou degradadas, numa superposição de diferentes idades.

"Dependendo do lugar, a 3" Era apresenta uma cidade a decifrar, a inventariar, a reciclar, mas também a inventar, a criar. Trata-se de cruzar lógicas e pensamentos diferentes em função dos bairros específicos" (PORTZAMPARC 1997, p 44).

Portanto, a contribuição das teorias, e mais tarde da aplicação concreta, do conceito da "quadra aberta" (Bloc ouvert - em francês) será de grande valia para esta tese no que condiz numa leitura sobre o tecido existente e em mutação ${ }^{50}$, possibilitando uma melhor análise sobre as transformações e futuras intervenções previstas.

Como colocado pelo autor, “... nossa época está caracterizada pelo crescimento constante da complexidade, a multiplicação dos pólos e dos critérios de decisão, a sofisticação e a diversificação das necessidades e das aspirações"(1997, p 46).

Da mesma forma, Portzamparc defende a pluralidade em que as novas intervenções urbanas devem conter, não somente em seus usos, mas também garantindo uma diversidade em seu cenário urbano com gabaritos múltiplos, enriquecendo a paisagem e cruzando as diferentes épocas da cidade.

Por fim, a arquitetura (edifício) é tratada como "corpos urbanos" que devem retomar a escala humana dentro do desenho das cidades, e assim, o autor recorre a uma "nova dimensão", mais sensível e conectado a identidade local e criando diversidade no desenho da cidade.

"Nas pequenas dimensões trata-se de reinventar uma espacialidade, um sentido de espaço não construído que perdemos. Ritmar a densidade, condensar e criar intimidades em locais específicos para abrir mais à frente zonas não construídas" (PORTZAMPARC 1997, p 49).

Mais recentemente a figura de Manuel Gausa Navarro, arquiteto e crítico de arquitetura espanhol, se destaca entre os pesquisadores da forma urbana e o desenho da cidade.

Professor da Universidad Politécnica de Cataluña (ETSAB) e da Escuela de Arquitectura de Génova vem atualmente se dedicando às pesquisas relacionadas ao tema desta tese, e em especial à transformação do desenho da cidade e seus cenários sobre a cidade contemporânea. ${ }^{51}$

50 . Apesar de nosso objeto de estudo não possuir as características físicas elencadas por Portzamparc, tão pouco os resultados de uma cidade em 3 Eras.

51. Manuel Gausa foi sócio-fundador em 1994 da editora Actar Arquitectura, dedicada a arquitetura e urbanismo. Entre 1991 e 2000 foi diretor da revista Quaderns d'Arquitectura i Urbanismo, publicação do Colegio de Arquitectos de Cataluña. 

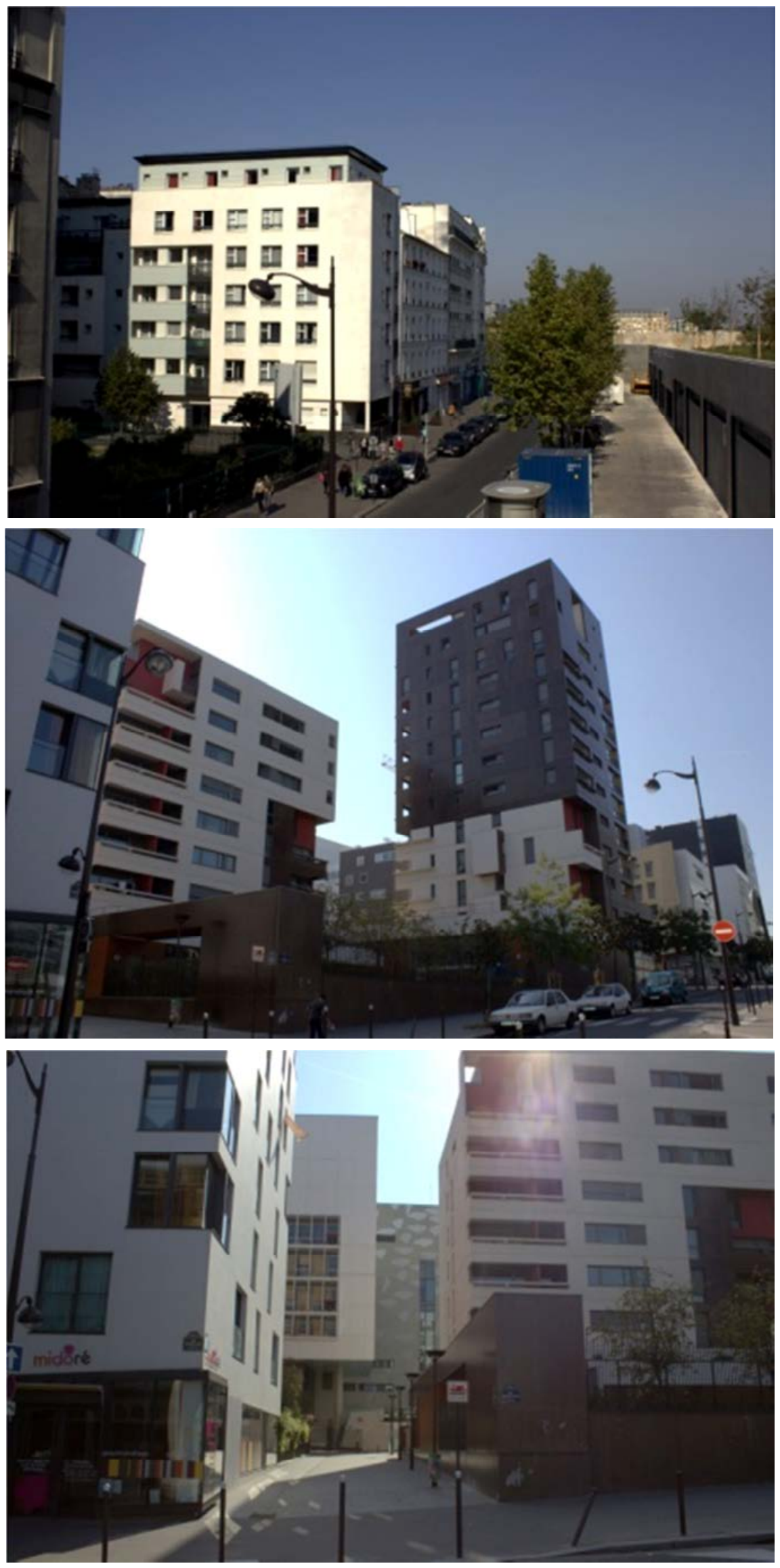

Figura 34.Bairro de Rive Gauche - Paris - França

Fotos: Elvis Vieira, 2011 
Autor de diversas publicações inicialmente dedicadas às questões habitacionais, mas sempre com a preocupação com o resultado com que o objeto arquitetônico (edifício) contribui para o desenho da cidade (urbanismo); ao longo dos anos desde a primeira publicação em $1994,{ }^{52}$ suas pesquisas e análises levaram às discussões relacionadas à morfologia urbana e a cidade contemporânea. Em 2010 Gausa publica o livro OPEN Espacio Tiempo Información: arquitectura, vivienda y ciudad contemporánea. Teoría e historia de un cambio, pela editora Actar de Barcelona. Resultado de sua tese de doutorado defendido em 2005 pela ETSAB-UPC, tal publicação será um marco no início do século XXI e um importante instrumento de pesquisa e análise sobre nosso tema: novas formas urbanas na cidade contemporânea.

"A principal tesequese defende é, com efeito, a emergênciadurante os últimos vinte anosde umnovo tipo depensamento- ou,se preferir,de uma nova lógica operacional - novos territórios associados a uma pesquisa - um novo 'mapa mental' - relacionado com uma concepção e organização mais aberta, dinâmica e irregular, do espaço; e, portanto, com uma formulação espacial - e uma veiculação - mais eficaz, sem preconceitos e relacionadas de informação (entendida em seu significado mais amplo, como vetor ativo de troca)" (GAUSA 2010, p 14). ${ }^{53}$

Em sua tese o autor propõe uma nova lógica relacionada à compreensão do entorno e aos sistemas dinâmicos em que as cidades estão suscetíveis entre as estruturas urbanas existentes e a capacidade de transformação do território a partir da alteração dos cenários urbanos.

Como proposta de análise da cidade contemporânea, Gausa aponta a "necessidade" de ler a cidade a partir de sua heterogeneidade e capacidade de mutação ao longo dos anos, concebendo num primeiro instante uma "leitura multiescalar" por meio de novos elementos que o autor denomina "tipos de dispositivos", como: lógicas, ordens, organizações, representações, sistemas etc, capaz de abordar as questões da dinâmica das cidades complexas, mutáveis, irregulares (GAUSA 2010), capaz de instrumentalizar a análise urbana.

"Neste sentido é que nos interessaria analisar aqui aquelas possíveis linhas de ação - e investigação - iniciais, propícias a favorecer uma eficaz implicação entre a abordagem contemporânea ao espaço local e global" (GAUSA 2010). ${ }^{54}$

Abordando a cidade contemporânea como um "organismo mutável" e em plena transformação pelas intervenções urbanas com que nas últimas décadas os administradores e agentes públicos são "forçados" a se adequarem às novas dinâmicas com que o tecido urbano, segundo Manuel Gausa (2010), é capaz de combinar lógicas

\footnotetext{
52. Além das várias colaborações em publicações e revistas, Manuel Gausa é autor dos seguintes livros:

- Housing: nuevas alternativas, nuevos sistemas (1994);

- Singular Housing (2000), junto a Jaime Salazar;

- Housing/Single family housing (2002), junto a Jaime Salazar;

- Diccionario Metápolis de la Arquitectura Avanzada (2001), junto a Willy Müller, Vicente Guallart, Federico Soriano, José Morales y Fernando Porras.

53 . Tradução do autor, 2011

La principal tesis que se defiende es, en efecto, la emergencia durante los ultimos veinte años de un nuevo tipo de pensamiento - o, si se prefiere, de una nueva lógica operativa - asociada a un nuevo territorio de búsqueda - a un nuevo 'mapa mental' - relacionado con una concepción y una organización más abiertas, dinámicas e irregulares, del espacio; y, por tanto, con una formulación espacial - y una vehiculación - más eficaz, más desprejuiciada y relacional de la información (entendida en su acepción más amplia, como vector activo de intercambio).

54 . Tradução do autor, 2011

En este sentido es en el que nos interesaría analizar aquí aquellas posibles líneas de acción - e investigación - iniciales, susceptibles de favorecer una eficaz implicación entre el abordaje contemporáneo del espacio local y global.
} 
genéricas (abstratas e globais) e lógicas específicas (concretas, locais), no qual o autor classifica de "saltos de escalas" entre os critérios gerais e particulares da morfologia urbana: Estratégicos, Táticos, Operativos.

Assim, o conceito de leitura, ou aproximação do objeto, através dos "dispositivos abertos" possibilita uma releitura dos pesquisadores até então estudados nesta tese, como defendido por Gausa: “... essas abordagens seriam encaminhadas, em última instância, a uma nova compreensão da cidade e das atuais organizações existentes..." (2010, p 21). ${ }^{55}$

Ainda a respeito da cidade contemporânea, o autor declara:

"A cidade contemporânea realmente parece, num primeiro momento e como já esperado, como a manifestação mais evidente dessa condição progressiva dinâmica do nosso entorno que estão subjacente em sua própria natureza, complexa e irregular" (GAUSA 2010, p 23). ${ }^{56}$

Resultando para o autor num objeto de investigação conceitual e empírico de suas análises, num primeiro momento como ensaios e buscas do que se deseja conhecer, e mais tarde como possibilidade de novos instrumentos de leitura da morfologia urbana sobre a cidade contemporânea.

A partir desta compreensão sobre conhecer a natureza das coisas para atuar sobre ela, o autor define um conjunto de instrumentos de análise no qual os julga passível de ser aplicados sobre a análise da morfologia urbana no tecido contemporâneo, manifestando assim, uma nova lógica projetual, propiciando uma possível rede de ligações, conexões e acordos entre os sistemas e estruturas urbanas existentes.

Por fim, podemos afirmar que o novo olhar proposto por Manuel Gausa em suas pesquisas e construção de dispositivos urbanos capaz de construir a leitura da cidade contemporânea está em consonância aos demais pesquisadores estudados nesta tese ao "alinharmos" os conceitos já utilizados no início do século XX por Argan, Sitte, Rossi, ou mesmo por pesquisadores contemporâneos como Montaner ou Portzamparc, cada qual com sua defesa e/ou "recorte urbano" em que se configuram.

A possibilidade de compreender este "novo olhar" sobre a cidade contemporânea nos foi de grande valia no enriquecimento das análises e discussões sobre a morfologia urbana e sua constante mutação sobre o tecido da cidade. O que Manuel Gausa propõe vem em encontro a uma leitura da cidade sobre diversas escalas e em terceira dimensão, possibilitando uma visão geral sob diversos aspectos como o urbano, o local, além de olhares extra-urbano relacionados diretamente sobre os resultados após sua aplicabilidade concreta no tecido urbano, abrindo novos olhares sobre o processo de gentrificação na área de intervenção.

55. Tradução do autor, 2011

...serían éstos planteamientos que remitirían, en última instancia, a una nueva comprensión de la ciudad y de las actuales organizaciones urbanas...

56 . Tradução do autor, 2011

La ciudad contemporánea aparecería en efecto, en un primer momento y tal y como ya se ha anticipado, como la manifestación más evidente de esa progresiva condición dinámica de nuestro entorno que subyacería en su propia naturaleza, compleja e irregular. 
“... projetos, portanto, que remete a possíveis 'camadas' da cidade: 'momentos' sintéticos (táticos) de 'movimentos' genéricos (estratégicos)" (GAUSA 2010, p 449). ${ }^{57}$

Projetos urbanos que como tal, possam se articular entre escalas e acontecimentos, dispositivos e esquemas que venham a interagir entre si como mecanismos próprios, onde a cidade contemporânea seja construída como resposta concreta às solicitações contingentes.

57 . Tradução do autor, 2011

...proyectos, pues, que remitirían a posibles "capas" de la ciudad: a "momentos" sintéticos (tácticos) de "movimientos" genéricos (estratégicos). 


\subsection{Morfologia Urbana como Método de Análise}

Construir um arcabouço de estudos, análises e conceitos a respeito da morfologia urbana de uma área de estudo não nos parece tarefa fácil, visto que ao nos aprofundarmos sobre o tema entendemos que o grande número de pesquisadores aponta a um conjunto de variáveis e possibilidades de leituras sobre o desenho da cidade, ora de forma "pontual" em sua essência, como por exemplo, os estudos elaborados por Camillo Sitte, Kevin Lynch ou Gordon Cullen, que se detiveram ao estudo da tipologia sob "olhares específicos" - a construção das cidades segundo seus princípios artísticos, a imagem da cidade ou a paisagem urbana consecutivamente estudada e analisada por cada pesquisador, porém ainda de forma isolada.

Tendo como referência o raciocínio de José Lamas (1992), em que o termo morfologia urbana designa ao estudo da estrutura e da configuração exterior ao objeto, ou seja, a morfologia enquanto "ciência que estuda as formas e as interliga com os fenômenos que Ihes deram origem", e ainda segundo o autor, "a morfologia urbana é a disciplina que estuda o objeto - a forma urbana - nas suas características exteriores, físicas, e na sua evolução no tempo" (LAMAS 1992, p 38), que podemos afirmar tratar-se do estudo da forma do meio urbano, tendo em atenção os elementos morfológicos e a construção tridimensional da paisagem.

Mais recentemente percebemos a preocupação de estudar e analisar o desenho da cidade a partir de diversos elementos com que a morfologia urbana é composta - sejam os programas quantitativos (densidades, fluxos, volumetria...), as utilizações (uso do solo), os elementos naturais (redes hídricas, geografia, paisagem,...), os processos (históricos, culturais, sociais), assim como sua relação entre o entorno, o que de modo geral, precede o Desenho Urbano.

Ao analisarmos as teorias formuladas por Manuel de Solà-Morales i Rubió, em especial os conceitos expostos no livro Las Formas de Crecimiento Urbano(1997), além da experiência de Oriol Bohigas e o próprio Solà-Morales para Barcelona, podemos observar uma nova forma de compreender o desenho da cidade e sua transformação a partir do entendimento de sua composição morfológica analisadas como combinação, no tempo e no espaço, dos processos de Parcelamento, Urbanização e Edificação $(\mathrm{P}+\mathrm{U}+\mathrm{E})$.

Do ponto de vista do projeto, "o conceito de morfologia esclarece-se por meio da distinção entre as formas da infra-estrutura e as formas do parcelamento"(SOLÀMORALES i RUBIÓ 1997, p 15), ${ }^{58}$ no qual para nossa tese, nos interessa o modo como qual o desenho da cidade se configura a partir da composição, ou decomposição, das formas urbanas com que a morfologia urbana se compõe.

Nesta mesma lógica, a proposta de análise apontada por Christian de Portzamparc nos demonstra a idéia de ordem e de vida urbana associada ao resultado com que a morfologia e o desenho urbano se comportam perante aos moradores das grandes cidades.

A contínua transformação das cidades, e no caso das análises de Portzamparc - a cidade de Paris resultou num "esquartejamento das cidades", promovendo a diversidade sobre o tecido e em sua forma urbana resultante das consecutivas intervenções e crescimento urbano. A divisão destes "períodos", no qual o autor os demonima de Eras (num total de três), como três cidades (autônomas ou não) fez com que pudéssemos identificar em que época nos encontramos. Como apontado por Portzamparc para

58. Tradução do autor, 2011

El concepto de morfología se ha de aclarar distinguiendo las formas de la infra-estructura de las formas del parcelario. 
designar "nosso tempo": "foi com o intuito de tentar compreender o momento atual, de resistir ao risco do imobilismo, e também de resistir à tentação oposta de uma saída fácil" (PORTZAMPARC 1997, p 36).

Neste sentido o que nos interessa na construção desta tese é a leitura tridimensional com que Portzamparc faz a respeito da $3^{\circ}$ Era da Cidade, a cidade ao qual hoje vivemos, conhecemos, intervimos, e que como método de análise, nos interessa a forma com que o autor propõe uma nova forma de ocupar o quarteirão (bloc - em francês) a partir do "miolo de quadra" com a diversidade de usos sobre o solo, agora, aberto e público.

"Reconhecer a cidade como acumulação, agregação, coexistência de épocas diferentes e por vezes contraditórias. O híbrido resultante é quase sempre o mais belo acabamento"(PORTZAMPARC 1997, p 43).

Da mesma forma com que Manuel Gausa nos apresenta um "novo olhar" sobre a cidade contemporânea colocando em pauta as transformações contínuas com que as mesmas passam e/ou estão sujeitas a se adequarem às novas condições urbanas globais.

"O surgimento de tal mudança tem marcado nas últimas duas décadas: a exploração, os seus progressos, as suas hesitações e transições, suas definições e concreções tem formado um quadro de ação compartilhada entre trajetórias diversas, especialmente envolvido com uma reinterpretação do urbano e/no geográfico"(GAUSA 2010, p 09 - grifo nosso). ${ }^{59}$

O que Gausa nos coloca é a possibilidade da análise da cidade através do método defendido em sua tese (ETSAB-UPC, 2005) sob a leitura dos dispositivos e esquemas, no qual a análise interescalar é capaz de abordar essa dimensão complexa, dinâmica, simultânea e mutável da morfologia urbana contemporânea.

Considerando as características específicas de cada território a ser explorado, estudado e analisado nesta tese, entendemos que a utilização de um método de análise da forma urbana sobre a cidade contemporânea nos seria fundamental para chegarmos às respostas necessárias às indagações colocadas como hipótese deste estudo. Não nos cabe aqui apontarmos a melhor e/ou mais eficiente análise urbana, tão pouco identificarmos as soluções adotadas pelos pesquisadores estudados neste capítulo, entendendo que cada qual teve seus conceitos e convicções à seu tempo, chegando à resultados plausíveis para a discussão que se colocava naquele instante. Por outro lado, não podemos deixar de mencioná-los como importantes contribuidores para nossos estudos, e que no qual, nos colocamos na condição de "espectadores" sobre o tema.

Para tanto, entendemos que a construção de novos métodos de análise da morfologia urbana não seria necessária, visto o conjunto de estudos já realizados pelos autores estudados, porém a "revisitação" e "contemporanização" do tema se tornam fundamentais para a adequação à realidade de nossas cidades, focando nos principais conceitos já estudados, relativizando-os e contextualizando-os à nossa história, cultura e relações políticas, econômicas e sociais.

Como já mencionado, não pretendemos aqui defender novos métodos ou "olhares" sobre a análise da cidade contemporânea, no entanto, a experiência acadêmica e a prática profissional nos possibilibitou construir um arcabouço teórico e prático sobre

59. Tradução do autor, 2011

La emergencia de dicho cambio ha marcado las dos últimas décadas: su exploración, sus anticipos, sus titubeos y transiciones, sus definiciones y concreciones han configurado un marco de acción compartido entre diversas trayectorias especialmente involucradas con una reinterpretación de lo urbano y/en lo geográfico. 
a "leitura da cidade" capaz de gerar resultados satisfatórios a partir de métodos analíticos, relacionando processos de crescimento e preexistências territoriais, incorporando dimensões processuais ao estudo da forma urbana e aprofundando a análise morfológica em função de variáveis históricas e urbanísticas. ${ }^{60}$

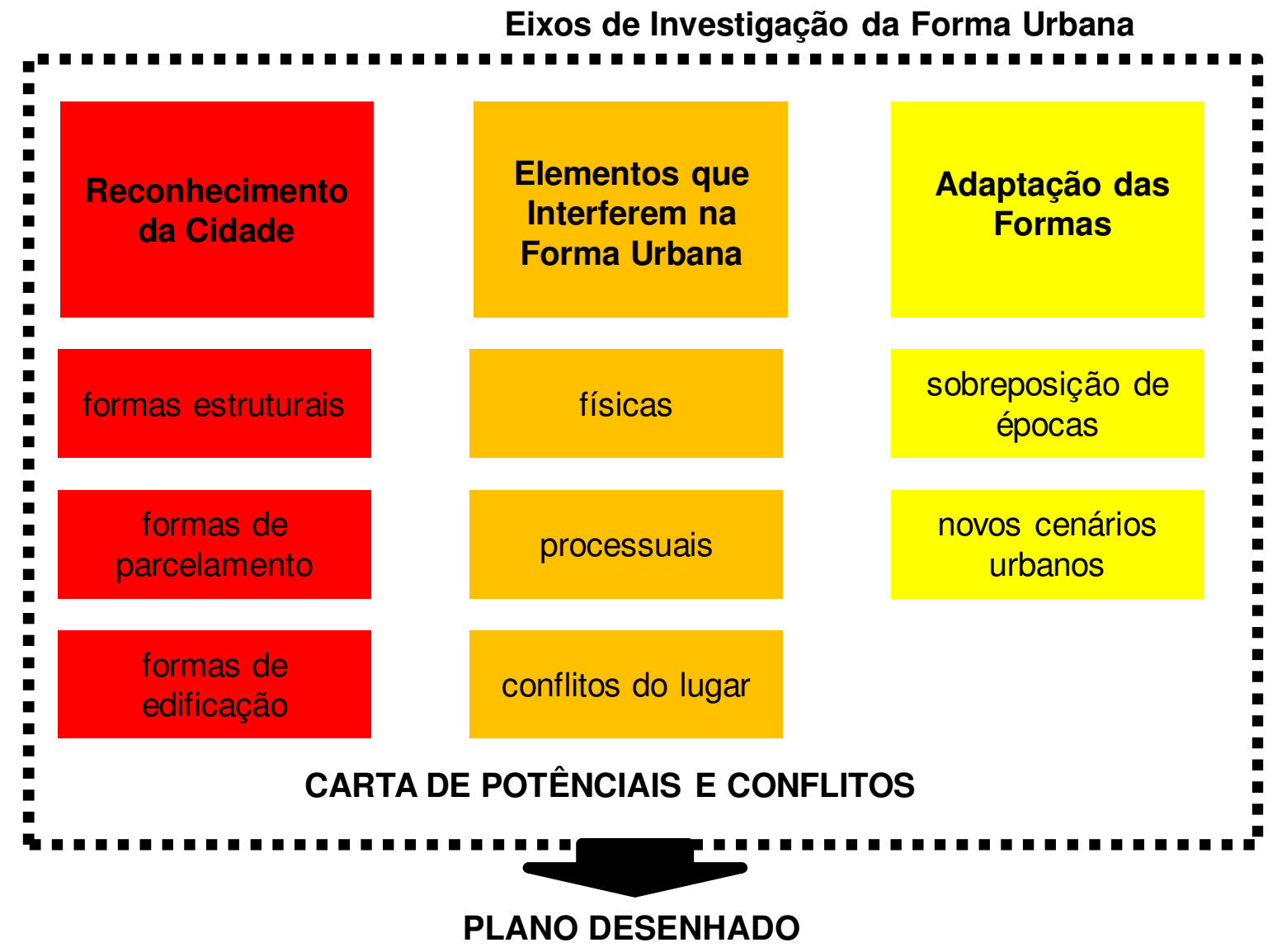

Figura 35. Diagrama dos Eixos de Investigação da Forma Urbana Organização: Elvis Vieira, 2010

Assim, defendemos que a "leitura da cidade" pode ser analisada a partir de Três Eixos de Investigação da Forma Urbana no qual se tem como objetivo desvendar os "potenciais" e "conflitos" com o qual a área de intervenção, direta ou indiretamente, possa ou esteja passando no momento de sua análise urbana, como se segue:

1. Reconhecimento da Cidade: eixo destinado às leituras das formas estruturais de ocupação e crescimento urbano, de forma interescalar e integrados entre os diversos territórios (local, entorno e global), possibilitando a primeira abordagem de análise urbana da área de intervenção, suas relações com o entorno próximo e interação com o tecido da cidade.

60. As experiências acadêmicas foram adquiridas desde 1998, primeiramente como monitor da disciplina de Projeto Urbano, sob responsabilidade dos professores Dr. Paulo Amaral e Dra. Marta Maria Lagreca de Sales, na FAUUBC. Mais tarde como professor auxiliar (2000-2002) e professor responsável (2003 até o momento) da disciplina de Projeto Urbano na FAUUBC e desde 2005 na FAUUMC. Profissionalmente estive no cargo de Secretário Adjunto de Política Urbana na Prefeitura Municipal de Suzano de 2005-2006 e atualmente ocupando o cargo de Diretor de Projetos Públicos - SMPU na mesma cidade desde 2007, responsável pela conceituação desenvolvimento e gerenciamento dos Planos e Projetos Públicos de Suzano. 
- formas estruturais: traçados viários, redes de infraestruturas, margens de rios e córregos, nós de circulação, grandes acessos;

- formas de parcelamento: o desenho do solo com toda variedade de formas, composições geométricas, por repetição ou espontâneas;

- formas de edificação: tipos, densidades, ocupado x não ocupado, alinhamentos $x$ construções, público $x$ privado.

2. Elementos que Interferem na Forma Urbana: eixo destinado à análise das variáveis do lugar, onde os elementos da forma urbana devem ser estudados como "objetos urbanos" capaz de transformarem o espaço urbano ao longo do tempo, de forma direta ou indireta, por ação de novas intervenções ou a degradação urbana, econômica e/ou social.

- físicas: situações topográficas / geográficas, infraestruturas urbanas, uso do solo, ocupação do solo, tipos de parcelamento, tipos edificatórios;

- processuais: significados históricos - culturais, processos de transformação ou substituição da forma urbana, aspectos normativos e legais, aspectos econômicos;

- conflitos do lugar: sobreposição de funções, sobreposição de eixos de circulação e transportes.

3. Adaptação das Formas: eixo de análise destinado ao estudo da sobreposição de épocas da área de intervenção e/ou cidade sobre o mesmo tecido urbano, resultando no conflito entre o tecido pré-existente e o novo proposto e delineando uma nova morfologia urbana e consequentemente "novos cenários urbanos" sobre o desenho da cidade contemporânea. A sobreposição do centro urbano antigo (centro histórico), subúrbios (bairros industriais e/ou operários, por exemplo), bairros jardins, conjuntos habitacionais, ocupações irregulares (favelas, cortiços) e, projetos novos, resultam numa análise sobre a transformação da cidade e o resultado sobre a imagem urbana a qual a intervenção se propõe.

Acreditamos que o método apresentado, e testado de forma acadêmica e profissionalmente, possibilite a "leitura da cidade"de forma igualitária e adequada à nossa realidade. O que buscamos com estas análises é num primeiro instante compreender a cidade, ou área de intervenção, por temas que constroem a forma urbana da cidade contemporânea, numa "desfragmentação" dos diversos elementos urbanos através dos Eixos de Investigação propostos, e a partir disto, chegar a dois "olhares" sobre o objeto de estudo: a Carta de Potenciais, na qual os elementos positivos na área de intervenção ou que influenciem sobre o objeto de estudo direto ou indiretamente de forma à possibilitar a reabilitação da área de estudo; e Carta de Conflitos, em que os elementos negativos que "degradam", ou contribuem, à área de forma direta ou indireta, sejam eles de ordem física, econômica ou social, são registrados possibilitando um "olhar" global sobre estas duas referências.

Estes dois produtos deverão subsidiar não somente a "leitura da cidade", como desvendar as potencialidades e conflitos da morfologia urbana da área de estudo, consolidando em registros que justifiquem a construção do Plano Desenhado, ou as intervenções urbanas sobre a cidade contemporânea, propriamente dita, num conjunto de ações, projetos e estratégias urbanas que se articulem formal e funcionalmente entre toda a área de intervenção e/ou a cidade em questão, resultando num documento de Intervenções Urbanas capaz de regenerar a área em questão. 


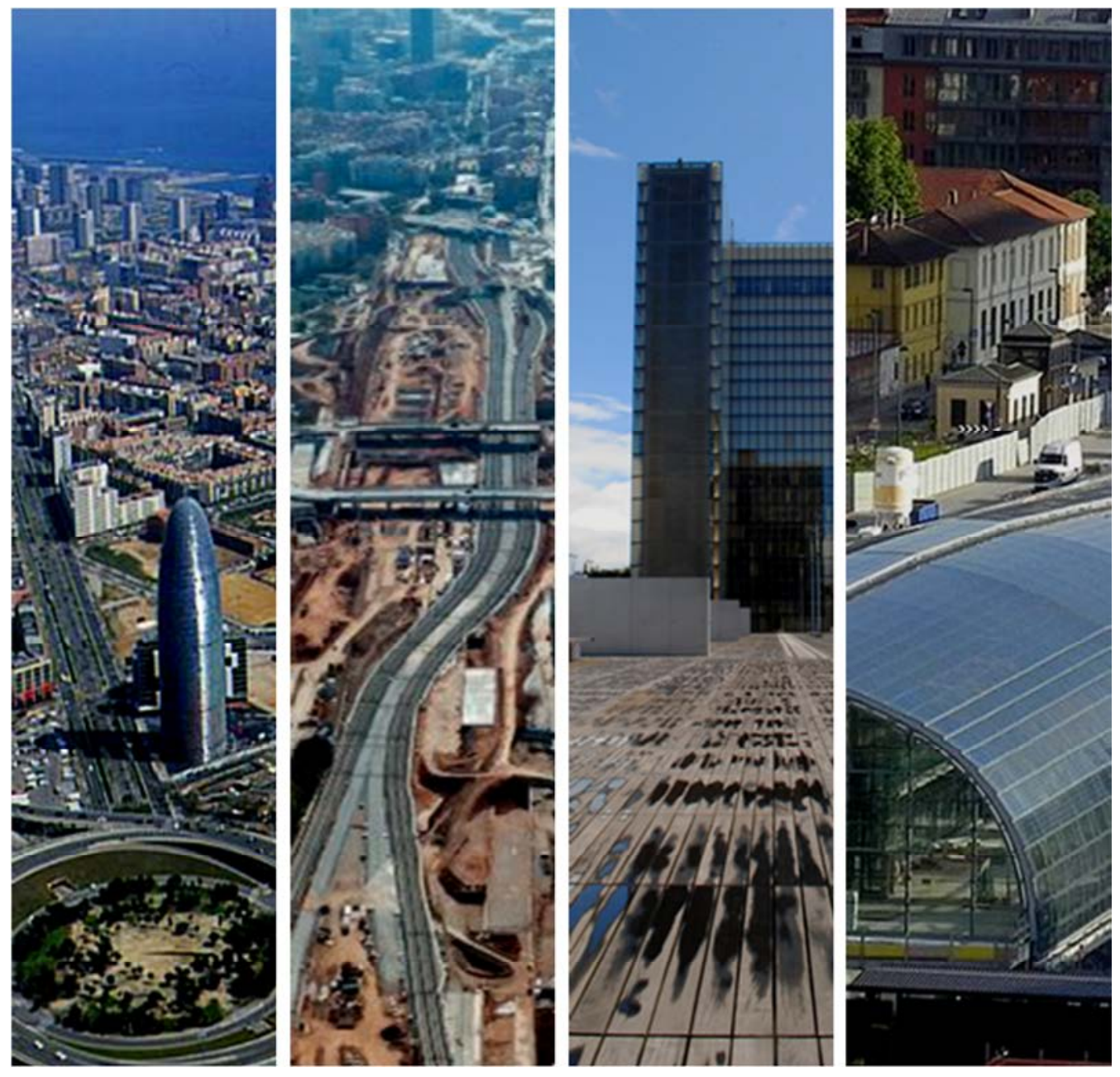

PARTE II

GRANDES PROJETOS URBANOS NA CIDADE CONTEMPORÂNEA 



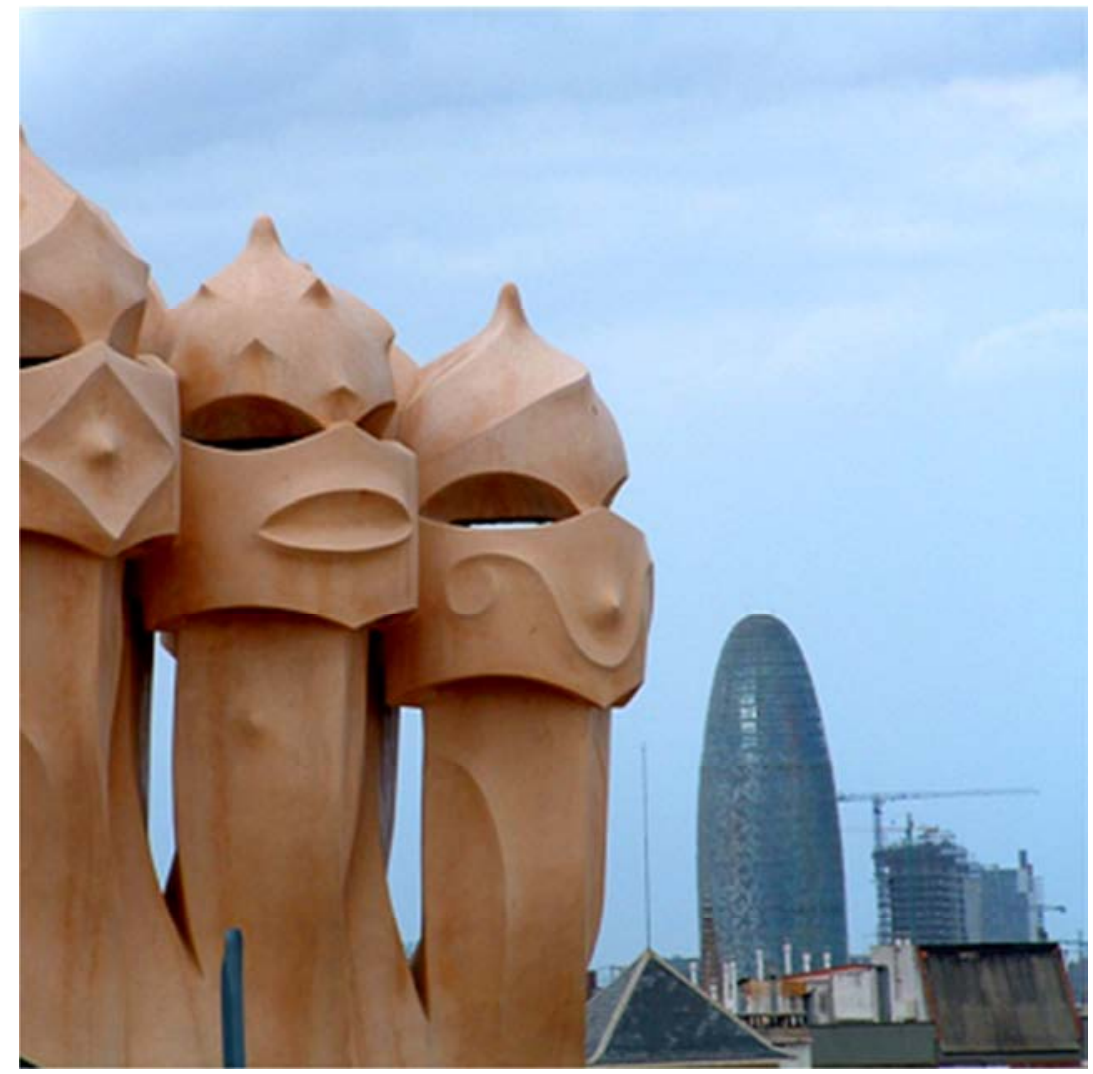

Capítulo 2

Barcelona | Espanha 



\section{Barcelona: Modelo de Urbanização Inovadora}

A primeira metade do século XIX é caracterizado pelas transformações urbanas e sociais com que as cidades se "obrigam" a se preparar para o Modernismo. Todavia, "o desenho urbano vai continuar as regras tradicionais de composição do espaço e de relacionamento das suas partes, ou 'elementos morfológicos'."(LAMAS 1992, p 203).

"No século XIX, marca quase todas as cidades européias pelas grandes transformações e forte crescimento: Paris, Barcelona, Madrid, Lisboa, Viena, Berlim, Milão, Turim, Washington e mais cidades americanas, e tantas outras."(LAMAS 1992, p 204).

Salvo suas diferenças entre cada plano e cidade, cada escala e estratégia, existem princípios comuns entre eles que, segundo Lamas, "prolongam e aperfeiçoam o urbanismo clássico barroco".

Em sua maioria, com a evolução estratégica militar e o aparecimento de novas armas, entre elas o canhão; além das alterações na organização das cidades e a necessidade de expandir seus territórios em detrimento do grande crescimento demográfico, fez das muralhas, sinônimo de fortificações, elementos de "engessamento" do crescimento físico destas cidades.

Segundo Morris, Barcelona teve sua origem na cidade romana de Barcino, que devido a sua localização privilegiada tornou-se um importante centro comercial com uma base naval importante e próspera (MORRIS 1995). Ocupada temporariamente pelos mouros desde o ano de 713 até 801 , antes de ser reconquistada pelos francos que a converteram na capital do condado de Barcelona.

Com o passar dos séculos a cidade foi se estabelecendo gradualmente desde seu núcleo histórico, consolidando a zona portuária comercial e crescendo até alcançar uma superfície de 100 hectares em princípios do século XIV. Limitado e protegido pela muralha medieval, o núcleo histórico estava restrito em seu crescimento territorial, por mais que já naquela época já houvesse outros núcleos periféricos à "cidade formal intramuros", tais como Gràcia, Sant Martí, Sant Andreu, Sarriá, Sants, entre outros que estavam localizados a uma distância segura do alcance dos canhões em caso de ataques.

Até princípios do século XVIII Barcelona pouco alterou em sua configuração territorial. Em quatro séculos a cidade havia apenas dobrado seu território, incorporando Arrabal ao bairro fortificado e garantindo uma área ainda protegida. ${ }^{61}$ Depois de finalizada a guerra de Sucessão, Felipe V ordenou a construção da "Ciudadela", no lugar ocupado pelo bairro da Ribera, junto ao mar e com cerca de 2.000 habitações, que em 1752 iria ser substituído por um novo bairro marítimo - Barceloneta. ${ }^{62}$

Barcelona chega a meados do século XIX com uma população de 150 mil habitantes (1850), somada com a combinação de demandas por autonomia política frente à prosperidade econômica da região catalã e a expansão de sua capital, foi autorizada a demolição das fortificações que protegiam a cidade até então, "obrigando" o rei a repensar o crescimento da cidade e a criar condições de elaborar um plano geral para o desenvolvimento da urbe no futuro.

61. A decisão da implantação de Arrabal foi tomada em 1350, no entanto o processo de urbanização se deu de forma lenta, chegando em 1492 com apenas alguns edifícios alinhados junto às vias principais. O Arrabal viria a converter-se na cidade moderna no famoso passeio das Ramblas.

62 . O projeto de urbanização foi traçado em 1755, segundo um esquema baseado em uma retícula elementar, obra do engenheiro militar Pedro Cermenõ, para proporcionar habitações às famílias desalojadas da construção da "Ciudadela". 

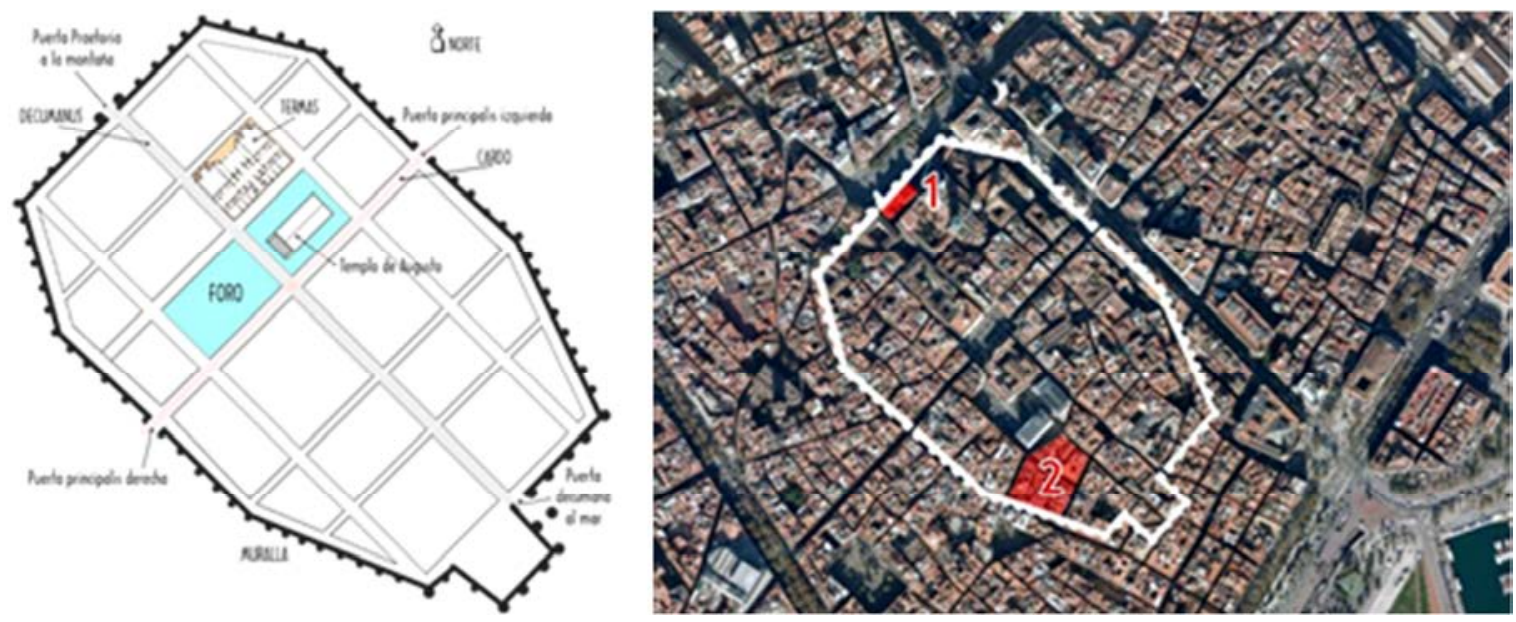

Figura 36. Cidade de Barcino no século IV protegida pelas 78 torres, à direita: foto-inserção da muralha sobre o tecido existente da "cidade gótica"

Fonte: www.fotosdebarcelona.com, acessado em 19/04/2011

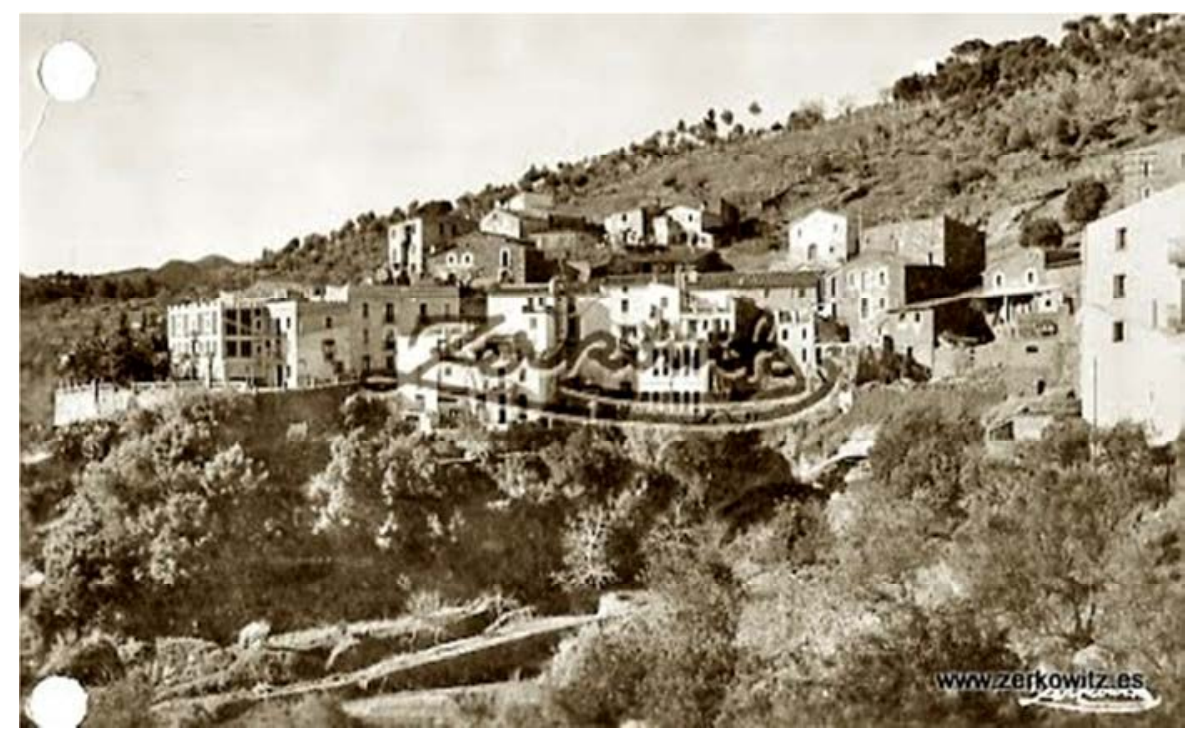

Figura 37. Vista de Arrabal - Barcelona em princípios do século XVII

Fonte: ARCHIVO ZERKOWITZ - fotografías antiguas

Em 1858 foi elaborado o primeiro esquema de expansão pelo arquiteto Miguel Garriga y Roca que propõe uma junção entre Barcelona e núcleo de Gràcia, através de uma planta em tabuleiro xadrez e de praças quadradas (DEBRASSI 2006, p 76). "Mas ao se enviar o plano para o governo central de Madrid, com exigências à elaboração de 'ensanche' e renovação da cidade, a administração municipal convoca, em 1859, um concurso público para a redação de um plano regulador definitivo"(SICCA 1981).

O concurso tem como resultado treze trabalhos inscritos, tendo como vencedor 0 arquiteto Antonio Rovira e Trias, o segundo lugar atribuído para o engenheiro Francesco Soler i Glòria e, o projeto do engenheiro Josep Fontseré i Mestres em terceiro colocado. Segundo Bresciani (1998, p 6), a proposta de Rovira e Trias "retrata a imagem clássica de grande beleza, a cidade organizada em aglomeração, prevendo a separação das classes sociais na cidade nova". 
No entanto, é o projeto de Ildefonso Cerdà i Sunyer o escolhido pela rainha Izabel II para a expansão da cidade de Barcelona. ${ }^{63}$ Diferentemente da proposta de Rovira e Trias, a proposta do "ensanche" e renovação da cidade propunha:

“...projeção espacial da cidade ideal, tal como elaborada em seu universo ideológico que pressupunha que uma sociedade só poderia atingir a perfeição através de uma projeção no espaço tão perfeita quanto possível. O espaço toma então um valor curativo, meio terapêutico contra os males da sociedade. Nele a urbanização perfeita seria o resultado da junção ideal da natureza humana e do progresso técnico e cientifico. Sua cidade deve assegurar um máximo de higiene pública preservando a independência da moradia; deve facilitar as relações sociais graças a um sistema eficaz de comunicações". (BRESCIANI 1998, p 06).

O Plano de Ildefonso Cerdà foi para a cidade de Barcelona, capital da Comunidade Autônoma de Catalunha, a libertação de suas "amarras urbanas" de forma organizada e moldando uma nova imagem para a cidade.

"Em lugar de muralhas, realizam-se avenidas, que facilitarão a circulação em anel, e a construção de novos bairros. A cidade estende-se e fragmenta-se pelo território envolvente; a periferia cresce como cintura habitacional e industrial."(LAMAS 1992, p 206).

Com um casco antigo com aproximadamente 4.000 anos, onde seu núcleo central delimitado pelas muralhas já possuía uma ocupação densa, e com a coexistência de outros núcleos ${ }^{64}$ (Gràcia, Sant Martí, Sant Andreu, Sarrià, Sants, etc), que a partir do século XIX, a alta densidade demográfica, as péssimas condições de habitabilidade e a necessidade de expansão física do núcleo central levaram ao governo a encomendar um plano que fosse capaz de criar uma aliança entre os cidadãos, o governo local e as forças econômicas e políticas locais.

Em 1856 Ildefonso Cerdá elabora a "Monografia de la classe obrera", importante documento de análise sobre as necessidades sociais, econômicas e de alimentação com que a cidade intra-muralhas passava naquele momento. Era certo que Barcelona necessitava expandir-se sob uma nova ótica e de forma controlada.

O Plano de Cerdá neste sentido aborda "duas ordens de problemas: a organização da grande expansão - o <ensanche > - e a investigação sobre a quadrícula e do quarteirão" (LAMAS 1992, p 216), onde o primeiro analisa os elementos pré-existentes e parte da compreensão dos mesmos e a vontade de adaptar o "novo território" à geografia; ${ }^{65}$ enquanto que a quadricula - "La Manzana" - se coloca como um elemento de predominância de valores coletivos sobre os individuais, rediscutindo os espaços públicos da cidade e sua importância para a valorização da cidadania.

Por fim, o "Ensanche" de Cerdá se antecipa aos demais planos centro-europeus considerados como pioneiros, e introduz aos planos de expansão novos instrumentos de planejamento, influenciando durante muitos anos urbanistas e planejadores urbanos em diversos países.

63. A escolha da proposta de Cerdà y Sunyer se deu antes mesmo dos resultados do concurso convocado pela administração de Barcelona, ainda em 1858 - ano do concurso, que de forma soberana a rainha aprova o "Ensanche de Barcelona". Em 1855 Cerdà já havia realizado os levantamentos dos terrenos destinados à expansão da cidade.

64 . Estes núcleos periféricos estavam em sua maioria afastados da cidade protegida pela muralha, numa forma de garantir sua integridade física num momento de guerra e contra-ataque da cidade formal, no entanto estes mesmos núcleos eram dependentes da ocupação formal.

65. A cidade esta localizada diretamente ao Mar Mediterrâneo, sua expansão se limitou ao norte na Serra de Colserolla e a Montanha de Montjuic, e leste-oeste pelos rios Llobregat e Besòs. 


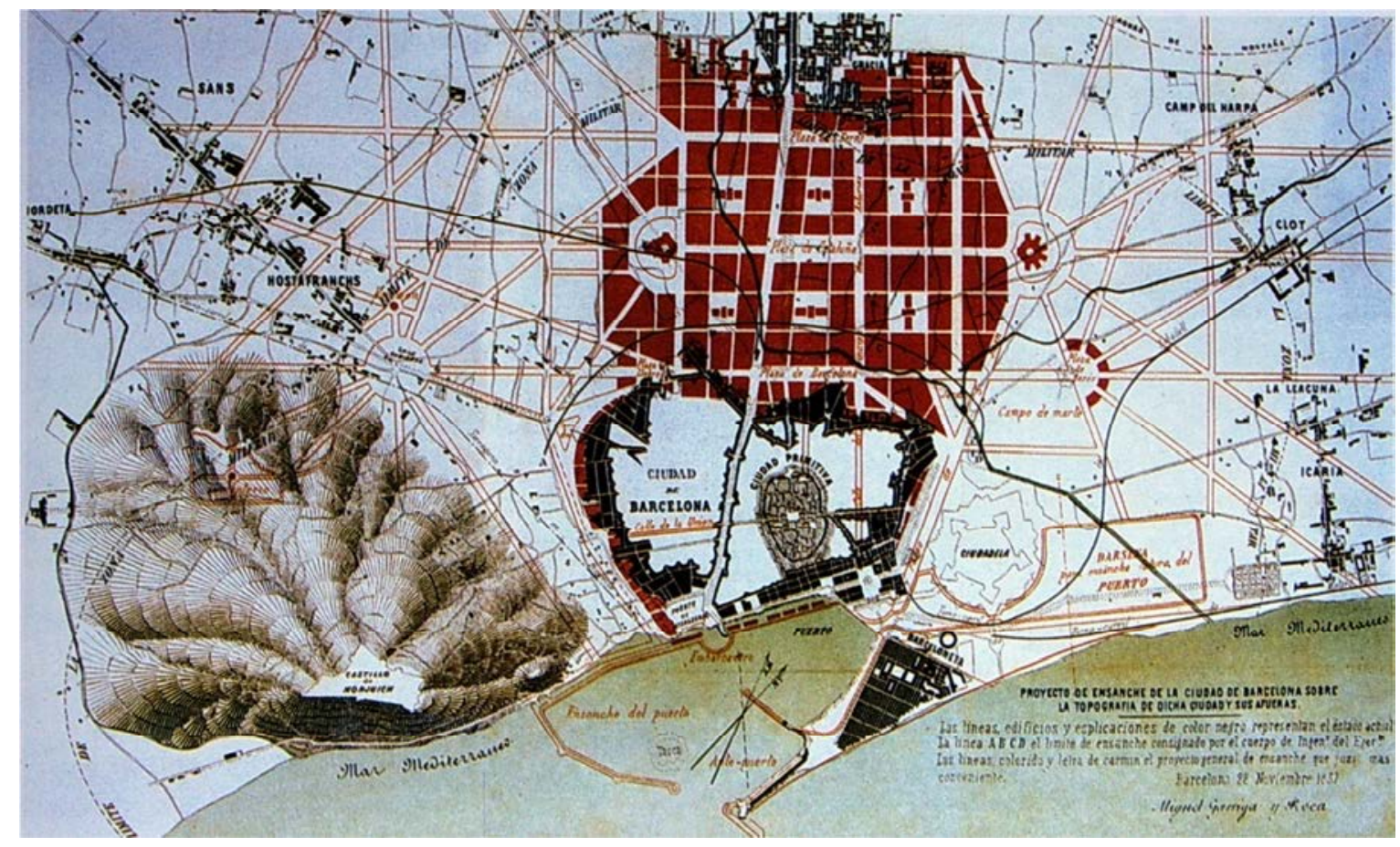

Figura 38. Esquema de Expansão de Miguel Garriga y Roca, 1858

Fonte: http://www.esacademic.com, acessado em 19/04/2011

Figura 39. Projeto vencedor do concurso: arquiteto Antonio Rovira e Trias

Fonte: Barcelona: the urban evolution of a compact city, 2005
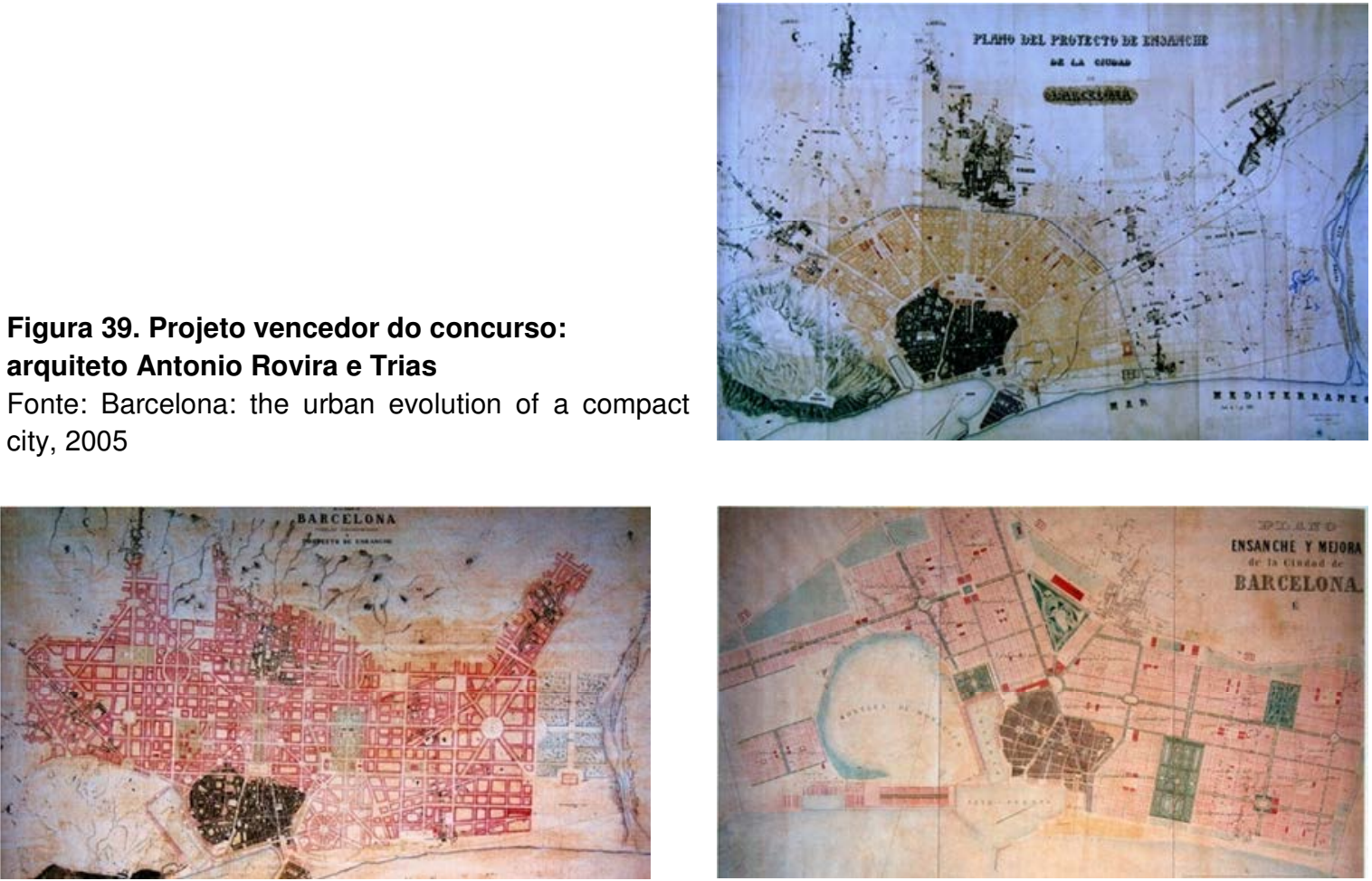

Figura 40. Segundo e terceiro colocados: engenheiro Francesco Soler i Glòeria e projeto do engenheiro Josep Fontseré i Mestres, consecutivamente

Fonte: http://www.esacademic.com, acessado em 19/04/2011 
Segundo Françoise Choay, a importância da obra de Cerdá, cuja teoria foi tirada do esquecimento, constitui, doravante, "a certidão do nascimento e o arquétipo das teorias de urbanismo" (CHOAY 1985, p 308).

Ao analisarmos a proposta de Cerdá, fica claro que o mesmo conhecia bem os problemas em que a cidade passava. A alta densidade sobre o território intra-muralhas estava gerando grandes problemas de higiene e circulação. Neste sentido, a demolição das muralhas permite a livre expansão urbana e é, pois, a medida indispensável para resolver os problemas higiênicos e sociais da cidade, assim como possibilitaria a resolução dos problemas e dificuldades de circulação, tanto em seu território existente como na ligação entre a cidade e sua região.

Todavia, a abertura e expansão do território de Barcelona não viriam agradar a todos barceloneses, em especial os proprietários fundiários do interior da cidade, "uma vez que a demolição das muralhas e a extensão ilimitada da cidade representavam o fim do monopólio fundiário e o rebaixamento imediato das rendas advindas da terra urbana." (DEBRASSI 2006, p 81). Fica claro que este setor da sociedade seria hostil ao plano, visto que a expropriação das terras estimularia o mercado fundiário sob o território em expansão de forma socialmente igualitária, fato que os proprietários deste setor da cidade eram contrários.

Com a publicação no Jornal Oficial em 12 de outubro de 1854 ordenando a demolição das muralhas de Barcelona, a cidade estava livre das "amarras urbanas" que a "engessavam" sobre seus limites físicos, protegidos dos ataques, porém confinado em seu crescimento urbano e econômico. Neste sentido, tem-se o início ainda em meados do século XIX a "batalha" pela extensão de seu território de forma ordenada e com objetivos muito claros sobre o que a proposta, ou propostas, deveriam alcançar em seus resultados.

Diferentemente da proposta vencedora do concurso, em que o arquiteto Rovira desenha uma expansão concêntrica ao núcleo antigo, organizado em três setores maiores e dois setores marginais. Em análise a Carta do "Plano del Proyecto de Ensanche" apresentado a comissão do concurso, observamos que alguns núcleos pré existentes não foram contemplados, em especial Gràcia e Sant Martí que possuíam já naquela época um número significativo de habitantes. A proposta de Cerdà se assemelhava muito mais com o traçado proposto em 1958 por Miguel Garriga y Roca, num sistema de grelha em xadrez, que apesar de se pensar a expansão entre o núcleo antigo e o de Grácia, o desenho insinuava uma malha urbana passível de crescer continuamente conforme o crescimento demográfico da cidade.

A proposta de Cerdà se coloca sobre o mesmo panorama, o Plano de Expansão de Barcelona possui um conjunto de necessidades em que a cidade possuía em desenvolver de forma contínua e com a garantia de infraestrutura urbana. A obra de Ildefonso Cerdà, traduzido por Antonio Lopez de Aberasturi - La Théorie Générale de L'Urbanisation (1979), expõe os fundamentos e a aplicação inovadora da teoria no Ensanche de Barcelona. 


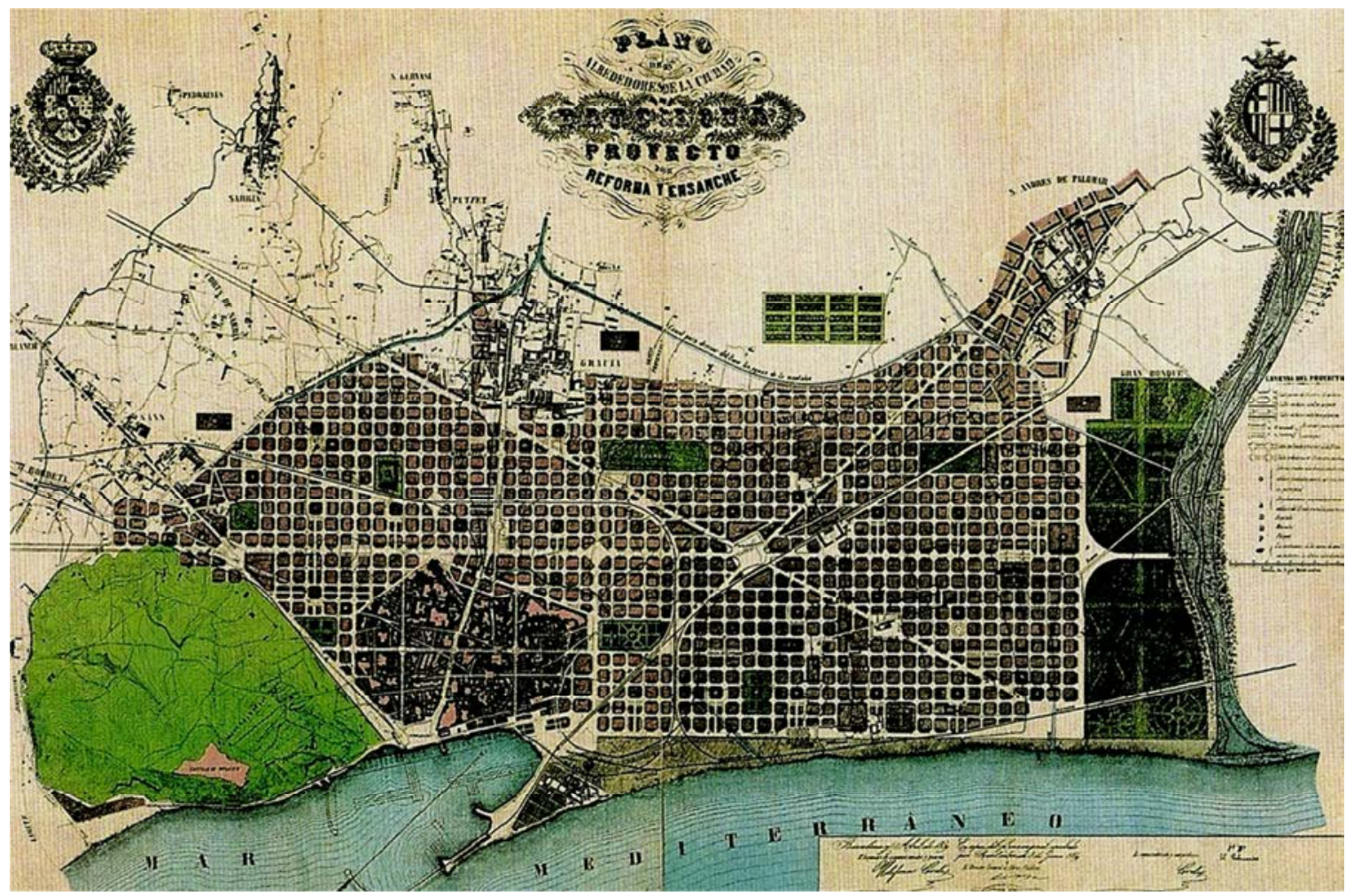

Figura 41. Mapa do Eixample de Barcelona de Ildefonso Cerdà, 1859

Fonte: Barcelona: the urban evolution of a compact city, 2005

"Como ciência urbanística, da planificação territorial e urbana, Cerdà estabelece a origem da necessidade de alojamento e a causa do desenvolvimento dessa urbanização na sociabilidade do homem, enquanto elementos civilizadores. E é dentro dessa visão complexa que estrutura, em cinco bases, a sua Teoria Geral da Urbanização"(DEBRASSI 2006, p 87):

1. Base facultativa da urbanização: vias, ruas, quadrículas, problemas de habitação;

2. Base legal da urbanização: define os direitos e deveres dos proprietários e da administração, onde ao maior interesse público correspondem os maiores benefícios privados;

3. Base econômica da urbanização: estabelece os critérios e mecanismos para o financiamento das obras de urbanização e como se repartiam os encargos e benefícios;

4. Base administrativa da urbanização: que define a gestão urbanística;

5. Base política da urbanização: transições políticas, harmonizando o desejável com o possível.

Dos cinco elementos acima citados, podemos dizer que a primeira base (facultativa) da urbanização nos interessa para a compreensão física da expansão da cidade. A relação entre vias, ruas, quadrículas e habitação vão determinar essencialmente o traçado urbano, procurando tê-las como parâmetros para a análise da nova estruturação do espaço urbano do século XIX, por meio de seu Plano Urbanístico. 
Segundo Soria y Puig (1996), em Cerdà: As cinco bases de la teoria de la urbanización, é possível identificar a importância destas bases para a consolidação do Plano de Expansão de Barcelona utilizando-se de um número limitado de instrumentos que organizasse o espaço físico pré-existente (o casco antigo e os núcleos) e o proposto no território ainda não explorado. ${ }^{66}$ Neste sentido, podemos apontar alguns instrumentos que nortearam a formulação do Ensanche de Cerdà:

a) Casa: este elemento é o ponto de partida de seu raciocínio e será utilizado por Cerdà como o suporte fundamental do urbanismo e peça-chave da qualidade de vida. Pode-se dizer que dois elementos junto à unidade familiar iriam nortear as soluções para este instrumento urbano: a privacidade do individuo no lar como reconhecimento de uma sociedade culturalmente avançada (o ser urbano), e o higienismo onde a unidade habitacional deveria atender às necessidades $\mathrm{e}$ qualidades passíveis de serem habitadas (ar, sol, ventilação, iluminação natural), fato que as habitações no casco antigo e núcleos periféricos não possuíam em sua maioria;

b) Quadra (quarteirão): La Manzana será utilizado por Cerdà como elemento de controle da compactação da cidade e solução ao crescimento demográfico em que Barcelona enfrentava. É a unidade reguladora dos edifícios, a profundidade edificável, o jardim interno resultante do vazio no centro da quadra, a fachada mínima ou a relação de altura máxima com a largura da rua;

c) Viário: este componente será elevado por Cerdà a um elemento organizador do espaço não-construído, tendo um valor simbólico excepcional que, com o tempo, comprovou sua funcionalidade, se comparado com outras tramas urbanas. Diferentemente da trama até então conhecida no casco antigo de Barcelona onde grande parcela do sistema de circulação era composta por ruas com menos de $3,00 \mathrm{~m}$ de largura e a mais ampla não possui mais que $10,00 \mathrm{~m}$, as vias propostas por Cerdà eram de no mínimo de 20,00 m de largura, no que garantia fácil circulação na nova trama urbana e a possibilidade de melhor iluminação natural sobre a cidade. Os cruzamentos são pensados por Cerdà como artifícios de segurança no trânsito (distância de visibilidade, zonas de espera), para a continuidade do trânsito e para as operações de carga e descarga de mercadorias e pessoas. ${ }^{67}$ Apesar de assegurar a continuidade dos fluxos através da nova calha proposta, as grandes avenidas (Gran Via, Diagonal, Meridiana) garantem a conexão metropolitana com baixo impacto sobre o tecido interno da cidade. Por fim, a tipologia da trama ortogonal, homogênea e igualitária, oposta às configurações tradicionalmente radiocêntricas e congestionadas, é elaborada como "tecido contínuo" capaz de crescer em conjunto com a cidade;

d) Redes de serviços: como apontado por Dupuy (1995), as redes propostas confirma o valor funcional e econômico da trama de Cerdà na aplicação das infraestruturas necessárias ao bom funcionamento da cidade: água, saneamento, eletricidade, telegrafia, ferrovias tiveram um tratamento pioneiro;

e) Densidade: este elemento será de grande importância para o controle das infraestruturas necessárias na Expansão de Barcelona. Nisto a densidade estará presente em todo o projeto de Cerdà. ${ }^{68}$

66 . Deve-se entender que estes espaços ainda não explorados ora são resultado das áreas do raio de alcance dos canhões (aproximadamente 1.200 metros), ora áreas ainda não exploradas pelos proprietários de terras, provavelmente a espera da especulação imobiliária.

67 . Outro dado relevante esta no sistema de transporte proposto por Cerdà que estava ligado diretamente ao bonde à tração animal, que necessitava de um raio de giro considerável, no qual justificava as esquinas mais abertas. Atualmente tais esquinas são utilizadas as vagas de estacionamento rápido, além da carga e descarga de mercadorias e pessoas.

68 . Na época do plano, a cidade murada de Barcelona tinha 900 hab./ha, valor excessivamente maior aos encontrados em Paris e Madri que possuíam 300 hab./ha ou em Londres com 100 hab./ha.

Fonte: Publicação Catálogo - 3ª Bienal de Arquitetura de São Paulo, 1997, p. 133. 


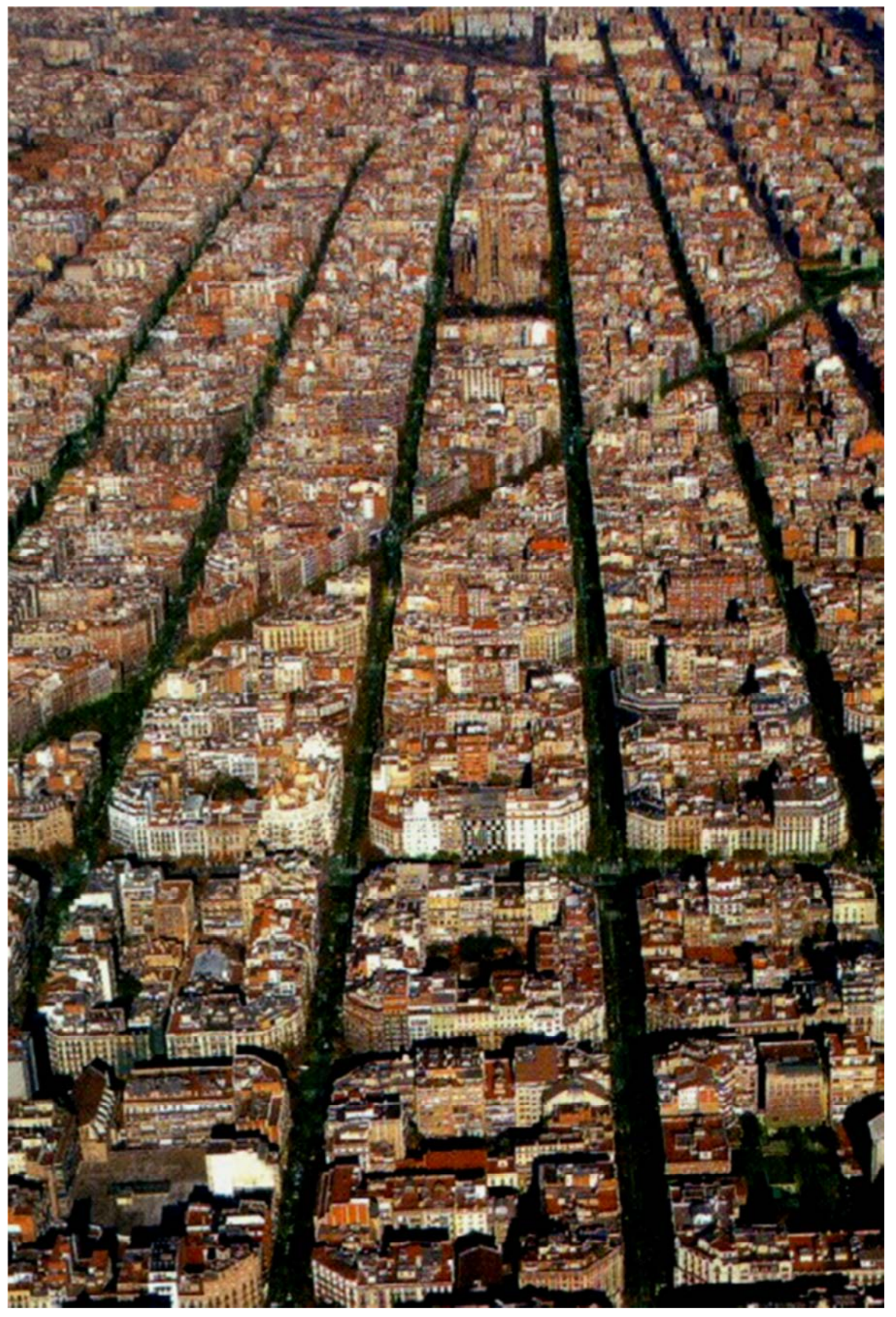

Figura 42. Vista aérea do Eixample de Cerdà

Fonte: www.fotosdebarcelona.com, acessado em 19/04/2011 
Como já apontado acima, para Soria y Puig (1996), o Ensanche de Barcelona proposto por Cerdà tinha como objetivo a expansão urbana da cidade sobre território ainda não ocupado e/ou de produção rural, de forma ordenada sobre as zonas exteriores ao núcleo antigo, racionalizando e institucionalizando, através das formas definidas, a concepção e o desenvolvimento do crescimento urbano. Assim, podemos afirmar que a primeira dessas "peças urbanas" apareceu com a idéia de "ensanche", "como peça urbana nova, homogênea, bem definida, que se justapunha ao casco antigo oferecendo uma alternativa diferente de cidade ordenada, cuja conceituação teórica e prática encontram-se na elaboração de Cerdà"(TERÁN 1978, p 25).

Para Solà-Morales, "quando Cerdà projetaseuEnsanche de Barcelona, tem muito claro tanto quanto Haussmann, em Paris - os tempos e os atores da festa urbanistica que querem criar" ${ }^{69}$ (SOLÀ-MORALES i RUBIÓ 1997, p 20). Para isto, a reticula urbana desenhará o processo de urbanização não somente como ritmo de crescimento do lugar, mas como elemento unitário que estabelece a forma original do assentamento sobre o novo território. Assim, estas peças possibilitam um crescimento uniforme, e ao mesmo tempo capaz de ser implantado de forma progressiva, lenta ou ao longo do tempo. "Ritmo de urbanização e ritmo de parcelamento foram diferentes, mas o projeto de Cerdà tinha igualmente bem incorporados: a primeira determinação absoluta, 0 segundo na escala de possíveis variações" ${ }^{70}$ (SOLÀ-MORALES i RUBIÓ 1997, p 20).

Quanto a edificação do "Ensanche", Solà-Morales defende que seconverte em um terceiro momento, muito mais difuso e multiplicador, pois se o projeto do traçado de Cerdà dava lugar a mais de 800 "manzanas", gerando em mais de 20.000 projetos arquitetônicos, de forma que as edificações do "Ensanche" poderia perdurar por quase um século com uma grande diversidade de arquitetos e promotores, ainda assim resultando numa grande diversidade de tipologias e construindo a cada instante "cenários urbanos" diferenciados ao longo dos anos.

Neste sentido, quando analisamos o Plano de Cerdà para a Expansão Urbana de Barcelona, tendo como método analitico da morfologia urbana, a publicação de Manuel de Solà-Morales i Rubió, de 1997 - Las formas de crecimiento urbano, em que as tipologias estruturais do crescimento urbano são entendidos como um conjunto de operações materiais de construção da cidade, segundo uma ordem e a importância de cada uma dessas operações, tem-se como componentes materiais do processo:

- Parcelamento $(P)$ : entendido como transfomação do solo rural em urbano, como atribuição do uso do solo;

- Urbanização (U): operação da construção dos elementos físicos coletivos da cidade;

- Edificação (E): construção da edificação.

69. Tradução do autor, 2011.

Cuando Cerdà proyecta su Ensanche de Barcelona, tiene muy claro - tanto como Haussmann en Paris - los tiempos y los actores del baile urbanístico que quieren escenificar.

70 . Tradução do autor, 2011.

Ritmo de urbanización y ritmo de parcelación fueron distintos, pero el proyecto de Cerdà los tenía igualmente bien incorporados: el primero en su determinación absoluta, el segundo en su gama de posibles variaciones. 


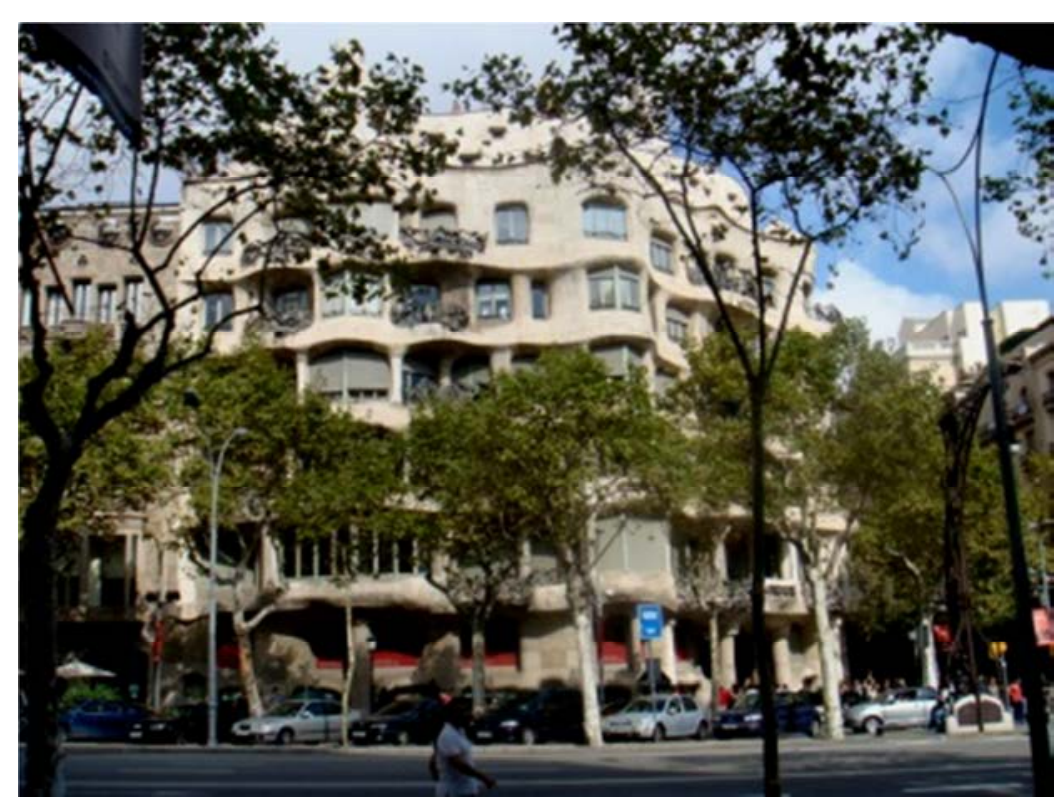

Figura 43. A diversidade tipológica sob a malha regular do Desenho das Esquinas do Plano de Cerdà Fonte: Elvis Vieira, 2009
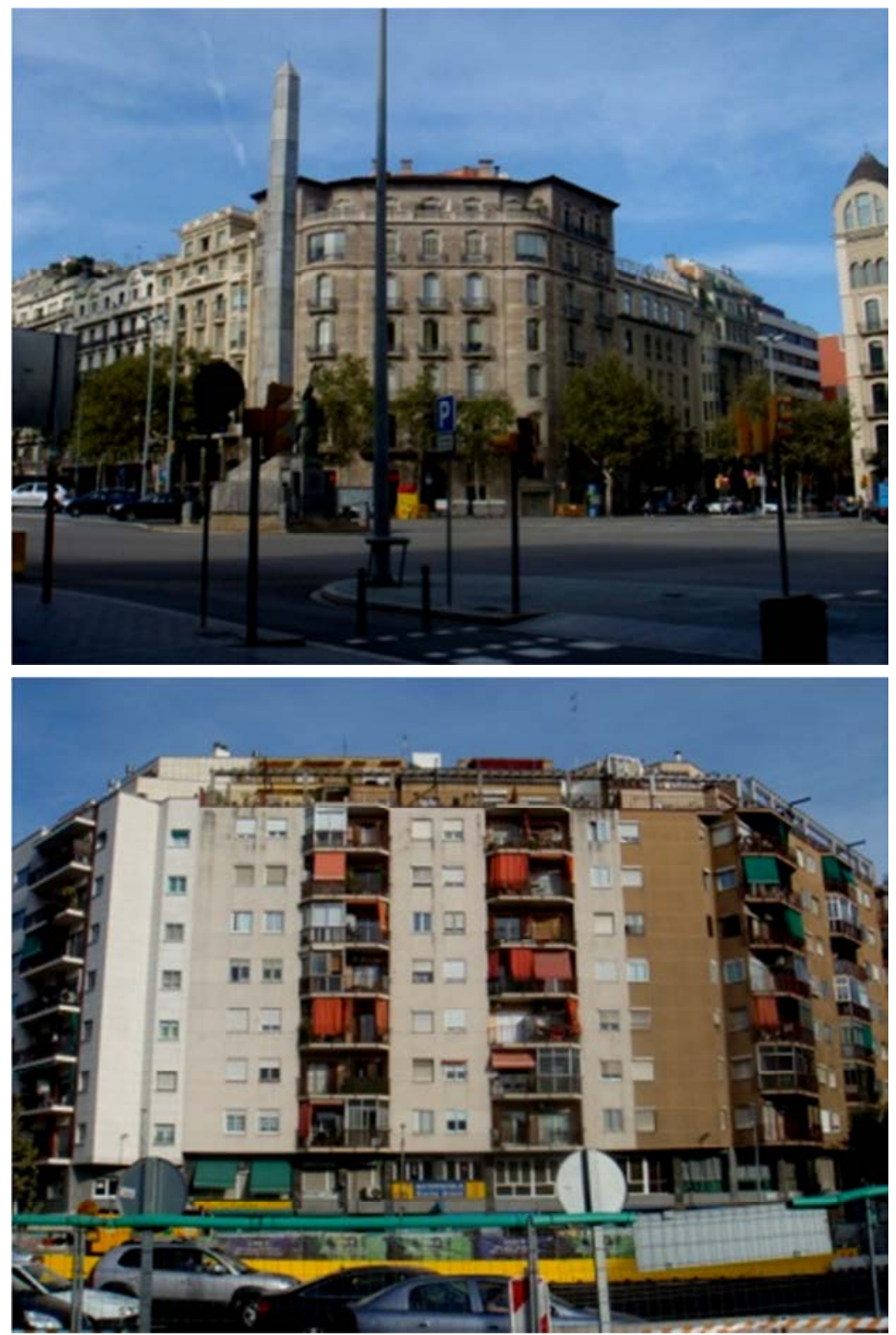
Assim, a ideia da quadrícula como modelo de ocupação do solo pela edificação, frente a concepção da malha urbana ortogonal acentuando os sistemas de acessos e implantação da infra-estruturas urbanas, faz da propsota de Cerdà um modelo até os tempos atuais utilizados como referência urbana pesquisada por diversos urbanistas. Porém podemos concluir que a "Manzana" é o elemento urbano do "Ensanche" que mais contribui para a diversidade do desenho da cidade, por mais que seja composto por uma solução regular e igualitária, as características geométricas e suas diretrizes de ocupação possibilitam a "mutação urbana" a cada instante, a cada trecho da cidade.

A Manzana possibilitou medir as necessidades e infra-estruturas necessárias para 0 desenvolvimento da cidade, ela torna-se a "unidade de medida urbana" e concentra as alternativas de concepção volumétrica na construção do Novo Cenário Urbano de Barcelona.

Ao analisarmos suas dimensões com mais cautela, onde as faces correspondem a $113,50 \times 113,50 \mathrm{~m}$ com as esquinas chanfradas $(19,80 \mathrm{~m})$ possibilitando maior flexibilidade para o desenho da cidade, sua área resulta numa dimensão de $10.000,00 \mathrm{~m}^{2}$ (1 ha). Índice de medição da densidade urbana capaz de gerenciar 0 desenvolvimento e crescimento da cidade.

Por mais estátil que pareça a geometria proposta por Cerdà, este elemento urbano possibilita sua reconstrução contínua sem qualquer prejuízo ao conjunto urbano da cidade, como apontado por Solà-Morales (1997, p. 134-135) as alternativas teóricas de ocupação da manzana pela edificação são: ${ }^{.1}$

1) Volume acumulado no meio da quadra. Acesso e conexões de serviços unificados. A perda do papel dos serviços de distribuição para a rua junto ao bloco.

Gestão unificada da edificação a nível da quadra;

2) Edifício que ocupa uma faixa (largura) ao redor do perímetro do bloco. O valor máximo das ruas circundantes como infraestrutura de serviços da habitação.

Reserve o pátio central, com funções de iluminação e ventilação. Protótipo como modo de ocupação do "ensanche";

3) Ocupação total da quadra. Edificação de pouca altura tipologicamente diversa. Manutenção funcional de todas as ruas, embora sem a perda de valor das fachadas. Ocupação habitual dos "ensanches" de cidades menores.

71 . Tradução do autor, 2011.

1) Volumen acumulado en el centro de la manzana. Acceso y acometidas de servicios unificados. Pérdida del papel de distribución de servicios de las calles que delimitan la manzana.

Gestión unitaria de la edificación a nivel de manzana;

2) Edificación que ocupa una faja (ancha) en todo el perímetro de la manzana.

Máxima valoración de las calles circundantes como infraestructura de servicio a la vivienda.

Reserva de patio central con funciones de ventilación e iluminación.

Modo de ocupación prototípico del ensanche;

3) Ocupación total de la manzana. Edificación de poca altura y tipológicamente diversa.

Mantenimiento de la función de todas las calles, aunque pérdida de valor por menor importancia de las fachadas. Modo de ocupación habitual en ensanches de ciudades menores;

4) Edificación ocupando una faja (estrecha) en todo el perímetro de la manzana.

El patio como principal espacio de servicio y acceso a la vivienda. Reducción del papel de la calle a las conexiones a nivel urbano.

Especialización residencial.

Característico de los proyectos de reconversión de áreas de ensanches existentes. Límites de la evolución del caso anterior. Edificación organizada sobre la malla viaria. 
4) Edifício que ocupa uma tira (estreita) ao redor do perímetro da quadra. O pátio como principal espaço de serviço e acesso à habitação. Reduzir o papel da rua às conexões urbanas.

Especialização residencial.

Característica dos projetos de reconversão de áreas de "ensanche" exsitentes. Limite da evolução do caso anterior. Edificação organizada sobre a malha viária.
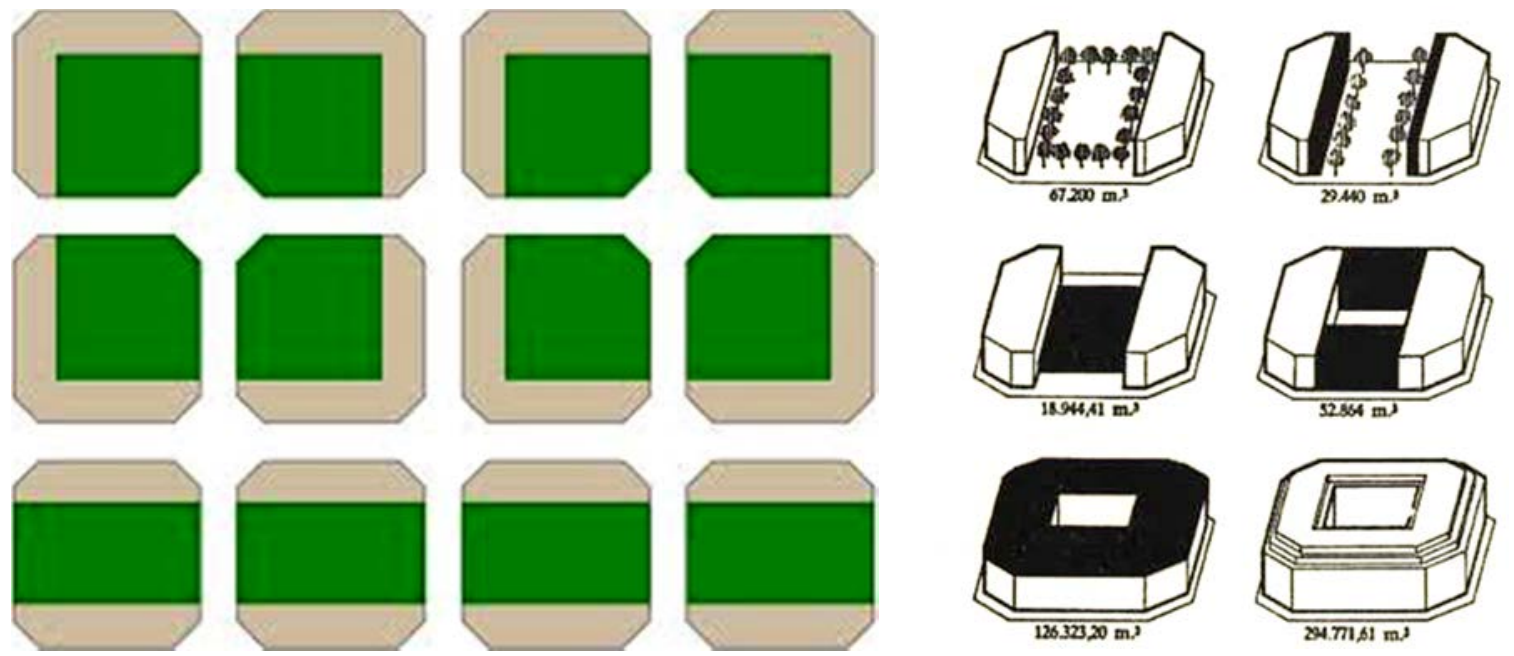

Figura 44. Possibilidades de ocupação sobre las manzanas no Plano de Cerdà Fonte: Barcelona: the urban evolution of a compact city, 2005
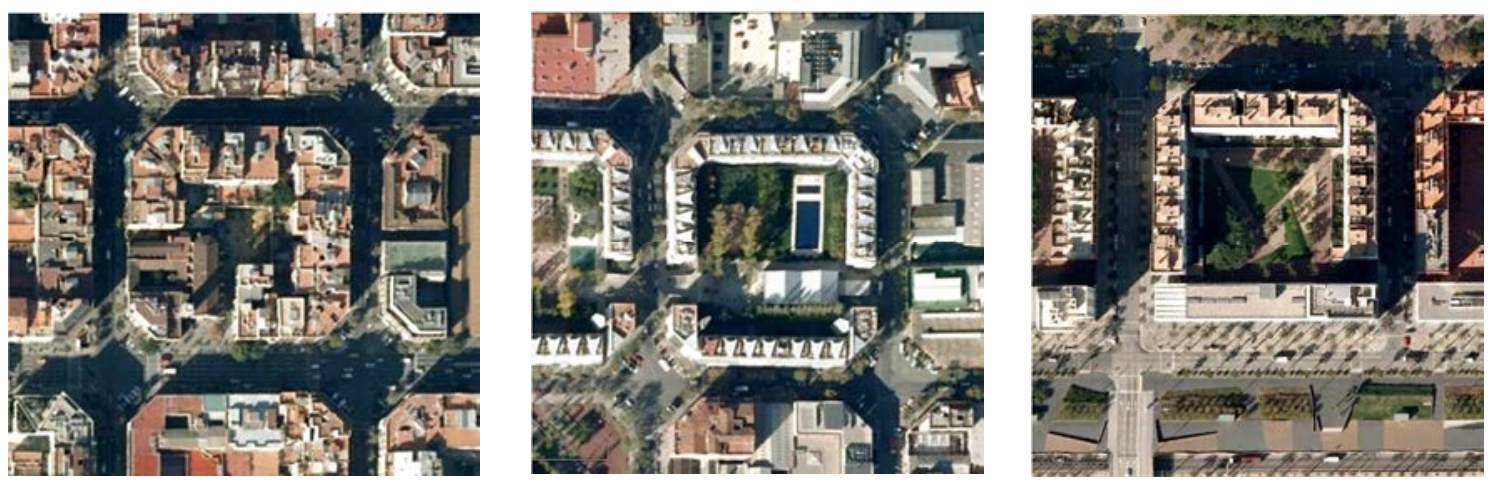

Figura 45. Ocupação das manzanas atualmente no Eixample de Cerdà Fonte: Google Earth, 2011

$\mathrm{Na}$ concepção de Cerdà, "la manzana" cumpre não somente a função de desenhar a extensão da cidade, integrando o espaço pré-existente a sua proposta. Segundo Figueroa (2006, p 03), "a quadrícula estende-se até os núcleos urbanos e envolve a cidade medieval,. Apesar de aparentar a imposição de uma nova ordem, indiferente ao contexto, o ajuste das bordas é feita com extrema habilidade tendo como suporte avenidas diagonais que surgem a partir de conexões pré-existentes".

Por outro lado, as esquinas são tratadas como espaços livres sobre a cidade. $O$ "chanfro" em $45^{\circ}$ possibilitou a abertura de visão sobre as esquinas, além de acomodar a geometria necessária a instalação do sistema de transporte público (bonde) e, recriando sobre a malha em expansão, lugares de encontros e ampliação visual dos edifícios de esquina, que deveriam ser mais valorizados por apresentarem três fachadas. 
"Ressalta-se que Cerdà pretendia resolver as disfunções e desafios que a sociedade da metade do século XIX tinha e que em síntese se centravam na higiene e salubridade, na mobilidade, onde cada modo de transporte tinha sua rede específica, a integração de rendas no mesmo edifício e o equilibrio entre 0 construído e o verde que não é mais que o equilíbrio entre funcionamento urbano e descompensação urbana" (MIANA 2010, p 64).

Neste sentido, o modelo geométrico de Cerdà proporcionou um novo modelo de cidade, que se sustenta em argumentos teóricos capaz de gerar o crescimento de Barcelona de forma gradativa e contínua ao longo dos anos, porém num modelo urbano intemporal na cidade.

São estes aspectos, ou instrumentos urbanísticos, possibilitaram não somente a implantação do "ensanche" de Cerdà de forma gradativa, mas adaptando-se às condições de cada época, sem qualquer prejuízo ao desenho urbano proposto inicialmente em meados do século XIX.

A capacidade com que a cidade, e o Plano Urbanístico, foram se "adaptando" aos novos projetos ao longo dos anos, demonstra a sustentabilidade em que a proposta de Cerdà se consolida a cada instante em Barcelona. Segundo Solà-Morales (2008, p 12), "construir na cidade, construir a cidade, exige um equilíbrio delicado entre o tecido urbano e a construção, entre a substância comum e os objetos especiais, entre a regra ea exceção". E é neste sentido que Barcelona vai se ajustando aos planos e projetos implantados até os tempos atuais.

Em 1929 Barcelona cedia a Exposição Internacional, celebrada na Montanha de Montijuic, numa área de 118 hectares. ${ }^{72} \mathrm{~A}$ exposição originou uma remodelação de parte da cidade, neste caso a montanha, e áreas adjacentes que receberam um conjunto de obras e ações urbanísticas para atender a grande demanda de visitantes em que a exposição iria receber.

Idealizada pelo arquiteto Josep Puig i Cadafalch, a proposta foi configurada em três setores específicos, que o autor possibilitou o desenho de outros arquitetos, resultando em uma diversidade tipológica muito interessante para aquele momento: 1) a parte baixa da montanha, destinada a Seção Oficial, ficando sob responsabilidade do próprio Puig i Cadafalch, com Guillem Busquets, onde encontravam-se os palácios (dedicados às seções oficiais) e os pavilhões (países, instituições ou sociedades), quatro grandes hotéis para os visitantes, sobre um eixo que conduziria ao Palácio Nacional (obra mais monumental da exposição); 2) Lluís Domènech i Montaner e Manuel Vega i March, ficaram encarregados em desenhar a Seção Internacional da Exposição, localizada na parte alta da montanha, no qual deveriam ser implantado os pavilhões dos países participantes da grande exposição; ${ }^{73}$ 3) destinado a uma possível Seção Marítima, o setor Miramar foi desenvolvido por Enric Sagnier i Villavecchia e August Font i Carreras, no entanto tal setor não foi executado para a Exposição.

\footnotetext{
72 . O "ensanche" de Cerdà não utilizava o território de Montijuic, que a considerava como um elemento natural limítrofe de ocupação, assim como a Serra de Corserolla e o Mar Mediterrâneo.

Entre os países participantes estavam: Alemanha, Bélgica, Dinamarca, França, Hungria, Itália, Noruega, Romênia, Suíça, assim como expositores privados japoneses e norte-americanos.

73. Dos pavilhões construídos, podemos afirmar que o da Alemanha, projeto do arquiteto Mies van der Rohe, é considerado uma das obras mais significativas deste setor. Um dos melhores exemplos da Arquitetura Moderna (estilo internacional), sua concepção espacial e empregabilidade dos materiais o tornaram um paradigma da arquitetura do século XX.

Demolido depois da exposição, em 1987 o mesmo foi reconstruído no seu local original por Cristian Cirici, Ignasi de SolàMorales e Fernando Ramos, tendo como referência os projetos deixados por Mies.
} 
Por fim, a Exposição de 1929 implicou num grande impacto urbanístico para a cidade, não somente a montanha de Montijuic, que recebe o maior montante dos investimentos financeiros, mas a oportunidade da instalação de redes de infra-estrutura urbana em diversas partes da cidade, como o melhoramento do asfalto, rede de esgoto e substituição da iluminação pública de gás pela elétrica, assim como a melhoria paisagística em diversas praças da cidade. Do ponto de vista urbanístico, o prolongamento da Avenida Diagonal para oeste e a Grande Via das Cortes Catalanas para sudoeste pode ser considerada um dos maiores impactos urbanos em que Barcelona se beneficiou.

Figura 46. Plano Urbanístico da Exposição Internacional de Barcelona 1929, montanha de Montijuic

Fonte: www.bcn.com, acessado em 17/04/2011
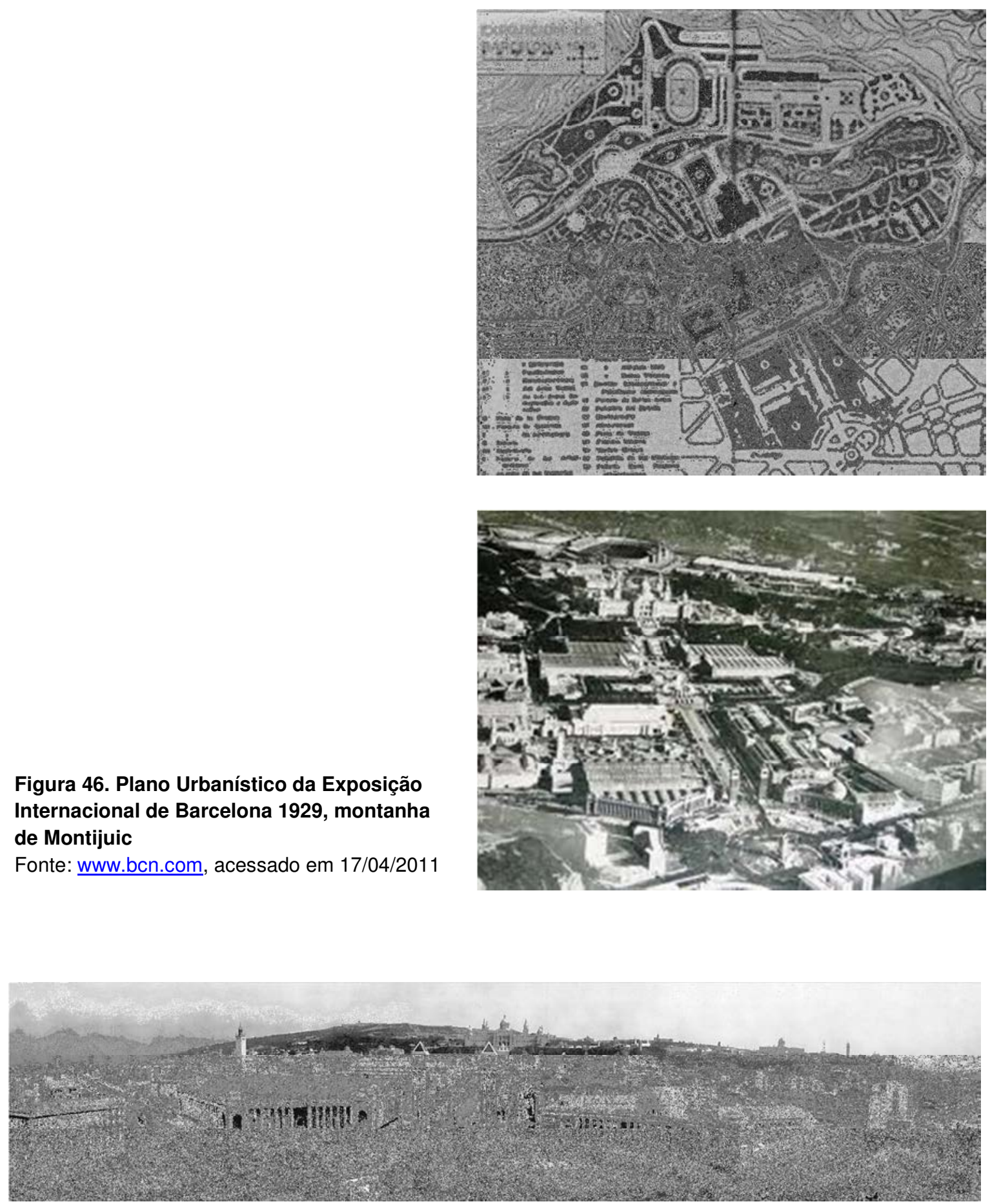

Figura 47. Vista atual da área da Exposição Internacional de Barcelona

Fonte: www.bcn.com, acessado em 17/04/2011 
A partir da década de 1980, os grandes projetos urbanos em Barcelona podem ser classificados em três fases que ilustram o "renascimento urbano" da cidade:

1. Acupuntura Urbana, resultante de pequenos projetos nos anos oitenta;

2. Infra-estrutura de 1987-1992 para os Jogos Olímpicos de Barcelona;

3. Regeneração Metropolitana de 1993-2004 como estratégia de desenvolvimento urbano a partir da "Cidade Global".

Após o fim da Ditadura de Franco (1979), os anos oitenta foram marcados pelo determinismo de um processo de auto-estima em referência com a melhoria com o meio ambiente urbano, uma unidade social para evitar a consolidação dos "guetos", a segregação e a exclusão social e, finalmente, um senso comum cultural que pressupõe a capacidade de regenerar o tecido urbano, que naquele momento passava por um número considerável de áreas degradadas, em especial no então conhecido "Bairro Gótico".

Neste momento, podemos apontar a figura de Oriol Bohigas como o elemento norteador da condução desta regeneração urbana, no qual ficou reconhecida como "Acupuntura Urbana". Com a estratégia de requalificar a cidade a partir de pequenos projetos sobre 0 tecido urbano degaradado, um conjunto de arquitetos foram chamados a colaborar com o "mentor urbano" desta ação, colocando em prática o redesenho de pequenos espaços que deveriam influenciar, direta ou indiretamente, sobre a qualidade urbana de toda a cidade. ${ }^{74}$

"Oriol Bohigas, ohomematrás daidéia, ressalta, o processo nãofoi aresposta a umasistematizaçãoprévia-a necessidade deaçãoimediatafoiuma prioridadeabsoluta.No entanto, como oprogramaavançou, uma maior racionalizaçãofoi introduzidanoprocessodeintervençãonoespaçoverdee aberto"75 (BUSQUETS 2005, p 354).

Como apontado por Manuel de Solà-Morales, em seu livro "De cosas urbanas", "acupuntura projetiva não tem muito a ver com os pequenos, minusio ou delicado, como com o estratégico, sistêmico e interdependente" ${ }^{, 76}$ (SOLÀ-MORALES 2008, p 24). A partir desta exposição, devemos entender que os projetos urbanos devem estar relacionados entre si, na busca de um objetivo comum, a transformação da cidade a partir do tratamento estratégico do tecido urbano relacionadas à causa-efeito das intervenções colocadas em prática.

O final dos anos 80 se deu com a candidadtura e confirmação da cidade como sede dos Jogos Olímpicos de 1992. Este fato fez com que, segundo Pedro Sales (1999), Barcelona retomasse sua economia como aporte de capitais externos, conferindo recursos e garantindo o apoio do governo central.

74. Os arquitetos contratados por Bohigas e Acebillo, alguns deles ainda na Câmara de Vereadores, foram: Ignasi de Lecea, Lluís Mestras (engenheiro), Luisa aguado, Andreu Arriola, Pedro Barragan, Rosa Maㅡ clotet, Jordi Farrando, Carme

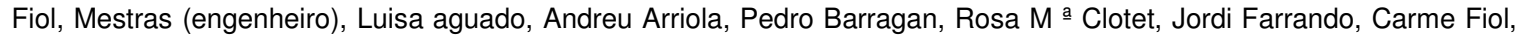
Beth Gali, Jaume Graells, Jordi Henrich, Josep Maㅡ Julià, Ramon Marqués, Enric Pericas, Màrius Quintana, Carme Beth Gali, Graells Jaume, Jordi Henrich, Josep M a Júlia, Marqués Ramon, Pericás Enric, Mário Quintana, Carme Ribas, Bernardo de Solà, Olga Farrassó, Pepita Teixidor. Ribas, Bernardo de Solà, Farrassó Olga, Teixidor Pepita

75 . As Oriol Bohigas, the man behind the idea, points out, the process was not the response not to a prior systematisation - the need for immediate action was an absolute priority. However, as the programme advanced, greater rationalisation was introduced into the process of intervention on green and open space.

Tradução do autor, 2011

76. La acupuntura proyectual no tiene que ver tanto con lo pequeño, lo minucioso o lo delicado, como con lo estratégico, sistémico e interdependiente.

Tradução do autor, 2011 

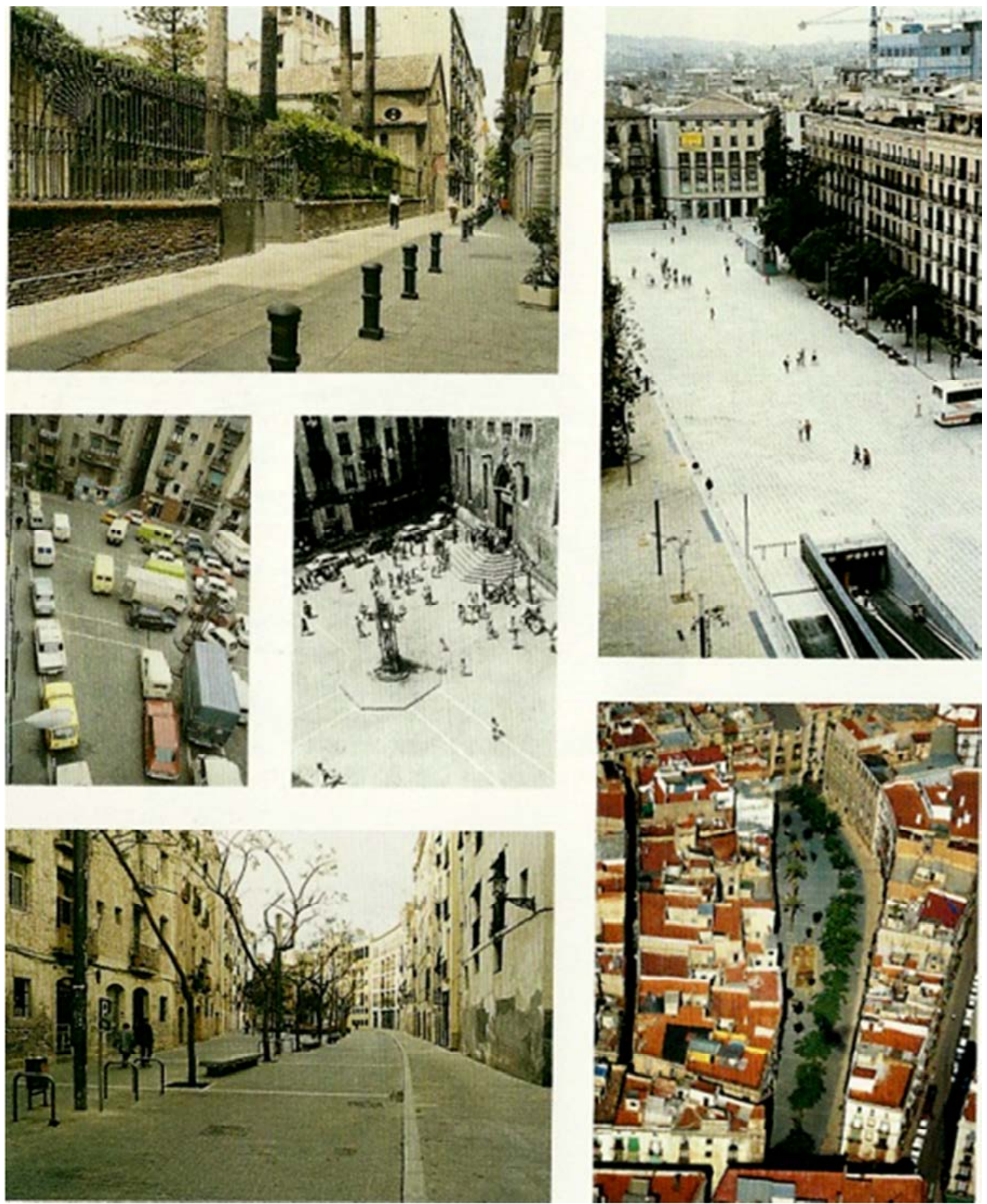

Figura 48. Reabilitação e criação de espaços públicos na Cidade Velha (acupuntura urbana) Fonte: Barcelona: the urban evolution of a compact city, 2005 
Segundo Joan Busquets, "a candidatura foi um processo de representação conduzido por Jordi Serra e uma equipe pequena. O desenvolvimento urbano iniciou com os planos para os diferentes setores e os projetos preliminares para as grandes infraestruturas em 1983-86. O processo foi de grande complexidade,os planos apresentaram uma hipótese de que a candidatura olímpica poderá ratificá10"77(BUSQUETS 2005, p 400).

As intervenções urbanas neste momento, são em diversas escalas sobre o tecido urbano de quase toda cidade, ora como "acupunturas" em estruturas pré-existentes capaz de se regenerer e reahilitar-se rapidamente para atender ao programa dos Jogos Olímpicos, ora na transformação do tecido urbano degradado. Como já apontado anteriormente, tanto a quadrícula como a manzana propostos por Cerdà possibilitavam sua regeneração ou transformação sem qualquer prejuízo a sua concepção original, onde justamente a proposta de intervenção para os Jogos Olímpicos de 92 ancora-se sobre a possibilidade de uma estratégia geral de reurbanização e renovação da cidade, garantindo no final de todo o processo a melhoria nas infra-estruturas urbanas e a qualidade de vida em geral. Para tanto, quatro áreas distintas da cidade foram eleitas como "objetos de intervenção urbana" para receber as instalações olímpicas:

1. Área de Montjuic, que abrigaria os principais equipamentos desportivos (Estádio Olímpico, Pavilhão Desportivo), e que de certa forma, buscava reafirmá-la como lugar representativo da cidade, desde a Exposição de 1929;

2. Espaço Diagonal, com os demais equipamentos desportivos, porém junto à Avenida Diagonal;

3. Vall d'Hebron, nos limites da Montanha de Colserolla, que abrigaria entre outros equipamentos o Velódromo de ciclismo;

4. Parc de Mar (Poblenou), área responsável pelos esportes aquáticos, no qual a implantação do Porto Olímpico.

Das quatro áreas acima descritas, acredita-se que a última foi a que mais se beneficiou das transformações urbanas, onde além do Porto Olímpico outros equipamentos e edifícios deveriam ser implantados junto a esta área, como a Vila Olímpica, Habitação Escritórios e Centros de Negócios, Hotéis (investimentos privados). É notória a transformação sobre o cenário urbano nesta área da cidade, que se beneficiou e teve como principal "legado" dos Jogos Olímpicos, como apontado por Pedro Sales (1999, p 219-220): "a Vila Olímpica de Poblenou respondeu a outro tipo de preocupações: abrir a cidade para o mar, dando novo uso àquela faixa até então isolada pela ferrovia $e$ reverter assim às orientações e tendências estabelecidas pelos vetores de crescimento interior da cidade".

Após os Jogos Olímpicos de 92, podemos afirmar que Barcelona reassume seu posto de "Referência Urbanística" para as cidades européias e demais no mundo. A partir de então a cidade já não é mais concebida, ela é programada. Os Grandes Projetos Urbanos colocados em prática desde então tem por entendimento a importância da cidade como "Cidade Global", impulsionada por novas tecnologias e formas econômicas e sociais de se relacionar com os habitantes e usuários desta cidade.

É neste panorama que a extensão da Avenida Diagonal encontra o mar, sob um território em plena transformação em sua vocação urbana, econômica e social. Sediar em 2004 o Fórum de las Culturas possibilitou ensaiar sobre um território ainda pouco explorado a celebração de um "novo desenho de cidade".

77 . Tradução do autor, 2011.

The candidature was a process of representation conducted by Jordi Serra and a small team. The urban development wheel began to roll with plans for the different sectors and the preliminary projects for major infrastructures in 1983-86. The process was a highly complex one, as the plans presented a hypothesis that only Olympic nomination could ratify. 

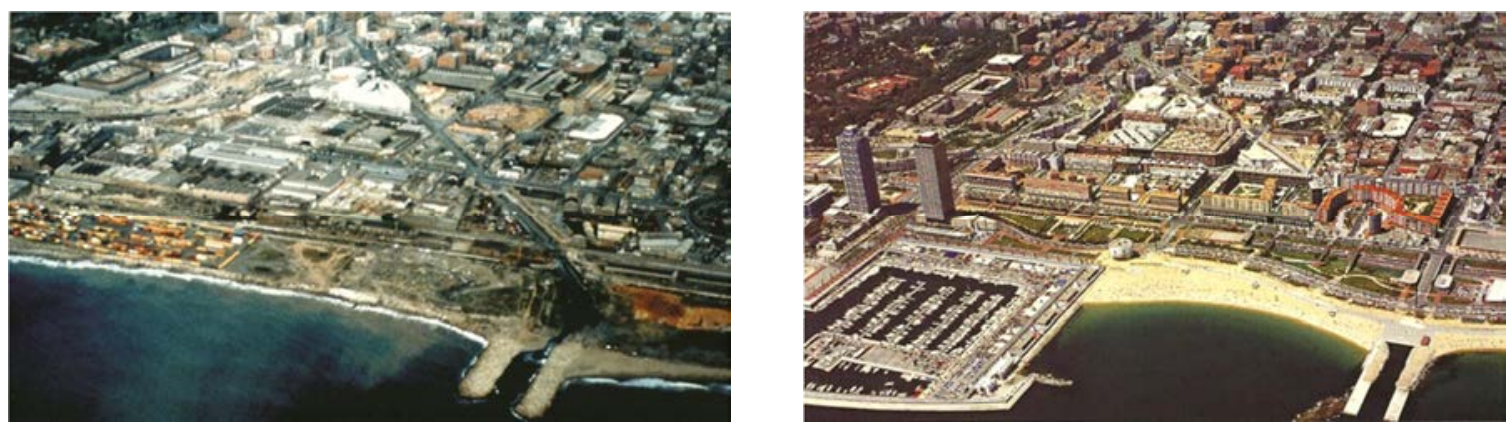

Figura 49. A frente costeira, em 1987, com instalações obsoletas, os containers do Porto nas praias e esgotos que escoam para o mar. Vista do mesmo local, transformada em1992

Fonte: Barcelona: the urban evolution of a compact city, 2005
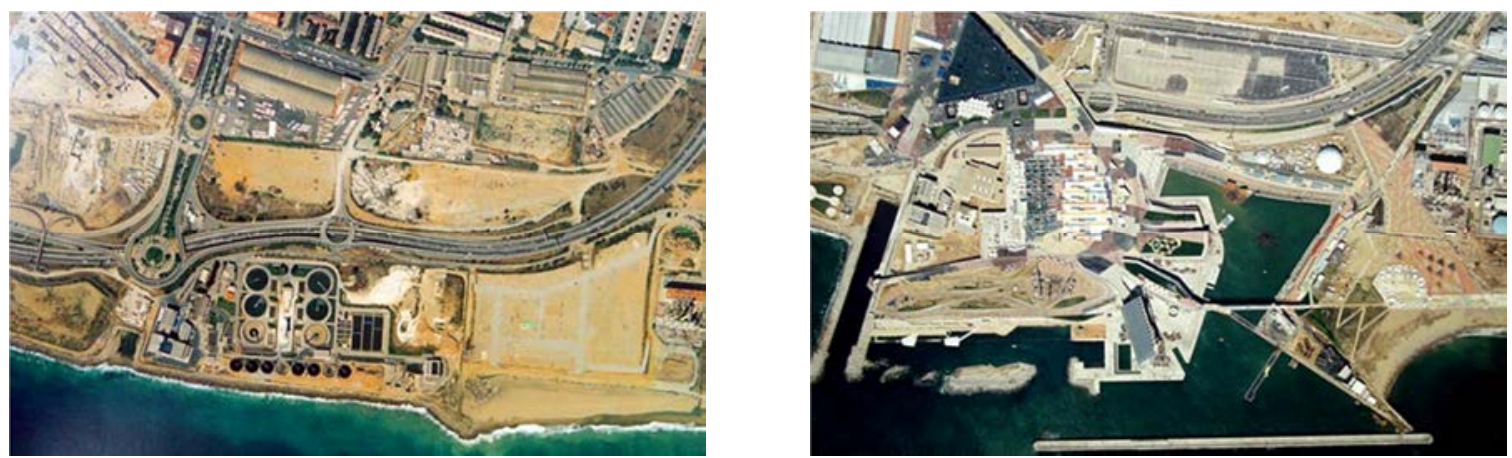

Figura 50. Área do FÓRUM DE LAS CULTURAS 2004, antes e depois das intervenções urbanas Fonte: Institut Cartogràfic de Catalunya

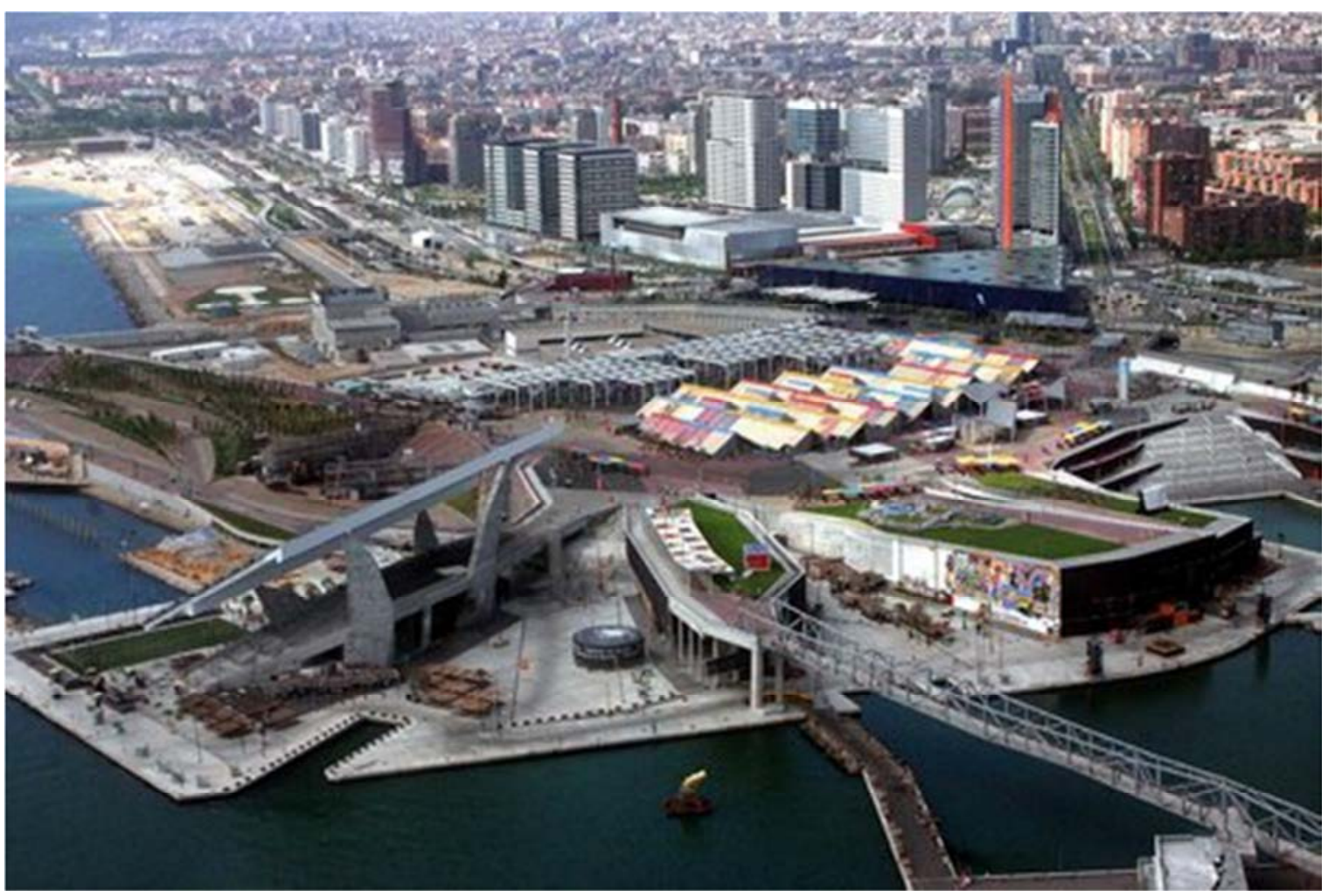

Figura 51. Vista aérea do FÓRUM 2004

Fonte: www.barcelona2004.org, acessado em 17/04/2011 
Sob o lema plural das culturas, este novo fragmento de Barcelona substitui a quadrícula racional de Cerdà por um tecido "descontraído" e como uma espécie de "colagem urbana", os edifícios cumprem o papel de integradores do espaço urbano. Com isto, um edifício torna-se protagonista deste cenário urbano, de autoria de Herzog \& de Meron, o Fórum 2004 representa o "totem" de uma cidade tribal e, transformando-se numa marca turística oferecido ao mercado de logotipos como um destino desejável, capaz de cumprir as necessidades de uma cidade polivalente.

Outros mais Projetos Urbanos estão hoje em desenvolvimento e implantação em diversas áreas da cidade. Se Barcelona é considerada uma cidade global, esta expressão deve ser representada como um mapa dos desejos coletivos e, portanto, de um modelo apresentado às novas formas de se compreender a cidade contemporânea. Neste sentido, os projetos 22@Barcelona e La Sagrera, ambos em processo de implantação, representam estas possibilidades em que as Novas Centralidades Urbanas têm como instrumentos de regeneração do tecido urbano desarticulado ou de áreas subutilizadas em regiões de grande valor urbano para a cidade. Neste sentido, os dois projetos acima deverão ser mais bem estudados, analisados e compreendidos, por se tratar de experiências relacionadas à esta tese e de grande contribuição para as discussões e reflexões em relação ao "objeto de estudo". 


\subsection{Projeto 22@ Barcelona}

Considerado como um Plano de Inovação Urbana, o Projeto 22@BCN propõem a transformação de 200 hectares, numa área de 115 manzanasda antiga zona industrial de Poblenou, com fábricas que se tornaram obsoletas e foram fechadas ao longo dos anos desde o final do século XIX e início do século XX. Aprovado em 2000 pela Câmara Municipal de Barcelona, ${ }^{78}$ a lei destinava a transformar o centro urbano desta região em novas atividades mais contemporâneas sem a perda de sua vocação industrial e possibilitando sua diversidade econômica e a ampliação de habitação nesta região da cidade.

"Com a renovação urbana, responde à necessidade de restaurar o dinamismo econômico e social de Poblenou e cria um ambiente diverso e equilibrado em que as instalações de produção ao lado de equipamentos, habitação e áreas verdes que melhorem a qualidade de vida e trabalho."79(A. D. BARCELONA 2008)

A possibilidade de transformação deste tecido urbano degradado e construções obsoletas em um modelo de cidade compacta, onde as empresas mais inovadoras convivem com centros de pesquisa, formação acadêmica e de tecnologia, bem como habitação (temporárias, estudantes e de interesse social), equipamentos e áreas verdes, em simultâneo a um modelo de desenho urbano que leva em consideração o patrimônio industrial por meio da adoção do Plano de Salvaguarda do Patrimônio Industrial, resulta em uma "nova cidade" em que seus usos são utilizados de forma diversa e em harmonia entre si, garantindo maior qualidade urbana aos usuários desta região da cidade.
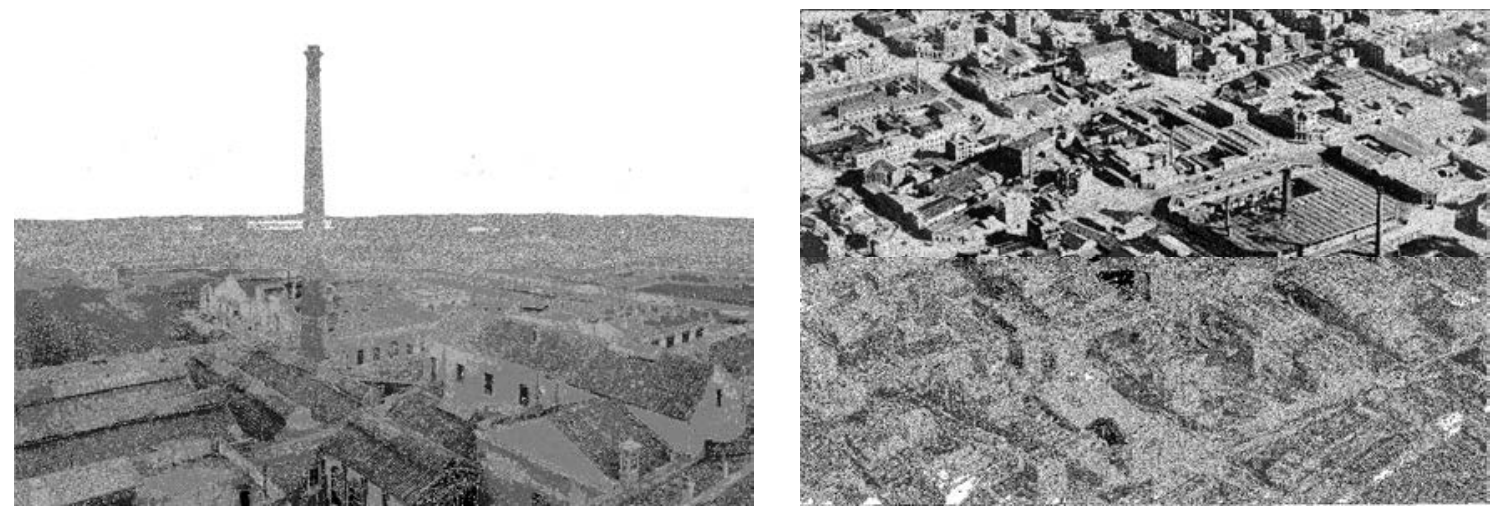

Figura 52. Distrito de El Poblenou em 1922 e 1928

Fonte: www.lallacuna.org/el-poblenou/, acessado em 28/04/2011

78. O Plano Especial de Infraestruturas (PEI) foi aprovado em 27 de outubro de 2000 e prevê a urbanização integral de todo o distrito de 22@ Barcelona segundo os seguintes critérios: Sustentabilidade: controle e redução da poluição sonora, utilização de energias renováveis, favorecimento do transporte público e economia energética; Prestação de Serviços em regime de competências (telecomunicações e energia) - definição de soluções mais idôneas para favorecer este processo. Sistema de hierarquia de espaços públicos e privados sobre os quais se implantam as redes (troncais, de distribuição, salas de manutenção técnicas, recolhimento de resíduos e outros).

79. Tradução do autor, 2011

Com a renovació urbana, respon a la necessitat de recuperar el dinamisme econòmic i social del Poblenou i crea un entorn divers $\mathrm{i}$ equilibrat, en què els espais productius conviuen amb habitatges protegits, equipaments $\mathrm{i}$ zones verdes que milloren la qualitat de vida i de treball. 
Para que se concretizasse a estratégia de ampliar as áreas livres e públicas sobre os perímetros delimitados no Projeto 22@BCN, a proposta estabelece que 30\% da terra antes utilizada por indústrias de plantas que ocupavam a totalidade da quadra urbana, fossem substituídas por plantas compactas (verticalizadas) abrindo a possibilidade de redesenho urbano mais generoso e com diversidade de usos. Assim, o incremento de novas edificações, em especial de usos habitacionais e instituições de ensino superior de tecnologia contribuem para a progressiva reurbanização de toda a área de intervenção de Poblenou, como a ampliação na qualidade espacial por meio de um novo modelo de sistema viário e a implantação de generosas áreas verdes (praças e parques) estabelecendo junto ao bairro um novo modelo mais flexível aos instrumentos urbanísticos de transformação urbana em Barcelona, nisto o projeto resulta em:

- Potencial máximo construtivo: 4.000.000,00 m²;

- Atividades produtivas: $3.200 .000,00 \mathrm{~m}^{2}$;

- Outras atividades (equipamentos, habitação): 800.000,00 m²;

- Requalificação de 4.614 unidades habitacionais existentes;

- Criação de 4.000 novas unidades habitacionais públicas (25\% destinadas para aluguel);

- Ampliação das áreas verdes existentes: $114.000,00 \mathrm{~m}^{2}$ de praças e parques;

- Novos equipamentos para o distrito: $145.000,00 \mathrm{~m}^{2}$ de terreno;

- Aumento de empregos: 150 mil empregos estimados;

- Plano de Investimentos: €180 milhões.

Da mesma forma que o Projeto 22@BCN proporciona a ampliação das áreas construtivas e o uso diversificado sobre um território anteriormente ocupado por indústrias têxteis, a proposta leva a cabo a ampliação do potencial construtivo além do coeficiente líquido dos índices urbanísticos já utilizados pelo MPGM, ${ }^{80}$ ou seja, 2,2 sendo que 0,2 corresponderia à compensação ao empreendedor pelo incremento dos custos de urbanização atrelados ao PEl. Em consequência a nova vocação da área estabelecida pelo Projeto 22@BCN foi estabelecido um coeficiente adicional de 0,5 a ser somado ao coeficiente de aproveitamento líquido, tal índice deveria ser destinado aos usos relacionados à tecnologia da informação e comunicação (atividades @).

Por fim, foi estabelecido um coeficiente complementar adicional de 0,3 que deve ser destinado à municipalidade, que obrigatoriamente será destinado à habitação de interesse social e ao incremento de áreas verdes no distrito de Poblenou.

Ao analisarmos este instrumento de incremento urbanístico em relação ao Plano de Cerdà, no qual estabelecia desde a proposta original (1858) um coeficiente construtivo de 2,0, o MPGM já estabelece um adicional de 0,2 sobre o de Cerdà ( $10 \%$ acrescido do Eixample de Cerdà). Quanto ao índice de 0,5 correspondente as atividades @, tem-se uma massa construtiva de $25 \%$ de acréscimo e mais $15 \%$ destinados à municipalidade para a implantação de habitação social, garantindo a diversidade de usos sobre este novo território. Junto a isto, uma parcela da ocupação sobre este solo (30\%) deveria ser reservada a novos usos destinados aos espaços livres públicos. Ao analisarmos sobre este item, fica claro que a porcentagem destinada a estes espaços são inferiores ao proposto inicialmente por Cerdà, que tinha como meta a reserva de $50 \%$ da quadra destinada a estes espaços, no entanto, após mais de um século e meio da implantação do Plano de Expansão de Cerdà, nota-se que muitas das manzanas estão ocupadas quase que em sua totalidade, desarticulando as propostas iniciais de seu autor. Diferentemente das propostas colocadas por Cerdà, o Projeto 22@BCN representa uma

80. A Alteração do Plano Geral Metropolitano (Modificació del Pla General Metropolità - MPGM), favorece a diversidade de usos sobre o território, reconhecendo as habitações existentes e planos de adicionais com novos usos que são complementares à habitação e compatível com as atividades de produção. 
nova fase do urbanismo de Barcelona e coloca em prática uma forma de redesenhar o tecido urbano a partir da massa construída pré-existente e seu resultado, quanto desenho proposto, já estabelece todas as formas de ocupação e as responsabilidades de cada agente urbano sobre os perímetros a serem desenhados.

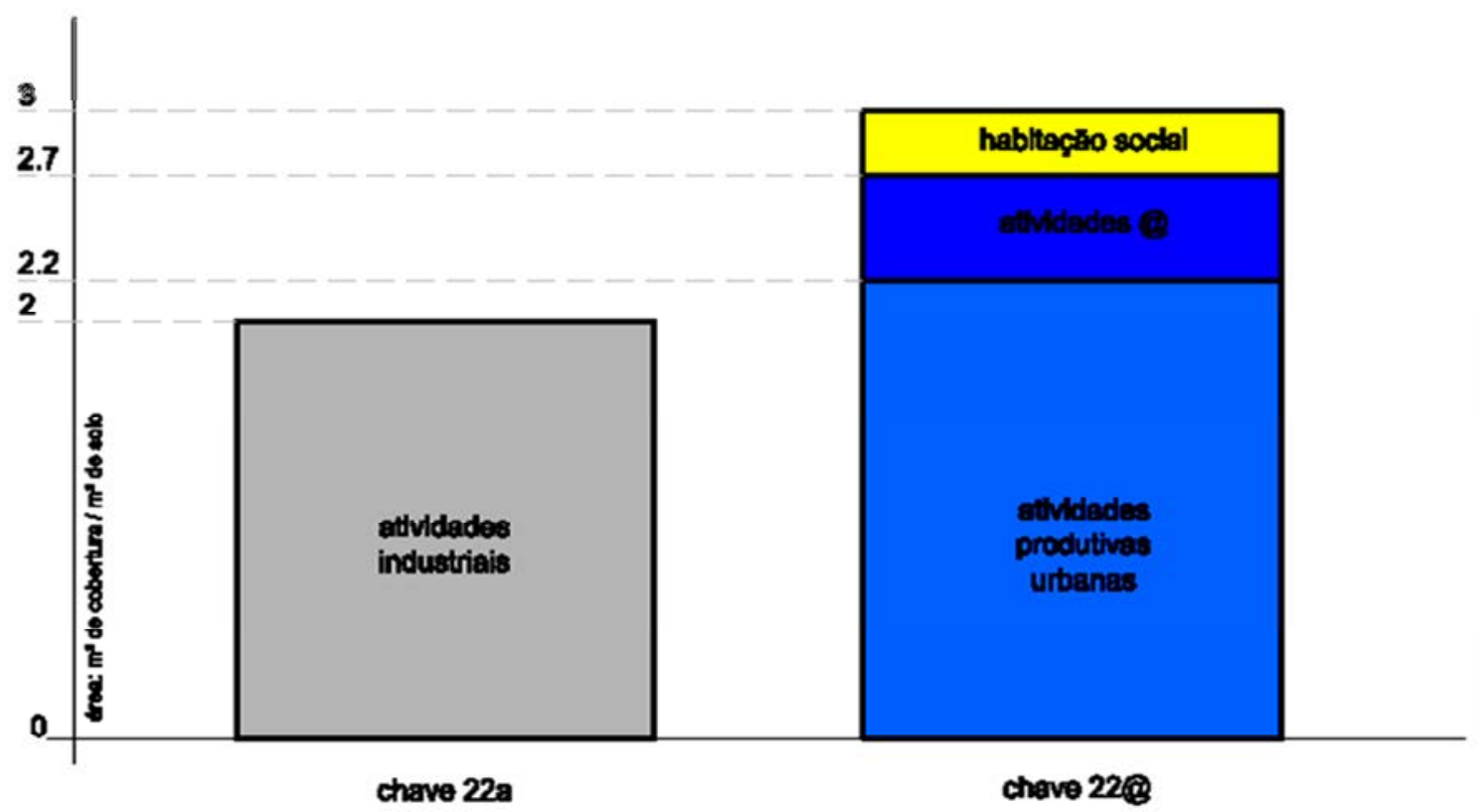

Figura 53. Gráfico da ampliação de densidade construtiva, elaborado a partir das informações do Relatório 22@Barcelona

Elaboração: Elvis Vieira, 2011

Quanto a isto, o Projeto 22@BCN estabelece seis Planos Especiais de Reforma Interior (PERI), nos quais deveriam ser desenvolvidos pela iniciativa pública por meio da Prefeitura de Barcelona - Departamento de Planejamento Urbanístico:

1. Campus Audiovisual: delimitada entre a Avenida Diagonal e as ruas Llacuna, Almogàvers e Ciutat de Granada, as quadras neste perímetro são compostas por antigas plantas industriais em sua maioria desativadas ou subutilizadas. Para este setor, as propostas se norteiam em sete conceitos fundamentais: 1) ter como pressuposto a trama de Cerdà; 2) a disposição de momumentabilidade; 3) a implantação de novos edifícios; 4) a diversidade social entre os usos e as atividades @; 5) a existência de um eixo Teatro/Auditório - Campus Audiovisual; 6) a preservação de antigos edifícios industriais; 7) a incorporação de uma torre como elemento urbanístico singular, ${ }^{81}$

2. Eixo Llacuna: compreende o conjunto de quadras em ambos os lados da rua Llacuna, entre as ruas Almogàvers e Doctor Trueta e uma parcela das quadras da rua Doctor Truetae Carmen Amaya. Este setor tem como proposta ordenadora uma tripla intenção de estabelecer um eixo estruturante que reforce a relação mar-montanha, dar continuidade ao viário como parte do sistema de

81. BARCELONA e 22@BCN. Pla Especial de Reforma Interior del Sector del Campus Audiovisual de la MPGM per a la Renovació de les Àrees Industrials del Poblenou - districte d'activitats 22@bcn, 2001, p. 24. 
ruas primárias de Poblenou e reforçar as condições urbanas e de centralidade do núcleo histórico e residencial do bairro, tendo como referência doze conceitos: 1) configurar o espaço da rua Llacuna baseado em um alinhamento duplo de fachadas e ampliando o skyline em relação à malha de Cerdà; 2) estabelecer uma sequência de espaços livres com a ampliação dos espaços públicos das vias e as passagens entre os vazios; 3) garantir a diversidade de usos públicos e privados, os edifícios existentes e a nova arquitetura e a variedade tipológica ao longo da rua Llacuna; 4) assegurar a continuidade da malha viária existente, especialmente ruas Pujades e Ramon Turró e a implantação de habitação e equipamentos que assegurem o uso ao longo do dia; 5) manter uma parcela do conjunto edilício destas quadras como parte da memória do setor industrial de Poblenou; 6) apoiar a implantação de novas edificações, de alturas variadas e que possibilite a reinterpretação do mecanismo morfológico com passagens pedonais pelo interior da quadra; 7) dotar o setor de um equipamento de educação; 8) expandir a zona verde do setor para garantir maior qualidade aos edifícios existentes e os novos; 9) reservar uma pequena porção de espaços destinados a estacionamento aos moradores do setor; 10) possibilitar total acessibilidade nos pisos ligados ao nível da rua; 11) abrir o trecho interrompido da rua Llacuna, entre Pallars e Pere IV, para garantir a continuidade funcional e visual de todo o eixo viário; 12) com as áreas livres e de lazer incorporadas ao PERI, em conjunto ao MPGM, o conjunto deste setor assegura a correta formalização do espaço livre com as demais construções e equipamentos; ${ }^{82}$

Llull Pujades Ponent: composto pelo conjunto de quadras em ambos os lados da rua Pujades, entre as ruas Joan d'Austria e Roc Boronat, três quadras situadas entre as ruas Llull, Ramon Turró, Àvila e Roc Boronat, mais uma parcela das quadras delimitadas pelas ruas Llull, Ramon Turró, Joan d'Austriae Pamplona, de frente para a rua Llull. Quanto aos critérios de ordenamento urbano para este setor, foram definidos doze conceitos, que se segue: 1) manter uma parcela do patrimônio edificado para assegurar a continuidade formal e a memória do setor industrial de Poblenou; 2) possibilitar a criação de espaços livre que potencialize a conexão entre as vias através dos pátios internos das novas edificações; 3) garantir a diversidade de usos, públicos e privados, a variedade tipológica e volumétrica entre as edificações existentes e as novas; 4) assegurar as condições de continuidade das vias (Pujades e Ramon Turró), reforçando a conexão entre o bairro e o centro da cidade; 5) dotar o setor de áreas livres públicas capazes de abrigar equipamentos urbanos para o bairro; 6) definir como "porta de entrada" para Poblenou as fachadas da rua Joan d'Austria; 7) apropriar-se das ilhas triangulares como elemento de perspectiva visual para este setor; 8) tratar os espaços resultantes do novo desenho das vias como conectores entre o espaço livre e as construções existentes e propostas; 9) recompor a morfologia urbana proposta tratando as quadras como espaços intersticiais entre os edifícios existentes e os novos; 10) estabelecer critérios manutenção do conjunto edilício, tanto no seu valor tipológico e espacial, que garantam a incorporação dos processos de transformação da paisagem deste setor; 11) definir espaço a ser reservado a estacionamento (500 vagas) para atender a demanda deste setor; 12) definir sub-setores capaz de possuírem gestão independentes entre eles; ${ }^{83}$

82. BARCELONA e 22@BCN. Pla Especial de Reforma Interior del Sector Eix Llacuna de la MPGM per a la Renovació del les Àrees Industrials del Poblenou - districte d'ativitats 22@bcn, 2002, p. 16-17.

83. BARCELONA e 22@BCN. Pla de Millora Urbana per a la Reforma Interior del Sector de Llull-Pujades-Ponent de la MPGM per a la Renovació de les Ârees Industrials del Poblenou - districte d'ativitats 22@bcn, 2004, p. 24-25 
Figura 54. Barcelona 1976 | Distrito de Poblenou

Fonte: BCN Historic Maps

Figura 55. Barcelona 1987 | PréOlimpíadas 92, imagem da área hoje conhecida como 22@Barcelona

Fonte: BCN Historic Maps
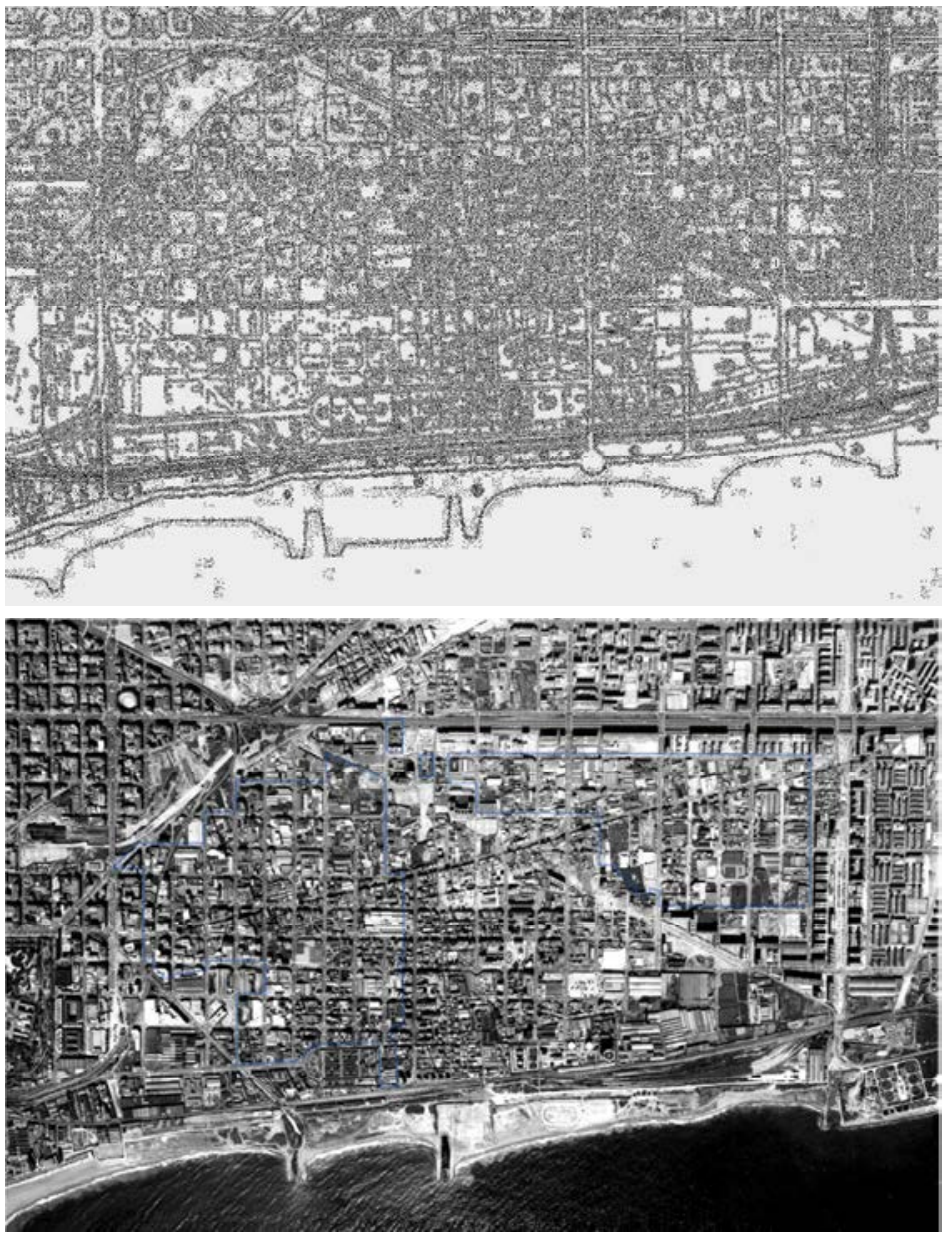

Figura 56. Barcelona 2011 | Projeto 22@BCN, Planos Especiais de Reforma Interior (PERI)

Fonte: Google Earth, 2011

Organização: Elvis Vieira, 2011

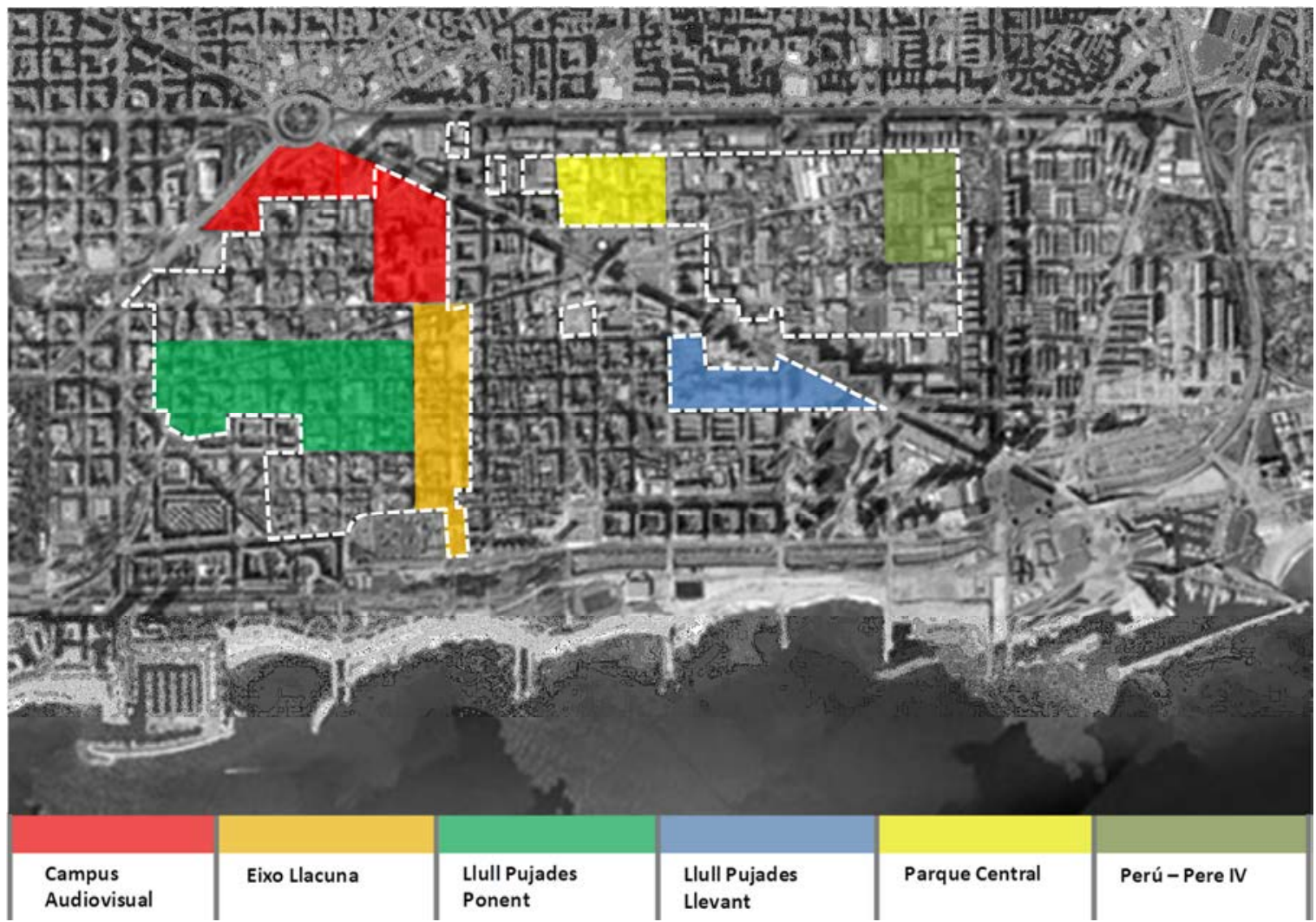


3. Llull Pujades Llevant: composto por três quadras (denominadas 22@) sobre a rua Llull, entre Bac de Roda e Selva de Mar, uma denominada 22@ delimitada entre as ruas Bac de Roda, Pujades, Fluvià e Pallars, e uma denominada 7@ de forma triangular delimitada pela via Diagonal e as ruas Llull e Selva de Mar. Diferentemente dos demais setores do Projeto 22@BCN, os conceitos foram apontados em forma de objetivos a serem alcançados com as intervenções, tendo como conceito geral fomentar a gestão urbanística através da: participação da comunidade na concepção dos projetos urbanos e arquitetônicos como ferramenta concreta de equilíbrio entre as propostas e a realidade do local; os projetos deverão propiciar o equilíbrio entre as funções do setor garantindo a transformação do setor através da implantação de áreas verdes, equipamentos etc; ${ }^{84}$

4. Parque Central: a área é composta por seis quadras entre as ruas Perú, Bac de Roda, Marroc e Bilbao. Devido a sua proximidade do PERI Diagonal Poblenou, este setor deverá articular os grandes eixos estruturantes (Diagonal, Pere IV e Cristóbal de Moura) levando em consideração as novas infraestruturas de transporte público. Neste setor, apesar de não pertencer ao perímetro proposto, a implantação de uma grande área verde (Parc Central) cumpre a função de articular as quadras do Eixample (Cerdà) com a malha viária existente, garantido a permeabilidade entre os espaços novos e os existentes no bairro de Poblenou;

5. Perú - Pere IV: composto por sete ilhas situadas entre as ruas Paraguai (prolongamento rua Perú), Maresme, Cristóbal de Moura e Josep Pla. A área é caracterizada pela sua rica diversidade de parcelamento, de pequenos a grandes lotes no qual possibilita um novo redesenho da morfologia proposta. Diferentemente dos demais setores, este é caracterizado pela baixa densidade populacional, estando mais presente as "antigas indústrias" do bairro de Poblenou.

Como estratégia urbana, o Projeto 22@BCN culmina num processo de transformação urbana do bairro de Poblenou em conjunto com os demais projetos em andamento em toda Barcelona, em especial com os Planos de Sant Andreu-Sagrera, o Projeto de Melhora Urbana da Plaça de les Glòries e Plano de Renovação da Frente Marítima Besòs.

Devido a sua importante localização, o Projeto 22@BCN é considerado como uma nova centralidade urbana que se conecta a dois importantes pólos de atividade econômica e cultural: Plaça de les Glòries, que abrigará o futuro centro administrativo e cultural de Barcelona, e Centro de Convenções Internacional de Barcelona, com acomodação de até 20.000 pessoas. Ainda segundo relatório apresentado pela Prefeitura de Barcelona, "através de uma extensa rede de transportes, o distrito 22@Barcelona garante excelente acessibilidade urbana, metropolitana e internacional". ${ }^{85}$ (A. D. BARCELONA 2008, p 04). Nisto, algumas das estruturas e intervenções implantadas no perímetro do Projeto Urbano ou fora dele, vão influenciar direta $e$ indiretamente sobre 0 desenvolvimento urbano do distrito 22@, tais como:

84. BARCELONA e 22@BCN. Modificació Puntual del Pla Especial de Reforma Interior del Sector Llull Pujades Llevant de la MPGM per a la Renovació de les Àrees Industrials del Poblenou - districte d'ativitats 22@bcn, 2002, p. 14 85 . Tradução do autor, 2011

A través d'una completa xarxa de transports, el districte 22@Barcelona garanteix una excel·lent accessibilitat urbana, metropolitana i internacional. 

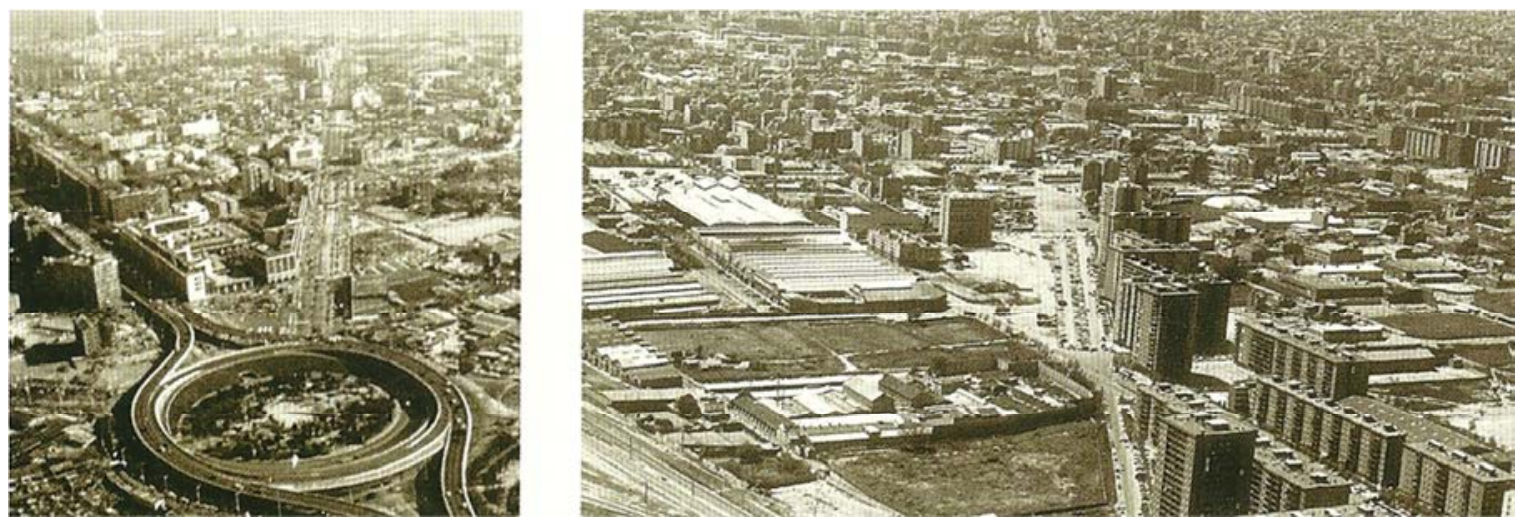

Figura 57. A continuação da Diagonal como uma conexão urbana com Poblenou

Fonte: Barcelona: the urban evolution of a compact city, 2005

Figura 58. Abertura da Avenida Diagonal

Fonte: 22@Barcelona: el district de la innovació, 2008

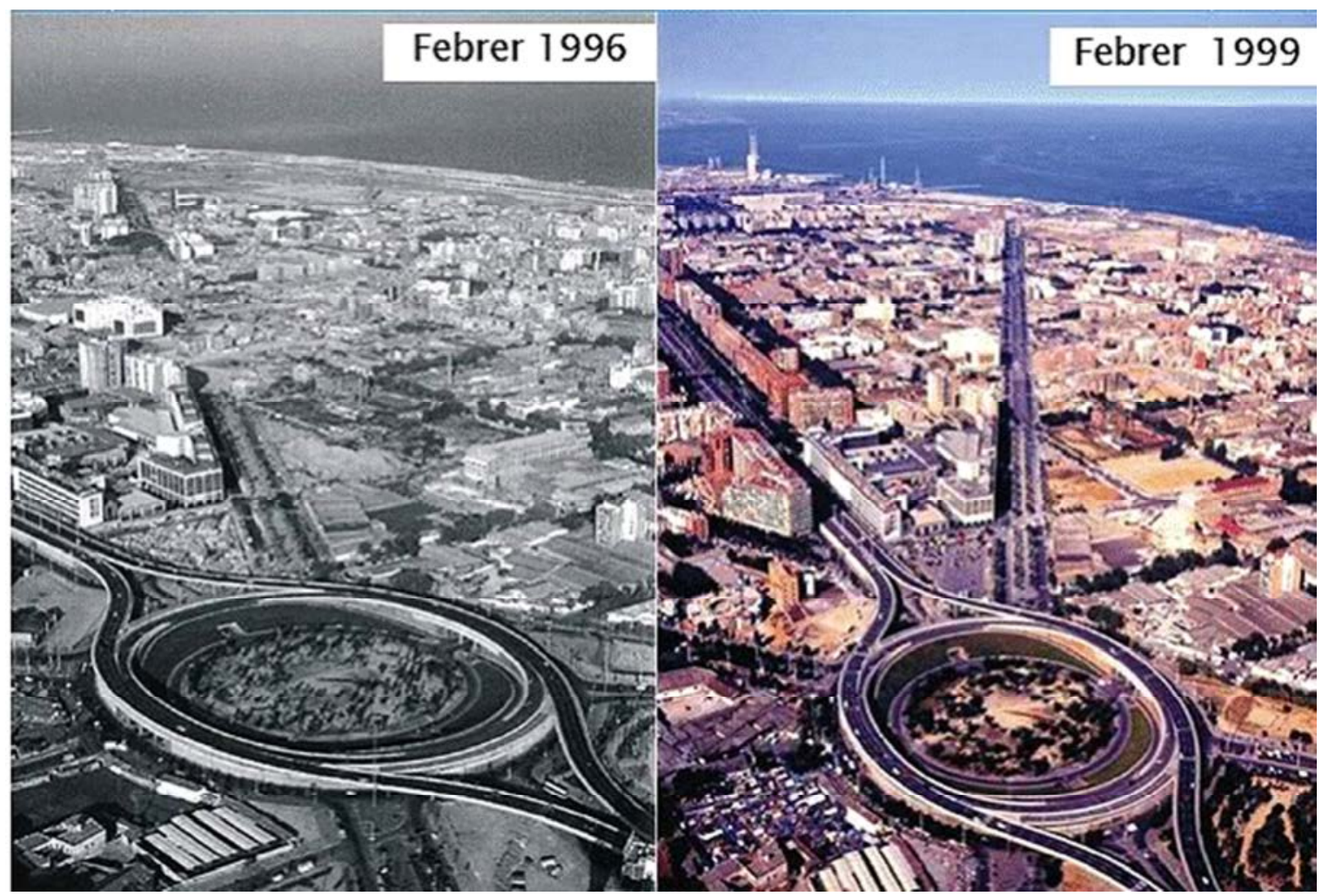

Figura 59. Maquete volumétrica do Projeto22@BCN, em primeiro plano Torre Agbar Fonte: www.22barcelona.com, acessado em 25/04/2011

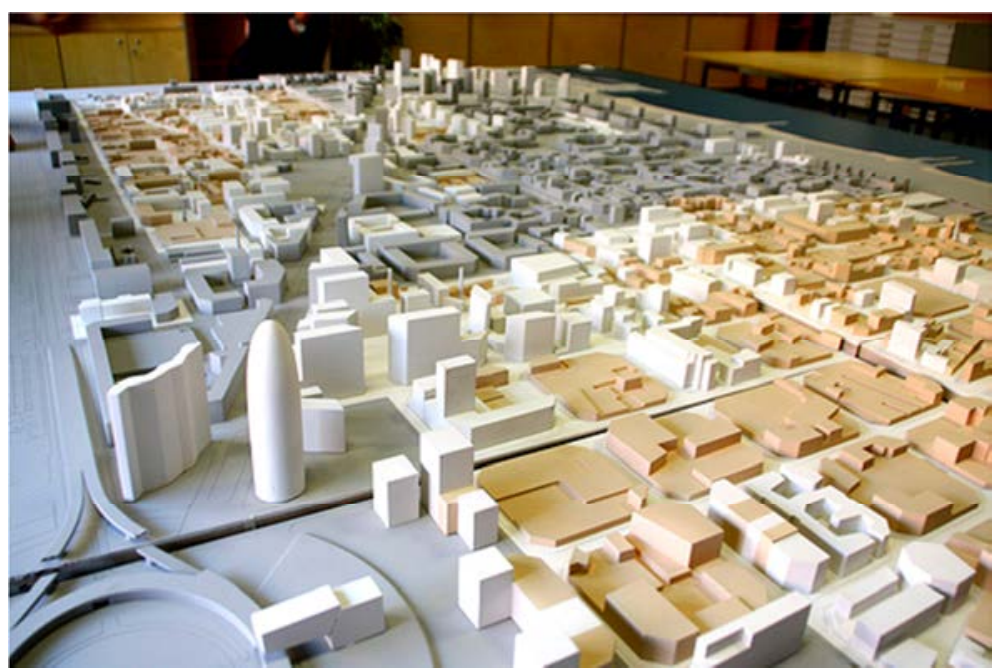


- Ronda del Litoral responsável pela conexão do distrito com a Região Metropolitana de Barcelona (RMB) e a rede de auto-estradas de transporte internacional;

- as linhas do Metrô (L1, L4 e futura L9 em execução), além do VLT (Trambesòs) ligando a área com a região leste da cidade e os principais municípios metropolitanos;

- a nova estação ferroviária conectando o futuro Centro Intermodal de Transportes (Plaça de Glòries) com o Aeroporto Internacional del Prat;

- a futura estação central de alta velocidade Sagrera, localizada a cinco minutos do novo bairro produtivo e conectando Barcelona à rede nacional e européia de transporte de alta velocidade;

- o serviço de bicicletas (Bicing) como alternativa de transporte público sendo implantado como uma nova rede de circulação e alternativa de mobilidade sobre a cidade.

No mais, o Projeto 22@BCN como estratégia de requalificação urbana vai garantir, através do Plano Especial de Infraestrutura (PEI), a implementação de redes de energia modernas, telecomunicações, climatização centralizada (ar condicionado), cabos de fibra ótica e coleta pneumática de resíduos (lixo), priorizando eficiência energética e de gestão responsável dos recursos naturais, permitindo melhorias significativas sobre a prestação de serviços públicos e utilizando como ferramenta de atração aos novos investimentos sobre o distrito.

Dez anos após a aprovação do Projeto Urbano, os resultados alcançados podem ser considerados como satisfatório, visto que a renovação urbana recuperou a dinâmica econômica e social de Poblenou. Os instrumentos de planejamento utilizados possibilitaram recuperar a área industrial deste distrito, reduzindo sua área de ocupação e garantindo, ainda assim, a implantação de empresas multinacionais e sedes corporativas por meio de seus cinco setores estratégicos, ${ }^{86}$ a criação de novas áreas verdes para o distrito e a implantação de novas instituições de ensino técnico e superior. A ampliação do número de unidades habitacionais possibilitou assegurar a vitalidade dos espaços públicos ao longo do dia e a garantia de se poder viver próximo ao local de estudo e trabalho, com toda infarestrutura urbana garantida e áreas livres com grande qualidade urbana.

Durante esta década (2001-2011), o projeto recuperou mais de 4.600 casas construídas nas zonas tradicionais industriais afetadas desde 1953, quando o Plano Regional estabeleceu o uso exclusivamente industrial no distrito de Poblenou (A. D. BARCELONA 2008 , p 08). Além das casas renovadas, o Projeto $22 @ B C N$ promoveu a construção até o momento de 4.000 novas unidades habitacionais valorizando a diversidade social e a vitalidade dos espaços públicos ao longo do dia. Desta forma, o projeto incentiva a preservação do patrimônio histórico (casas e indústrias), amplia a oferta de habitação no bairro (estima-se a construção de um total de 40.000 unidades habitacionais), garantindo uma proporção de aproximadamente $50 \%$ dos edifícios, garantindo 0 equilíbrio entre o espaço para viver e locais de trabalho e lazer.

86. Como estratégia econômica de atração de lideranças internacionais foi criada os clusters de determinadas áreas de conhecimento, através da concentração no território de empresas, instituições públicas e centros de referencia cientifica e tecnológica em cinco setores: Mídia, Tecnologia da Informação e Comunicação (TIC), Medicina (TECMED) e Energia. 

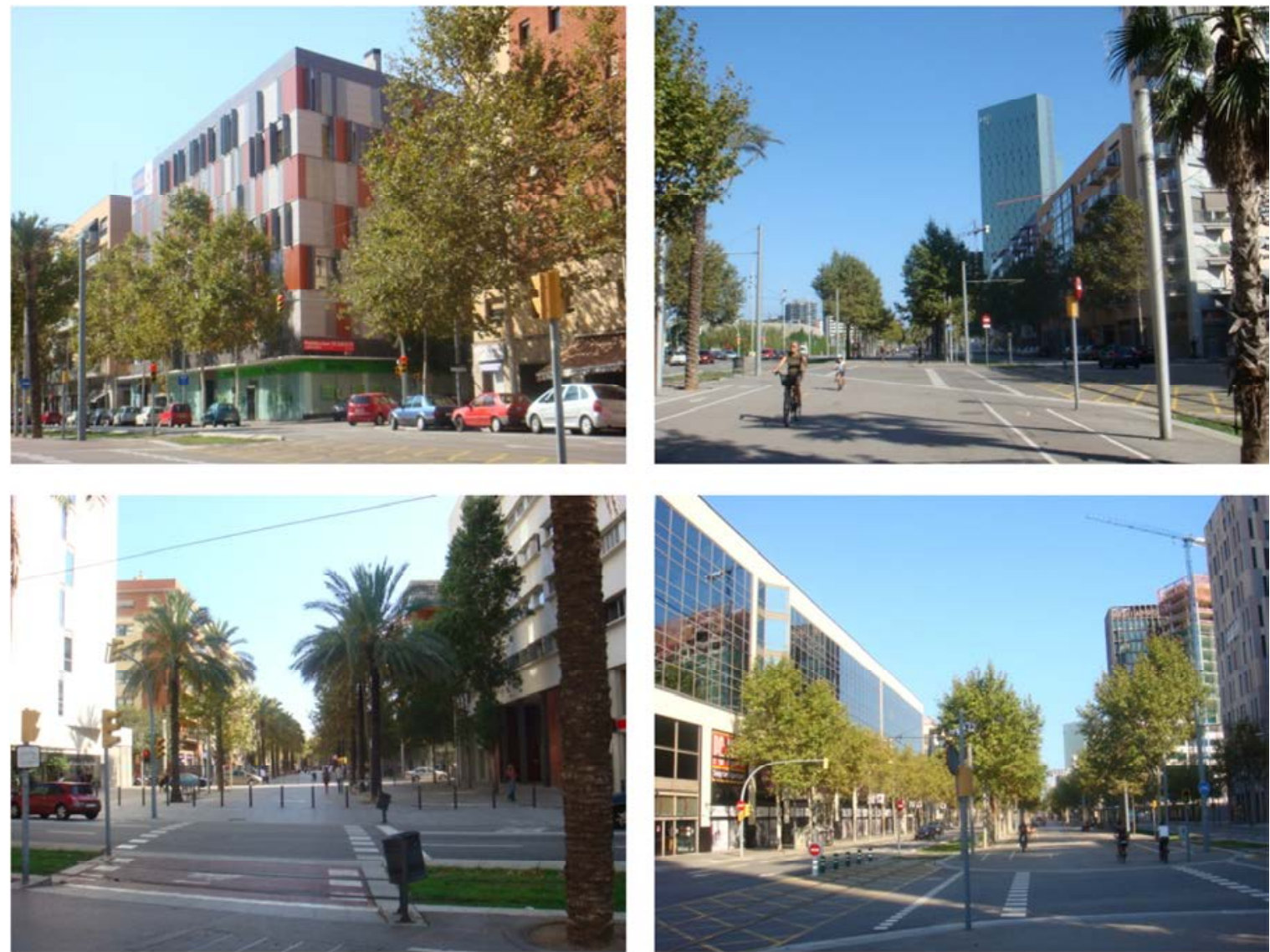

Figura 60. Vistas da área do Projeto 22@BCN, mudança do cenário urbano de Poblenou Fotos do autor, 2009
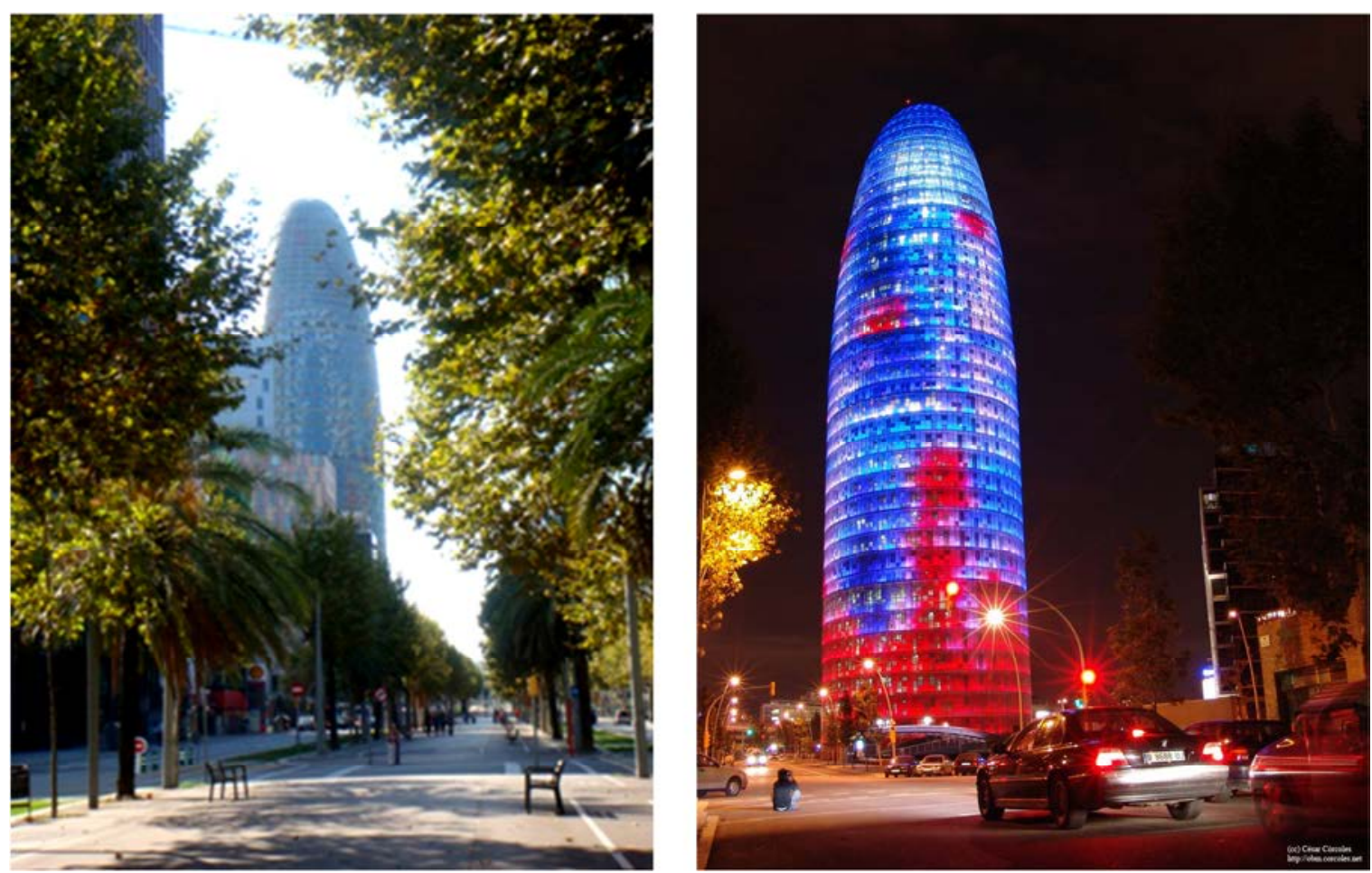

Figura 61. Vistas da Torre Agbar: diurna e noturna, uma nova paisagem do distrito de Poblenou Fotos: diurna - Elvis Vieira, 2009 | noturna - César Corcoles, s/d 
No que tange esta tese, o resultado alcançado sob a volumetria construída em Poblenou, gerou Novas Formas Urbanas diferenciadas em relação ao Eixample de Cerdà no qual propõem uma volumetria constante sobre as manzanas de seu Plano de Expansão. A diversidade no skyline, a forma com que as edificações se relacionam entre si e entre os espaços públicos e privados, o desenho dos espaços públicos tratados de forma contínua ao construído, as novas tecnologias das infraestruturas urbanas aplicadas sobre o bairro de Poblenou possibilitaram redesenhar parte do tecido urbano da Expansão de Barcelona, no qual se deteriorou nos últimos 50 anos, transformando a vocação anteriormente exclusivamente industrial (Plano Regional) para uma "nova vocação urbana" - um bairro de inovação tecnológica abrigando instituições de ensino, empresas e indústrias limpas capaz de garantir a dinâmica econômica da cidade com uma diversidade de usos e equidade social sobre este setor da cidade.

Como desenho da cidade o Projeto 22@BCN se tem claro a alteração do cenário existente em Poblenou, porém de forma consciente desde sua concepção, quando analisamos os PERIs propostos no projeto urbano, em espacial Campus Audiovisual item 7 dos conceitos fundamentais, no que diz respeito "a incorporação de uma torre como elemento urbanístico singular"(BARCELONA e 22@BCN 2001), é perceptível a inserção da Torre Agbar (projeto do arquiteto francês Jean Nouvel) como elemento arquitetônico que viria a tornar-se a referência urbana para o Projeto 22@BCN.

Por fim, a estratégia de renovação urbana utilizada em Poblenou alcançou um rápido resultado, atraindo novos investimentos privados, instituições de ensino e pesquisa, além de ampliar a reserva de habitações neste trecho da cidade. Como desenho urbano, nota-se que os espaços públicos recebem um tratamento especial em que o pedestre é o elemento prioritário do projeto, em conjunto com a nova rede de ciclovias, o transporte público menos poluente (VLT) e a ampliação de áreas verdes garantindo melhor qualidade urbana sobre este bairro. Enquanto a transformação dos cenários urbanos de Poblenou, antes dominado pelas edificações industriais e casas em sua maioria deterioradas e com baixa qualidade arquitetônica, é substituído num período de apenas uma década, por construções contemporâneas em sua maioria assinadas por arquitetos renomados mundialmente, com uma diversidade de tipologias e usos consolidando, agora, um bairro com qualidade urbana e equidade social. 


\subsection{Projeto La Sagrera - Sant Andreu}

Sagrera está localizada na antiga cidade de Sant Martí de Provence, ${ }^{87}$ a nordeste da cidade gótica de Barcelona. Apesar de esta região estar englobada no Plano de Expansão de Cerdà (Eixample), até 1950 este território possuía ainda grandes parcelas de áreas voltadas essencialmente a produção agrícola.

A terra era cultivada para a produção de cereais, legumes e frutas. A industrialização dos séculos XIX e XX alterou a paisagem desta região da cidade. Fábricas como: Pegaso, Fraba i Coats, Califes Sert de farinha, a fábrica de produtos químicos Nevin e a de chapéus Valera i Ricci tornaram-se as responsáveis pela economia e geração de empregos no bairro durante longo tempo.
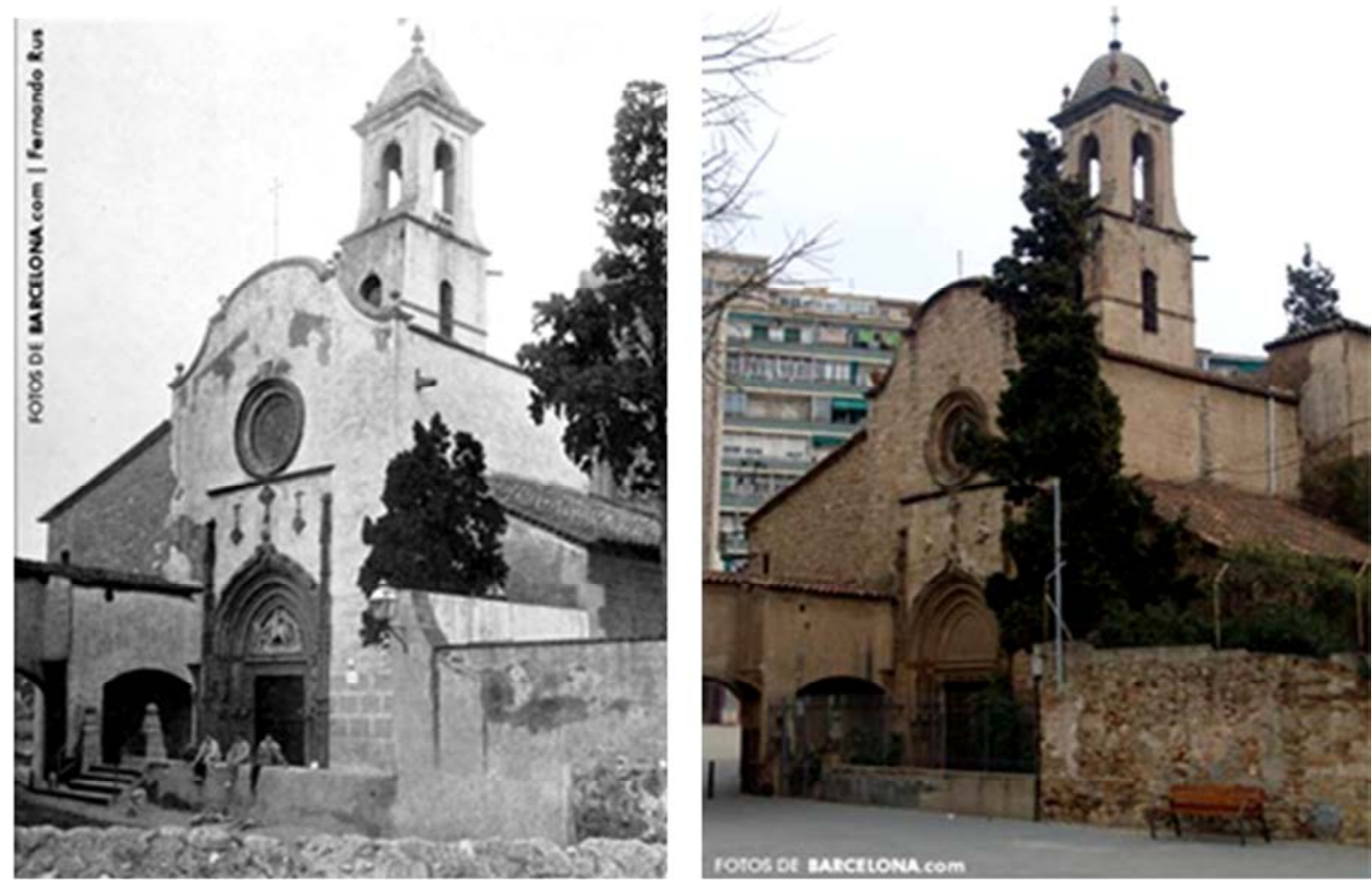

Figura 62. Paróquia de Sant Martí

Fonte: www.barcelona.com, acessado em 15/04/2011

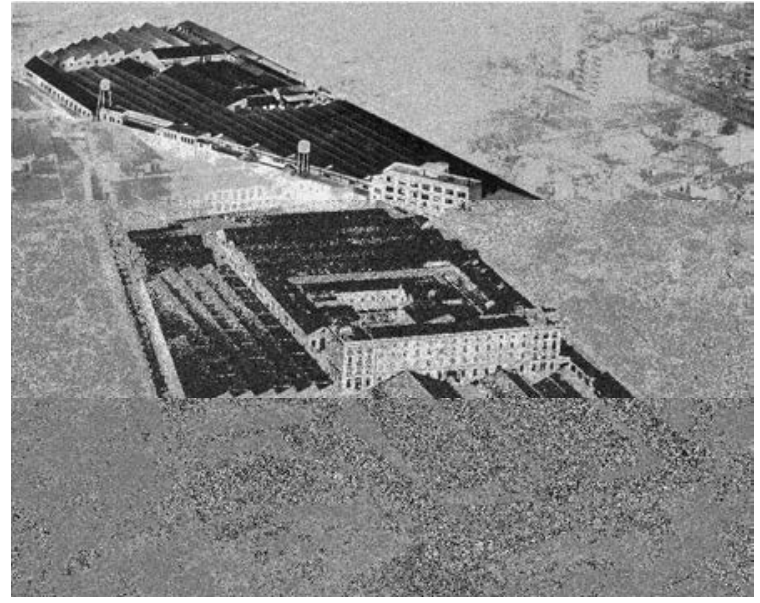

Figura 63. Distrito de Sant Martí, La Sagrera em 1948

Fonte: www.barcelona.com, acessado em $15 / 04 / 2011$

87.0 nome de Provence provém da palavra latina provincialis, utilizada pelos romanos para denominar os campos situados para além das muralhas das cidades. Por outro lado, o nome de Sant Martí é o da primeira igreja edificada. 
Subdividido em dois setores distintos: a parte mais recente sobre a via La Meridiana, que com a recente remodelação urbana ampliou a permeabilidade entre os dois lados, e o núcleo antigo no envoltório da Plaça Masadas, junto a linha férrea já prevista por Cerdà desde meados do século XIX (Ferrocarril de Granollers), que neste caso, foi produzindo um tecido urbano fragmentado pelo eixo ferroviário e consolidando, já no final do século XX, num bairro com diversos problemas de acessibilidade entre seus setores de demais distritos de Barcelona. No entanto, segundo Relatório da Prefeitura de Barcelona, Sagrera sempre esteve ligada historicamente às infraestruturas das estradas de ferro, "definida como uma área geograficamente complexa e alguns desafios".(A. D. BARCELONA s/d, p 14).

Desde 2002, com a aprovação do acordo entre o Ministério do Desenvolvimento, o Governo da Catalunha e do Município de Barcelona, se configura a Sociedade Pública Mercantil "Barcelona Sagrera Alta Velocitat", responsável pelas ações de implantação da requalificação de uma área de intervenção entre La Sagrera e Sant Andreu, num total de 164 hectares, e implantação do Trem de Alta Velocidade, conectando a cidade de Barcelona com a Europa.

Segundo relatório de atividades da Prefeitura de Barcelona (A. D. BARCELONA 2010, p.06), as ações correspondentes a implantação do TAV e transformação urbana da área de intervenção, os projetos devem estar norteados sob três eixos:

- a remodelação do sistema ferroviário e de transportes públicos;

- promover e gerenciar o desenvolvimento urbanístico nos limites de La Sagrera, com a participação dos sistemas de cargas e benefícios derivados do planejamento com os fundamentos aportados pelos sócios;

- projeto e execução de obras que irão ser delegados pelos sócios. ${ }^{88}$

Entre as ações de ordem urbana o Projeto La Sagrera - Sant Andreu tem como conceito geral o reordenamento do tecido urbano fragmentado pela linha férrea através do aterramento do novo sistema de trem e a implantação de duas novas estações do TAV (La Sagrera e Sants) tornando-se a nova porta de entrada da cidade e conectando ao aeroporto da cidade, um novo centro estratégico ligado a rede de transportes públicos (conexão com os arredores, novas linhas de METRÔ [linhas 4 e 9 do metro], TAV, rede viária), um parque linear de 40 hectares, no qual cerca de $70 \%$ cobrirá a nova infraestrutura de transportes da área e cumpre a função de conexão entre La Sagrera e Sant Martí, e for fim, a nova estação intermodal como elemento arquitetônico de conexão entre o tecido fragmentado e atração de novas atividades sobre o parque linear.

"A implantação nos terrenos de La Sagrera e Sant Andreu da linha de alta velocidade e seu soterramento previsto não só eliminará o efeito de barreira urbana existente nesta área a décadas atrás, mas que serve também para levar em conta a maior operação urbanística da cidade desde a construção da Vila para os Jogos de Barcelona de 1992"(LORENZO 2010, p 16). ${ }^{89}$

88. Tradução do autor, 2011

- coordinar los proyectos correspondientes a la remodelación del sistema ferroviario y de transporte público;

- promocionar y gestionar el desarrollo urbanístico del ámbito de La Sagrera, con la participación en el reparto de cargas y beneficios derivados del planeamiento con los terrenos aportados por los socios;

- proyectar y ejecutar aquellas obras que le deleguen cualquiera de los socios.

89 . Tradução do autor, 2011

La implantación en los terrenos de La Sagrera i Sant Andreu de la línea de alta velocidad y su previsto soterramiento no sólo eliminará el efecto barrera existente en esta zona urbana desde hace décadas, sino que servirá también para llevar a cabo la mayor operación urbanística de la ciudad desde la construcción de la Villa de Barcelona para los Juegos de 1992. 
Figura 64. Sobreposição do Plano Cerdà com

Cartografia atual de Barcelona

Organização: Elvis Vieira, 2011

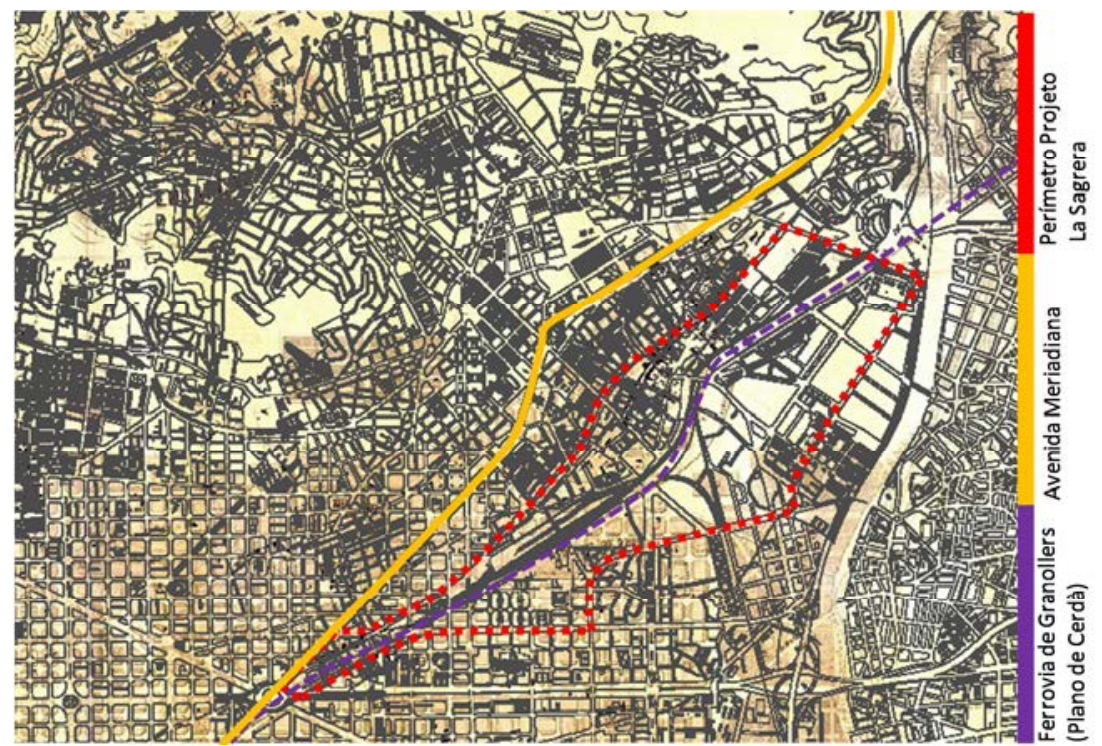

Figura 65. Mapa das novas conexões de transporte de massa

Fonte: Barcelona Sagrera Alta Velocitat, 2010

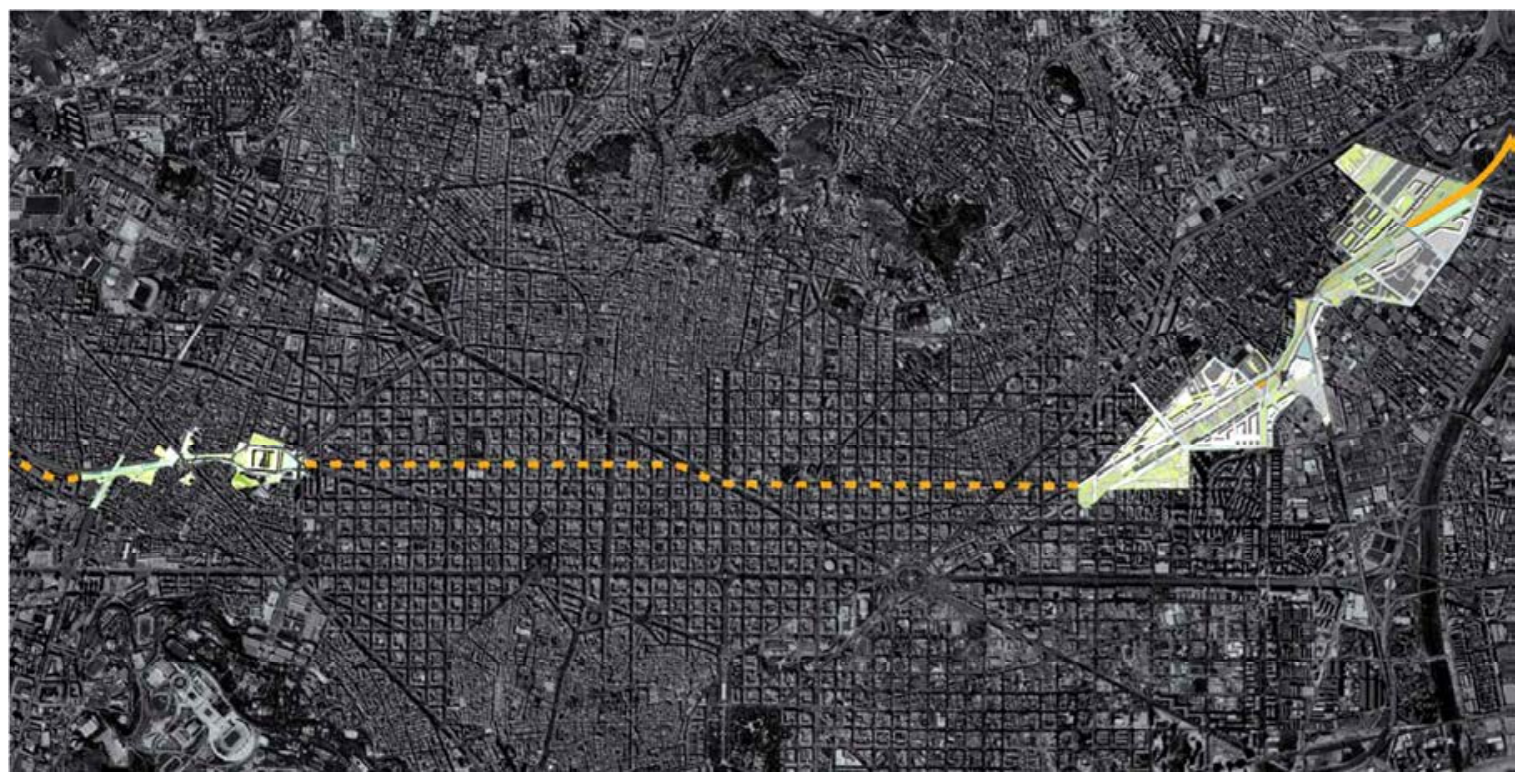

Figura 66. Contexto dos Projetos Urbanos e sua inter-relação entre as propostas e o tecido urbano existente

Fonte: Barcelona Sagrera Alta Velocitat, 2010

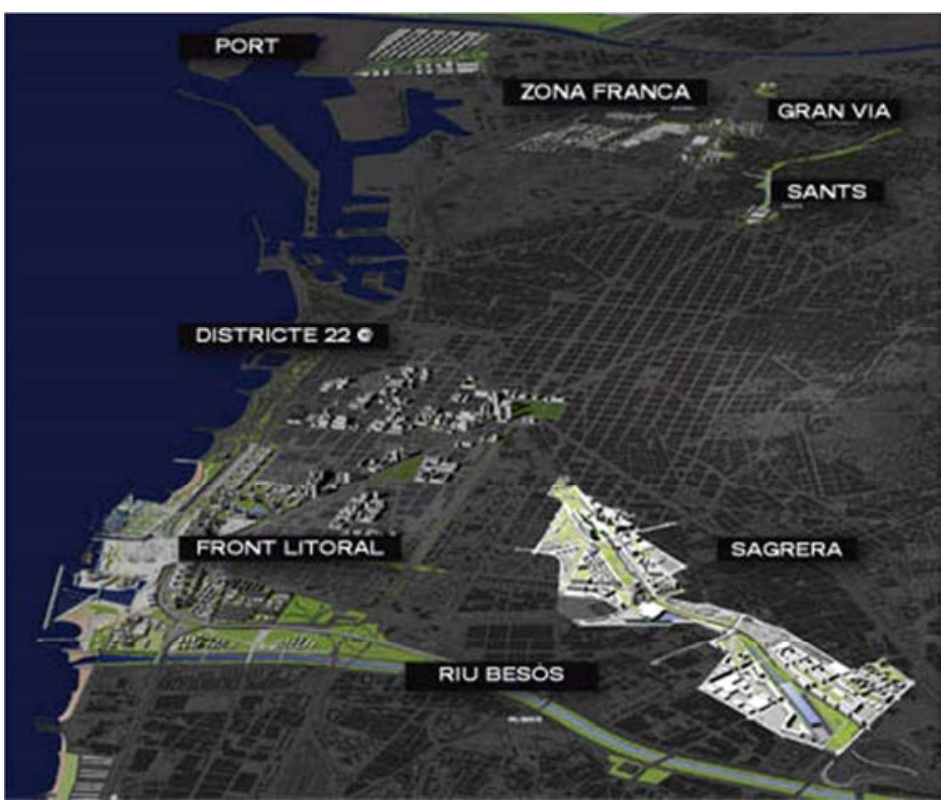


Com isto, a proposta de intervenção urbana sobre o eixo ferroviário desde La Sagrera, passando por Sants até o Aeroporto da cidade (Ports), reordena o tecido urbano ao redor do corredor ferroviário, ampliando as áreas verdes de Barcelona e possibilitando a implantação de novos usos (escritórios, centros comerciais e hotéis), além de habitação garantindo o uso continuo sobre todo o dia na área e seu entorno.

1. DADOS DO PROJETO LA SAGRERA - SANT MARTí

\begin{tabular}{l|l}
\hline descrição & área \\
\hline área de intervenção & 164 hectares \\
\hline distância entre os extremos & $3,7 \mathrm{Km}$ \\
\hline superfície de novos parques urbanos & 48 hectares \\
\hline superfície de novos equipamentos & 20 hectares \\
\hline ferrovia enterrada & 38 hectares \\
\hline
\end{tabular}

Como demonstrado em tabela acima, a proposta de requalificação urbana para La Sagrera - Sant Martí se organiza sobre um vasto território (164 ha), ancorado sobre a implantação de uma nova rede de transportes internacional (TAV - Madri - Barcelona França), metropolitana, metrô e rodoviário, no qual coloca este distrito na condição de "porta da cidade" e tornando Sagrera uma nova centralidade urbana para Barcelona.

Diante destes desafios, a ação governamental vem construindo um projeto de intervenção urbana capaz de redesenhar o tecido fragmentado e fortalecer economicamente 0 distrito com a implantação de novas habitações, edifícios corporativos, hotéis e um novo parque linear sobre a malha de transportes coletivos. Correspondendo a aproximadamente $30 \%$ do território do Projeto Urbano, este espaço verde surge como ferramenta de articulação entre o distrito desarticulado e até então fragmentado pela linha férrea. Assim, o programa do parque foi construído de forma a garantir a diversidade de seu uso e a qualidade urbana sobre o parque linear e as áreas lindeiras ao projeto urbano(conforme tabela 3, pag. 144).

Da mesma forma, a ação do governo barcelonês em conjunto com o Governo da Catalunha e a empresa de transportes de trens de alta velocidade (RENFE) possuem como estratégia comum a qualidade urbana do distrito de La Sagrera, ampliando a rede de serviços e equipamentos públicos na região, que possibilitem o desenvolvimento econômico e social da área e revitalize este trecho da cidade hoje fragmentado pela rede férrea.

Ao analisarmos a carta de uso do solo proposta pelo Projeto Urbano concluímos que a diversidade de usos propostos sobre o parque linear e em sua orla amplia consideravelmente a dinâmica urbana do distrito e possibilita a criação de uma centralidade urbana tendo como eixo estruturador as redes de transportes coletivos que integram o distrito aos demais de Barcelona, a Região Metropolitana da Catalunha e a Europa, elevando o distrito de Sant Andreu a uma nova dinâmica urbana de grande valia à economia da cidade. 

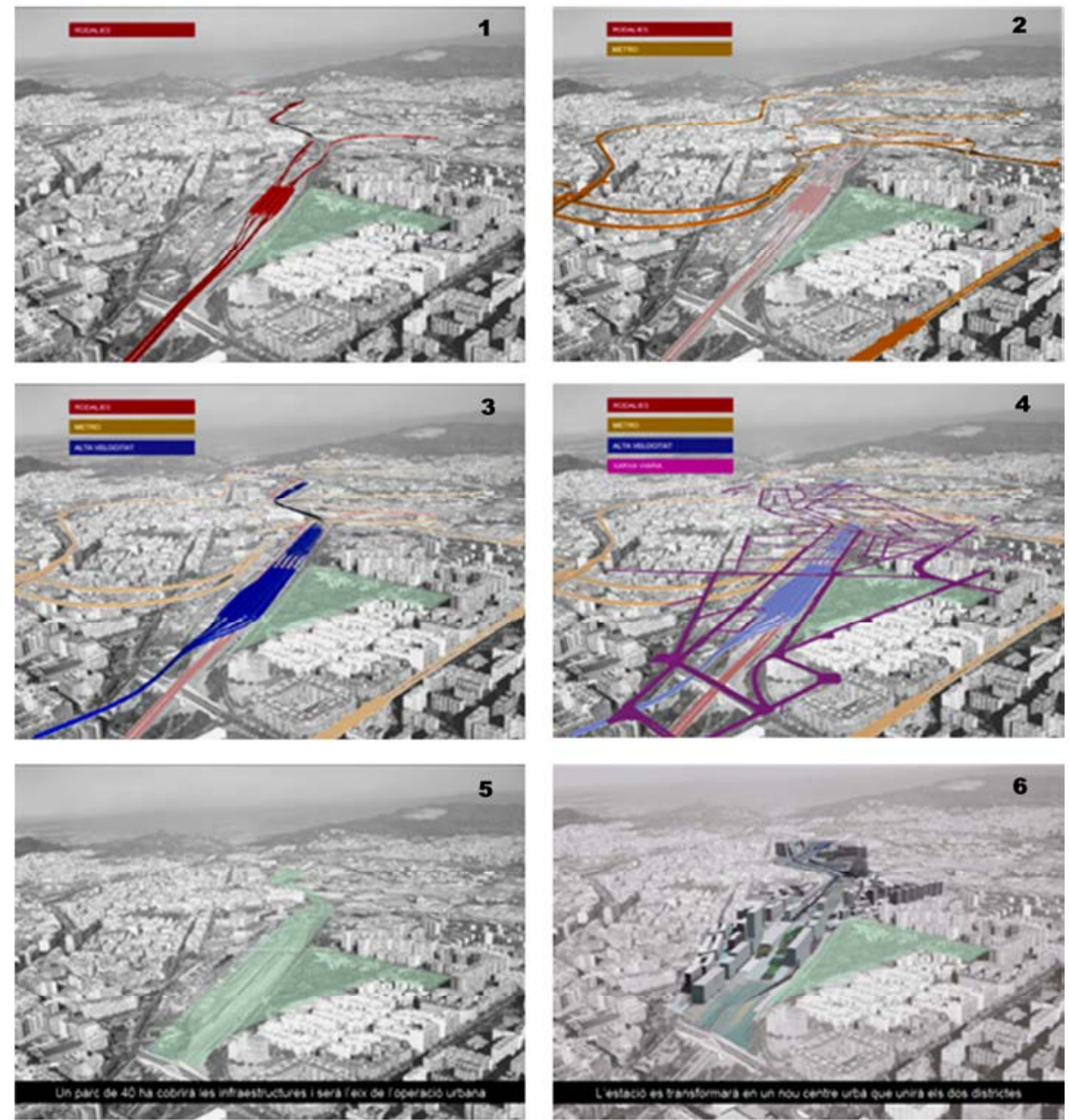

Figura 67. Infraestruturas propostas pelo Projeto La Sagrera | 1) suburbano; 2) metrô; 3) alta velocidade; 4) rede viária; 5) parque urbano; 6) novo centro urbano

Fonte: Barcelona Sagrera Alta Velocitat, 2010

Figura 68. Parque Linear La Sagrera | Perímetro dos programas

Fonte: Project d'Urbanització del Parc Lineal: pla director i projectes constructius fases 1, 2 i 3

Organização: Elvis Vieira, 2011

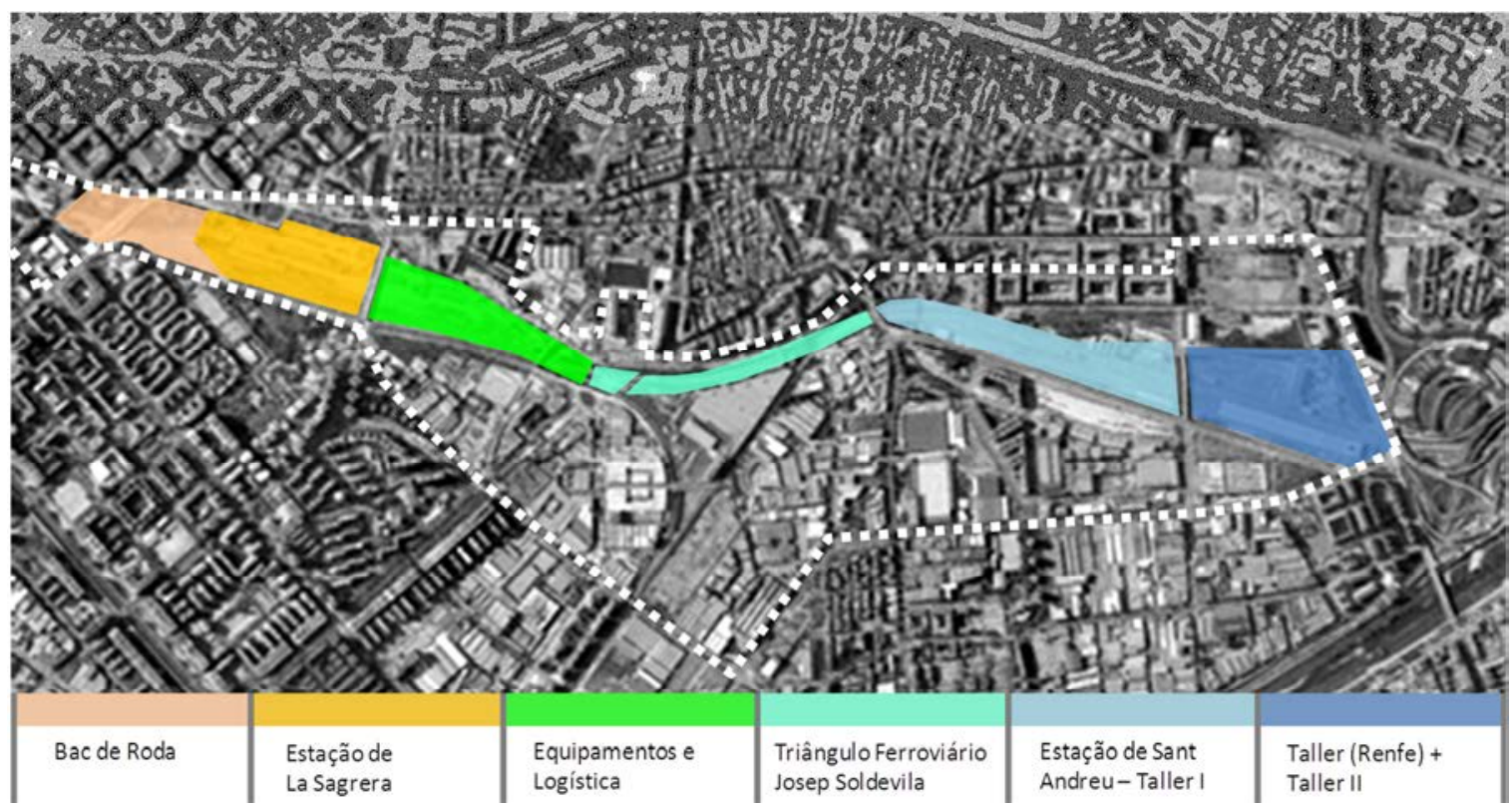




\section{PROGRAMA PROPOSTO E QUANTIFICAÇÃO DO PROJETO LA SAGRERA - SANT ANDREU}

Fonte: Barcelona Sagrera Alta Velocitat, 2009

Organização: Elvis Vieira, 2011

\begin{tabular}{|c|c|c|c|c|c|c|}
\hline área | $\mathbf{m}^{2}$ & $\begin{array}{c}\text { habitação } \\
\text { social }\end{array}$ & $\begin{array}{c}\text { habitação } \\
\text { privada }\end{array}$ & $\begin{array}{c}\text { comercio e } \\
\text { serviços }\end{array}$ & hotel & $\begin{array}{c}\text { áreas } \\
\text { verdes }\end{array}$ & $\begin{array}{c}\text { equipamento } \\
\text { s }\end{array}$ \\
\hline COLORANTES & 56.944 & 30.406 & 9.040 & & 38.460 & 4.498 \\
\hline $\begin{array}{c}\text { CASERNES } \\
\text { SANT ANDREU }\end{array}$ & 65.251 & 65.352 & 11.730 & & 78.178 & 32.642 \\
\hline $\begin{array}{c}\text { ENTORNO } \\
\text { SAGRERA }\end{array}$ & 107.073 & 71.404 & 67.436 & 25.497 & 98.845 & 53.917 \\
\hline $\begin{array}{c}\text { RENFE- } \\
\text { TALLERES }\end{array}$ & 45.500 & 22.260 & 19.531 & & 36.079 & \\
\hline $\begin{array}{c}\text { TRIANGULO } \\
\text { FERROVIARIO }\end{array}$ & 145.600 & 119.126 & 29.414 & & 7.436 & 23.008 \\
\hline $\begin{array}{c}\text { PRIM } \\
\text { ESTAÇÃO } \\
\text { SAGRERA }\end{array}$ & 21.663 & 8.281 & 3.324 & & 57.115 & 21.799 \\
\hline $\begin{array}{c}\text { CAM } \\
\text { PORTABELA }\end{array}$ & 442.031 & 316.829 & 389.911 & 55.497 & 320.802 & 136.183 \\
\hline total m ${ }^{2}$ & & & 150.000 & 30.000 & & \\
\hline
\end{tabular}

Observamos a partir da tabela acima exposta que o grande número de habitações propostas (social e privadas) supera a quantidade dos demais usos previstos na área de intervenção com a implantação de equipamentos públicos, comércio e serviços, garantindo assim, uma dinâmica constante sobre o território do Parque Linear e ampliando a qualidade urbana do distrito.

Outro dado relevante é quanto a intermodalidade da Estação Sagrera, que ao abrigar as diversas formas de transportes (local, regional, internacional), faz deste objeto arquitetônico o pólo de atração e convergência de um considerável número de usuários sobre esta área. Nota-se também, assim como no Projeto 22@BCN, a estratégia da transformação da paisagem do distrito e referência urbana para a área na construção de um "edifício-ícone" onde deverá transformar-se no protagonista desta requalificação urbana do distrito de Sant Andreu, apontando na paisagem local como um objeto singular vertical, projetado pelo arquiteto Frank Gehry, em que os estudos resultam em dois edifícios contínuos, como segue:

"O primeiro, terá $145 \mathrm{~m}$ de altura e 34 pisos e as fachadas revestidas de metal e vidro com um desenho diferente em cada fachada. O edifício disponibilizará de um estacionamento para 700 vagas e o conjunto se completará com $12.000 \mathrm{~m}^{2}$ adicionais, para acomodar equipamento e área verde".90(VELOCITAT 2009, p16)

90 . Tradução do autor, 2011

El primero, tendrá $145 \mathrm{~m}$ y 34 plantas y las fachadas cubiertas de paneles metálicos y de vidrio con un perfil diferente en cada fachada. El edificio dispondrá de un aparcamiento para 700 plazas y el conjunto se completará con $12.000 \mathrm{~m}^{2}$ adicionales, que acogerán un equipamiento y una zona verde. 


\section{PARQUE LINEAR DE SANT MARTí - PROgRAMA}

Fonte: Project d'Urbanització del Parc Lineal: pla director i projectes constructius fases 1, 2 i 3 Organização: Elvis Vieira, 2011

\begin{tabular}{|c|c|}
\hline setor & programa \\
\hline BAC DE RODA & $\begin{array}{l}\text { - acesso à Torre del Fang (rua e parque); } \\
\text { - conexão entre El Clot e Sant Martí; } \\
\text { - continuidade do espaço verde Trinitat-Glòries. }\end{array}$ \\
\hline ESTAÇÃO DE LA SAGRERA & $\begin{array}{l}\text { - espaço do parque linear; } \\
\text { - conexão interior-exterior da estação com o parque; } \\
\text { - recuperação do espaço privado do entorno; } \\
\text { - permeabilidade transversal, integrando a praça da } \\
\text { estação e o parque Sant Martí. }\end{array}$ \\
\hline $\begin{array}{l}\text { EQUIPAMENTOS E } \\
\text { LOGÍSTICA }\end{array}$ & $\begin{array}{l}\text { - Zona de Pont de Treball, relacionando os sistemas } \\
\text { de trem, ônibus, estacionamentos; } \\
\text { - Zona de equipamentos: } 8.000,00 \mathrm{~m}^{2} \text { de } \\
\text { estacionamento de ônibus, Escola Bressol, Centro } \\
\text { Cívico, casa para idosos, Ludoteca; } \\
\text { - } 10.000,00 \mathrm{~m}^{2} \text { de equipamentos esportivos; } \\
\text { - Zona extensa com plantio de arvores e espaços } \\
\text { esportivo de pouco impacto que permitem a } \\
\text { realização de ações e feiras. }\end{array}$ \\
\hline $\begin{array}{l}\text { TRIÂNGULO } \\
\text { FERROVIÁRIO- JOSEP } \\
\text { SOLDEVILA }\end{array}$ & $\begin{array}{l}\text { - união entre os passeios, espaço singular de } \\
\text { reunião, ponto central do parque. Edifício privado de } \\
\text { referência urbana (145m) para singularizar como } \\
\text { ponto simbólico; } \\
\text { - facilitar os passeios transversais; } \\
\text { - plantar conjunto de arvores como referência de } \\
\text { sensação de profundidade na paisagem; }\end{array}$ \\
\hline $\begin{array}{l}\text { ESTAÇÃO DE SANT } \\
\text { ANDREU - TALLER I }\end{array}$ & $\begin{array}{l}\text { - integração da estação com o parque a Plaça Orfila } \\
\text { La Maquinista; } \\
\text { - integração dos espaços adjacentes ao parque de } \\
\text { La Maquinista, a praça da estação e da Ponte de } \\
\text { Sant Adrià e também a zona verde do triangulo; } \\
\text { - plantação de arbustos na cobertura da estação, } \\
\text { plantação arbórea no restante da área. }\end{array}$ \\
\hline TALLER (RENFE-TALLERS) & $\begin{array}{l}\text { - estudar a ordenação edificatória do MPGM; } \\
\text { - planejar a transferência de equipamentos } \\
\text { edificatórios de La Sagrera; } \\
\text { - facilitara a relação entre as ruas Pessoa e } \\
\text { Casernes. }\end{array}$ \\
\hline TALLER II & $\begin{array}{l}\text { - transferir } 15.000 \mathrm{~m}^{2} \text { de equipamentos esportivos } \\
\text { para La Sagrera; } \\
\text { - implantar dois campos de futebol; } \\
\text { - facilitar as relações transversais para as pessoas; } \\
\text { - solucionar as conexões entre Potosí e ponte de } \\
\text { Sant Coloma. }\end{array}$ \\
\hline
\end{tabular}


A partir desta etapa concluída, inicia-se a construção da Estação Sagrera, peça urbana fundamental para a consolidação de um novo ponto de atração e dispersão de pessoas. Considerada a maior infraestrutura ferroviária da Catalunha, a estação intermodal deve ser responsável pelo grande impulso econômico de todo o trecho do Parque Linear e sua orla degradada urbana e paisagisticamente. Conforme Andrés del Castillo, "uma das grandes realizações da estação é sua integração no entorno dos distritos de Sant Andreu e Sant Martí e a criação de um novo espaço urbano a seu redor. ${ }^{91}$ (CASTILLOS 2010, p 3)

Com esta estratégia, o Projeto Urbano transforma o velho distrito industrial de Sant Andreu em um novo centro urbano dedicado as atividades econômicas sob o olhar das estruturas de mobilidade urbana e transportes coletivos, no qual deve contribuir para a qualidade urbana de toda Barcelona, como defendido pelo então Prefeito da cidade, Jordi Hereu, "estamos financiando uma transformação urbana sem precedentes: 164 hectares e cerca de quatro quilômetros de comprimento, com 48 hectares de espaços livres, sendo 20 para equipamentos, 44 de novas estradas e 13.000 habitações." ${ }^{92}$ (HEREU 2010, p 6). Da mesma forma, o Projeto Urbano em implantação em Sant Andreu possui um valor de requalificação urbana e transformação da vocação econômica deste trecho da cidade, capaz de redefinir e recompor o tecido que por muitos anos estava fragmentado pela linha férrea:

"Falamos de uma nova área de centralidade urbana, de desenvolvimento equilibrado, que criará um tecido de máxima qualidade e que vai fazer uma trama urbana com a nova Praça Las Glòries e a fachadado rio Besòs." ${ }^{93}$ (HEREU 2010, p 6)

91. Tradução do autor, 2011

Uno de los grandes logros de la estación es su integración en el entorno de los distritos de Sant Andreu y Sant Martí y la creación de un nuevo espacio urbano a su alrededor.

92 . Tradução do autor, 2011

Estamos haciendo realidad una transformación urbana sin precedentes: 164 hectáreas y casi cuatro kilómetros de longitud, con 48 hectáreas de espacios libres, 20 para equipamientos, 44 de nueva vialidad y 13.000 viviendas.

93 . Tradução do autor, 2011

Hablamos de una nueva área de centralidad urbana, de desarrollo equilibrado, que creará un tejido de máxima calidad y que hará trama urbana con nueva plaza de las Glòries y la fachada del rio Besòs. 


\section{EL PARC LINEAL: LES IPERACIDNS URBANÍSTIQUES}

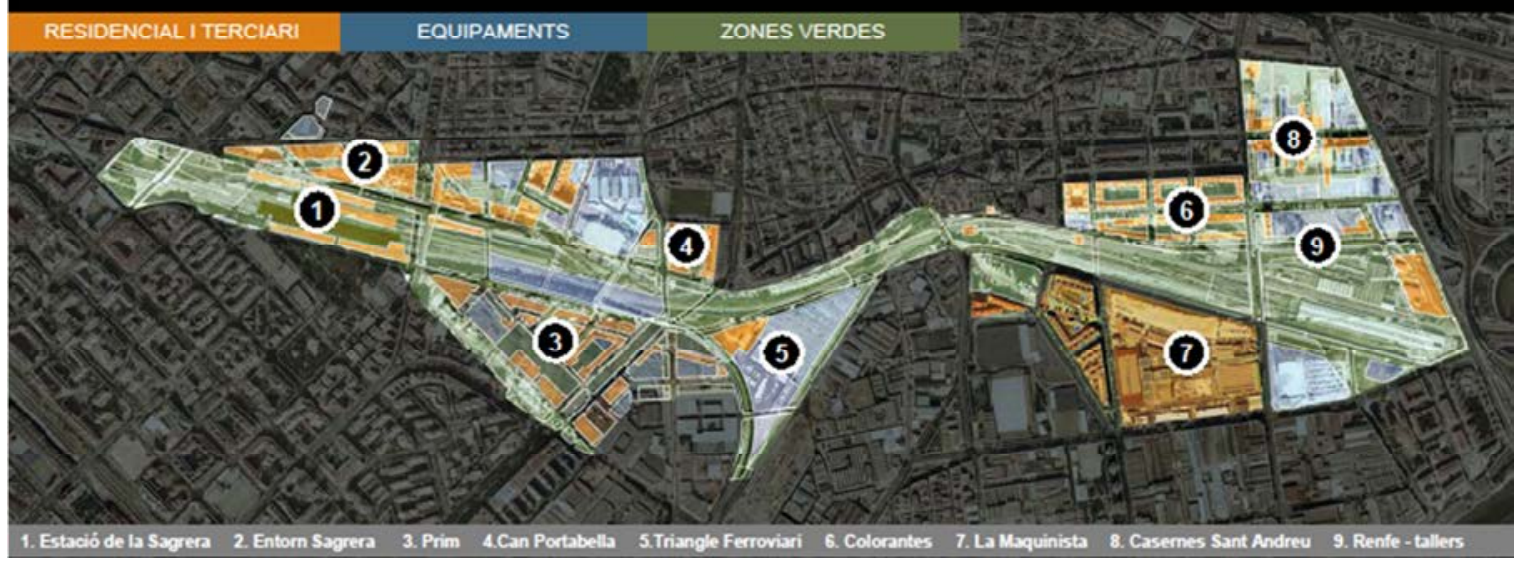

Figura 69. Carta de Uso do solo proposto no Projeto La Sagrera

Fonte: Project d'Urbanització del Parc Lineal: pla director i projectes constructius fases 1, 2 i 3
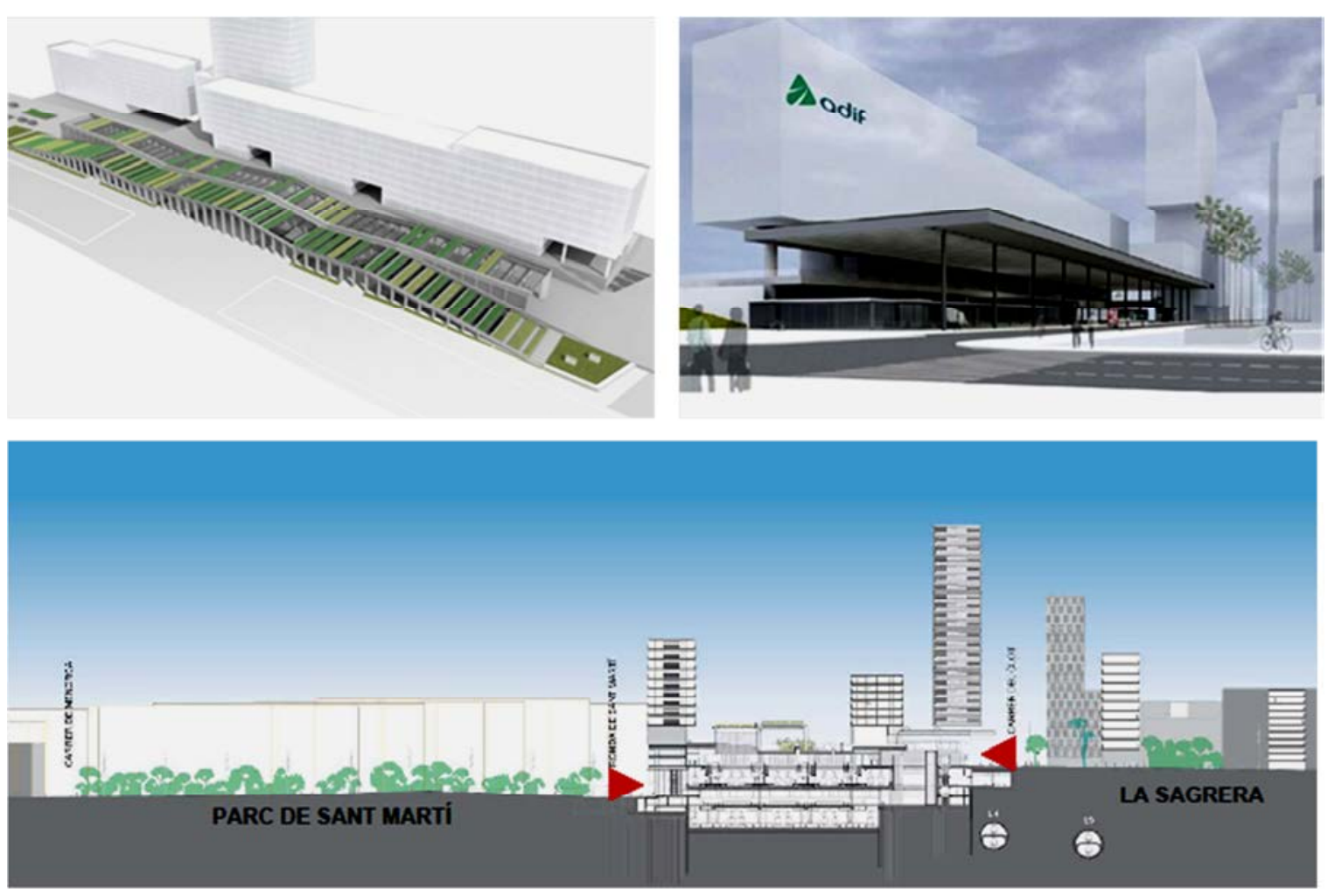

Figura 70. Estação Intermodal La Sagrera, edifício semi enterrado que garante a conexão entre Sagrera e o Parque Sant Martí

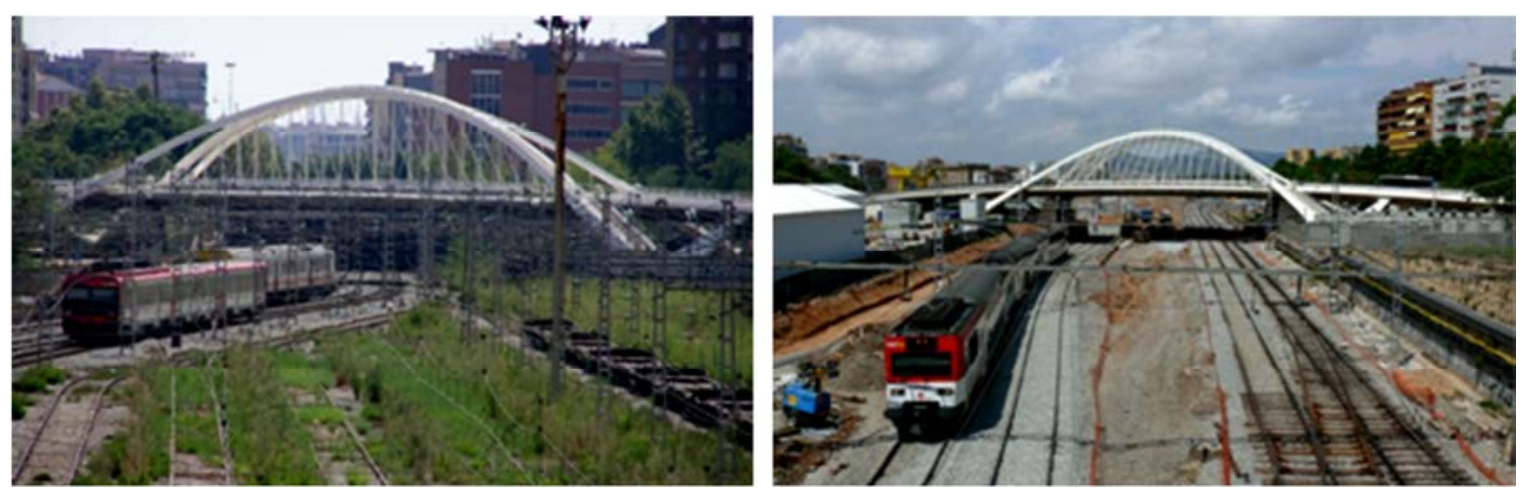

Figura 71. Estado atual da área de intervenção em Sagrera: 2005 e 2009

Fotos: Elvis Vieira, 2005 e 2009 


\subsection{Considerações Finais}

$\mathrm{Na}$ cidade a rua é considerada o principal elemento organizador do espaço desde sua concepção, no qual o espaço não construído é representado pelo sistema viário e sua relação entre os "lugares urbanos", como fios condutores de interligação entre o centro e os bairros periféricos, e vice-versa. Barcelona por outro lado se demonstra com valores diferentes aos que conhecemos da maioria das grandes cidades.

Como defendido por Solà-Morales em seu curso sobre "As formas do crescimento urbano" (Universitat Politècnica de Catalunya - UPC) tendo como objeto de estudo a cidade de Barcelona, as cidades podem ser analisadas a partir da construção de suas "estruturas urbanas", defendidas pelo autor por "três elementos da forma urbana": P+U+E - Parcelamento + Urbanização + Edificação (SOLÀ-MORALES i RUBIÓ 1997). Desta forma, ao analisarmos Barcelona desde sua origem (Barcino - $2000 \mathrm{AC}$ ) tais elementos podem ser identificados sobre a cidade fortificada através de seus eixos estruturantes (Cardus Maximus - Decumanus Maximus) e a conformação dos vazios urbanos (Fórum - Templum) e seus elementos construídos.

Desde então em seus diversos períodos de crescimento - cidade intramuros (El Raval), os primeiros bairros planejados (Barceloneta) ou mesmo em sua concepção maior com o Ensanche de Cerdà, o espaço público define a cidade "como cidade", indicando a qualidade de vida das pessoas que a usufruem e principalmente a qualidade destes espaços como "direito à cidadania" a todos habitantes.

No entanto, é com o Plano de Ildefonso Cerdà que Barcelona se tornará referência para diversas cidades, inicialmente centro-européias e mais tarde em outros continentes, assim como urbanistas do século XIX que terão como "base de estudos" a proposta para a capital catalã. Assim, podemos afirmar que a contribuição de Cerdá esta muito além da concepção de ferramentas de planejamento e controle do solo urbano, mas também na apreensão de um novo "modelo de cidade", uma "política que foi possível através da obtenção de terrenos para espaços públicos e equipamentos coletivos"(BORJA e MUXÍ 2004, p 172) ${ }^{94}$.

A utilização do "elemento base" - La Manzana - como instrumento de crescimento constante e controle do solo urbano possibilitou também a reconstrução de seu tecido urbano sobre a mesma ordem urbanística. Prova disto esta na oportunidade excepcional na organização dos Jogos Olímpicos de 1992, no qual segundo Oriol Bohigas:

"Permitiu saltar dos projetos medianos aos grandes mantendo sua vocação de cidadania, e a potente liderança política municipal, o que estimulou e unificou num amplo consenso cívico" (BOHIGAS in BORJA 2004). ${ }^{95}$

94. Tradução do autor, 2011

Política que fue posible mediante la obtención de suelo para espacios públicos y equipamientos colectivos.

95 . Tradução do autor, 2011

que permitió saltar de los proyectos medianos a los grandes manteniendo su vocación ciudadana, y el potente liderazgo político de la alcaldía, que estimuló y unificó un amplio consenso cívico 
A realização deste grande evento esportivo possibilitou a cidade a enfrentar seus problemas e rever trechos da cidade que já estavam apresentando um desgaste urbano muito além de sua capacidade de regeneração natural. Os projetos coordenados por Bohigas e equipe deram respostas coerentes e poderosas quanto a inovação às políticas, instrumentos, instituições e cultura urbanística, resultando em um famoso modelo de reabilitação urbana, onde o "legado" deixado pelo evento esportivo, já não está mais nos equipamentos e edifícios construídos para o curto período dos jogos, mas na consolidação de novas áreas urbanas e a possibilidade de ampliar seu conjunto habitacional, melhorar e qualificar os sistemas de mobilidade e garantir ao habitante, uma cidade mais igualitária e de ampla qualidade urbanística. Ainda assim, como já apontado por Pedro Sales, os projetos possibilitaram "abrir a cidade para o mar, dando novo uso àquela faixa até então isolada pela ferrovia e reverter assim as orientações e tendências estabelecidas pelos vetores de crescimento interior da cidade" (P. M. SALES 1999, p 219-220).

A mudança da base fordista a uma nova economia terciária provoca também a transformação do tecido urbano, da mesma forma que este processo vai resultar na degradação de grande parte da trama e do patrimônio arquitetônico herdado dos séculos XIX e XX. Por outro lado, este fenômeno gera novas oportunidades de repensar a cidade e o papel da iniciativa privada como agente dinâmico sobre a transformação do cenário da cidade.

O grande desafio estava justamente em regenerar, reorganizar e reabilitar o tecido urbano de forma equilibrada.

Este "novo urbanismo" que emerge no final do século $X X$, e visto como Laboratório Urbano, sem duvida foram vistos como possibilidades de desenvolvimento urbano em áreas mais problemáticas, mas ao mesmo tempo a vislumbração de projetos que reforçasse a condição de Barcelona como Cidade Global.

Nesta condição, o eixo Meridiana/Sagrera possibilitaria a costura do tecido urbano fragmentado pelo eixo ferroviário a partir de seu extenso parque urbano proposto, abrigando usos mistos e a nova estação intermodal que integrasse os espaços construídos e consolidasse um novo eixo de serviços entre a região de Besós e Plaça de les Glories. Apesar de sua lenta aplicabilidade, onde é visível o vagaroso ritmo das obras, que nesta primeira fase depende muito mais da aplicação de recursos do Ministério de Fomento para a conclusão das obras de implantação da rede de transporte urbano metropolitano e nacional (TAV, trem, metro), acaba por "atrasar" a continuidade das demais fases e a materialização do eixo verde na cidade.

Este mesmo eixo pode ser encarado como organismo ativo compreendendo a complexa articulação das "peças arquitetônicas" existentes com seus diferentes usos e tipos, com a promoção de um eixo de conexão com novas formas urbanas e grande responsabilidade urbana. 
"A estratégia geral tem sido a de completar a forma da cidade, tentando resolver suas grandes deficiências: construir em grandes terrenos vazios ou liberados do uso de infraestruturas obsoletas - estações e linhas ferroviárias, edifícios industriais, etc" (BORJA e MUXÍ 2004, p 204). ${ }^{96}$

Neste raciocínio as revitalizações de trechos da cidade também estavam sendo colocados na condição de Novas Centralidades, com a criação de novos espaços públicos, repensando as áreas urbanas e fortalecendo as redes de mobilidade na cidade e sua região inserida.

No caso do Projeto 22@ BCN a busca por um Grande Projeto Urbano baseado na reordenação do solo urbano, novos usos que substituísse o conjunto edilício industrial obsoleto, com a construção de espaços livres, redes de infraestruturas urbanas contemporâneas e o experimento de formas urbanas que atendessem a uma dinâmica da economia terciária.

Estas premissas que deveriam respeitar o tecido urbano e adaptar-se a morfologia urbana existente do Plano de Cerdà, a preexistência dos usos industriais e sociais, visto que seu conjunto construtivo habitacional não poderia ser descartado a partir das novas estratégias urbanas adotadas. Da mesma forma, deveriam dar respostas as novas tecnologias de informação e tecnologia, no qual François Ascher tem denominado como a "terceira revolução urbana moderna".

Por outro lado, a adoção por edifícios ícones como estratégia de um "reconhecimento global", com projetos assinados por arquitetos "star system", como objetos de negócios, é promotora de formas urbanas conflitantes com o desenho urbano, e principalmente com a tipologia do Ensanche, tornando-se peças isoladas e conflitantes com seu entorno e referencias arquitetônicas já consagradas. Em 22@BCN a cena é roubada pela Torre Agbar se tornando o ponto inicial entre a Plaça de les Gloriese a área do Fórum 2004 - outro laboratório experimental de formas e objetos isolados sobre uma grande área junto à Besós.

Por fim, é certo que estas experiências urbanas tratam de um novo urbanismo baseado numa normativa mais flexível, em compensações estudadas caso a caso, e a criação de espaços públicos como premissa. Ainda que os últimos Grandes Projetos Urbanos implantados ou em construção na cidade tenham demonstrado a oportunidade da construção de novas centralidades mais coerentes e em sintonia a cidade contemporânea, há uma clara demonstração da ação direta da iniciativa privada e da economia terciária sobre a construção da forma urbana da cidade.

Diferentemente destas estratégias, as experiências colocadas por Oriol Bohigas, durante as décadas de 80 e 90, podem ser vistos como "modelos urbanísticos" bem sucedidos: 
"As três manzanas na Vila Olímpica ou as cinco manzanas na Frente Marítima, o processo paulatino, passando pela Vila Olímpica e chegando as torres de Diagonal Mar, tem sido a de eliminar a relação entre tipologias residenciais, separando o edifício e enfraquecendo a resistência do tecido na cidade"(BORJA e MUXí 2004, p 218). ${ }^{97}$

No mais, estas apostas por Grandes Projetos Urbanos em Barcelona vêm tomando cada vez mais o caráter de produtos urbanos essenciais a cidade global: bairros residenciais fechados (Diagonal Mar), centros comerciais sem qualquer relação com seu entorno (22@BCN, Diagonal Mar), centros terciários representativos na paisagem urbana (Plaza de las Glorias, Port Olimpic). Por outro lado, no que se refere esta tese, as novas formas urbanas aplicadas nos GPU de Barcelona nos demonstrou a capacidade de regeneração do tecido urbano de forma rápida e competente, principalmente tendo em vista os investimentos privados colocados a disposição destas transformações urbanas, apesar de polêmicas e até mesmo "gritantes" os elementos arquitetônicos utilizados como "objetos de atração" aos investimentos privados sobre estes territórios, apesar de cumprir sua função nas estratégias de aplicabilidade e consolidação dos projetos urbanos, são tido como objetos arquitetônicos isolados na trama urbana e da imagem da cidade.

Ainda assim, é possível afirmar que tais estratégias se transformaram em modelos plausíveis a serem estudados e explorados, modelos de adequação da discussão urbanística de um momento da realidade local, em que a participação, o reequilíbrio territorial e a qualidade dos novos espaços e edifícios podem ser considerados como exemplares.

97 . Tradução do autor, 2011

Las tres manzanas en la Villa Olímpica o las cinco manzanas en el frente marítimo, el proceso paulatino, pasando por la Villa Olímpica y llegando a las torres de Diagonal Mar, ha sido el de eliminar la relación entre tipología residencial, independizando el objeto edificio y debilitando la fuerza de la trama de la ciudad. 


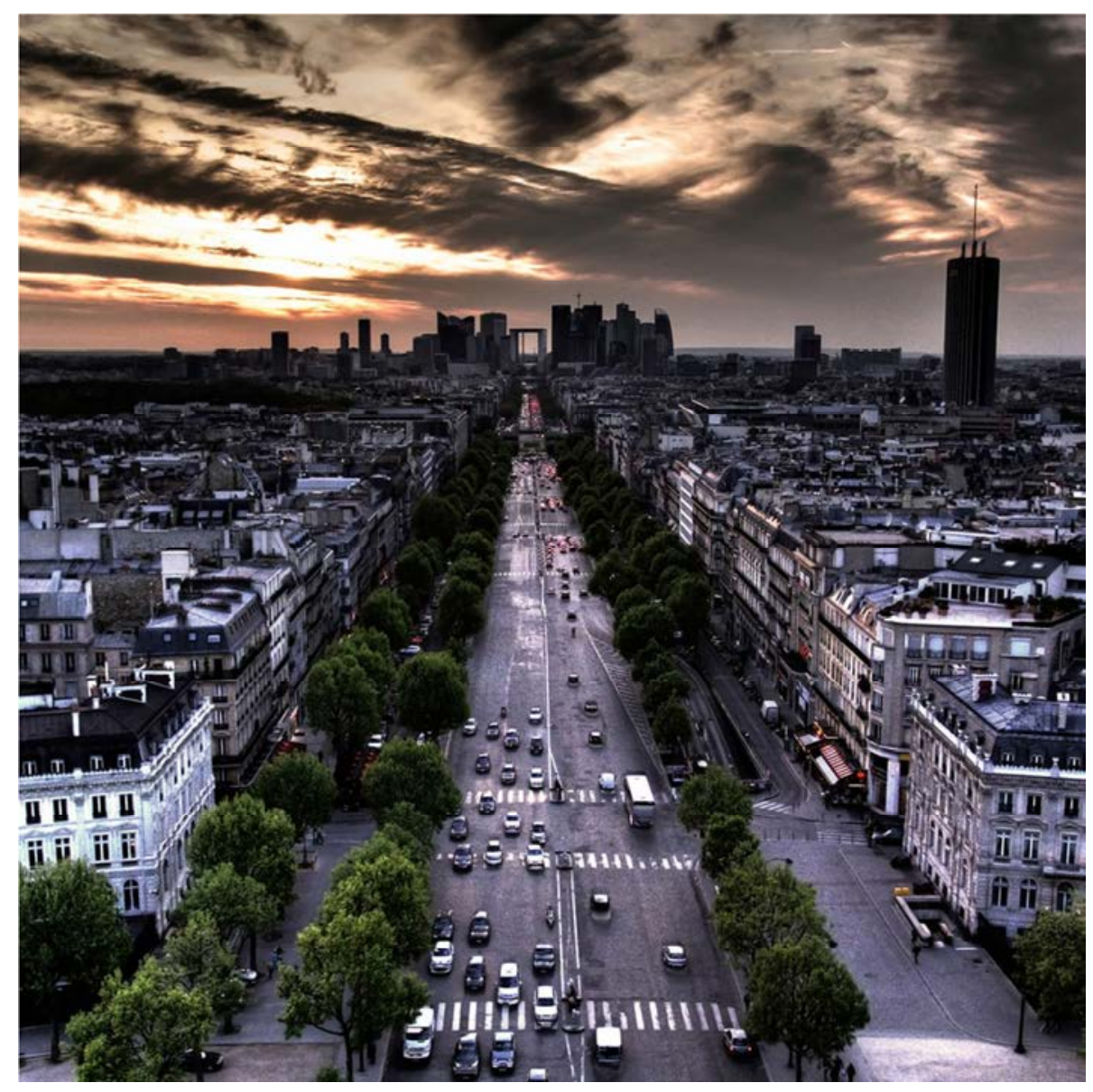

Capítulo 3

Paris | França 



\section{Paris: Intervenções Urbanas e a Homogeneidade do Tecido Urbano}

Em meados do século XIX a capital francesa era uma das cidades mais importantes da Europa $^{98}$ e passava por grandes dificuldades com a falta de infra-estrutura como rede de água e esgoto, poucos equipamentos urbanos (hospitais, escolas, colégios, prisões e, sobretudo parques públicos) que não atendiam a demanda da alta densidade demográfica alcançada, ocasionando grandes problemas de salubridade e segurança para seus habitantes e toda a cidade. ${ }^{99}$

Haussmann ${ }^{100}$ a pedido do imperador inicia seu Plano Urbanístico planejando uma nova cidade e melhorando os parques existentes além da criação de outros novos. Um dos principais objetivos da reforma urbana foi a liberação do tecido urbano para facilitar as manobras militares. É sabido que a configuração da malha urbana da cidade de Paris naquele momento era composta por um conjunto de quadras irregulares e calhas estreitas, no entanto, tais condições resultavam em uma cidade de difícil controle militar em eventual ataque ou rebelião. Nisto, a grande transformação da cidade ocorre em um terço do tecido da cidade sobre a idéia da grande expansão.

Com esta visão, Haussmann propõem um plano para Paris que deve visar os interesses de Napoleão, interesses esses, de cunho estritamente militares, no qual defende que "a arquitetura é um problema administrativo". A partir daí, foi produzido um urbanismo totalmente racionalista visando apenas a técnica e desconsiderando o aspecto histórico.

Tendo como foco principal a melhoria da circulação, o acesso rápido a toda cidade como visão estratégica, estabelecendo uma nova imagem geral de modernidade, tendo como "pano de fundo" a questão da insalubridade, a proposta de Haussmann traça novos eixos sobre a malha pré-existente sem muita preocupação com a ocupação consolidada.

Segundo Lamas (1992), as renovações com novos traçados, as reestruturações fundiárias, construção de infra-estruturas de equipamentos e espaços livres, obedeceram a um triplo objetivo:

- Circulação fácil e cômoda dentro da cidade, indo de gare a gare, ou de bairro a bairro;

- Eliminação da insalubridade e degradação dos bairros, "arejando" os densos interiores, estabelecendo uma imagem geral de modernidade, criando uma cidade com luz, espaço e arborização e uma arquitetura nova;

- Revalorização e reenquadramento dos monumentos, unindo-os através de eixos viários e perspectivas.

Entre 1851-70 o plano foi desenvolvido e implantado dividido em três categorias: Obras Viárias (criação de uma nova malha), Edificações (novas edificações como marco urbano) e Novas Instalações Hidráulicas e Elétricas (dotando a cidade de infra-estrutura básica).

98. A população de Paris em meados do século XIX era superior a 1 milhão de habitantes e, equivalente a Madri, Londres, Roma, entre outras.

99 . Naquela ocasião a população passa de 1.200 .000 para 2.000 .000 de habitantes num pequeno território insalubre. 100 . Georges-Eugène Haussmann (1809-1891), nasceu e morreu em Paris, advogado, funcionário público, político, administrador francês, foi nomeado prefeito por Napoleão III. Tinha título de Barão. 
Figura 72.Plano

Haussmann para Paris, 1867

Fonte: Lamas, 1992

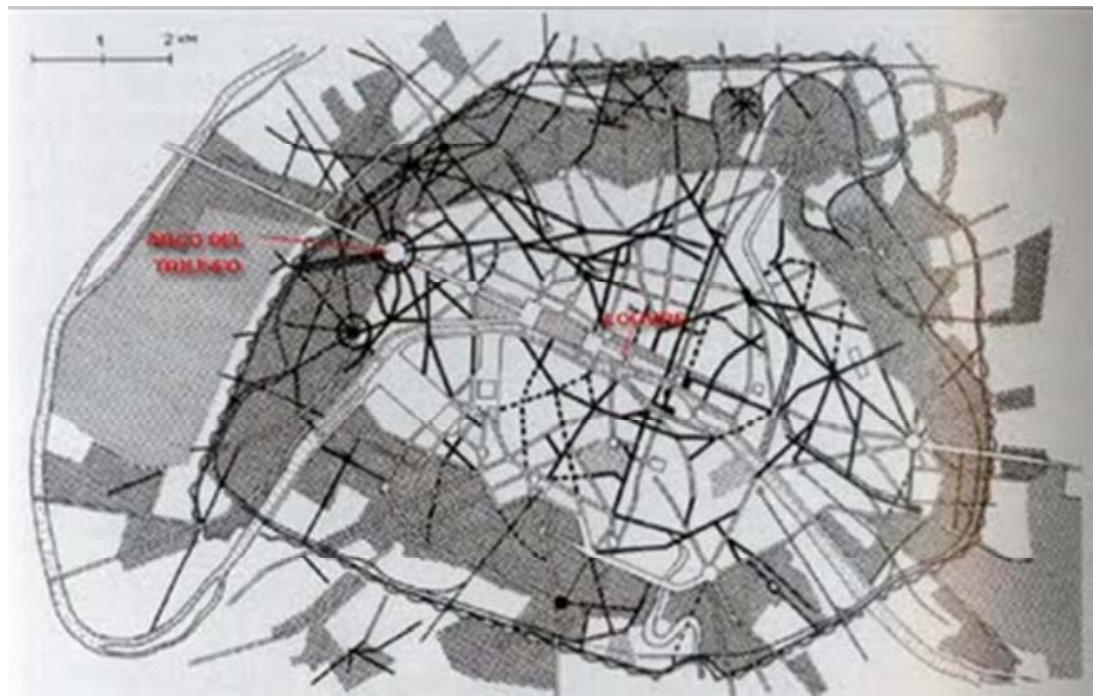

Figura 73.Crescimento de Paris intramuros ao longo dos séculos

Fonte: Google Earth, 2010

Organização: Elvis Vieira, 2011

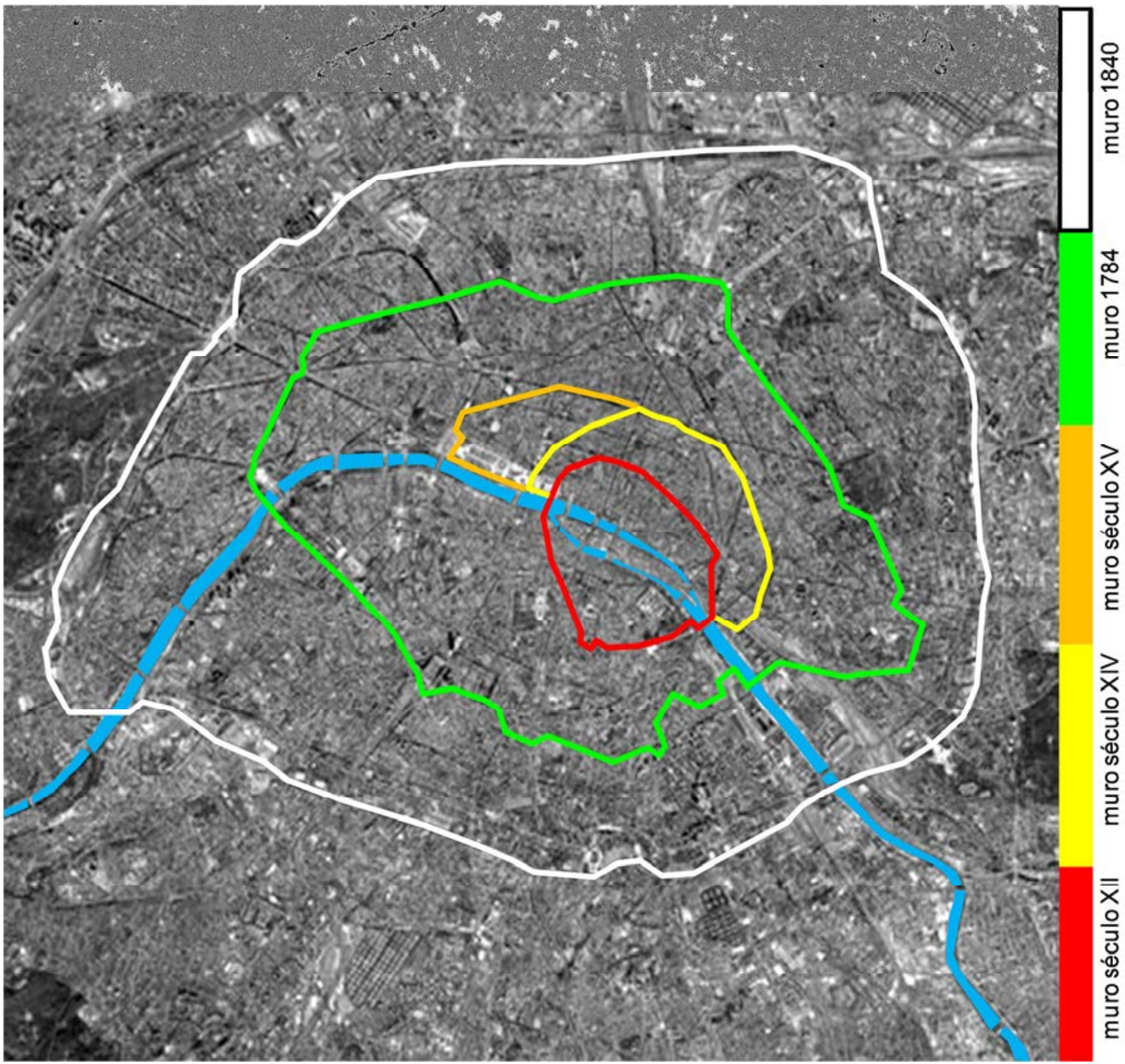


"Haussmann retalha a cidade segundo traçados que partem em feixes de praças ou cruzamentos. No essencial, este desenho continua as tradições barrocas do século XVIII" (LAMAS 1992, p 213-214), mas diferentemente das propostas contemporâneas em outras cidades, as intervenções tinham a clara intenção em enobrecer o novo ambiente urbano, buscando a regularidade e uniformidade nas fachadas de ruas e praças importantes e colocando um poder maior aos edifícios-monumentos como pano de fundo para a nova paisagem proposta. ${ }^{101}$

Fica claro que nas propostas de Haussmann o que mais chama atenção e ficou marcado como referência da "Cidade Luz", são as grandes vias arborizadas formando um importante "cinturão verde" na cidade, colocando o novo traçado viário como elemento-chave para a constituição da paisagem da cidade, a construção do "cenário urbano" a partir da configuração do espaço construído; monumentos ou edifícios, praças, cruzamentos e pedestres, rotatórias e o trânsito de veículos numa nova estrutura urbana de compreensão do desenho da cidade.

Outro fator esta na reestruturação administrativa do território urbano, até então a cidade era dividida em 12 distritos (nove à direita e três à esquerda do rio Sena), a partir de então a cidade foi redimensionada em 20 "arrondissements" (distritos), parcialmente autônomos (quarteirões), mas capaz de criar um "mapa virtual" na mente de cada cidadão parisiense.

É necessário reconhecermos que o Plano Haussmann influenciou o urbanismo tanto por seu reconhecido valor estético como por seu valor estratégico, porém com um grande número de variáveis envolvidas em suas propostas, tais como: o redesenho da propriedade urbana, gerando em alguns casos, conflitos com antigos proprietários; o levantamento preciso das condições existentes da cidade, tendo uma visão real naquele momento; a busca de boas condições salubres, mesmo com a densificação urbana prevista e a necessidade de implantação de infra-estrutura que respondesse a necessidade de seus habitantes.

"A importância de Paris decorre dos resultados extraordinários obtidos e da influência que exerceu em outras francesas e européias e no urbanismo em geral"(LAMAS 1992, p 216).

Como estratégia, Haussmann transforma a ìlle de la Cité no coração da cidade (1ํ arrondissement), passando a ser a área militar e administrativa. Na "reforma da cidade" foram destruídos $49 \mathrm{~km}$ de ruas estreitas e antigas, substituídas e ampliadas para 165 $\mathrm{km}$ de novas vias, além do significativo número de áreas verdes na cidade.

Milton Braga, em sua tese "Infra-estrutura e Projeto Urbano", defende que "talvez uma das principais lições que uma observação atenta de Paris possa encontrar seja o exemplo constituído pelos atributos do seu tecido urbano, pois é evidentemente desejável que os arranjos morfológico e tipológico de qualquer cidade confiram aos programas e estruturas de maior interesse social o devido valor paisagístico e, assim, emblemático". Sem dúvida Paris se coloca nesta posição como uma cidade onde seus cenários urbanos "encantam" a cada eixo viário que se possa ter o espaço construído como pano de fundo de uma "perspectiva urbana".

O Projeto Urbanístico de Haussmann acaba, desta forma, sendo caracterizado por uma abordagem ampla sobre o então território da cidade, realizando um "diagnóstico" da cidade em escala global e propondo ações integradas sobre todo o território, tanto o existente quanto o novo. Apesar de não dispor de uma teorização sobre a metodologia

101. Esta estratégia de desenho urbano também se coloca como elemento-chave em busca da ampliação na potencialidade de venda da terra, na justificativa de negociação dos custos de desapropriação e da urbanização prevista. 
adotada para esta leitura urbana de Paris, podemos apontar que suas contribuições são pertencentes aos primórdios ao urbanismo moderno.

Para que as propostas de Haussmann fossem colocadas em prática, considerando que o novo traçado viário resultava em um número considerável de desapropriações sobre propriedades privadas, criou-se neste momento uma comissão para cuidar das negociações com os proprietários nos processos de desapropriações e indenizações das áreas atingidas: Comission des Indemnités. ${ }^{102}$ Como estratégia urbanística e econômica, as áreas eram desapropriadas por interesse público incorporando as áreas lindeiras ao novo traçado viário projetado, gerando novos lotes que seriam vendidos posteriormente com a renovação do tecido urbano; assim tal estratégia possibilitava gerar fundos que cobririam os dispêndios com a abertura das vias e a implantação das infraestruturas e equipamentos urbanos. Além disso, foi adotado em paralelo à ação pública, um sistema de concessões para que empresas privadas financiassem as operações viárias e de reconstrução de novos prédios, com posterior direito de revenda (SIMÕES JUNIOR 2009, p 06). Considerando que a proposta de Haussmann ampliava o número de distritos na cidade, esta estratégia seria de suma importância para angariar recursos financeiros que garantissem a conclusão das obras previstas no Plano Urbanístico apresentado, no entanto, mesmo com a inclusão destes recursos, após $1860 \mathrm{com}$ a anexação de novos arrondissements, as obras foram de maior vulto, o que desequilibrou as finanças do sistema. No final da década de 60 (1869) o déficit acumulado atingiu a enorme cifra de 1,5 bilhões de francos (aproximadamente $R \$ 525$ milhões), o que levou o imperador a destituir Haussmann da função de prefeito.

Apesar de todos estes "percalços" que resultaram na destituição de Haussmann, os resultados alcançados pelo Projeto Urbanístico foram de grande valia e provocaram a alteração da paisagem da cidade de Paris de forma planejada e organizada. A normativa de padronização arquitetônica: gabarito de fachadas aliadas a um traçado viário composto por ruas obsessivamente retas são a marca da paisagem haussmanniana (SIMÕES JUNIOR 2009, p 06). Neste sentido, as normativas e regulamentações construtivas deveriam conferir um caráter monumental aos boulevards, onde os novos edifícios deveriam apresentar as seguintes tipologias:

- pavimento térreo e sobreloja em acabamento padrão em pedra;

- segundo pavimento de caráter mais nobre, com balcões;

- terceiro e quarto pavimentos segundo a estética do segundo, mas sem os balcões e com acabamento mais simplificado nas vergas e ombreiras das janelas;

- quinto pavimento com balcão contínuo e sem elementos decorativos;

- último pavimento com mansardas e inclinação a $45^{\circ}$;

- concordância nas linhas mestras das fachadas em cada rua, em função da padronização dos pés direitos e do número de pavimentos, propiciando unidade arquitetônica a toda a quadra.

Tais normativas garantiram uma linguagem contínua e a integração da paisagem entre a cidade real e a expansão proposta por Haussmann. Assim, a expansão do território parisiense e a ampliação dos distritos possibilitaram, e asseguraram um tecido contínuo e "uniforme" paisagisticamente, com uma trama urbana que se referenciava ao tecido existente e constituía com isto uma linguagem urbana e arquitetônica única em todo o território da cidade.

102. O aparato jurídico foi respaldado pela Lei Mélun de 13 de abril de 1850 e pelo decreto de 25 de março de 1852 . 
Após mais de um século da consolidação das intervenções do barão Haussmann em Paris, de 1853 a 1870, durante o Segundo Império, a atual organização da cidade com suas vias de grande circulação hoje em dia (Boulevard Saint-Germain, Boulevard de Sébastopol, entre outros), os alinhamentos das construções de mesma altura ao longo das avenidas ladeadas de árvores, as fachadas ritmadas pelos ornamentos do segundo andar e pelos balcões contínuos do quinto andar, ainda podem ser considerados como elementos da imagem da cidade.

Por outro lado, é com os elementos arquitetônicos que a cidade de Paris ficou marcada, como por exemplo, o Museu do Louvre, o Arco do Triunfo ou a Torre Eiffel ${ }^{103}$ que se tornaram referência mundial e organizam a paisagem dos principais eixos viários da cidade.

No início do século XX, Paris era considerada uma das metrópoles mais importantes do mundo; com uma população de 10.471 habitantes $(1911)^{104}$ e crescendo constantemente, a cidade estava fadada a uma estagnação em seu território limitado pelo Plano Haussmann. A necessidade de uma cidade moderna que suprisse os anseios de seus habitantes e fosse adaptada ao acelerado crescimento populacional existente na época, fez com que começassem a surgir as primeiras propostas revolucionárias de criação e organização das cidades. Em 1925 Le Corbusier apresenta uma proposta urbanística para Paris que tinha como meta uma cidade que representasse o "espírito da época", que respondesse aos anseios do homem da nova era que se iniciava.

Conhecido como "Plan Voisin", a cidade proposta por Le Corbusier deveria existir separação entre os usos, grandes áreas livres, unidades de vizinhança, separação entre veículos e pedestres etc.

Nessa perspectiva, ele propõe a construção de um centro comercial com torres isoladas, dispostas em um plano ortogonal ocupando uma importante área do centro da capital francesa, a margem direita do rio Sena. O plano possuía apenas duas artérias de circulação que possibilitaria o trânsito de automóveis. As demais áreas do centro da cidade abrigariam a circulação exclusiva para pedestres. Além da organização do centro administrativo, o plano também previa habitações com áreas verdes e distribuição de classes como mostra as imagens abaixo.

Apesar das propostas de Le Corbusier não serem colocadas em prática, podemos afirmar que as soluções desenhadas pelo arquiteto preconizavam as discussões e manifestos do IV Congresso Internacional de Arquitetura Moderna (CIAM), realizado em 1933 em Atenas - Grécia. A Carta de Atenas, que trata da chamada "Cidade Funcional"(Le Corbusier, 1933), propunha a separação das áreas residenciais, de lazer e de trabalho, propondo, em lugar do caráter e da densidade das cidades tradicionais, uma "cidade jardim", no qual os edifícios se desenvolvessem em altura, localizados em áreas verdes.

103. O Museu de Louvre, instalado no Palácio do Louvre e inaugurado em 1793, organiza o eixo da Avenida ChampsÉlysées, através da Praça da Concórdia até a Praça Charles de Gaulle, onde está localizado o Arco do Triunfo, monumento construído entre 1806-1836 em comemoração às vitórias militares de Napoleão Bonaparte. Localizada no Campo de Marte (Champ de Mars), a Torre Eiffel foi construída entre 1887-1889 como o arco de entrada da Exposição Universal de 1889, projetada pelo engenheiro Gustave Eiffel, a torre metálica possui 324 metros de altura, sendo o elemento arquitetônico mais alto de Paris.

104 .Fonte: INSEE (Institut National de la Statistique et des Études Économiques), estimativas populacionais 2010. 


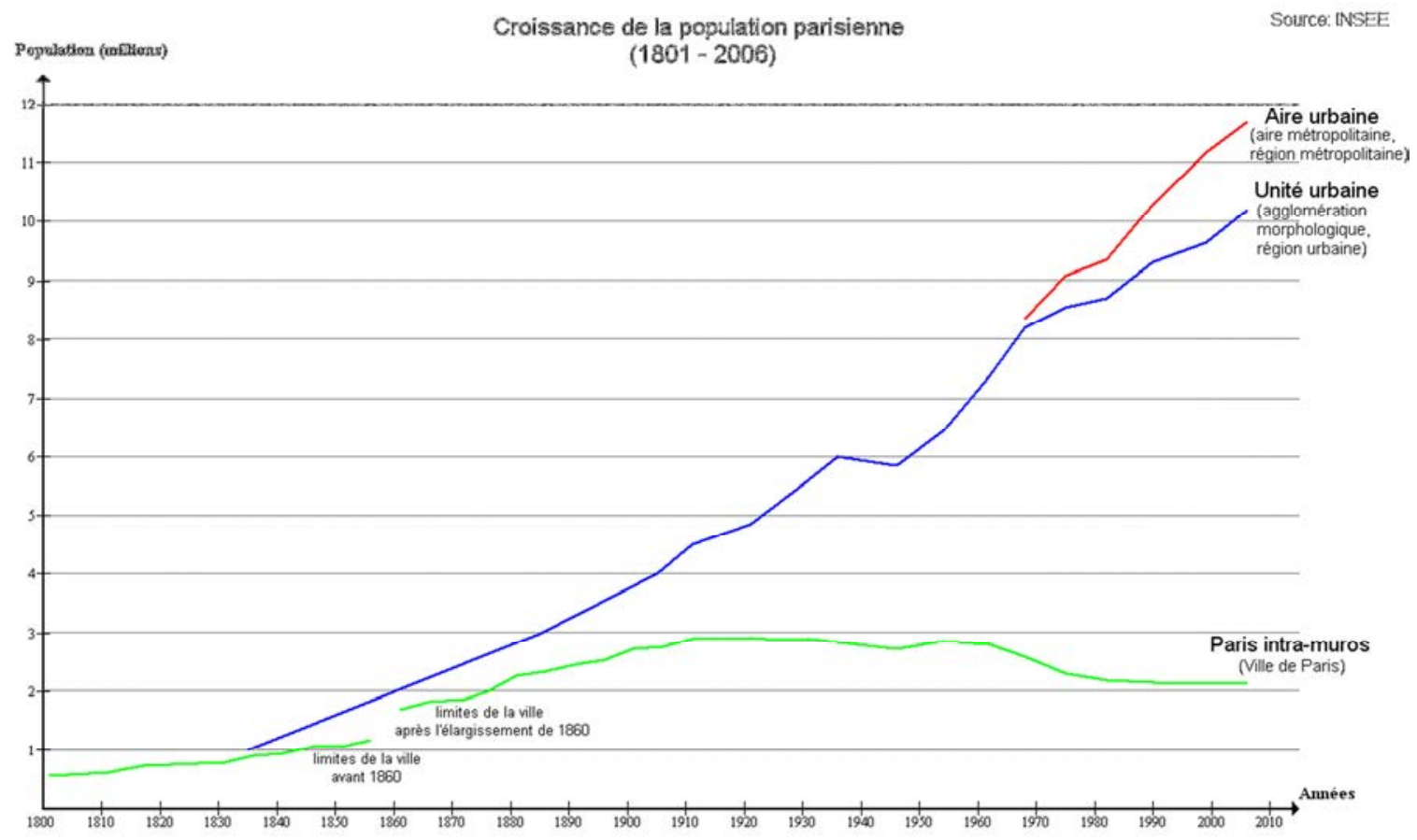

Figura 74.Evolução Demográfica de Paris

Fonte: Institut National de la Statistique et des Études Économiques, pesquisado em 17/10/11

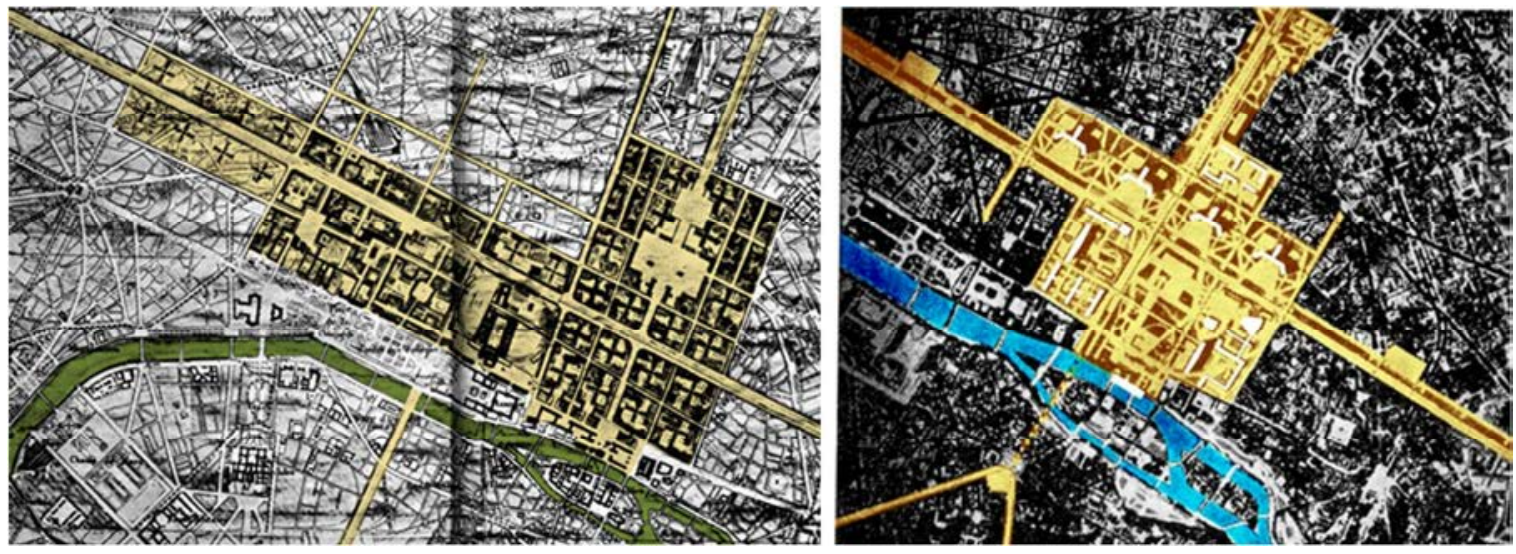

Figura 75.Plano Voisin propostos por Le Corbusier: acima esquerda - Plan Voisin em 1925; acima direita - Plan Voisin em 1937; abaixo - maquete física

Fonte: Bibliothèque publique d'information Centre Pompidou, 2011

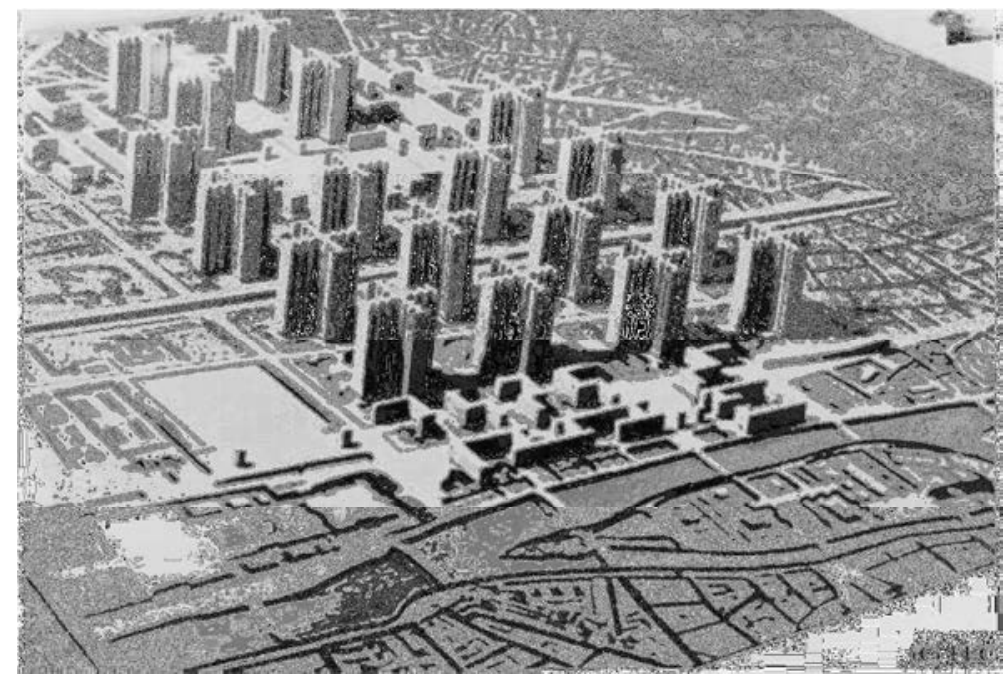


Desde então, os grandes projetos urbanos não tiveram o mesmo "peso" sobre as decisões dos administradores do século XIX, sendo substituídos por intervenções pontuais como estratégia de renovação do tecido urbano e fortalecimento de Paris como cidade turística e midiática.

Esta "estagnação urbana" se deu até meados do século XX com a grande demanda de expansão do setor de serviços em que Paris torna-se ponto central deste efeito. A fim de atender este processo de atração às grandes empresas, o governo francês decide desenvolver uma área de negócios em torno de La Défense, apresentando inovadores programas de construção e de novas formas urbanas. Com uma localização geográfica privilegiada sobre o eixo histórico no extremo oeste de Paris, ${ }^{105}$ a área de intervenção era ocupada por moradias degradadas e pequenas fábricas, algumas fazendas e favelas ao longo do uma área de aproximadamente 30 hectares no qual ficaria sob a responsabilidade da Établissement public pour l'aménagement de La Défense - EPAD (Instituição pública para o desenvolvimento de La Défense), criada em 1958 para gerenciar e executar as obras do novo bairro financeiro de Paris, que apesar de não estar sob o território físico da cidade, localizado nas fronteiras de três municípios, Courbevoie, Puteaux e Nanterre, garantindo com isto a implantação de edifícios modernos e grandes arranha-céus fora do centro de Paris como forma de "salvar" e proteger o horizonte histórico da cidade, consolidado com edifícios baixos e de estruturas emblemáticas como a Torre Eiffel e a colina de Montmartre.

O primeiro projeto urbano desenvolvido para La Défense foi desenhado pelos arquitetos Robert Camelot, Jean de Mailly e Bernard Zehrfuss, ainda em 1956, baseado numa ocupação dos edifícios ao nível do solo estruturado entorno do eixo histórico. Mais tarde o princípio básico da separação dos fluxos de tráfego foi adotado sob o conceito de uma praça artificial, ou laje reservada aos pedestres, tornando-se uma grande esplanada delimitada nas laterais por pequenos quadrados. No entanto, o que prevalece na paisagem de La Défense é a concentração dos elevados edifícios de serviços; tendo como peça central na construção do cenário urbano deste trecho da cidade, o Grand Arche de la Défense (Arco de La Défense) ${ }^{106}$ enquadra a paisagem sob o eixo histórico desde o Museu do Louvre, passando pelo Arco do Triunfo até chegar a La Défense, no mais os arranha-céus dominam o cenário urbano do local: primeiramente com torres que obedecem ao primeiro plano urbano (Camelot, Mailly e Zehrfuss) chamadas de primeira geração, todas de uma morfologia idêntica - uma base de $42 \times 24$ metros, limitadas a uma altura de 100 metros e superfície de $30.000 \mathrm{~m}^{2}$. No início da década de 70 surgem as torres da segunda geração com alturas de 184 metros e 44 andares, ampliando a superfície para $100.000 \mathrm{~m}^{2}$. Dez anos mais tarde, constroem-se as torres da terceira geração, seguindo um modelo mais econômico - menos largas e menos altas, a crise econômica e construtiva desta região se perdurará até o final do século XX (1997) com uma espetacular recuperação financeira tornando-se o maior distrito de negócios da Europa.

Na década de 70, um importante concurso internacional mobilizou um grande número de arquitetos para a concepção do que seria o maior centro cultural do mundo, ${ }^{107}$ tendo

105 . Este eixo histórico, ou também conhecido caminho real que estruturou o eixo oeste de Paris desde 1640 , traçado inicialmente por André Le Nôtre, arquiteto real, tinha sido utilizado muito antes desta data por antigos reis da França para ir caçar na floresta de Saint-Germainen-Laye. Em 1599, no reinado de Henrique IV, um caminho foi traçado a partir do Louvre para o castelo de Saint-Germain. Este caminho foi gradualmente ampliado e enriquecido ao longo dos séculos seguintes. Sob o rei Luís XIV, Le Nôtre o eixo foi alinhado como via central do Jardim das Tulherias, e em seguida, teve sob a ordem de Neuilly uma ponte construída sobre o rio Sena, prolongando ainda mais o eixo, sendo mais tarde nomeado por Napoleão como Avenida Camps-Elysées.

106 . Realizado em 1989 segundo um projeto do arquiteto dinamarquês Otto von Spreckelsen, simboliza uma janela aberta ao mundo. Um cubo oco de 112 metros de altura coberto de mármore branco e aberto no centro, apoiado por 12 pilares de 30 metros cada, é considerado um dos edifícios contemporâneos mais importantes da França.

107 . Naquele momento o concurso contou com a participação de 681 concorrentes de diversos países. 
como júri, entre outros: Jean Prouvé, Philip Johnson e Oscar Niemeyer. O projeto vencedor foi dado aos arquitetos Renzo Piano e Richard Rogers com uma proposta ousada e arquitetura de grande valor simbólico e que despertou intensos debates e controvérsias à época, sendo hoje considerado um dos principais exemplos da arquitetura high-tech. Apesar de muitos criticarem sua solução plástica com as estruturas e equipamentos como uma "pele" para o edifício e, independente das soluções encontradas, a proposta é eleita vencedora, entre outras soluções demonstradas, configura a existência de um espaço público - a Praça do Centro, para o qual as suas atividades internas se estendem (Arquitecturas 2005), assim como o novo edifício cultural redesenha e requalifica o bairro Beaubourg que passava naquele momento por um processo de degradação urbana intensa. O Centro Cultural Georges Pompidou foi inaugurado em 1977, sob a administração do presidente Valéry Giscard d'Estaing (1974-1981) deixando este imponente conjunto cultural como herança de sua administração.

Outros presidentes também deixaram sua "marca urbana" através de seus grandes trabalhos pontuais (arquitetônicos) e/ou de desenvolvimento urbano (grandes projetos urbanos). Entre eles, um dos mais significativos foi o presidente François Mitterrand que em sua gestão contribuiu com uma grande diversidade de planos e projetos, como por exemplo, o Parque La Villette (Bernard Tschumi - 1982), Instituto do Mundo Árabe (Jean Nouvel - 1981-1987), Arco La Défense (Otto von Spreckelsen - 1989), Biblioteca Nacional de Paris (Dominique Perrault - 1989-1995) e o Plano Seine-Rive Gauche (1991- em andamento) no qual trataremos mais adiante.
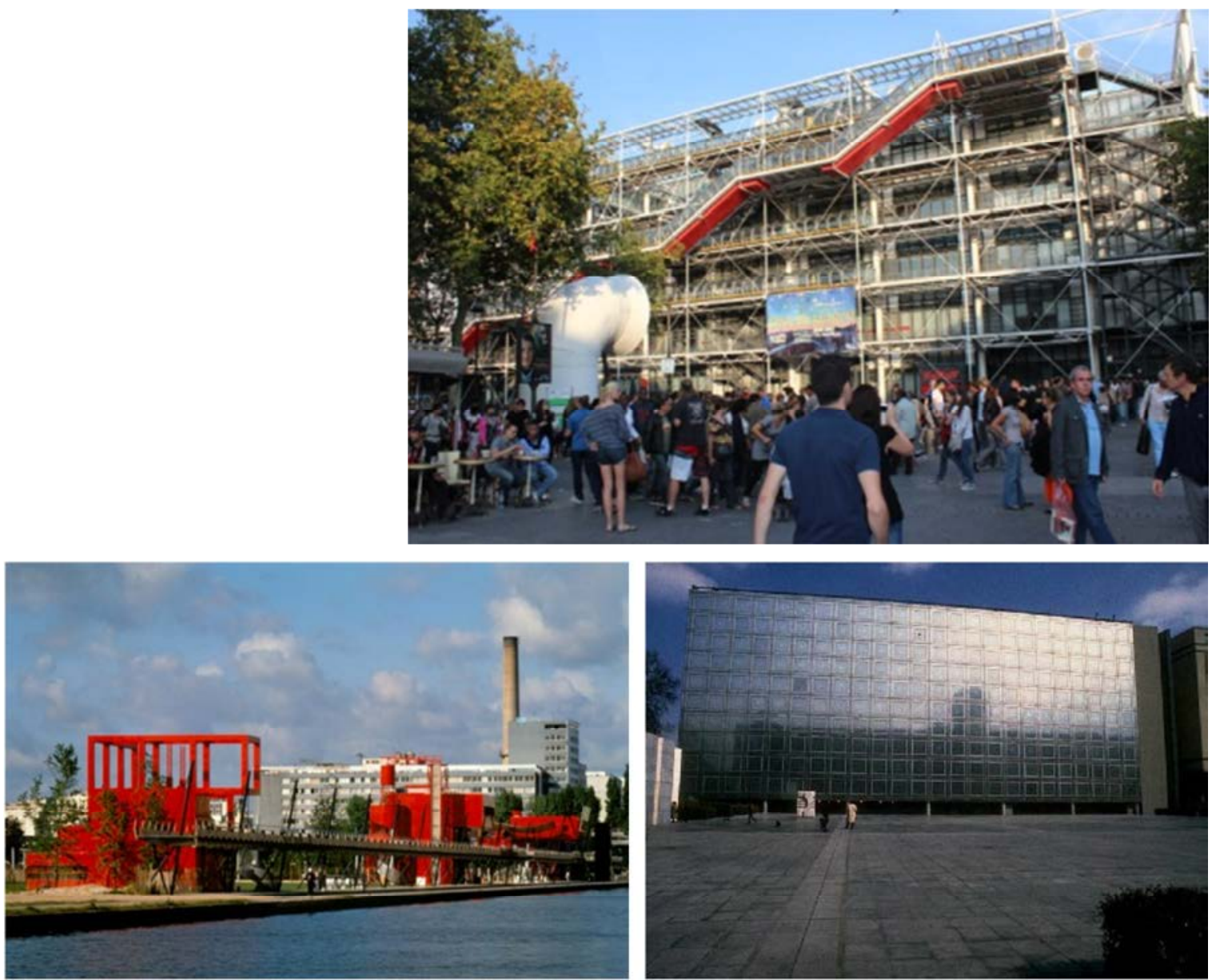

Figura 76. Centro Cultural Georges Pompidou (1977), Parque La Villette (1982), Instituto do Mundo Árabe (1987)

Fonte: Elvis Vieira, 2011 


\subsection{As ZACs parisiense e os Grandes Projetos Urbanos para Paris}

A partir da segunda metade dos anos 80, algumas cidades européias se viram obrigadas a repensar sua forma de tratar o desenvolvimento urbano e econômico de seus territórios, ora com seu tecido desarticulado devido às grandes áreas abandonadas e/ou degradadas física e economicamente, ora com o esvaziamento industrial e sua reestruturação econômica, as cidades se encontravam com grande parte de seu tecido urbano degradado. "Na medida em que os projetos urbanos passaram a integrar a agenda das grandes cidades no final do século, o modelo foi se sofisticando. Ao mesmo tempo, a competição entre cidades foi se acentuando, na disputa pelos investimentos voláteis no novo processo de financeirização mundial"(SOMEKH e CAMPOS NETO 2005).

A França por sua vez, e em particular Paris, desde meados do século XX vem trabalhando as questões do planejamento urbano como peça central da "disputa mundial" em busca de um desenvolvimento estruturado sob os grandes planos e projetos coordenados por sociedades de economia mista que estruturaram a passagem de um modelo de planejamento hierárquico para o "modelo negociado".

Com a evolução demográfica em ascensão na capital francesa, num crescimento populacional de cerca de 8 milhões para 14 a 16 milhões de habitantes na virada do século (VILLE DE PARIS), o então presidente Charles de Gaulle(1959-1969)inicia uma política de planejamento na construção de novas cidades num raio a partir do centro de Paris de 15 a 50 km de distância, no intuito de evitar a concentração urbana na capital francesa e alcançar um desenvolvimento urbano multipolar.

Georges Pompidou, primeiro-ministro naquele momento, exige a elaboração de um "plano mestre" (plan directeur) ${ }^{108}$ da Grande Paris e de um esquema estrutural para as demais metrópoles francesas (Lion, Marselle, Lille etc). Como resposta ao desejo de planejar o território e a necessidade de melhor estruturar o desenvolvimento da aglomeração parisiense, a solução dava-se na criação das Villes Nouvelles, num esforço de humanizar, ordenar e controlar os movimentos de urbanização.

Segundo Ricardo Trevisan em sua tese "Cidades Novas", as Villes Nouvelles podem ser definidas como organismos que:

“... se apresentam num contexto de reestruturação da área metropolitana. $O$ conjunto de projeto de planejamento se articula entre a reconstrução do centro tradicional da metrópole e a criação de alguns nós de armadura urbana. Cada cidade nova terá uma vocação privilegiada (setor terciário ou quaternário). Enfim, a cidade nova francesa e isola da metrópole (seja geograficamente, seja por um cinturão verde, um lago, ou por questões de topografia), mas ao mesmo tempo ela se situa sobre um dos principais eixos de comunicação da região. Em termos de categoria de análise, a cidade nova francesa não é nem satélite, nem autônoma, mas uma cidade secundária; nem completamente diferenciada, nem especializada, mas de vocação privilegiada; nem concentrada, nem difusa, mas um pólo integrado ao conjunto da área metropolitana" (AHTIK 1969 in TREVISAN 2009, p 63).

108. O plano mestre (termo dado a planejamento) foi regido pelo Institut d'Aménagement et d'Urbanisme de la Région Parisiense (IAURP), responsável pela concepção e criação das novas cidades. Fundado em 1960, o IAURP lançou cinco anos mais tarde o Esquema Diretor de Planejamento e de Urbanismo da Região de Paris (Schéma directeur d'aménagement et d'urbanisme de la région de Paris - SDAURP), no qual constava um esboço de crescimento direcionado da Grande Paris sobre dois eixos. 
No início da década de 60 dá-se a implantação das que seriam as Villes Nouvelles. Originalmente foi determinada a criação de oito novas cidades no entorno de Paris, mas sem decidir sua localização precisa, sendo mais tarde reduzidas para cinco: Évry, Cergy-Pontoise, Marme-la-Vallée, Melun-Sérnat e Saint-Quentin-en-Yvelines. Para a concepção destas Cidades Novas o programa sugeria "um plano de conjunto, com articulação coerente entre diferentes bairros, tipos de arquitetura, diversidades de habitações, situadas ao redor de um centro administrativo e moderno, oferecendo a seus habitantes lazer e cultura" (ROULLIER 2004 in TREVISAN 2009). Sob a ótica dos arquitetosCristoforo Sergio Bertuglia, Silvia Prodan Tich e Andréa Stanghellini, em seu estudo sobre as Villes Nouvelles (Formazione di un'identitá urbana: il caso delle villes nouvelles), o Estado francês pretendia:

“... frear o desenvolvimento da mancha urbana de Paris, canalizando a urbanização em áreas definitivas, situadas na periferia e interligadas à capital por estradas tangenciais sem perpassar a região central; e evitar nestas áreas os fenômenos de periferização e da formação de cidades-dormitórios, pela criação de um verdadeiro e próprio centro urbano, dotado de habitação, serviço e postos de trabalhos"(BERTUGLIA, TICH e STANGHELLINI 2004).

Como resultado prático sobre estes "novos territórios" satélites à capital francesa, o Estado promoveu uma sequência de concursos capaz de gerar um conjunto de discussões e "experiências urbanas", divididas em três grandes grupos: urbanismo (arquitetura e organização urbana de áreas de 700 a 7.000 moradias), habitação (áreas de 70 a centenas de moradias) e espaços públicos.

"A quantidade de concursos possibilitou uma diversidade de projetos, realizados por mais de 260 arquitetos, dos quais se destacam: Ricardo Bofill, Christian de Portzamparc, Jean Nouvel, Alain Sarfati, Tomasz Fiszer, Manuel Nuñez Yanowsky etc. nesse rico acervo urbanístico e arquitetônico pós-moderno encontramos: o Espaço de Abraxas, um complexo residencial composto por três prédios: Teatro, Palácio e Arco, desenhado pelo arquiteto espanhol Bolfill em 1982, e as Arenas de Picasso, um conjunto de habitação para baixa renda, construído entre 1980 e 1984, elaborado pelo arquiteto Yanowsky" (TREVISAN 2009, p 71).

Figura 77.Villes Nouvelles em Ile-deFrance - em roxo: Sénart, Saint-Quentin en Yvelines, Evry, Cergy, Marne-la-Vallée Fonte: Ville de Paris, 2011

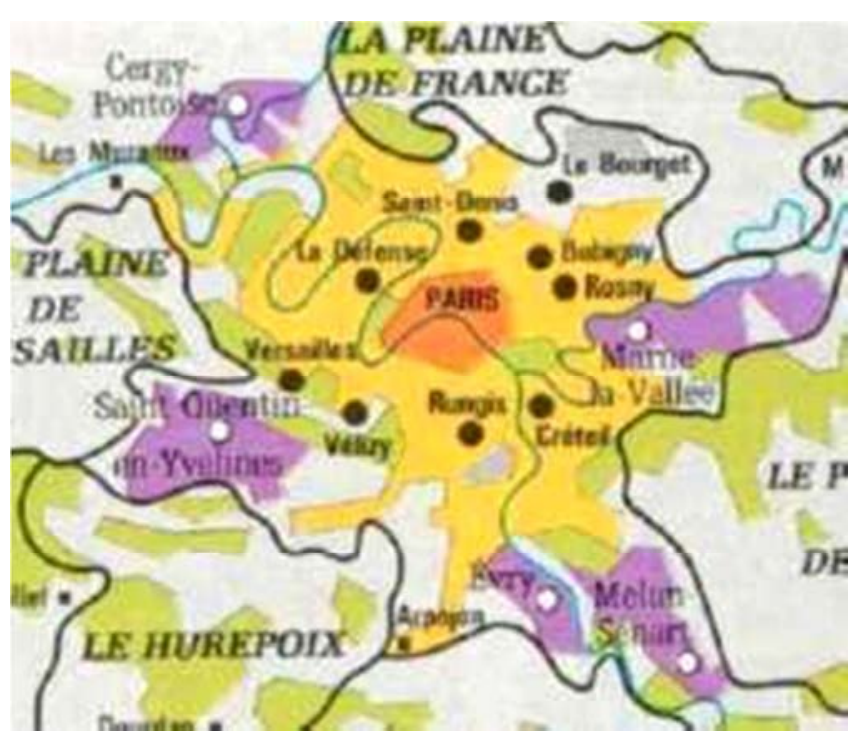


Já como resultado morfológico, as Villes Nouvelles possibilitaram um vasto campo de experimentação sobre o desenho e a concepção das novas formas urbanas. Diferentemente da "Cidade Sede" - Paris, que apesar de ter seu crescimento controlado, em determinado período de sua história pelo Plano do Barão Haussmann, o desenho das novas cidades tinham sua concepção proposta tridimensionalmente, com um programa delimitado e definido de forma a viabilizar e qualificar cada "Satélite Urbano de Paris". Especificamente sobre o programa destes novos organismos urbanos, identificaram-se dados precisos na organização espacial dos núcleos:

"O centro da cidade nova deve ser o nível superior da hierarquia funcional e espacial. Ele é importante e densamente ocupado, com serviços atrativos, o ponto nodal da rede de transportes da nova aglomeração e a principal plataforma de transportes para sair da cidade. Os bairros constituem o nível médio, a maioria destinada à habitação, agrupando milhares de moradias, com equipamentos e meios de transportes que dariam acesso ao centro" (HAUMONT, 1997b in TREVISAN, 2009).

Ao contrário das cidades que tiveram seu crescimento natural e espontâneo, as novas cidades surgem com suas formas e funções estabelecidas sobre uma ordem própria, configurando o espaço a partir da hierarquização das funções mínimas da cidade: "a ordenança do espaço, mesmo contendo em seu traçado uma aparência irregular"(CHALINE 1985). Neste sentido, para José Osvaldo de Meira Penna, a Cidade Nova é fruto da "ação consciente do homem que procura propor, em formas e espaços racionalmente concebidos, os objetos do estabelecimento coletivo do solo"(PENNA 1958).

Como cenário urbano as Villes Nouvelles provocaram a produção de formas ordenadas, racionalmente concebidas e espelhos de uma cultura, em que o homem nem sempre é o elemento chave do desenho da cidade, enquanto que o automóvel ganha espaço no seu ideário, transformando o traçado e o tecido urbano, isto é, de suas vias, de seus parcelamentos e de suas edificações.

Passados pouco mais de meio século após a implantação das primeiras "Cidades Satélites" da Paris haussmanniana do século XIX, "o crescimento urbano perde sua característica centralizada para se tornar aracnídea, pela introdução das ferrovias e das indústrias no espaço urbanizado" (BENSAID e LE JEANNIC 1989), ao mesmo tempo, estas mesmas cidades foram tornando-se autônomas econômica e politicamente da "cidade sede", deixando de serem satélites para tornar-se "Cidades Estelares". 109

Paris hoje não é apenas uma cidade de $105 \mathrm{Km}^{2}$ e pouco mais de 2 milhões de habitantes. ${ }^{110}$ Não se limita à espiral de seus 20 distritos. Nem tão pouco podemos dizer que seus limites físicos estão inseridos em seu "anel verde" junto ao Sena.

A realidade metropolitana de Paris, ainda que esta cidade desenvolveu-se de maneira muito singular, é sintomática destas grandes estruturas urbanas onde vive uma parte crescente da humanidade, em que as atividades, usos sobre o território e o capitalismo são marcados por coerências múltiplas.

A crescente aceleração do crescimento das cidades, e em especial as megalópoles parece inevitável, mas que devemos considerá-la como "domável". Assim, estudar Paris

109. Ricardo Trevisan em artigo publicado em sessão temática do XIV ENANPUR (Rio de Janeiro, 2011), intitulado Villes Nouvelles Parisienses: um Savoir-Faire defende a autonomia das cidades criadas na década de 60, criando sua própria autonomia econômica e política em relação a capital francesa.

110. Apesar de Paris abrigar hoje cerca de 2,2 milhões de habitantes, aproximadamente 6 milhões moram ao redor de seus limitem dependendo de trabalho, lazer e cultura da capital francesa. 
como uma Metrópole e todos seus componentes políticos, administrativos, econômicos, sociais, históricos, geográficos, físicos, pitorescos e ambientais, possibilitando um novo olhar para o futuro da capital francesa tornou-se necessário para garantir o desenvolvimento urbano e econômico da capital francesa e as cidades metropolitanas (Grande Paris) para as próximas décadas.

É com este espírito que em junho de 2008, o presidente francês Nicolas Sarkozy anunciou a elaboração de um grande plano para a cidade de Paris intitulado "Le Grand Pari" (A Grande Aposta), reunindo 10 equipes de arquitetos e planejadores urbanos para proporem uma "capital mundial" mais sustentável, e, ao mesmo tempo, ousada.

"O projetado está sendo considerado o mais ambicioso desde que o Barão Haussmann dramaticamente mudou a cara de Paris em meados do século XIX com um projeto que rasgou a cidade com largos bulevares e a famosa Champs Elysees"(ARQBACANA, 2009).

O desafio destas 10 equipes era imaginar uma Metrópole Européia em 30 anos, através da análise e propostas para a Grande Paris. As equipes são representadas pelos arquitetos ou ateliês:

1. Antoine Grumbach, coordenador da equipe Agencia Grumbach \& Associados;

2. Yves Lion, coordenador da equipe Grupo Descartes;

3. Richard Rogers, coordenador da equipe RSH \& Partners;

4. Roland Castro, coordenador da equipe Atelier Castro / Denisof / Casi;

5. Djamel Klouche, coordenador da equipe l'AUC;

6. Michel Cantal-Dupart, Jean-Marie Duthilleul, coordenadores da equipe Ateliers Jean Nouvel / Michel Cantal-Dupart / Jean-Marie Duthilleul;

7. Bernardo Secchi e Paola Vigano, coordenadores da equipe Studio 08;

8. Winny Maas, coordenador da equipe MVRDV;

9. Finn Geipel, coordenador da equipe LIN;

10. Christian de Portzamparc, coordenador da equipe Atelier Portzamparc.

Cada equipe, durante 9 meses, tiveram total liberdade de propor uma nova Paris que respondessem as novas necessidades de uma cidade que não se serve mais a conhecida "Cidade Luz", mas que respondesse aos problemas "estéticos" dos subúrbios, "que além de feios, afrontam a vida urbana ao serem distantes dos locais de trabalho, do comércio, do serviços e do centro de Paris"(ARQBACANA, 2009).

Uma grande diversidade de soluções foi dada pelas equipes, como a conexão dos subúrbios por um trem de alta velocidade elevado, percorrendo toda a cidade, e revendo toda a rede de transporte da cidade, apontada pelo arquiteto Christian de Portzamparc. A compreensão da cidade como um grande organismo sustentável, com telhados verdes para os blocos de apartamentos parisienses e transformando os principais bulevares em ruas verdes para bicicletas e pedestres, colocados pela equipe coordenada por Richard Rogers, ou então, como propõem o arquiteto Antoine Grumbach, uma Paris que extrapola os limites de seus distritos em direção ao mar, com a ligação da cidade ao litoral por um trem de alta velocidade.

Outras equipes também tiveram como premissa de suas propostas a melhoria nos transportes e conexões entre trens, ônibus e metrôs e abrir o Sena para mais barcos.

Por fim, o que se busca com estas dez propostas é "promover o debate democrático sobre o futuro da cidade"(ARQBACANA, 2009), garantindo a possibilidade de todos os cidadãos em construir uma Paris para as próximas três décadas. 
Por outro lado fica claro que estes grandes planos reestruturantes da composição morfológica, econômica e social das cidades são soluções a médio e longo prazo, necessários para o futuro das cidades, mas que devam estabelecer diretrizes e propostas para reordenar também trechos das cidades.

Com a constante transformação das cidades em detrimento das alterações econômicas e tecnológicas globais, trechos das cidades se deterioram ao longo dos anos tornandose territórios subutilizados, degradados paisagisticamente e, em alguns casos, com grande índice de violência, gerando problemas não somente no perímetro destes bairros, mas refletindo sobre o entorno próximo e sobre toda a dinâmica da cidade.

Como resposta ao grande número de extensas áreas urbanas degradadas na maioria dos arrodiment de Paris, o governo municipal francês utiliza de uma estratégia de transformação do desenho urbano a partir dos Grandes Projetos Urbanos com perímetros muito bem delimitados e a utilização de instrumentos legais e urbanísticos que possibilitasse a transformação de forma ágil e eficaz.

Da mesma forma que muitas das cidades européias que se viram, na segunda metade dos anos 80 , com problemas semelhantes de esvaziamento industrial e reestruturação econômica, sentem-se "obrigados" a repensar sua forma de intervir sobre o tecido existente. Paris elege como ferramenta desta necessária "requalificação urbana", sob a forma dos Grands Projects, intervenções coordenadas por sociedades de economia mista nas ZACs "que estruturaram a passagem do modelo de planejamento hierárquico para o 'modelo negociado', quase sempre dentro de diretrizes definidas por planos urbanos gerais" (CALLON, 1996 in SOMEKH e CAMPOS NETO, 2005).

Esta nova fase de experimentação urbana a partir da década de 1980, em resposta à rejeição da urbanização moderna - torres, grandes conjuntos habitacionais, a zonificação dos usos propostos, resultam em projetos urbanos em pequena escala que deve integrar-se ao tecido urbano haussmanniano existente, porém respeitando a escala humana dentro destes nouveaux quartiers (novos bairros).

As ZACs foram responsáveis pelo redesenho do tecido urbano degradado ou subutilizado ao longo dos anos no qual a expectativa de restabelecer, de certo modo, a rua e o lote como unidades de planejamento, com a criação das Unidades de Vizinhança, defendidas naquele momento pelo APUR (Atelier Parisien-d'Urbanisme), respeita a continuidade histórica na sua diversidade e consagra a tradição. Como observado por José M. Ressano Garcia Lamas, “... verifica-se que existe um grande esforço de controlo sobre o desenho dos edifícios: altura, alinhamentos, implantações, volumes, materiais, fachadas e cores, numa tónica contextualista, não sem tensões e contradições entre orientações urbanísticas e os projectos de arquitectura" (LAMAS 1992, p 446-447).

Neste contexto, o Governo de Paris identificou um conjunto de áreas de intervenção urbana capaz de regenerar o tecido urbano hausssmanniano, requalificar os espaços públicos e a habitação para reduzir o desequilíbrio entre os distritos da capital. Como podemos observar (vide fig. 79, pag. 166), as intervenções estão localizadas em sua maioria junto à coroa externa de Paris, em bairros dos subúrbios claramente insalubres e mal construídos. Resultantes da desindustrialização destes bairros-subúrbios e com um número considerável de imigrantes, o "envelhecimento" do tecido urbano se deu de forma muito rápida e com conseqüências assustadoras para o desenho da cidade e seu cenário urbano. 

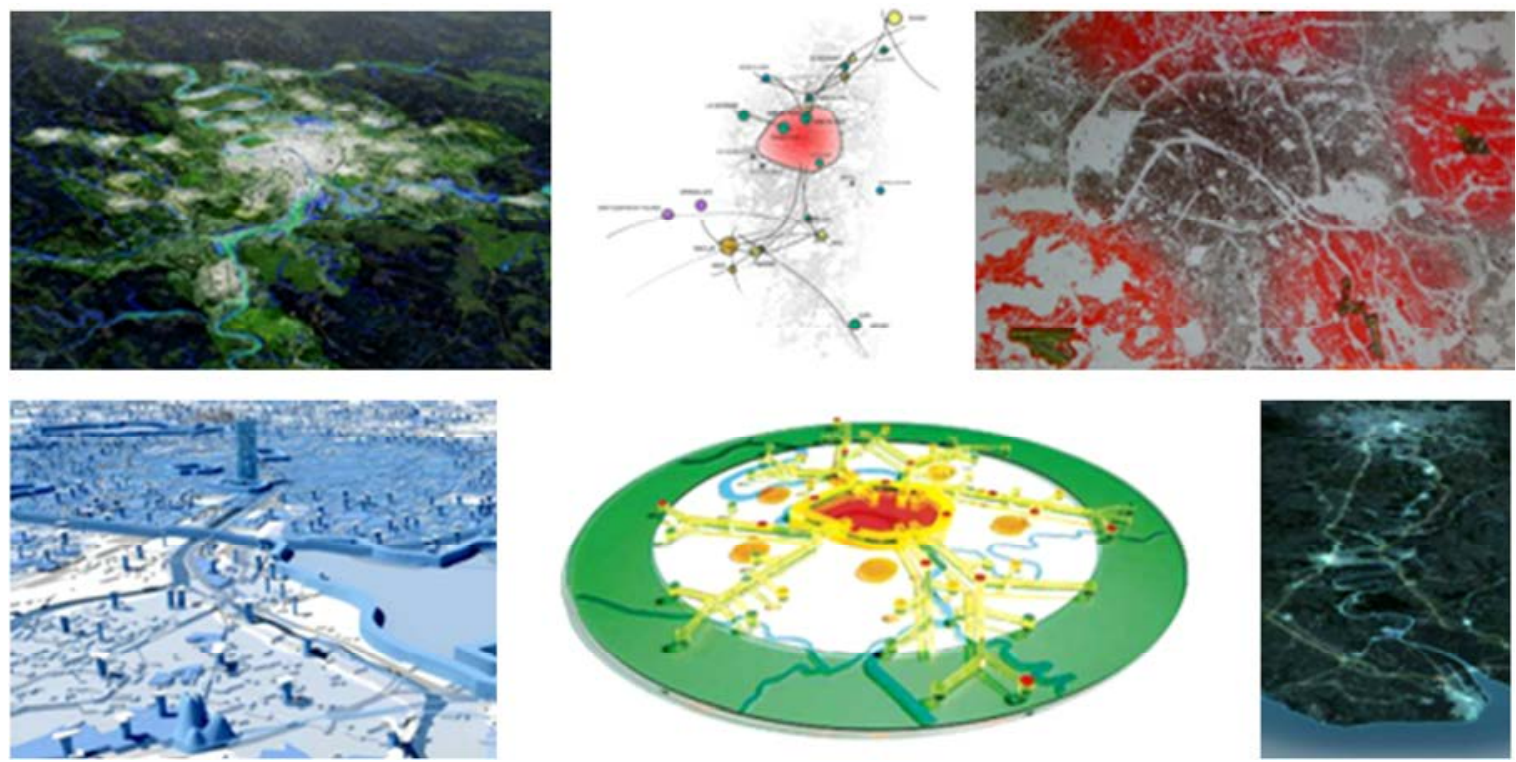

Figura 78.Propostas para o Plano Le Grand Pari - na seqüência: equipe Lin, Christian de Portzamparc, Jean Nouvel, MVRDV, Richard Rogers, Antoine Grumbach, 2010

Fonte : Plano Le Grand Pari, 2010

Figura 79.Operações Urbanas Ativas

Fonte: Ville de Paris, 2010

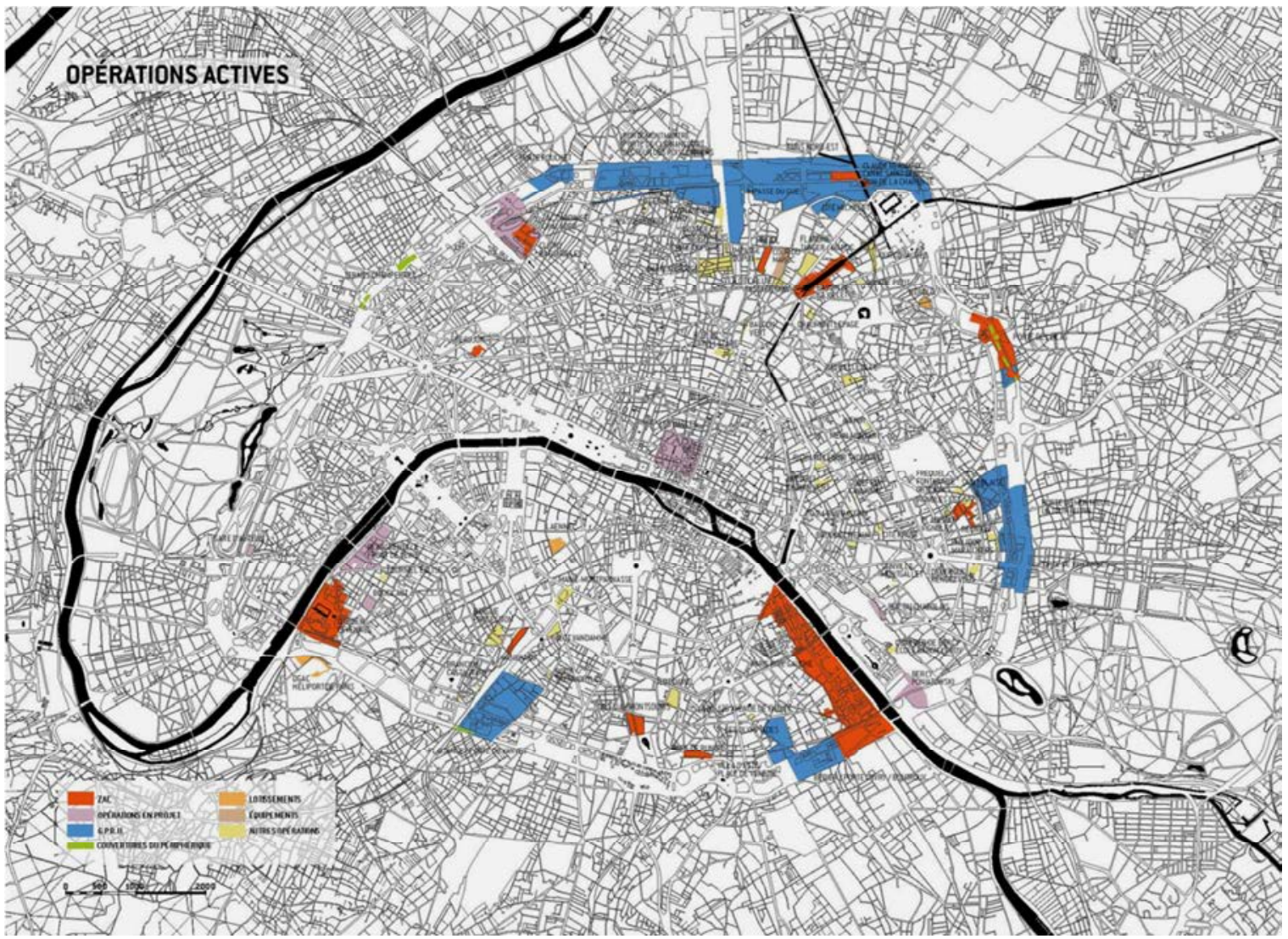


No que tange as ZACs (Zone d'Aménagement Concerté) atualmente estão em desenvolvimento 12 Operações Urbanas: Beaujon, Cugy Batignolles, Cour du Maroc, Bassin de la Villette, Claude Bernard Canal Saint Denis Quai de la Charente (Norte); Porte Deselas, Vignobles Est (Leste); Paris Rive Gauche, Gare de Rungis, Mesia Montsourts (Sul); Naugrad, Citöen Cevennes (Oeste), no qual foram chamados arquitetos, planejadores e urbanistas à refletirem sobre a "inovação urbana" e aplicar sobre as áreas propostas o conceito do "Novo Urbanismo". Segundo Bertrand Delanoë, Prefeito da cidade de Paris (2001-2014), os objetivos destas operações são claras: "desenvolver a cidade, reparar lesões ou avarias, para restaurar a alma de alguns bairros abandonados, cumprirem os objetivos do desenvolvimento sustentável, renovar a criação de valor e diferentes heranças em Paris" ${ }^{111}$ demonstrando a preocupação não somente de requalificar o tecido urbano, mas também garantir a reestruturação social da maioria dos bairros-subúrbios junto à "coroa urbana" de Paris, impulsionando uma cidade ativa e dinâmica.

"Estes dão origem a habitação, edifícios públicos, lojas, mas também espaços verdes. É parte de uma visão diversificada da paisagem urbana, com uma vontade de levar em conta a identidade de cada bairro no coração de Paris, no tecido suburbano, na cidade Haussmann e nos arredores de Paris" (DELANOË, $\mathrm{s} / \mathrm{d}) .{ }^{112}$

Tais operações levam a mudança do "olhar" da administração pública à chamada "coroa" junto à "borda urbana" de Paris, onde sua mancha se funde as cidades criadas a partir da década de 70 (Villes Nouvelles) e as demais surgidas no intervalo territorial entre elas, compondo hoje o espaço da região metropolitana (Grand Paris). O desenvolvimento destes territórios tem uma dimensão social fundamental, que exige em curto prazo uma combinação de ações que possam melhorar as condições de vida das pessoas que habitam e/ou usufruem destas áreas, onde as intervenções urbanas, em longo prazo, cumprem a função de transformar não somente o espaço, como também os cenários urbanos existentes na cidade contemporânea.

Por fim, podemos observar que as intervenções urbanas procuram melhorar as áreas públicas, reforçar os transportes públicos, os espaços de processo de conexões (com a função de "costurar" o tecido urbano fragmentado), localizadas em sua maioria nas zonas ribeirinhas com programas diversificados e próximos aos principais equipamentos de transportes de massa (portes de la ville), no qual podemos concluir que foram divididas em duas categorias tipológicas: 1) áreas resultantes do "esvaziamento urbano" ocasionado pelas mudanças econômicas e áreas junto aos transportes ferroviários (Gare de Rungis) e, 2) áreas a serem reparadas urbanisticamente, resultantes do planejamento urbano moderno (lajes e usos setorizados, edifícios altos) cuja incompletude ou o desgaste resulta em cenários degradados urbano e socialmente (Paris Rive Gauche).

111. Tradução do autor, 2011

Développer la ville, réparer les blessures ou dommages, de rétablir l'âme de certains quartiers abandonnés, d'atteindre les objectifs du développement durable, le renouvellement de la création de valeur et des différents patrimoines à Paris 112 . Tradução do autor, 2011

Elles donnent lieu à un logement, bâtiments publics, commerces, mais aussi des espaces verts. II fait partie d'une vision diversifiée du paysage urbain, avec une volonté de prendre en compte l'identité de chaque quartier en plein coeur de Paris, dans le tissu de banlieue, Haussmann dans la ville et la périphérie de Paris 


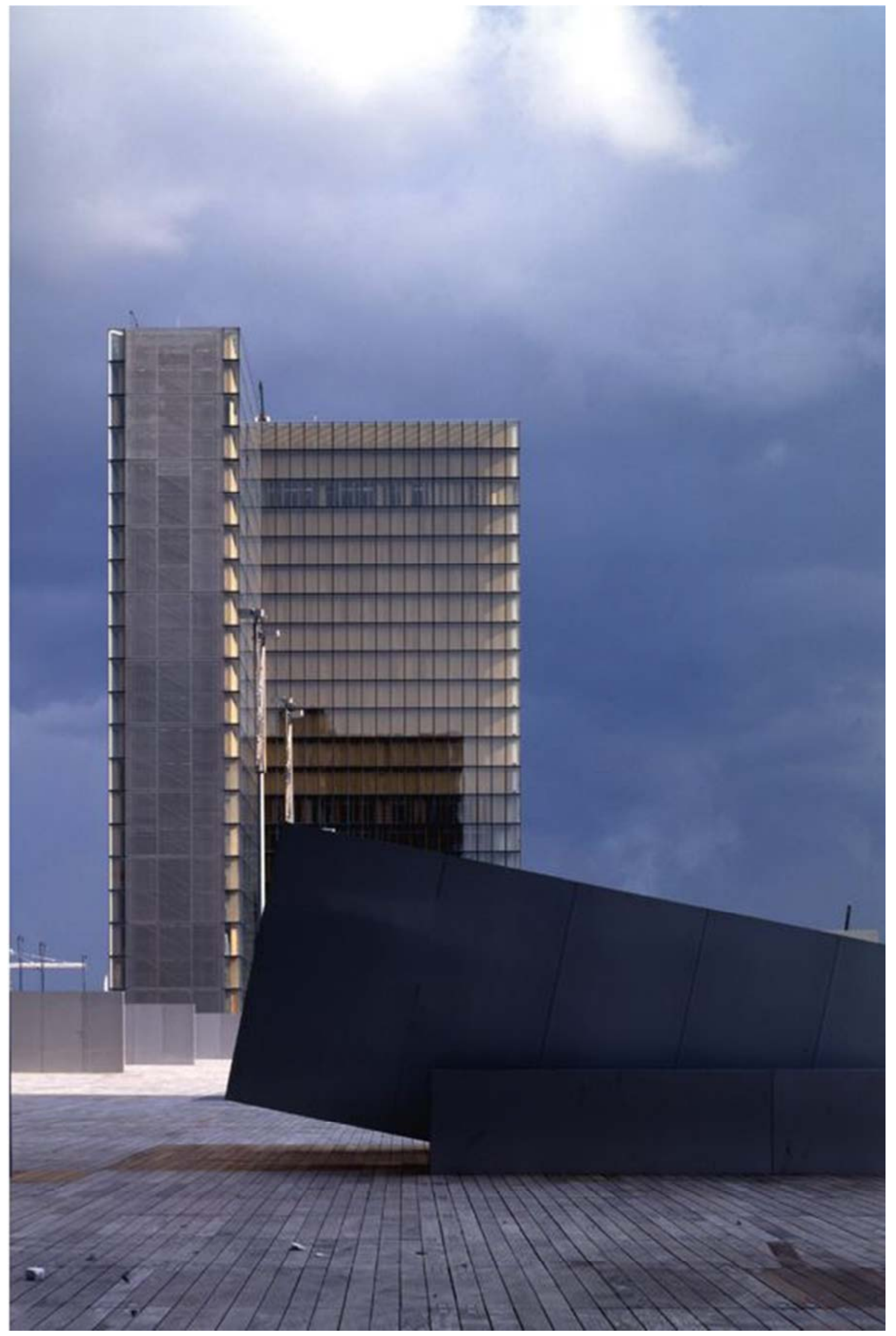

Figura 80.Bilblioteca Nacional da França - arquiteto Dominique Perrault Foto: Elvis Vieira, 2011 


\subsection{ZAC Paris Rive Gauche}

Com a constante transformação das cidades em detrimento das alterações econômicas e tecnológicas globais, trechos das cidades se deterioram ao longo dos anos tornandose territórios subutilizados, degradados paisagisticamente e, em alguns casos, com grande índice de violência, gerando problemas não somente no perímetro destes bairros, mas refletindo sobre o entorno próximo e sobre toda a dinâmica da cidade.

O $13^{\circ}$ Distrito de Paris, localizado a leste da cidade, foi se degradando ao longo do século XX em detrimento das transformações tecnológicas $e$ as decisões governamentais de criar estratégias de desenvolvimento em outras regiões, como por exemplo, o Distrito Financeiro de La Défense, a oeste da cidade dotando esta zona de um conjunto de edificações comerciais e serviços capaz de redirecionar o coração financeiro para este setor.

Por outro lado, este distrito tem sido desde sua origem no século XIX, um dos mais pobres de Paris, tendo no início do século XX se consagrado majoritariamente com uma população provincial e de imigrantes (orientais principalmente), com uma taxa de desemprego de 11,3\% (Ville de Paris 2004).

Paris Rive Gauche é uma operação urbana composta a partir de grandes expropriações liberais, em sua maioria pública: terrenos baldios produto de indústrias desativadas, áreas ferroviárias e portuárias, sem qualquer tipo de equipamento público ou rede de infraestrutura.

"Claramente de acordo com o modelo francês, esta iniciativa foi desencadeada por meio do investimento estatal para construir um projeto âncora, a biblioteca nacional, e promover a cobertura da linha férrea. Promovendo um conceito de cidade aberta, este projeto urbano considerou a mistura de usos, a recuperação de espaços públicos e a construção de habitações para os mais diferentes níveis de renda"(DURVAL in SOMECKH e MARQUES, 2007, p 4-5).

Frente a isto surge a visão do governo francês em executar uma intervenção na intenção de criar um pólo urbano misto, incluindo em sua maioria a implantação de empresas terciárias. A dupla visão era de remediar a perda substancial de Paris em detrimento da saída de numerosas empresas, em sua maioria para o setor oeste da cidade (La Défense) e impulsionar todo o setor Seine-Amont.

Outro elemento significativo deste projeto é a vontade de vincular os novos bairros com os existentes, desta forma trata-se de conectar o $13^{\circ}$ Distrito com o rio, e que os novos bairros tenham a mesma leitura que o restante de Paris, em outras palavras que se siga a paisagem homogênea da cidade como um todo.

O projeto para Paris Rive Gauche se inicia em 1991 com a criação da ZAC (Zone de développement concentré) com uma área de 130 hectares em $3 \mathrm{~km}$ de extensão pela margem do rio Sena. ${ }^{113}$

A partir das regras estabelecidas na ZAC PRG, plano mestre que ordenar espacialmente a área de intervenção, dividida em três áreas através dos PAZ (Plano de Desenvolvimento da Zona), ao qual após o concurso público, os arquitetos e urbanistas deveriam se orientar por meio de regras gerais para a implantação de todo o plano.

113. Apesar de esta data marcar oficialmente o inicia do projeto, a área para a implantação da Biblioteca Nacional da França se deu em 1988, num conjunto de "grandes projetos" de François Mitterrand, como parte do Plano Bicentenário. 
Figura 81.Proposta de Intervenção para a ZAC Rive Gauche, autoria de Jean Nouvel

Fonte: SEMAPA, 2010

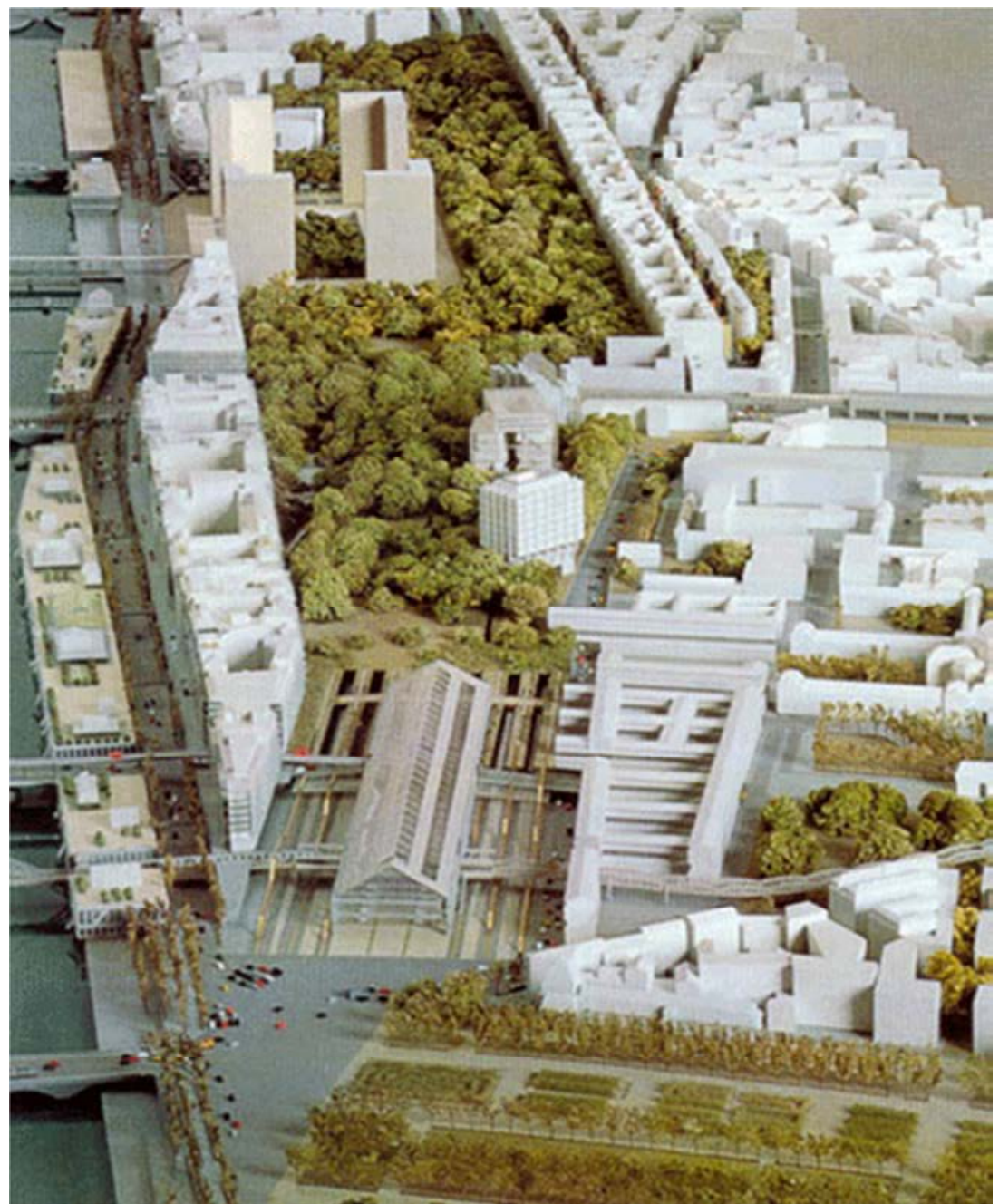

Figura 82. Implantação para ZAC Rive Gauche, de autoria de jean Nouvel Fonte: SEMAPA, 2010

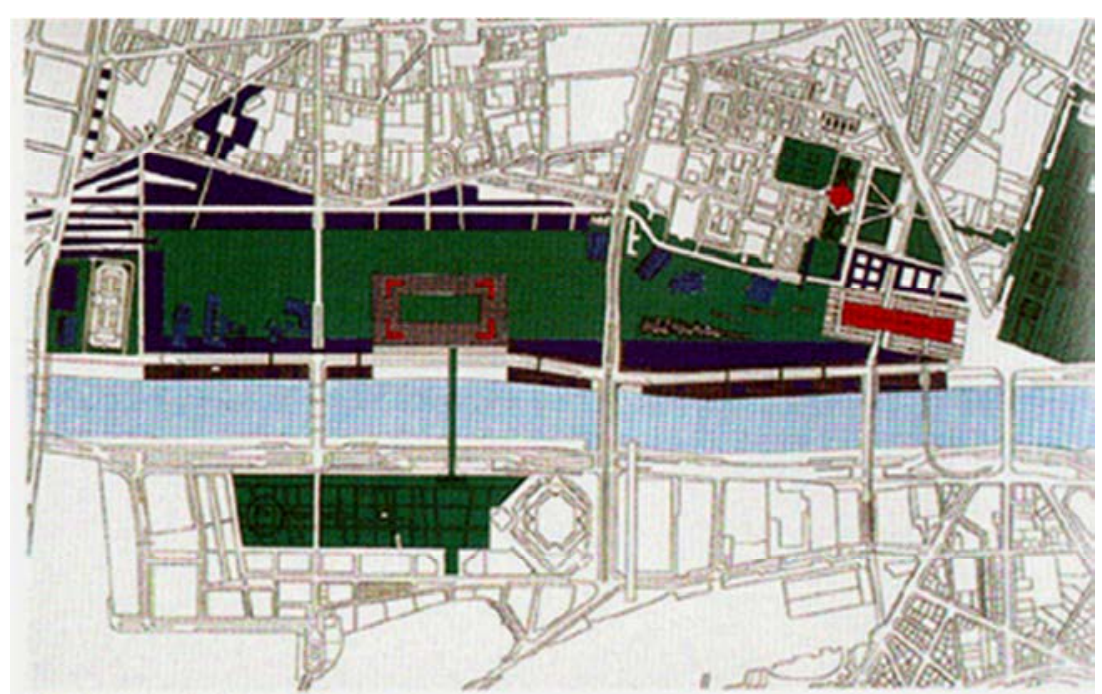


Criado na década de 80, após os grandes projetos da "Era Miterrand", o SEMAPA (Société d'économie mixte d'aménagement de Paris)é encarregado de coordenar e gerenciar o desenvolvimento dos projetos urbanos e arquitetônicos da cidade, em particular as ZACs que compõem o conjunto de ações do governo parisiense. Composto por uma sociedade de economia mista, numa parceria de três setores distintos: o poder local (Ville de Paris), a SNCF (Société Nationale des Chemins de Fer) e investidores privados.

Inicialmente o SEMAPA atribuiu, através de carta-convite, a alguns arquitetos apresentarem suas propostas de renovação para a área deteriorada, no qual totalizavam dez arquitetos: Kenzo Tange; Renzo Piano; NormanFoster; Dusapin \& Leclercq; Chaix \& Morel; Bertrand Warnier; Bornell, Gil \& Lucan; RudolphLuscher; Valode \& Pistre e Jean Nouvel. Dos projetos urbanos apresentados, talvez a proposta de Jean Nouvel seja naquele momento a mais audasiosa, enquanto os outros participantes propõem a renovação a partir dos elementos pré-existentes na área de intervenção, “... Nouvel apresenta a única proposta que coloca um olhar especulativo para a área, apresentando a idéia de alteração radical de uso e imagem"(SOUZA 2002, p 142). ${ }^{114}$ Apesar das várias propostas apresentadas, e passados vários anos de intensos debates, "o grupo estatal de projeto adotou seu próprio projeto urbano, mesclando várias das idéias propostas"(SOUZA 2002), definindo a separação da área em três setores homogêneos, que constituíram uma ZAC (zone d'amanagement concertée).

A divisão dos três territórios em "bairros autônomos", porém integrados entre si e com o entorno existente foram definidos em: Masséna, Tolbiac e Austerlitz, cada qual com sua especificidade, mas com a garantia de se manter a multiplicidade de usos nas três áreas. Para a garantia de um projeto urbano que respondesse às necessidades e ansiedades do SEMAPA, foi colocado sob a responsabilidade de um "arquiteto-chefe" o gerenciamento dos trabalhos a serem realizados: Masséna: um grande quadrilátero de 15 ha ocupados por galpões industriais (arq. Christian de Portzamparc), Tolbiac:nas imediações da área hoje dominada pela nova Biblioteca Nacional, oposta ao novo Parc Bercy(arq. Roland Schweitzer) e Austerlitz: ao redor da estação de trem de Austerlitz, junto ao centro histórico (arq. Chritian Devillers).

Dos 130 ha totais da ZAC, 26 ha correspondem às vias férreas, que cumpririam o papel de geradora da continuidade e conexão com toda a cidade. Apesar de o plano ter como estratégia principal a construção de escritórios, o uso previsto para a área é de grande diversidade. A superfície total edificada que estabelece o PAZ (Plan d'Amanagément de Zone)é de 70 ha, com um máximo de $1.640 .000,00 \mathrm{~m}^{2}$, dos quais $520.000,00 \mathrm{~m}^{2} \mathrm{se}$ destinam ao uso habitacional que correspondem a 5.000 unidades. ${ }^{115}$ Por outro lado, se destina uma superfície para escritórios de $900.000,00 \mathrm{~m}^{2}$, que junto com os $150.000,00$ $\mathrm{m}^{2}$ destinados as atividades comerciais, industriais e artesanais geram um total estimado de 50.000 empregos.

Para as áreas verdes são reservados $98.000,00 \mathrm{~m}^{2}$, porém diferentemente do que Jean Nouvel propunha para a área, não se concebe em nenhum caso um grande parque dentro do projeto, de forma concentrada, distribuindo em toda a área de intervenção através das ruas arborizadas e pequenas praças.

114. Norman Foster apresentou um desenho urbano homogêneo e tradicional, com um programa baseado nos serviços e maciço investimento privado. Renzo Piano assume a existência do eixo ferroviário como articulador do tecido urbano degradado, propondo habitação e escritórios que se compõem à tipologia local. Kenzo Tange propõe mais um eixo monumental para a cidade, com uma malha urbana retangular com edifícios de escritórios e habitação de baixa densidade.

115. Das unidades habitacionais, 2.000 são sociais, 2.000 livres e 1.000 para estudantes, aos quais 600 sociais e 400 livres, gerando um total de aproximadamente 15.000 pessoas morando na área e garantindo uma dinâmica por todo o dia não somente nos bairros novos, mas em toda a região do $13^{\circ}$ Distrito. 


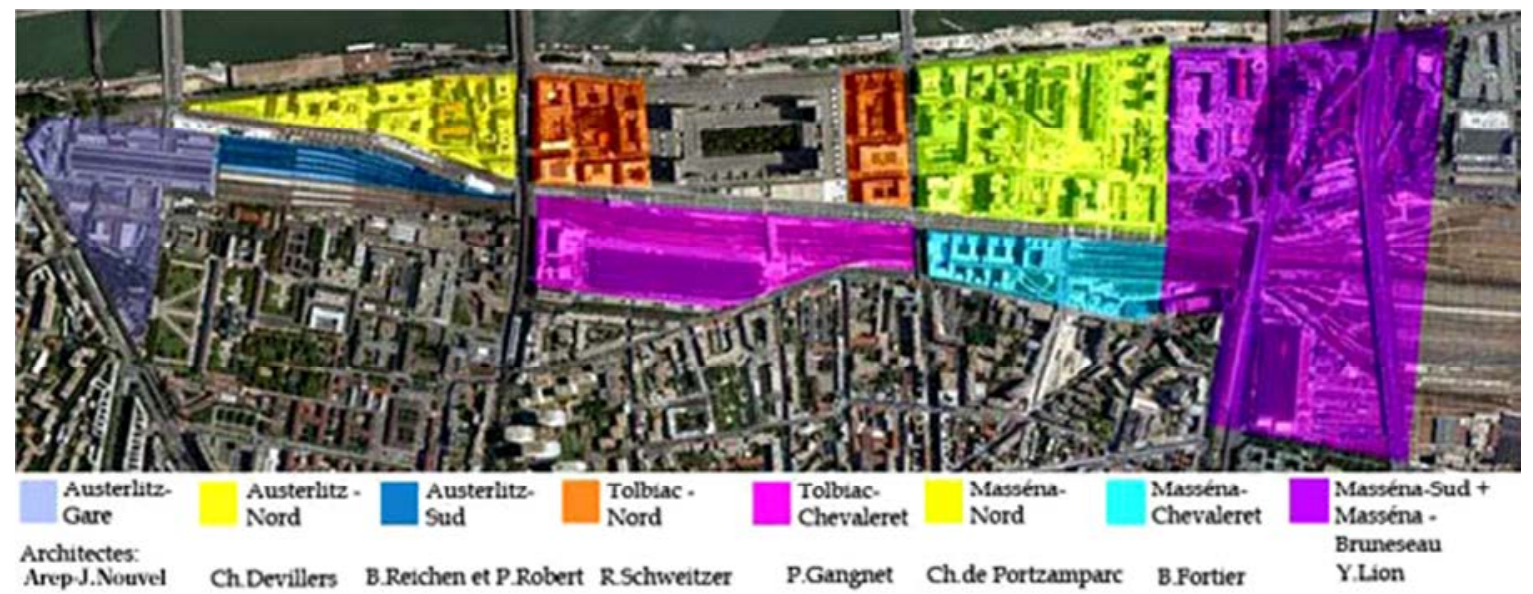

Figura 83.ZAC Rive Gauche: setorização das áreas de intervenção

Fonte: Paris Rive Gauche, 2010

Figura 84.Vista da Biblioteca Nacional da França a partir da Torre Eiffel

Foto: Elvis Vieira, 2011

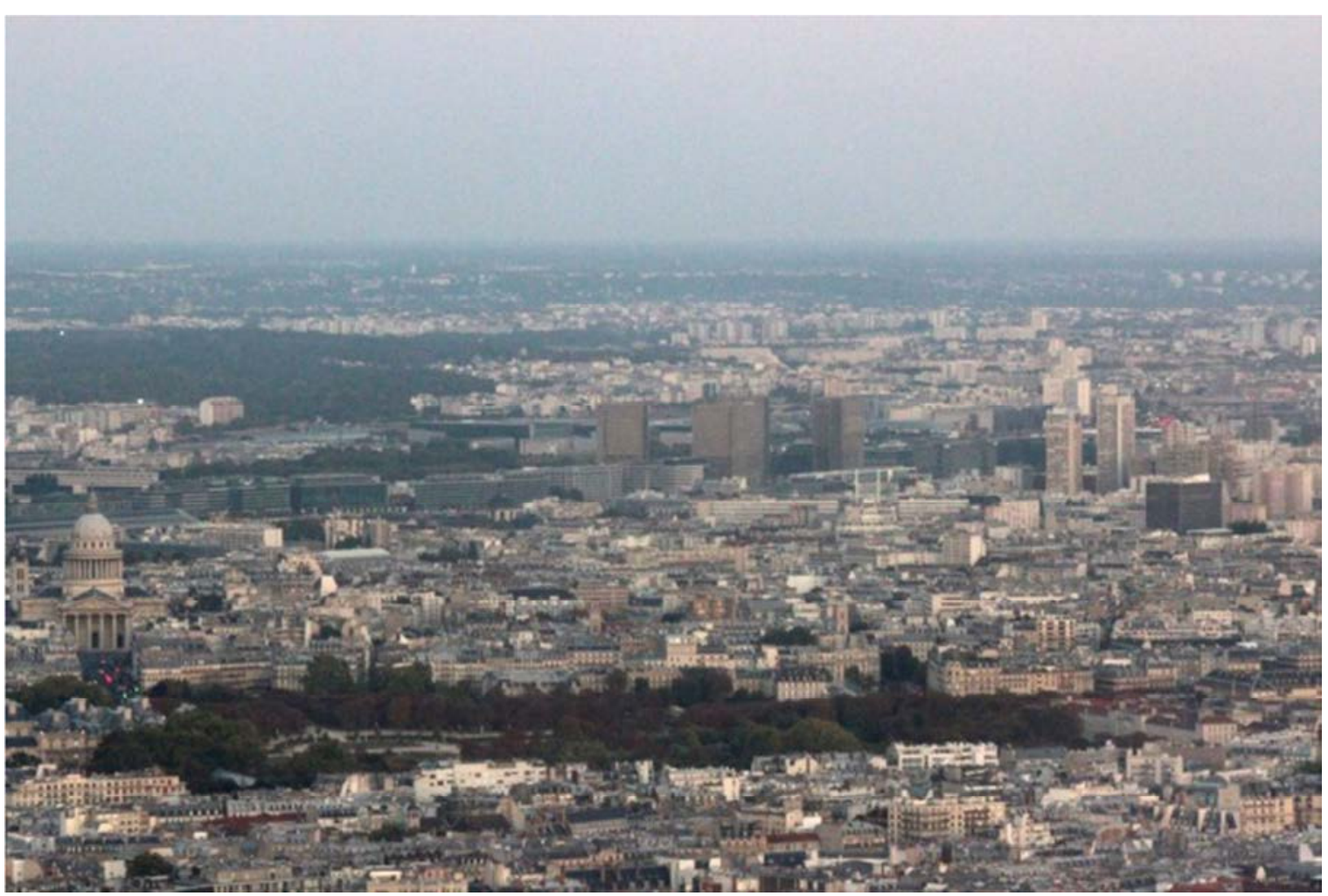

Figura 85.Biblioteca Nacional da França, Estação Ferroviária Austerlitz e Hospital Pitie-Salpetriere Foto: Elvis Vieira, 2011
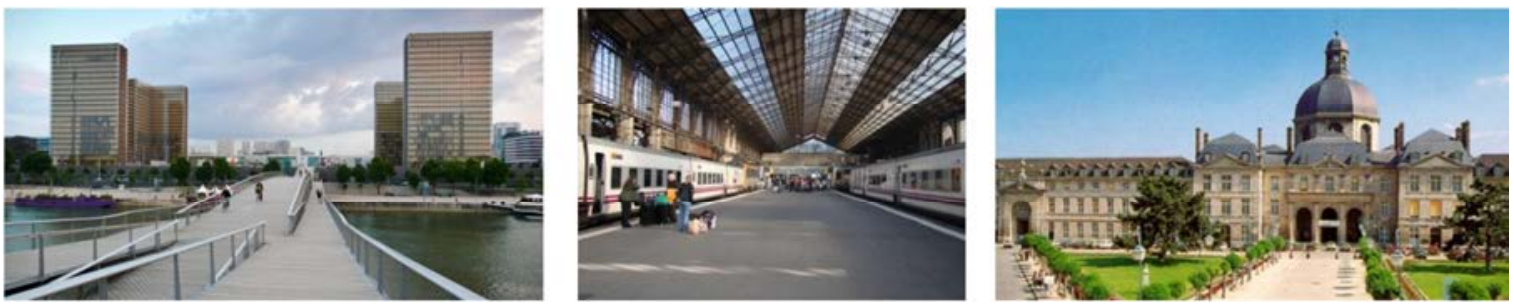
Segundo Jérôme Coumet, prefeito do $13^{\circ}$ distrito e presidente do SEMAPA em 2007 e 2008 (SEMAPA 2007), o Projeto PRG "é o maior em magnitude de Paris, desde as intervenções do Barão Haussmann. A proposta trata de um novo bairro para morar, equilibrado com escritórios, compras, educação, artes, cultura e recreação, de acordo com o ambiente urbano", ${ }^{116}$ dando a oportunidadee novas vantagens de transformação econômica e social junto às atividades de serviços e equipamentos de Paris e recriando um setor da cidade com possibilidade de competitividade internacional.

Todas estas ações em conjunto com a implantação dos "grandes projetos" como a Biblioteca Nacional de Paris, de autoria do arquiteto Dominique Perraut, a estação Austerlitz, da linha 14 do Metrô responsável pela ligação com os demais distritos e o centro da cidade e o Hospital Pitie-Salpetriere, um dos conjuntos hospitalares mais importantes da Europa, somam-se a vontade do governo francês em dar condições ao $13^{\circ}$ Distrito de contribuir para a melhoria econômica, social e urbanística de Paris.

Assim, o Projeto Urbano PRG tinha como um dos objetivos macros o retorno da área de intervenção para a trama existente e a conexão com o distrito Bercy $\left(12^{\circ}\right.$ arrondissement) do outro lado do rio Sena, que desde o início da década de 70 já era vista como uma área desarticulada pelo eixo fluvial. Além disso, o projeto sugere a seguinte pergunta: $O$ que fazer em cerca de $3 \mathrm{Km}$ de extensão entre o principal rio da França, uma malha ferroviária responsável por uma das "portas da cidade" e, como integrar a área a trama urbana original de Paris de forma "homogênea" e com um perfil horizontal?

Assim, Paris Rive Gauche está focada em gerar um pólo de desenvolvimento urbano misto no setor leste de Paris, junto aos demais distritos vizinhos (12ํㅡㄹ Arrondissement: Reuilly; 14ำ Arrondissement: Observatoire; 5ำ Arrondissement: Panthéon; além das cidades de Ivry-sur-Seine a leste do distrito), que composto de postos de trabalho terciário, busca superar a perda economica substancial com a saída de muitas empresas desta região.

Para garantir a plena conexão entre os distritos vizinhos e todos os demais de Paris, a proposta deveria ser adequada em sua infraestrutura existente com as demais da cidade e assegurar um dinamismo no interior de toda a área de intervenção. Para atingir este objetivo, foi previsto as seguintes intervenções:

- A RATP (administração autônoma de transporte em Paris) é responsável pela realização da linha 14 do Metrô e sua extensão para o $13^{\circ}$ distrito, além de melhorar o transporte público (ônibus) e a construção de estações intermodais em Austerlitz e BNF (Biblioteca Nacional da França);

- Previsão de $662.000 \mathrm{~m}^{2}$ de construção de equipamentos e serviços públicos, incluindo a BNF $\left(250.000 \mathrm{~m}^{2}\right)$. Somente para equipamentos estão previstos $55.000 \mathrm{~m}^{2}$ de construção;

- O PAP (Porto Autônomo de Paris) gerencia os portos da cidade, a ele estão previstos a conversão das portas pluviais ( $3 \mathrm{~km}$ em PRG) em um lugar de chegada, caminhada e estar adequados para a instalação de comércio, restaurantes, bares, como por exemplo as piscinas públicas junto ao rio Sena (piscina flutuante Joséphine Baker - 2006);

116. Tradução do autor, 2011

Est de plus grande ampleur à Paris depuis les interventions du Baron Haussmann. La proposition est un nouveau quartier à vivre, équilibré avec des bureaux, commerces, éducation, arts, culture et loisirs, selon le milieu urbain. 
- Para garantir a conexão entre a BNF no distrito de Tolbiac e o distrito de Bercy (12ำ arrondissement) e as Universidades de Bercy, na margem direita do Sena, está prevista a construção da passarela Tolbiac-Bercy (passarela Simone de Beauvoir - 2006 - arq. austríaco radicado na França Dieter Feichtinger);

- Construção da Avenida França ${ }^{117}$ sobre a linha ferroviária que deverá ligar a estação Austerlitz com o boulevard Massena, no limite sudeste do projeto, tornando-se a espinha dorsal da operação, em torno dos três bairros e as ruas transversais ao Sena;

- A costura entre os novos bairros e os antigos através da Rua Chevaleret, onde as novas ruas transversais, os espaços livres e os edifícios deverão compor uma única paisagem. Para tanto, as ruas deverão ser redesenhadas com uma calha de 12 a 20 metros de largura.

Figura 86. Projeto Paris Rive Gauche e entorno

Fonte: SEMAPA, 2010
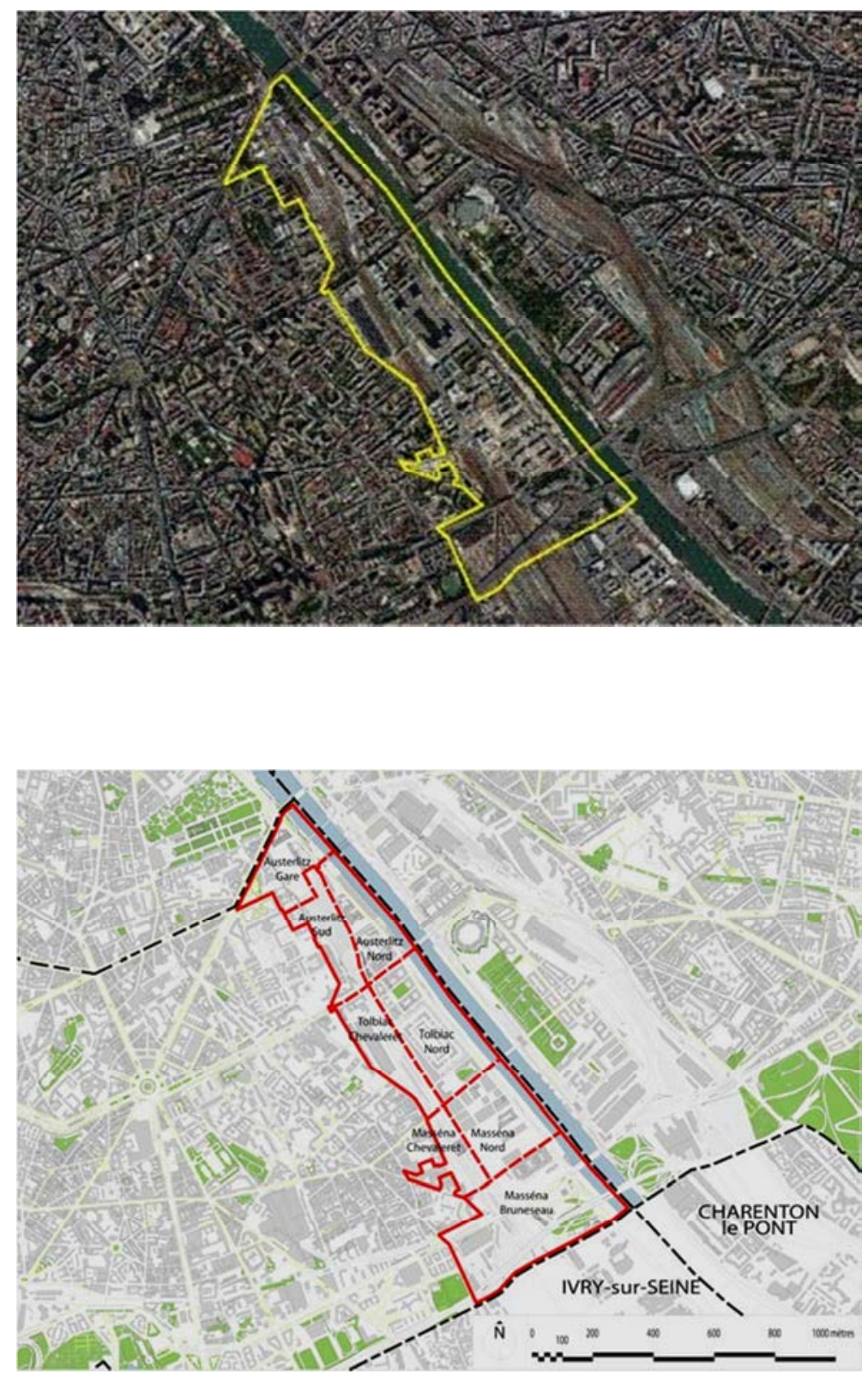

117. Esta avenida foi projetada pelo arquiteto Paul Andreu, tendo ganhado concurso organizado pela SEMAPA. 
As ações e projetos acima expostos foram necessários para garantir a reabilitação urbana da área de intervenção, no qual os três setores do PRG deveriam estar incorporados num espaço "único e permeável", como resposta ao desequilíbrio econômico que gerou a "degradação urbana". Por outro lado, a proposta do Projeto Urbano PRG possui a preocupação de garantir a uniformidade tipológica dos demais distritos de Paris. Tal afirmação pode ser comprovada em entrevista do arquiteto Christian de Portzamparc dada à revista Treize Urbain: "Para mim, o sucesso foi demonstrar que se podem ter arquiteturas 'comuns', uma cidade agradável', e complementa reforçando a importância não somente da tipologia, mas também de seus usos em todo o bairro de Rive Gauche, "... o importante para mim é a diversidade das arquiteturase em segundo lugar, à habitação, esta variedade de pontos de vista e luz funciona bem em casas, em áreas de blocos e ruas"(PORTZAMPARC 2010, p08). ${ }^{118}$

Vinte anos após a aprovação do primeiro plano urbanístico para Rive Gauche, ${ }^{119}$ inicialmente pensada como um projeto urbano capaz de reabilitar a área degradada, em função do abandono de diversas indústrias, com edifícios de escritórios, estabelecendo ali um setor de negócios, como previsto anteriormente no setor oeste de Paris, em La Defénse; observa-se que as estratégias econômicas, financeiras e urbanísticas obtiveram um resultado muito positivo.

A divisão da ZAC (Zone d'Amanagement Concertée)em setores distintos e, em certo ponto "temático", me parece coerente por se tratar de uma área de intervenção urbana de grande vulto territorial. Os 130 hectares propostos pelo Atelier Parisien d'Urbanisme (APU) como objeto deste Grande Projeto Urbano possuía uma diversidade morfológica relacionadas diretamente aos seus usos presentes naquele momento, como por exemplo, as Gares d'Austerlitz e de Lyon, Hospital la Pitié-Salpêtrière, o Ministério da Economia, Indústria eEmprego, ou até mesmo o rio Sena como elemento natural e referência urbana da cidade e o Parque Bercy junto à margem direita do rio, no qual a experiência bem sucedida junto a este distrito (12ํㅜ arrondissement) foi determinante para a ascensão do ambicioso partido do Projeto PRG (Paris Rive Gauche):

"Promover a recuperação da área a partir da cobertura de 10 hectares de linha férrea desde a Gare d'Austerlitz e da construção de uma nova avenida com três quilômetros de extensão, a Avenue de France. A intenção maior do projeto era integrar esse trecho isolado e subaproveitado ao tecido da cidade" (MALERONKA 2010, p 59).

Apesar das modificações da proposta original do início da década de 90, a natureza do projeto não foi alterada. Naquele momento (1991) foram estabelecidos seis pontos estratégicos que deveriam orientar o desenvolvimento dos projetos: 1) organização do traçado viário a partir de um eixo estrutural paralelo ao rio Sena; 2) limite de gabarito para os edifícios; 3) proteção e reabilitação dos edifícios históricos; 4) desenvolvimento de uma rede de transporte público eficiente para diminuir o uso do automóvel; 5) setorização da intervenção e, 6) grandes equipamentos públicos e de infraestrutura (DURVAL-ZAC 2006 in MALERONKA 2010).

118 . Tradução do autor, 2011

Pour moi, la réussite, c'était de démontrer que l'on peut avoir, avec des architectures « ordinaires», une ville agréable.

L'important, pour moi, c'est cette diversité des architectures et d'autre part, pour l'habitat, que cette variété des vues et des lumières fonctionne bien dans les logements, dans les espaces d'îlots et dans les rues.

119. O primeiro Plan d'Amanagément de Zone (PAZ) foi elaborado e aprovado pelo Conselho de Paris em 1991. 

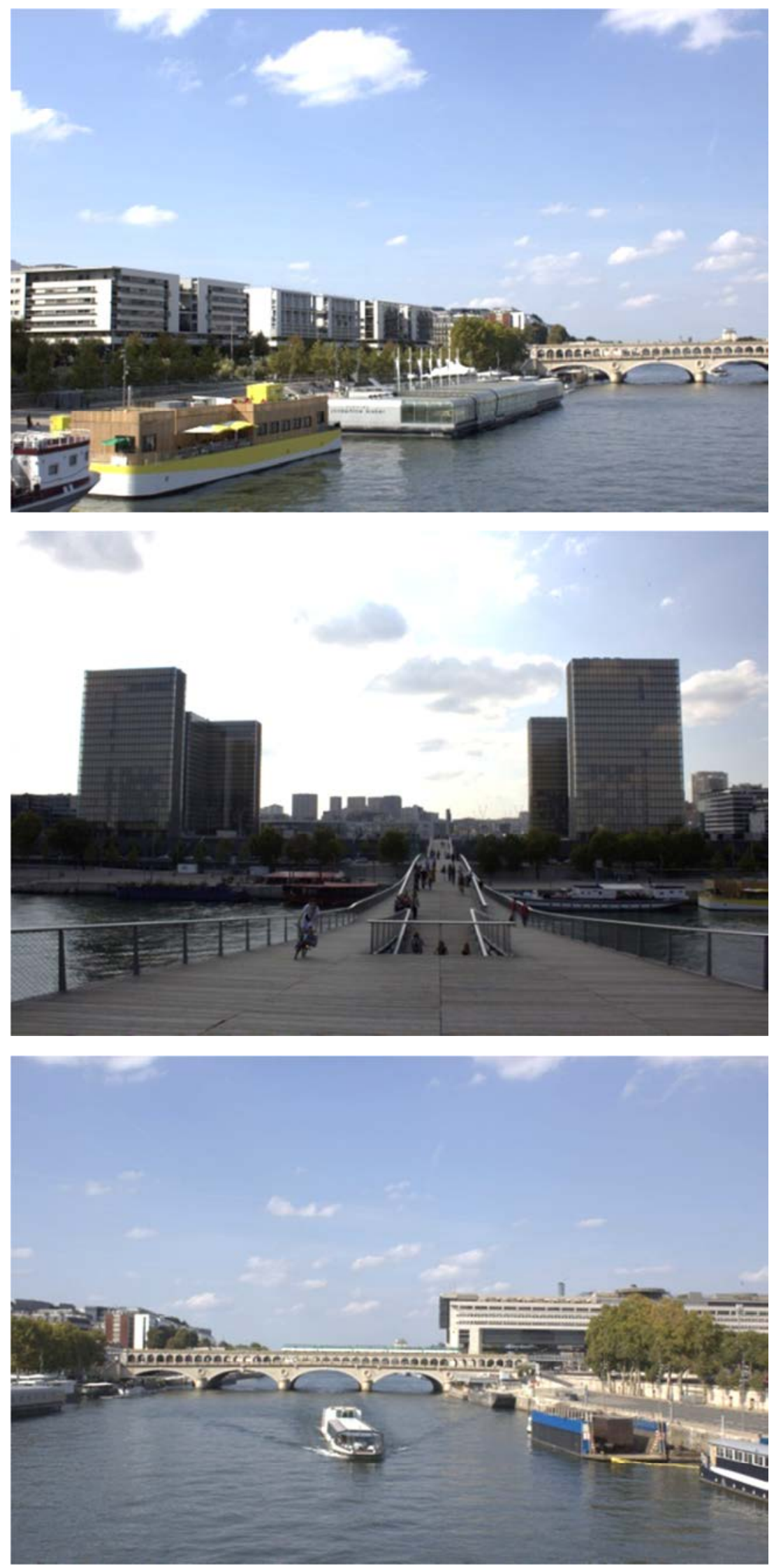

Figura 87. Elementos urbanos e arquitetônicos referenciais no PRG: rio sena e suas atividades fluviais, Biblioteca Nacional da França, Ministério da Economia, Indústria e Emprego

Fotos: Elvis Vieira, 2011 
Ao analisarmos hoje a situação em que se encontram as intervenções em PRG, observamos que as estratégias estão ainda sendo levadas a cabo nos "trois quartiers" (três bairros): Austerlitz, Tolbiac e Masséna, no qual cada um deles possui uma "peça urbana", ou como defendida por Solà-Morales (2008), cada área é composto por "cosas urbanas": respectivamente "a estação de trem (Gare d'Austerlitz), a Biblioteca Nacional e a Universidade Paris7-Denis-Diretot"(MALERONKA 2010, p 61).

"Para garantir ao conjunto da operação uma diversidade em acordo com a realidade urbana de Paris" (PARIS RIVE GAUCHE (PRG) 2008), e como já apontado acima, cada quartier (bairro) possui um arquiteto-coordenador responsável pelo Plano de Massas detalhado, que deverá nortear o partido volumétrico e arquitetônico de cada quadra, no qual descrevemos abaixo a atual situação dos setores definidos a partir do Projeto Rive Gauche (PRG).

1. Austerlitz Norte: 0 desafio encontrado pelo arquiteto Christian Devillers ${ }^{120}$ estava na concepção de um bairro de uso de serviços que deveria se integrar ao entorno composto por habitações. Propondo uma massa volumétrica de 12 pavimentos de altura, pode-se desta forma organizar as escalas do conjunto edilício e possibilitar novas passagens sob os edifícios.

Das edificações propostas inicialmente uma grande parcela está concluída e as obras neste setor estão aceleradas, demonstrando o grande interesse dos investidores neste setor do PRG. Com um volume construtivo de mais de $130.000 \mathrm{~m}^{2}$ (PARIS RIVE GAUCHE (PRG) 2008), a imagem deste setor hoje é marcado pelos novos edifícios de serviços e uma nova referência junto ao rio Sena; de autoria do escritório Georges Morin-Goustiaux, Puis D. Jakob \& B. Macfarlane, uma Instalação de Cultura, Comércio e Lazer, construída em 2008, com 280 metros de comprimento que se integra à paisagem do Sena com seus terraços e formas inusitadas;

2. Tolbiac Norte: este setor é marcado pelo que denomino como "edifício catalisador", onde o vazio proposto pelo arquiteto Dominique Perrault (1995) provocou uma nova releitura deste trecho desenhado e coordenado pelo arquiteto Roland Schweitzer, ${ }^{121}$ onde propõe um conjunto de edifícios de usos mistos que se contrapõem as quatro "torres livros" da Biblioteca Nacional da França.

Devido à rápida implantação deste importante equipamento de cultura e educação (1989-1995), sua conclusão provocou que este setor fosse o primeiro a ser concluído. No geral, este quartier (bairro) atraiu um número considerável de empresas multinacionais, que transferiram suas sedes administrativas para o "novo bairro de Paris", como Accor - 1997 (hotéis), Sanofi-Aventis - 1998 (farmacêutica), Accenture - 2001 (consultoria), Natixis - 2001(banco corporativo), responsáveis pelo rápido desenvolvimento e conclusão deste setor. Outro ponto relevante ao desenvolvimento deste é a concepção e conclusão da Avenue de France (P. ANDREU - J.-M. WILMOTTE, 1995) como importante eixo estruturador entre os quartiers, "conectando a Gare d'Austesrlitz ao Boulevard Masséna. $E$ na outra margem da linha férrea, a Rue de Chevaleret"(MALERONKA 2010, p 61), que no limite do perímetro da ZAC, estabelece a transição entre 0 novo e 0 velho tecido urbano do $13^{\circ}$ arrondissement;

120. Christian Devillers nasceu em 1946 na cidade de Paris - França, após estudar arquitetura na Escola Nacional de Belas Artes, foi trabalhar nos Estados Unidos no estúdio de Louis Kahn, onde se associou com Paul Chemetov. Fundou sua agência em 1990, onde realiza projetos urbanos e construções. Recebeu o Grand Prix de Urbanismo em 1998.

121. Roland Schweitzer, nascido em 1925, é ex-aluno de Auguste Perret e Jean Provado. Arquiteto e urbanista, professor da Faculdade de Arquitetura Tolbiac Paris (1969-1991). Consultor da UNESCO-UIA e arquiteto-coordenador do BIA no $12^{\circ}$ distrito. 
3. Mássena Norte: coordenado pelo arquiteto Christian de Portzampac, ${ }^{122}$ este setor é o mais recente junto à margem esquerda do rio Sena, permitindo ao autor do Plano de Massas colocar em prática sua teoria de "ilha aberta", mantendo os edifícios abertos e separados por parques verdes privados visível da rua. Segundo Portzamparc, "uma vez colocado para fora das ruas, as orientações definem um conjunto de regras de diferentes alturas e direitos de passagem variada do lugar perto de cada local com influência sobre o próximo, que é completamente contrário ao espírito da regulamentação para o planejamento tradicional da cidade" (SEMAPA 2008, p 29). ${ }^{123}$

O uso deste quartier é marcado por sua diversidade entre comércio, serviços e habitação (privada e social), além da implantação de diversas universidades que se instalaram neste setor do PRG: Université Joseph Fourier - UFR de biologie (2008), UFR de physique (2006), UFR sciences de la vie (2007), criando uma incrível dinâmica sobre este trecho do distrito entre os moradores, trabalhadores e estudantes.

4. Masséna Bruneseau: apesar de ser um dos menores setores deste Grande Projeto Urbano, o desafio colocado a Yves Lion ${ }^{124}$ é de suma importância para o desenho dos limites da cidade de Paris, como colocado pelo próprio arquiteto: "neste setor, é impossível traçar caminhos simples ou ortogonal, parecem lugares inóspitos e os obstáculos são as infraestruturas intransitáveis. A escala é a metrópole, as questões da Grande Paris" (SEMAPA 2008, p 39). ${ }^{125}$ É com esta estratégia que Lion se apropria do território, divisa com a cidade de Ivry-surSiene, para reorganizar as áreas subutilizadas e o novo eixo da Avenue de France.

Entre os edifícios propostos, a École d'architecture Paris Val de Seine, assume a referência urbana deste setor; de autoria do arquiteto Frédéric Borel, a escola é proposta em duas torres - uma existente e outra nova que se contrapõe à primeira, com $15.000 \mathrm{~m}^{2}$ de construção esta foi inaugurada em 2007, onde já estavam concluídos a maioria dos demais edifícios deste bairro;

5. Masséna Chevaleret: limitada entre o final da Avenue de France e a Ruedu Chevaleret, limite do Projeto Urbano, e com uma diferença de nível de aproximadamente 8 metros de altura, confiado ao arquiteto Bruno Fortier, ${ }^{126} \mathrm{o}$ autor propõe em desenho que articula os vários níveis do quartier através de escadas, novos caminhos ou simplesmente cruzamentos pedonais, "recortes urbanos" como ele os chama, pontuando as fachadas densas e altas dos novos edifícios;

6. Austerlitz Gare | Tolbiac Chevaleret | Austerlitz Sul: talvez um dos setores menos desenvolvidos até o momento, este trecho está subdividido em três áreas de intervenção, cada qual sob o comando de um escritório: Jean Nouvel e Jean-

122. Depois de estudar arquitetura na Escola Nacional de Belas Artes em 1968, Christian de Portzamparc, nascido em 1944 na cidade de Casablanca - Marrocos, tem sua primeira obra concluída em 1972 na cidade de Marne-la-Vallée Torre da água. Ficou famoso pela obra da Cidade da Música em Paris (1984-1995) e por suas analises sobre as formas urbanas (bloco-aberto). Vencedor do prêmio Pritzker Prize (1994) e Grand Prix de Urbanismo (2004). É professor na cadeira de criação artística no College de France.

123 . Tradução do autor, 2011

Une fois posé sur les rues, les lignes directrices définissent unensemble de règles pour différentes hauteurs et des droits variéedu lieu ainsi à proximité de chaque site ayant une influence sur les autres qui est complètement contraire à l'esprit de la réglementation pour l'urbanisme traditionnel.

124. Yves Lion, nascido em 1945 em Casablanca - Marrocos, formado em arquitetura pela Escola Nacional de Belas Artes. Fundou sua agência em 1974 tendo seus primeiros projetos em desenvolvimento urbano. Professor da Faculdade de Arquitetura de Marme-la-la-Vallée, onde é diretor desde 1998. Em 2007, recebeu o Grand Prix de Urbanismo.

125 . Tradução do autor, 2011

Ce secteur, il est impossible de tirer des chemins simples ou orthogonale semblent des obstacles infranchissables sontinhospitalières et les infrastructures. L'échelle est la métropole, les enjeux du Grand Paris.

126 . Tendo sido professor, designer, autor de projetos e pesquisador, Bruno Fornier, que nasceu em 1946, inicia sua carreira com projetos ligados ao planejamento urbano e grandes projetos. Recebeu o Grand Prix de Urbanismo em 2002, e atualmente ensina projeto na Escola de Arquitetura de Paris Beleville. 
Marie Duthilleul (AREP), Pierre Gangnet, Bernard Reichen consecutivamente. ${ }^{127}$ Os atrasos a conclusão dos projetos e execução das obras se dão às peculiaridades deste setor: próximo a Estação Austerlitz os limites do hospital da Salpêtrière, a priori intransitáveis, tem sido um "empecilho" ao desenvolvimento dos projetos urbanos no envoltório da estação, ou, por exemplo, as antigas instalações ferroviárias - Halle Freyssinet, onde atualmente é utilizada como espaço para eventos, mas que ainda não se tem definido seu destino final para o PRG. Assim como o projeto do arquiteto Rudy Ricciotti, intitulado Îlot T8 (ilhota T8), conjunto edilício sobre a linha férrea e junto a Avenue de France e a BNF, mas que até o momento se encontra em projeto.

A partir desta breve exposição, podemos depreender que a coordenação e gerenciamento tanto dos projetos urbanos quanto arquitetônicos através da SEMAPA (Société d'Économie Mixte d'Aménagement de Paris), criada em 1985, possui suas vantagens em garantir uma "flexibilidade" na gestão administrativa, dos planos e projetos e econômica, dando respostas mais rápidas e exatas às necessidades do perímetro do PRG.

Outro dado relevante está no resultado tanto urbano quanto socioeconômico em que, após 20 anos da criação da ZAC Rive Gauche, o distrito (13ํarrondissement) tem respondido aos problemas de desemprego. "O $13^{\circ}$ Distrito tem sido desde sua origem no século XIX, um dos mais pobres, consagrado majoritariamente com uma população provincial e imigrante (orientais principalmente), com uma taxa de desemprego de 11,3\%"(VIEIRA 2010), estrategicamente a composição de usos mistos sobre o Grande Projeto Urbano possibilitou reduzir a taxa de desemprego, assim como garantir a permanência dos moradores e usuários deste distrito.

Assim, a partir deste ponto de vista, podemos afirmar que o Projeto Paris Rive Gauche possibilitou a requalificação de um bairro que passava por grandes problemas de ordem urbana, social e econômica, onde "terrenos baldios produto de indústrias desativadas, áreas ferroviárias e portuárias, sem qualquer tipo de equipamento público ou rede de infraestrutura"(VIEIRA 2010), se transforma num "Pólo Misto de Serviços e Habitação", atraindo investimentos privados em diversas áreas e possibilitando a "vivacidade" da cidade neste trecho de Paris. Atrevo-me a dizer que o Projeto Paris Rive Gauche, apesar de ainda não estar concluído, visto que o último cronograma segundo a Prefeitura de Paris, está previsto seu término em 2020 (Ville de Paris 2004), os resultados apontam para um dos poucos Grandes Projetos Urbanos que não provocaram o "temido" processo de gentrificação, visto que, até o ponto em que pesquisamos tanto os projetos urbanos quanto arquitetônicos não se detém apenas na sua concepção construtiva, no qual todos os projetos devem atender as "regras" de todas as hierarquias no PRG: 1) Ville de Paris (governo local); 2) APUR (Atelier Parisien d'Urbanisme); 3) SEMAPA (Société d'Économie Mixte d'Aménagement de Paris); 4) CPC (Comité Permanent de Concertation).

127 . Jean Nouvel é nascido em Fumel, Lot-et-Garonne, França em 1945, estudando arquitetura na Escola Nacional de Belas Artes. Entre os prêmios recebidos estão Prêmio Aga Khan para a Arquitetura (Instituto do Mundo Árabe), o Prêmio Wolf em Artes em 2005 e o Pritzker prêmio em 2008.

Jean-Marie Duthilleul, nascido em 1952, é engenheiro e arquiteto. Ele é o diretor de planejamento (DAAB) para a SNCF(responsável por todos os projetos urbanos e arquitetônicos da companhia ferroviária) e Presidente da AREP.

Pierre Gangnet, arquiteto formado em 1973 pela Escola Nacional de Belas Artes de Paris. Professor da Escola de Arquitetura de Marne la Vallée e Escola Nacional de Belas Artes. Ganhador do Grand Prix de Urbanismo em 2008.

Bernard Reichen é arquiteto e planejador urbano, possuem agência com Philippe Robert no qual possuem trabalhos na renovação ou reabilitação de edifícios históricos, particularmente edifícios industriais. Em 2005 eles obtêm o Grand Prix Urbanismo. 
Figura 88. Imagem aérea do PRG antes das intervenções, 1991

Fonte: SEMAPA, 2010

Figura 89.Início das obras da BNF Fonte: SEMAPA, 2010

Figura 90.Imagem aérea durante a execução das obras

Fonte: SEMAPA, 2010

Figura 91.Imagem da situação atual do PRG, 2010

Fonte: SEMAPA, 2010
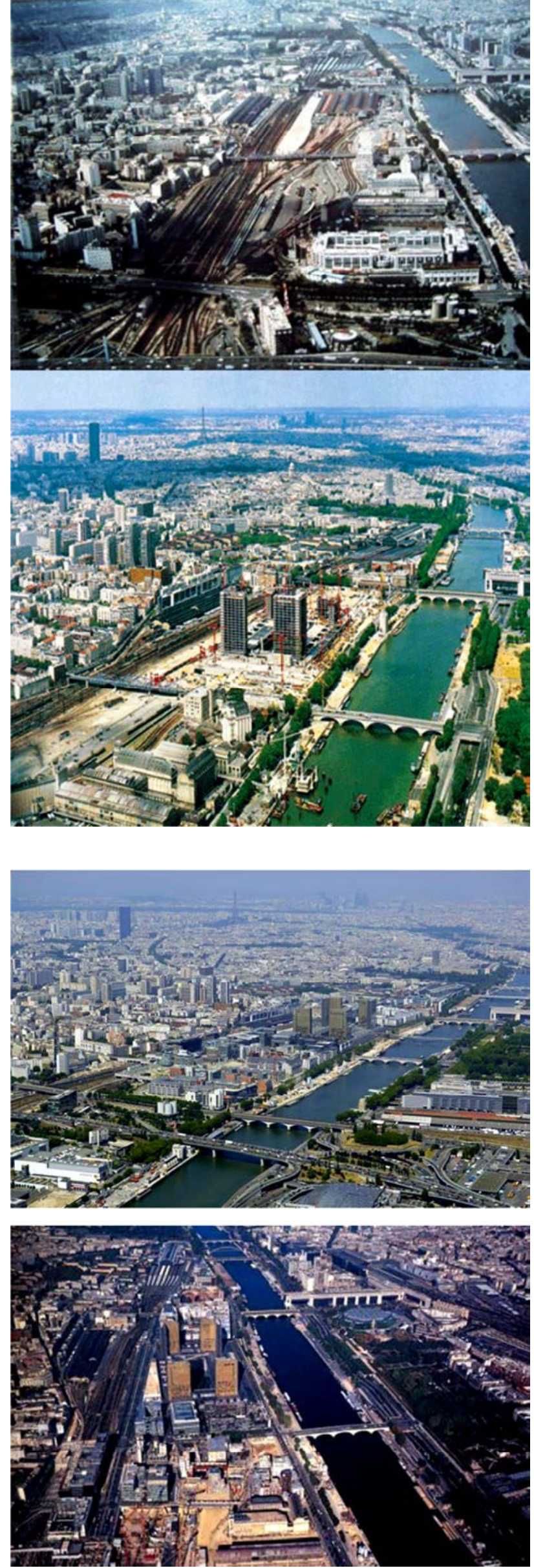
Como desenho urbano, o Projeto Paris Rive Gauche possibilitou a criação de um "grande laboratório urbano" sobre o tecido haussmanniano. Fica claro que a implantação da Biblioteca Nacional da França de autoria do arquiteto Dominique Perrault foi um importante catalisador (como já dito anteriormente) para a atração de investidores na área, além do mais, o edifício como referência urbana, possibilitou a confirmação de mais um elemento arquitetônico junto ao rio Sena, somando-se aos já existentes em Paris (Torre Eifell, Catedral de Notre-Dame, Museu do Louvre, entre outros). Independente das críticas sofridas, a BNF redefiniu o Cenário Urbano no extremo leste de Paris e aponta como referência de Paris Rive Gauche.

Como desenho do tecido urbano, as propostas colocadas em prática pelos arquitetoscoordenadores dos setores, e em particular, no setor sob responsabilidade de Portzamparc (Mássena Norte), apontou caminhos para a "revisão" das cidades contemporâneas a partir do tecido consolidado. Nisto, os exercícios colocados em prática pelo arquiteto demonstrou uma cidade mais justa e desenhada para o pedestre, no qual, defendo ser um dos elementos estruturadores do sucesso dos projetos urbanos em PRG. 

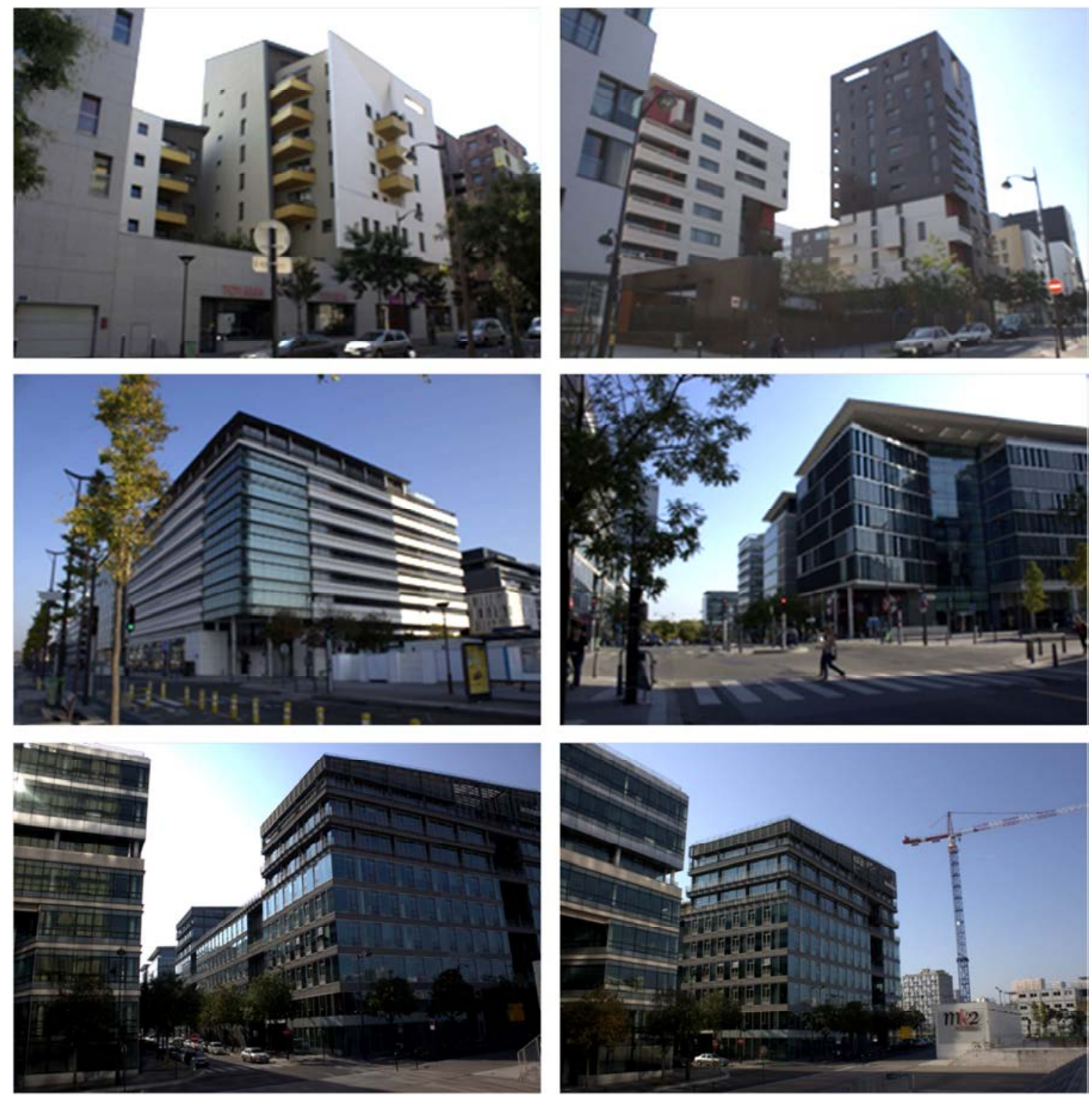

Figura 92. Imagens do bairro de Rive Gauche após as intervenções urbanas, 2011 Fotos: Elvis Vieira, 2011 


\subsection{Considerações Finais}

Paris é uma cidade constituída de um conjunto de sobreposição de tecidos urbanos na qual a relação entre os espaços construídos e os vazios urbanos pode ser considerada o elemento norteador da configuração urbana da capital francesa.

Em grande medida, as propostas promovidas por Haussmann foram as grandes responsáveis pela consolidação do que hoje Paris é considerada uma das cidades mais emblemáticas do mundo e aquela que mais recebe turistas no mundo (UNWTO, 2011). Ainda assim, as razões de modernização da infraestrutura da cidade, sua "higienização urbana", assim como as não tão claras razões estratégicas militares, assinaladas nos traçados e grandes eixos de conexão entre os principais elementos urbanos da cidade, possibilitaram a "criação" de uma nova cidade mais moderna e controlada por sua estrita regulação das construções privadas.

A "cidade Haussmaniana" significou a oportunidade de uma cidade que se impunha como uma das metrópoles mais imponentes do mundo no qual a sobreposição dos bulevares, avenidas ruas, cais e passagens sobre o tecido urbano consolidado da Paris Velha não deixam de apagar os vestígios de uma cidade heterogênea.

"É necessário reconhecermos que o Plano Haussmann influenciou o urbanismo tanto por seu reconhecido valor estético como por seu valor estratégico, porém com um grande número de variáveis envolvidas em suas propostas" (VIEIRA 2010).

No mais, o poder com que os vazios urbanos possuem sobre a morfologia urbana da cidade, reflete diretamente sobre a qualidade de vida de seus habitantes e são utilizadas, juntamente com os elementos de referência urbana (monumentos, paisagem urbana), como "objetos de atração" ao desenvolvimento urbano e econômico da cidade.

"O sistema viário de Paris apresenta uma estrita padronização de tratamento, o que contribui para a construção de uma forte imagem associada à cidade, assim como uma maior coesão do tecido urbano, reforçado, como já ressaltado, pela uniformidade e abrangência da arquitetura neoclássica haussmanniana" (BRAGA 2006, p 54).

As diversas intervenções que irão suceder o Plano Haussmann terão por base a configuração dos vazios urbanos, sua inter-relação e proporção escalar entre os espaços construídos e não construídos, da mesma forma que os Grandes Projetos Urbanos, independente de sua escala de atuação, representavam a confirmação da importância dos vazios sobre o tecido urbano como elemento potencializador da dinâmica urbana da cidade, tal fato é confirmado com o "Projeto Urbano para o Bairro de Beaubourg, no $3^{\circ}$ distrito de Paris, que se tem como elemento chave a construção do Centro Cultural George Pompidou"(VIEIRA 2010), no qual a volumetria proposta pelos arquitetos assumia o vazio como "espaço organizador" das funções do edifício, enquanto que o bairro se fortalece com a multiplicação de praças e eixos pedonais que se interligam. 
Prova disto está nas afirmações de Milton Braga (2006):

"Talvez uma das principais lições que uma observação atenta de Paris possa encontrar seja o exemplo constituído pelos atributos do seu tecido urbano, pois é evidentemente desejável que os arranjos morfológico e tipológico de qualquer cidade confiram aos programas e estruturas de maior interesse social o devido valor paisagístico e, assim, emblemático"(p 55, grifo nosso).

Estes mesmos "arranjos morfológicos e tipológicos" apontados por Braga podem ser confirmados como atributos urbanos capazes de funcionarem como elementos regeneradores do tecido urbano e de sua dinâmica sobre o território.

Tal fenômeno é comprovado com a implantação das ZACs (Zone d'aménagement concerté) que permitiram intervir e gerenciar o solo urbano de forma controlada, principalmente sobre a forma urbana desejada e os resultados econômicos e sociais sobre as áreas afetadas. Apesar das diversas experiências colocadas em pratica desde a década de 1970 em Paris, tanto em escala como estratégia de ação sobre o território, nos chama a atenção o fato das propostas colocadas em prática estarem ancoradas sobre duas vertentes, segundo nossa análise: a transformação da forma urbana em consonância às dinâmicas da cidade contemporânea, e a permanência de seus habitantes e usuários sobre as áreas impactadas.

Enquanto a maioria dos Grandes Projetos Urbanos está fadada a gerarem o "fenômeno da gentrificação", resultando na expulsão de seus moradores tradicionais e/ou usuários e trabalhadores do comércio e serviços locais, em função da circulação financeira e a valorização da terra e seu custo de vida elevado e crescente, observamos que as propostas das ZAC em Paris resultaram em desenhos urbanos igualitários socialmente, ao mesmo tempo em que parte do território se renova e atualiza urbanisticamente.

Entre as diversas "Operações Urbanas", Paris Rive Gauche pode ser caracterizado

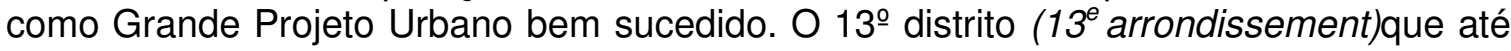
então apresentava altos índices de criminalidade, déficit em equipamentos urbanos e transporte, assim como um grande número de habitação e massa edilícia de baixa qualidade arquitetônica e urbanística, após 20 anos da aprovação do Plano de Desenvolvimento da Área de Intervenção, a conclusão dos equipamentos públicos propostos como âncoras e referência urbana, dos novos edifícios de serviços e habitação, garantindo moradia digna aos que ali já se encontravam e possibilidade de emprego, além da implantação de mais de $80 \%$ das infraestruturas previstas (trem, metrô, novas avenidas e passagens pedonais sobre o rio Sena) percebemos a consolidação de uma estratégia urbana aportada sob a ótica da regeneração do tecido urbano e social.

"Ações ou gestão de operações destinam-se a implementação de um projeto urbano, uma política de habitação local, organização de atividades de extensão, manutenção ou casa econômicas, promover o desenvolvimento de lazer e turismo, realizar equipamentos coletivos, contra a insalubridade, permitindo a renovação urbana, para preservar ou ampliar o patrimônio construído ou não, e os espaços públicos" (SEMAPA 2007). ${ }^{128}$

128 . Tradução do autor, 2011

Les actions ou opérations d'aménagement ont pour objet de mettre en œuvre un projet urbain, une politique locale de l'habitat, d'organiser le maintien, l'extension ou l'accueil des activités économiques, de favoriser le développement des loisirs et du tourisme, de réaliser des équipements collectifs, de lutter contre l'insalubrité, de permettre le renouvellement urbain, de sauvegarder ou de mettre en valeur le patrimoine bâti ou non bâti, et les espaces publics. 
Ainda que a Biblioteca Nacional da França projetada pelo arquiteto Dominique Perrault sofresse diversas críticas quanto ao resultado formal e solução técnica proposta, ela cumpriu sua função de elemento urbano captador de novos investimentos da iniciativa privada em seu entorno, o setor denominado Tolbiac-Nord foi eleito o primeiro a sofrer as intervenções e consolidar este território numa região terciária com a implantação de multinacionais e a ampliação de oferta de empregos no bairro.

Por outro lado, podemos afirmar que a experiência em Paris Rive Gauche demonstrou a importância de um Grande Projeto Urbano utilizado como ferramenta de transformação da forma urbana e controle do uso do solo. Os arquitetos responsáveis por cada setor encontraram condições favoráveis às novas experiências aplicadas à cidade contemporânea, e como defendidas por Bohigas em Barcelona, a utilização destes espaços como "laboratórios urbanos" capaz de gerar novos discursos e repertórios para futuras intervenções tendo como base os GPUs.

Destas "experiências urbanas" podemos destacar as colocadas em prática por Christian de Portzamparc no setor Masséna-Nord no qual identificamos com clareza os conceitos já defendidos pelo arquiteto desde o final da década de 90 , e publicado em seu famoso texto "A terceira era da cidade" - La troisième était la ville - em francês (1997). Suas teorias e conceitos sobre a Quadra Aberta (blocouvrir) consolidam neste setor de PRG a possibilidade de uma cidade com uma dinâmica própria atendida por usos mistos, equipamentos públicos e transporte urbano de qualidade. Da mesma forma em que os resultados alcançados, mesmo que suas intervenções valorizaram o solo urbano, não refletiram na tão temida gentrificação dos que ali moravam.

Hoje, após quase duas décadas e ainda em obras, ${ }^{129}$ é possível perceber a dinâmica urbana que esta área possui, seja nos escritórios que ali se instalaram, no uso intenso da Biblioteca Nacional da França, o Parque Berçy e a orla do rio Sena, ou com o grande número de estudantes que se direcionam diariamente para este setor da cidade. $O$ bairro ainda mantém as características residenciais, no entanto, agora as habitações estão inseridas sobre quadras mistas e com espaços públicos generosos, o vazio urbano agora delimita o espaço construído e fomenta a importância e o equilíbrio entre os espaços construídos e os não construídos.

129. Em última visita à área de intervenção realizada em 2011, observamos que os setores Austerlitz-Gare, AusterlitzSud, Tolbiac-Chevaleret, Masséna-Sud + Masséna-Bruneseau ainda estão em desenvolvimento e execução das principais obras de infraestrutura urbana. 



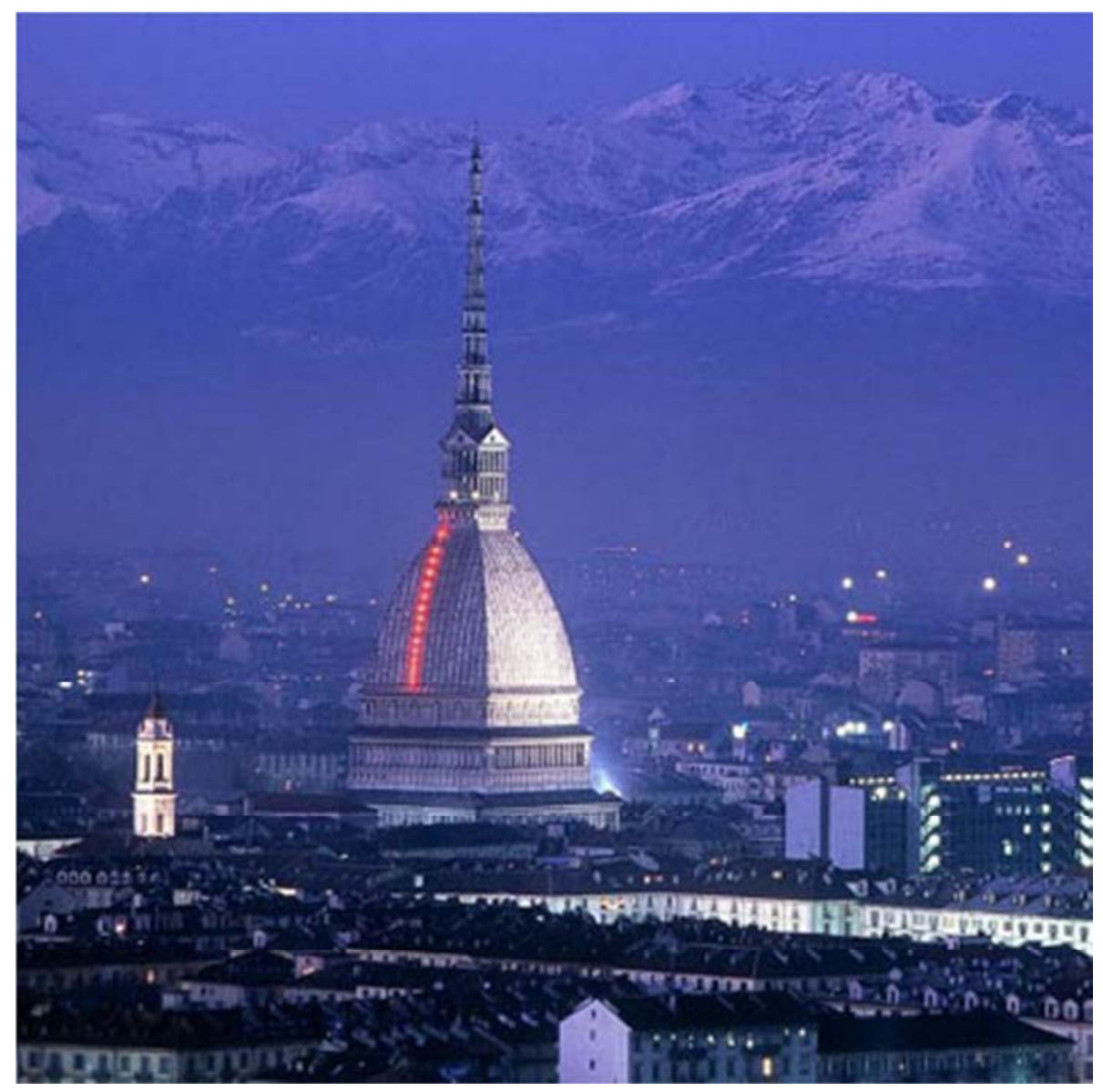

Capítulo 4

Torino | Itália 



\section{Torino: Transformação Contínua sobre um Tecido Existente}

Cidade de origem romana, Torino após a Proclamação do Reino da Itália, foi a capital do país entre os períodos de 1861 a 1864, transferindo-se em 1865 para Florença e para Roma em 1870, onde permanece até hoje. Apesar do curto período, a cidade se beneficiou significativamente com a produção urbana e importantes edifícios, não somente de cunho administrativo, mas também um grande número de habitação, no qual resulta naquele momento numa cidade com "ruas largas e retas, elegantes palácios, adequado para os ministros da habitação e legações estrangeiras com decoro e racionalidade" (FEl 1971, in TeMA, p 17). ${ }^{130}$

Em constante desenvolvimento desde o início do século XIV, sob o reinado de Carlo Emanuele, a cidade foi adquirindo durante mais de dois séculos um imponente conjunto edilício e infraestrutura urbana que contribuíram para a consolidação da forma urbana de Torino - Piazza San Carlo e o distrito de Porta Nuova à sul da cidade em 1584, Palazzo Reale e Palazzo Carignano no final de 1600, já no início do século XVI, Filippo Juvarra (arquiteto real), realizará o Senado, a Basílica di Superga e o Palazzo di Stupinigi, além da contribuição urbanística com um Projeto de Desenvolvimento na cidade devastada pelo "cerco" de 1706, ${ }^{131}$ com a criaçãode "novos bairros de arcos altos e imponentes, expansão de praças e ruas, construção de edifícios de inspiração simétrica elegante e regular" (FEl 1971, in TeMA, p 17). ${ }^{132}$

Até o final do século XVIII, a cidade permanecia cercada pelas muralhas, alguns caminhos barroco que ligavam a cidade a núcleos distantes ou palácios e castelos Castello di Rivoli a leste, Catello del Viboccone a norte e a sul a Palazzina di Casccia di Stupinigi. Estes caminhos partiam dos principais espaços livres do núcleo como a atual Piazza Castello e Pallazzo Reale, passando pelos portões principais para o território envolvente ainda não explorado. Naquele momento, sua localização geográfica era envolvida por um vasto território plano, junto aos rios Stura e Pó (principal rio da Itália), além de sua proximidade das cordilheiras junto à Suíça. Quanto a sua forma urbana, ainda não percebemos uma configuração regular, mas podemos afirmar que os espaços livres e públicos são os elementos urbanos organizadores dos objetos construídos, enquanto que os caminhos barroco organizam os eixos de ocupação em sentido dos portões e território envoltório.

Avançados um século de ocupação a partir da "cidade barroca" (séc. XVIII), um Plano Urbanístico desenvolvido a partir de meados do século XIX, possibilitando a expansão além muralhas que "protegiam", no qual neste período este território se consolida dentro dos portões sobre os limites impostos pela proteção militar. Fora destes limites, já no final dos anos 1880, os caminhos barrocos se consolidam e surgem novos eixos de expansão da cidade consolidada, desenvolvendo-se num território muito mais extenso e esparso, inclusive além das barreiras físicas dos dois rios (Stura e Pó), com uma urbanização configurada a partir da nova economia de capitais privados, resultando num rápido crescimento fora dos limites da cidade do século XVIII.

130. Tradução do autor, 2011

Dalle strade larghe e diritte, dai palazzi eleganti, idonei ad alloggiare ministri e legazioni straniere con decoro e razionalità. 131. O Cerco de Torino de 1706 ficou conhecido pelos danos sofridos na cidade, e em particular ao Palazzo Reggia di Venaria Reale, quando os franceses instalaram-se na residência, danificando as estruturas físicas desta obra.

132 . Tradução do autor, 2011

nuovi quartieri militari dalle altissime ed imponenti arcate, ampliamento di piazze e strade, costruzione di palazzi d'ispirazione classica e di signorile e regolare simmetria. 


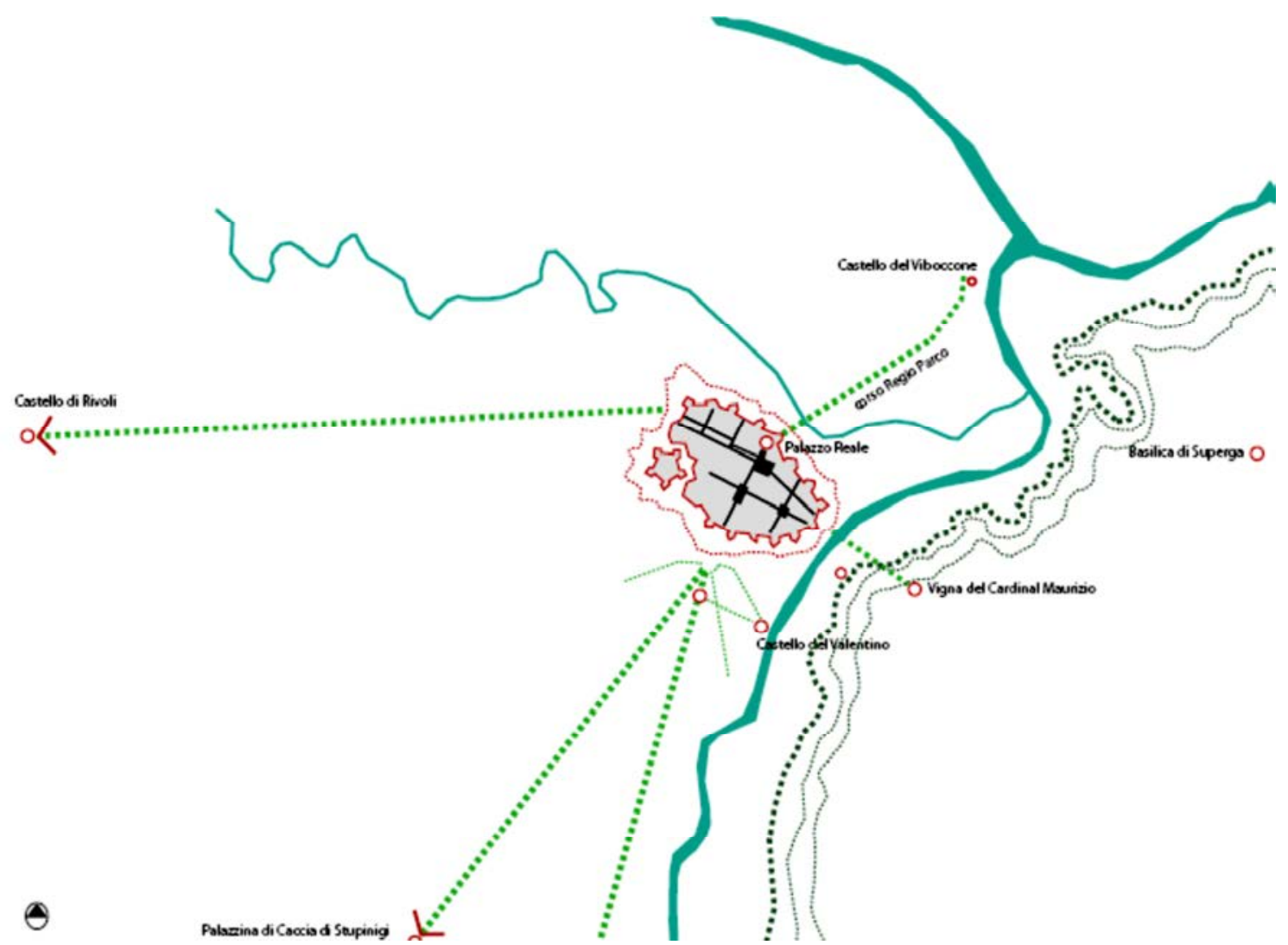

Figura 93. Cidade Barroca (século XVII) protegida pelas muralhas e implantada na junção entre os rios Po e Stura

Fonte: Urban Center Metropolitano Torino

Figura 94. Cidade Burquesa (final século XIX) a cidade se desenvolve além das muralhas com a chegada da rede ferroviária (Porta Nuova) e as primeiras indústrias (Manifattura Tabacchi)

Fonte: Urban Center Metropolitano Torino

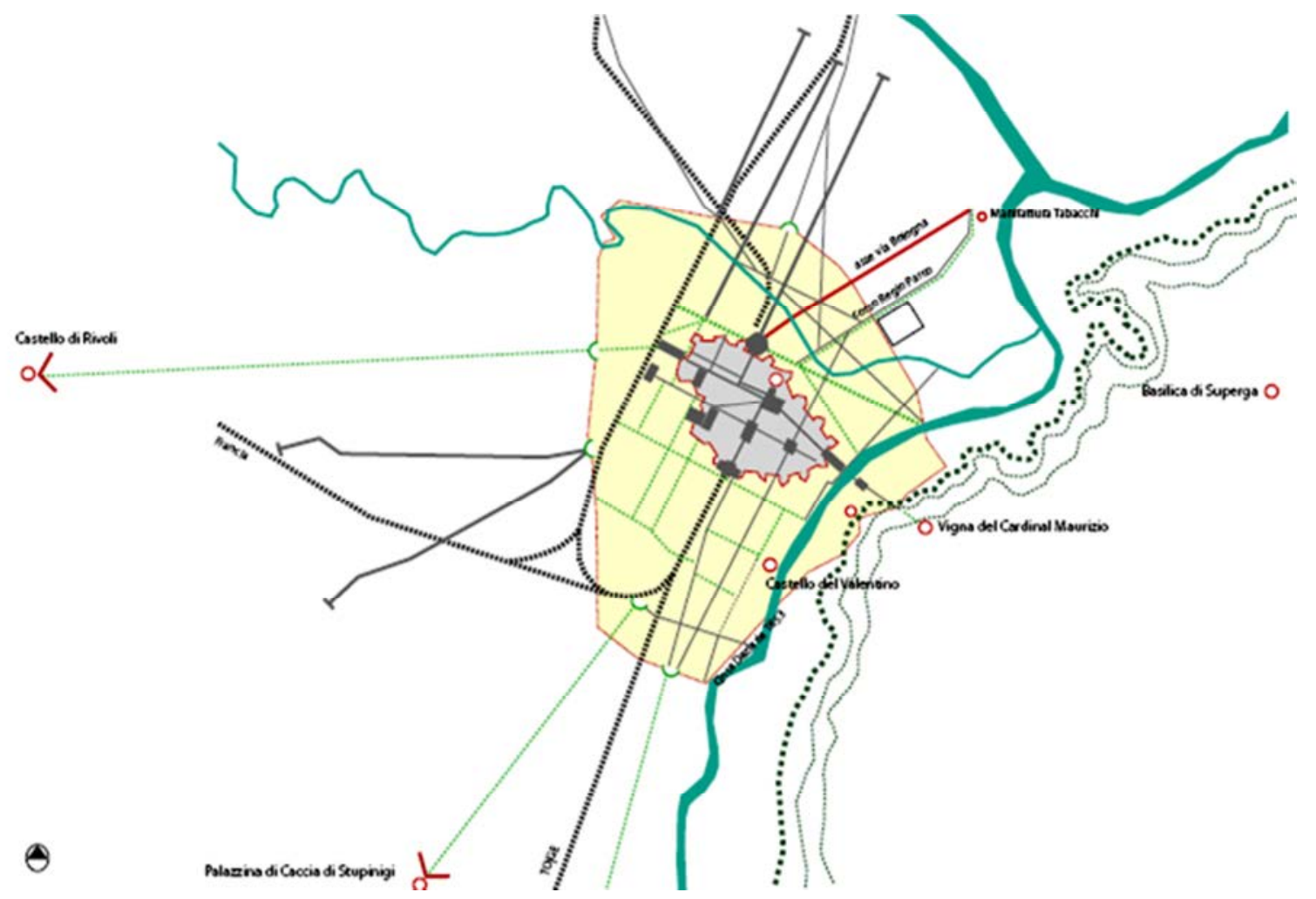


Resultado desta nova economia foi a implantação da primeira indústria de Torino, a nordeste da cidade (atual eixo de Bologna), sobre as ruínas do Castello del Viboccone, a Manifattura Tabacchi era responsável pela fabricação de cartas, selos fiscais e marcas d'água.

Como estrutura física, Torino recebe neste período sua primeira linha férrea conectando a cidade a região noroeste, a ferrovia Torino-Ciriè-Lanzo (1869) tinha a extensão de 153 quilômetros e poderia ser o grande eixo de escoamento de produção da cidade. Além desta, surgem outras ferrovias, neste caso de passageiros, ligando a cidade à França (oeste), Milão (norte) e Genova (sul) surgindo neste período as primeiras estações ferroviárias de Torino - Porta Nuova (1861) e Porta Susa (1854), a primeira a margem da muralha da cidade, já a segunda localizada na sua expansão urbana, à leste da Piazza Reale, sobre uma malha urbana mais regular (em forma de tabuleiro) e desprendida das amarras das antigas muralhas e com uma área territorial além dos limites físicos que configuravam a cidade, neste momento os rios Stura e Pó são vencidos e a mancha urbana se expande em diversas direções.

O início do século XX foi marcado pela alteração das áreas produtivas de Torino onde a presença das linhas férreas provocam o crescimento industrial junto a estes eixos de conexão entre a cidade e demais italianas, concentrando-se em sua maioria nos limites e/ou fora do "segundo anel" urbano consolidado até o final do século XIX, mais precisamente até os anos $1880 \mathrm{com}$ a implantação das ferrovias em Torino. Este processo induziu a instalação de diversas indústrias, como por exemplo a FIAT (Fabbrica Italiana Automobili Torino), que apesar de ser fundada em 1899, teve sua consolidação a partir da década de 20 e 30, além de outras indústrias de produção química, metalúrgica, de papel e vinho.

Em paralelo, a cidade permanece em contínuo crescimento urbano sobre uma quadrícula em "xadrez", grandes eixos viários e o surgimento de "bairros industriais" junto aos edifícios fabris. Neste contexto, podemos apontar três importantes bairros, ou indústrias, que provocaram a transformação do tecido urbano da cidade - a nordeste 0 conjunto residencial junto à Manifattura Tabacchi, primeira indústria da cidade, Docks Dora a norte nas proximidadas do pátio de manobras de mercadorias e a sul, o bairro de Lingotto, região da Indústria FIAT no qual se formou um grande bairro residencial desde a fábrica até as margens do rio Pó.

Estes fatores fizeram com que Torino ampliasse seu território urbano, praticamente dobrando sua área alcançada até o final do século XIX, consequentemente sua população cresce continuamente até meados do século XX, passando de 329 mil (1901) para 719 mil habitantes em 1951, porém foi a apartir das décadas de 60 e 70 que a cidade assistiu um grande crescimento populacional, chegando em 1971 à 1.167 milhões de habitantes (ISTAT - Istituto Nazionale di Statistica 2011).

\section{CRESCIMENTO POPULACIONAL DE TORINO}

Fonte: ISTAT - Istituto Nazionale di Statistica 2011

Elaboração: Elvis Vieira, $2012 \quad 1.400$

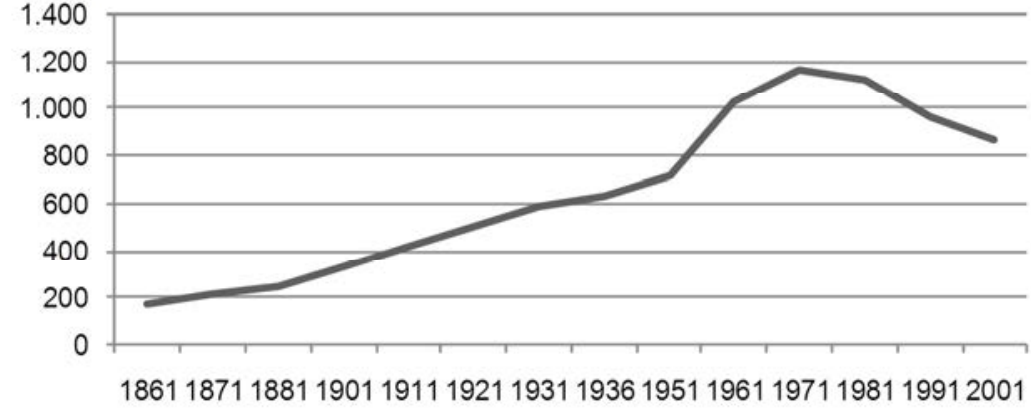




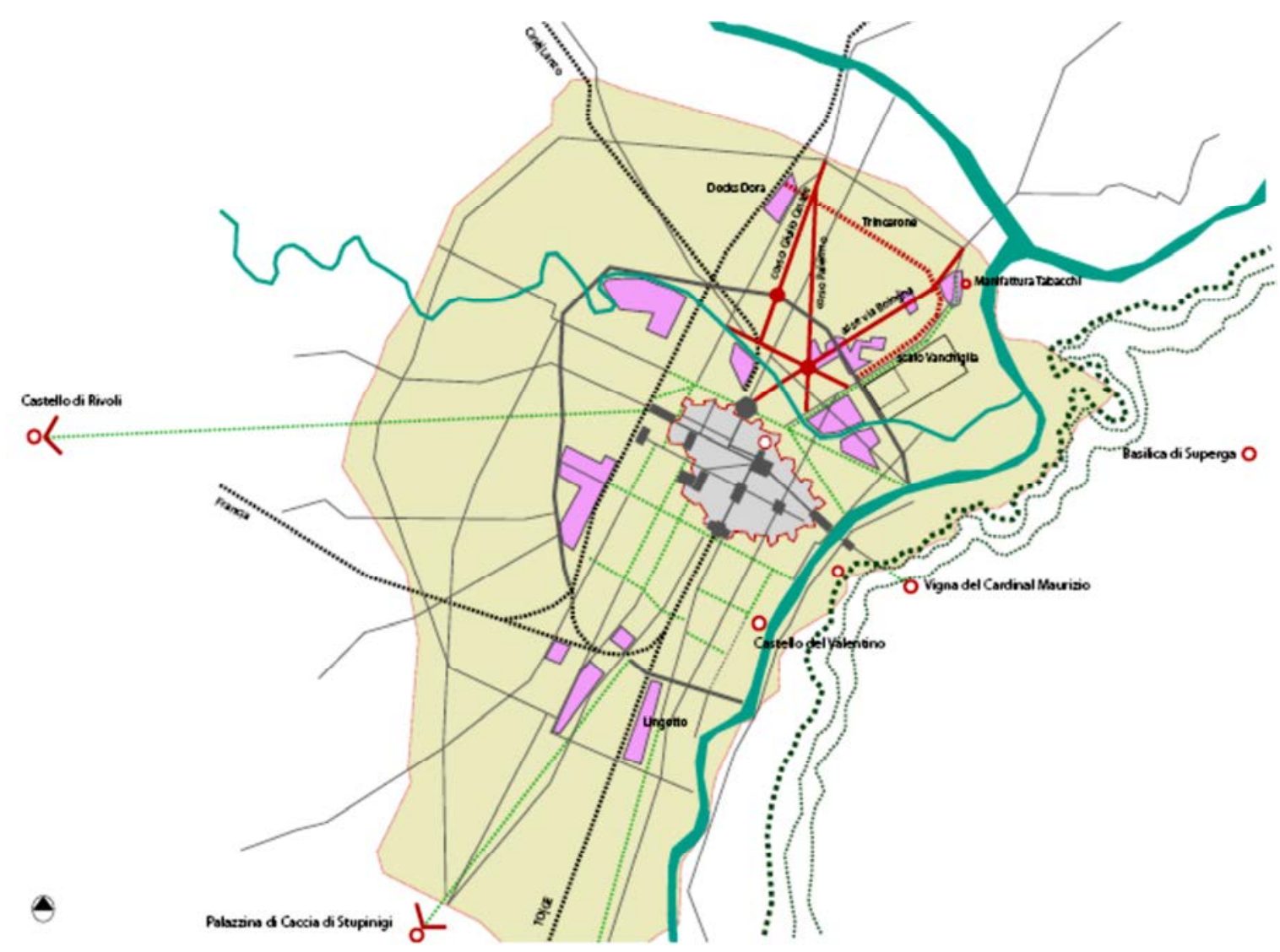

Figura 95. Cidade Industrial (anos vinte do século XX) com o advento da ferrovia a cidade amplia seu parque industrial, mudando radicalmente sua localização geográfica, onde antes era os rios, agora a ferrovia determina a implantação das indústrias

Fonte: Urban Center Metropolitano Torino

Figura 96. Indústria Manifattura Tabacchi, uma das primeiras indústrias de Torino junto ao rio Po Fonte: Cittá di Torino, 2012

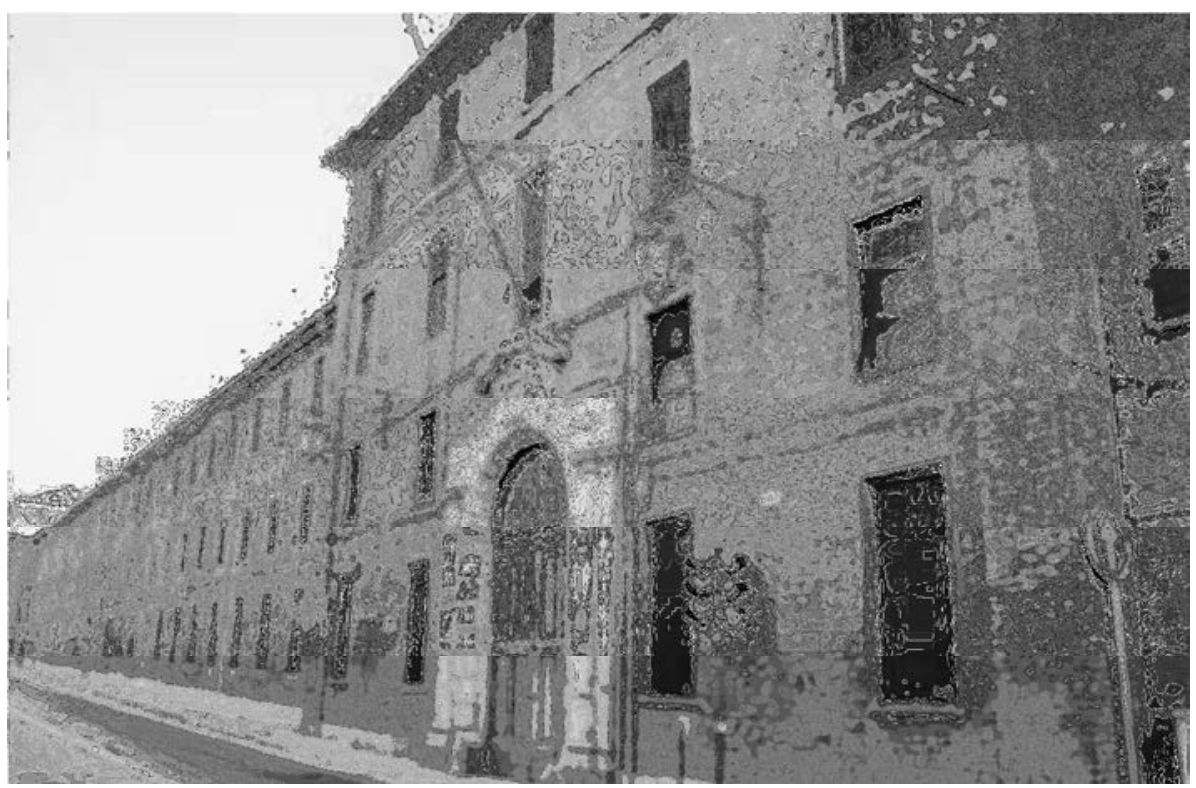


Após a década de 1950, a cidade foi obrigada a se reconstruir devido aos constantes bombardeios sofridos durante a II Guerra Mundial, ${ }^{133}$ crescendo continuamente desde 0 início do século, Torino se torna obrigado a se desenvolver de forma organizada, com infraestrutura e uma malha urbana em grelha que se entende pelas diversas direções do território da cidade. Nesta "nova estrutura" o tecido se articula às expansões de assentamentos residenciais e de produção, resultando num incrementalismo progressista e rápido.

Nesta linha de desenvolvimento os rios Pó, Dora e Stura já não são mais as barreiras naturais que "controlam" o crescimento da cidade, tornando o território urbano cada vez mais esparso conectando-se entre todos os "bairros industriais" já consolidados, principalmente no eixo norte-sul onde se instalam cada vez mais um número maior de indústrias, ao sul por conta da FIAT Mirafiori, enquanto que a norte o desenvolvimento industrial se estende além rio Stura (Torino-Setimo).

A cidade contemporânea é resultado de um conjunto de projetos urbanos colocados em prática a partir do Plano de Regulação Geral de 1995 (II Piano Regolatore Generale di Torino) que tinha por objetivo "aceitar o processo de desindustrialização, tentar acelerar a mudança para a terceirização da cidade" (COMUNE DI TORINO 1995), ${ }^{134}$ tendo para isto, como apontado pelo PRG, como elemento fundamental do plano "a transformação 'interna' da cidade, a reorganização da infra-estrutura e mobilidade e a proposta de um novo desenho urbano"(COMUNE DI TORINO 1995) ${ }^{135}$ mudando consideravelmente o quadro urbano de Torino.

As principais áreas que surgiram na década de vinte do século $X X$, consolidaram Torino como "cidade-industrial" e mudaram sua forma urbana e funcional. Percebe-se também que a partir da década de 80 a cidade já não se expande tão rapidamente quanto as anteriores, consolidando o território da cidade e possibilitando maior controle sobre as funções do solo urbano. Em paralelo, o plano urbano identificou três áreas, ou eixos, que norteariam a transformação da "cidade-industrial" para a "cidade-serviços" ou "ciddade-tecnológica" - Eixo do rio Pó, Spina Centrale (Espinha Central) e Corso Marche ${ }^{136}$ - que ao longo dos anos mostraram-se como elementos estruturadores e ordenadores para reler e repensar a cidade, aliados com dois grandes eixos de mobilidade urbana representados pela linha 1 e 2 do Metrô. ${ }^{137}$

Atualmente, Torino, capital da província de mesmo nome e da região autônoma de Piemonte, no noroeste da Itália, estende-se por uma área de $130 \mathrm{Km}^{2}$ de superfície territorial, tendo uma densidade populacional de $6.596 \mathrm{hab} / \mathrm{km}^{2}$, totalizando uma população de 910.188 habitantes (COMUNE DI TORINO s.d.).

133. Torino foi repetidamente bombardeada pelos Aliados: o primeiro ataque ocorreu em 11 de junho de 1940, o último em 1945 (intensidade máxima foi alcançada em 1943).

134 . Tradução do autor, 2012

Accettare il processo di deindustrializzazione, cercare di accelerare il passaggio verso l'outsourcing della città.

135 . Tradução do autor, 2012

La trasformazione "interna" alla città, la riorganizzazione infrastrutturale e della mobilità e la proposta di un nuovo disegno urbano.

136. Eixo rio Pó - o projeto envolve a valorização do rio ao longo do eixo de grandes museus e instituições culturais e sua integração com a paisagem e recursos ambientais localizados nela; Spina Centrale - projeto urbano que redesenha um eixo sobre a linha férrea existente, que atravessa a cidade de norte (ligação do nó rodoviário Torino-Caselle Torinese) à sul (Largo Turati), explorando um novo desenho urbano dividido em 4 grandes eixos; Corso Marche - pertence ao eixo multimodal que liga o núcleo urbano de Venaria, à norte com a junção de Drosso, à sul, numa extensão de $9 \mathrm{Km}$. $\mathrm{O}$ projeto fornece a base para redesenhar o tecido urbano e as funções da área metropolitana de Torino.

137. As linhas 1 e 2 do Metrô tem por objetivo promover a mobilidade urbana, reduzindo os impactos do transporte individual sobre a malha urbana da cidade e possibilitando a conexão entre as funções e equipamentos urbanos de Torino, tais como universidades, hospitais, áreas industriais etc, contribuindo para a regeneração dos espaços urbanos. 


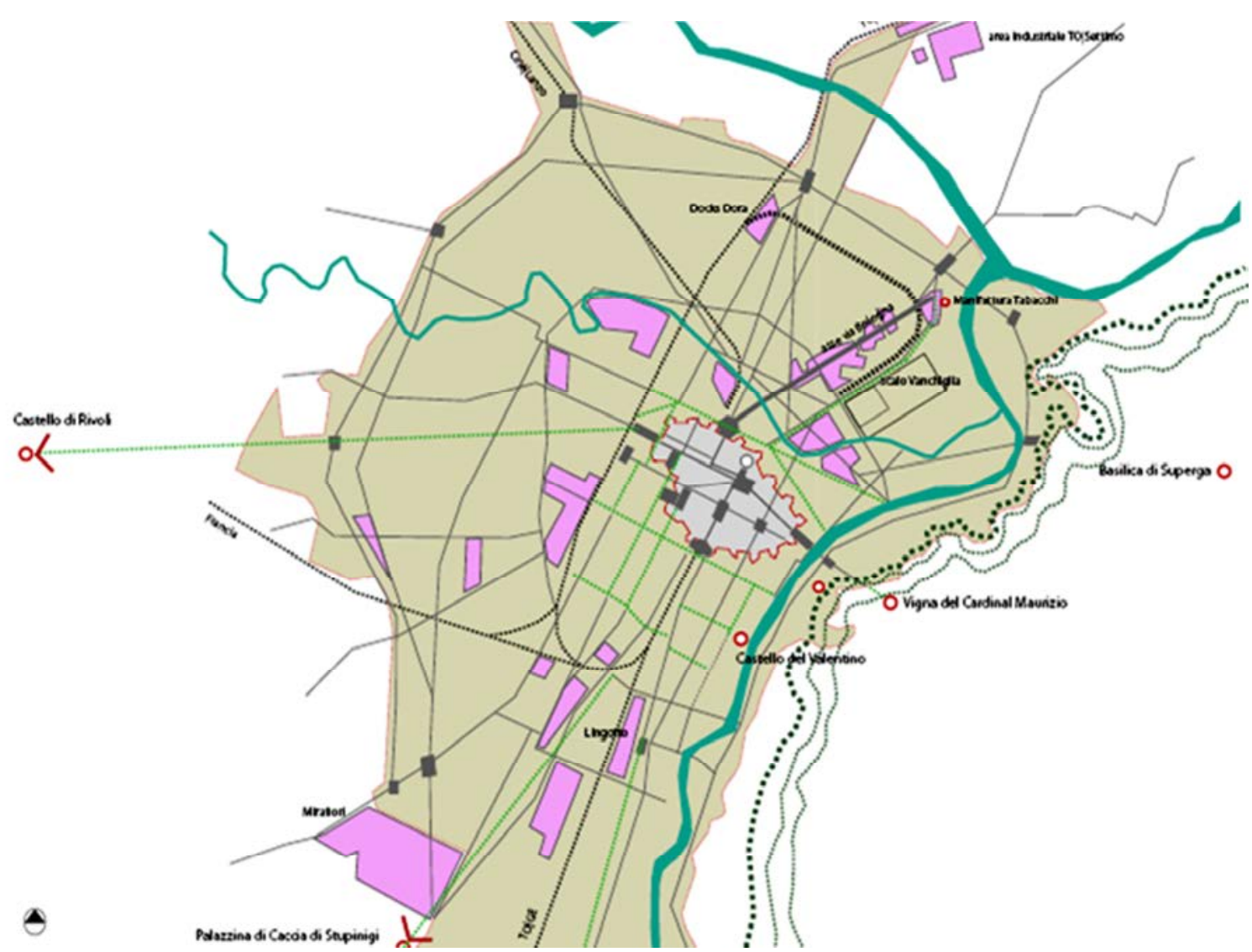

Figura 97. Grande crescimento territorial pós II Guerra Mundial com desenvolvimento de uma infraestrutura urbana em grelha

Fonte: Urban Center Metropolitano Torino

Figura 98. A cidade atualmente num processo de reabilitação urbana desencadeada em 1995, agora caracterizada como uma cidade funcional, marcados por três questões: eixo rio Po, Spina Centrale e Corso Marche, além das linhas de metrô 1 e 2 (laranja e violeta)

Fonte: Urban Center Metropolitano Torino

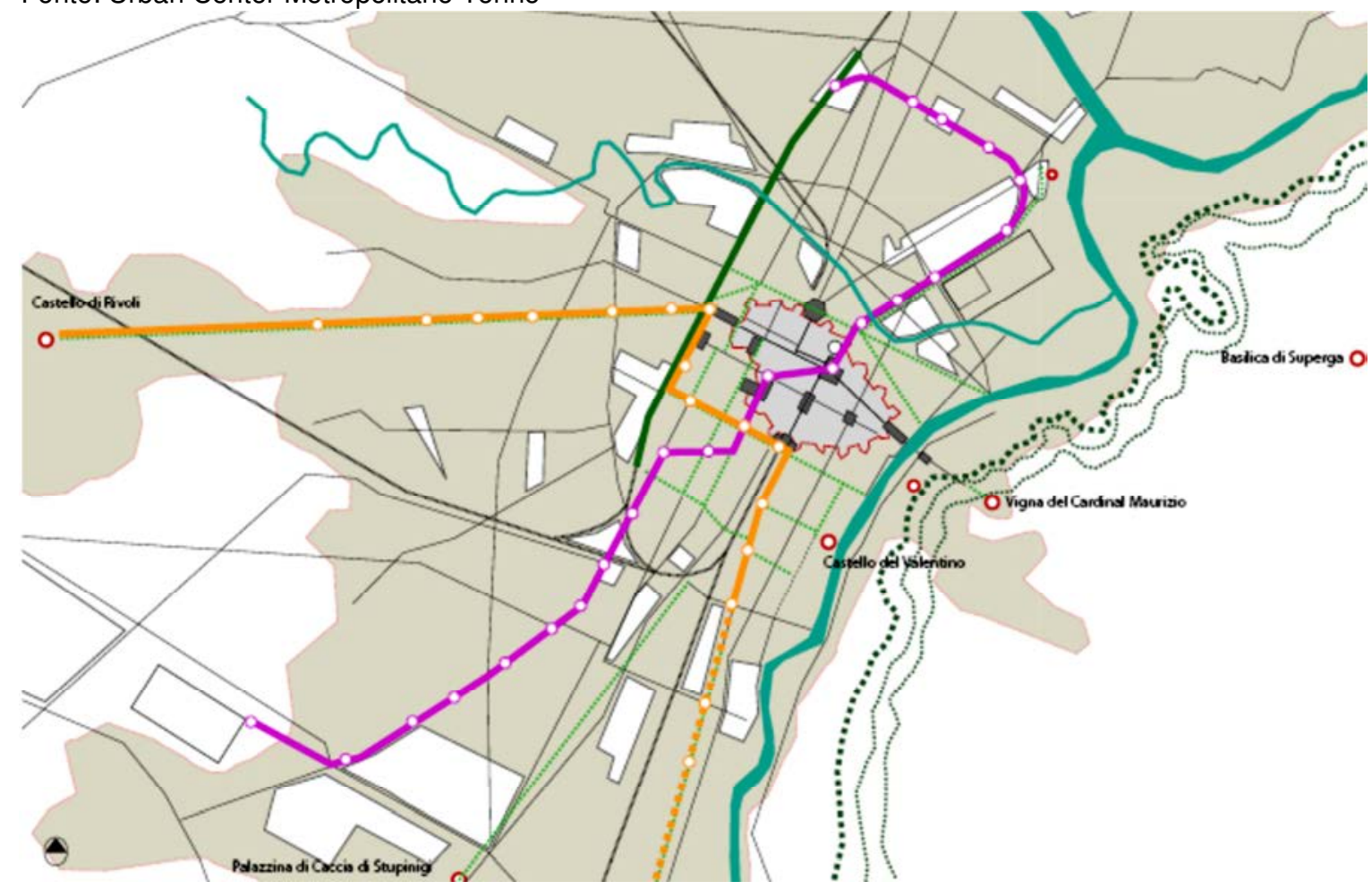


Por se tratar de uma cidade de origem romana, com uma trama urbana consolidada e protegida pelo patrimônio e, uma malha regular que se ramificara a partir da cidade protegida pelas muralhas até o início do século XIX, as intervenções são tomadas como "objetos de valor", tendo em vista que a maioria das edificações e espaços públicos deve ser confirmada como "memória viva" de seus habitantes e usuários.

A crise industrial ocorrida na década de 80 produziu resultados assustadores para a cidade de Torino, no qual dispara processos de transformação social e não apenas urbanas nos próximos 20 anos. Como exemplo deste fato, a "crise" da FIAT em Lingotto e Mirafiori reduz seus funcionários, concentrados em grandes aglomerações urbanas, cerca de um décimo: "mais de 150 mil para menos de 15 mil trabalhadores" (MONTANARI s.d.) ${ }^{138}$, conseqüentemente reduzindo a população da cidade, que entre os anos 1980 a 2010 perdeu cerca de 300.000 habitantes (MONTANARI s.d.).

Por outro lado as áreas industriais abandonadas que cresciam continuamente, fruto da redução e/ou desativação de milhares de pequenas indústrias e empresas em sua maioria localizadas no segundo anel de expansão da cidade, resultando em cerca de 3 milhões de metros quadrados de áreas subutilizadas ou abandonas (COMUNE DI TORINO 1995).

Diante de um cenário como este, com a escolha de Valentino Castellani (centroesquerda) ${ }^{139}$ para prefeito de Torino, aceita o processo de desindustrialização e inicia 0 de aceleração e mudança para a terceirização da cidade. Para tanto, Castellani utiliza como principal ferramenta de análise e discussão para as ações a serem tomadas no desenvolvimento da cidade um novo Plano Diretor coordenado pelo arquiteto milanês Vittorio Gregotti e Cagnardi Augustus.

Como estratégia principal o Piano Regolatore Generale, constituído pela Região Metropolitana de Torino conduz à definição de uma proposta específica para a escala da cidade.

"A partir da oportunidade de transformação que os processos de reestruturação industrial liberaram espaços no tecido urbano central num total de cinco milhões de metros quadrados, o plano coloca em seu objetivo a perspectiva geral de promover novas estratégias metropolitanas através de uma redefinição territorial do conceito de centro e conseqüente articulação das propostas. As reformas propõem transformações urbanas para identificar as partes de importância excepcional e transformações generalizadas de pontos menores, que vai mudar a imagem de lugares e apresentar diferentes formas de uso na cidade" (COMUNE DI TORINO 1995). ${ }^{140}$

\footnotetext{
138. Tradução do autor, 2012

Da oltre 150.000 a meno di 15.000 lavoratori.

139. Valentino Castellani, nascido em Varmo - Itália - 1940, foi prefeito de Torino de 1993-2001, quando liderou a coalizão do centro-esquerda, professor e ex-aluno do Politécnico de Torino e Presidente da Comissão Organizadora para Jogos Olímpicos de Inverno de 1999-2006.

140 . Tradução do autor: 2012

A partire dalle oportunità di trasformazione che i processi di ricoversione industriale aprono liberando spazi nel tessuto urbano centrale per un totale di cinque milioni di mq, II piano colloca i propri obietiivi nella prospettiva generale di promuovere nuove strategie metropolitane attraverso una ridefinizione territoriale della nozione di centro e la conseguente articolazione delle proposte. Le riforme urbane proposte individuano trasformazioni per parti di eccezionale significato e trasformazioni diffuse su punti minori, che modificheranno l'immagine dei luoghi e introdurrano modi d'uso diversi della città.
} 


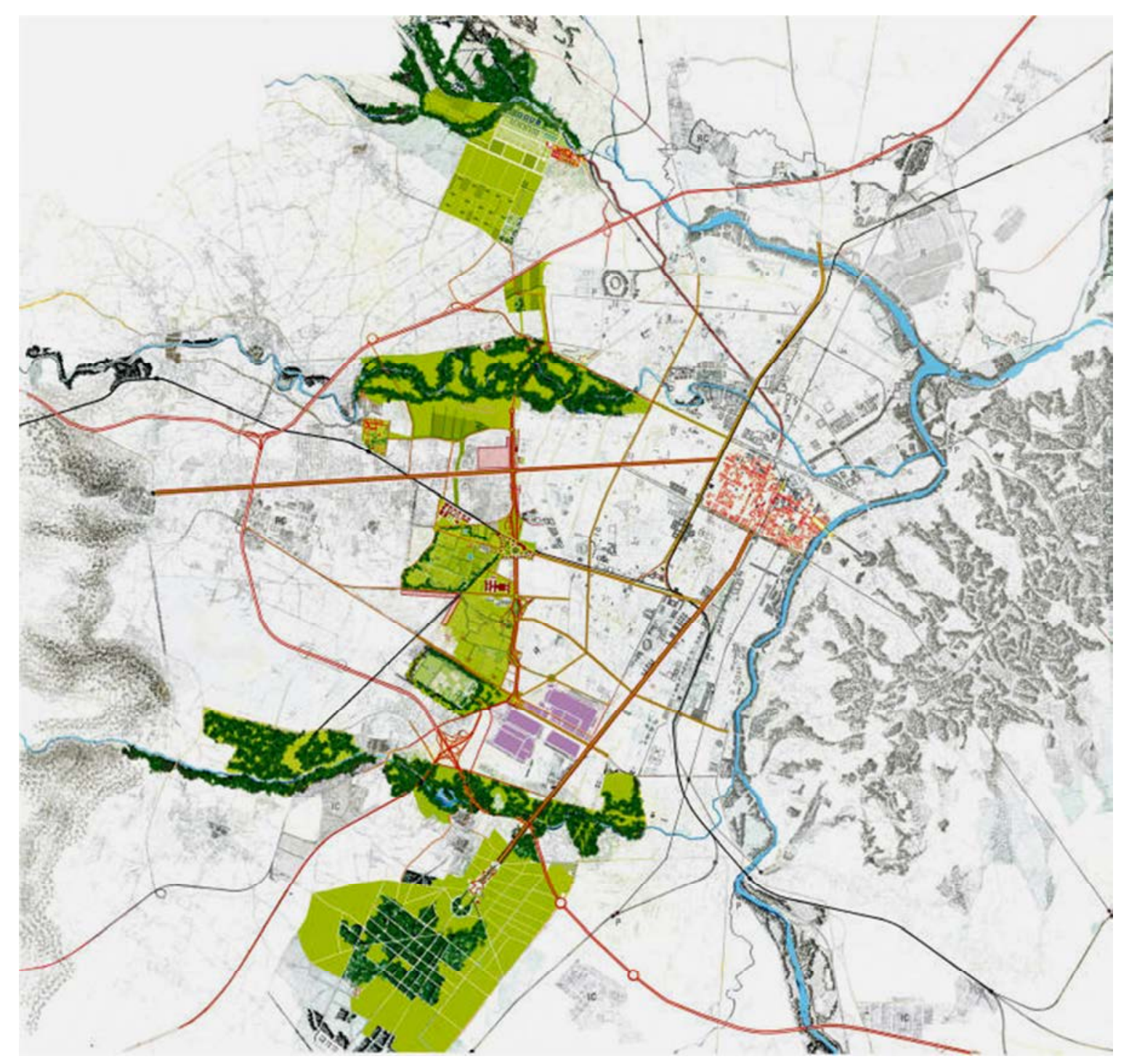

Figura 99. Piano Regolatore Gerale, 1995

Fonte: www.ilgiornaledellarchitettura.com, acessado em 19/10/2012

Como resposta ao tema da renovação e regeneração urbana, o Plano propõem um conjunto de políticas, ferramentas e processos de implementação(COMUNE DI TORINO 1995) para os próximos 10 a 15 anos, tendo por referência, em meados dos anos 90 , dois fatores-chave (exógenos e endógenos) que provocaram a transformação da cidade: 1) a crise fordista na cidade, que deixou mais de cinco milhões de metros quadrados de áreas industriais abandonadas, obrigando a repensar não somente sua identidade, como cidade-industrial, mas também à reavaliação sobre os "vazios urbanos" em processo de transformação; 2) a oportunidade de investimentos provenientes de recursos nacionais e europeus, tanto públicos como privados, capaz de gerar um novo impulso à renovação urbana, por meio de grandes projetos urbanos de transformação urbana, ancorada na idéia de planejamento urbano como instrumento de ajuste e transformação da cidade.

Estes dois fatores levaram a administração a pensar nas mudanças econômicas e sociais provocadas pelo fechamento das indústrias, e consequentemente pela produção "voluntária" de vazios urbanos na cidade, nas novas funções destas grandes áreas industriais. Por outro lado, as áreas centrais eram cenários de abandono das habitações 
existentes e o aumento da "violência urbana" provocada pela redução de densidade habitacional e o fluxo de pessoas durante o período noturno, levando o Quadrilatero Storico ${ }^{141}$ a um processo de crise urbana, por exemplo, nos bairros históricos de Porta Palazzo e San Salvario. No entanto, estes fatores poderiam refletir, no caso do centro histórico, em processos de regeneração urbana e de recuperação e reparação do tecido social, assim como nas áreas resultantes do abandono industrial, a criação de novos bairros e centros urbanos que consolidariam na reabilitação do tecido urbano e uma nova "vocação" econômica para a cidade de Torino.

"A cidade então é um organismo complexo que precisa de projetos de território, é preciso regenerar o tecido urbano dos bairros já habitados. A cidade já está habitada, e é essencial para trabalhar com as políticas de "segunda geração" sobre as casas, pensando em garantir uma necessidade - a qualidade de vida - $e$ para produzir a qualidade urbana, feita de serviços, usos mistos, conexões"(CURTI s.d.). ${ }^{142}$

É certo que a questão urbana exige um pensamento complexo permitindo ver a cidade contemporânea como camadas de usos e estruturas urbanas que se sobrepõem sobre um tecido em transformação contínuam, evitando distinguir entre centro e periferia, o material e imaterial, a cidade visível e submersa ou escondida, reconhecendo o direito de socializar para destacar a primazia a cidade, levando com isto, à projetos urbanos de transformação urbana, por meio de um processo de renovação e regeneração urbana sem os riscos de gentrificação, a expulsão dos grupos populacionais mais vulneráveis.

Netse sentido, para que os objetivos fossem alcançados e possibilitasse a transformação da cidade de forma contínua e "sustentável", garantindo que todos atores urbanos contribuissem para esta valorização da identidade de Torino, como apontado no Piano Regolatore Generale (1995), três escalas ou abordagens foram adotadas:

1. Abrangente: olhando para a cidade como um todo, melhorando a qualidade de vida e promovendo uma abordagem intersetorial, a integração de atores especializados e superar a fragmentação das áreas de especialização, para renovar os sistemas e formas de trabalho;

2. Territorial: conectar as políticas gerais à zonas geográficas específicas, e mobilizar as energias sociais e institucionais dos locais, garantindo a melhoria de cada território da cidade;

3. Especifico (pontual): participação, parceria e associação através da produção de projetos que reorganize o tecido desarticulado e amplie as possibilidades e diversidade de usos.

Estas três abordagens têm por objetivo melhorar a qualidade de vida de seus habitantes e usuários, valorizar a memória histórica da cidade e seus territórios, promover a "mistura de usos" sobre as novas centralidades recriadas e, acima de tudo, uma cidade competitiva junto as demais cidades italianas e européias.

141. O núcleo central de Torino, denominado pela administração por Quadrilátero Histórico, é o perímetro da fortaleza romana e a colônia Augusta Taurinorum. Este perímetro ainda é reconhecido pelos seus vestígios importantes da cidade preservada até hoje.

142 . Tradução do autor, 2012

La città quindi è un organismo complesso che ha bisogno di progetti di territorio, perché ha necessità di rigenerare il tessuto urbano dei quartieri già abitati. La città è già abitata, ed è indispensabile lavorare a politiche di "seconda generazione" sulle case, pensando a garantire un bisogno - la qualità dell'abitare - e a produrre qualità urbana complessiva, fatta di servizi, di mixité, di connessioni. 


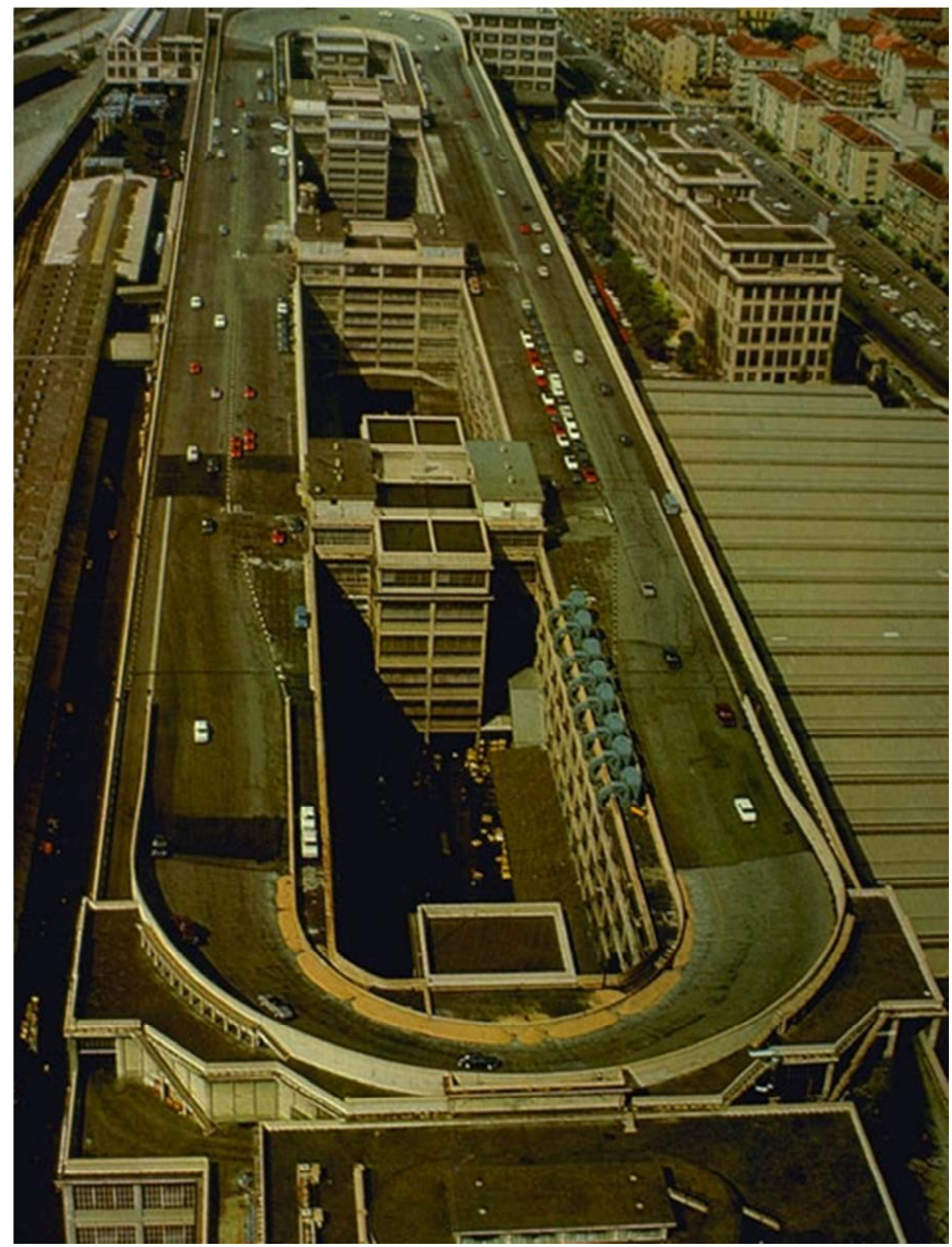

Figura 100. Fábrica FIAT Lingotto - Torino

Fonte: FIAT, 2012 


\subsection{Grandes Eventos Internacionais e as transformações da Forma Urbana}

O processo de transformação urbana de Torino a partir da "falência" da economia industrial que movia a cidade desde o surgimento das primeiras plantas industriais na região norte da cidade, obrigou a administração a repensar suas estratégias urbanas capaz de gerar e redefinir sua "vocação", mantendo-a entre as principais cidades da Região de Piemonte e da itália, além de garantir sua permanência como cidadecompetitiva entre as principais economias européias.

Diante disto, dois fatores podem ser apontados como elementos-chave para esta transformação e estímulo à atual fase de desenvolvimento arquitetônico e urbano de Torino. O primeiro fator foi a adoção em 1993 de uma nova lei sobre a eleição direta de prefeito que marcou o fim de um período de governos de curta duração. Para as cidades italianas, o prefeito tornou-se finalmente um líder de longo prazo, livre para planejar os projetos para a renovação da cidade.

O segundo fator foi a adoção a partir de 1994 de uma nova lei de Obras Públicas, apelidada "Lei Merloni", que entre outros, estimula e regula o concurso para a atribuição de projetos arquitetônicos, chamada pelos torinenses de "convocação de novos projetos" (invito a presentare progetti nuovi, em italiano), dirigidos para a promoção de projetos urbanos e arquitetônicos que redesenhassem o tecido urbano degradado da cidade. Com isto, estas duas datas marcaram o início de um processo gradual que tem estimulado o renascimento atual da arquitetura pública que, após os anos 2000, tem promovido a cidade a um nível comparável a outros grandes centros europeus (CITTÀ DI TORINO 1997).

Esta nova fase é distinguido por dois movimentos particularmente significativo: por um lado, o surgimento na Itália, e em particular em Torino, de muitos renomados arquitetos e urbanistas europeus com grande experiência em obras públicas, que desde os anos 80 vem consolidando suas obras e construindo um arcabouço e conjunto edilício de relevância para o "patrimônio" da cidade. Por outro lado, a afirmação progressiva de um número de jovens arquitetos italianos, nascidos nos anos 70 , que devem trabalhar em prol da transformação urbana da cidade.

Desde então, o Piano Strategico della Città(2000) levou ao estudo e lançamento de muitos programas de transformação urbana, incluindo uma série de projetos urbanos e arquitetônicos para a recuperação do tecido urbano degradado e áreas abandonadas e/ou subutilizadas junto às antigas indústrias da cidade. Entre os projetos, podemos considerar dois planos como "elementos estratégicos" para o desenvolvimento da cidade: Spina Centrale - em que se tem como estratégia o redesenho urbano a partir da realocação dos eixos ferroviários que cortam a cidade, novas centralidades lineares sobre a criação de eixos viários e a construção de vários edifícios, de ordem cultural, educacional, saúde, além de comércios e serviços que possibilitem a reabilitação urbana deste eixo.

Outro desdobramento dessas iniciativas combinadas foi o projeto para os Jogos Olímpicos de Inverno, coordenada pela Agenzia 2006, que num curto prazo, resultaria na construção em várias áreas de Torino em doze principais conjuntos arquitetônicos: sete Vilas de Mídia, quatro Arenas de gelo e uma Vila dos Atletas (AGENZIA TORINO 2006 s.d.).

Em geral, as transformações providas dos grandes eventos como Exposições Universais, Jogos Olímpicos, Copa do Mundo, dão as cidades sedes a oportunidade de renovar suas estruturas urbanas defasadas como premissa para a valorização do 
acontecimento. Do mesmo modo, as estruturas específicas como pavilhões de exposição, estádios, centros olímpicos conduz à novas referências urbanas sobre 0 desenho da cidade, no qual podemos citar: a Torre Eiffel, construída para a Exposição Universal de 1889, o Estádio Olímpico em Roma feito para a Copa do Mundo de 1960, o papel dos Jogos Olímpicos de 1992 no renascimento da beira-mar e grande tecido urbano de Barcelona, o antigo porto de Genova com as celebrações de Colombo, ou a recuperação de grandes porções do tecido urbano em Sydney em 2000.

No caso de Torino, os Jogos Olímpicos de Inverno vêm ao encontro do desejo da nova administração em encontrar respostas à grande perda econômica e o surgimento de inúmeras áreas vazias e/ou subutilizadas com o fechamento das indústrias na cidade.

Em 1999, Torino é designado pelo Comitê Olímpico Internacional como o local dos XX Jogos Olímpicos de Inverno de 2006: "o comitê organizador (TOROC) vai gerir os territórios de oito municípios do vale alpino de norte-oeste e nascerá uma instituição com a tarefa especifica de gestão da contratação das obras ligadas às Olimpíadas" (AGENZIA TORINO 2006 s.d.). ${ }^{143}$

Segundo Angelo Bagnasco, "a gestão de uma operação desta envergadura sempre representa tanto um risco e oportunidade, ainda mais no caso de uma antiga "cidadeindústria" em transição para um modelo pós-fordista"(BAGNASCO in CARMANINNI e CECCARELLI 2007), ${ }^{144}$ no qual as melhorias e alterações sociais e ambientais possuem, neste momento, o caráter de "legado" para os que poderão usufruir após a realização dos eventos esportivos, mesmo considerando o grande montante financeiro dispensado para tal realização. É certo que grande parcela é provida de financiamento estatal, no qual foram dispensados cerca de 1.600 milhões de euros num total de cerca de 2.100 milhões investidos em Torino entre 1999 e 2006 (COMUNE DI TORINO s.d.)

Num primeiro instante, a construção de novos equipamentos esportivos antecipou as futuras mudanças que a cidade deveria passar para abrigar aos jogos oficiais, como 0 Pavilhão Oval de patinação e o Estádio de Futebol. ${ }^{145}$ Da mesma forma, a escolha da área para a implantação da Vila dos Atletas próximo ao novo Centro Multiusos de Lingotto, concomitante à construção da ponte pedonal sobre a rede ferroviária possibilitou a consolidação de uma nova centralidade na região sul da cidade, além da reabilitação das áreas industriais e a remodelação da rede ferroviária (pátios de manobra) abandonados, unindo trechos da cidade "fragmentados" ao longo dos anos.

$\mathrm{Na}$ mesma direção da recuperação de trechos abandonados da cidade, a reabilitação de edifícios existentes, patrimônio deixado pela Esposizione Itália $61,{ }^{146}$ como o Centro di Formazione Internazionale - ITCILO, no qual abrigou o Centro de Mídia durante o evento, ou Palazzo delle Mostre - Palavela, originalmente projetado em 1960-61 pelo engenheiroFranco Levi e arquitetos Annibale e Ricotti Giorgio, ficando a cargo de Bernardi e Gae Aulenti a proposta de reabilitação para um local de patinação e hockey.

143. Tradução do autor, 2012

II comitato organizzatore (TOROC) gestirà i territori di otto comuni delle valli alpine di nord-ovest e nascerà un'istituzione con lo specifico compito di gestire gli appalti per le opere connesse all'Olimpiade.

144 . Tradução do autor, 2012

II management di un'operazione di tale portata rappresenta sempre sia un rischio che un'opportunità e,ancor più nel caso di una ex "città-fabbrica" in transizione verso un modello postfordista.

145 . Torino Oval Lingotto é uma arena coberta construída para os Jogos Olimpicos de Inverno para abrigar as competições de patinação de velocidade, com capacidade de 8.500 espectadores, projetado pelo Studio Zoppini de Milão e Buro Happold.

146. A EXPO 61 - Esposizione Internazionale del Lavoro, foi organizado para celebrar o primeiro Centenário da Unificação da Itália. Realizada às margens do rio Pó, no qual o parque recebeu novo tratamento paisagístico, além da construção do Pavilhão do Trabalho e o Palácio da Mostra - Palavela, tendo como atração principal o monorail ALWEG numa extensão de 1.800 metros. 
Certamente as intervenções acima expostas nem sempre podem ser consideradas como um "legado" deixado para a população de Torino, afinal os equipamentos utilizados durante os eventos olímpicos se permanecem sobre o uso originalmente projetado, salvo alguns possíveis de se adequarem a novos usos e/ou atender a demandas da cidade, como por exemplo, a Vila dos Atletas que se tornou num importante bairro residencial junto à Lingotto. Porém, por outro lado, os Jogos Olímpicos de Inverno possibilitou a retomada das discussões a respeito da mobilidade urbana sobre a cidade e seus arredores. Naquele momento, o Comitê Olímpico apontou a necessidade de uma rede de transporte coletivo que interligasse os equipamentos esportivos.

Torino possui uma rede de transporte público exemplar provido de ônibus e bonde elétrico (TMV - trem de média velocidade), ${ }^{147}$ no entanto a implantação da primeira linha de Metrô (linha 1) ampliou suas conexões entre os sistemas já existente, além de reafirmar a ideia da criação de novas centralidades sobre o território da cidade(GTT GRUPPO TORINESE TRASPORTI 2008).

Os planos e projetos, tanto de ordem arquitetônica quanto urbana, promoveram na cidade um grande "laboratório urbano" a favor da transição da cidade-indústria para a cidade-cultura, no qual a tendência de transformar a forma urbana da cidade, gradativa ou imediatamente após as intervenções, instala-se sobre os novos projetos e funcionam como ferramentas de desenvolvimento urbano para os demais necessários para garantir os objetivos previstos no Piano Strategico(ASSOCIAZIONE TORINO INTERNAZIONALE s/d).

Entre as questões atuais do planejamento urbano da cidade, amplamente debatida, é a oportunidade de superar a abordagem conceitual e uma legislação mais tradicional que resultasse numa cidade contemporânea e competitiva entre as Cidades Globais Europeias. Nos últimos 40 anos, a cidade passa por um processo de transformação urbana fruto da desativação do parque industrial da cidade e o surgimento de grandes áreas vazias resultante do abandono dos pátios e áreas de manobras ferroviárias.

"A imagem associada com a indústria, que acompanha há muito tempo a cidade de Torino, nos últimos anos, deixa espaço para novas visões que refletem as facetas de uma transição gradual para uma função de renovação" (CITTÀ DI TORINO 1997). ${ }^{148}$

O Piano Regolatore Generale (Plano Geral) (PRG), aprovado em 1995, assumiu um papel decisivo no desencadeamento da transformação da morfologia urbana da cidade, buscando responder os problemas de recuperação dos espaços degradados ou abandonados, a reabilitação de trechos da cidade afetados com a desativação das indústrias e a reconversão de áreas históricas, em particular o centro da cidade, definindo uma "nova imagem mais moderna de Torino, com padrões de recuperação urbana encontrado em todas as cidades de grande e médio porte europeu" (AGENZIA TORINO 2006 s.d.). ${ }^{149}$

147. Todo o controle e ordenamento do sistema de transporte da cidade são executados pelo GTT - Gruppo Torinese Trasporti.

148 . Tradução do autor, 2012

L'immagine associata al settore, che è venuto tempo fala città di Torino, negli ultimi anni, lasciando spazio anuove intuizioni che riflettono le sfaccettature di una transizione graduale ad una funzione di aggiornamento.

149 . Tradução do autor, 2012

La nuova immagine più moderna di Torino, con modellidi rigenerazione urbana che si trovano in tutte le cittàgrandi e medie imprese europee. 


\section{CELEBRAZIONI CENTENARIO UNITA D'ITALIA - TORINO MAGGI0-0TTOBRE 1961 \\ PLASTICO DELIA ZONA DELIE ESPOSIZIOHI}

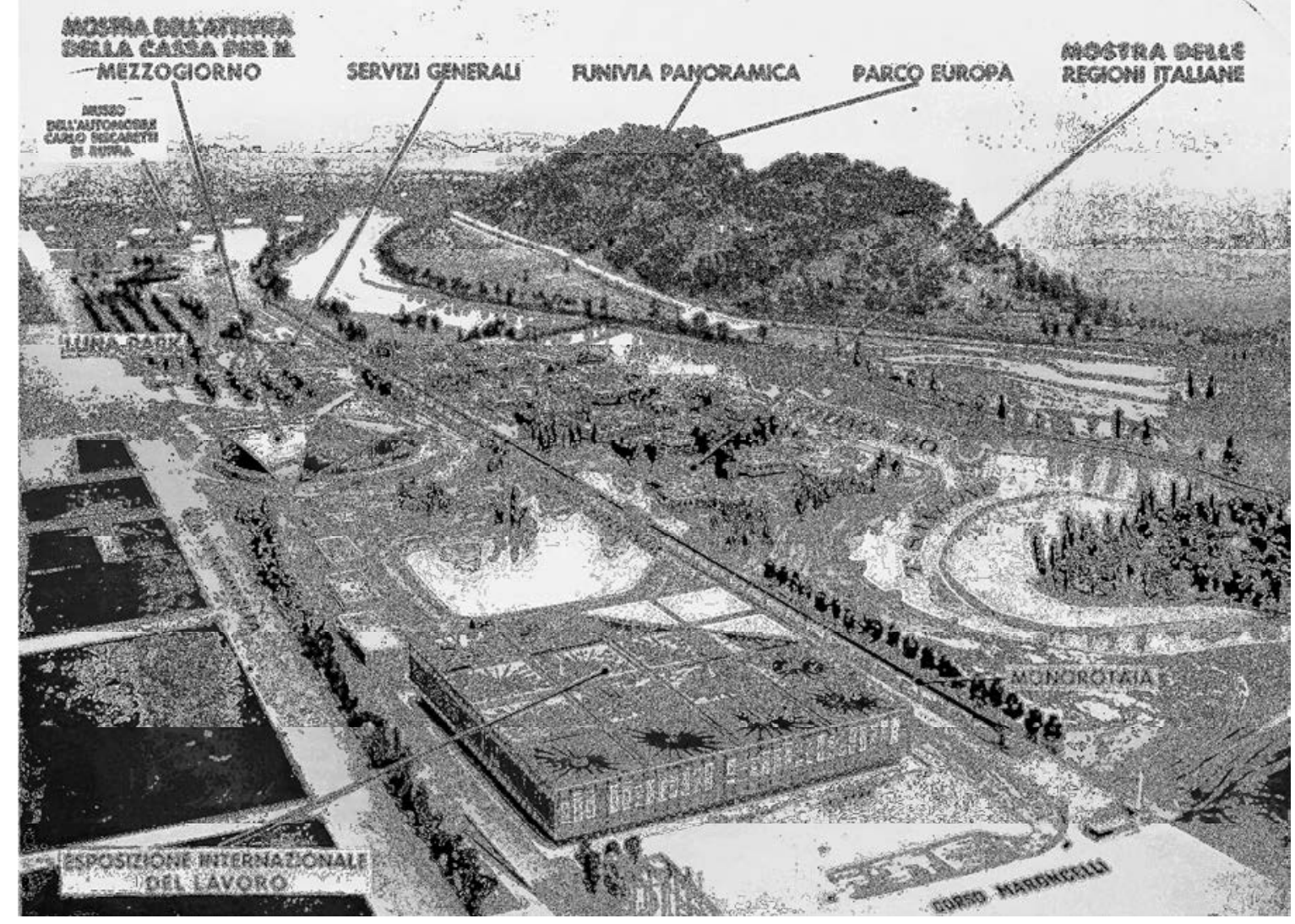

Figura 101. Exposição Internacional do Trabalho, 1961 em celebração ao centenário da unificação da Itália

Fonte:www.italia61.it, acessado em 19/10/2012

Figura 102. Palavela de Torino, antiga estrutura da Exposição de 61 readequadoa para as Olimpíadas de Inverno em 2006

Fonte: XX Jogos Olímpicos de Inverno, 2006

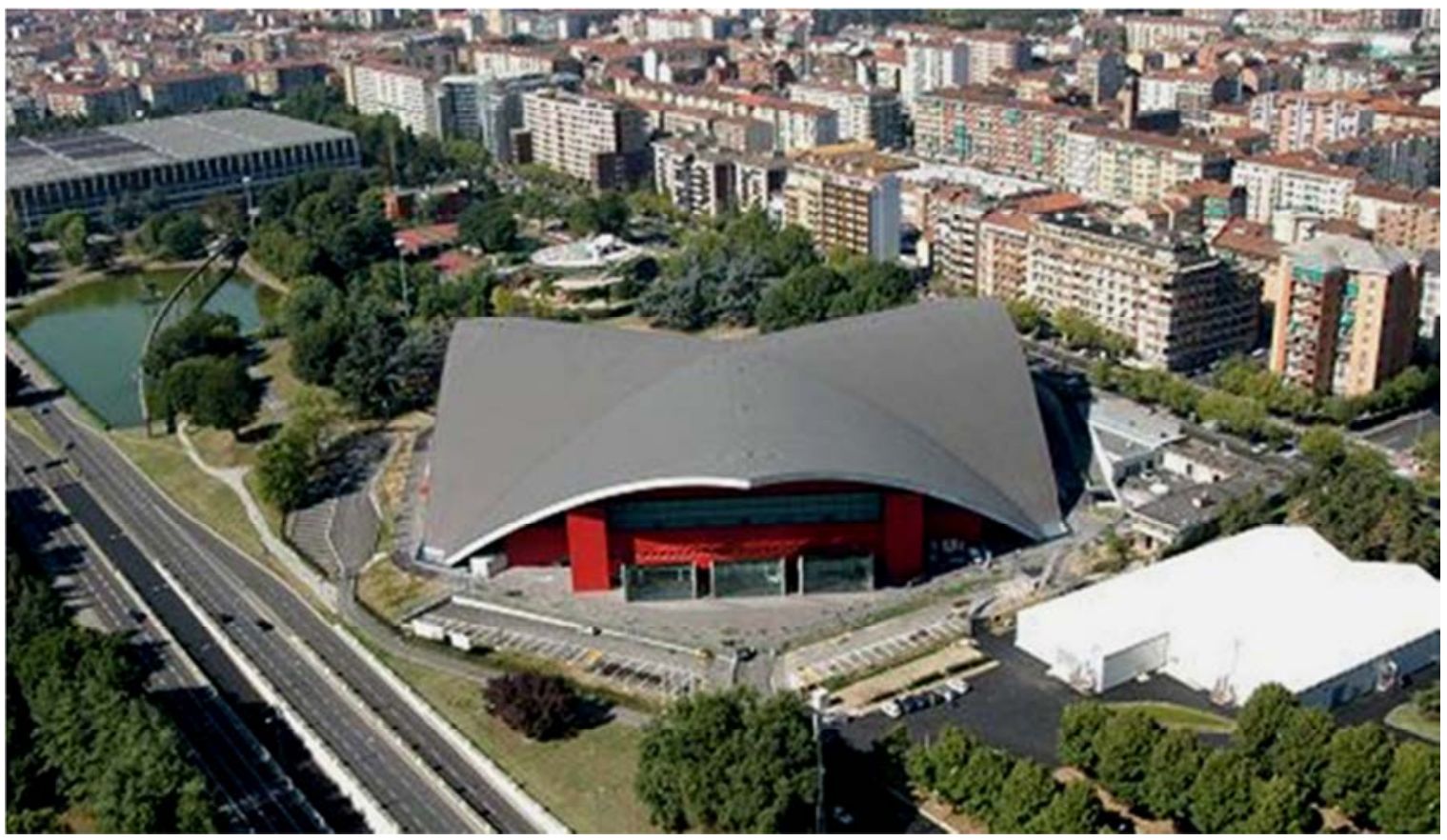


Ao longo dos anos, o conjunto de linhas férreas que cortam o tecido da cidade foi se tornando num elemento divisor, expondo a malha urbana numa sequência de espaços fragmentados e desconectados entre si. $O$ debate sobre a separação da cidade pela estrada de ferro inicia-se em 1887, quando na apresentação de um projeto do Engenheiro Vincenzo Borgatta (1906), que propunha já no inicio do século XX a redução das linhas de ferro, enterrando grande parcela de seu traçado e "deixando livre de obstrução o tecido urbano para futura expansão" (BORGATTA 1906). Tal proposta foi precursora entre os projetos do início do século XX, e que manteve viva a discussão sobre a questão das barreiras físicas fruto da rede ferroviária da cidade.

A partir da década de 1990, a cidade começou a discutir novas políticas de renovação e regeneração urbana. A necessidade de repensar o desenvolvimento da cidade em detrimento da transformação da cidade a partir da crise fordista e a reavaliação dos vazios urbanos fruto do "abandono fabril" e pátios ferroviários subutilizados, impulsionou à uma renovação, com novas ferramentas e processos de implementação de políticas urbanas, em conjunto com as econômicas, sociais e habitacionais, por meio de investimentos de recursos europeus e nacionais, tanto públicos como privados, desencadeando Grandes Projetos Urbanos de transformação de sua forma urbana, ancoradas na idéia de planejamento urbano como instrumento de ajuste e transformação da cidade: novos distritos foram criados, novos centros urbanos (CURTI s.d.).

"A cidade então é um organismo complexo que precisa de projetos territoriais, é preciso regenerar o tecido urbano dos bairros já habitados"(CURTI s.d.)

Desde então, os processos de regeneração urbana e de recuperação do tecido social, tanto em áreas urbanas centrais (Porta Palazzo, San Salvario) como nas zonas periféricas como Lingotto e Susa, são tomados como prioridade pelo governo municipal no intuito de alterar a imagem da cidade.

A candidatura da cidade como sede dos XX Jogos Olímpicos de Inverno, a partir do ponto de vista da transformação e, por conseguinte, um enriquecedor e fundamental elemento de aceleração das propostas apontados no Plano Geral (1995) e, a garantia, de iniciar o processo de transformação, regeneração e reestruturação da morfologia urbana e suas infraestruturas. No entanto, as obras para abrigar os Jogos não teriam a capacidade de sozinhas regenerarem o tecido desarticulado pela linha férrea, ou os problemas sociais causados pela desativação do parque industrial da cidade.

Como solução a estes problemas a Prefeitura de Torino propõe uma vasta intervenção estrutural sobre um eixo ferroviário de quatro quilômetros de extensão de norte a sul da cidade.

Em 1987, o escritório Gregotti Associati - Milão, em conjunto com Settore Progetti di Riassetto Urbano e Progetto Speciale - Città di Torino, inicia os projetos que deveriam redesenhar o tecido urbano desarticulado e fragmentado pelas linhas férreas que chegam à cidade.

Denominado Spina Centrale, o projeto "corresponde a um processo de conclusão e de reorganização de grandes áreas, muitas delas abandonadas pelos usos industriais, com vista sobre a linha férrea, um remendo da área urbana a ser substituído em uma importante estrada estrutural (uma rua arborizada, com três faixas direção e dupla direção) e espaços verdes (parque da 'ampulheta', entre Orbassano e Corso Turati) pontuada por instalações de arte pública"(ALLEMANDI \& C. 2008, p. 21). ${ }^{150}$ 


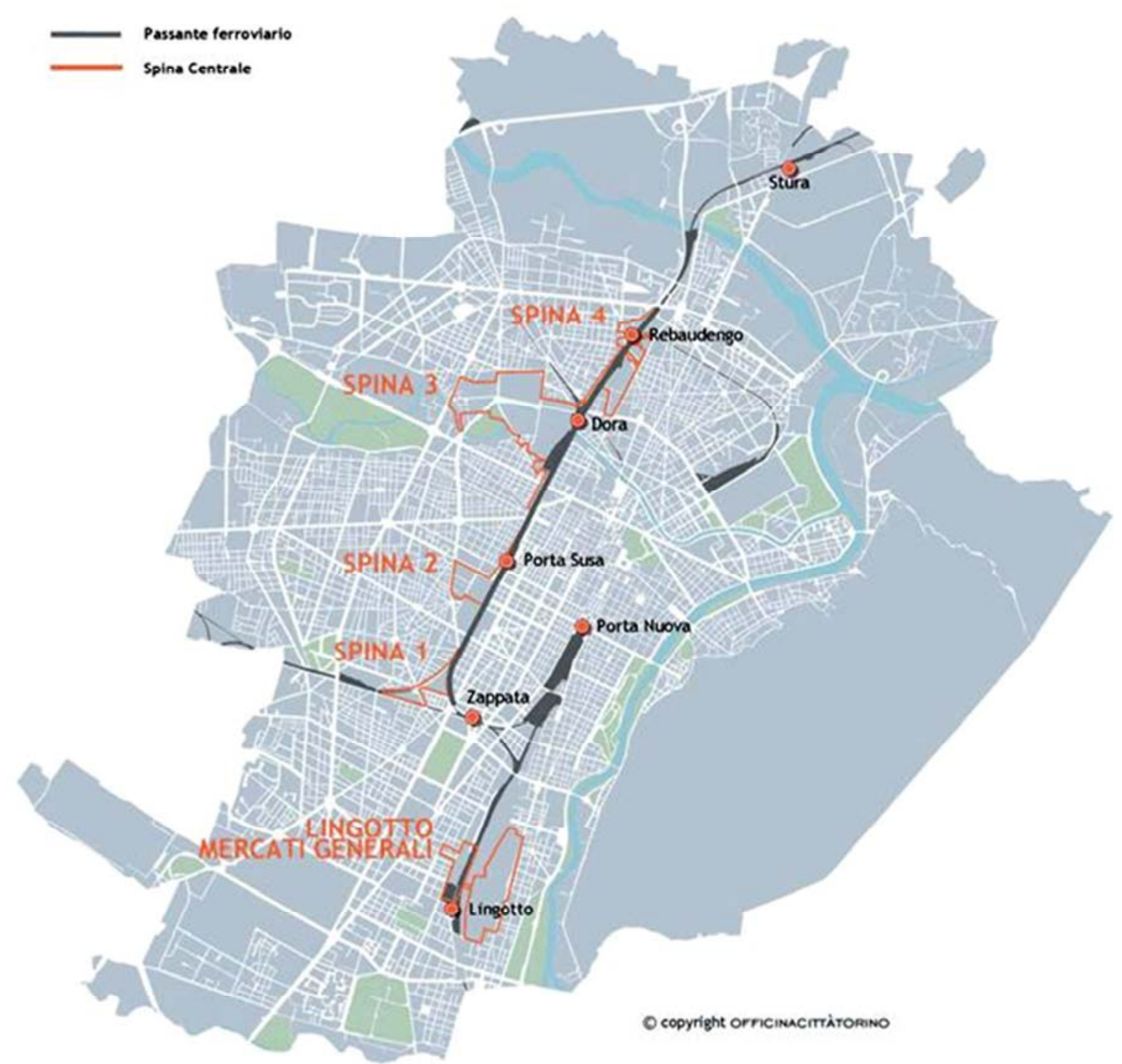

Figura 103. Implantação do Grande Projeto Urbano Spina Centrale e Passante Ferroviário Fonte: www.comune.torino.it, acessado em 20/10/12

Figura 104. Vista do Eixo da Spina Centrale em obras, 2005

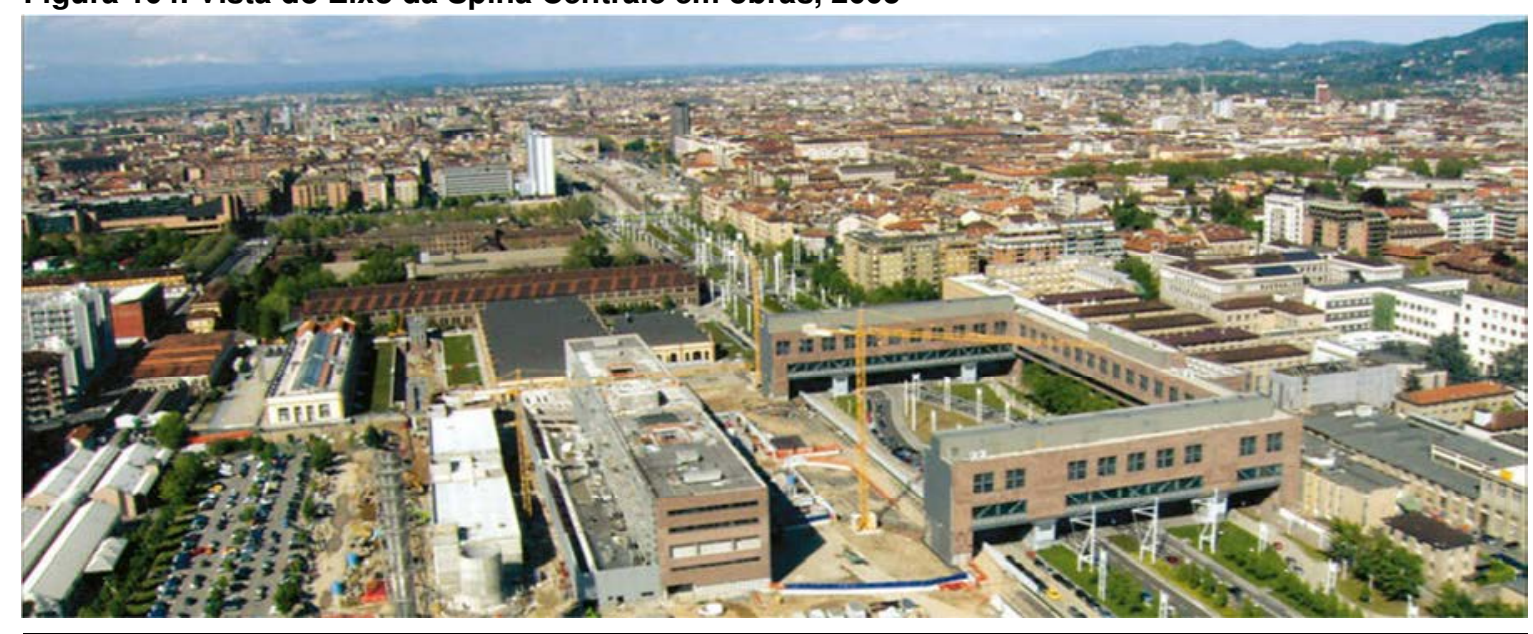

Corrisponde a un processo di completamento e riorganizzazione di grandi aree, molte delle quali dismesse da usi industriali, che si affacciano sul tracciato ferroviario: una ricucitura del tessuto urbano, sostituita in superficie da un'importante infrastrutura stradale (un viale alberato a tre corsie per senso di marcia e controviali) e da spazi verdi (il parco della 'clessidra', compreso tra largo Orbassano e corso Turati) punteggiati da installazioni di arte pubblica. 
A proposta centra-se no aterramento da rede ferroviária da cidade e a reabilitação de áreas abandonadas industriais, num total de mais de 2 milhões de metros quadrados. Divididos em quatro áreas (Spina 1, 2, 3 e 4) e o eixo rodoviário central de conexão, responsável pela "costura urbana" do tecido fragmentado pela ferrovia, desde a periferia (Lingotto) para o centro e leste da cidade.

"A existência de grandes plantas industriais e instalações que são abandonadas ou inativas, subutilizadas, representam em tamanho e localização, uma oportunidade única para renovação urbana, e para mudar a geografia da própria cidade, criando novos centros e elementos de consolidação urbana que se formaram no passado, uma fratura no consolidado tecido" (DANSERO, GOVERNA e EMANUEL 2003). ${ }^{151}$

A "Spina Centrale" inteiro foi dividida em quatro áreas principais. É geralmente identificado como "Spina 1" o setor à Sul, entre os Corsos Lyons, Mediterrâneo, Rosselli e Tirreno, onde, por sua vez, foram localizados as Oficinas de Materiais Ferroviários (Materferro) de propriedade das industrias automobilística FIAT, este complexo trata-se de uma área de 142.000,00 $\mathrm{m}^{2}$. O trecho chamado "Spina 2", no entanto, resultante das áreas abandonadas das antigas Oficinas de Manutenção, delimitado pelos Corsos Castelfidardo e Ferrucci, de um lado e Corso P.C. Boggio por outro, numa área de $340.000,00 \mathrm{~m}^{2}$, trecho este servido pela nova Estação Intermodal "Porta Susa" além de outras intervenções importantes como a duplicação do Politécnico de Torino, a Nova Biblioteca Central Municipal, Auditório e Área de Exposição. A chamada "Spina 3" é a área de maior transformação do PRG (Piano Regolatore Geral), no valor de mais de um milhão de metros quadrados; a área é dividida em sete distritos e subdividida em 15 subdistritos: Michelin, Valdocco - onde fica localizado o Parque Ambiental - Vitali, Valdellatorre, Paracchi, Savigiano e Ingest. O programa de regeneração "Spina 4" está localizado nas áreas industriais na periferia à norte da cidade. Cabe salientar que à sul encontramos o Centro Multiuso "Lingotto", antiga fábrica da FIAT transformado em Centro de Conferência, Auditório, Hotel "Le Méridien", Shopping Center com cinemas e supermercado, além da Pinacoteca "Giovanni e Marella Agnelli" (TALARICO 2003, p 04), projeto de autoria do arquiteto italiano Renzo Piano em 1983.

Em termos de área total de construção, cada setor (Spina) tem sua quantidade estimada conforme a capacidade de construção previstas nos planos definidos, como PRIU (Piani de Riqualificazione Urbana) que possui um valor mais significativos entre os demais, as "transformações contratadas" como ATS (Aree di Trasformazione a Sevizi) e ZUT (Zona Urbane di Trasformazione). A maioria das ferramentas utilizadas (planos urbanos) tem afetado principalmente o setor residencial em busca de "ajustes sociais" (COMUNE DI TORINO 1995), exceto no caso dos Piani Particolareggiati (PP) direcionados para a remodelação do tecido urbano e o campo produtivo (econômico); no geral, os índices urbanísticos são mais elevados para garantir a arrecadação de fundos da iniciativa privada para a consolidação das intervenções projetadas.

151. Tradução do autor, 2012

L'esistenza di grandi stabilimenti industriali abbandonati e di impianti ormai inattivi o sotto-utilizzati ha rappresentato, per dimensioni e localizzazione, una straordinaria occasione di rinnovo urbano, in grado di mutare la stessa geografia della Città, creando nuove centralità ed elementi di ricomposizione urbana in zone che hanno costituito, nel passato, una frattura nel tessuto consolidato. 


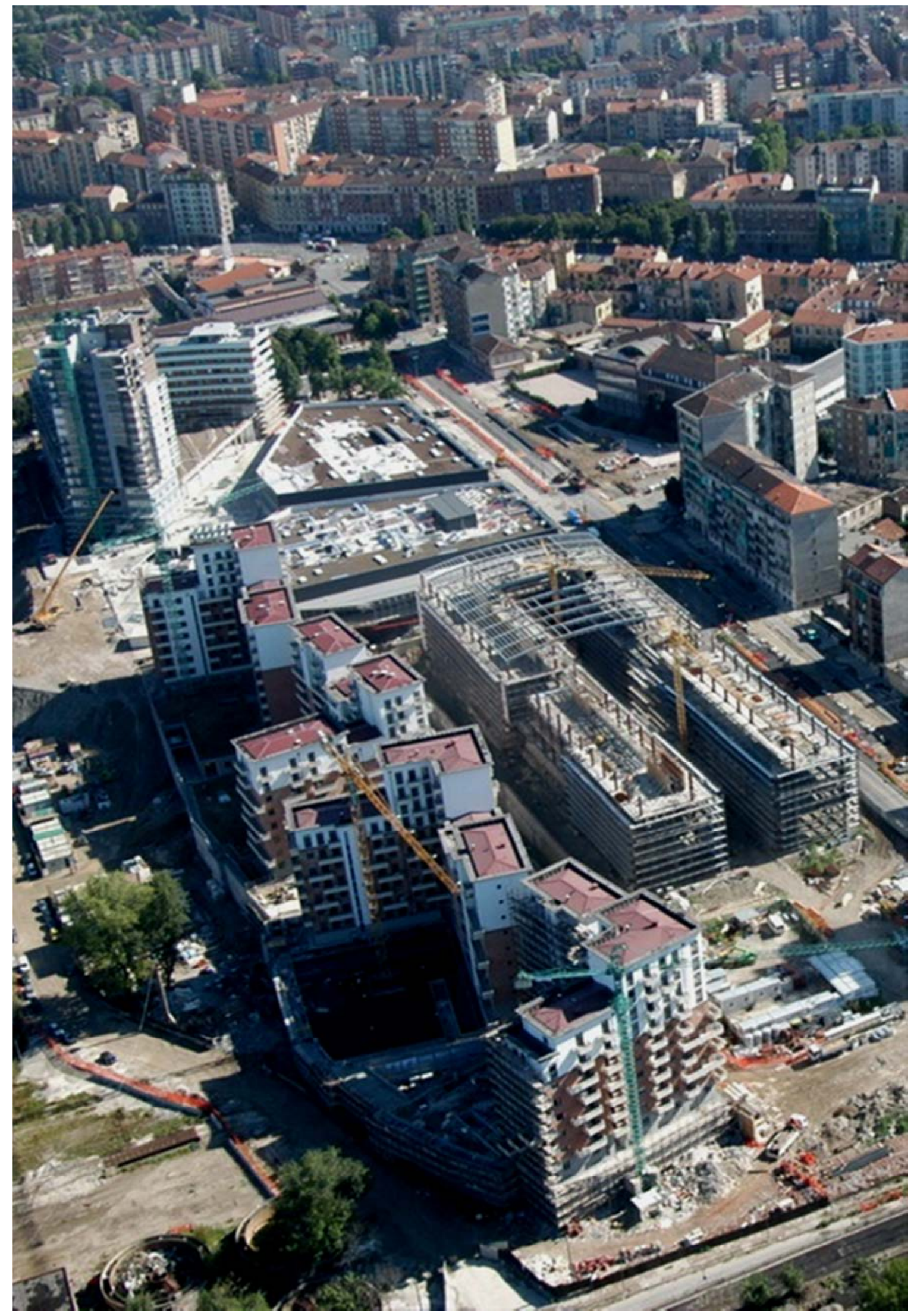

Figura 105. Obras em andamento da Spina 3, 2005

Fonte: Museo Torino 


\begin{tabular}{|c|c|c|c|c|c|c|c|}
\hline \multicolumn{8}{|c|}{ Spina Centrale - destinação dos usos previstos } \\
\hline & \multirow{2}{*}{$\begin{array}{c}\text { superf. total } \\
\mathrm{m}^{2}\end{array}$} & \multicolumn{2}{|c|}{$\begin{array}{l}\text { superf. proj. } \\
\text { residencial }\end{array}$} & \multicolumn{2}{|c|}{$\begin{array}{l}\text { superf. proj. outras } \\
\text { atividades }\end{array}$} & \multirow{2}{*}{\begin{tabular}{|c|}
$\begin{array}{c}\text { superf. proj. } \\
\text { total }\end{array}$ \\
$\mathbf{m}^{2}$ \\
\end{tabular}} & \multirow{2}{*}{\begin{tabular}{|c|}
$\begin{array}{c}\text { novas } \\
\text { residências }\end{array}$ \\
unidade \\
\end{tabular}} \\
\hline & & $\mathrm{m}^{2}$ & $\%$ & $\mathbf{m}^{2}$ & $\%$ & & \\
\hline Spina 1 & $163.336,00$ & $51.321,00$ & 67,67 & $24.514,00$ & 32,33 & $75.835,00$ & 1.509 \\
\hline Spina 2 & $147.228,00$ & $39.392,00$ & 42,98 & $52.267,00$ & 57,02 & $91.659,00$ & 848 \\
\hline Spina 3 & $1.002 .956,00$ & $348.375,00$ & 59,6 & $236.167,00$ & 40,4 & $584.542,00$ & 10.246 \\
\hline Spina 4 & $149.953,00$ & $77.492,00$ & 88,8 & $9.778,00$ & 11,2 & $87.270,00$ & 2.279 \\
\hline
\end{tabular}

Tabela 2. Destinação dos usos previstos no Projeto Urbano Spina Centrale

Fonte: Comune di Torino, 1995.

A tabela acima aponta a preocupação de garantir com a regeneração do tecido urbano uma densidade fixa habitacional que possibilite 0 uso constante durante 24 horas diárias.

A cidade habitada torna-se indispensável para o trabalho das políticas urbanas previstas nos Projetos e Planos. A qualidade de vida é representada neste Grande Projeto Urbano na implementação de usos mistos sobre o eixo da "Spina Centrale" e as conexões do tecido fragmentado durante mais de um século.

Neste sentido, podemos concluir que as estratégias urbanas utilizadas pela cidade de Torino, tendo como ferramenta de transformação da forma urbana, os grandes eventos ancorados sobre um Plano Geral (Piano Regolatore Generale di Torino 1995) redesenharam ao longo dos últimos 30 anos grande parcela do território da cidade.

As Olimpíadas de Inverno, em 2006 podem ser consideradas como o "start" para as propostas apontadas por Gregotti em 1995, no qual as intervenções, num primeiro momento atenderiam ao propósito do evento esportivo, deixando como legado um conjunto de obras de infraestrutura (linha 1 e 2 do metrô, parques urbanos requalificados) e um conjunto edilício que contribuíram para o processo de transformação para toda a escala da cidade. Outros eventos como Congresso Mundial de Arquitetura - XXIII UIA Torino 2008 e a Exposição por ocasião do 150ํ Aniversário da União de Itália resultaram num grande número de turistas para a cidade.

Já as propostas colocadas em prática a partir do Grande Projeto Urbano "Spina Centrale", chama a cidade a "reinventar o seu futuro e o desenvolvimento econômico, ambiental e físico" (CITTÁ DI TORINO 2008) com a finalidade de renovar o tecido urbano de uma metrópole do século XIX, com um programa complexo e capacidade de envolver toda a cidade num "pacto urbano" em busca de uma cidade que transformou sua força motriz econômica de cidade-industrial para cidade-cultural e terciária, colocando um grande número de planejadores, urbanistas e arquitetos a pensar a cidade para o século XXI. ${ }^{152}$

152. Entre os planejadores, urbansitas e arquitetos, temos: Renzo Piano, Vittorio Gregotti, Gae Aulenti, Cino Zucchi, Andreas Kipar, Mario Bellini, Benedetto Camerana, Norman Foster, Mario Botta, Arata Isozaki, Massimiliano Fuksas, Jean Nouvel, John Barrow, Aimaro Isola, além dos escritórios Latz+Partner e AREP dos arquitetos Jean-Marie Duthilleul e Étienne Tricaud, entre outros. 
Figura 106. Projeto PEC Porta Susa - Spina 2

Fonte: Comune di Torino, 2010

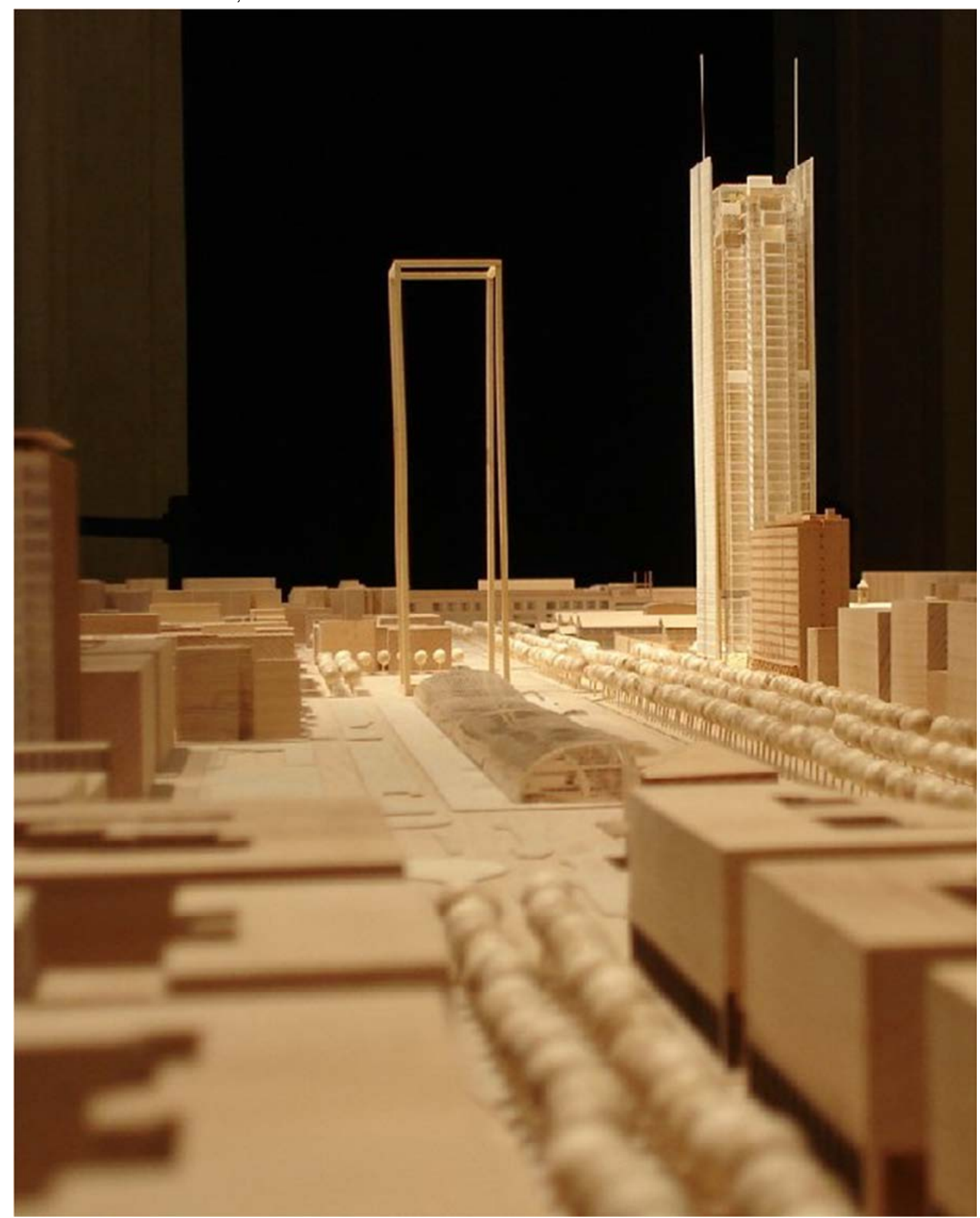




\subsection{Torino Porta Susa: PEC Spina 2}

Os Planos Estratégicos Urbanísticos para a cidade de Torino definem uma visão de um futuro desejável, à ser alcançado por estratégias e ferramentas específicas de renovação, regeneração e reabilitação do tecido urbano degradado, tendo como estímulo três visões, segundo o governo municipal: Torino como metrópole européia; Torino tecnológica, uma cidade de ação e know-how; Torino tomadora de decisões, a inteligência do futuro e da qualidade de vida (COMUNE DI TORINO s.d.); justificativas dadas à história e os recursos da cidade, no qual as visões se complementam e constituem como um todo na busca desta nova "vocação" urbana pelo qual a cidade vem se empenhando com investimentos prioritários em grandes programas sociais, de educação, investigação, tecnologia e mobilidade, em diferentes níveis, constituindo oportunidades e vantagens decisivas para o desenvolvimento econômico e urbanístico para o crescimento da cidade.

Destinado a se tornar um dos Novos Centros Urbanos de Torino, Spina 2 está delimitada pelo eixo ferroviário, entre Corso Vittorio Emanuelle à Francesco Ferrucci, concentrado em mais de 340 mil metros quadrados na fronteira com o centro da cidade, que na segunda metade do século XIX foram localizados diversos equipamentos como o Matadouro Público, Mercado de Gado, Presídio, adicionados ao longo dos anos a um conjunto de edifícios de apoio aos serviços ferroviários: Oficina Nebiolo, Westinghouse e Oficina de Reparos da Estrada de Ferro (le Officine Nebiolo, Westinghouse e le Officine Grandi Riparazioni delle Starde Ferrate, em italiano).

O Plano Urbano aprovado em 1995, de autoria dos arquitetos Gregotti e Cagnardi, foi capaz de perceber a importância de um processo integrado de transformação da cidade a partir de sua infraestrutura, ou melhor, pela sua mutação por meio dos espaços degradados e subutilizados resultantes da desativação do parque industrial da cidade, "o enterramento da linha férrea e sua substituição no cenário urbano, com uma grande avenida, quer dizer Spina Centrale" (D'ASCIA 2010, p 71). ${ }^{153}$

O eixo ferroviário, que para muitas cidades, foi o "fio condutor" da transformação urbana e econômica, hoje é um tema muitas vezes provocador e prioritário de um processo de regeneração urbana e da retomada de novas possibilidades de sua vocação, urbana e econômica, em que o eixo tornou-se o elemento divisor do tecido urbano, neste momento encarado como uma "reserva urbana" capaz de gerar novos cenários com a garantia do redesenho de sua morfologia urbana.

A presença da estação ferroviária Porta Susa, caracterizada como objeto de polaridade, foi tomado como o elemento principal da transformação deste eixo - Spina 2 inicialmente como objeto que deve "costurar" o tecido urbano entre os bairros: Centro Crocetta, San Paolo - Cenisia - Pozzo Strada - Cit Turin - Borgata Lesna, e San Donato - Capitol - Parella. Desta forma, a presença da Nova Estação Porta Susa deve cumprir a função de elemento articulador do tecido fragmentado, mas também articular as novas formas de transporte urbano pensados para a cidade, a região do Vall de Susa, além da integração entre Torino e Lyon - França, através da implantação do trem de alta velocidade (TAV) entre os dois países - Itália e França.

Neste sentido, o Projeto Urbano Spina 2 tem por objetivo, "ajustar o tecido urbano dividido pela linha ferroviária" (CITTÀ DI TORINO 1997) recompondo os fragmentos urbanos junto ao Centro Histórico de Torino com profundas transformações de seu cenário e composição da forma urbana existente.

153. Tradução do autor, 2012

l'interramento della ferrovia e la sua sostituzione sulla scena urbana con un grande boulevard, detto la Spina Centrale. 


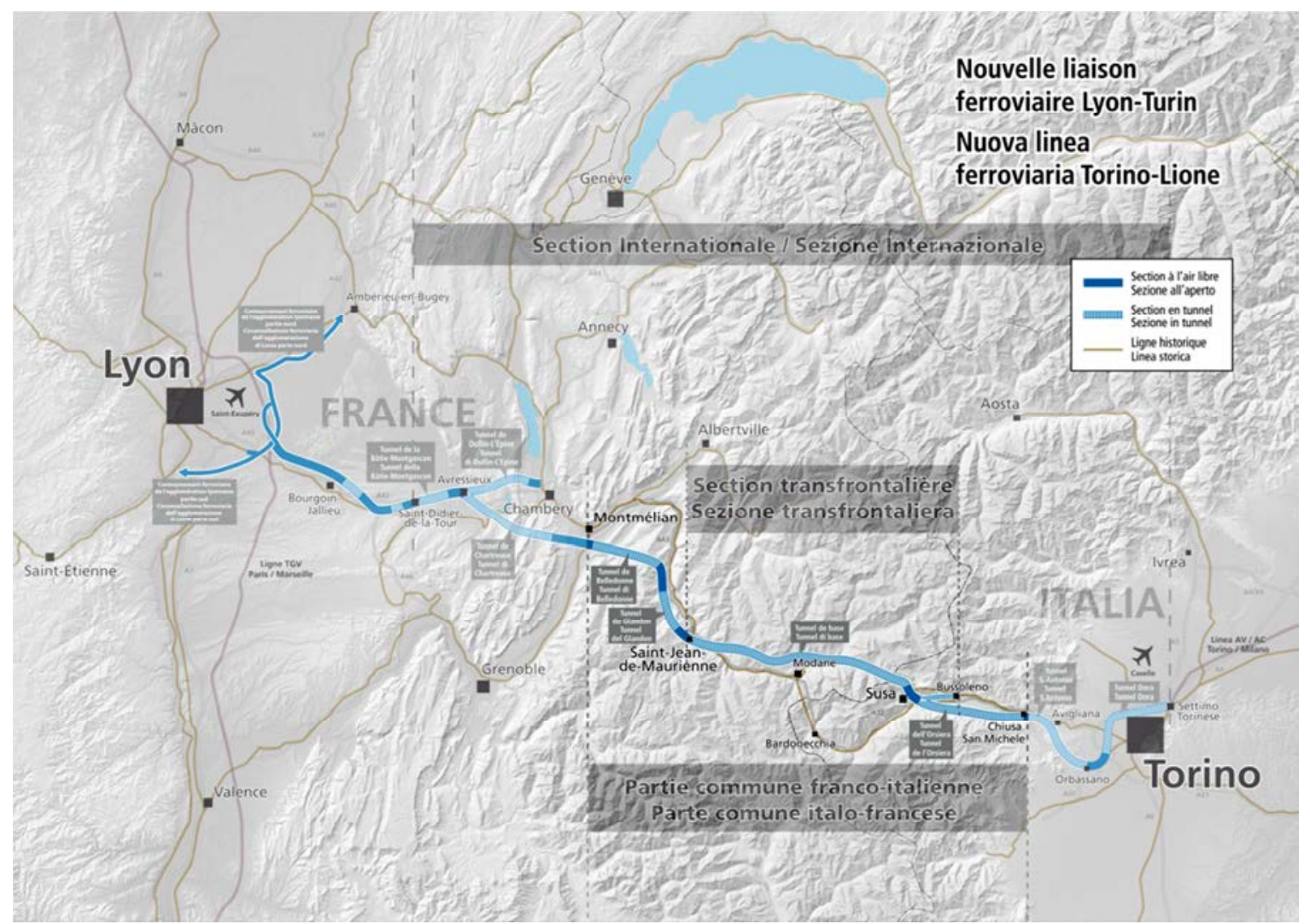

Figura 107. Projeto Nova Linha TAV Lyon - Torino

Fonte: Revue de géographie alpine

Figura 108. Vista da Área de Intervenção Spina 2 - Porta Susa, entre os bairros Centro - Crocetta, San Paolo - Cenisia - Pozzo Strada - Cit Turin - Borgata Lesna, e San Donato - Capitol - Parella

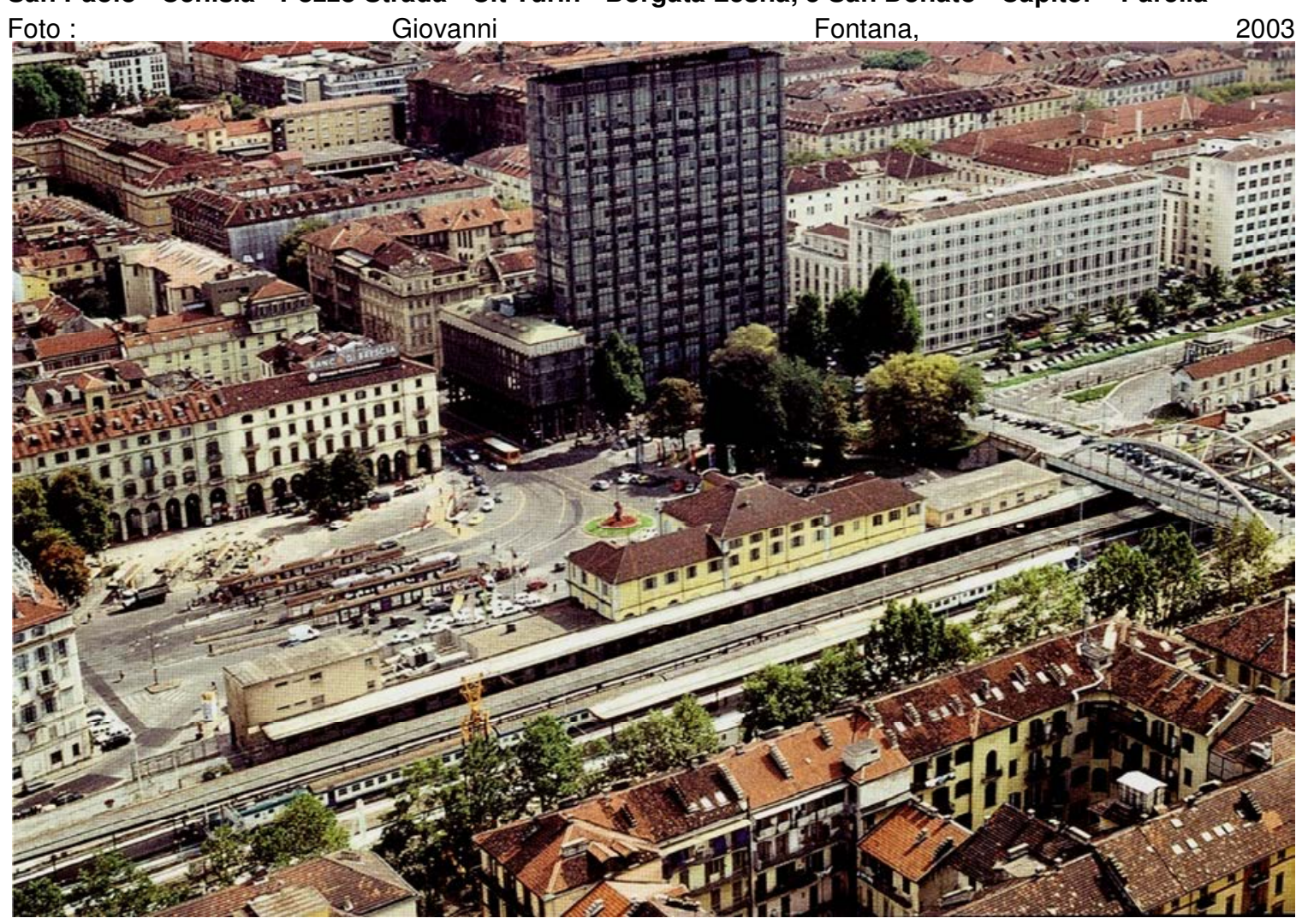


A antiga estação, projetada em 1856-57 pelo engenheiro Edoardo Pecco, é mantida como "memória viva" da história deste setor da cidade, como marco zero da transformação urbana em que o Plano Urbanístico se propõe. A nova avenida que surge sobre a linha férrea (agora enterrada) capaz de gerar novos espaços urbanos neste trecho da cidade, conectando os diversos setores do Plano Geral - Spina Centrale.

Os diversos projetos propostos sobre o eixo - Spina 2 - são colocados na condição de "peças" ou "coisas" urbanas que articuladas entre si, ampliam as possibilidades da cidade regenerar seu tecido a partir dos novos usos e a dinâmica entre a forma urbana existente e a proposta; Projetos como: Oficina Grandi Riparazioni e Carceri Nueve, transformadas em espaços de exposições e convenções, ampliando a densidade flutuante deste setor significativamente; novas residências, comércio e serviços propostos na "única porção de natureza particular, tanto na propriedade quanto suas

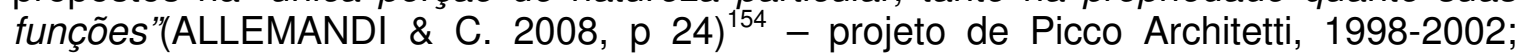
Cittadella Politecnica, a cidade universitária está localizada numa área de aproximadamente 100 mil metros quadrados, sobre o novo eixo da Spina Centrale, acomodando a expansão para oeste do Politécnico de Torino, sua proximidade com a sede histórica da Faculdade de Engenharia ea presença da nova residência para os estudantes, tendo como responsáveis o escritório Gregotti Associatti Milano (masterplan) - 1997-2010; Impianto Polisportivo, projeto de Mario Bellini Architetti Milano - 2004-2007, o centro de esportes é parte, em conjunto com o novo parte público, de uma grande variedade de edifícios de esportes e culturais; Centro direzionale Intesa Sanpalo, projetado entre 2006-2008 e com construção prevista para ser entregue entre 2011-2012, proposto pelo arquiteto Renzo Piano, o projeto deve ligar o edifício ao tecido urbano e à vida da cidade(RENZO PIANO s.d. $)^{155}$, o novo edifício se coloca como "símbolo" da Torino do século XXI, com um arranha-céu de 160 metros de altura, deve sediar um dos principais grupos bancários europeus.

No entanto o maior protagonista urbano do Projeto Spina 2 está centrada na construção da Nova Estação Intermodal Porta Susa, que cumpre a função de articular o tecido urbano fragmentado, promover novas conexões de Porta Susa com os demais bairros da cidade, com uma enorme gama de meios de transportes oferecidos (TAV - Torino Lion, Trem Metropolitano, Metrô - linha 2) além de novas transposições por passagens em nível de automóveis entre o Centro Histórico e os demais bairros à oeste, e pedonal por diversas passagens pela própria estação, ampliando a permeabilidade do tecido urbano até então interrompida pelo tramo ferroviário norte-sul.

A intervenção de Porta Susa pode representar uma espécie de ponte entre o passado e o futuro da cidade em rede em uma série de eventos, ou usos concatenados entre si, passagens, ligações e transportes de usos coletivos conectados por uma praça linear protegida pela cobertura de vidro que protege estes usos.

"A estação Porta Susa, graças à sua posição, está destinada a se tornar a principal estação ferroviária e do espaço público que liga duas partes da cidade, antes dividida"(ALLEMANDI \& C. 2008, p 29). ${ }^{156}$

\footnotetext{
154 . Tradução do autor, 2012

Unica porzione di natura privata, sia nella proprietà che nelle funzioni.

155. Tradução do autor, 2012

The project should link the building to this urban tissue and city life.

156. Tradução do autor, 2012

La stazione di Porta Susa, grazie alla propria posizione, è destinata a divenire il principale scalo ferroviario cittadino e grande spazio pubblico di collegamento tra due parti di città prima divise.
} 


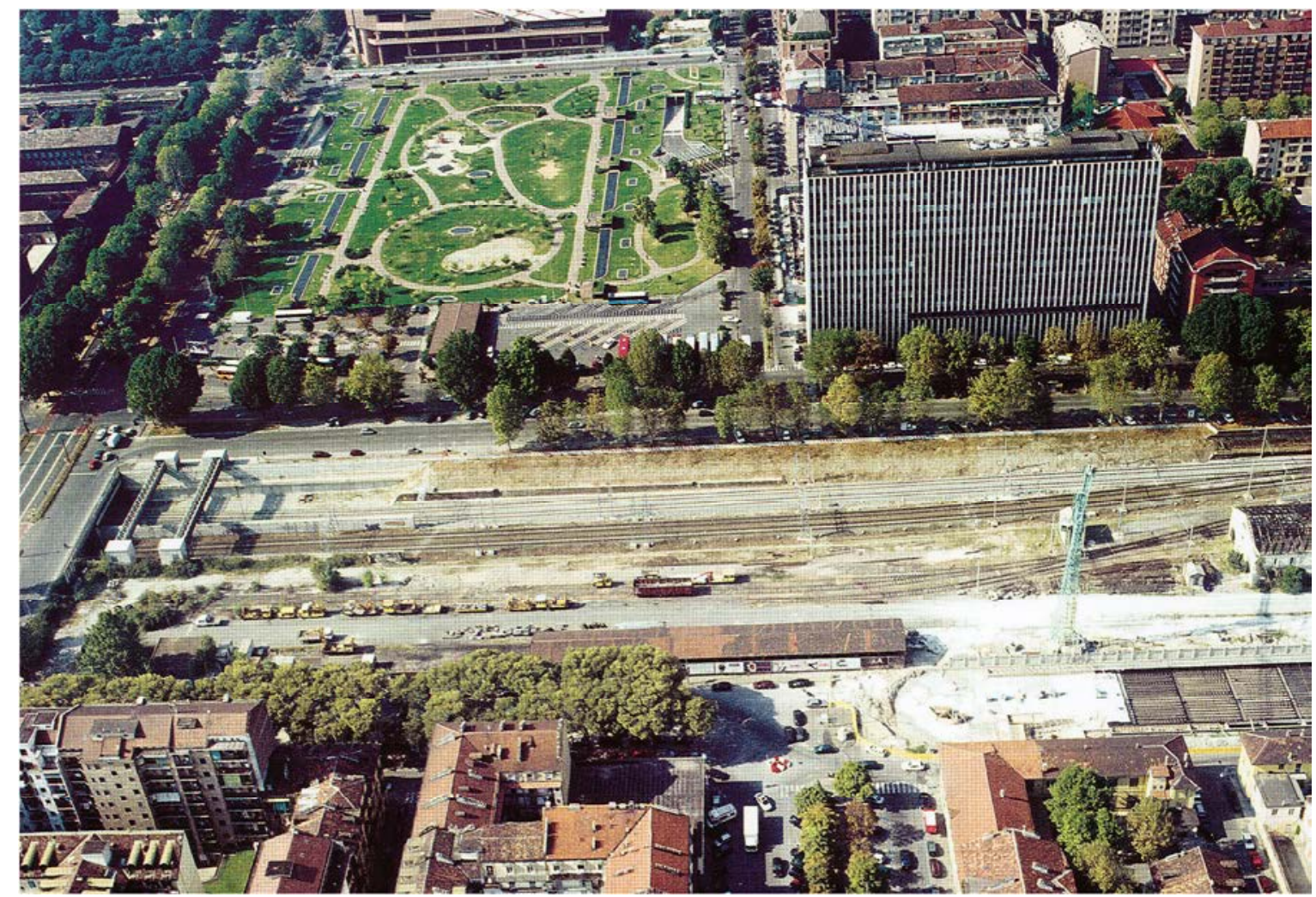

Figura 109. Início das obras da Estação Porta Susa - Spina 2

Foto : Giovanni Fontana, 2005

Figura 110. Obras em andamento da Estação Porta Susa - Spina 2

Foto: Giovanni Fontana, 2010

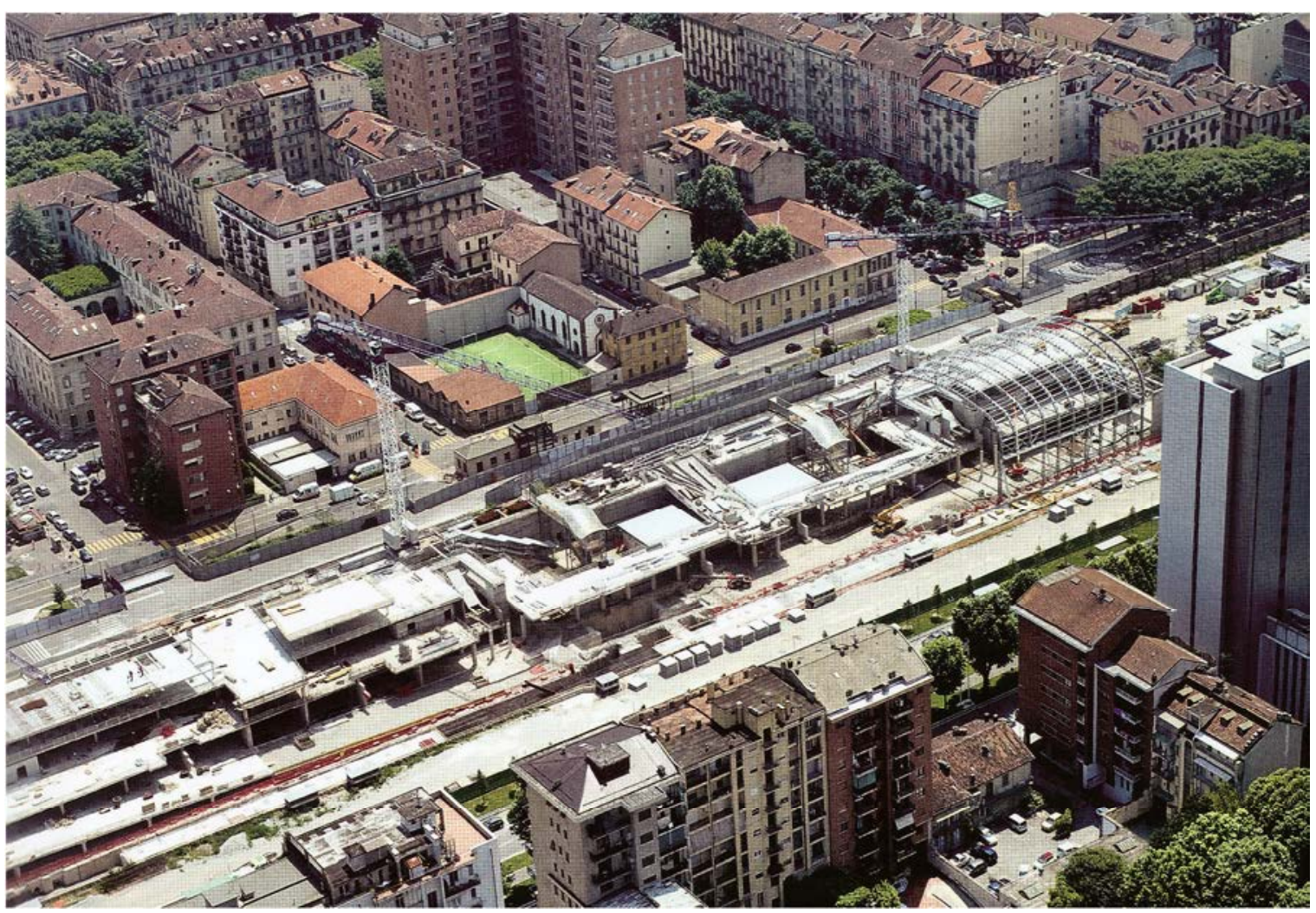


Como elemento físico, a Nova Estação Porta Susa não altera o desenho do tecido urbano consolidado, tão pouco pretende formatar uma nova morfologia urbana das quadras do Centro Histórico (leste-Torino do século XIX) e os bairros à oeste criados a partir das primeiras décadas do século XX. No entanto, a forma com que os autores propõem sua implantação, "um edifício que cobre a calha ferroviária com o surgimento de novos espaços livres para a cidade" (STUDIO AREP 2004), ${ }^{157}$ possibilita a permeabilidade entre os eixos viários existentes em ambos os lados da cidade, vias como Grassi, Susa, Duchessa lolanda, Avigliana e Corso Matteotti, se colocam agora na condição de conexões pedonais perpendiculares entre Corso Bolzano (leste) e Corso Inghilte (oeste), atual Via Spina Centrale.

Neste sentido, segundo Silvio D'Ascia, a estação se coloca como um lugar urbano, em continuidade direta com a cidade e seus caminhos, que refere-se tanto a nossa imaginação além do contexto meramente físico para sugerir a presença na cidade de um "outro lugar", "a inspiração que se refere à essência da idéia de viagens..."(2010).

O edifício da estação - um túnel sinuoso de aço e vidro compostos por 106 arcos diferentes uns dos outros e 385 metros de comprimento - torna a construção em uma espécie de símbolo, um símbolo do movimento de presença de viajar de um ponto a outro, sobre uma cidade contemporânea, onde o trem, antes motivo da fragmentação do tecido, agora objeto que "desaparece" sob a nova Avenida Spina Centrale, abrindo caminho a novos percursos entre os dois lados da cidade.

O volume horizontal transparente é interrompido pela Torre de Serviços propostos como uma "figura tipológica da nova urbanidade" (STUDIO AREP 2004), uma nova forma de pensar a Torino verticalizada do século XXI.

O conceito da torre como um lugar de passagem na rota dos transportes urbanos, reforça a ideia de "pontuar" o novo tecido urbano que surge com a proposta da Spina Centrale (eixo norte-sul), expressado sobre um volume de esteriometria simples, um retângulo de $32 \times 43$ metros e 160 metros de altura, dentro do qual uma multiplicidade de usos (escritórios, hotel, exposições, convenções) definem um livre jogo de sólidos e vazios, resultando em uma morfologia vertical que se desprende das existentes em seu entorno já consolidado entre os séculos XIX e XX.

"A partir desta estrutura básica, é nas duas extremidades do núcleo central que são introduzidos alguns volumes de formas transparentes de um ou dois níveis que 'animam' os grandes espaços vazios verticais definidos para norte e sul das duas lâminas da torre e cobertura com jardins verticais" (D'ASCIA 2010, p 82). ${ }^{158}$

A proposta de verticalizar a paisagem urbana neste trecho da cidade resultou em princípio, na composição e organização funcional e tipológica do espaço, a fim de ser capaz de gerar maior dinâmica diária sobre esta nova centralidade proposta pelo Piano Urbanistico Spina Centrale.

157. Os projetos da Nova Estação Nova Susa são de autoria do Studio AREP (Jean Marie Duthilleul) - Paris, Silvio D’Ascia Parigi, Agostino Magnaghi - Torino.

158. Tradução do autor, 2012

A partire da tale impianto di base, è alle due estremità del nucleo centrale che si introducono solo puntualmente alcuni volumi trasparenti di uno o due livelli che animano i grandi vuoti verticali definiti a nord ed a sud dalle due lame della torre ed rivestiti da giardini verticali. 


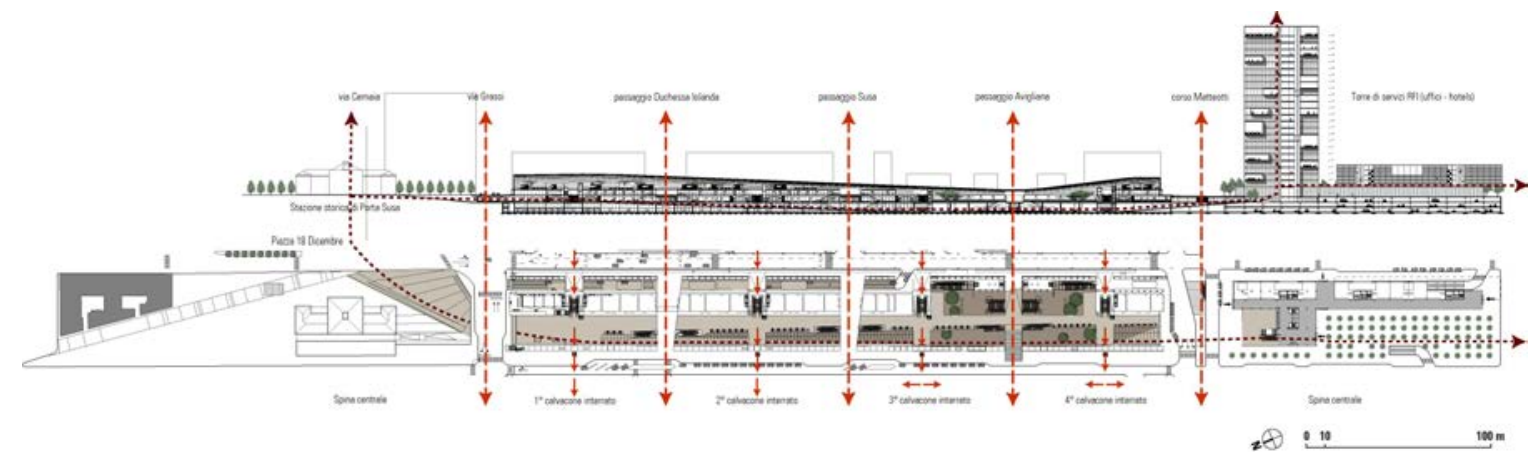

Figura 111. Projeto da Estação Porta Susa

Fonte: Comune di Torino, 2011

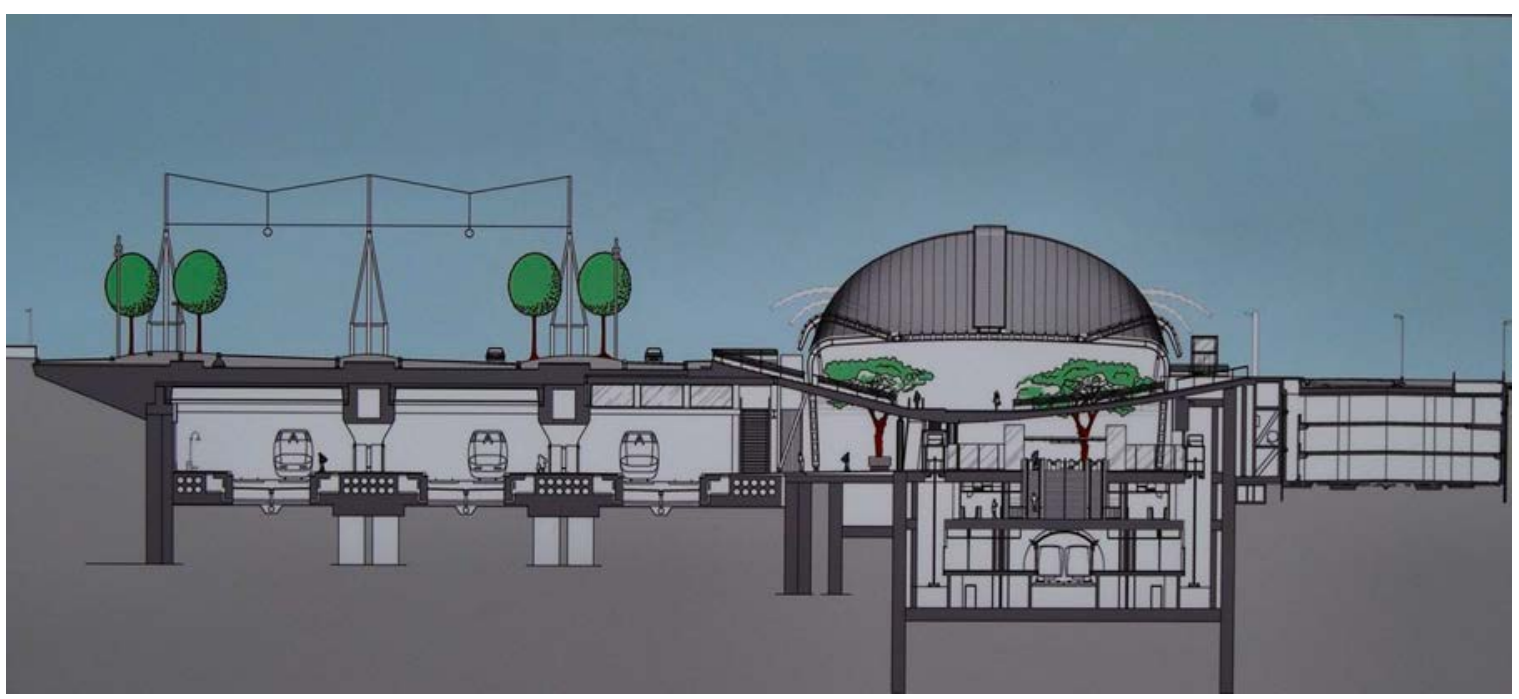

Figura 112. Corte Transversal sobre a Estação Porta Susa e Avenida Spina Centrale

Fonte: Comune di Torino, 2011

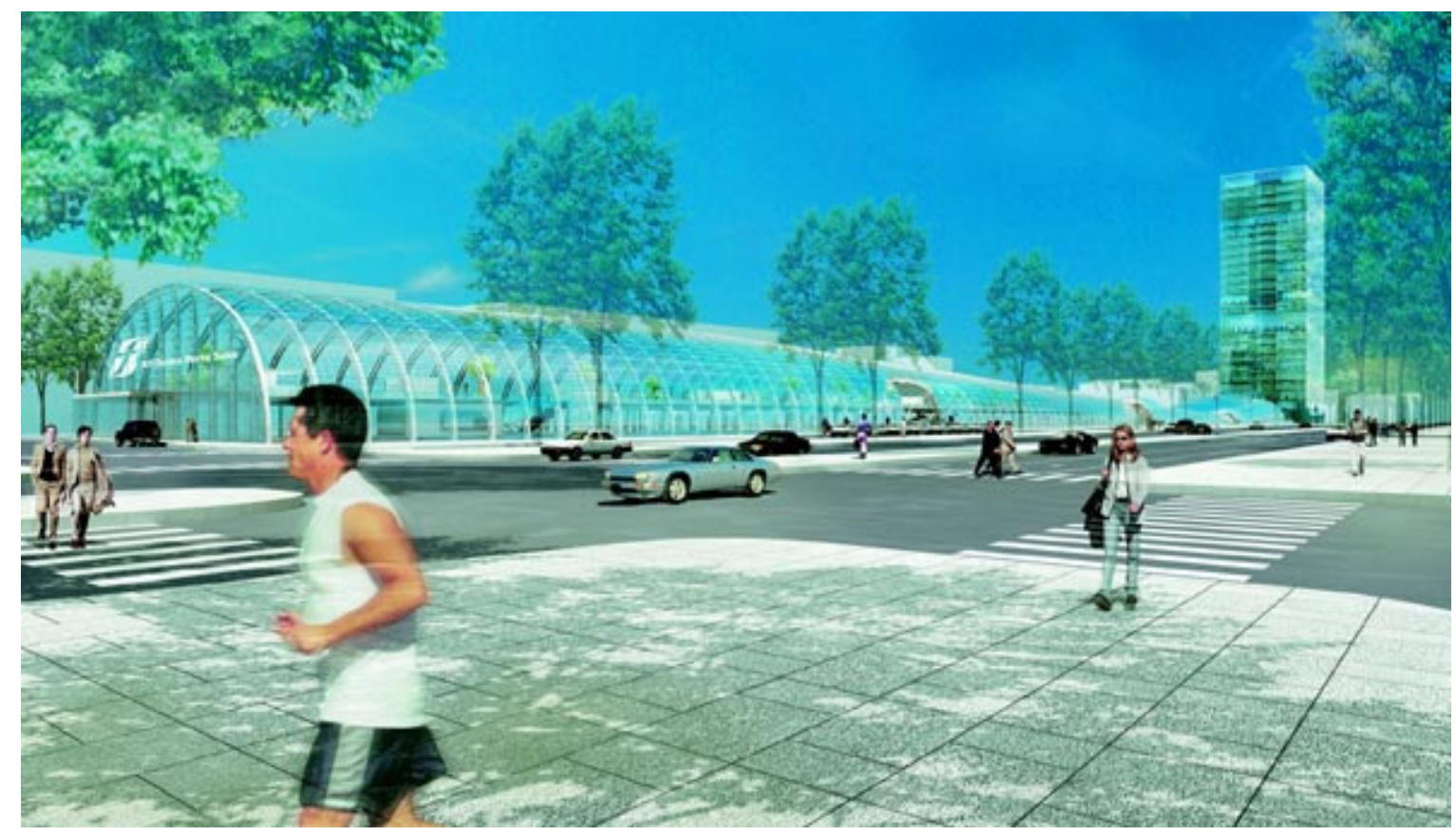

Figura 113. Maquete volumétrica da Nova Estação Porta Susa

Fonte: Grupo AREP, 2011 


\subsection{Considerações Finais}

A cidade, que sempre foi construída com seus vazios, lugares públicos de encontro, intercâmbio e interação entre indivíduos, muitas vezes resultantes da agregação entre períodos históricos da transformação urbana da cidade, é capaz de gerar mudanças radicais nas estruturas existentes e/ou anteriores, numa "mutação constante" entre os espaços construídos (edifícios) e os não construídos (vazios urbanos).

Torino desde sua origem romana tem presenciado a transformação de sua morfologia urbana ligada diretamente aos eventos políticos e econômicos que possibilitaram o crescimento de seu território muito além das muralhas que preservaram e protegeram a cidade até meados do século XVIII.

A promulgação da cidade como a primeira capital do país eleva Torino a condição e oportunidade de transformação de seu território de forma excepcional, consolidando-a numa das cidades mais belas e modernas, segundo Silvano Fei, no qual as largas ruas, elegantes palácios e sua morfologia racional (FEI 1971) Ihe garantiu uma contínua expansão desde o final de 1500, sob o reinado de Charles Emmanuel.

O século XIX foi marcado como o período das expansões do tecido urbano da cidade, que ocupa um vasto território em dois sentidos, a sul até o rio Po e a norte junto ao núcleo de Borgo Dora. Em meados deste século (1853), foi tomada a decisão de se expandir a cidade a oeste do "centro histórico" (antigas muralhas romanas) surgindo neste momento o núcleo Porta Susa, local este estabelecido a tornar-se uma nova entrada da cidade a partir de Genova. Além da própria estação foram implantados na região outros equipamentos de serviços públicos como a prisão, matadouro e quartel da cidade, direcionando para este setor um novo vetor de crescimento da cidade.

A implantação de novas estruturas e equipamentos urbanos resultou positivamente sobre os cenários e a paisagem da cidade, sendo comparada as grandes metrópoles como Paris e Londres, consagrando Torino a uma das capitais de potencial econômico. No entanto, a transferência da capital para Florença e Roma, causou uma série de profundas consequências sociais e econômicas, mas também a oportunidade para repensar o papel da cidade.

Estas condições levaram Torino a "apostar" numa nova "vocação" como estratégia para o desenvolvimento social, econômico e urbano, a decisão em transformar a cidadeadministrativa em cidade-industrial, concomitantemente ao nascimento da estrada de ferro na Região de Piemonte, produziu efeitos de crescimento do tecido urbano vertiginoso e a realocação dos espaços produtivos dentro da cidade, onde antes localizados às margens dos rios, agora é a ferrovia o pólo de atração das principais indústrias que se instalam entre o primeiro e segundo anel de crescimento da cidade.

Sem dúvida a estratégia utilizada naquele momento, no intuito de redirecionar a cidade para outro vetor econômico e social alcançou resultados positivos, e Torino "obteve" um conjunto significativo de indústrias tecnológicas e mecânicas, como por exemplo, a FIAT que será considerada a mais importante para a cidade e o país, da mesma forma 0 surgimento deste parque industrial induziu a instalação de escolas técnicas que dessem suporte as pesquisas e produção das novas indústrias, como o Politecnico di Torino, ${ }^{159}$ que se torna um importante instrumento de pesquisa e produtor de técnicos e mão de obra especializada.

159. O Politécnico de Torino, fundada em 1859, é a universidade mais antiga da Itália, classificadas entre as melhores universidades de engenharia do mundo (entre as 75 melhores em 2011), além das engenharias automotiva, aeroespacial, biomédica, computação, outros cursos são oferecidos como arquitetura e engenharia arquitetônica. 


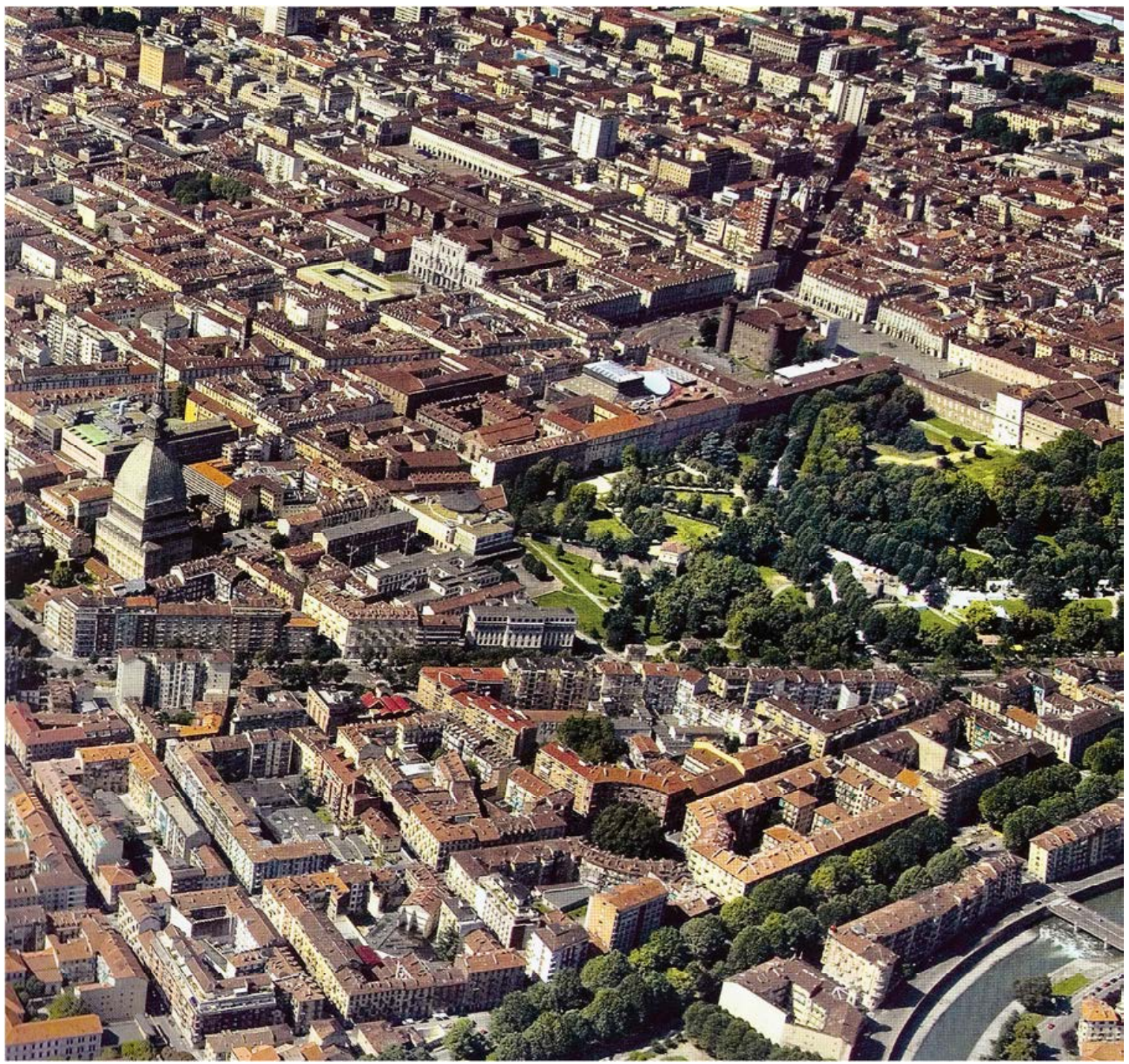

Figura 114. Vista aérea de Torino

Foto: Giovanni Fontana, sd

Figura 115. Vistas da cidade de Torino

Foto: Elvis Vieira, 2011
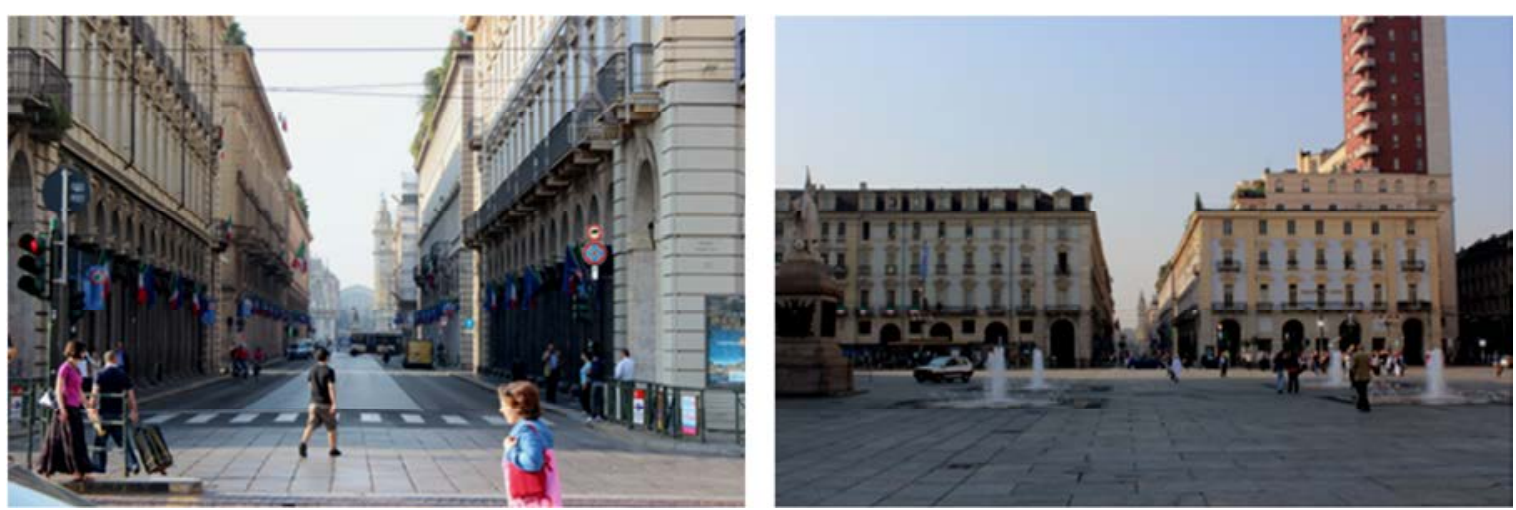
Como forma urbana as contínuas transformações e desenvolvimento urbano ao longo dos anos provocaram, ao mesmo tempo, o crescimento do tecido de forma contínua e "repetitiva", o rompimento da malha urbana controlada pelas muralhas da cidade romana sobre o território ainda pouco explorado viabilizou um desenho de quadras regulares que resultou em formas edificatórias igualmente regulares. A ocupação controlada no qual o térreo se integra com a dinâmica da cidade, protegida pelas varandas cobertas resultantes do alinhamento ao meio foi a partir do primeiro andar até o quarto, constituiu uma forma urbana peculiar no qual é possível caminhar pela cidade protegido das intempéries (calor, chuva, frio), além da conexão entre as quadras pelas arcadas que se multiplicam sobre os principais eixos da cidade, conexões entre pontos de referência urbana que se articulam como redes de equipamentos urbanos, parques e edifícios do poder.

Por outro lado, o parque industrial consolidado entre o segundo e terceiro anel de crescimento da cidade, em particular as áreas a sul e norte junto à linha férrea e o rio Po, que após sua contínua desativação das atividades fabris, resultaram num grande número de áreas vazias e/ou subutilizadas que necessitavam ser redesenhadas para atender as demandas de uma cidade contemporânea e sua condição como capital da Região de Piemonte.

Neste sentido, sediar os Jogos Olímpicos de Inverno foi o primeiro passo para consolidar as propostas apontadas no II Piano Regoalatore Generale di Torino, em 1995, e repensar a cidade como sede de pesquisa de alta tecnologia, consolidando o setor terciário como estratégia de garantir, como desenvolvimento econômico e social, uma nova vocação urbana para a cidade.

Já os grandes projetos estruturantes da forma urbana foram direcionados como "instrumentos de transformação"(COMUNE DI TORINO 1995) redesenhando os vazios produzidos da desativação do parque industrial e suas atividades ferroviárias que exigiam grandes áreas de manobras sobre o tecido urbano.

O Progetto Spina Centrale ofereceu condições de costurar o tecido urbano fragmentado pela linha férrea ou as grandes plantas industriais na periferia da cidade, criando novas condições de centralidade urbana, integrando fisicamente, funcionalmente, e morfologicamente parte da cidade.

No caso de Spina 2 - Porta Susa o enterramento da via férrea e a implantação da Nova Estação Ferroviária sobre o leito permanentemente fragmentando o tecido urbano, não somente garantiu a modernização dos sistemas de transportes coletivo, tanto de ordem local como regional e nacional, com a consolidação de uma estação intermodal conectando o eixo norte-sul aos demais bairros da cidade através da linha 1 do Metrô, o trem urbano que integra a cidade a Região de Piemonte e o TAV conectado Torino a Lion - França, reforçando a idéia de sua importância como Cidade Global.

Como instrumento da transformação do desenho urbano da cidade, o trecho da Spina 2 ofereceu condições de ajustar o tecido urbano, divididos até então pelo eixo ferroviário, por meio de um novo elemento articulador entre a "Cidade Velha" a leste e o tecido urbano do século XIX a noroeste de Torino. 


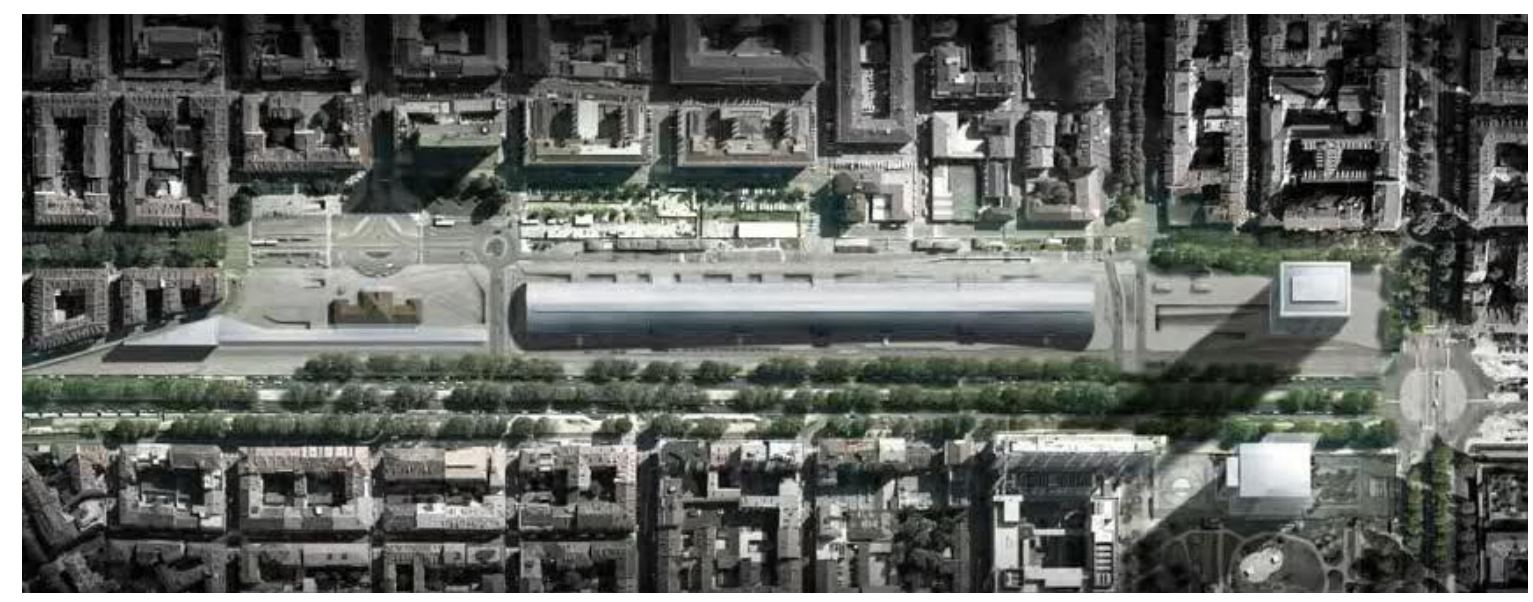

Figura 116. Implantação da Nova Estação Porta Susa na malha urbana existente Fonte: Comune di Torino, 2011

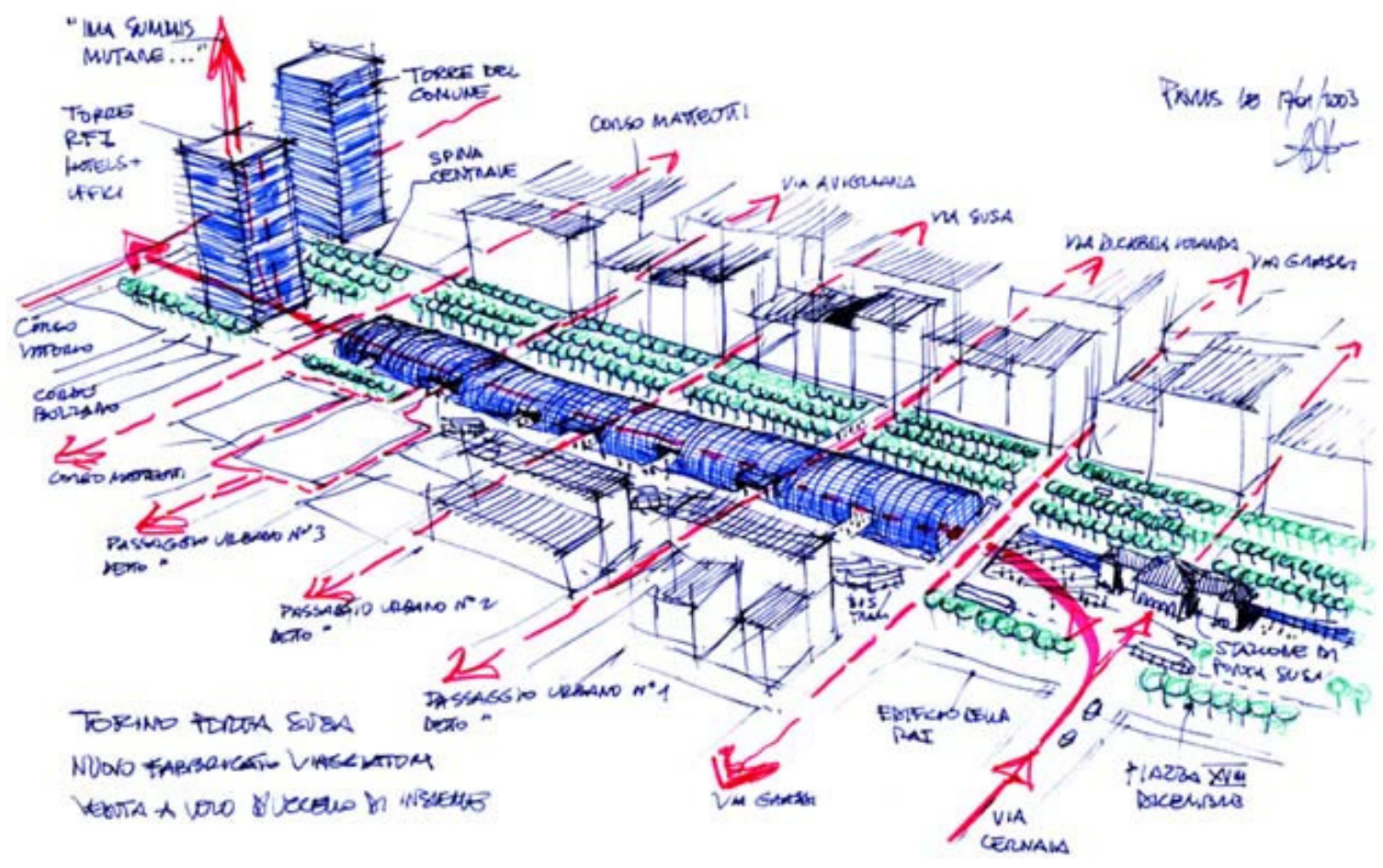

Figura 117. Croquis da implantação da Estação Porta Susa

Fonte: Grupo AREP, 2000

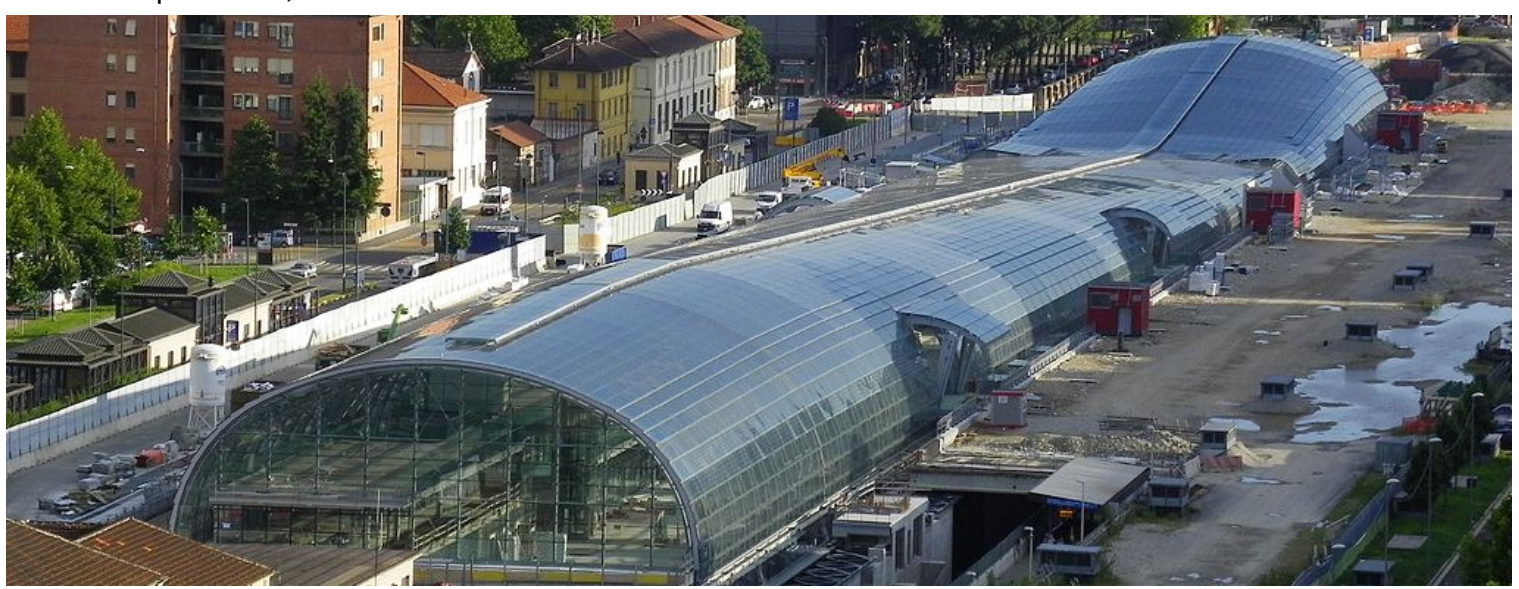

Figura 118. Estação Porta Susa parcialmente em funcionamento

Foto: Elvis Vieira, 2011 
As intervenções previstas no eixo norte-sul da Spina Centrale leva em consideração a "reconquista de centenas de milhares de metros quadrados disponíveis a partir do 'abandono' e transferência das áreas industriais e históricas" (ASSOCIAZIONE TORINO INTERNAZIONALE 2000) capaz de regenerar o tecido desarticulado e transformar a paisagem de aproximadamente 30 anos atrás, se produziam carros, caminhões, trens, chapas de aço, em áreas com novos edifícios residenciais e serviços, mas também estruturas que marcam o futuro econômico da cidade.

Neste sentido, a Nova Estação Porta Susa estabelece uma relação entre os dois lados da cidade fragmentada. É certo que sua presença não alterou o desenho das quadras de seu entorno, visto que sua forma urbana se permaneceu consolidada há muitos anos. Porém, o surgimento de um novo equipamento de transportes de caráter local, regional e nacional consolidou esta região da cidade como pólo de atração de novos investimentos públicos e privados, reforçando a estratégia do poder local em constituir uma nova centralidade a oeste da "Cidade Velha".

Ainda assim, a Nova Estação, projeto do Grupo AREP - França, estabelece a continuidade do tecido a partir da permeabilidade transversal com que o edifício se coloca diante dos eixos viários existentes entre os dois "lados da cidade' (Cidade Velha - Porta Susa).

Em análise ao projeto, observamos a preocupação em transformar a Gare da Estação num "lugar de vida e passagem" (STUDIO AREP 2004). Um lugar urbano, em continuidade direta com a cidade e seus caminhos, que se refere tanto a imaginação além do contexto meramente físico, como referência urbana na cidade, tanto de um lado, relacionando a estação ao conjunto edilício existente da Cidade Velha, a Estação histórica e a Praça XVIII de Dezembro, como estabelecendo a leitura de uma nova imagem para a cidade que se redesenha a partir da via Spina Centrale, tendo como pano de fundo a Torre de Serviços, que devem se comportar como "figuras vivas" no novo cenário urbano da cidade.

Sua implantação ao longo do eixo norte-sul da Spina Centrale, numa extensão de 400 metros de comprimento, reforçou a ideia de um "edifício ponte" entre os dois lados da cidade. As extremidades da Gare dão lugar a novas conexões sobre o nível da cidade, configurando os acessos e possibilitando mais flexibilidade e alternativas de rotas sobre a malha viária existente, seja a norte pela via Giuseppe Grassi (oeste) para a via Fratelli Ruffini (leste) que se conectam a um importante eixo viário norte-sul (corso Gionvanni Agnelli) desde as indústrias da Mirafiori FIAT Factory, passando pelo Estadio Olimpico até a região de Susa, ou a nova conexão a sul da estação Porta Susa pelas vias Giovanni Carlo Cavalli e corso Giacomo Matteotti que integra a região de Susa à Piazza Carlo Felice, junto a Estação Porta Nuova. Já o volume da estação é "interrompido" a cada 100 metros pelas passagens internas à Gare que possibilita a permeabilidade pedonal entre os dois lados da cidade (Cidade Velha e Susa), no qual estão dispostas como continuidade do tecido urbano ora interrompidas pela chegada da via férrea há séculos. Neste sentido, estas passagens podem fornecer ao transeunte um conjunto de conexões pelo hall principal da nova estação que a transforma numa continuidade da cidade, com sua dinâmica própria e eixos estabelecidos a partir do tecido urbano préexistente. 

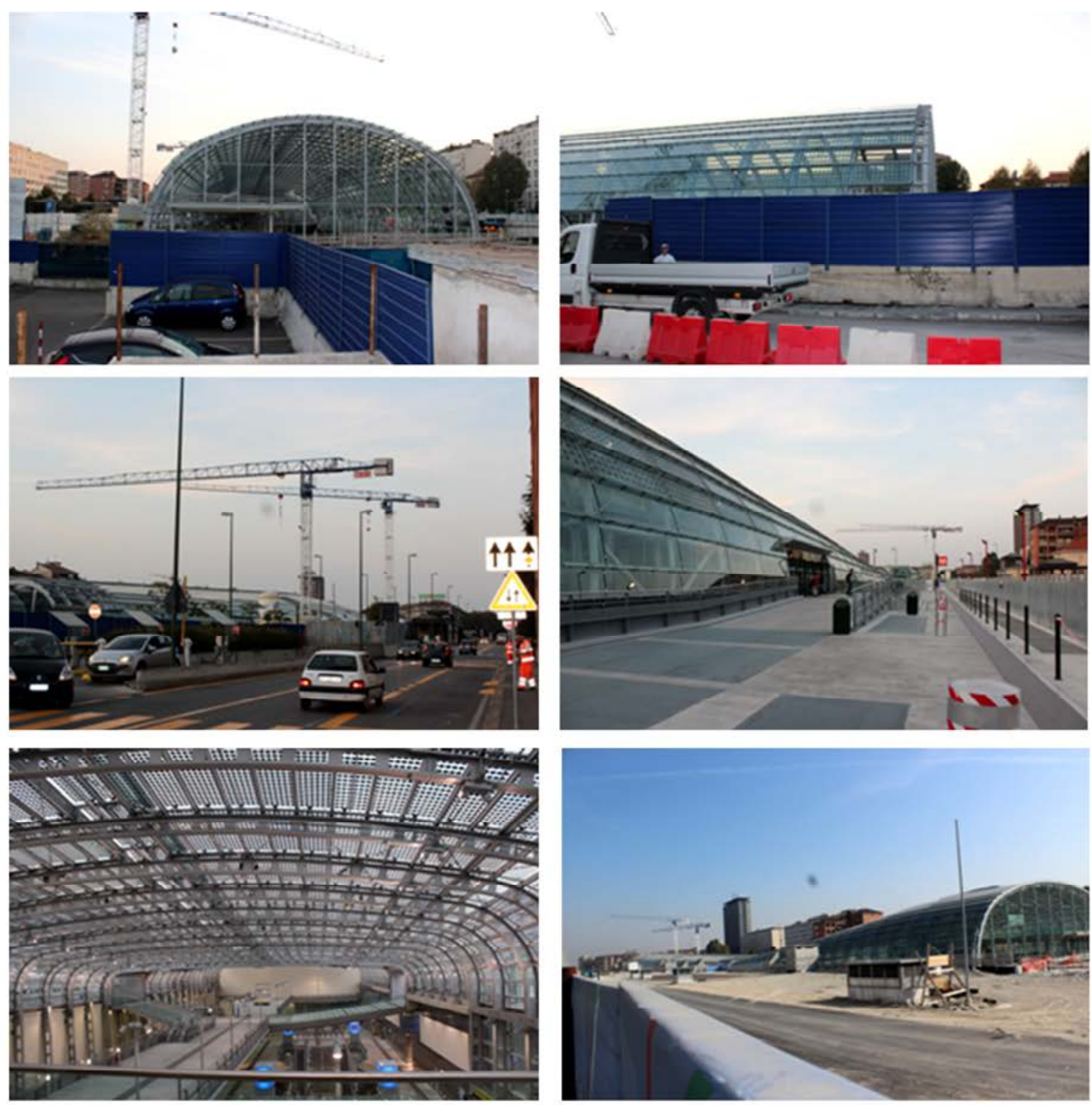

Figura 119. Obras da Novas Estação Porta Susa - Spina 2

Fotos: Elvis Vieira, 2011

Figura 120. Montagem da Cobertura Metálica da Nova Estação Ferroviária Fonte: Comune di Torino, 2010

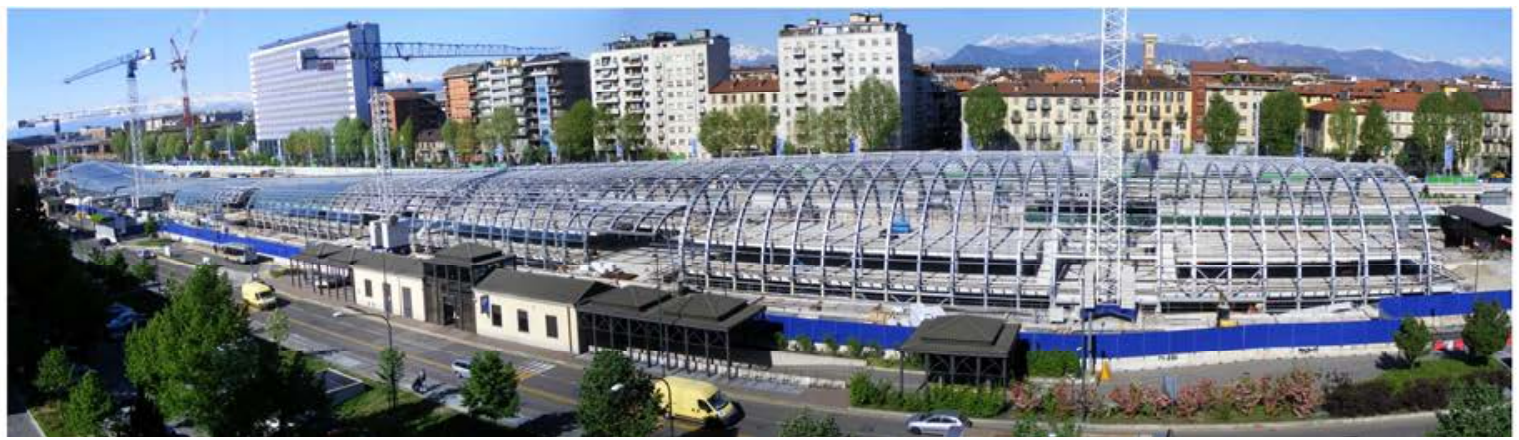


Por outro lado, as extremidades da estação são tratadas como "portas da cidade" (STUDIO AREP 2004), criando-se um eixo pedonal (norte-sul) entre a Praça XVIII de Dezembro (Estação Porta Susa histórica) e o novo complexo da Torre de Serviços, localizada a sul da nova estação. Assim, o volume longitudinal da estação em conjunto com o vertical da torre foi reconhecido como uma grande alameda coberta, remetendo as varandas das quadras regulares da região central de Torino.

Estas conexões fazem da estação o centro de gravidade entre os sistemas de transportes (trem, metrô, ônibus) e o resgate aos novos percursos pedonais possíveis. A singularidade de um nó que se destaca como ponto de inflexão na silhueta da cidade, o encontro entre o passado e o futuro, no qual a intervenção sobre a calha ferroviária possibilitou redesenhar de forma direta e indireta sua forma urbana, seja pela garantia da permanência de elementos históricos, como a antiga estação Porta Susa, pelo fortalecimento das atividades do entorno ou a atração de novos investimentos da iniciativa privada (escritórios, serviços, hotel) como elemento estruturador de nova centralidade sobre este território.

A integração da Nova Estação Porta Susa com a cidade seja pela sua transparência exibida, seja pela grande cobertura de vidro (400 x 40 metros) ou pelas possibilidades de percursos com que o usuário, transeunte ou habitante daquele território tem agora a sua disposição, repensa o intercâmbio entre o lugar público da cidade contemporânea e a nova forma de urbanidade para a cidade do futuro, com seus usos múltiplos e integrados entre si e possibilitando um novo cenário para a cidade.

Para tanto, as intervenções previstas para o Progetto Spina Centralle, apesar de apontar como tema central, segundo o I/ Piano Regoalatore Generale di Torino(1995), a ampliação dos serviços públicos e uma sequência de novos espaços urbanos ao longo de seu eixo de intervenção, a proposta do escritório Gregotti Associates não considerava a alteração da forma urbana sobre as quadras já consolidadas, apesar de sua "degradação" urbana e paisagística ser nítidas por conta de seu contínuo "esvaziamento" das áreas férreas e industriais ao longo dos anos. No entanto, o que percebemos após mais de uma década e meia (17 anos) da aplicabilidade do PRG e seus contínuos projetos (Spina 1, 2, 3, 4), são num primeiro momento um investimento maciço do poder público (municipal, regional, nacional) no intuito de requalificar os espaços degradados e/ou subutilizado, assim como possibilitar a conexão entre os espaços fragmentados, dando condições ao poder privado de "reagir" aos impulsos à uma nova vocação urbana e social sobre estes trechos do território, e assim confirmando a reabilitação como instrumento de transformação do tecido urbano.

Uma breve visita onde há pouco tempo foram os antigos pátios de manobras, galpões de manutenção abandonados e áreas subutilizadas, é possível notar as transformações sobre o novo eixo que se formou a partir da Spina Centrale, permitindo que a cidade gerasse "novas centralidades da integração entre os diversos períodos da constituição da cidade, construída a partir da idéia do espaço público como excelência desta transformação" (MORANDI 2009, p 08), ${ }^{160}$ fortalecendo a idéia da Cidade Global, sempre inquieta, sempre em movimento.

160. Tradução do autor, 2012

Nuovi centri di integrazione tra idiversi periodi della costituzione della città, costruita sull'idea di spazio pubblico come l'eccellenza di questa trasformazione. 



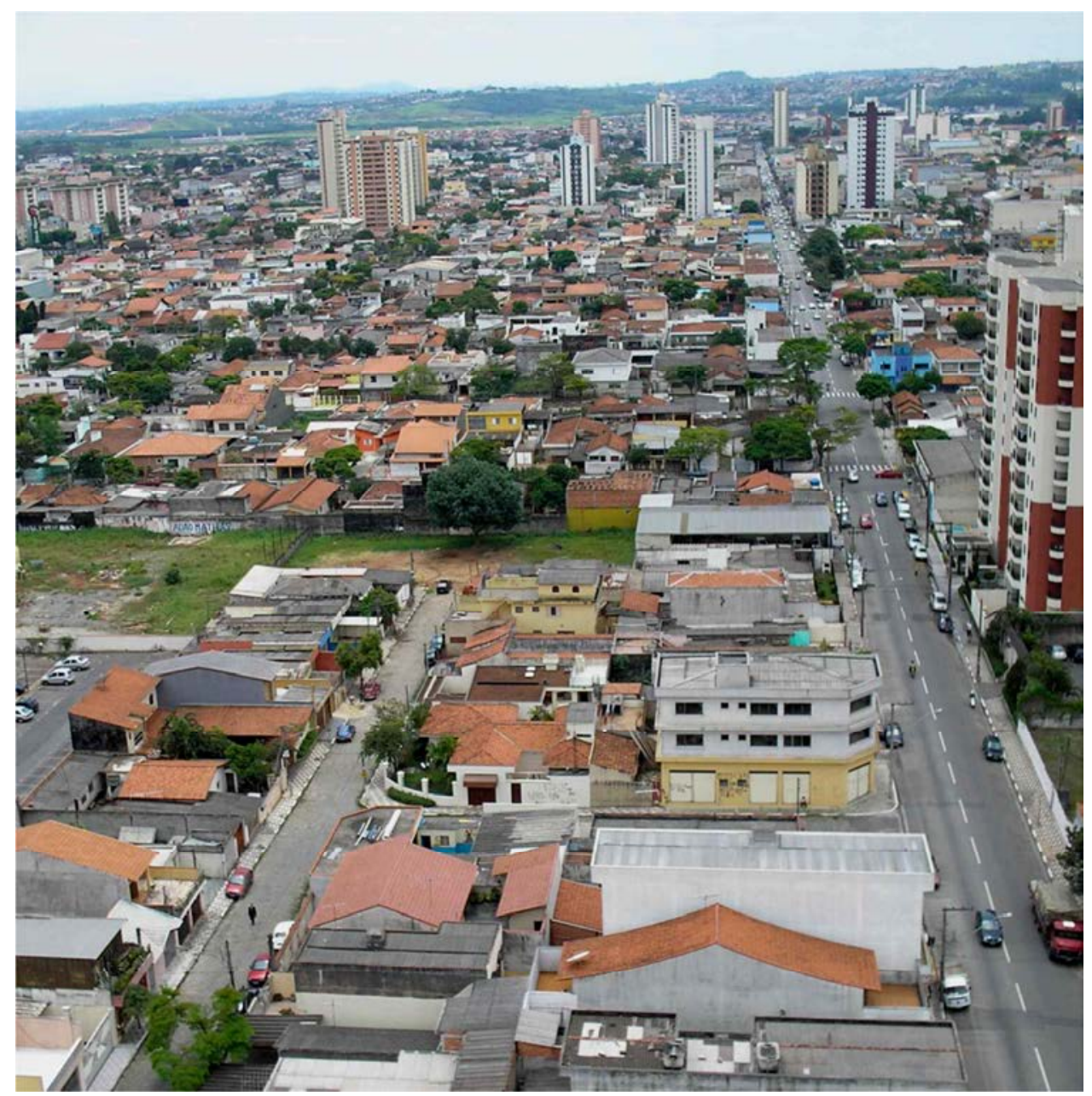

PARTE III

SUZANO E A CONSTRUÇÃO DE UM NOVO TERRITÓRIO 



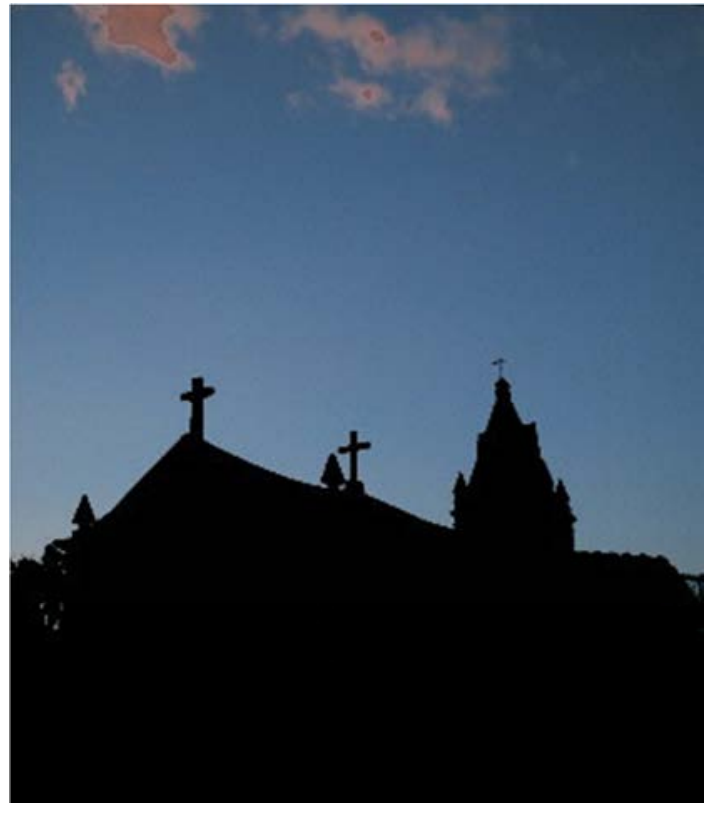

Capítulo 5

A configuração urbana da cidade 



\subsection{A consolidação do primeiro núcleo | Baruel}

A história da cidade de Suzano deve ser relatada e compreendida sobre o reconhecimento de dois instantes e dois locais significativos na formação de sua configuração urbana hoje existente, um primeiro momento num território ainda pertencente à Mogi das Cruzes no vilarejo do Baruel e num segundo, a chegada da ferrovia nos Campos de Mirambava, atualmente o centro urbano da cidade.

"No início do século XVII, já existe a vila de São Paulo de Piratininga, a umas duas léguas a Oeste de M'Boigy Mirim, a atual Mogi das Cruzes,foi sendo conhecido como um sertão, que se situava no local onde, séculos depois, viria a ser instalada a nossa Suzano"(AZEVEDO 2004, p 17).

Em análise as plantas antigas de São Paulo, em especial as do início do século XIX, retratam a reduzida expansão da cidade na época. Porém é notório a existência da cidade de Mogi das Cruzes à leste da capital paulista, conforme defesa do historiador Isaac Grinberg, cuja primeira ocupação da então vila se deu entre 1610 a 1640, aproximadamente 56 anos após a fundação da Vila de Piratininga pelos jesuítas.

Estabelecer neste momento um período para esta análise da configuração urbana é necessário antes recorrer às ocupações sobre o território brasileiro, as explorações lusitanas e, consequentemente, as transformações de todo o planalto paulista, e em particular os diversos núcleos indígenas, "que habitavam a região entre a vila de São Paulo e a de Sant'Anna, especialmente os pequenos Guainás, ou Guaianases, como os chama Taunay, entre outros"(AZEVEDO 2004, p 64).

O Tratado de Tordesilhas, assinado em 7 de junho de 1494, estabelecia que seriam portuguesas as terras encontradas até 370 léguas a oeste do Arquipélago de Cabo Verde. Após a descoberta de Pedro Álvares Cabral em 1500, legitimado por este documento, o Brasil passaria por várias divisões administrativas.

Por outro lado fica claro que a intenção da Coroa Portuguesa não era exatamente de ocupação sobre as "novas terras", mas de simples exploração com o intuito de gerar lucros ao país europeu. Inicialmente, a exploração do pau-brasil, seguido posteriormente a outros gêneros como o açúcar e o tabaco, mais tarde por pedras preciosas e o ouro; e em seguida o algodão e o café.

Neste sentido, as terras brasileiras foram ocupadas essencialmente por indígenas da nação tupi, que se dividiam nos grupos tupiniquins, tamoios, tupinambás e termiminós, de São Vicente para o Norte, enquanto que do limite desta capitania, ao sul de Cananéia, a ocupação era dos guaranis. 
Figura 121.Esquema de Demarcação fixada pelo Tratado de Tordesilhas, 1494

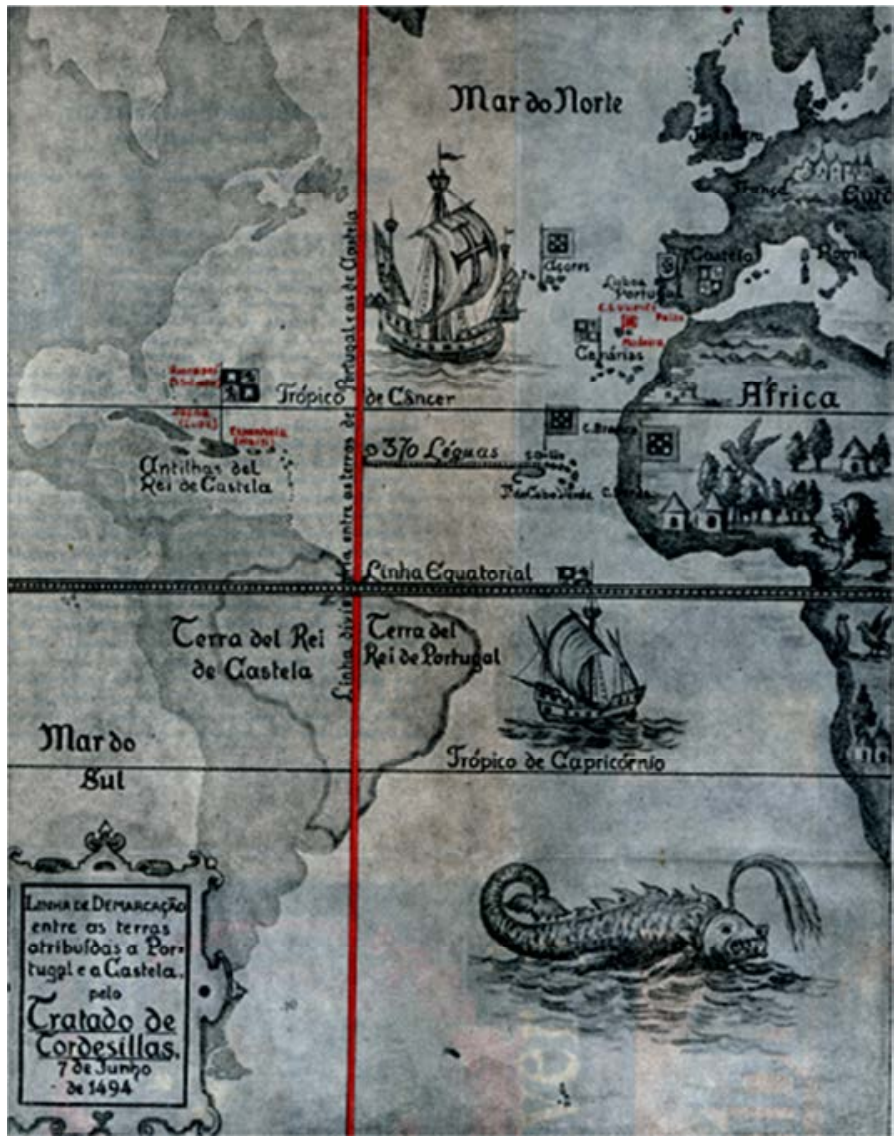

Fonte: www.igeo.ufrj.br, acessado em 15/09/2010

"Especialmente, na região que nos interessa aqui e agora, a da Capitania de São Vicente, no século XVI, o domínio indígena era dos tupiniquins. E seu grande líder era, sem qualquer sombra de dúvida o chefe Tibiriçá" (AZEVEDO 2004, p 40, grifo nosso). ${ }^{161}$

No entanto, as ocupações portuguesas levaram cerca de meio século para uma exploração além da "muralha verde", a Serra do Mar por muito tempo foi à barreira física para uma ocupação sobre o interior do país, que até então, se davam no litoral, principalmente em São Vicente, primeira cidade de nosso país. ${ }^{162}$

Em 1554, foi fundado no Planalto de Piratininga, entre os rios Tamanduateí e Anhangabaú, não muito distante do rio Tietê, conhecido naquele momento por rio Anhembi, o Colégio dos Jesuítas por José de Anchieta, ${ }^{163}$ aldeamento este com o intuito de catequizar os índios daquela região onde mais tarde se tornou a Vila de Piratininga. "Vila essa que entra em imediato desenvolvimento, sendo ponto de passagem necessários a todos que se dirigissem em qualquer sentido pelo interior vindo do litoral, primeiro, da Vila de São Vicente, depois, da Vila de Santos"(AZEVEDO 2004, p 49).

161. Suami descreve em seu livro que o "grande rei, senhor daqueles campos", como dizia Pero Lopes de Souza no seu "Diário de Navegação", o "grande rei" Tibiriçá era o chefe da aldeia de Piratininga.

162. O marco da fundação da Vila de São Vicente se deu em 22 de janeiro de 1532 por Martim Afonso de Souza. Alguns cronistas e historiadores modernos defendem a existência desta vila desde 1503.

163 . José de Anchieta ainda noviço chega a Vila de São Vicente em 1553, que por ordem de Padre Manuel da Nóbrega irá fundar o aldeamento no Planalto de Piratininga. 
Apesar dos constantes ataques indígenas a Vila de São Paulo de Piratininga continuava em pleno crescimento. Em 1589, a população da vila seria de mais de 150 fogos, o que corresponderia, conforme interpretação de Taunay (1961 (3 tomos)), a aproximadamente novecentas pessoas. Já em 1561, apenas sete anos após sua fundação, sua população seria de cerca de dois mil habitantes, segundo informa José Mariz de Morais (FERREIRA 1995). Devido a este constante crescimento outros aldeamentos eram criados para catequizar os índios em outras regiões, entre elas nas terras compreendidas entre a Vila da São Paulo e o rio Guaió, no qual se "há registros de núcleos estabelecidos em Itaquaquecetuba e em São Miguel (atual São Miguel Paulista, bairro paulistano)"(LEONE e Azevedo] 2009, il., p 23).

Como descrito anteriormente, hoje a cidade que conhecemos como Mogi das Cruzes tem sua criação no início do século XVII, por Gaspar Vaz que teria sido ordenado pelo então governador-geral do Brasil Francisco de Souza, que com o intuito de estabelecer comunicação fácil de São Paulo até as Minas Gerais, estabelece uma ligação entre os territórios a ser feita por meio de um "caminho". No entanto, segundo Grinberg: "Vaz, chegando até a região do Alto Tietê, encanta-se com o local e estabelece-se ali".

A vila de Sant'Anna foi descrita por Langenbuch, em sua tese sobre "A Estruturação da Grande São Paulo". Ainda que sua pesquisa detesse na consolidação da Grande São Paulo a partir do século XIX, dá indícios da importância de Mogi das Cruzes como um dos principais "núcleos urbanos" mais afastados da cidade de São Paulo.

No entanto, a Vila de Sant'Anna vai se permanecer como um pequeno núcleo no extremo leste da Vila de São Paulo de Piratininga, interligado precariamente por "caminhos" junto à várzea do Rio Anhembi (atual Tietê), conforme descrito por Langenbuch:

"As estradas, de modo geral, eram bastante precárias. Os trechos calçados eram escassos, constituindo exceção à regra. Era o caso do trecho serrano da estrada de São Paulo-Santos. Segundo narrativa de Saint Hilaire era também calçado o aterrado da estrada de São Paulo-Rio existente na travessia da várzea do Tietê nas proximidades de Mogi das Cruzes"(1971, p 27).

Afonso E. Taunay reforça a existência destes caminhos como importante ligação entre os núcleos, no entanto como apontado por Grinberg, eles viviam com sua conservação muito deficiente.

"Os caminhos, como é natural, cortavam rios, maiores ou menores, obrigando a construção de pontes. Elas também eram absolutamente precárias e estavam igualmente a cargo dos índios escravizados pelos moradores"(1981 p 16).

Tal dado pode ser comprovado quando analisamos o número de habitantes no povoado que apontava cerca de 2.500 "almas", enquanto que todo o município foi de 11.460, sendo 1.159 escravos, em 1876 (I. 1. GRINBERG 1979, p 73). Ao compararmos com a 
Vila de São Paulo, que em 1874 possuía uma população de 31.364 habitantes, ${ }^{164}$ fica claro que o núcleo de Mogi era muito tímido.

Cabe esclarecer que os números referentes à população da Vila de Sant'Anna, principalmente, entre o período de seu povoamento em 1601 até o final do século XIX, não se tem registro dos habitantes desta vila, mesmo em análise aos estudos de Isaac Grinberg, nota-se que não é apontado um número de habitantes neste período, apenas a informação das "tão poucas casas", por outro lado podemos compreender indícios de sua ocupação:

"Esta vilasinha apresenta mais ou menos a forma de um paralelograma. As ruas são bem largas mas de casario pequeno e bem feio. No largo principal, que é quadrado, contam-se diversos sobrados, ,mas não mais bonitos do que os outros prédios. A igreja principal ocupa um dos lados da praça. É bastante grande, mas mal ornamentada"(Augusto de SAINT-HILAIRE in LANGENBUCH 1971 p 47).

Temos que considerar, inicialmente, que desde o século $\mathrm{XVI}$, poucas Capitanias conseguiram sucesso, enquanto que no Planalto, a partir da Vila de São Paulo de Piratininga eram conquistados continuamente, como o caso de Sant'Anna, ou M'Boigy, como também era conhecida e que mais tarde será a de Mogi das Cruzes.

Estas terras ocupadas primordialmente por tribos indígenas, e que sofrem diretamente com a "exploração de terras" por ordem da Coroa Portuguesa para o aumento de seus domínios por meio de donatários, eram expulsos de suas terras em detrimento da expansão dos núcleos populacionais "civilizados". Nesta região onde hoje temos várias cidades além de Mogi das Cruzes, foram ocupadas pelos pequenos Guaianás, ou Guaianases, entre outros.

Neste sentido, as "sesmarias" foram os documentos que "concediam o direito" de ocupar, cultivar e até mesmo aforar para o uso de terceiros, concedido pelo governadorgeral, que representava o Reino, dando um prazo de cinco anos para estas ações se consolidarem, sob pena de serem tornadas devolutas e retomadas pela Capitania.

Tomando como referência a tese do historiador mogiano Isaac Grinberg, que atribuiu a Gaspar Vaz o papel de fundador de Mogi das Cruzes, outros receberam sesmarias do governo português no processo de colonização. Desta forma, sabe-se que já em fins de 1609 foi dada sesmaria a um certo "Rodrigues" dos "Campos de Ytacurubitiba no caminho que fez Gaspar Vaz que vai para Boigi Mirim a saber partindo da barra dum rio que se chama Guayao por elle arriba até dar em outro que se chama...dali dará volta a demarcação pelas faldas de outeiro da banda do sudeste e correrá avante até dar no rio grande Anhemby e por o rio grande abaixo até dar digo eté tornar aonde começou a partir da assim mas meia...com dois capões que estão de fronte da dita dada a saber um capão que se chama de Ytucurubitiva e outro...assupeva..."(AZEVEDO 1994, p 19).

164. O número de habitantes de São Paulo foi extraído da Tabela IV - População em 1874 do livro de Langenbuch, 1971. 
Outro dado importante segundo Azevedo, diz respeito à referência a uma "Estrada Real do Guaió", ainda no século XVII, já citada em documento de delimitação da Vila de Sant'Anna, datado de 1663, ao qual deveria estar sendo usada (praticamente como obrigatória) para quem seguia o trecho entre a vila e o litoral. Assim como, com o maior movimento entre São Paulo e as Minas Gerais, a vila de Sant'Anna torna-se passagem entre estes dois pontos.

Tal estrada ainda é mencionada por Saint-Hilaire: "Perto do lugar chamado Casa Pintada... tem-se ainda péssimo caminho". A descrição desta "pousada"deixa claro que a viabilidade desta parece ter sido verdadeiramente precária, na travessia da várzea do rio Guaió, hoje limite físico entre os municípios de Poá e Suzano. A respeito o viajante narra: “...depois do rio Guayão encontramos pântanos muito perigosos. Os burros atolaram-se quasi que até o peito num lodo preto como tinta. Um delles cahiu duas vezes e foi preciso descarregá-lo outras tantas"(LANGENBUCH 1971, p 28).

Apesar das descrições acima citadas por estudiosos e viajantes, pouca informação se tem a respeito dos limites físicos da Vila de Sant'Anna, mais tarde cidade de Mogi das Cruzes. ${ }^{165}$ No entanto, sabe-se que parcela deste território, ao longo dos anos, foi sendo "destacado" do original para a formação de novos vilarejos e cidades independentes do núcleo principal. ${ }^{166}$

Esta tese não se detém especificamente sobre a cidade de Mogi das Cruzes, nem tão pouco a pesquisas e/ou descobertas sobre a transformação territorial desta cidade. No entanto, a compreensão do "desmembramento" e divisão territorial nos foi colocado como elemento importante para a compreensão da formação territorial da cidade de Suzano, ao qual pertenceu até meados do século XX à seus territórios de origem. Neste sentido, a construção dos "mapas temporais", elaborados a partir de dados levantados através do breve histórico das atuais cidades autônomas política-administrativamente de seu núcleo original, nos deu um panorama da transformação física desde a Vila de Sant'anna, passando pela cidade de Mogi das Cruzes até o surgimento das cidades, e em especial a objeto desta tese.

Em 1879, foi publicado a 1aㅡ edição, com dois volumes, dos "Apontamentos Históricos, Geographicos, Biographicos, Estatísticos e Noticiosos da Província de São Paulo, de autoria de Manoel Eufrásio de Azevedo Marques, seguido de um rico conjunto de dados e cronologia dos acontecimentos mais notáveis desde a fundação da Capitania de São Vicente até o final do século XIX.

165. Em 1865 a vila é elevada à cidade e, em comarca em 1874, conforme descrito no site da Prefeitura Municipal de Mogi das Cruzes. Porém, no livro Gaspar Vaz - fundador de Mogi das Cruzes, de autoria de Issac Grinberg, este dado é colocado como "elevada à cidade por lei provincial de 13 de março de 1855 sobre proposta do deputado Dr. Salvador José Corrêa Coelho".

166. Mogi das Cruzes é o quarto município mais antigo do Estado de São Paulo, e de seu desmembramento ao longo dos seus 401 anos originaram-se os seguintes municípios: 1) Jacareí [1653] - São José dos Campos [1767], Paraibuna [1832], Santa Branca [1856], Buquira [extinto 1934], Natividade [1935], Monteiro Lobato [1949]; 2) Santa Isabel [1832] Igaratá [1873 - extinto em 1934], Igaratá [1954], Arujá [1959]; 3) Salesópolis [1857]; 4) Guararema [1898]; 5) Suzano [1949]; 6) Poá [1949] - Ferraz de Vasconcelos [1954]; 7) Itaquaquecetuba [1954]; 8) Biritiba-Mirim [1964]; 9) Brás Cubas [1964 - extinto em 1970]. Obs.: O município de Buquira, extinto em 1934, foi recriado com o nome de Monteiro Lobato pela Lei 233 de 24 de dezembro 1948.

Fonte: Divisão territorial do Estado de São Paulo. 
"Mogy das Cruzes. - Povoação situada a ENE da capital. Em tempos remotos denominara-se Boygy... Consta que no adro da primeira igreja matriz existiram plantados três cruzeiros e d'ahi resultou aquella qualificação de Mogy das Cruzes. A povoação está assentada a 22ํ3' de lat. e 33143',35” de long. da Ilha do Ferro, em uma lomba (plateau) formada pelos valles do rio Tieté ao Norte do ribeirão chamado de cima ao Sul e do Ipiranga a Oeste... de então em diante foram-se alli aglomerado moradores emigrados da villa de $S$. Paulo..., que foi elevada á villa a 3 de Setembro de 1611, pelo capitão-mór Gaspar Conqueiro" (MARQUES in GRINBERG 1979 p 71-72).

A descrição acima dá vestígios do território da Vila de Sant'Anna, tendo como referência os elementos naturais existentes na época como os rios Tietê e Ipiranga. Assim, até a emancipação dos primeiros núcleos ainda em meados do século XVII, a vila se estendia num amplo território sobre as várzeas do rio Paraíba e Tietê tendo a oeste, naquele momento a Vila de São Paulo de Piratininga. ${ }^{167}$

Já a sul percebe-se que a Serra do Mar é a barreira e limite da então vila, tendo a atual cidade de Ribeirão Pires como "núcleo" limítrofe da Vila de Sant'Anna. Porém a leste, alguns relatos colocam em questão os limites de Mogi das Cruzes.

Langenbuch, mencionando Saint-Hilaire descreve: "Entre São Paulo e Mogi, na estrada do Rio, havia o pouso da Casa Pintada, sito entre a atual Itaquera e São Miguel" (1971 p 38), enquanto que Azevedoreferência a uma "Estrada Real do Guaió": "Há informação que já vem citada em documento de delimitação da Vila de Sant'Anna, datado de 1663. A nova povoação limitava-se com os domínios de São Miguel justamente pelas águas do Rio Guaió"; ou em outro trecho: "Compreenda-se que os limites da vila de São Paulo chegavam até o Rio Guaió, o mesmo rio que ainda hoje separa os atuais municípios de Poá e Suzano"(AZEVEDO 2004, p 64-65).

Estes limites se tornam imprecisos quando cruzamos os dados obtidos na Divisão Territorial de São Paulo, que aponta que a cidade de Poá se emancipou de Mogi das Cruzes em 1949, identificando tal povoamento como pertencente a antiga Vila de Sant'Anna, diferentemente das descrições acima citadas, tanto por Langenbuch como Suami, que identificam a atual cidade de Poá como núcleo da Vila de São Paulo de Piratininga.

Para compreendermos melhor a transformação do território da Vila de Sant'Anna do início do século XVII até a então cidade de Mogi das Cruzes que hoje conhecemos, assim como para construirmos com maior precisão a configuração urbana da cidade de Suzano, objeto desta tese, construímos a partir de dados coletados pelos pesquisadores como Grinberg (1979, 1981, 1992) e Azevedo (1994, 2004), além de Langenbuch (1971) e os órgãos oficiais de cartografia do Estado de São Paulo, a seqüência cartográfica da Vila até a cidade que conhecemos, com suas transformações territoriais, considerando o surgimento de novas cidades ao longo dos anos e sua emancipação políticoadministrativa.

167. Tal afirmação é defendida por nós devida à situação geográfica da atual cidade de Jacareí, que originou mais tarde outras cidades, localizadas no Vale do Paraíba, a leste de Mogi das Cruzes. 
Tal reconstrução se fez necessário para a configuração cronológica da vila até a cidade. Neste sentido, de 1611, data defendida por Grinberg pela criação da Vila da Sant'Anna até 1652, a configuração territorial da então vila se perfazia numa área de aproximadamente $6.616 \mathrm{Km}^{2}$ (seis mil seiscentos e dezesseis quilômetros quadrados), ${ }^{168}$ tendo como limites a leste o vale do rio Paraíba, a norte Minas Gerais, a Vila de São Paulo de Piratininga a leste e a "muralha" da Serra do Mar a sul, que se estendia desde as proximidades da Vila de São Vicente até a então cidade de Ubatuba. Um ano após, em 1653, surge a cidade de Jacareí com um território de 3.807 Km² (três mil oitocentos e sete quilômetros quadrados), ${ }^{169}$ reduzindo o território da Vila de Sant'Anna em 57\% (cinquenta e sete por cento), inclusive alterando significativamente seus limites entre a vila e Minas Gerais e a extensão junto à Serra do Mar.

A Vila de Sant'Anna permanece com seu território de $2.809 \mathrm{Km}^{2}$ (dois mil oitocentos e nove quilômetros quadrados) até o segundo quarto do século XIX, exatamente por 179 anos, até a emancipação de Santa Isabel em $1832,{ }^{170}$ perfazendo naquela ocasião um território de $2.103 \mathrm{Km}^{2}$ (dois mil cento e três quilômetros quadrados). Já em 1857 uma área de $1.678 \mathrm{Km}^{2}$ (mil seiscentos e setenta e oito quilômetros quadrados) para a fundação da cidade de Salesópolis.

Elevada à cidade em 1865 (PMMC s.d.), Mogi das Cruzes se permanece com o mesmo território até final do século XIX, reduzindo apenas para Guararema uma área de 270 $\mathrm{Km}^{2}$ (duzentos e setenta quilômetros quadrados) em 1898, em detrimento de sua emancipação político-administrativa, onde permanece com um território de $1.408 \mathrm{Km}^{2}$ (mil quatrocentos e oito quilômetros quadrados) até final da década de 1940.

Em meados do século XX, a cidade de Mogi das Cruzes sofre alterações em seu território até 1970 com a emancipação de diversas cidades e a extinção de Brás Cubas, que possui uma curta emancipação entre 1964 - 1970, retornando para a cidade-origem e ampliando seu território. Em 1949 Suzano e Poá se emancipam (da segunda nasce Ferraz de Vasconcelos em 1954), Itaquaquecetuba conquista sua emancipação em 1954 e dez anos depois, em 1964, Biritiba-Mirim e Brás Cubas (extinto em 1970).

Todas estas transformações ao longo destes mais de três séculos e meio, reduziram e transformaram significativamente a cidade de Mogi das Cruzes desde seu surgimento no início do século XVII como a Vila de Sant'Anna de Mogy Mirim, perfazendo hoje uma área de $714 \mathrm{Km}^{2}$ (setecentos e quatorze quilômetros quadrados), ${ }^{171}$ segundo a EMPLASA, hoje com pouco menos de 11\% de seu território original em 1611.

168 . Atualmente esta configuração urbana é composta pelas seguintes cidades: Mogi das Cruzes, Jacareí, São José dos Campos, Monteiro Lobato, Paraibuna, Natividade da Serra, Santa Branca, Santa Isabel, Igaratá, Arujá, Salesópolis, Guararema, Suzano, Poá, Ferraz de Vasconcelos, Itaquaquecetuba, Biritiba-Mirim.

169 . O território de Jacareí vai se permanecer "intacto" por mais de um século, onde deste surgirão as cidades de São José dos Campos (1767) - Buriqua (extinto 1934) - Monteiro Lobato (1949). Paraibuna (1832) - Natividade (1863) Natividade da Serra (1935). Santa Branca (1856).

170. O território de Santa Isabel se permanece até 1873, de onde surgem as cidades de Igaratá (extinto em 1934) Igaratá (1954). Arujá (1959).

171. Este dado leva em consideração que em 1994 Mogi das Cruzes perde para Suzano uma área de $8 \mathrm{Km}^{2}$ (oito quilômetros quadrados) fruto do plebiscito realizado naquele momento para a definição da região do Jardim Gardênia bairro limítrofe entre as duas cidades. 

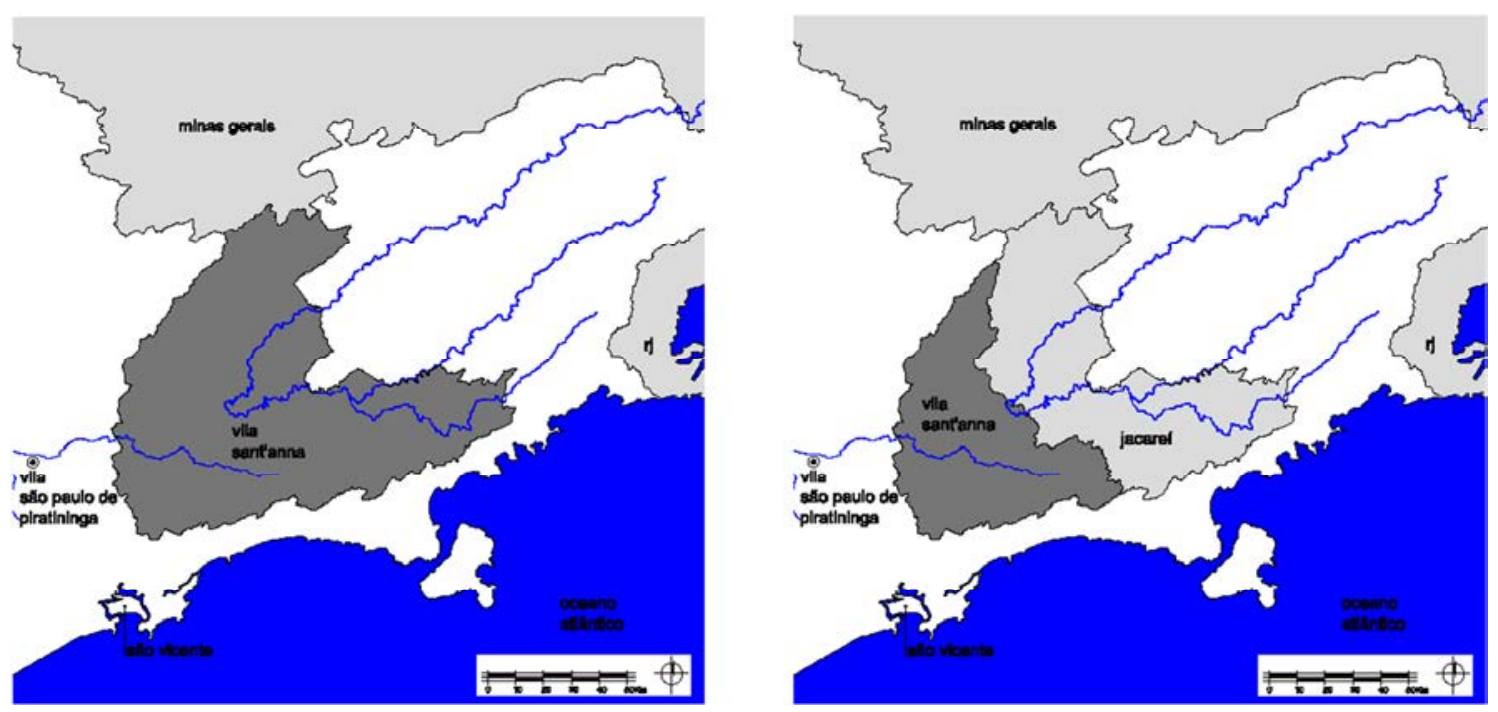

Figura 122. Esquerda: Vila Sant'anna a partir de 1610. Direita: Vila de Sant'anna em 1653

Elaboração: Elvis Vieira, 2010
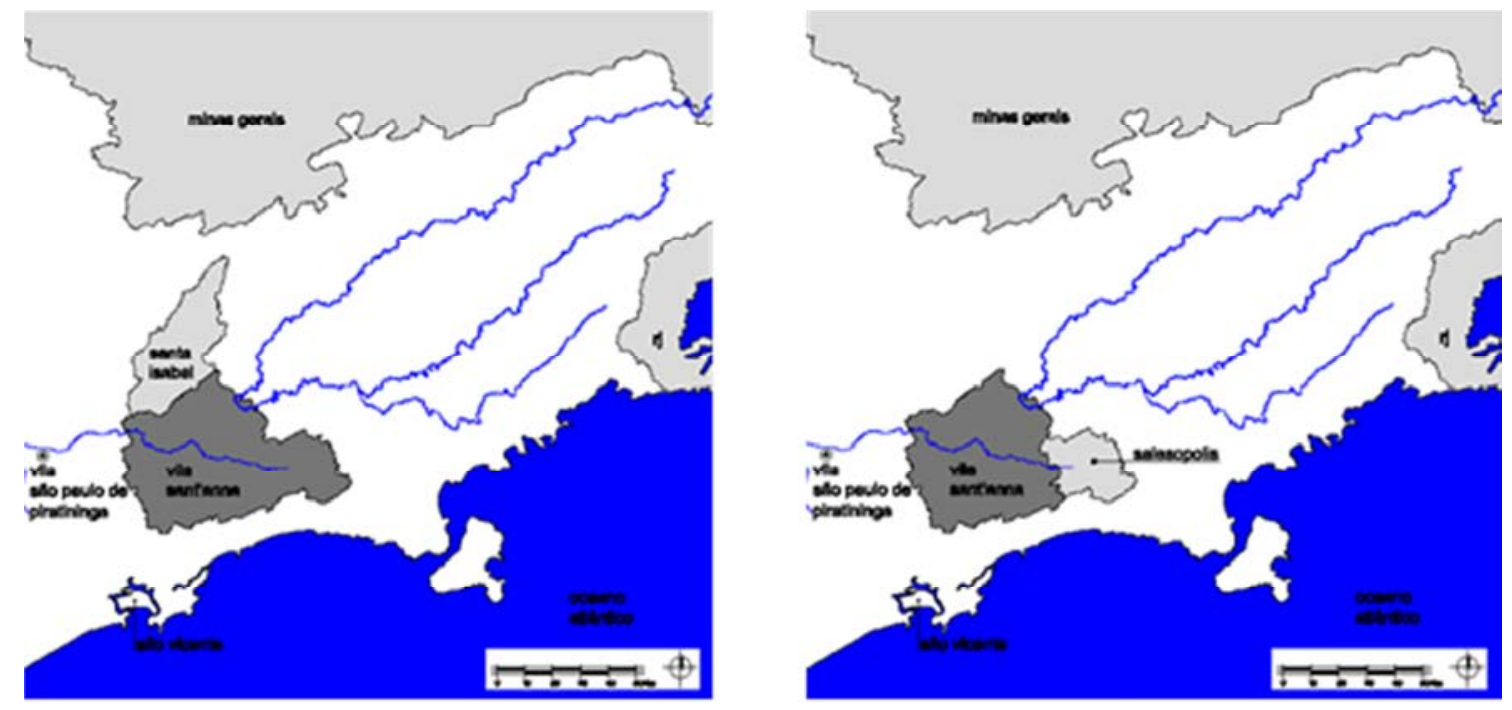

Figura 123. Esquerda: Vila Sant'anna em 1832. Direita: Vila sant'anna em 1857 Elaboração: Elvis Vieira, 2010

Entre tantas cidades que surgiram ao longo destes anos, Suzano recebe sua autonomia político-administrativa em 1949. No entanto, sua ocupação se deu muito anterior a isto, ainda no século XVII, na região entre as várzeas dos rios Guaió e Taiaçupeba.

Descrições como a sesmaria dada a "Rodrigues" e a respeito da "Estrada Real do Guaió" (AZEVEDO 1994), como importante passagem entre a Vila de Sant'Anna e o litoral, nos dá alguma pista sobre a construção deste território.

Pesquisadoras da Universidade de São Paulo (CEDHAL / USP) em trabalho realizado em 2000 para a Secretaria Municipal de Cultura - PMS aponta os mesmos indícios tanto da sesmaria como os caminhos entre o litoral, a Vila de Sant'Anna e as Minas Gerais. $^{172}$

172 . O Trabalho realizado sob coordenação da Prof. PhD Eni de Mesquita Samara, e sua equipe de pesquisadoras: Eliana Rea Goldschmidt, Madalena Marques Dias e Suzana P. Pasqua; com o objetivo de resgatar a história da cidade desde a suas raízes nos tempos coloniais. No entanto os levantamentos históricos e estudos não foram publicados. 
Esta estrada, em meados do século XVII, torna-se passagem obrigatória entre Mogi e o Litoral ou a sede da capital paulista. Até então os pesquisadores aqui comentados não apontam com exatidão seu percurso sobre o território da cidade, mas segundo Azevedo, "esse caminho deveria passar ao sul da atual sede do município de Suzano, percorrendo passagem entre os rios Guaió e Taiaçupeba-Mirim" (1994 p 19), como demonstrado em mapa abaixo elaborado a partir das descrições destes historiadores.

É nestas terras que um pequeno povoado se estabelece por diversos motivos, o que foi inicialmente apenas um local de passagem e paragem, provavelmente para descanso da tropa e dos animais, começou a receber mais gente tornando-se uma localidade, um pólo de centralidade neste caminho entre o Litoral, São Paulo e Mogi, crescendo populacionalmente e começando a ser reconhecida como Taiaçupeba, nome dado a esta região. É justamente neste primeiro núcleo da cidade que se ergue uma capela em homenagem a Nossa Senhora da Piedade, fundada pelo Padre Antonio de Souza e Oliveira, onde mais tarde, em princípios do século XVIII, dois séculos depois, outra capela surge sobre a primeira, por iniciativa de Roberto Bianchi, e que existe até hoje no atual bairro do Baruel.

A particularidade da origem e consolidação deste nome é contada por diversos autores em momentos e diferentes relatos pela pouca bibliografia encontrada sobre o tema. Podemos afirmar segundo Leone (e outros autores), em seu livro "Memórias de Suzano", publicado em 2009, como Azevedo em "Retratos de Suzano", de 2004, que o nome do povoado tem origem num personagem longínquo. O pirata corsário Henry Barewell, deixado para trás juntamente com Anthony Knivet (que morreu em viagem à Inglaterra em 1614) por Thomas Cavendish em fuga às pressas.

Já com o nome aportuguesado, após retorno da Europa, Henrique Baruel casou-se com uma viúva rica, tornando-se uma das famílias mais afortunadas, numa rápida ascensão social do ex-pirata. Por fim, o Baruel que dá nome ao atual bairro de Suzano, e por alguns defendidos como o marco inicial da cidade, é referente a Antonio Francisco Baruel, trineto do pirata Barewell.

Em material disponível na página virtual da Prefeitura Municipal de Suzano, esta narração é mais bem descrita ao longo dos anos por estas terras pouco exploradas e com inúmeros conflitos entre o povo indígena local e a população residente.

"Durante anos, o Frei Salvador Baruel, seu irmão padre Francisco Baruel e outros irmãos não religiosos se instalaram na região e, por volta de 1660 , construíram a capela dedicada à Nossa Senhora da Piedade, ajudando a controlar a rivalidade entre as tribos, os novos aventureiros e os bandeirantes que rondavam a região em busca de ouro"(PMS s.d.). 

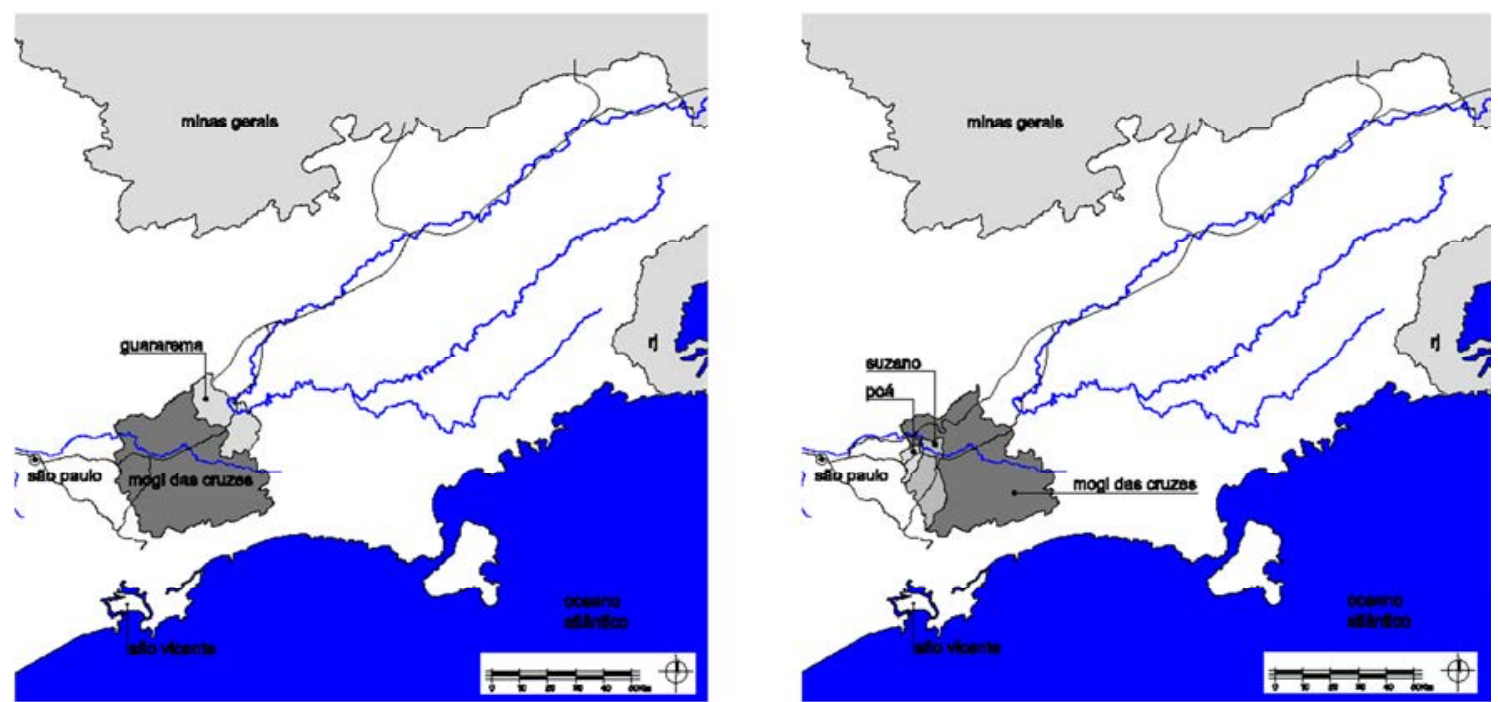

Figura 124. Esquerda: Mogi das Cruzes em 1898. Direita: Mogi das Cruzes em 1949, emancipação político-administrativo de Suzano

Elaboração: Elvis Vieira, 2010
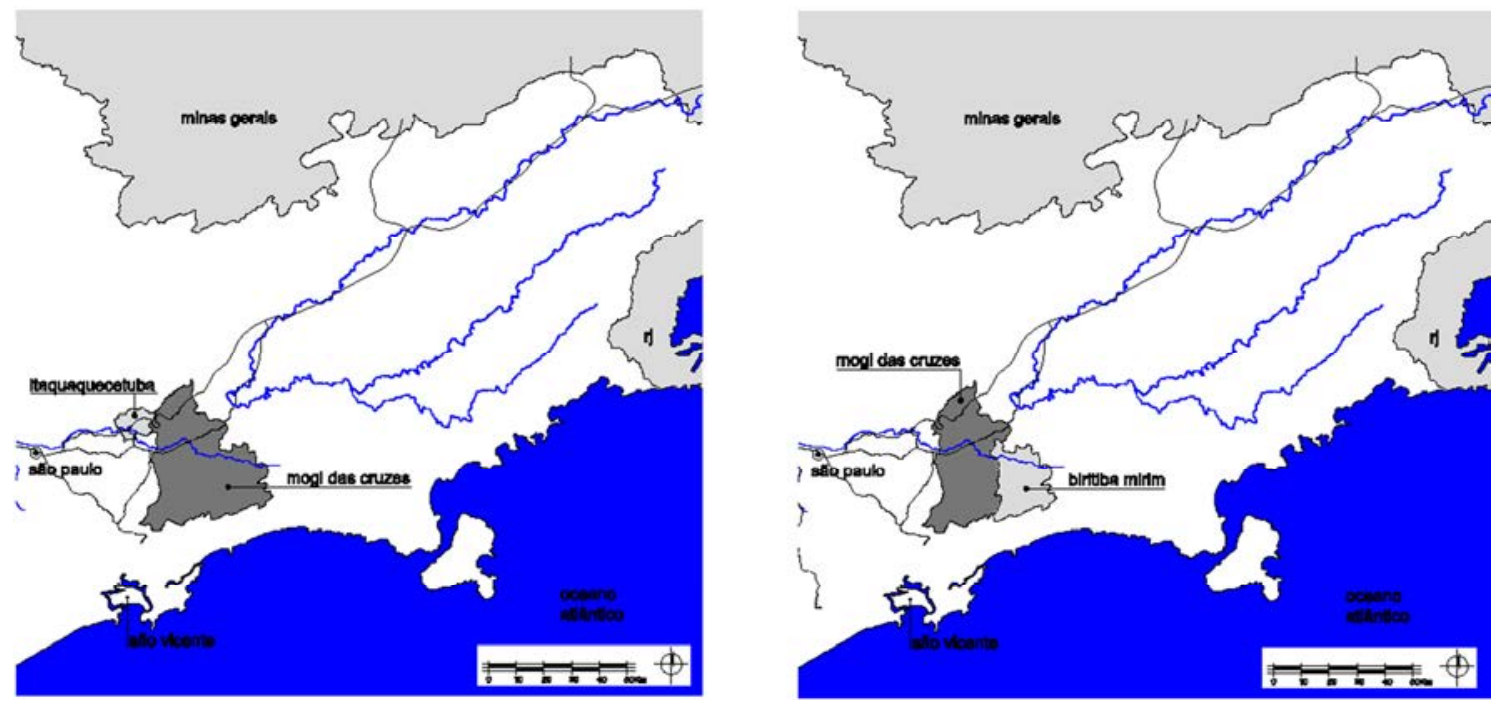

Figura 125. Esquerda: Mogi das Cruzes em 1954. Direita: Mogi das Cruzes em 1964 Elaboração: Elvis Vieira, 2010
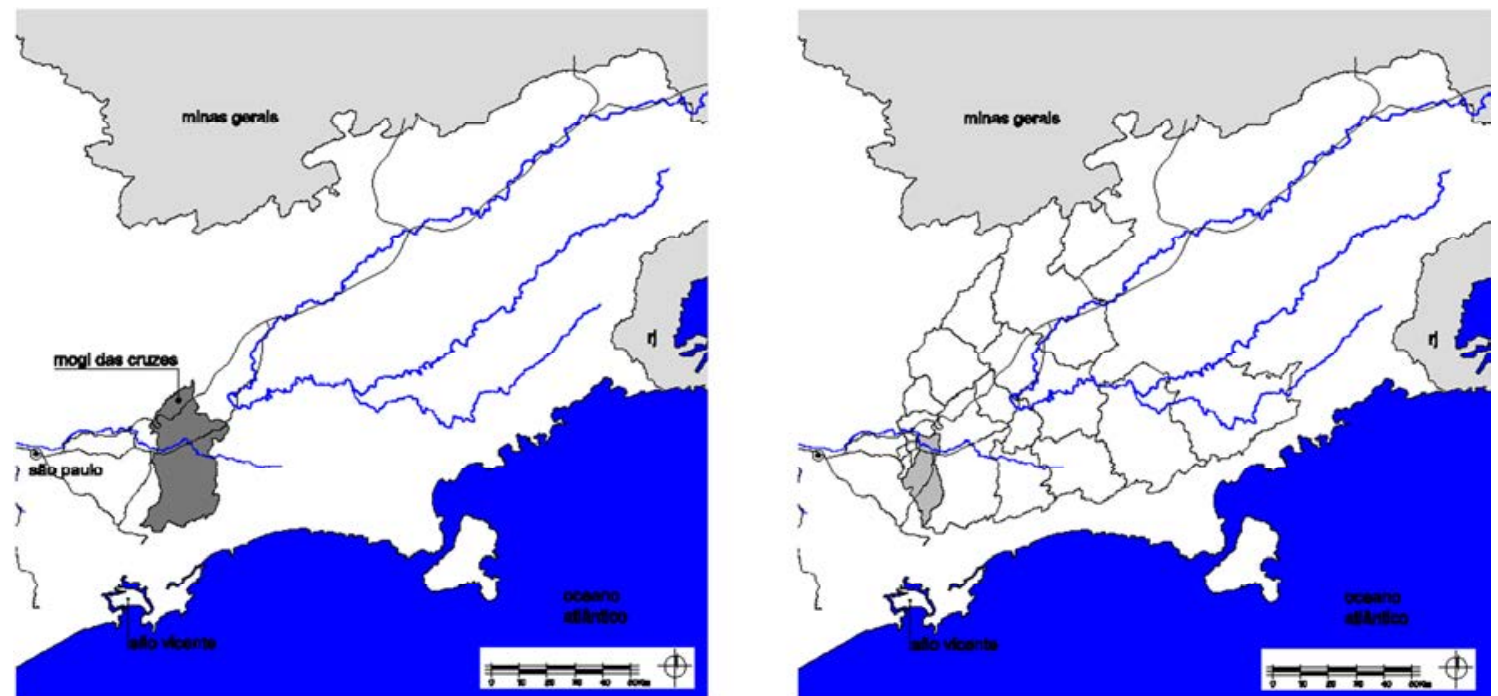

Figura 126. Esquerda: Mogi das Cruzes em 1970. Direita: Configuração atual das cidades originadas do território de 1610

Elaboração: Elvis Vieira, 2010 
Pelo acima exposto, observa-se que a região já era povoada por indígenas, que ao longo dos anos foram sendo "expulsos" de suas terras. Isto fica mais claro com a existência do primeiro cemitério da cidade, conhecido por "Cemitério Indígena" e localizado próximo a primeira capela deste povoado. ${ }^{173}$ Da mesma forma, se descreve sobre o trineto do pirata, porém sem mencionar este fato, pois as famílias mais tradicionais da cidade, entre elas a Bianchi e os Figueiras, entre outros, evitam mencionar este feito do corsário, com o receio de denegrir o nome do bairro e da cidade.

"Em meados deste século (século XVIII), toma posse de terra na região outro membro da família Baruel, o capitão Antônio Francisco Baruel, que manteve no local uma próspera fazenda, chamada de lavras do Baruel, trazendo para trabalhar os primeiros escravos negros. A família Baruel permaneceu na região até meados do século XIX, quando a maioria das minas de ouro se extinguiu"(PMS s.d., grifo nosso).

Também conhecida como "Caáguaçu"devido as minas de ouro desta região, apesar de não se ter qualquer vestígios deste "tempo áureo", esta parada pela Estrada Real do Guaió foi se tornando referência e atraindo a cada ano um número maior de pessoas que se instalavam neste local.

Da configuração morfológica desta ocupação não se tem qualquer tipo de material gráfico, enquanto que os vestígios daquela época são insuficientes e imprecisos. As descrições apresentadas pelos historiadores da região, como Grinberg de Mogi das Cruzes e Suami Azevedo de Suzano, não são satisfatórios para a reconstrução exata do que consideram a primeira ocupação da futura cidade de Suzano.

Se considerarmos que o território brasileiro era ocupado em sua maioria pela Coroa Portuguesa, desde a Vila de Todos os Santos até o Planalto de Piratininga, não é de se admirar que a ocupação na região do Baruel fosse consolidada a partir dos princípios de uma ocupação jesuítica, onde a construção principal era o "clero católico", este fato também é identificado na consolidação da Vila de Piratininga, como descrito por Toledo em 2004:

"Há um século a Imperial Cidade de São Paulo guardava ainda a sua feição colonial. Todas as principais funções se concentravam num triângulo cujos vértices eram balizados pelos conventos de São Francisco, São Bento e Carmo" (2004 p 09).

Neste sentido, se considerarmos que a "igrejinha" existente foi construída por Roberto Bianchi sobre a capela que desmoronou numa tempestade quase dois séculos depois de sua construção, podemos reconstruir esta ocupação a partir destas referências.

173. O cemitério possui vestígios do povoado indígena, assim como dos primeiros componentes da Família Bianchi, servindo até hoje de local para rituais das tribos indígenas existente na região entre o município de Suzano e Ribeirão Pires. 

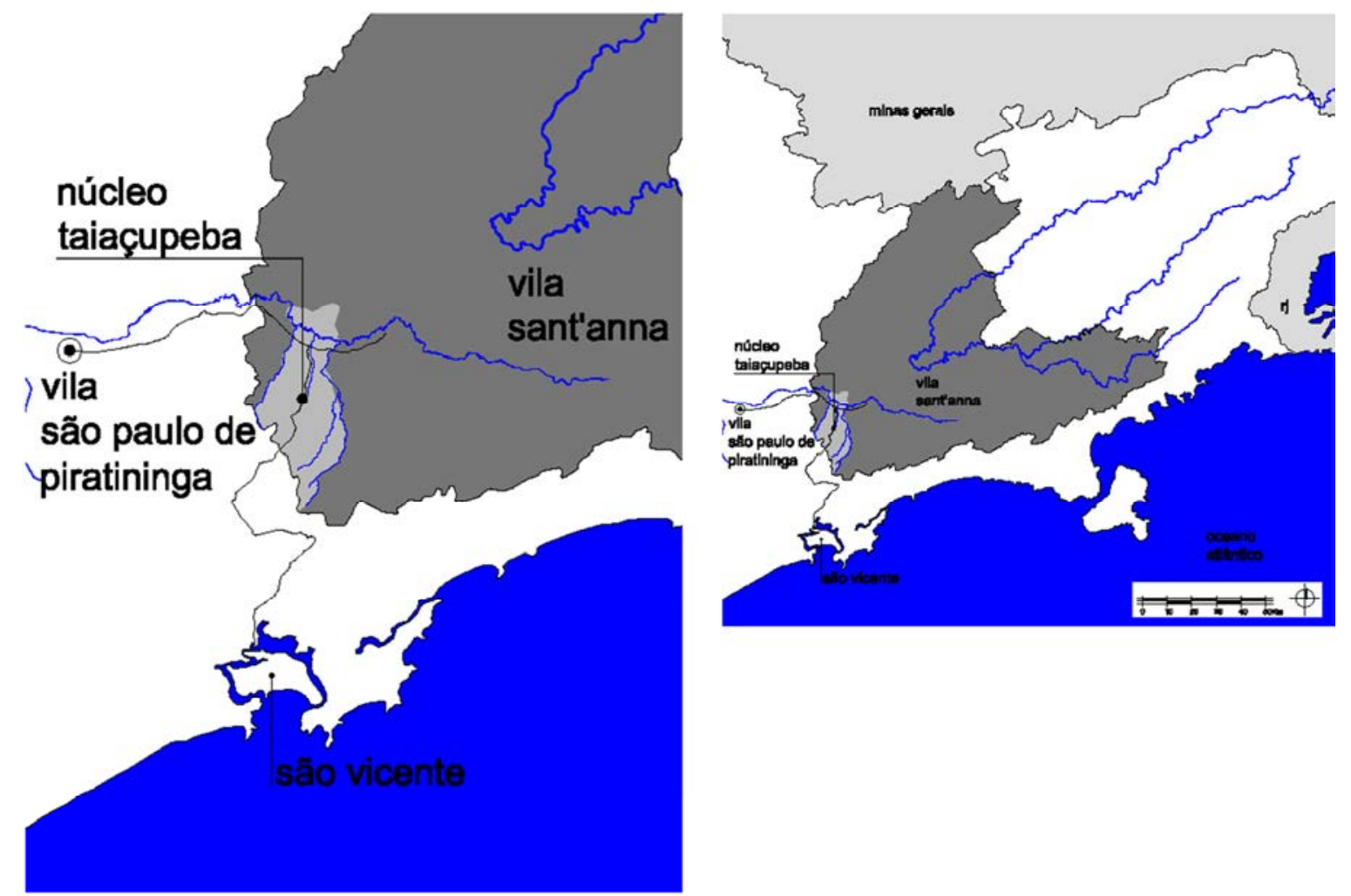

Figura 127. Mapa de Suzano em meados do século XVII com a localização da "Estrada Real do Guaió", segundo descrição de Suami Azevedo quanto a sua localização entre os rios Taiaçupeba (direita) e Guaió (esquerda), estrada de ligação entre a Vila de Sant'anna, o Litoral e a Vila São Paulo de Piratininga

Elaboração: Elvis Vieira, 2010

Figura 128.Formação do núcleo do Baruel do final do século XIX, composição espacial elaborada a partir de relatos

Elaboração: Elvis Vieira, 2010

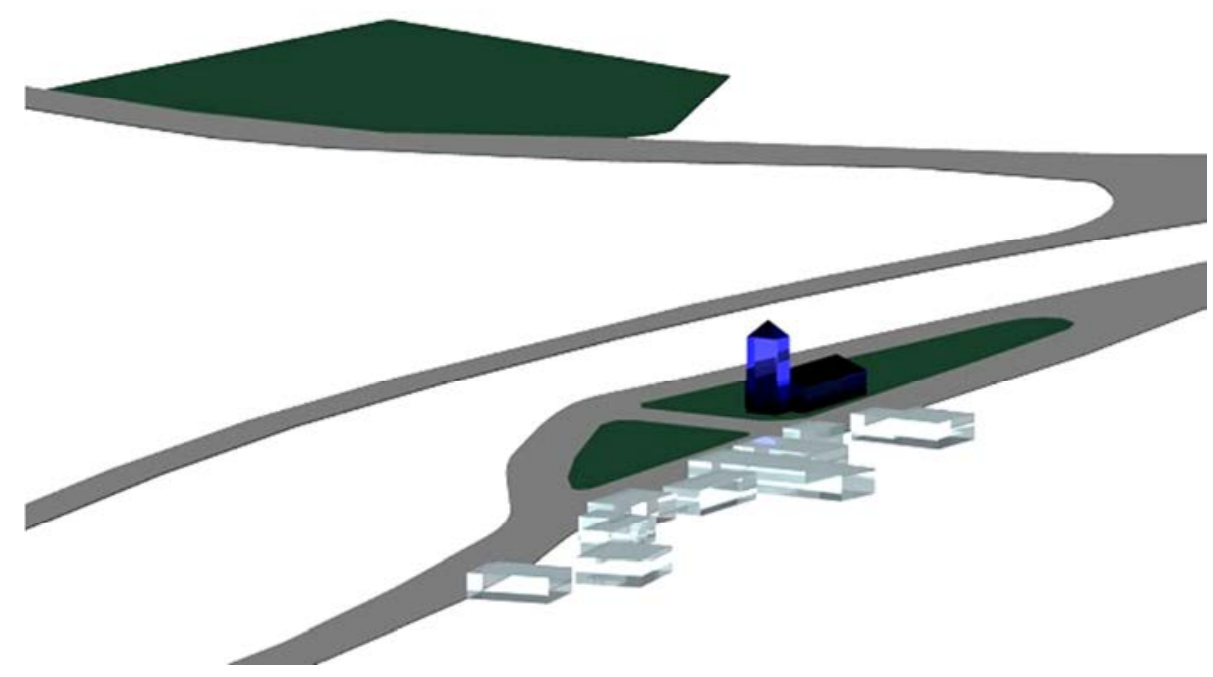


A Capela de Nossa Senhora da Piedade, do século XVII, comporia como elemento estruturador do povoado, o cemitério nas imediações da capela, à esquerda da construção e existente até hoje, anexa a capela, a primeira escola, ${ }^{174}$ este último que demonstra a maturidade adquirida, e no entorno as construções dos moradores deste povoado. Esta configuração provavelmente se deu durante séculos, já que se tem vestígios de residências de outra família importante para a região e a cidade, os Bianchi.

Filhos de italiano, Roberto Bianchi chega ao Brasil com 12 anos, em 1887, desceu em Santos, pegou um trem e foi parar para os lados da atual Ribeirão Pires(LEONE e Azevedo] 2009, il., p 29). Casa-se no início do século XX com Ernestina Maria de Jesus, neta de índios que morada nas redondezas do Baruel, e que por ali compôs família e se instalou próximo à "igrejinha do Baruel".

É justamente Roberto Bianchi que "restaurou" a Capela de Nossa Senhora da Piedade, que tinha ruído anos atrás, como presente à sua esposa que acabara de dar a luz à sétima filha (Dolores); enquanto a santa, foi mandada para Mogi das Cruzes para ser restaurada. ${ }^{175}$ Este feito foi em setembro de 1916, que a partir desta data comemora-se a Festa do Baruel em homenagem a Nossa Senhora da Piedade.

Roberto Bianchi, personagem central deste "renascimento" da igrejinha junto à história do surgimento do povoado do Baruel, ainda contribuiu para o crescimento deste povoado e também foi uma das peças importantes para a segunda formação da cidade, desta vez em outro território, cerca de 13 quilômetros do que foi considerado por alguns historiadores, em especial Suami Paula de Azevedo, o marco zero da cidade de Suzano.

174. Foi criada "uma classe", a primeira escola, promulgada pela Lei oo 39 de 28 de março de 1870, uma "cadeira de primeiras letras para o sexo masculino".

175. A santa existente hoje no altar já não é mais a original, pois em 2002 ladrões invadiram a capela e sumiram com ela, não sendo encontrada até agora. 
Figura 129. Capela do Baruel atualmente, preservada pela PMS e a família Bianchi Foto: Elvis Vieira, 2010

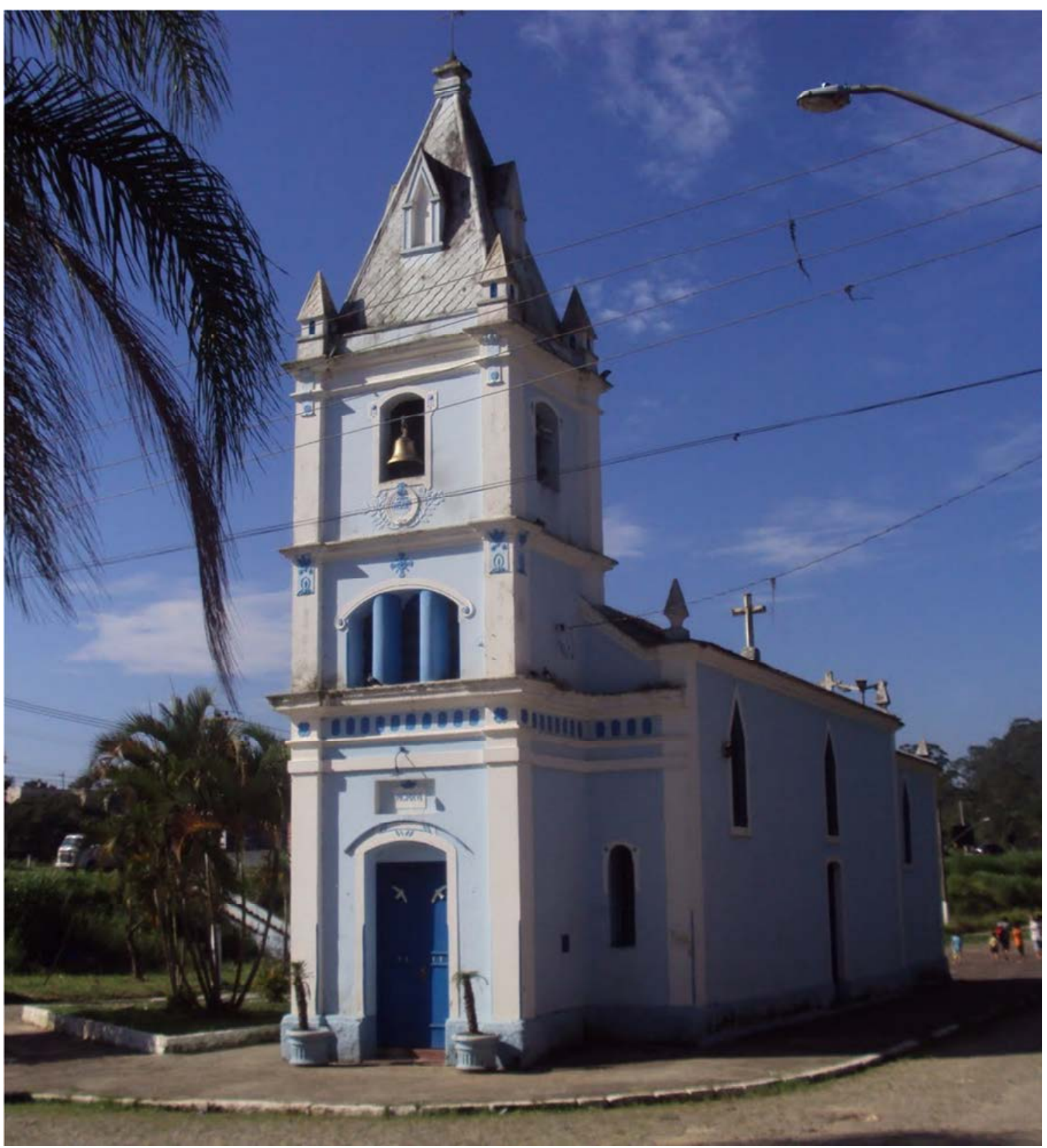




\subsection{Configurar um Novo Território}

O período de desenvolvimento ferroviário no Estado de São Paulo coloca-se entre 1855 e 1940, data fixada historicamente como o "fim da era ferroviária", principalmente devido à concorrência das rodovias.

A São Paulo Railway Company Ltda nasceu cobrindo o trecho Santos-Jundiaí, e assim ficou até 1946. Nunca se interessou em prolongar sua linha, pois estava na "boca do funil ferroviário", ou seja, o trecho São Paulo-Santos:toda mercadoria de exportação ou de importação por aí passava(VIEIRA 1998, p 07). De início, tentou dificultar o tráfego mútuo que mantinha com a Cia. Paulista, a qual cobria o trecho Jundiaí-Campinas.

Com uma extensão de 139 quilômetros, sendo 79 de Santos a São Paulo e 60 da Capital à Jundiaí, construída entre 1860 e 1867, com importantíssimas obras de arte, em especial no trecho da Serra do Mar, esta linha foi por muito tempo o principal caminho de escoamento da produção cafeeira do interior de São Paulo para o porto de Santos.

Esta linha que passava pela várzea do rio Tamanduateí, no extremo sul do povoado do Baruel, com uma parada em Rio Grande da Serra, e a poucos quilômetros deste ponto. Em 1867 é inaugurada a Variante Rio Grande da Serra-Suzano, com um traçado de sul a norte junto à várzea do rio Taiaçupeba em encontro ao Tietê. Apesar de poucas informações sobre esta linha, concluímos que ela tinha o caráter apenas de transporte de cargas e, segundo o Mapa do Sistema Ferroviário da RFFSA - Superintendência Regional de São Paulo - SR 4, existiria duas paradas no território em que mais tarde seria a cidade de Suzano: Ouro Fino, área próxima a Rio Grande da Serra e provavelmente região das minas de ouro daquele território e Suzano Novo próxima aos Campos de Mirambava. No entanto, a data de inauguração destas duas paradas não é apontada neste documento, não nos dando a possibilidade de "cruzar" os dados e informações históricas sobre esta região.

Já a descrição de Azevedo (1994) sobre este período nos coloca sob outro olhar quanto à existência desta linha e sua influência sobre o vilarejo do Baruel, que vê na existência desta linha como um "fio condutor" para o progresso nesta região, considerando que a passagem e principalmente a parada do trem induz a um progresso mais rápido, como já visto em São Paulo e as demais paradas da São Paulo Railway e confirmado por Langenbuch:

"A fixação suburbana de residência não se restringe a núcleos previamente industrializados; trata-se de processo areolarmente muito mais amplo e mais generalizado. Vários trechos lindeiros a ferrovias, não dotados de fabricas, conheceram um expressivo desenvolvimento suburbano de cunho residencial, formando-se em torno de suas estações autênticos subúrbios-dormitório"(1971 p 149 - grifo nosso). 
Figura 130.Mapa da rede ferroviária de carga - SR4 - São Paulo

Fonte: www.transportes.gov.br, acessado em $01 / 03 / 12$

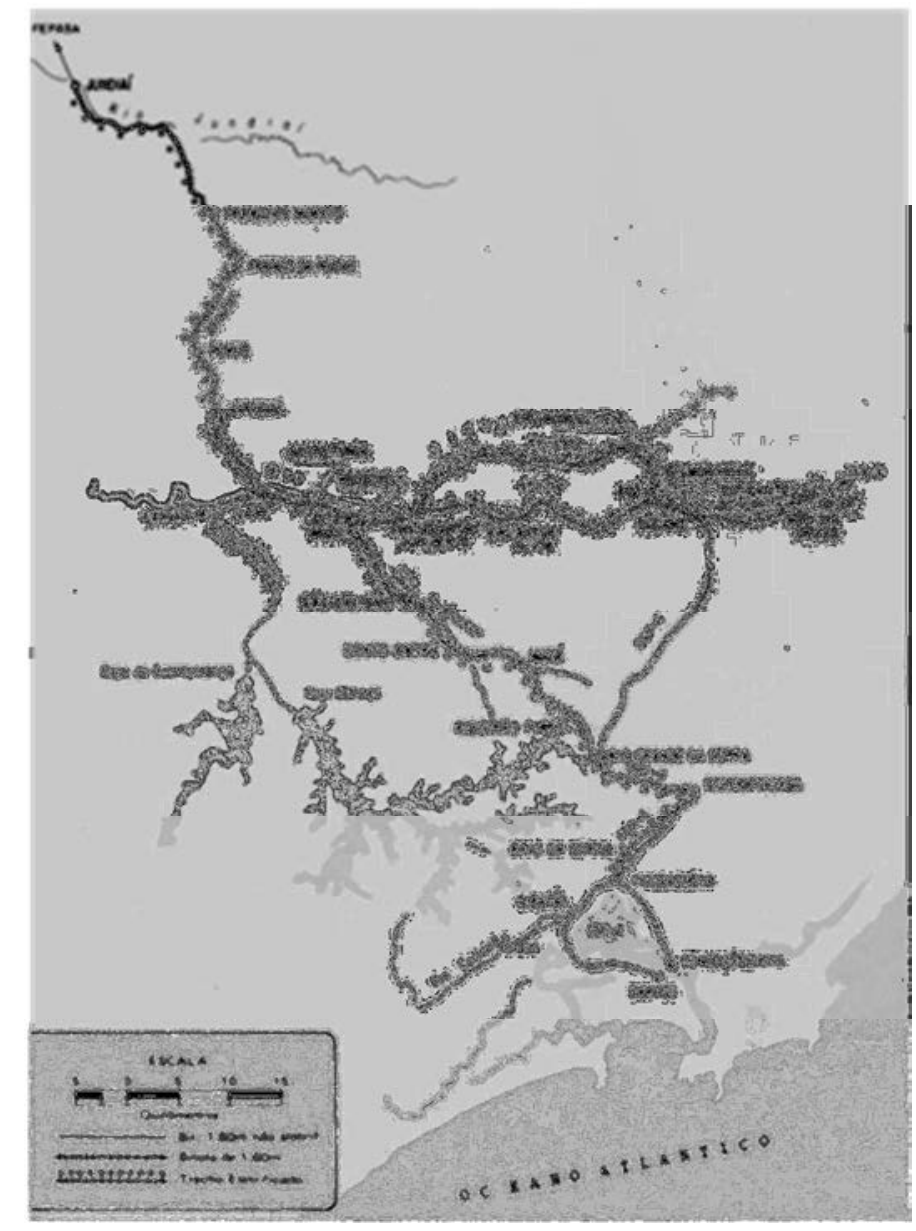

Neste sentido, para os moradores do então vilarejo do Baruel, o ramal ferroviário que partia de Ribeirão Pires tornou-se a esperança de todos. Porém, anos depois de verem criadas as suas esperanças de desenvolvimento para o vilarejo, aquela gente do Baruel viu ruir por terra o seu sonho, como um castelo de cartas(AZEVEDO 1994, p 27). Autorizados pelo Império, Irineu Evangelista de Souza, o Barão de Mauá, e João Ribeiro dos Santos Camargo tinham um projeto para construir um ramal de Ribeirão Pires a Jacareí, ${ }^{176}$ que segundo seus cálculos passaria pelo Baruel, alterando significativamente a dinâmica naquela área.

Concomitante a este fato negociações se faziam para a implantação de uma estrada de ferro que ligasse São Paulo ao Rio de Janeiro, tendo como traçado as várzeas do rio Tietê. Este traçado não passaria pelo vilarejo que estava a cerca de 15 quilômetros a sul dos Campos de Mirambava, ${ }^{177}$ como era conhecida a região naquele momento. Esta notícia fez com que Barão de Mauá e seu companheiro desistissem de sua empreitada, decisão esta recebida pelos moradores do Baruel e seu entorno com muita tristeza.

176. A cidade de Jacareí já existia desde 1653, fruto da emancipação político-administrativa de Mogi das Cruzes.

177 . Segundo Azevedo, a origem da palavra Mirambava vem da corruptela de uma expressão tupi-guarani. Vem de Maymbará (Mayum-wara). Seria formada pela justaposição de May'u (comer coisas) e wara (que poderia ser o guará, um lobo do cerrado, um flamingo brasileiro ou uma espécie de "mexilhão de rio", ou wara-ruha, caranguejo), onde para o pesquisador a terceira opção é mais adequada a esta região de várzeas, rios e inundações, é possível ali ter sido habitado por um povo que comia caranguejos do rio, o "povo Mirambava". 
Enquanto a nova linha da Companhia de Carris São Paulo - Rio de Janeiro, a Ferrocarril, ou Central do Brasil, ${ }^{178}$ teve suas obras iniciadas em 1873 em São Paulo. Em 1875, com o início da circulação de trens entre São Paulo e Mogi das Cruzes, a Parada de Piedade passa a ser um marco importante na região. Mesmo ainda isolada do vilarejo, esta parada que existia como ponto estratégico para abastecimento de água e lenha para as locomotivas a vapor, vai ao longo dos anos cada vez mais se tornar numa nova centralidade para a região e ponto de atração de famílias para esta região do território do então conhecido Campos de Mirambava.

Como descrito anteriormente, Suzano passa por dois momentos significativos de formação de seu território. O primeiro com a instalação de Barewell e a construção da Capela de Nossa Senhora de Piedade, que de forma radiocêntrica foi formando-se o vilarejo conhecido por Baruel, como que "espontaneamente" se consolidando como as ocupações portuguesas nas maiorias das cidades brasileiras, tendo o poder da igreja como elemento central de todo a composição do território, já num segundo momento, com a chegada da estrada de ferro e a ligação de Mogi das Cruzes com São Paulo, há o interesse cada vez mais constante de se instalar as margens deste eixo ferroviário.

Este fato é confirmado por Langenbuch remetendo as transformações urbanas da capital paulista em metrópole: "Todo o sistema de transporte abordado se transforma inteiramente com o surgimento da ferrovia, que vê sua primeira linha no Planalto Paulistano, instalada em 1867 (Estrada de Ferro Santos-Jundiaí)"(1971 p 41). É importante mencionar que neste período a linha férrea já provocava "esperanças" de crescimento urbano devido sua "proximidade" junto ao vilarejo do Baruel, mas que é derrubada com a notícia da construção da linha da São Paulo - Rio de Janeiro. No entanto, como apontado ainda por Langenbuch, "entre 1867 e 1875, as transformações, devidas à ferrovia, ainda são areolarmente muito localizadas, pois é apenas em 1875 que o essencial da rede ferroviária do Planalto Paulistano se estrutura com a entrada em funcionamento da Sorocabana e da ferrovia do "Norte" (atual Central do Brasil)"(1971, p 41 - grifo nosso).

É justamente em 1875, com a Parada de Piedade, em referência à distante capela à sul deste eixo leste-oeste da linha férrea, que podemos apontar como o primeiro processo de migração no que seria mais tarde a cidade de Suzano, e ao qual esta provocou a transformação desta parada como "pólo de atração" para este território sujeito a inundações e sem muitos interesses até então.

A construção da ferrovia mudou a rotina do lugar, conhecido também por Guaió em razão do rio, passou a crescer com a chegada de operários por conta da construção da nova linha férrea e pessoas de diversos lugares com a perspectiva de trabalho e negócios, "principalmente com a extração de madeira e fábricas de tijolos e carvão, as olarias, além da lavoura de subsistência"(LEONE e Azevedo] 2009, il., p 39).

178. As duas nomenclaturas são da mesma linha férrea que ligaria São Paulo ao Rio de Janeiro, a primeira apontada por Suami Azevedo e a segunda por Langenbuch. 


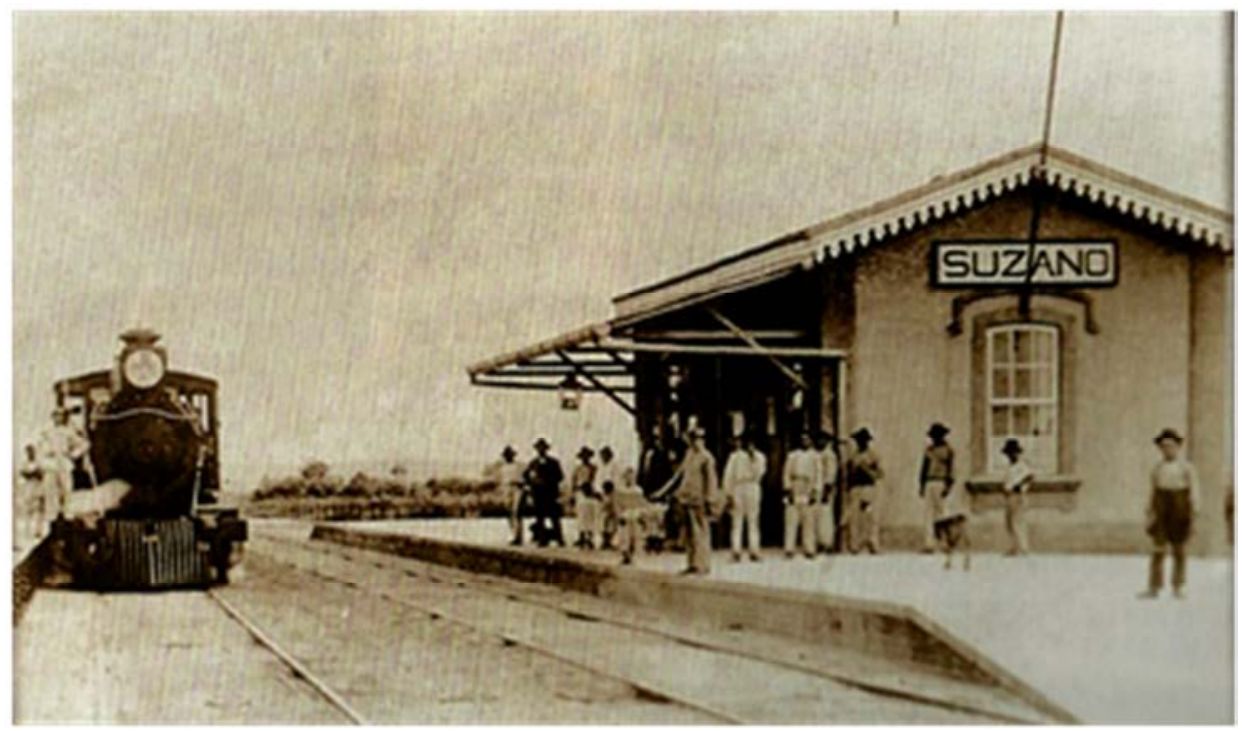

Figura 131.Estação de trem em 1915 - Parada Piedade

Fonte: Memórias de Suzano: histórias e fotos de todos os tempos, do vilarejo à cidade grande, 2009

Figura 132.A estação em 1948: inaugurada em 6 de novembro de 1875

Fonte: www.museuvirtualsuzano.com.br, acessado em 20/10/12

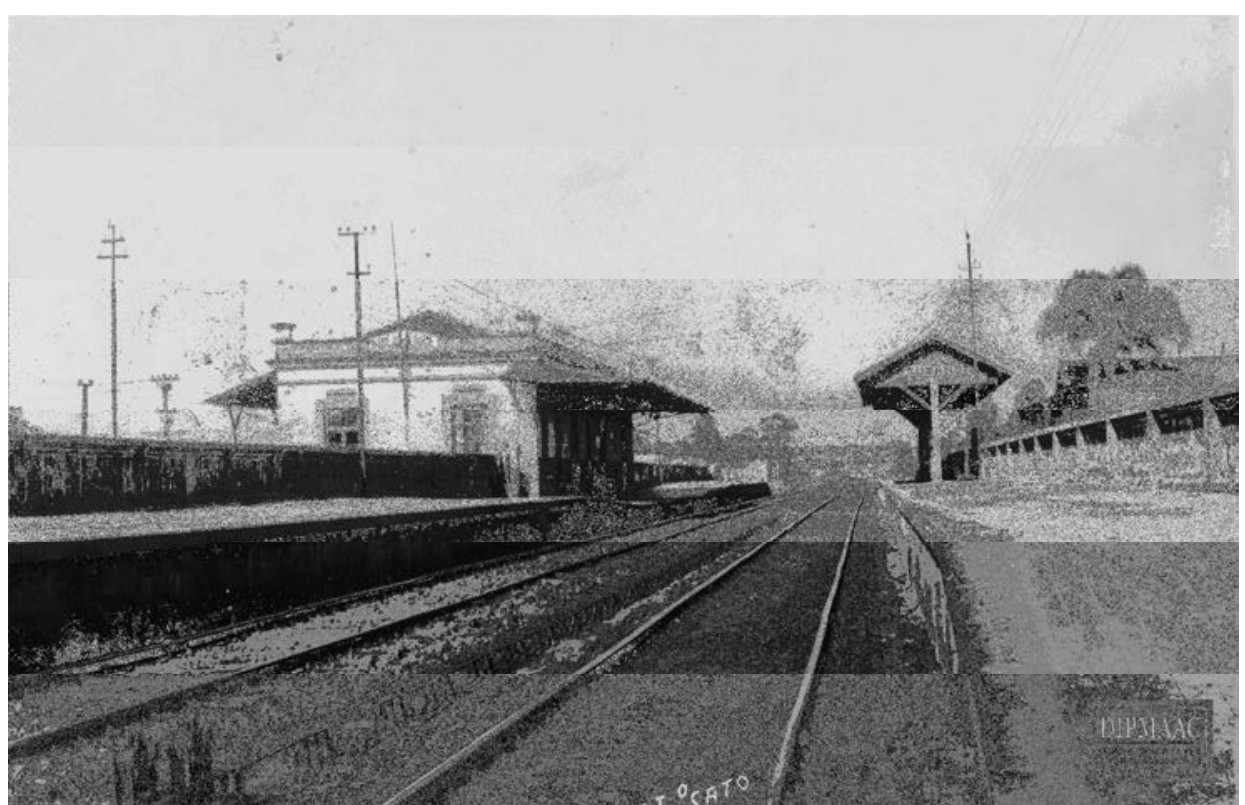

Figura 133.0 casarão de Antonio Marques Figueira - 1a casa do novo núcleo da cidade. Esquerda: casarão em 1952. Direita: imóvel atualmente preservado

Fonte: Memórias de Suzano: histórias e fotos de todos os tempos, do vilarejo à cidade grande, 2009
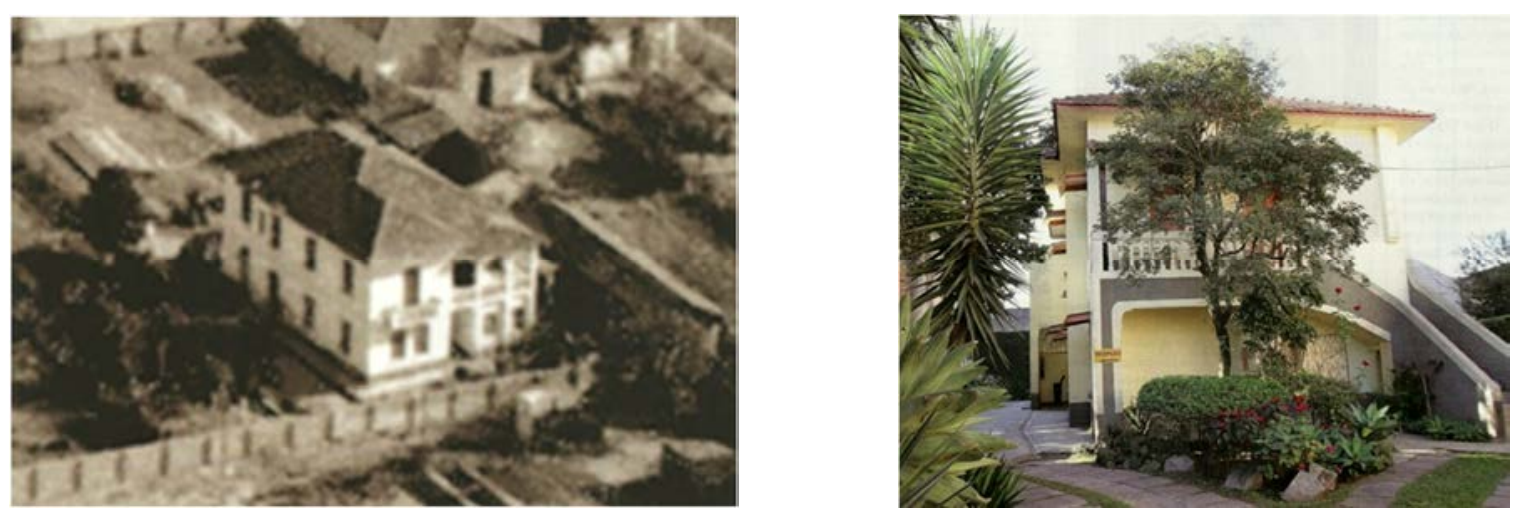
Infelizmente, tem pouca informação quanto à população desta época, pois os dados do IBGE (Instituto Brasileiro de Geografia e Estatística) somente estão disponíveis a partir de 1970. No entanto, Langenbuch aponta em seu doutorado uma população de 86.865 habitantes na Cidade de São Paulo em 1874, enquanto que em Mogi das Cruzes eram 11.460 pessoas nesta mesma data, considerando 30\% desta como a população efetivamente urbana, sendo aproximadamente 3.500 habitantes em Mogi das Cruzes. ${ }^{179}$ No entanto, se avaliarmos as freguesias, ou paróquias, próximas a este território, como Itaquaquecetuba e Arujá, ambos a norte, possuíam 1.878 e 1.568 habitantes respectivamente, e considerando o mesmo método para a população urbana, teríamos 563 em Itaquaquecetuba e 470 habitantes em Arujá. Pelo demonstrado acima, podemos concluir que o núcleo junto à Parada de Piedade não ultrapassava a 500 habitantes, no qual para este território até pouco tempo "deserto", podemos apontar como um fato significativo para a história da atual cidade.

Mas é em 1879 que chega aos 23 anos, Antônio Marques Figueira, português que desembarcou no Brasil três anos antes. Transferido de São José dos Campos para Suzano, ou melhor, uma vilazinha que começava a ser conhecida como Guaió, para trabalhar na estrada de ferro. Este seria o terceiro personagem mais importante para a história deste povo, mas que para outros, considerado o fundador de Suzano, como defendido por Azevedo em suas duas publicações sobre a cidade:

\begin{abstract}
"Apesar de tudo o que se pudesse dizer da Parada de Piedade, do seu isolamento, do fato de se localizar no meio de um campo cercado por muitos pântanos, aquele jovem português, de espírito aventureiro como só tem os pioneiros, encantou-se pelo lugar. E foi ele que ali construiu a primeira casa. É de fato o verdadeiro fundador de Suzano"(AZEVEDO 1994, p 28).
\end{abstract}

Pouco a pouco outras famílias foram atraídas para esta região, construindo suas casas, melhorando suas propriedades e ampliando a ocupação deste território a cada dia. Até mesmo a família Baruel foi aos poucos se mudando para o "centro" da cidade, "deixou a vila de olho no progresso que vislumbrava para os lados do Guaió, em ascensão desde a chegada do trem"(LEONE e Azevedo] 2009, il., p 47).

Percebendo que naquele território havia a possibilidade de "fundar uma cidade", e preocupado com a ocupação desordenada das famílias que chegavam a este local, Antônio Marques Figueira e seu irmão Tomé, que também vivia nas proximidades da Parada de Piedade, em conjunto com outras pessoas importantes como Major Francisco Pinheiro Fróes, dono das fazendas Boa Vista e Revista, a norte da linha férrea, e Major Guilherme Boucault, líder político em Mogi das Cruzes, encomendam ao Conde João Romariz, proprietário de pastagens na Vila Amorim, um "projeto de arruamento" a partir da linha férrea para a cidade que buscavam construir, enquanto a urbanização, ficou a cargo do engenheiro Portugal Freixo.

179. Foi tomado como referencia a Cidade de São Paulo e arredores, com suas devidas freguesias, apesar do autor também apontar os dados da Província de São Paulo, com um território mais extenso. Quanto ao índice adotado para a estimativa da população urbana, o autor não determina o mesmo método para a análise da Cidade de São Paulo, impossibilitando o cálculo para esta cidade. Cabe apontar que Mogi das Cruzes em conjunto com Jundiaí era considerado as paróquias mais populosas dos arredores paulistanos até o momento. 
Figura 134. Vila da Concórdia, desenho de João Romariz, o primeiro traçado urbano da cidade, 1890 Fonte: www.museuvirtualsuzano.com.br, acessado em 20/10/12

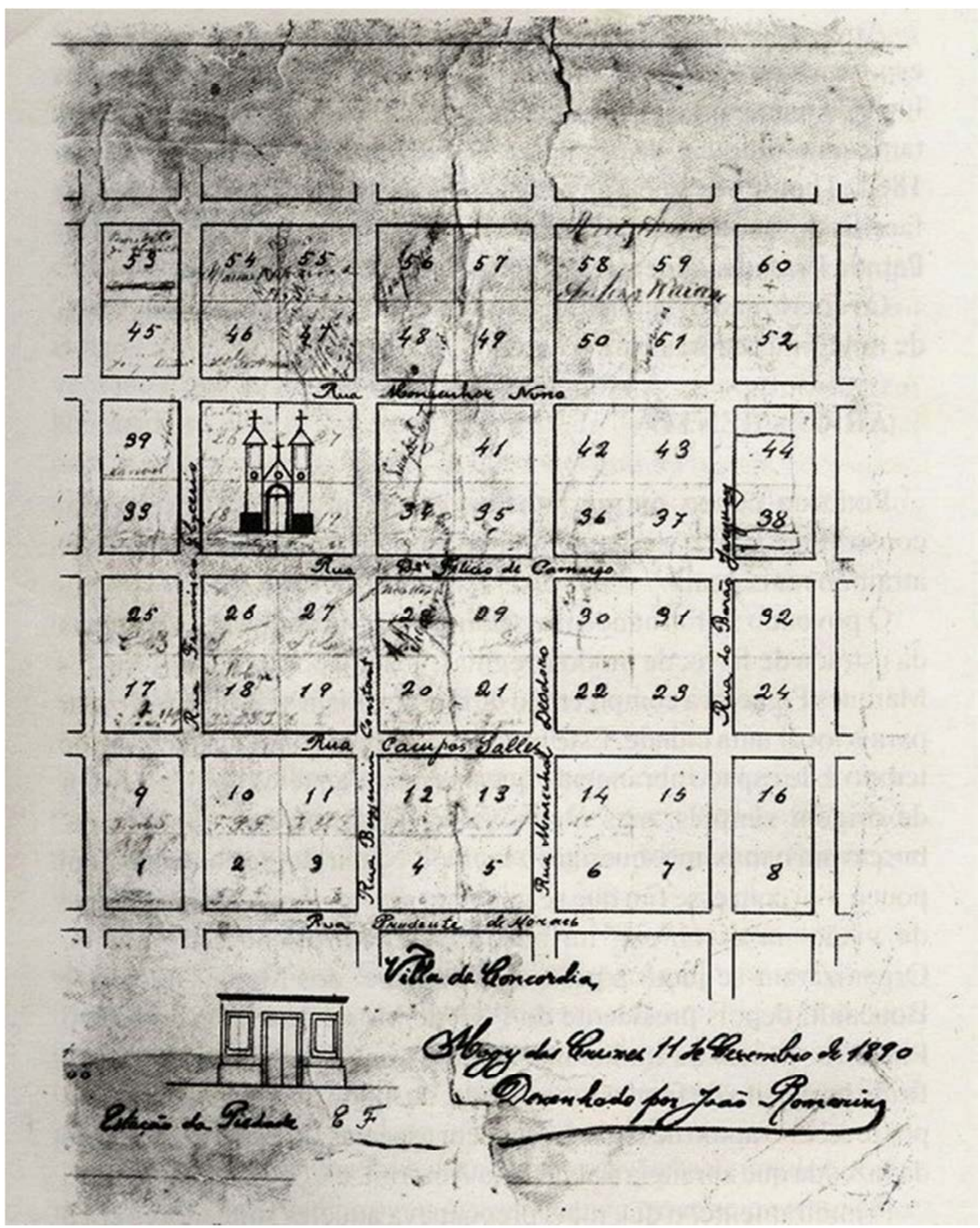


Apesar da aparente configuração simples, compostas por quadras urbanas regulares, 0 projeto aprovado e liberado por decreto federal de agosto de 1890 pelo então Ministro da Agricultura, Comércio e Obras Públicas, General Francisco Glicério Cerqueira Leite, percebe-se que a proposta colocada em prática era suficiente para a consolidação da cidade, como aponta Leone sobre a consciência de Antonio Marques Figueira sobre o projeto: "ele tinha noção de cidade, de urbanização, de civilidade monumental. Criou a cidade, a capela, a primeira banda da música"(LEONE e Azevedo] 2009, il., p 47).

Em 11 de dezembro de 1890, apenas 4 meses após a aprovação, declararam fundada a Vila da Concórdia. Vale ressaltar que a instabilidade governamental no Brasil poderia gerar novas transformações, em particular sobre a Estrada de Ferro, elemento norteador da nova ocupação, a República foi proclamada a apenas um ano por meio de golpe de estado militar e com isto, torno-se necessário a confirmação e consolidação desta "nova cidade" o mais rápido possível.

Desde então, já no final do século XIX, este ato de fundação e consolidação da Vila da Concórdia, rendeu a cada ano mais conquistas ao povo que ali vivia. No entanto, segundo Azevedo, persistia como a principal demanda do povoado, a construção de uma estação de passageiros. "Depois da encampação da Estrada de ferro, o povo consegue que no local de sua humilde parada seja inaugurada, no dia 11 de abril de 1891, a Estação de 'Piedade', feita de madeira".Apesar da grande conquista deste novo povoado que se formava a parada ainda recebia o nome do primeiro núcleo formado ao sul deste ponto, até porque as pessoas que ali viviam ainda não tinham abstraído o nome dado por seus fundadores e quando não a chamavam pelo nome da parada de trem, ainda era muito forte o nome popular dado aquela região em referência ao rio que passava por ali, o rio Guaió era ponto concentrador do que a geografia representava.

Fica claro que os habitantes daquele novo núcleo consideravam a Vila da Concórdia, ou popularmente a região do Guaió, como o marco para a "modernidade" do povoado que se localizava no Baruel, a 15 quilômetros daquela ocupação do século XVIII, primeiramente pelo fato de que naquele território a linha férrea que passava por ali e foi responsável pela ligação entre Mogi das Cruzes e São Paulo tornara-se o "elemento pulsionante" de atração de famílias que se instalavam nos "Campos de Mirambava", e depois este mesmo pólo de atração consolidava a cada dia a instalação da Vila neste local e consequentemente a instalação do comércio local, como a venda de carvão, lenha e madeira para o funcionamento da estação, ${ }^{180}$ garantindo a estabilidade da Estação e, consequentemente, a sobrevivência daquela gente que ali se instalara.

Com o passar do tempo a Parada Piedade ficou pequena para o tamanho movimento. Como já apontado, ainda no final do século XIX a Vila da Concórdia já possuía escola para meninos, posto teleférico e iluminação pública, ${ }^{181}$ que para aquele período, foi de grande valia e importância para o desenvolvimento deste núcleo central. Isto fez com Antonio Marques Figueira com outros importantes personagens da vila procurasse 0 então Engenheiro Residente da Estrada de Ferro Central do Brasil em Mogi das Cruzes, Joaquim Augusto Suzano Brandão para solicitar melhorias da parada ainda tímida e em

180. A Parada de Piedade foi implantada como um ponto de abastecimento de lenha e carvão para abastecimento das locomotivas.

181. A escola para meninos foi inaugurada em 1892; o Posto Telegráfico em 1894 e, no mesmo ano os primeiros (dez no total) lampiões com querosene. 
madeira. Atendendo aos pedidos, foi solicitado os estudos e em 1894 a pequena parada ganhou uma nova construção, feita em "alvenaria de tijolo com área de 58,91 $\mathrm{m}^{2} \mathrm{e}$ plataforma cimentada coberta de zinco"(AZEVEDO 1994, p 34), apesar de não diferenciar das demais estações padrão da Ferrovia, foi mais uma conquista daquele povoado que decide homenagear seu construtor dando o nome a nova estação de "Suzano".

"Em 22 de dezembro de 1907, a Vila da Concórdia promoveu uma grande festa, ali na parada de trem, que já se chamava 'Guaió', mesmo nome do posto telegráfico instalado em 1894, para trocar a tabuleta do nome da estação para 'Suzano'”(LEONE e Azevedo] 2009, il., p 55).

Um ano mais tarde, em 11 de dezembro, a vila passa a ser chamada oficialmente pelo nome de Suzano, que se desenvolve continuamente com o progresso paralelo da linha férrea. A bitola da linha ferroviária foi ampliada para que nela pudessem correr os trens "mais modernos", começando em 1911 a circular o trem de subúrbio de São Paulo a Mogi das Cruzes e com parada na então recém Suzano. Nos anos seguintes, as viagens aumentavam e, consequentemente, a "mancha urbana" da cidade crescia junto a estes avanços.

É evidente que a passagem da linha férrea sobre os "Campos de Mirambava" foi o fio condutor da "transferência" do antigo povoado de Piedade, no longínquo Baruel, para as terras planas junto às várzeas do rio Guaió, como aponta Lanchenbuch a respeito da influência da ferrovia no desenvolvimento de São Paulo e demais cidades que se formaram ao longo desta linha: "Se o grande crescimento de São Paulo constitui o fato gerador de dita metamorfose, a ferrovia, novel meio de circulação, irá funcionar como fator do arranjo espacial da nova organização" (LANGENBUCH 1971, p 98), da mesma forma, o autor ainda relata sobre a valorização das terras antes desvalorizadas por sua localização em terras baixas junto às várzeas aluviais, "as ferrovias provocaram uma valorização das faixas de terra por elas percorridas em detrimento daquelas que ladeavam estradas de tropa"(LEONE e Azevedo] 2009, il., p 101).

É com este espírito que o crescimento de Suzano foi impulsionado. As terras lindeiras a linha férrea foram cada vez mais se tornando ocupações destinadas a atender não mais somente à Central do Brasil, mas o comércio que por ali se estabelecia com uma diversidade de usos ligados ao setor alimentício e abastecimento cada vez mais atenderia as famílias que se instalavam a cada ano neste território.

"A cidade se ampliaria, assim, de forma crescente, num tempo físico e virtual, desenvolvendo uma estrutura mais aberta e multiplicadora em um novo cenário mais complexo e diversificado. A antiga necessidade de aglomeração capaz de facilitar a produção, o intercâmbio, defesa e comunicação se (des) localizaria, assim, nesse grande 'território-parque' - ao que se remete Dietmar Steiner - pontuado, de fato, áreas mais ou menos focais e de áreas residuais especializadas: espaços, finalmente, dedicados ao consumo, moradia, trabalho e lazer localizados em bolsões descontínuos interligados por redes de transporte"(GAUSA 2010, p 161). ${ }^{182}$

182. Tradução do autor, 2010, pag. 249 
Este território se estruturou cada vez mais se tornando independente do primeiro núcleo ao sul e, por outro lado, relacionando-se com a linha leste-oeste que ligava Mogi à São Paulo.

A proposta de ocupação desenhada pelo Conde João Romariz apresenta hoje um número de quadras singelo, mas talvez para aquela época (final do século XIX) suficiente para este novo núcleo urbano que nascera. Sessenta "lotes" implantados em quadras regulares de 1 ha (um hectare) e uma pequena parcela de $1 / 2$ ha (meio hectare), no que totalizavam naquela época 20 quadras. Curiosamente uma das quadras localizada entre as ruas Francisco Glicério, Felício de Camargo, Benjamin Constant e Campos Salles não foi contabilizada na divisão dos lotes, identificada para a implantação da capela do novo vilarejo e localizada no eixo da Estação da Piedade, esta quadra deveria receber a edificação que identificaria a religiosidade dos que ali se estabeleceram e desde já, mesmo de forma gratuita, iria compor um princípio de construção de "cenário urbano" para o novo núcleo urbano.

Em 1897, segundo Azevedo, foi celebrada a primeira missa, em 20 de janeiro, na recém construída Capela de São Sebastião. No entanto, a localização desta capela não se deu no local pré-definido pela planta do Conde Romariz sete anos antes, construída por Antonio Marques Figueira, esta foi implantada uma quadra a norte e mais próximo à estação. No entanto, a capela por um longo período foi pouco utilizada, afinal, foi de "propriedade dos Figueiras.

Após anos de discórdias entre a família, os populares que reivindicavam as missas na capela e a Mitra Diocesana de São Paulo, inclusive com o processo de usucapião, os Marques Figueira passaram a capela para a Igreja em 1936. "A prefeitura desapropriou a área que ficou reservada à praça, que, naquele tempo, nem jardim tinha"(LEONE e Azevedo] 2009, il., p 60).

Oito anos depois, em 1944, foi construído na praça o salão paroquial, que por muitos anos, funcionou como igreja do povoado durante a construção nos anos 50 da matriz atual, projeto considerado moderno até demais para a época, desenhado pelo arquiteto Octavio Lotufo, de São Paulo, no lugar da capelinha de uma única torre.

Como defendido por Langenbuch, "as estações ferroviárias que foram sendo estabelecidas nos arredores paulistanos se constituíram, assim, em pontos de convergência de produtos e pessoas das áreas circunvizinhas"(1971 p 104). Em Suzano, este fator se deu de forma gradativa nas duas primeiras décadas do século XX, o vilarejo que já possuía um conjunto de quadras urbanas, uma escola e a capela estavam cada vez mais se tornando autônoma do antigo vilarejo do Baruel ao sul deste território e progressivamente, de Mogi das Cruzes.

La ciudad se ampliaria, así, de forma creciente, física y virtual a un tempo, desarrollando uma estructura más abierta y multiplicada em un nuevo paisaje más complejo, y diversificado. La antigua necesidad de una aglomeración capaz de facilitar la producción, el intercambio, la defensa y la comunicación se (des) localizaria, así, en esse gran 'territorioparque' - al que se referiria Dietmar Steiner - salpicado, en efecto, de áreas más o menos focales y de áreas residuales especializadas: espacios, en definitiva, dedicados al consumo, la residencia, el trabajo y el ócio localizados en bolsas discontinuas enlazadas por redes de transporte. 


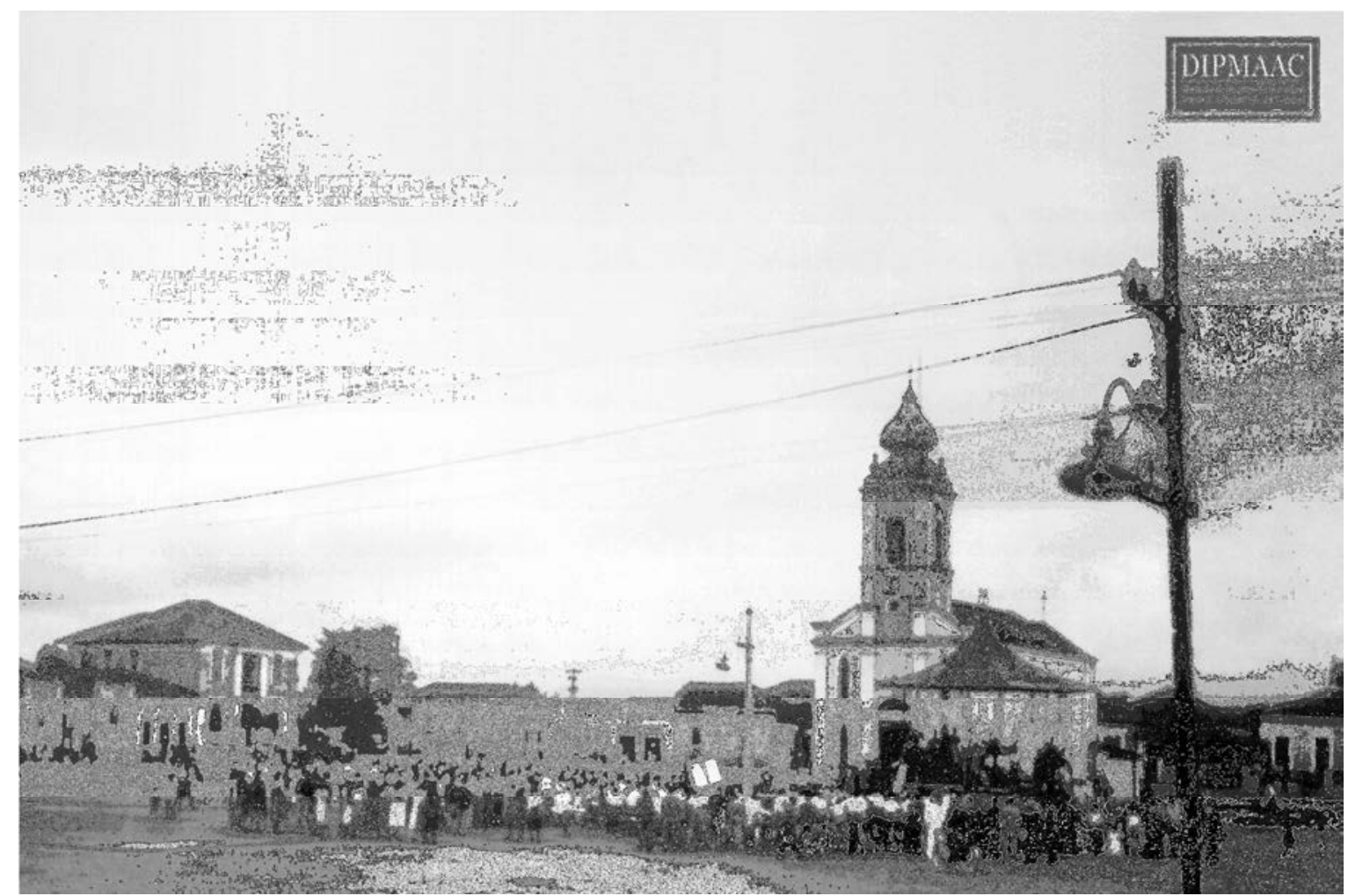

Figura 135. Capela de São Sebastião do Guaió, final do século XIX

Fonte: www.museuvirtualsuzano.com.br, acessado em 20/10/12

Figura 136. Igreja Matriz São Sebastião nos dias atuais

Foto: Elvis Vieira, 2011

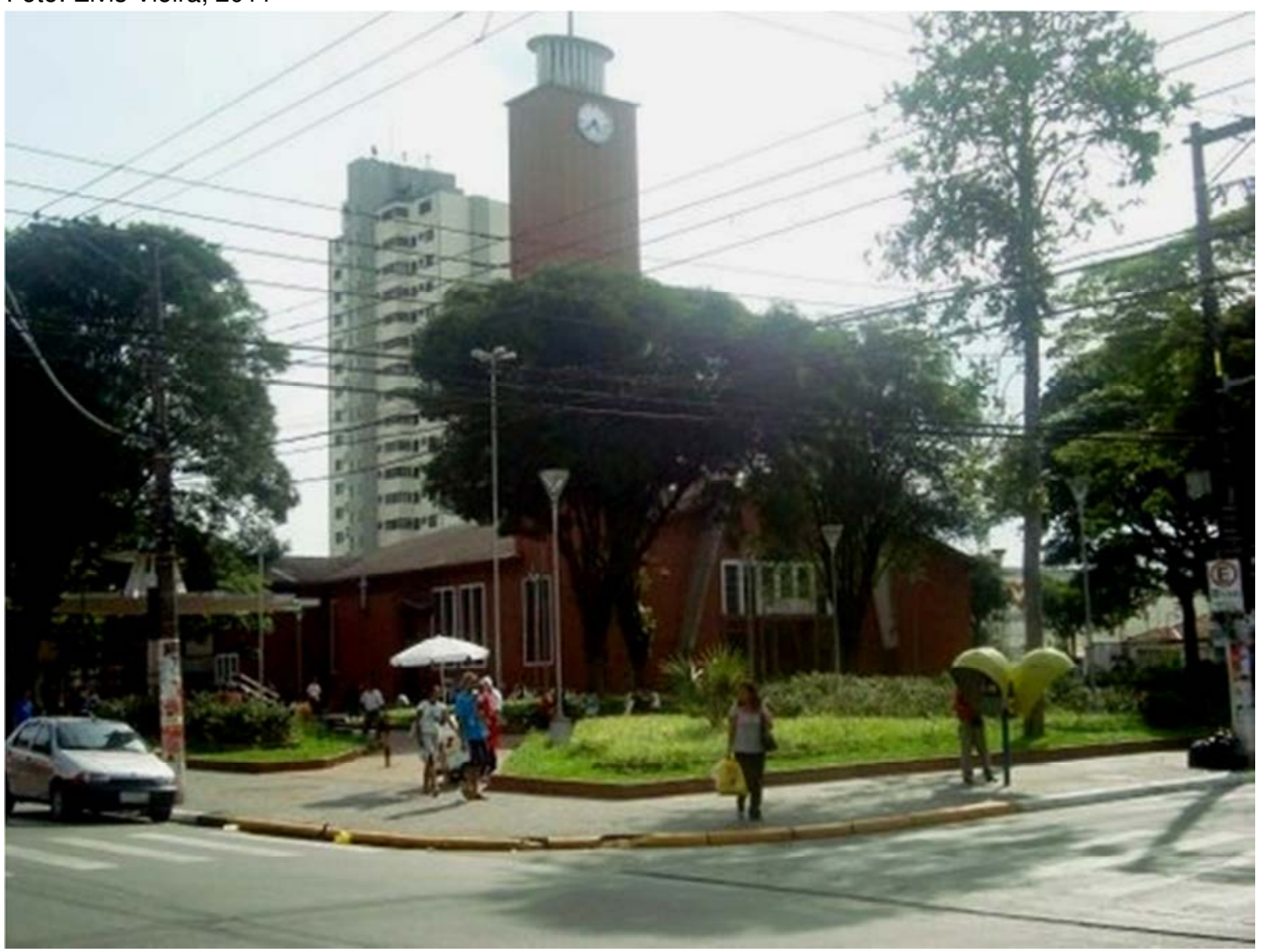


Outro fator relevante foi quanto a expansão demográfica em que se apresentava desde a chegada e instalação de Antonio Marques Figueira próximo a ferrovia, em 1879, até o início do século $X X$, onde há um número significativo de pessoas morando na então Suzano. Um documento elaborado por lideranças locais descreve o vilarejo em 1919: "havia 500 prédios habitados, população estimada em mil moradores, colégio eleitoral com 50 cidadãos alistados e distrito policial, mercado, igreja, casa de diversões, duas escolas públicas para meninos e meninas, diversas fazendas de criação $e$ cultura"(LEONE e Azevedo] 2009, il., p 83). Infelizmente a falta de registros desde a chegada dos Figueiras aos Campos de Mirambava, e mesmo no Vilarejo de Baruel, não temos a possibilidade de analisar a evolução e variação populacional entre estes períodos, até porque todo o território, hoje conhecido como a Cidade de Suzano, e outras hoje existentes, ainda pertenciam administrativamente à Mogi das Cruzes. No entanto, fica claro que mesmo com o acanhado número de moradores, a projeção populacional foi muito significativa nestes primeiros 40 anos.

Langenbuch utiliza de censos e apontamentos deste período para demonstrar o Efeito Demográfico e Variação da População de São Paulo e municípios (Unidades Territoriais Compatíveis) ao redor da capital, onde Mogi das Cruzes é demonstrada abaixo conforme tabela abstraída de sua tese de doutoramento:

3. EFEITO DEMOGRÁFICO E VARIAÇÃO DA POPULAÇÃO

\begin{tabular}{|c|c|c|c|c|c|c|c|c|}
\hline \multirow{2}{*}{$\begin{array}{c}\text { UNIDADES } \\
\text { TERRITORIAIS } \\
\text { COMPATÍVEIS } \\
\text { (Municípios) }\end{array}$} & \multicolumn{4}{|c|}{$\begin{array}{c}\text { POPULAÇÃO } \\
\text { (Número de habitantes) }\end{array}$} & \multicolumn{4}{|c|}{$\begin{array}{l}\text { VARIAÇÃO DA POPULAÇÃO } \\
\text { ÍNDICES (Ano anterior }=100)^{*}\end{array}$} \\
\hline & 1874 & 1886 & 1900 & 1920 & $1874 / 1886$ & $1886 / 1900$ & $1900 / 1920$ & $1874 / 1920$ \\
\hline Guarulhos & 2.604 & 3.646 & 3.455 & 5.961 & 140 & 95 & 173 & 229 \\
\hline $\begin{array}{l}\text { Mogi das } \\
\text { Cruzes }\end{array}$ & 16.584 & 19.454 & 15.694 & 29.158 & 117 & 81 & 186 & 176 \\
\hline São Bernardo & 2.787 & 3.667 & 10.124 & 25.215 & 132 & 276 & 249 & 905 \\
\hline Santo Amaro & 5.470 & 6.259 & 7.132 & 14.101 & 114 & 113 & 197 & 258 \\
\hline Itapecerica & 4.896 & 6.413 & 10.480 & 11.830 & 131 & 163 & 113 & 242 \\
\hline Cotia & 5.024 & 7.517 & 4.892 & 9.340 & 150 & 66 & 187 & 186 \\
\hline Parnaíba & 3.338 & 4.931 & 7.406 & 7.981 & 148 & 150 & 108 & 239 \\
\hline Juqueri & 2.720 & 3.363 & 5.263 & 9.098 & 124 & 156 & 173 & 334 \\
\hline Jundiaí & 7.805 & 10.254 & 14.990 & 44.437 & 131 & 146 & 297 & 569 \\
\hline $\begin{array}{l}\text { TOTAL } \\
\text { MUNICÍPIOS } \\
\text { VIZINHOS AO } \\
\text { DE SÃO } \\
\text { PAULO }\end{array}$ & 51.228 & 65.504 & 79.526 & 157.121 & 128 & 122 & 198 & 307 \\
\hline SÃO PAULO & 23.253 & 44.033 & 239.820 & 579.033 & 189 & 545 & 241 & 2.490 \\
\hline $\begin{array}{l}\text { TOTAL SÃO } \\
\text { PAULO E } \\
\text { ARREDORES }\end{array}$ & 74.481 & 109.537 & 319.346 & 736.154 & 147 & 292 & 231 & 988 \\
\hline $\begin{array}{l}\text { TOTAL DA } \\
\text { PROVÍNCIA } \\
(1874 \text { e 1886) } \\
\text { ESTADO } \\
(1900 \text { e 1920) }\end{array}$ & 762.873 & 1.111 .857 & 1962.933 & 3.856 .034 & 146 & 175 & 196 & 505 \\
\hline $\begin{array}{l}\text { TOTAL } \\
\text { PROVÍNCIA } \\
\text { (1874 e 1886) } \\
\text { ESTADO }\end{array}$ & 837.354 & 1.221 .394 & 2282.279 & 4.592 .188 & 146 & 187 & 201 & 548 \\
\hline
\end{tabular}

${ }^{*}$ Atente-se para o fato de o intervalo entre os censos variáveis

Fonte: 1874: Manuel Eufrazio de Azevedo MARQUES - Apontamentos... - 1886: Comissão Central de Estatística - Relatório... - 1900 e 1920 - Recenseamentos Gerais do Brasil. 
Ao analisarmos o quadro na pag. 251, observamos que o município de Mogi das Cruzes apresenta o maior índice demográfico em 1874, entre os demais ao redor de São Paulo. Apesar de seu crescimento ser o menor entre os demais apontados acima, tendo São Bernardo com o maior índice na variação da população entre o final do século XIX e início do XX, Mogi das Cruzes ainda apresenta em 1920 um número considerável de pessoas morando nesta Unidade Territorial. Este período nos interessa por se tratar do mesmo em que obtemos dados referentes aos moradores de Suzano.

Como já dito acima, em 1919 a população de Suzano era estimada em 1.000 moradores no vilarejo, no qual significa $3,5 \%$ do total da Unidade Territorial de Mogi das Cruzes naquela época, ${ }^{183}$ porém se considerarmos que em 1885 , data da construção da primeira casa junto a Parada de Piedade, se tinha pouquíssimos moradores neste território, mais especificamente os Figueiras, o crescimento entre meados da década de 80 e final de 10 no século $X X$, foi rápido e considerável, ampliando em aproximadamente 500 vezes o número de moradores em apenas 34 anos. Cabe ressaltar que não foi possível analisar a variação entre os períodos pela falta de dados concretos entre estes dois períodos. Já em 1920, segundo Suami Azevedo, a população chegara a 2.707 habitantes, ampliando em apenas um ano aproximadamente $270 \% \mathrm{em}$ relação ao ano anterior.

O mesmo podemos afirmar quanto ao número de comércio instalado neste território em relação ao núcleo de Baruel, que "em 1917 Suzano já contava com treze casas comerciais, no Baruel restavam apenas duas"(AZEVEDO 2004, p 101).

\section{EVOLUÇÃo URBANA dE SUZANO ATÉ INÍCIO dO SÉCULO XX}

Elaboração: Elvis Vieira, 2010

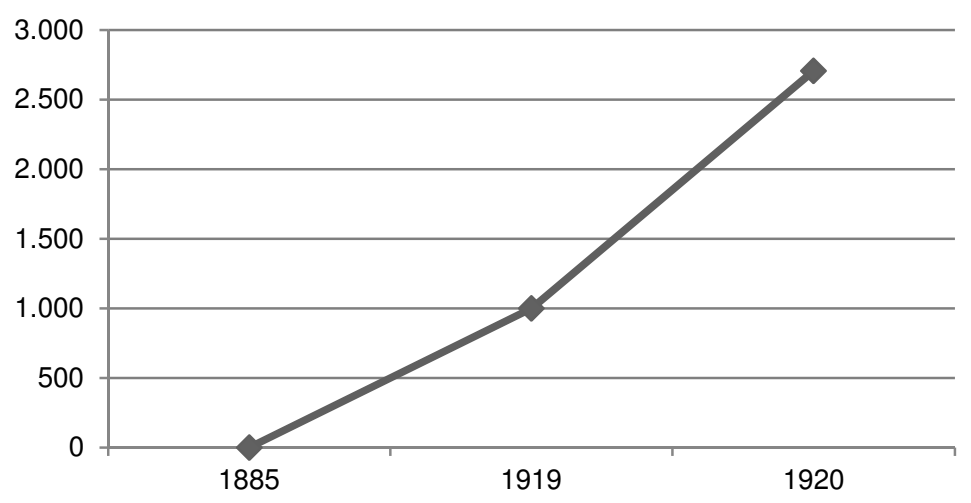

Estes fatores, entre outros, elevaram Suzano a Distrito de Mogi das Cruzes em 17 de dezembro de 1919, pela Lei Estadual no 1.705, outorgado pelo então Presidente do Estado, Dr. Altino Arantes. No entanto, sua instalação oficial se deu apenas em 4 de maio de 1920.

O primeiro subprefeito a assumir o distrito de Suzano foi Antonio José da Costa Conceição, nomeado em 1 de maio de 1920, tendo nos anos subseqüentes outros exercendo este cargo, como: Roberto Bianchi, José da Conceição, Batista Renzi,

183. Deve-se considerar que em 1920 Mogi das Cruzes possuía um território composto pelos atuais municípios: Mogi das Cruzes, Suzano, Poá, Ferraz de Vasconcelos, Itaquaquecetuba e Biritiba Mirim. 
Bernardino José Pereira, Benedito Alfredo Roberto, João Faggion e Antonio José Pereira, consecutivamente.

Apesar de seu visível crescimento, o capital aplicado sobre o novo território junto a Parada de Piedade com a instalação de mais comércio e, já neste momento no início da década de 20, a chegada das indústrias nas proximidades do eixo ferroviário do distrito, ${ }^{184}$ este local ainda era muito precário e carente de infraestrutura urbana, onde sequer uma rua era "calçada", a iluminação insuficiente com apenas algumas ruas servidas por lampião e qualquer tipo de instalação ou rede de saneamento básico. Já nos anos 30, a agricultura foi a principal economia do distrito; milho, feijão, cana, mandioca, batata, tomate, rabanete, repolho, alface, couve, chicória, escarola, entre outros eram produzidos principalmente pela colônia japonesa que crescia diariamente, além das granjas e criações de gado que existiam no território de Suzano. Toda a produção seguia para os grandes centros, inicialmente de trem e mais tarde de caminhão pela estrada São Paulo-Rio de Janeiro, caminho de terra aberto em 1924.

Era notório o crescimento urbano de Suzano, ao compararmos as duas imagens (fig. 137 e 138, pag. 254), a primeira de 1935 e a próxima de 1952, já emancipada de Mogi das Cruzes, percebemos que seu tecido urbano manteve um ritmo de crescimento continuo sobre as terras antes destinadas à produção agrícola ou de gado, como no caso das terras à leste, atual Vila Amorim.

No início da década de 40, o perímetro central da cidade era composto pelo conjunto de quadras traçadas inicialmente pelo "Plano Urbanístico de Romariz" e, outras em particular a sul deste traçado que se expandiam para suprir a demanda e crescimento do distrito. Observamos também a presença de ocupações ao norte, junto à linha férrea, no entanto, ainda de forma tímida e com maior incidência de produção agrícola, e as primeiras fabricas que se instalaram neste território (Vinícola Sóvis e Sedas Maluf). No mais, como apontado por Leone, "o perímetro central tinha as seguintes ruas: Coronel Souza Franco, Monsenhor Nuno, marechal Deodoro, Benjamin Constant, 27 de Outubro, General Francisco Glicério, Municipal, Baruel, Mirambava, Felício de Camargo, Prudente de Moraes, Major Pinheiro Fróes, travessa da Fábrica e rua 1 (atravessando a linha férrea)"(LEONE e Azevedo] 2009, il., p 84), nos levando a concluir que o distrito se expandir neste primeiro momento para sul da linha férrea duplicando seu território em relação ao primeiro traçado implantado no final do século XIX.

Pouco mais de uma década, observamos na foto área de 1952 uma cidade mais extensa e ocupada, com suas quadras quase todas ocupadas por casas, comércio e indústria. Consequentemente cresce a população da cidade ao longo destes anos; apesar de não termos registro da população durante o século XIX, já as primeiras décadas do século XX são apontadas por Leone e Azevedo em suas descrições sobre o distrito e mais tarde cidade de Suzano, nos possibilitando compreender o crescimento demográfico da cidade. "Por volta de 1940, o vilarejo tinha aproximadamente $\underline{6}$ mil moradores, que passaram para 11.157 habitantes em 1950" (LEONE e Azevedo] 2009, il., p 87 - grifo nosso).

184. As primeiras fábricas a se instalarem no distrito foram na década de 1920, como a Vinícola Sóvis, do italiano Amadeu Mazza, e a Sedas Maluf, do libanês Jorge Bey Maluf, especializada em seda e viscose. 
Figura 137.Suzano em 1935: o distrito tinha a maior arrecadação entre outros bairros que pertenciam a Mogi das Cruzes. Nota-se um número limitado de ruas, ainda em terra, das quais as existentes até hoje como Gal. Francisco Glicério, Benjamin Constant, Marechal Deodoro, Major Pinheiro Fróes, Monsenhor Nuno, Prudente de Moraes, onde a ocupação se limitava ao projeto do eng. Josão Romariz

Fonte: Memórias de Suzano: histórias e fotos de todos os tempos, do vilarejo à cidade grande, 2009

Figura 138.Suzano em 1952: emancipada, independente de Mogi das Cruzes

Fonte: Memórias de Suzano: histórias e fotos de todos os tempos, do vilarejo à cidade grande, 2009
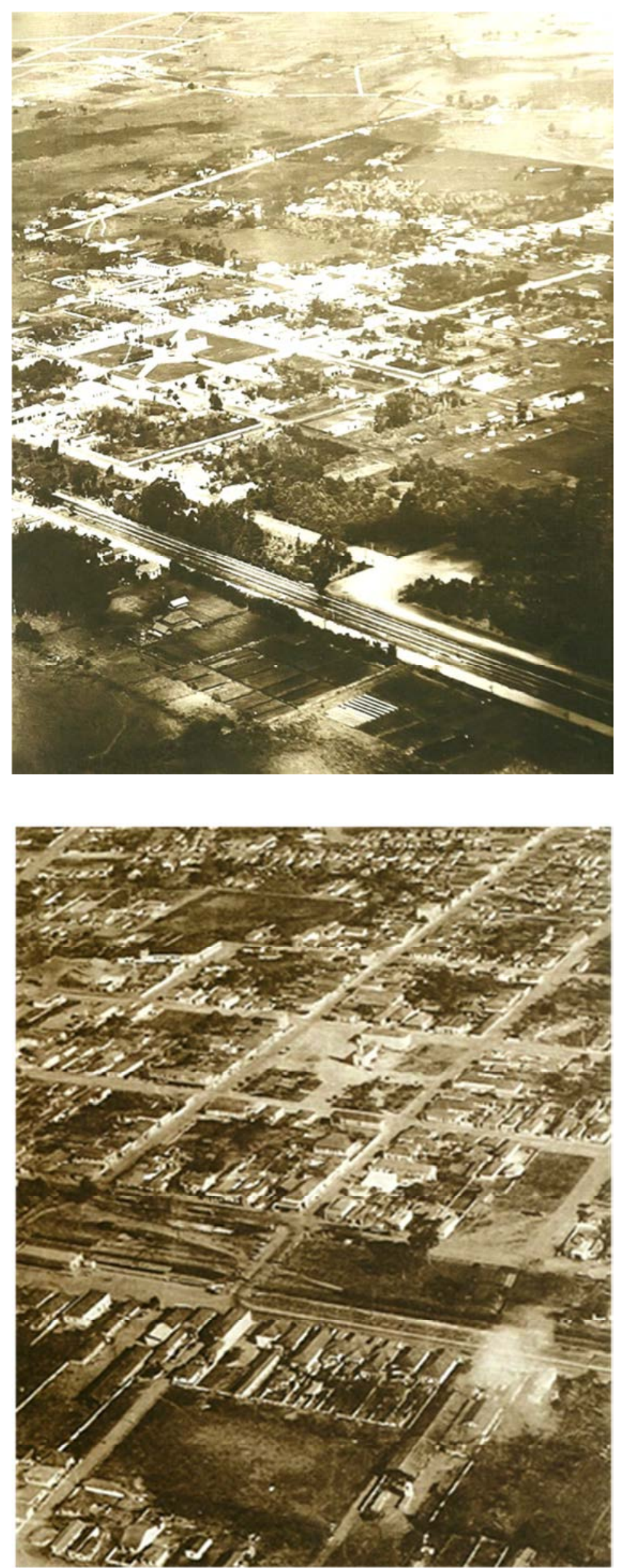


\section{EVOLUÇÃo URBANA DE SUZANO ATÉ MEAdOS DO SÉCULO XX}

Elaboração: Elvis Vieira, 2010

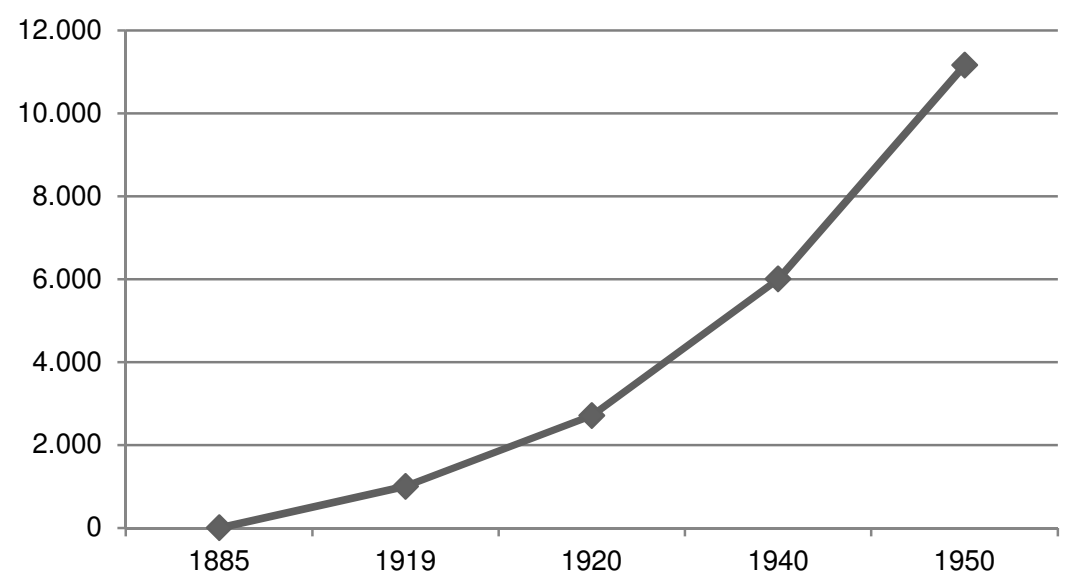

Todo este crescimento urbano como a ampliação continua da população da cidade, além da arrecadação que chegou ao final da década de 40 a mais representativa dos distritos de Mogi das Cruzes, tendo neste mesmo período a agricultura como produção responsável, $45,7 \%$ da arrecadação, enquanto que a indústria respondia por $20 \%$ e $11,3 \%$ para o comércio, chegando em 1947 a $\mathrm{Cr} \$ 209.038,70$, de janeiro a novembro daquele ano, levou a população e representantes do distrito a se organizarem em prol a emancipação de Mogi, que contribuíam significativamente para o "distrito central" e pouco recebiam em troca, visto que Suzano ainda era muito precária e carente social e urbanisticamente.

Leone em referencia à Azevedo, aponta que três pessoas proeminentes da época foram responsáveis ao principio de "rebelião" contra Mogi: Anis Fadul, Mário Marques de Carvalho e Horácio de Souza Coutinho.

"Políticos, industriais, comerciantes, operários, operários, autoridades e lideranças de vários segmentos da comunidade, enfim, e muitos outros que foram se solidarizando à causa, se reuniram em novembro de 1947 no salão da Associação Atlética União Suzanense e começaram a discutir a independência da cidade"(2009, il.p 89).

Em 7 de abril de 1948, foi apresentado o Requerimento n 292 que apresentava o pleito da população suzanense de emancipação política do distrito. Para tanto, foi necessária primeiramente uma arrecadação mínima de $\operatorname{Cr} \$ 100.000,00$, no qual neste período o distrito já arrecadava mais que o dobro deste valor, que garantiu o direito a consulta popular para a confirmação da emancipação solicitada.

"Os suzanenses, já mais organizados, estabeleceram um Regimento Interno. A Tesouraria foi dada a Carlos Molteni. Rubens Fink foi mais uma vez escolhido para conduzir o Alistamento, apoiado agora por Thadeu José de Moraes"(AZEVEDO 2004, p 108), além de outras personagens que contribuíram para os trabalhos e condução do Plebiscito, como: Antonio Rodrigues de Almeida, Keida J. Casado, Renato Della Lata, Francisco Marques Figueira, Waldemar Calil, João Alves Machado, João Braghiroli, Antonio da Costa Soares, Rubens Fink e Mario Marques de Carvalho, mais tarde 
juntaram-se ao grupo Anis Fadul, Orlando Papaiz Primo, João Raul Benvenuti, Abdo Rachid e Alberto Werner Fink.

Em 10 de outubro de 1948 foi realizado a que podemos chamar da "primeira eleição de Suzano", tendo um resultado muito positivo e refletindo claramente o sentimento da população suzanense. "De um total de 1.938 pessoas participantes, tivemos: 1.925 votos a favor da autonomia; 8 votos contra a autonomia, 4 votos nulos, e somente 1 voto em branco"(AZEVEDO 1994, p 65).

Vale ressaltar que se inscreveram 2.332 eleitores para o plebiscito, em que os interessados deveriam preencher um formulário com informações como dados pessoais, número de filhos, se eram proprietários e, curiosamente, deveriam assinalar quais melhorias desejavam para o distrito. "Uma pesquisa fundamental para nortear ações de governantes futuros"(LEONE e Azevedo] 2009, il., p 92). Infelizmente não tivemos acesso a estes documentos que poderiam apontar num primeiro instante as demandas do distrito e sua real situação urbana neste território. Outro dado importante é a porcentagem de interessados em demonstrar suas intenções da emancipação do distrito, considerando que no final da década de 40 , segundo Leone a população de Suzano chegara a 11.157 habitantes, no qual $21 \%$ da população se alistaram, ${ }^{185}$ número considerável para a época.

"Assim a Lei no 233/48 garantia a instalação do Município de Suzano a 1ำ de janeiro de 1949. Mas não era possível. Precisavam escolher os governantes. As eleições dos trezes Vereadores e do Prefeito foram marcadas para 13 de março de 1949"(AZEVEDO 2004, p 110).

Dois se candidataram ao cargo de prefeito, José Mariano de Souza Coutinho e Abdo Rachid, que acabou vitorioso por uma pequena margem de votos, dos 1.261 eleitores, 854 foram às urnas, tendo Rachid 515 votos, $60 \%$ dos votos validos naquela eleição.

"No dia 2 de abril de 1949, o Cine Suzano, com pequena capacidade, abre suas portas. Fica lotado. O Juiz de Direito de Mogi das Cruzes, Titular da 74a Zona Eleitoral, Dr. Sylvio Barbosa, às 16 horas da início à cerimônia de posse aos eleitos nas primeiras votações autônomas de Suzano. Oficializa-se assim o início de mais uma fase na vida da agora Município. A partir daí, por conta e risco dos seus cidadãos, que passam a assumir suas responsabilidades em plenitude"(AZEVEDO 2004, p 112).

Em análise ao plano de governo do primeiro prefeito do Município de Suzano, foi possível identificar os principais problemas que a cidade enfrentava no final da década de 40 , além das propostas do político.

Resumidamente, podemos apontar 6 temas a serem tratados em seu governo, que durou de 2 de abril de 1949 a $1^{\circ}$ de abril de 1953: Higiene, Educação, Estradas, Assistência à agricultura, Eletrificação e Jardim Público, além da organização

185. Deve-se observar que boa parcela da população de Suzano deveria ser analfabetos, menores de idade ou não residiam no distrito a mais de dois anos, condição imposta para o alistamento e direito a voto. 
administrativa "para que os serviços burocráticos da municipalidade funcionem com eficiência e com o mínimo de gastos". ${ }^{186}$ No entanto, vamos nos deter com mais detalhes no próximo capitulo desta tese.

Neste período, o território de Suzano era de $165 \mathrm{Km}^{2}$ (cento e sessenta e cinco quilômetros quadrados), sendo mais tarde ampliado para $184 \mathrm{Km}^{2}$ (cento e oitenta e quatro quilômetros quadrados), por meio da Lei Estadual de 1963, somando o Bairro dos Fernandes antes pertencentes à Poá, mantendo esta área até final do século XX, em 1994, o Município tem um acréscimo de $22 \mathrm{Km}^{2}$ (vinte e dois quilômetros quadrados) de territórios a norte da cidade e pertencentes à Mogi das Cruzes, chegando a uma área de $206 \mathrm{Km}^{2}$ (duzentos e seis quilômetros quadrados), depois do plebiscito, definido em Lei Estadual.

186 . Abdo Rachid, 1949. 
Figura 139.Inauguração do Paço Municipal na Rua Campos Sales - 1952

Fonte: www.museuvirtualsuzano.com.br, acessado em 20/10/12

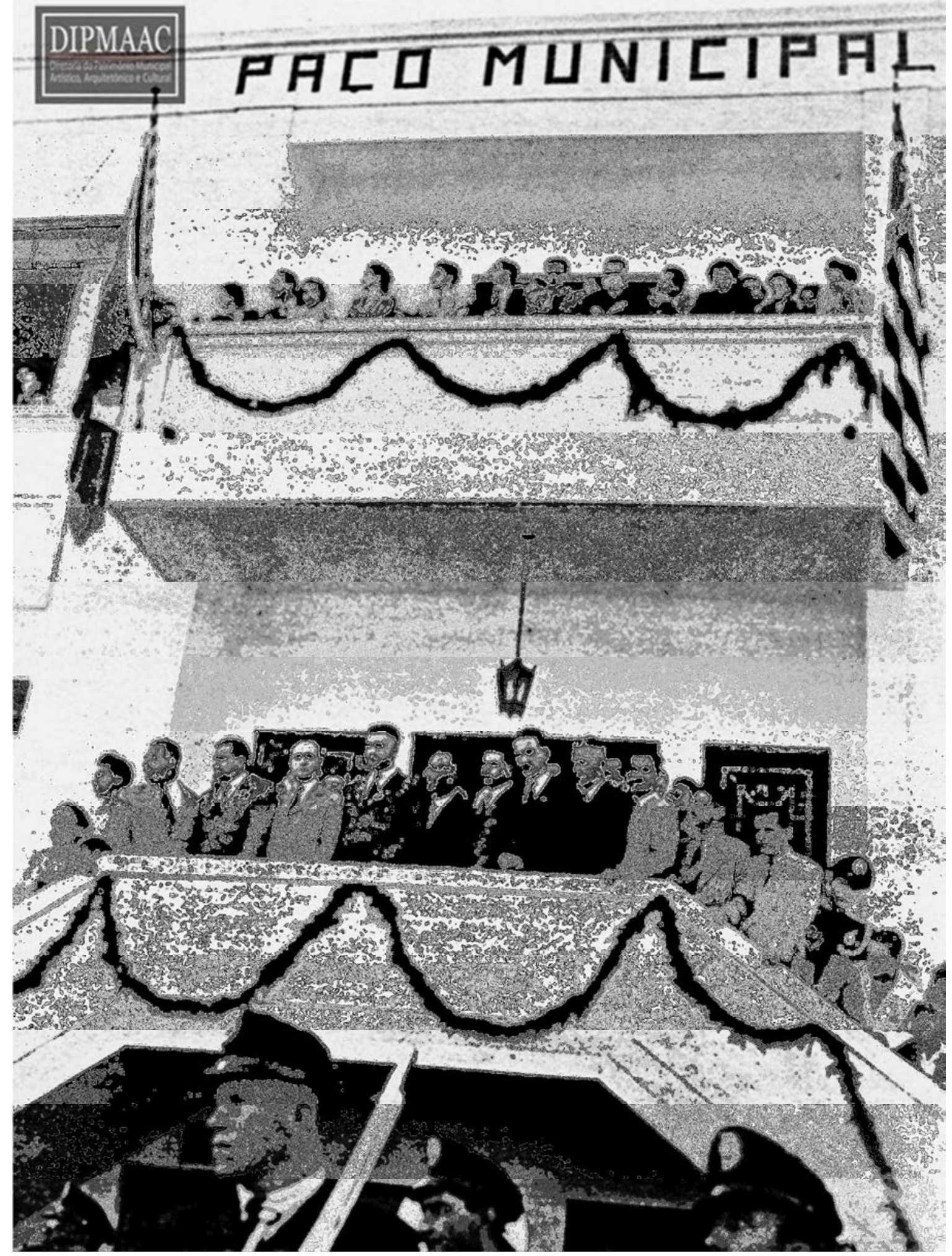




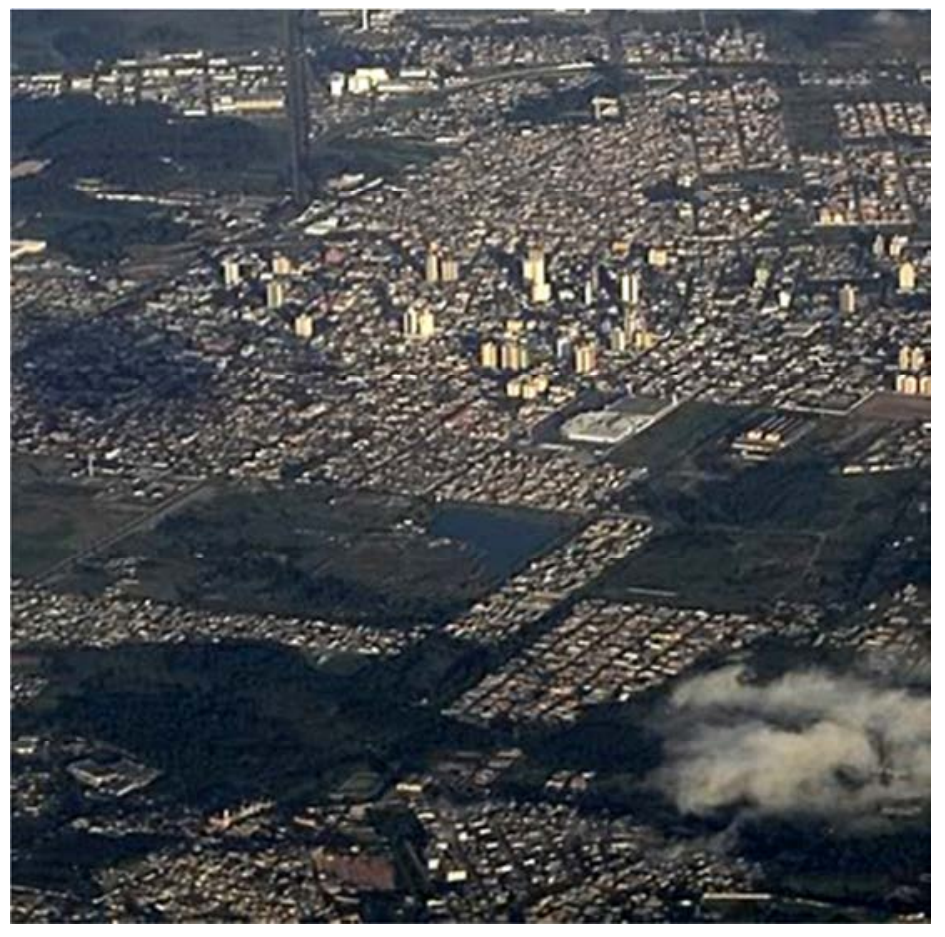

Capítulo 6

Inserção Urbana e Infraestrutura da Cidade: a construção de um novo território 



\subsection{A consolidação do novo território às margens da linha férrea}

É notória a importância da linha férrea como elemento estruturador da nova ocupação sobre as várzeas do rio Tietê. A parada de trens junto aos Campos de Mirambava foi visto pelas então famílias que viviam à sul deste território (bairro do Baruel), por exemplo, os Bianchi, como os que por lá chegavam, um lugar de prosperidade e crescimento econômico e, consequentemente, urbano.

O primeiro traçado urbano de 1890 , proposto por Conde de Romariz para a então chamada Vila da Concórdia, nos foi tomado como "ponto de partida" para a primeira análise sobre a consolidação do novo território às margens da linha férrea e sua evolução espraiando-se pelos imensos campos que se "espalhavam" pela recémformada cidade de Suzano.

A Vila da Concórdia era composta por 20 quadras (12 quadras de 1 hectare e 8 de meio hectare), no qual cada lote possuía uma área de $2.500 \mathrm{~m}^{2}$ (dois mil e quinhentos metros quadrados), totalizando 60 lotes ocupados gradativamente pelas primeiras famílias que consideravam aquela região da cidade prospera e fértil ao desenvolvimento urbano, principalmente os Figueiras e Bianchi. ${ }^{187}$

Do loteamento original, somente a quadra destinada a implantação da capela foi alterada, deslocada para a quadra a norte, aproximando-se da linha férrea, onde mais tarde foi construída a Igreja Matriz da cidade (1955). A partir da linha férrea e a Parada Piedade (mais tarde estação de passageiros Suzano), quatro quadras se desenvolviam à sul entre as já denominadas rua Prudente de Moraes até uma rua projetada (sem nome) acima da rua Monsenhor Nuno, enquanto que de leste a oeste as quadras se desenvolviam entre quadras urbanas com áreas de $1 / 2$ hectare a partir de ruas projetadas, sem nome.

Ao compararmos o traçado de João Romariz (1890) à cartografia atual da cidade (Google Earth, 2012), percebemos que seu parcelamento pouco se alterou, principalmente as quadras inteiras ( 1 hecatre), as demais localizadas nas extremidades leste e oeste do plano inicial dobraram ou ampliaram significativamente sua área de ocupação junto a este território. Quanto ao viário, se manteve intacto desde sua implantação, tanto em seu leito quanto aos nomes dados naquela ocasião. Por outro lado, concluímos que o parcelamento foi ao longo dos anos se alterando e cada vez mais este território foi sendo fragmentado em lotes de diversos tamanhos e formas, alterando drasticamente a morfologia urbana deste setor da cidade.

Das edificações daquele período pouco se tem vestígios das construções e usos de meados do século $\mathrm{XX}$, a maioria das casas foram substituídas pelo comércio que se estabeleceu ao longo dos anos, em especial sobre os eixos viários das ruas Gal. Francisco Glicério e Benjamin Constant. Até mesmo a antiga capela construída pelos Marques Figueira deu lugar para a Igreja Matriz da cidade que se permanece até os dias atuais (vide $\mathrm{p} 250$ ).

Ainda nas primeiras décadas do século XX, a ocupação das terras junto à linha férrea se deteve sobre o traçado proposto em 1890, "cada quarteirão pertencia a uma família em Suzano, ou quase. Eram os Guerra, os Viana, os Figueira, os Papais, os Renzi, os Bianchi, os Cusma e alguns outros"(AZEVEDO 1994, p 76).

187. Apesar da família Bianchi já estar consolidada há muito tempo a sul do vilarejo, sua migração para a Vila da Concórdia reforça a importância deste novo território como lugar prospero ao desenvolvimento urbano. 


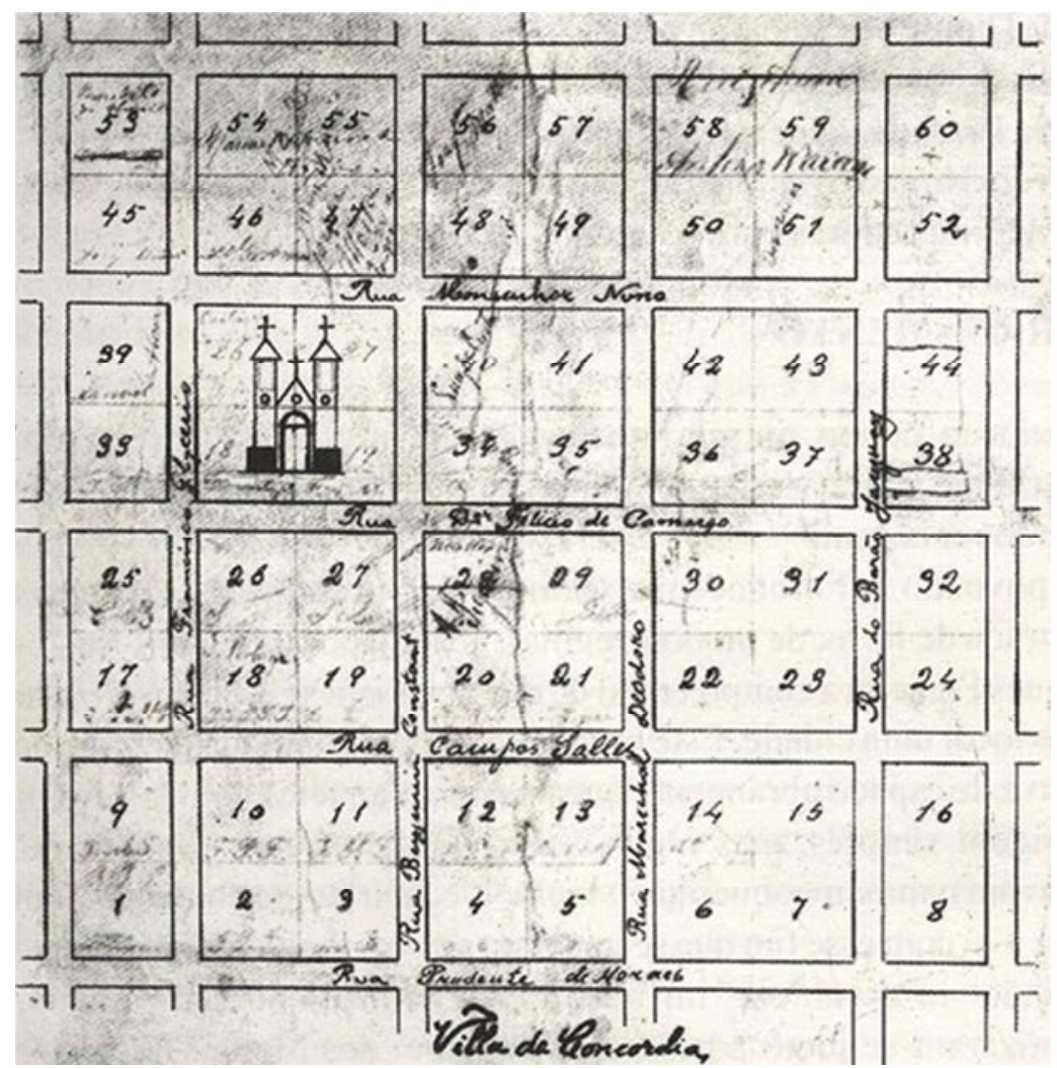

Figura 140. Comparação entre a proposta da Vila de Concórdia, proposta de João Romariz (1890) e o Centro Urbano atual de Suzano (2012)

Fonte: Museu Virtual Suzano e Google Earth, 2012

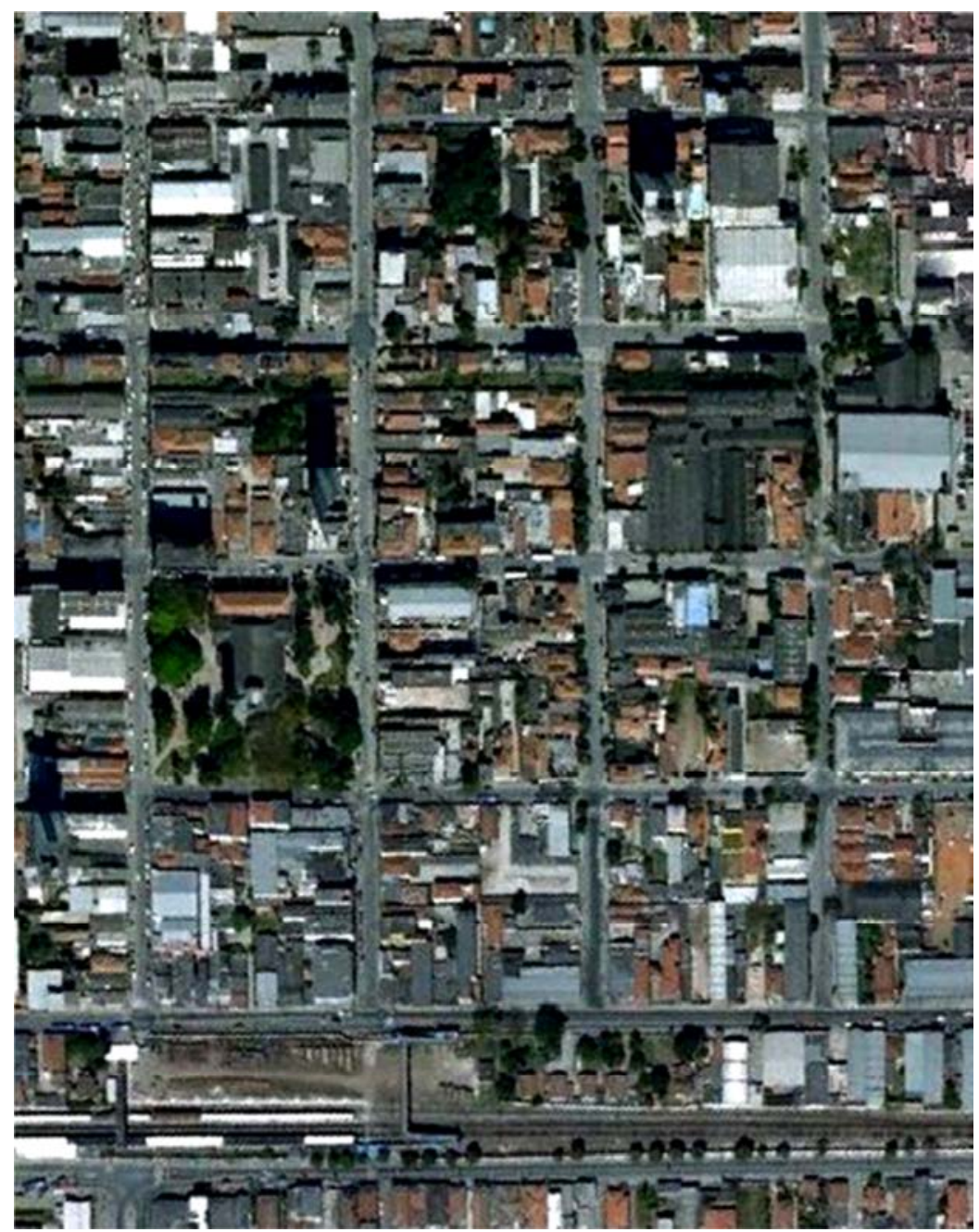


A partir dos anos 20 a cidade experimenta um crescimento vertiginoso, ampliando seu território ocupado nas diversas direções e espraiando-se tanto sobre as várzeas do rio Tietê, a norte da linha férrea, como sobre o eixo da rua Gal. Francisco Glicério, a sul. As primeiras indústrias da cidade começam a se instalar próximo ao eixo da linha férrea, dando origem ao primeiro núcleo industrial, fábricas como a Vinícola Sóvis e Sedas Maluf, ${ }^{188}$ especializada em seda e viscose, eram responsáveis por um grande número de empregados na época, chegando a 300 funcionários na primeira e na segunda cerca de 400 empregados (LEONE e Azevedo 2009, il., p 84).

Outro fator relevante que contribuiu para a ampliação deste território foi a melhoria na acessibilidade entre a recém-formada cidade de Suzano e suas vizinhas Mogi das Cruzes e Rio de Janeiro (leste) e a capital São Paulo a oeste. É evidente que a linha férrea ainda era a principal forma de conexão entre as cidades junto às várzeas do rio Tietê e a capital, no entanto, a abertura da Estrada São Paulo - Rio de Janeiro ${ }^{189}$ (atualmente SP-66), em 1920 passando em Suzano paralela a via férrea, possibilitou maior acessibilidade entre as cidades vizinhas e a capital paulista. Este fato favoreceu a saída de produtos para os grandes centros, não somente de trem, mas agora de caminhão fruto da produção agrícola que já se apresentava presente na economia da cidade: "milho, feijão, cana, mandioca, batata, tomate, rabanete, repolho, alface, couve, chicória, escarola, entre outros. Havia também granjas e criações de gado" (LEONE e Azevedo 2009, il., p 84).

Analisar a evolução urbana de Suzano a partir da proposta de João Romariz no final do século XIX não nos foi tarefa muito fácil, visto que tanto os órgãos municipais quanto as poucas bibliografias que tratam da história da cidade não possuem cadastro, tão pouco cartografia, entre os períodos do início do século XX até os anos 70 (base EMPLASAGEGRAN), no qual tomamos como ferramenta de pesquisa e compreensão do crescimento urbano da cidade. Outro material cartográfico relevante foram os mapas produzidos pela Secretaria Municipal de Política Urbana - PMS, fruto da análise e leitura técnica da proposta do Plano Diretor da cidade em 2007, ${ }^{190}$ que entre as Cartas Temáticas, utilizamos nesta leitura a de Evolução Urbana, mesmo entendendo que sua concepção tem por pressuposto os loteamentos aprovados junto ao órgão público, independente de sua implantação no território municipal.

188. A Vinícola Sóvis, do italiano Amadeu Mazza, instalou-se na Rua Felício de Camargo. Produzia vinhos e champanhes, também tinha a parte de vidraçarias, onde funcionou até 1977, quando faliu. Em 2006 a Prefeitura Municipal restaurou o que restou das instalações da fabrica, cerca de $1.000 \mathrm{~m}^{2}$ para abrigar o Restaurante Popular, intervenção do arquiteto Marcelo Suzuki.

A Sedas Maluf, do libanês Jorge Bey Maluf, é considerada a primeira indústria da cidade, instalada numa área de 22 mil metros quadrados, 12 mil deles construídos. Fundada em 1929 o conjunto era composto pelas instalações industriais e cerca de 20 casas para alojar seus principais funcionários, em área próxima a fabrica, onde mais tarde se formará a Vila Maluf. O conjunto de indústrias montado por Jorge Bey Maluf funcionou até 1965, mais tarde transformando-se em Tinturaria e Estamparia Romanato, no qual funcionou até 1998. Atualmente suas instalações estão fechadas e foi adquirida recentemente por um grupo de empresários de indústrias de extensões elétricas, no entanto, a área ao longo dos anos foi se fragmentando dando lugar a novos bairros e indústrias que ali chegavam, como por exemplo, a Indústria Têxtil Tsuzuki, adquirida em 1960, em atividade até hoje.

189. A SP-66 foi projetada no início do governo Washington Luís, em 1920. Sua construção começou em 1922 aproveitando o leito das vias já existentes, sendo inaugurada em 1928. É também conhecida como "Estrada Velha São Paulo-Rio", fazendo referência ao tempo em que Dom Pedro I, viajou de São Paulo ao Rio de Janeiro pela rodovia.

190. O Plano Diretor Participativo foi desenvolvido em 2007, sob a coordenação da PMS e FUPAM, pelo arquiteto Dr. Eduardo Alberto Cusce Nobre, mas até o momento não foi aprovado pela Câmara Municipal de Suzano, Projeto de Lei Complementar no 015-07/08. 
Figura 141. Tintura e Estamparia de Tecidos Suzano, uma das primeiras indústrias da cidade (primeira imagem 1980, segunda e terceira 2005)

Fonte: Primeira imagem - Museu Virtual Suzano, segunda imagem Elvis Vieira, 2005, terceira imagem Isamu Watanabe
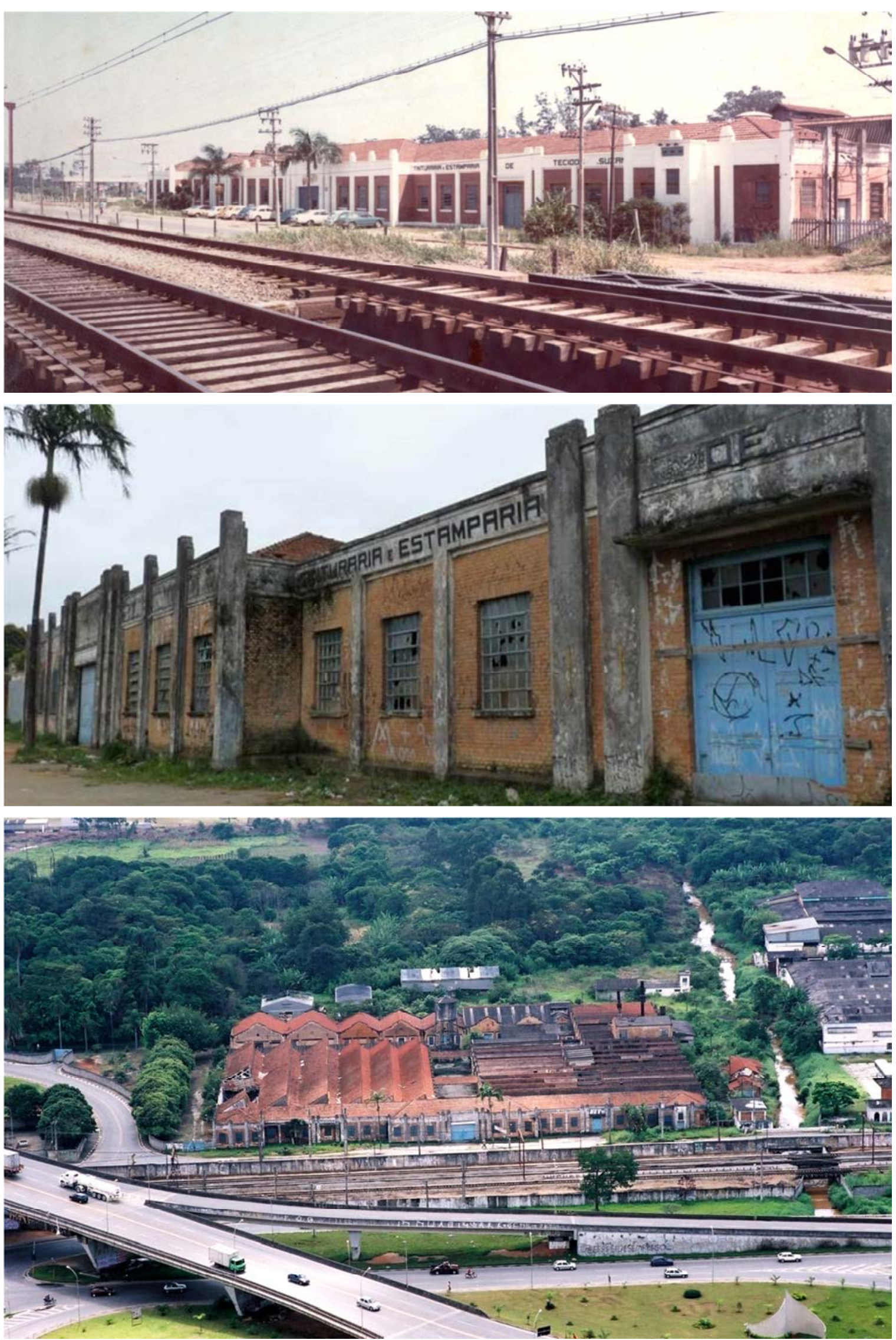
A vasta área livre com que este novo território apresentava, com grandes campos de pastagens e áreas de plantios, favorecia o desenvolvimento urbano de forma rápida e gradativa. Ao analisarmos duas imagens aéreas entre as décadas de 30 e 50, concluímos que num período de apenas duas décadas o território da cidade se expande não somente sobre o eixo da rua Gal. Francisco Glicério, chegando até o Largo do Cruzeiro (atualmente Praça dos Expedicionários) e a leste até as margens do rio Una. Neste período também percebemos a presença de diversas construções a norte da linha férrea, não somente os conjuntos industriais que se instalam naquela região, mas um número considerável de casas e alguns comércios que por ali já estão funcionando (vide imagens p254).

A topografia plana também favoreceu a acelerada expansão do território. Como já dito as primeiras quadras implantadas no final do século XIX possuíam uma morfologia urbana regular e constante, compostas em sua maioria por quarteirões com 1 hectare e parcelamento composto apenas por quatro lotes por quadra. Observamos que a Vila da Concórdia se permaneceu sobre este espaço por longo tempo, transformando-se gradativamente com a chegada das famílias que se instalavam por ali. É perceptível esta mudança quando analisamos as imagens da década de 1930, que apesar de ainda não estar totalmente ocupado, e já existir as primeiras expansões do território, o parcelamento apresentado era de lotes inferiores ao proposto por João Romariz. No que tange a tipologia destas ocupações, eram essencialmente compostas por casas térreas isoladas no lote.

As expansões urbanas que se seguem ao longo dos anos até meados do século XX são caracterizados por quadras também regulares e vias que se estendem a partir do traçado existente. Assim, ruas como Gal. Francisco Glicério, Benjamin Constant e Marechal Deodoro se prolongam a sul da estação ferroviária, enquanto que as ruas Campos Sales, Dr. Felício de Camargo e Monsenhor Nuno se estendem em encontro ao rio Una, próximo as pastagens do que mais tarde será a Vila Amorim a leste da primeira ocupação. No entanto, notamos que a configuração urbana das quadras não se manteve como as da Vila da Concórdia, a expansão do território se deu com quadras com diversas dimensões, apesar de regular e repetitiva a cada momento do crescimento do território.

Podemos ainda afirmar que este crescimento foi se afastando da linha férrea à medida que o "novo território" torna-se atraente para as famílias que migravam para aquele território a procura de trabalho ou negócios com que a cidade necessitava. Este processo se dá essencialmente nas cinco primeiras décadas da implantação do primeiro traçado e, encontrava-se em meados do século XX uma ocupação assentada sobre dois elementos-referência para a cidade: a estação e a igreja matriz a norte, e o Largo do Cruzeiro a sul, no qual delimitavam a cidade "formal" e funcional. ${ }^{191}$

A partir da década de 1970, o território da cidade se encontrava muito mais extenso e ocupado por diversos novos bairros implantados em vários setores da cidade, não somente em terras junto às várzeas dos rios Una e Guaió (o segundo rio - divisa administrativa com Poá), mas também no extremo norte, divisa com Itaquaquecetuba, com a implantação no final da década de 50 do bairro do SESC e mais tarde de um grande distrito residencial denominado Cidade Miguel Badra, aprovado nos anos 60, mas implantado uma década mais tarde, ampliando consideravelmente a mancha urbana da cidade.

191 . Não somente nos primeiros cinquentas anos, mas até o inicio dos anos 2000, o principal centro comercial da cidade se deu sobre o eixo da rua Gal. Francisco Glicério, entre as "duas praças" da cidade. Principal corredor comercial da cidade com a existência das principais lojas e prestação de serviços de Suzano, e mais tarde da Região do Alto Tietê. 
Figura 142. Foto aéreo da região central de Suzano na década de 1970 Fonte: Terrafoto, 1972

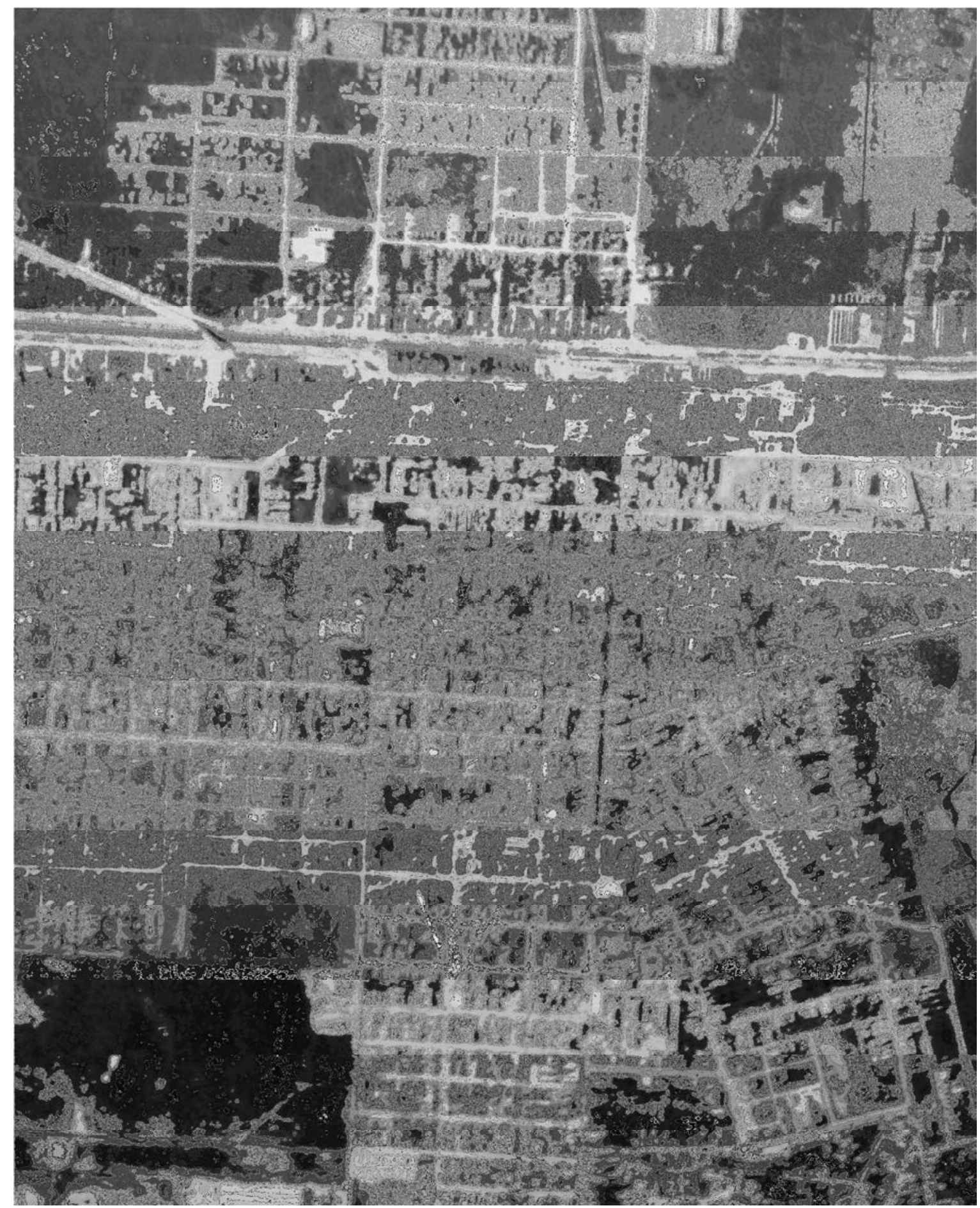


O bairro do SESC como ficou conhecido a Comunidade Brasílio Machado Neto, idealizado para tornar-se um "bairro modelo" para o Estado de São Paulo, apesar de sua localização longínqua do centro urbano de Suzano, era privilegiado pela bela vista das várzeas do rio Tietê e a "cidade" como plano de fundo, porém, a relativa distância era compensada por "duas linhas de ônibus, ambulância, cooperativa e tudo mais que era necessário para manter a qualidade de vida dos moradores"(LEONE e Azevedo 2009, il., p 352).

Construído pelo Serviço Social do Comércio (SESC) por meio de um convênio com o Instituto dos Aposentados e Pensionistas do Comércio (IAPC), o bairro era servido de infraestrutura urbana completa como serviços de esgoto, águas pluviais, pavimentação, energia elétrica, iluminação pública, além de um centro comercial, centro comunitário social e estação de tratamento de água. Já as vias do bairro já foram implantadas todas totalmente arborizadas, ampliando a qualidade urbana deste local. ${ }^{192}$

"O Sesc era uma cidade satélite que não pertencia a Suzano, por isso, não pagava impostos para a cidade"(LEONE e Azevedo 2009, il.).

Com 413 casas construídas, o bairro permaneceu sob a responsabilidade do SESC até 1971 quando foi integrado ao patrimônio municipal, resultando numa contínua "deterioração" do bairro, assim como a "perda" do uso dos equipamentos de lazer dos moradores. Somado a estes fatores, a implantação dos lotes na Cidade Miguel Badra e a consequente autoconstrução de baixo nível, resultado da "migração" de novos habitantes (zona leste e itaquaquecetuba) resultou na desvalorização do bairro ao longo destes 40 anos.

Suzano chega a década de 1970 com uma população de 55.460 habitantes (CNM s.d.), ampliando consideravelmente em relação à década de 50 , quando a cidade inicia seu processo de "rizoma" além das várzeas do rio Tietê, e seu território se expande para o vetor norte da cidade com a implantação de bairros como o SESC e Cidade Miguel Badra.

Neste momento sua morfologia urbana nestes bairros (extremo norte) já possui grande diversidade tanto em sua geometria, devido a adequação a topografia existente como na tipologia apresentada, visto que o SESC era ocupado essencialmente por habitações térreas de padrão médio-alto, isoladas no lote e com toda infraestrutura disponível, enquanto que a Cidade Miguel Brada os usos eram diversos, de baixo padrão, fruto da auto-construção que imperou sobre este setor da cidade. ${ }^{193}$

Por outro lado, o centro urbano da cidade se consolida cada vez mais como a região mais estruturada, consolidada e valorizada sob diversos aspectos. Como já mencionado inicialmente, para as análises morfológicas da cidade, e em especial o "recorte urbano" determinado por esta tese - o centro urbano da cidade, perímetro da Operação Urbana Orla Ferroviária - utilizamos de cartografia da década de 1970 (EMPLASA s.d.), possibilitando o cruzamento de dados e a transformação da forma urbana até este período e a atual situação morfológica deste trecho da cidade até os dias atuais.

192. Cabe ressaltar que neste mesmo período o centro urbano de Suzano ainda não possuía todas as infraestruturas urbanas implantadas, as ruas ainda não eram pavimentadas e poucas possuíam iluminação pública, sem considerar as redes de coleta de esgoto e drenagem.

193. Vale salientar que, se havia distinção na tipologia apresentada sobre estes dois bairros, sua morfologia também era diferenciada, no qual o SESC possui quadras irregulares adequando-se a um território irregular e remetendo às CidadesJardim da cidade de São Paulo, enquanto que a Cidade MiguelBadra era provida ora de quadras regulares que se assentavam sobre as várzeas do rio Tietê e ora irregulares devido às declividades apresentadas próximo ao então conhecido "morro do SESC". 

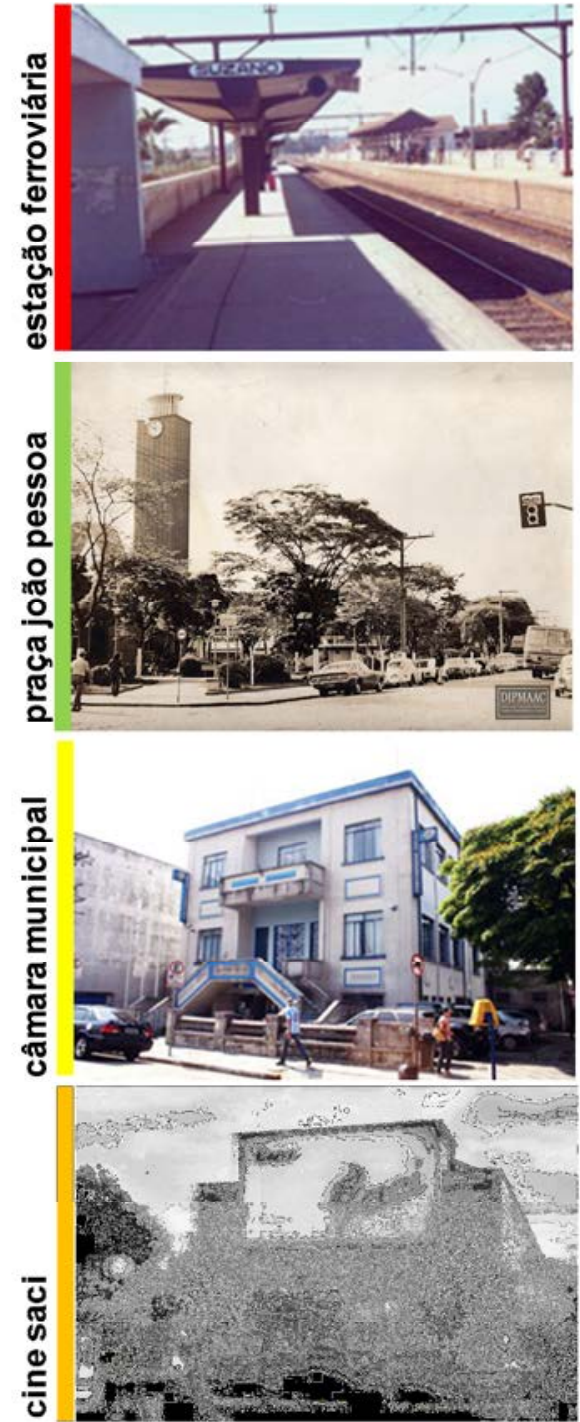

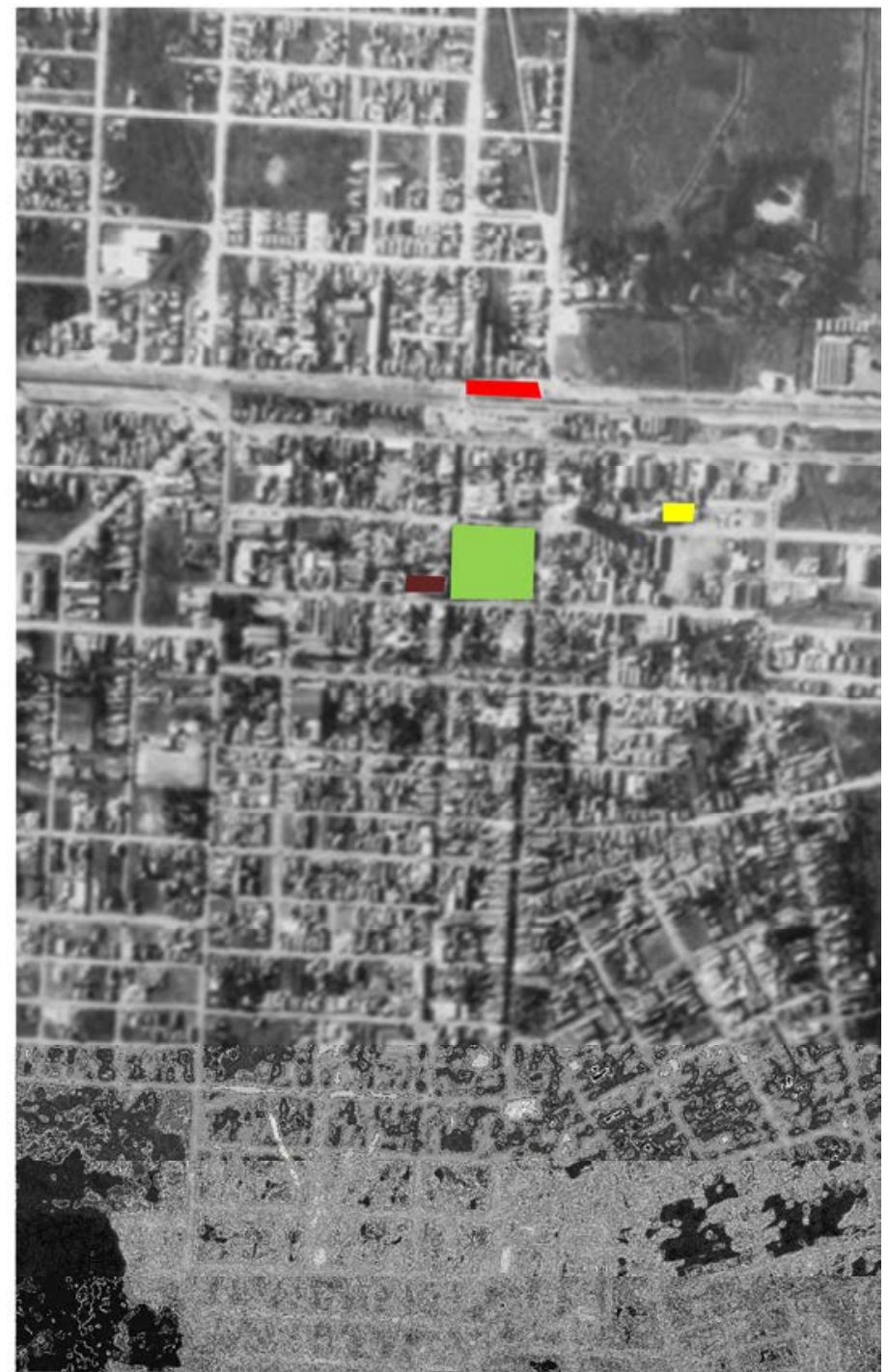

Figura 143. Principais referências urbanas de Suzano na década de 1970 Organização: Elvis Vieira, 2012

Figura 144. Bairro do SESC já implantado na década de 1970

Fonte: www.museuvirtualsuzano.com.br, acessado em 19/10/12

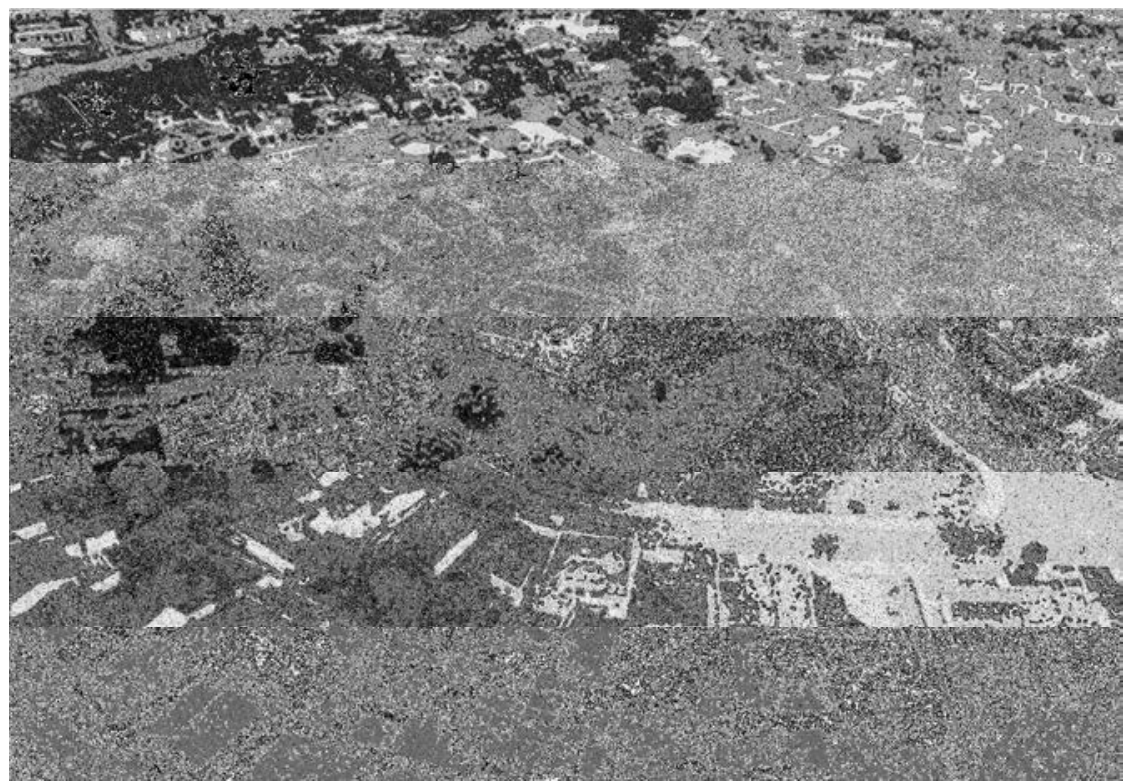




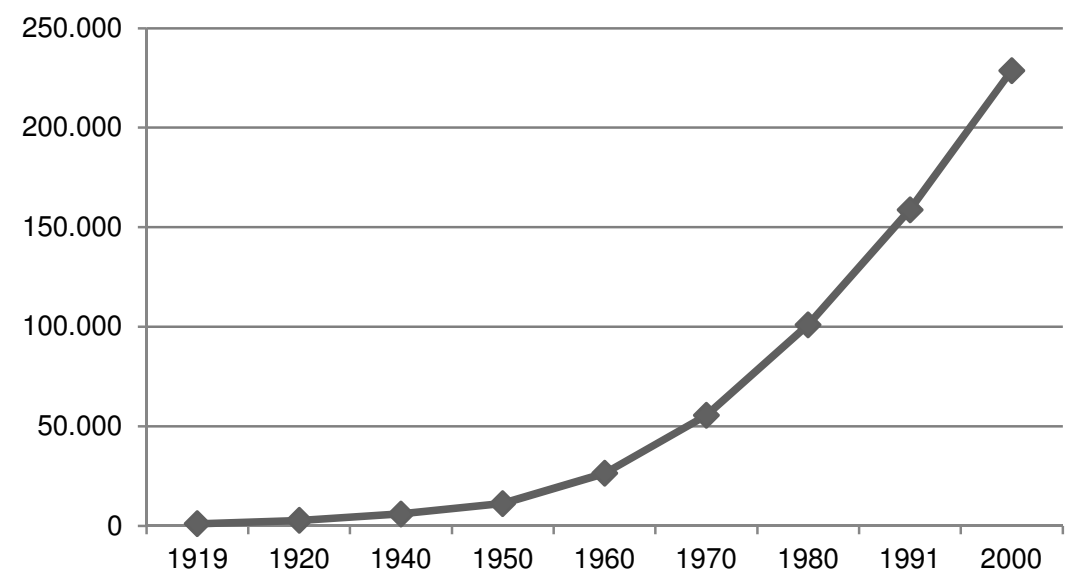

\section{EVOLUÇÃO URBANA DE SUZANO A PARTIR DO SÉCULO XX}

Fonte: IBGE | CNM

Elaboração: Elvis Vieira, 2010

Neste sentido, observamos que desde sua emancipação este trecho da cidade cresceu até a década de 1970, inicialmente sob a lógica do primeiro traçado proposto por João Romariz, no qual tanto as primeiras quadras como seus viários implantados nortearam o crescimento da cidade, principalmente para a região sul e leste desta região, onde num primeiro instante até o Largo do Cruzeiro - atual Praça dos Expedicionários (sul) e às margens do rio Una (leste), sob uma grelha regular e contínua, no qual o desenho das quadras - sua morfologia urbana - se mantém integra até os dias de hoje.

Da mesma forma que percebemos a consolidação do território junto à linha férrea às várzeas do rio Tietê, no qual se deu de forma rápida, confirmados ao analisarmos fotos de sobrevoos da década de 30 e 50, que a cada duas décadas verificamos o contínuo crescimento do tecido urbano e sua confirmação como nova centralidade. ${ }^{194}$ Por outro lado, tanto o parcelamento das quadras como sua tipologia foi se alterando concomitantemente as mudanças sociais e econômicas da cidade e seus habitantes, assim como sua importância junto às cidades vizinhas como Poá, Ferraz de Vasconcelos e Itaquaquecetuba que tinham a cidade como fonte de atendimento de alimentos e comércio.

As quadras ocupadas pelas primeiras famílias foram ao longo dos anos sendo parceladas e perdendo sua característica original, onde cada quadra possuía apenas quatro lotes (cerca de 2.500,00 $\mathrm{m}^{2}$ cada), já na década de 1970 , os lotes são de dimensões muito inferiores ao de duas décadas atrás, com grande diversidade de dimensões que consequentemente provocaram a transformação da tipologia urbana deste território. Das primeiras casas isoladas no lote entorno da pequena capela do final do século XIX, aos poucos esta região foi recebendo novas edificações destinadas ao comércio, inicialmente para atender aos moradores da "nova cidade" que se formava e mais tarde aos usuários do trem que ligava a cidade a capital paulista. A cartografia de 1973 (EMPLASA s.d.) nos mostra uma cidade já totalmente consolidada com um conjunto tipológico variado e com grande diversidade de lotes sobre as quadras regulares de 1 hectare em média. Neste momento, os usos nesta região da cidade eram diversos, desde casas térreas e assobradadas a pequenos edifícios (até 4 pavimentos) de usos misto compostos de comércio junto à rua (térreo) e habitação ou serviços nos demais pavimentos.

194. Neste momento podemos afirmar que o atual centro urbano de Suzano caracterizava-se como uma nova centralidade, considerando que a primeira ocupação se deu no bairro do Baruel, no externo sul da cidade. 
Figura 145. Imagens do Centro de Suzano atualmente Fotos: Wanderley Costa, 2006
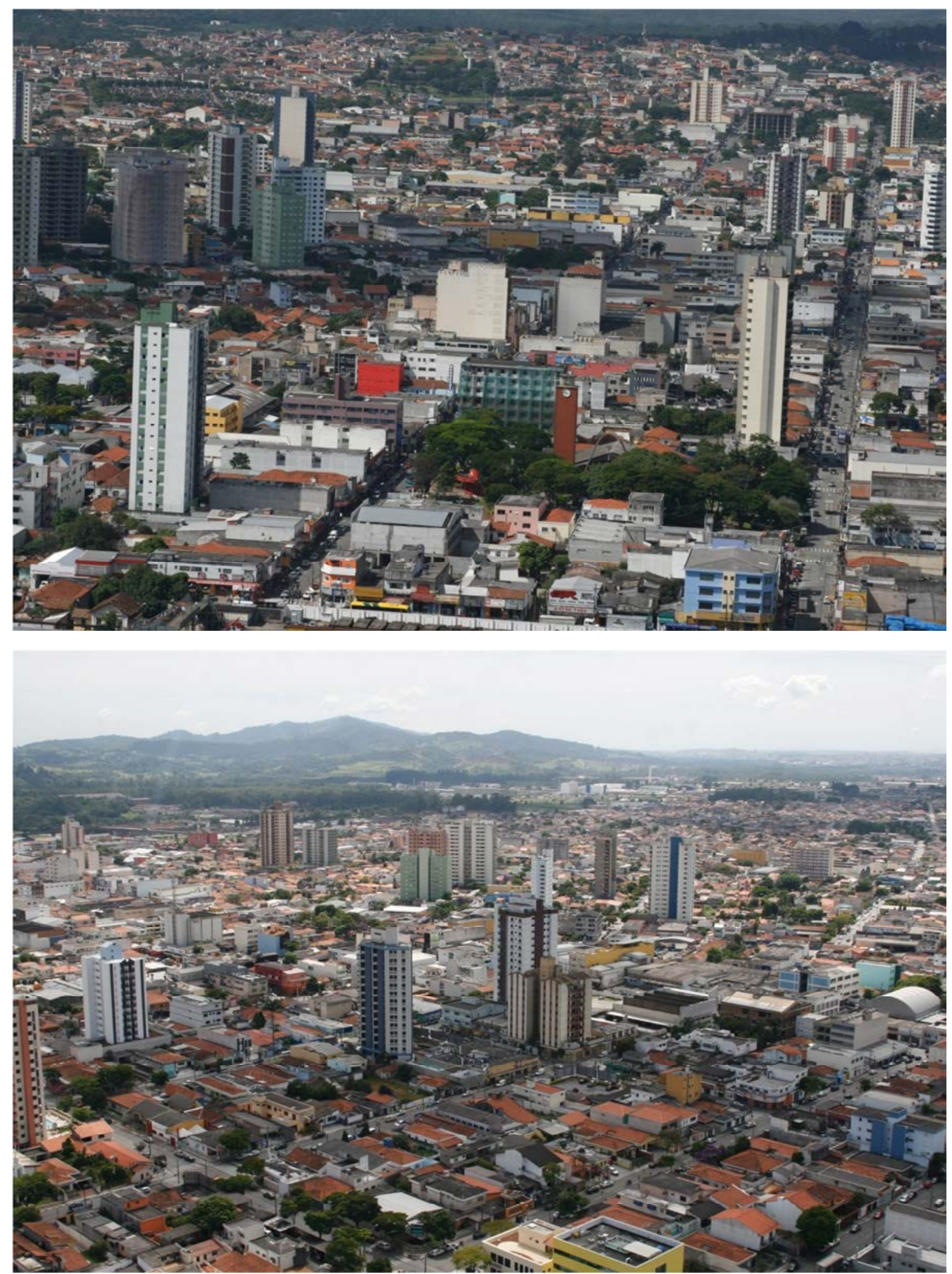
A década de 70 também foi marcada pelo processo de industrialização que se acentua com a instalação de grandes empreendimentos, principalmente multinacionais japonesas. Este fator foi culminante para a mudança vocacional da cidade que tinha até então a agricultura como principal economia, indústrias como Komatsu (tratores), NSK (rolamentos), Mitutoyo (equipamentos de medição) e Hoechst (química - no caso alemã) começam a reforçar o parque industrial da cidade, respondendo a significativa arrecadação de ICMS para o município. Localizadas em dois territórios distintos, 0 primeiro junto a linha férrea e a outra, mais recente, no eixo da Rodovia SP 31 - Índio Tibiriçá, está delimitada pelo Governo do Estado, provocando uma ocupação linear próximo a estas indústrias e em sua maioria nas Áreas de Proteção aos Mananciais.

Nas duas últimas décadas do século XX sua mancha urbana pouco se expande, com o surgimento de um número muito reduzido de novos loteamentos. No entanto, os que já existiam começam a consolidar e ampliar significativamente sua densidade habitacional, no que resulta num crescimento de mais de $500 \%$ sua população em relação à década de 70, chegando ao ano 2000, segundo IBGE, com 228.690 habitantes. Enquanto os loteamentos periféricos ficavam mais densos e a cada ano seus lotes foram ocupados por edificações auto-construídas, o centro passa por nova transformação em sua tipologia.

Neste período, inicia o processo de verticalização do centro urbano da cidade com a construção de condomínios residenciais verticalizados. Por conta do parcelamento das quadras com diferentes dimensões e proprietários, este processo resultou em poucas experiências sobre este trecho da cidade, possivelmente devido às dificuldades de negociação entre os proprietários e os investidores. Estas condicionantes levaram a um desenho destas quadras que sofreram "intervenção" em uma forma urbana conturbada, com edifícios verticais "salpicados" no tecido urbano do centro.

Apesar deste processo não se aplicar sobre os dois principais eixos viários da cidade, ruas Gal. Francisco Glicério e Benjamin Constant, estes se caracterizaram entre as décadas de 70 e início do século XXI como principal corredor comercial, resultando em uma das áreas imobiliárias mais valorizadas da cidade, mesmo não sendo exploradas em sua capacidade urbana integral.

Por fim, a cidade desde sua emancipação em meados do século $X X$, alterou significativamente seu território, como já explicitado na página 257, chegando a um território de $206 \mathrm{Km}^{2}$. Tais ampliações de seu território resultaram também no contínuo crescimento populacional, ora por habitantes destas regiões anexadas ou pela dinâmica migratória que ocuparam em sua maioria os loteamentos periféricos. 
Figura 146. Vista aérea do rio Una e suas vias marginais

Foto: Wanderley Costa, 2006

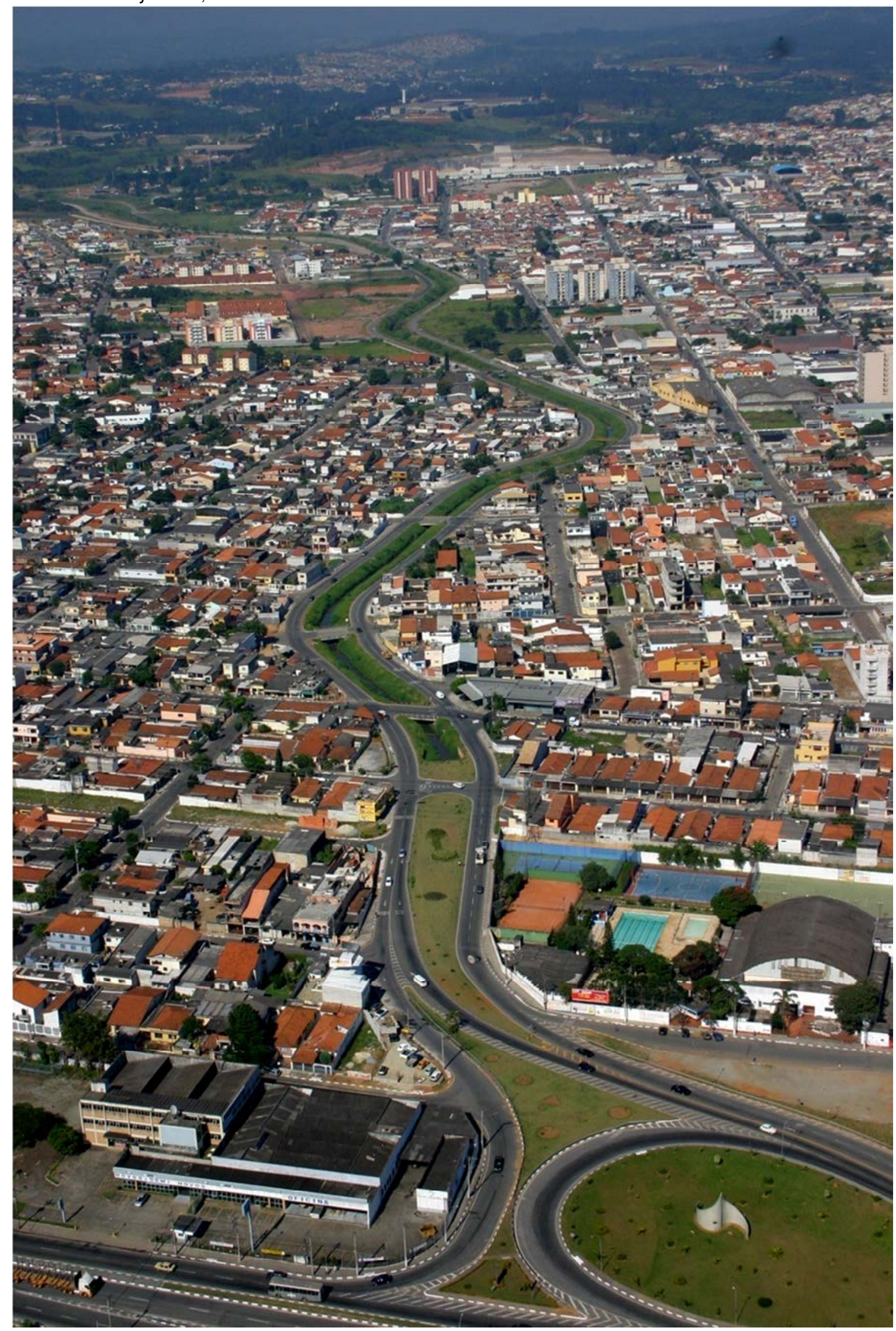




\subsection{Inserção e Infraestrutura Urbana: Suzano e a RMSP}

Suzano chega ao início do século XXI sendo considerado um dos municípios mais importantes econômica e socialmente da Região do Alto Tietê (RAT). Juntamente com o município de Mogi das Cruzes, as duas cidades representam mais de $80 \%$ das atividades econômicas e são responsáveis por mais de $70 \%$ da arrecadação de ICMS e pelo emprego formal da RAT. ${ }^{195}$

Inserido na Bacia Hidrográfica do Tietê-Cabeceiras, essa região constitui importante área de preservação de mananciais e reservatório de água para abastecer a Região Metropolitana de São Paulo (RMSP).

"Juntos, os 11 municípios inseridos nesta bacia compõem uma extensão territorial de 292,60 hectares, sendo que apenas 120,3 hectares estão disponíveis para urbanização intensiva, estando a maior parte do território protegido por leis ambientais estaduais"(PMS | FUPAM 2007, p 12). ${ }^{196}$

"O município de Suzano é um dos 39 municípios que compõem a Região Metropolitana de São Paulo, situado na sub-região leste da RMSP e distando $42 \mathrm{~km}$ da capital paulista"(PMS 2006, p 06). Com uma área territorial de $206 \mathrm{Km}^{2}$ (IBGE), sendo 7\% protegidos pela APA da Várzea do rio Tietê e $73 \%$ inserido na área de proteção aos mananciais. ${ }^{197}$

Atualmente sua localização geográfica privilegiada em relação às cidades do Alto Tietê, a proximidade com a capital paulista, o Vale do Paraíba, ABC Paulista e a Baixada Santista, além do Aeroporto Internacional de Guarulhos (Cumbica) e o Porto de Santos, colocam a cidade sob uma nova lógica comercial, no qual as empresas aqui hoje instaladas se beneficiam desta "centralidade" metropolitana. No que tange o comércio de mercadorias, Suzano é a maior representante do número de vendas neste setor, atendendo mais de $80 \%$ das cidades vizinhas. Já seu parque industrial, ao longo dos anos foi se consolidando tornando-se o principal setor econômico da região ( PMS s.d.), contando com uma atividade bastante diversificada e empresas atuando em praticamentetodos os segmentos industriais, produzindo uma enorme variedade de produtos, representando $38,83 \%$ dos empregos formais da cidade (SEADE 2010), ficando em segundo e terceiro posto, segundo SEADE, serviços com 33,04\% e comércio $23,10 \%$. Quanto ao setor agrícola, é notória sua redução gradativa desde a década de 70, quando a cidade inicia sua expansão industrial, representando atualmente apenas $7,83 \%$ do total de empregos formais na cidade (SEADE 2010).

A ferrovia ainda é considerada a melhor conexão entre a cidade e as demais vizinhas e a capital paulista. Atualmente a cidade é atendida pela Linha 11 - Coral da CPTM (Estudantes - Guainazes), atendendo $387 \mathrm{mil}$ passageiros/dia, sendo $170 \mathrm{mil}$ passageiros/dia na estação de Suzano (CPTM 2011), que ainda é considerado o principal sistema de transporte coletivo na Região do Alto Tietê e Metropolitano.

195 .Mogi das Cruzes e Suzano possuem o PIB mais elevados da região, sendo Mogi das Cruzes R $\$ 6.708 .697$ mil e Suzano $\mathrm{R} \$ 5.295 .159$ mil (Atlas de Desenvolvimento Urbano, 2000).

196. A Região do Alto Tietê é composta pelas cidades de Arujá, Biritiba-Mirim, Ferraz de Vasconcelos, Guararema, Itaquaquecetuba, Mogi das Cruzes, Poá, Salesópolis, Santa Isabel e Suzano, totalizando 1.511.078 habitantes (IBGE). A cidade de Guarulhos, apesar de não pertencer a RAT geograficamente, devido suas influências com estas cidades, é considerada como o $11^{\circ}$ município que contribui para o desenvolvimento do Alto Tietê.

197. APA da Várzea do rio Tietê, conforme Lei Estadual no 5.598/87, regulamentada pelo Decreto Estadual no 42.837/98; APM conforme definição da Lei Estadual no898/75. 
Figura 147. Suzano e sua inserção urbana na Região

Metropolitana de São Paulo

Elaboração: Elvis

Vieira, 2012

Figura 148. Suzano e sua inserção urbana na Região do Alto

Tietê

Elaboração: Elvis Vieira, 2012
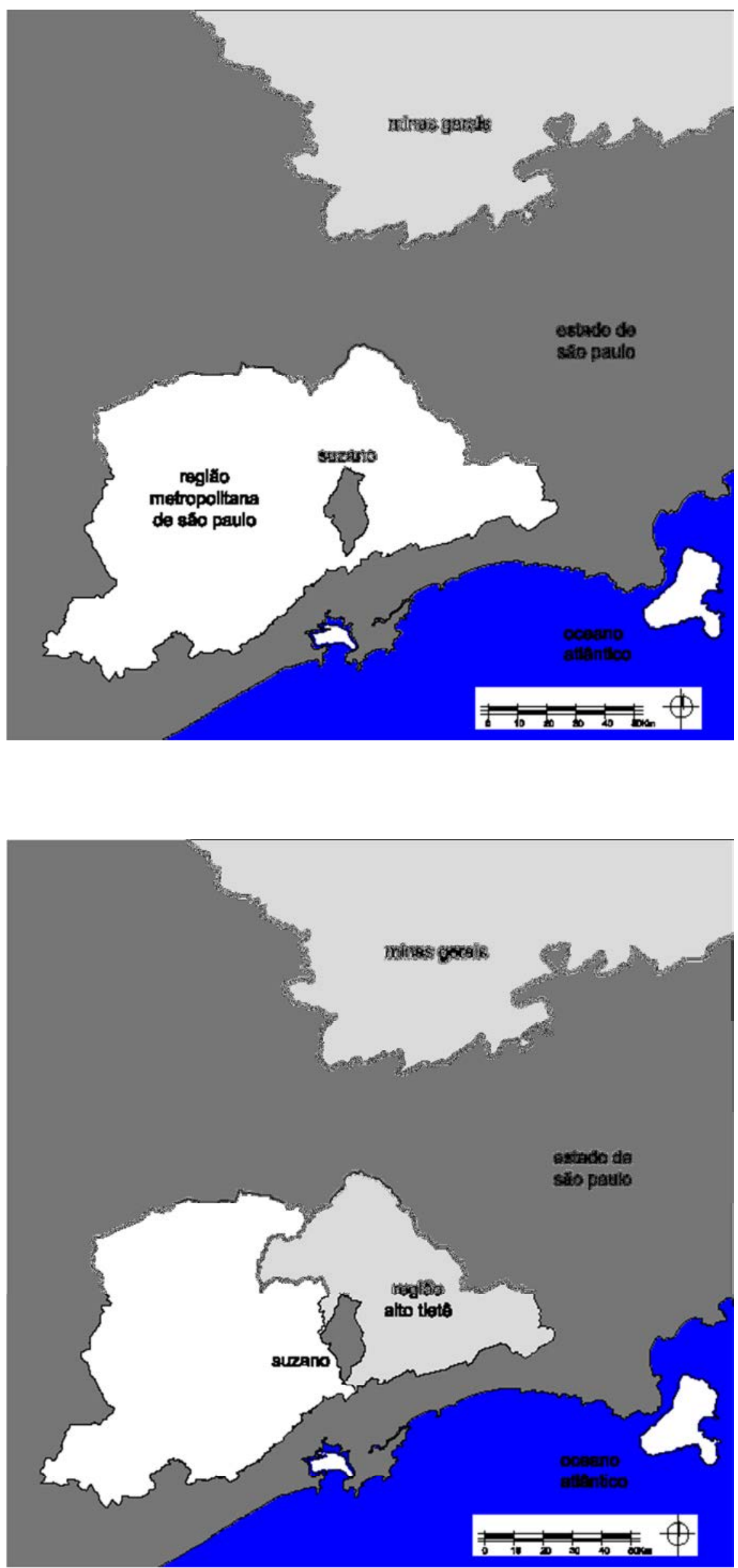


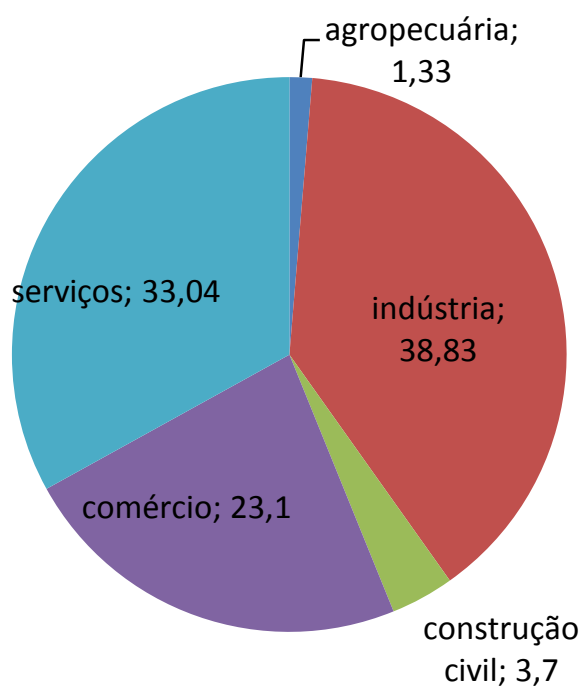

5. PERCENTUAL de EMPREgos formaIS NA CIDADE de SUZANO

Fonte: SEADE, 2010

Organização: Elvis Vieira, 2012

Devido às diversas rodovias que interliga a cidade, Suzano hoje possui várias "portas" de acesso ao território: rodovias como Ayrton Senna (SP-070), são acessadas por meio da interligação Poá-Suzano-Airton Senna, a partir da rodovia Enrique Eroles (SP-66), a rodovia Mogi-Dutra (SP-088) é acessada pela Avenida Francisco Marengo e Rua Guilherme Garijo, todas à norte da cidade. A rodovia Índio Tibiriçá (SP-071) e Estrada dos Fernandes dão acesso ao ABC Paulista a sul do território, enquanto que outras cumprem o papel de vias conectoras entre as cidades do Alto Tietê, como Avenida Brasil e Prudente de Moraes (antiga São Paulo - Rio) que fazem a conexão leste-oeste entre Poá e Mogi das Cruzes.

O sistema de ônibus municipal e metropolitano é outra opção de transporte coletivo na cidade. Atendida por uma rede de 17 linhas urbanas, na maioria partindo do Terminal de Transportes Urbano Norte (Vereador Diniz José dos Santos Faria), atendem todo o território. Já a EMTU (Empresa Metropolitana de Transportes Urbanos) é responsável pelas linhas regional e metropolitana, atendendo as cidades como Mogi das Cruzes, Poá, Ferraz de Vasconcelos, Arujá, Santa Isabel, Ribeirão Pires, além da capital São Paulo (EMTU s.d.).

"Um dos maiores desafios regionais está justamente em conciliar o desenvolvimento urbano e econômico da região com sua característica de singular importância ambiental para o estado de São Paulo e principalmente para a RMSP, utilizando meios para alavancar o desenvolvimento da região sem, contudo prejudicar a preservação ambiental, utilizando essa característica como viés de desenvolvimento para todos os municípios e sua população"(PMS | FUPAM 2007, p 13).

Segundo o Censo 2010 (IBGE ), a população atual é de 262.480 habitantes, o que representa $17,37 \%$ da população da Região do Alto Tietê, região esta que constitui um dos principais pólos de desenvolvimento do estado, com PIB per capita no valor de $R \$$ $18.952,00$ (segunda posição na RAT), correspondendo no total a $62 \%$ do PIB da RMSP e $77 \%$ do Estado de São Paulo. 
No contexto regional, o município destaca-se como o $3^{\circ}$ maior em número de habitantes, possuindo a quarta maior densidade demográfica com 1.275,43 habitantes $/ \mathrm{Km}^{2}$ (IBGE s.d.), assim como dentre os índices econômicos, a cidade está entre as cinco cidades mais significativas (IDH $-5^{\text {a }}$ posição, PIB e PIB per capita - $2^{a}$ colocação), podemos afirmar que Suzano atualmente possui índices econômicos positivos e favoráveis entre as cidades que compõem a Região do Alto Tietê. ${ }^{198}$

Por outro lado, ao analisarmos os índices urbanos, os dados demonstram uma cidade ainda deficitária em diversos aspectos que influenciam na qualidade de vida de seus habitantes. Como já explicitado, a partir das décadas de 60 e 70, "a cidade se desenvolveu urbanisticamente de forma descontrolada gerando bairros com pouca infraestrutura urbana e grande densidade habitacional" (VIEIRA 2010). ${ }^{199} \mathrm{O}$ centro, por sua vez, desde o início foi constituído por um desenho regular onde as quadras se desenvolviam a partir do ponto de parada da estação ferroviária.

Esta condição geográfica potencializou gradativamente este território como o mais atrativo e valorizado na cidade, sobretudo à acessibilidade do transporte ferroviário metropolitano transformando este setor num centro comercial e de serviços dinâmico e com relativa diversidade tipológica construtiva. Composta inicialmente por galpões industriais e estabelecimentos comerciais, num primeiro momento, condicionados ao eixo ferroviário, ora por conta da entrada e saída de produtos ora para atender a população que circulava nas proximidades da estação. Estas atividades com que o centro foi se estruturando ao longo dos anos passam por diversas fases de transformação em sua forma urbana, no entanto, o desenho das quadras pouco se altera desde a fundação deste novo núcleo da cidade, em sua maioria será o lote (em menor número) e o edifício a sofrer as maiores alterações sobre o desenho da cidade.

"A cidade se ampliaria, assim, de forma crescente, num tempo físico e virtual, desenvolvendo uma estrutura mais aberta e multiplicadora em um novo cenário mais complexo e diversificado. A antiga necessidade de aglomeração capaz de facilitar a produção, o intercâmbio, defesa e comunicação se (des) localizaria, assim, nesse grande 'território-parque' - ao que se remete Dietmar Steiner pontuado, de fato, áreas mais ou menos focais e de áreas residuais especializadas: espaços, finalmente, dedicados ao consumo, moradia, trabalho e lazer localizados em bolsões descontínuos interligados por redes de transporte"(GAUSA 2010, p 161). ${ }^{200}$

\footnotetext{
198. Ainda que exista certa polarização em relação a alguns municípios deve-se destacar a dependência econômica de Suzano em relação à capital, envolvendo principalmente o setor de serviços e empregos de maneira geral. $O$ fluxo e trânsito de população são maiores entre a capital e o município do que propriamente entre os municípios do Alto Tietê, uma vez que a demanda por serviços e empregos locais também não é suficiente para a população residente na Bacia do Alto Tietê.

199 . Tradução do autor, 2010

La ciudad ha desarrollando urbanísticamente sin control la creación de distritos con escasa infraestructura y la vivienda de alta densidad urbana.

200 . Tradução do autor, 2012

La ciudad se ampliaría, así, de forma creciente, física y virtual a un tempo, desarrollando una estructura más abierta y multiplicada en un nuevo paisaje más complejo, y diversificado. La antigua necesidad de una aglomeración capaz de facilitar la producción, el intercambio, la defensa y la comunicación se (des) localizaría, así, en ese gran 'territorio-parque' - al que se referiría Dietmar Steiner - salpicado, en efecto, de áreas más o menos focales y de áreas residuales especializadas: espacios, en definitiva, dedicados al consumo, la residencia, el trabajo y el ocio localizados en bolsas discontinuas enlazadas por redes de transporte.
} 
Neste sentido, o centro de Suzano se consolida rapidamente como referência à circulação de pessoas e mercadorias no Alto Tietê. Por outro lado "a cidade não possuiu políticas públicas capaz de garantir o desenvolvimento urbano deste trecho da cidade que se transformasse e acompanhasse as atualizações tecnológicas das cidades contemporâneas" (VIEIRA 2010). ${ }^{201}$

Como decorrência, este trecho da cidade resultou numa área de baixa qualidade urbana e paisagisticamente degradada. A falta de investimentos do poder público, assim como o desinteresse da iniciativa privada, gerou a deterioração do conjunto edilício - em particular nas primeiras quadras junto à linha férrea - ampliando a cada ano a sensação de insegurança e desvalorização imobiliária.

Assim, a partir de 2005, com a ascensão de um novo grupo político na cidade, ${ }^{202} a$ municipalidade decide desenvolver um conjunto de Planos e Projetos Urbanos que visavam à reestruturação física e ambiental de diversas áreas do centro expandido, ${ }^{203}$ adequando-as aos novos requisitos de infraestrutura e desenvolvimento urbano, e entendendo que cada projeto deveria ser considerado como integrantes de um conjunto de ações estratégicas, trabalhando de forma integrada e complementar com os objetivos de desenvolvimento urbano e social contemplados pelo Plano Diretor Participativo. ${ }^{204}$

201. Tradução do autor, 2010

La ciudad no era dueño de políticas públicas capaces de garantizar el desarrollo de este tramo urbano de la ciudad que se convirtió y acompañar la actualización tecnológica de las ciudades contemporáneas.

202 . Em 2005 o prefeito Marcelo de Souza Candido (PT) assume como prefeito da cidade, criando entre outras a Secretaria Municipal de Política Urbana, tendo como secretário Miguel Reis Afonso e Elvis José Vieira como secretário adjunto desta pasta, onde permaneci no cargo até 2007, assumindo desde então a Diretoria de Projetos Públicos.

203. A proposta de um Centro Expandindo está centrada na lógica do crescimento e desenvolvimento do centro comercial além dos limites antes delimitados entre as Praças João Pessoa e Expedicionários (Norte-Sul) e ruas Gal. Francisco Glicério e Benjamin Constant (Leste-Oeste), compondo naquele momento o "Quadrilátero Central", com uma nova área de 210 ha.

204 . O Plano Diretor Participativo foi desenvolvido em 2005, sob a coordenação da PMS e FUPAM, pelo arquiteto Prof. Dr. Eduardo Cusce Nobre, até o momento não foi aprovado pela Câmara Municipal de Suzano, Projeto de Lei Complementar no 015-07/08. 
Figura 149. Imagens do Centro Urbano de Suzano em 2005

Fotos: Elvis Vieira, 2005
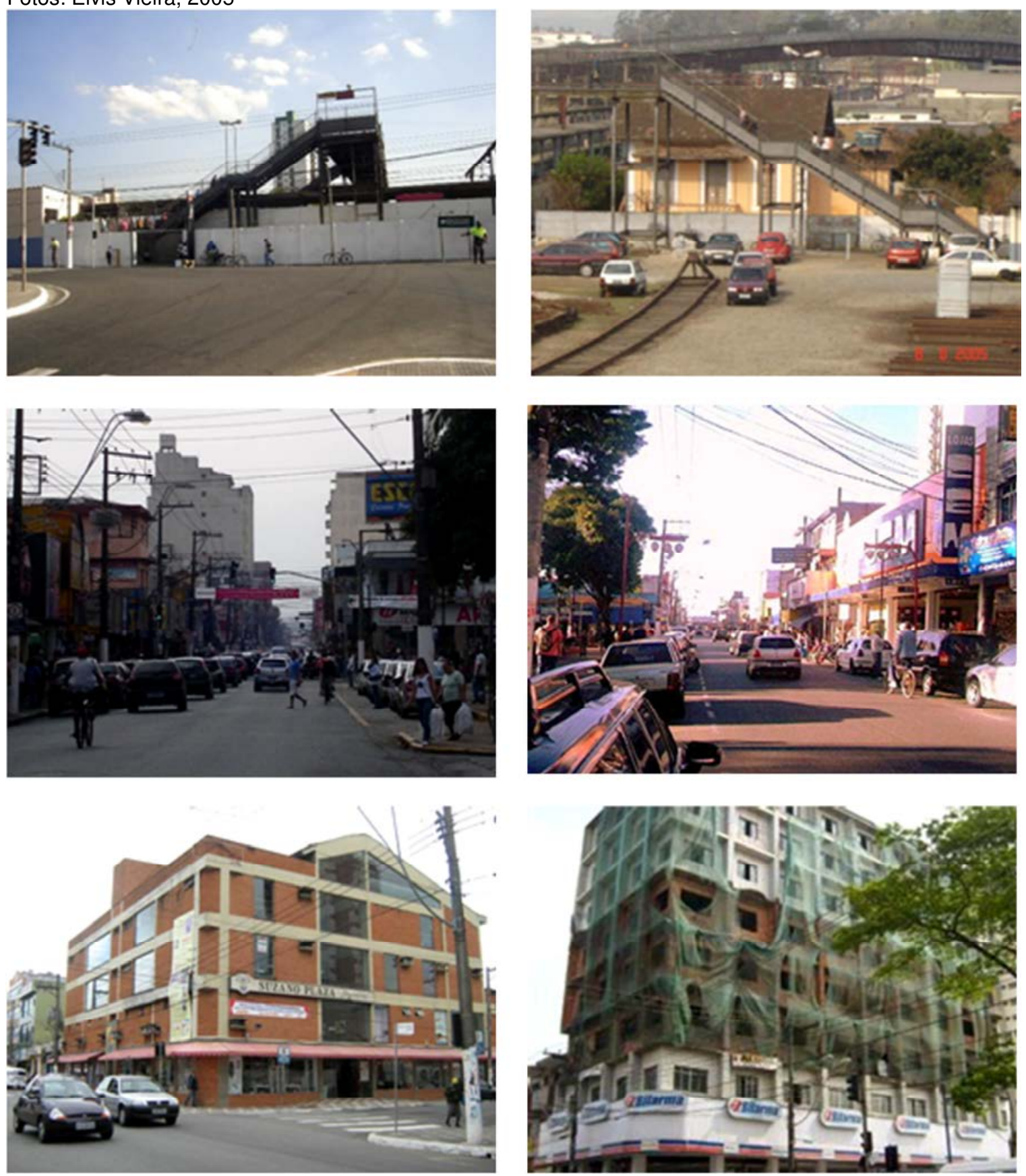


\subsection{Estratégias Urbanas e o Desenho da Cidade}

Os primeiros anos deste século, a cidade enfrenta um crescimento continuo sobre todo seu território. Com uma população de 228.690 habitantes (IBGE, 2000) a cidade se deparava com condições urbanas deficitárias em diversos temas, sobretudo os de infraestrutura e mobilidade urbana, refletindo diretamente o desenho da cidade que se torna pouco atraente aos novos investimentos da iniciativa privada. Por outro lado, o poder público, detentor das "ferramentas de planejamento urbano", capaz de regenerar e/ou transformar partes do tecido da cidade, se posicionava de forma neutra e "inoperante", ficando passiva as constantes deteriorações com que diversos bairros vinham passando.

Enquanto os bairros periféricos necessitavam de maiores investimentos em infraestrutura básica, como redes de água e esgoto, iluminação pública, pavimentação e transporte público de qualidade; o centro urbano da cidade, área já consolidada e densidade habitacional e flutuante muito mais representativa, foram se deteriorando gradativamente. ${ }^{205}$

Neste momento, a Região Central da Cidade, agora muito mais extenso que a ocupação de pouco mais de um século atrás, por mais que houvesse recebido um conjunto de ações e intervenções urbanas sobre um perímetro denominado então de "Centro Urbano" ainda mantinha um "cenário" descontínuo e desarticulado aos investimentos privados que ocorriam a cada ano, em particular na década de 1990 onde este setor da cidade experimenta uma verticalização residencial numerosa em relação às demais regiões da cidade. ${ }^{206}$ No entanto, as quadras junto à linha férrea e a estação ferroviária da cidade, ocupadas e consolidadas a partir da década de 20, continuavam a cada ano se deteriorando paisagisticamente e sem qualquer tipo de plano ou proposta urbana para esta região responsável pela inserção e surgimento do novo povoado no final do século XIX.

Por outro lado, os investimentos do governo estadual na cidade também não foram significativos nos primeiros cinco anos deste século. Apenas algumas áreas foram contempladas na cidade, de forma muito sutil, para não dizer tímida, pela SABESP avançando em números singelos no atendimento de água potável, coleta e tratamento de esgoto. Da mesma forma, a Companhia de Desenvolvimento Habitacional e Urbano (CDHU) propôs uma política habitacional frágil e que pouco atendia o déficit da cidade, com dois empreendimentos em construção na cidade: Conjunto Residencial Suzanópolis e Conjunto Residencial Jardim Varan, não atendendo ao déficit habitacional da cidade e gerando um processo migratório de outras cidades do Estado. ${ }^{207}$

205 . Em 2005 apenas 35\% das vias da cidade eram pavimentadas, $80 \%$ dos loteamentos em Áreas de Mananciais não eram atendidos por coleta e tratamento de esgoto, enquanto que mais de $50 \%$ dos loteamentos a norte não possuíam tratamento de esgoto. O transporte público da cidade era totalmente desorganizado sobre a malha viária e sem terminais urbanos que possibilitasse a integração do sistema de mobilidade urbana ( PMS, 2005).

206 . Até 2005 o perímetro considerado como Centro Urbano pela administração municipal era de apenas 50 ha (cinquenta hectares), apesar de os usos de comércio e serviços terem já naquele momento se expandido para muito além desta área. Deve-se salientar que os edifícios residenciais construídos durante as ultimas décadas não estavam atrelados a qualquer tipo de Operação Urbana ou Projeto de Requalificação do Centro que possibilitasse o redesenho do tecido urbano existente.

207. Segundo informações da Diretoria de Produção habitacional - DPH | SMPU | PMS, o Conjunto Residencial Suzanópolis, localizado na Estrada Santa Mônica - em loteamento próximo ao centro, em construção por construtora contratada pelo Estado, com 320 apartamentos (80 unidades para famílias em área em risco - PMS, e 240 sorteadas pela CDHU), enquanto o Conjunto Residencial Varan, localizado na Rua Washington Luis, está em construção sob o regime de mutirão e contratação direta coordenado pelo CDHU, com 760 apartamentos (180 em mutirão e 580 pela construtora). 


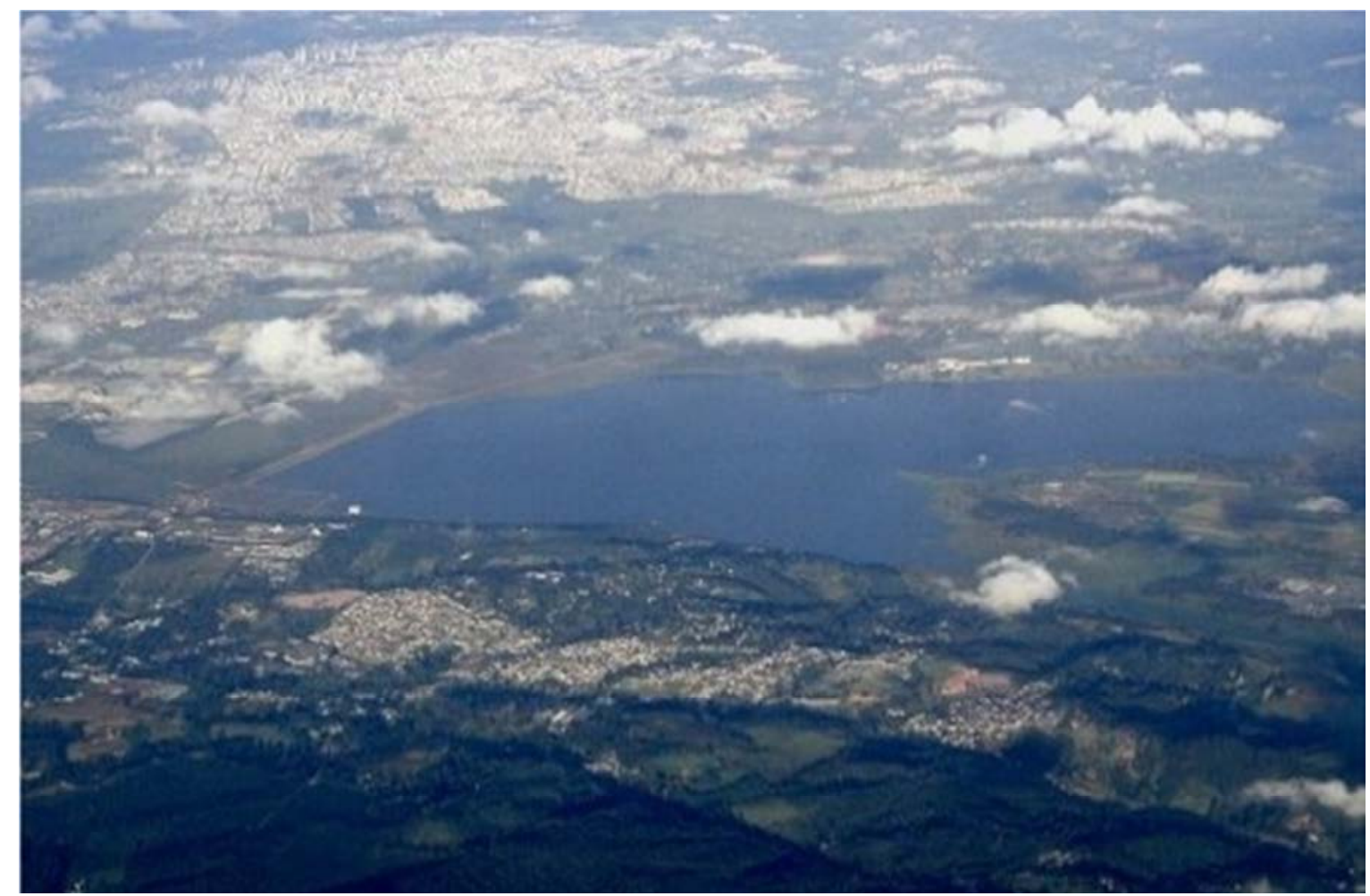

Figura 150. Vista para a Represa de Taiçupeba: em primeiro plano a cidade de Suzano, ao fundo a cidade de Mogi das Cruzes

Fonte: SABESP, 2012

Figura 151. Mapa de implantação do Rodoanel

Fonte: DERSA SP, 2012

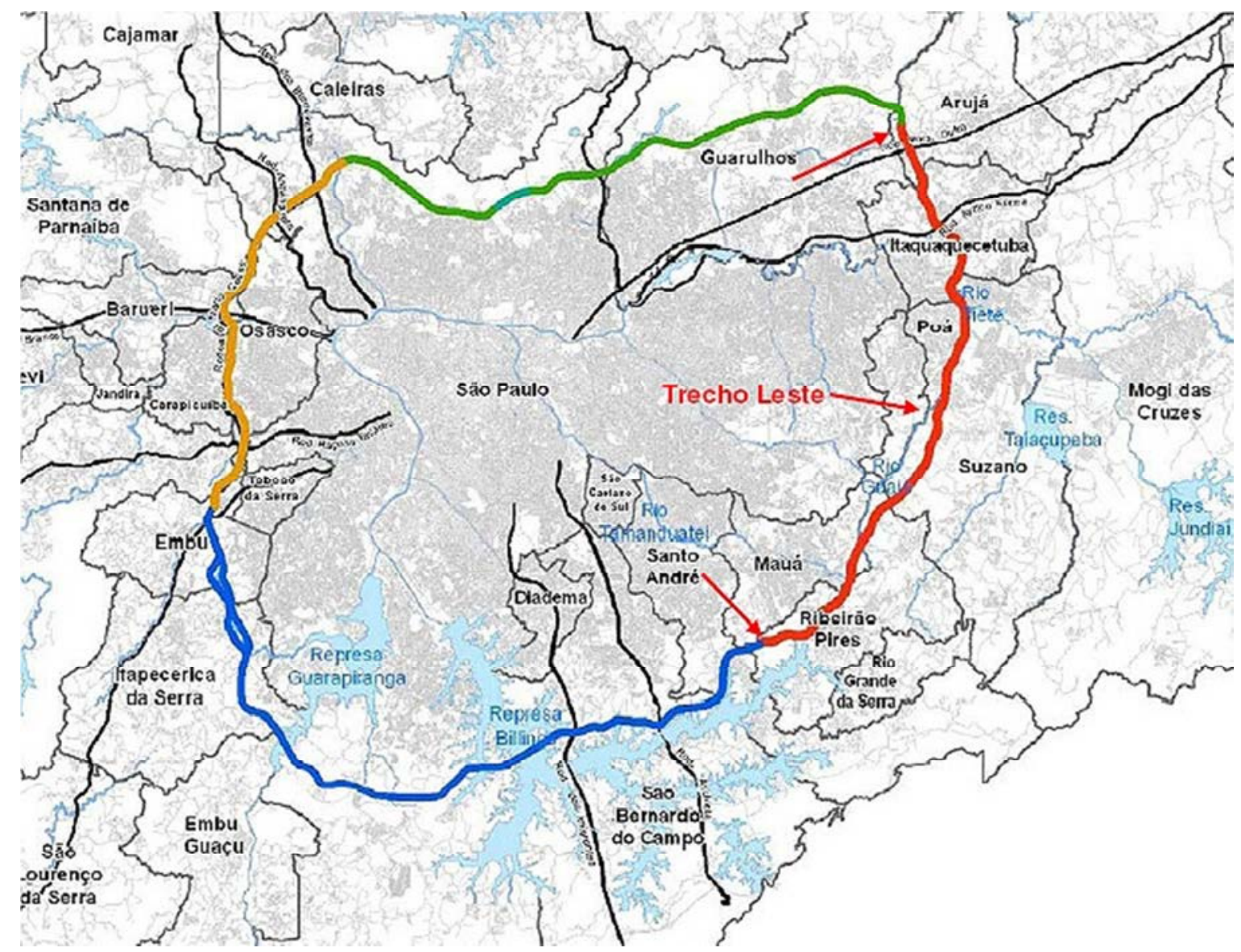


No que diz respeito ao sistema viário da cidade, podemos afirmar que os avanços foram mais significativos, apesar de ainda não atender completamente as demandas da cidade; algumas vias vicinais foram pavimentadas ampliando o acesso aos bairros em Áreas de Mananciais, chácaras e sítios afastados do centro urbano. Outro investimento que nos chamou a atenção foi a conclusão da Via Marginal do rio Una (Avenida Gov. Mario Covas) - projeto idealizado na década de 1970 e até então não concluída e, a construção do viaduto Leon Feffer (1999) criando novas alternativas de acesso e transposição sobre o eixo ferroviário.

As áreas como educação, saúde, segurança pública e cultura os investimentos pelo governo estadual foram insignificantes, gerando problemas diversos a seus habitantes, refletindo sobre aspectos econômicos e sociais da cidade, em particular quando cruzamos os índices de alfabetização (13.219 estudantes - ensino médio, 921matriculas no ensino superior - IBGE, 2005) com o número de empregos técnicos existentes naquela época nas indústrias e prestadores de serviços da cidade, que dispunha de mais de 160 mil empregos diretos, podemos concluir que mais de $70 \%$ da mão de obra destes setores eram "importados" das cidades vizinhas, em especial das cidades do ABC Paulista detentoras da mão de obra especializada em metalurgia, mecânica pesada e química, atividades presentes na cidade.

Desde então, o novo grupo político que assume a cidade e seus "males" herdados, tem como missão reverter este quadro negativo com que Suzano e seus habitantes vinham passando a quase três décadas. A vitória de Marcelo de Souza Candido (PT) pode ser considerada um marco na história política da cidade, que elege com 60.830 votos seu primeiro prefeito negro, rompendo com uma "tradição" administrativa de direita que imperou desde a década de 70. Graduado em Geografia (UNESP, 1996) e com especialização em Planejamento Urbano (UNB), sua gestão é norteada num "processo de administração pública compartilhada que busca o enfrentamento de questões prioritárias para o desenvolvimento sócio-territorial do município" (PREFEITURA MUNICIPAL DE SUZANO 2006, p 28), onde foram definidos cinco eixos de governo: Cidade Legal, Combate à Corrupção, Desenvolvimento Sustentável, Inclusão Social e Participação Popular, responsáveis pela reabilitação da cidade nos próximos anos. ${ }^{208}$

Concomitantemente a este fato, um conjunto de grandes intervenções urbanas de caráter público e privado vai influenciar e alterar diretamente o meio físico da cidade e seu desenho urbano como forma e paisagem. Nos últimos dez anos o governo estadual vem colocando em prática Planos e Projetos Metropolitanos que acabam por influenciar a Região do Alto Tietê e a cidade de Suzano diretamente.

A ampliação da Represa de Taiaçupeba, quinto reservatório do Sistema Alto Tietê, responsável pelo abastecimento de água potável para as cidades do AT e parte da RMSP, prevista desde a década de 1970 pelo DAEE (Departamento de Águas e Energia Elétrica), inicia seu processo de inundação a partir de 2011. Se por um lado sua ampliação torna-se benéfica para milhões de habitantes da RMSP, torna-se necessário a remodelação da ocupação próxima a esta barragem e novas condições de acessibilidade, visto que seu novo perímetro provocou o fechamento de um dos acessos ao bairro de Ipelândia, composto por casas de veraneio, chácaras e sítios produtivos.

Segundo explica Antonio Costa e Silva (2010), assistente executivo da Diretoria de Tecnologia e Meio Ambiente da SABESP, “... a ETA Taiaçupeba aumentará em cinco mil litros a capacidade de produção,... visando abastecer uma população de 20 milhões de pessoas na Grande São Paulo".

208 . A primeira gestão do prefeito Marcelo de Souza Candido de seu entre 2005-2008 tendo como vice Mauro Vaz (PCdoB) e a segunda entre 2009-2012 com Walter Roberto Bio (PMDB) como vice. 


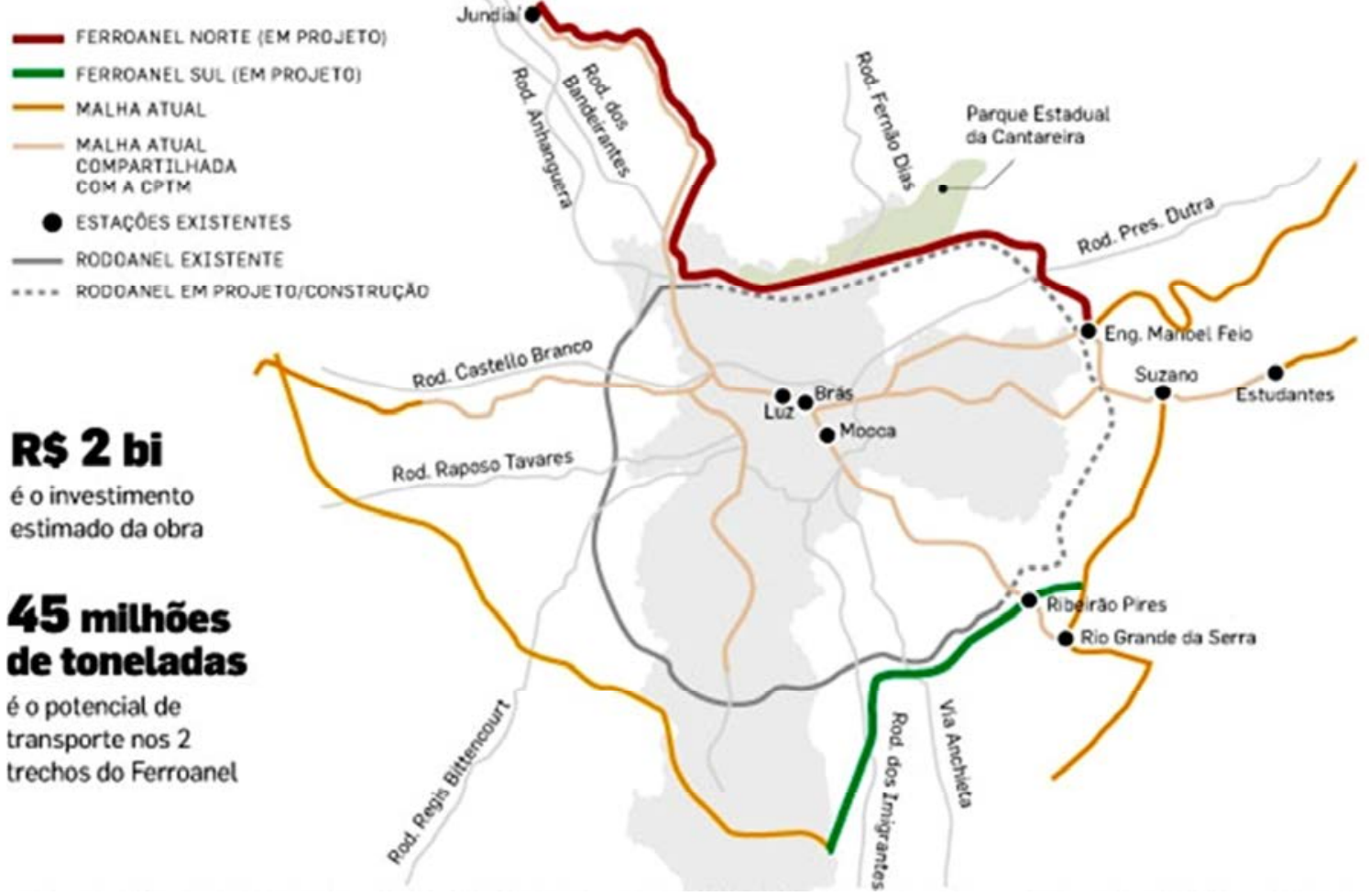

Figura 152. Projeto do Ferroanel da RMSP

Fonte: MRS Logística, 2012

Figura 153.Articulação Arquitetônica e Urbanística do Estudo de Pré-viabilidade Técnica, Econômica e Ambiental do Hidroanel Metropolitano de São Paulo

Fonte: Grupo Metrópole Fluvial - FAUUSP, 2012

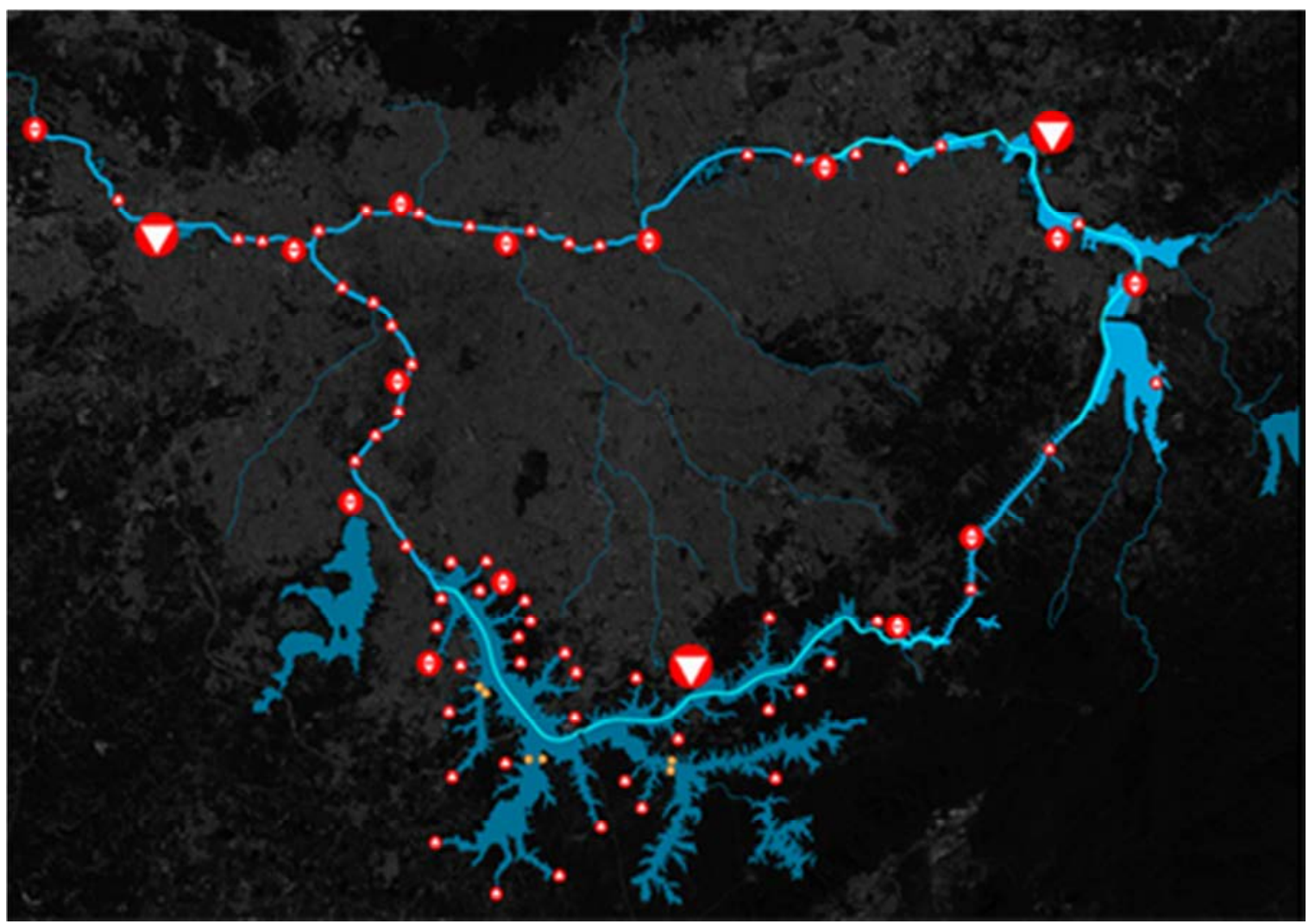


Obra de grande impacto metropolitano o Rodoanel tem por objetivo reduzir o número de automóveis que passam pelas principais rodovias de São Paulo, possibilitando novas alternativas de conexão entre as cidades das três regiões metropolitanas (RMBS RMSP - RMC). O Trecho Leste do Rodoanel tem influência direta sobre a Região do Alto Tietê, especificamente sobre duas cidades - Poá que deverá receber a praça de pedágio com entrada e saída deste trecho e Suzano com os acessos diretos ao Rodoanel. Com uma extensão de $43,5 \mathrm{Km}$ de um total de $182 \mathrm{Km}$ na conclusão dos quatro trechos, o setor leste em seu traçado deve impactar diretamente o meio ambiente, com a supressão de 200 hectares de vegetação nativa, incluindo nascentes florestais em diversos estágios de regeneração e vegetação de várzeas e bosques, assim como para a implantação das "obras de arte", estão previstos 875 desapropriações entre áreas rurais, industrias, casas e comércios, sendo 688 edificações habitacionais neste setor (ARTESP 2011).

A importância desta obra, orçada em $R$ \$ 2,8 bilhões (2011) e com previsão de entrega para 2014, de caráter metropolitano,é notória, da mesma forma que os impactos na malha viária de Suzano também são previsíveis, principalmente ao analisarmos 0 quadro abaixo que nos demonstra um crescimento contínuo do volume de tráfego (Trecho Leste) até o final da concessão da SPMar, empresa responsável pela construção e gerenciamento deste trecho por 35 anos.

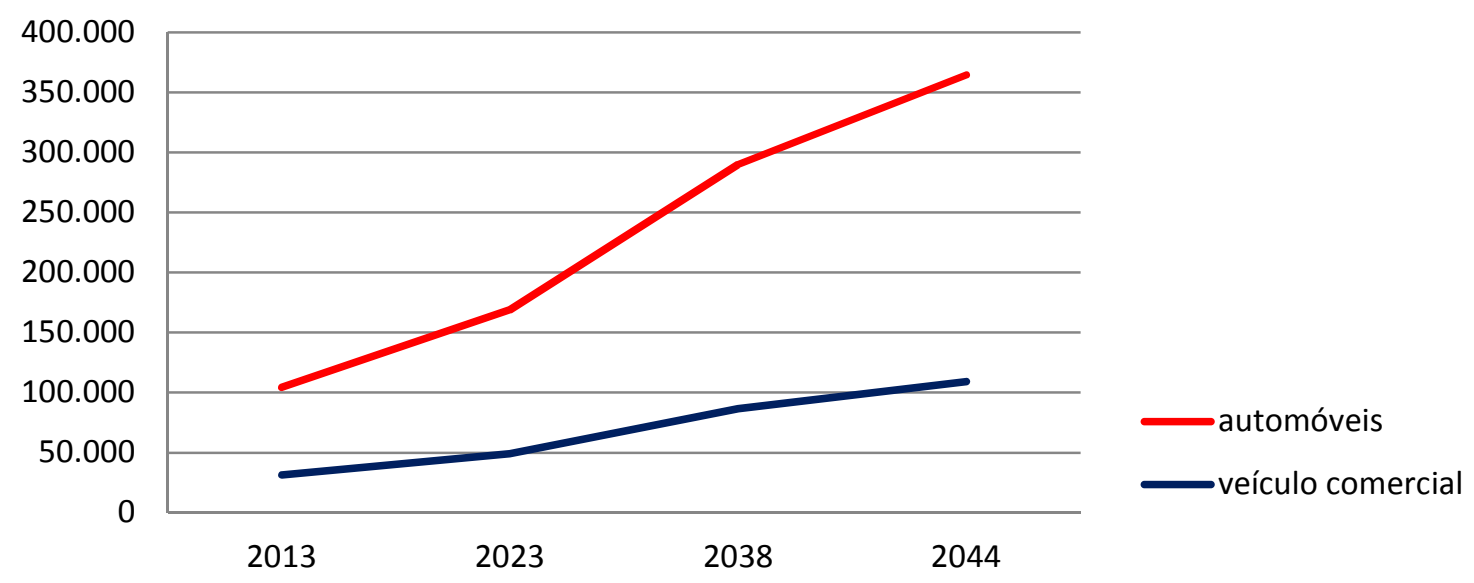

6. Rodoanel Trecho Leste - Volumes diários médios projetados

Fonte: ARTESP, 2011

Organização: Elvis Vieira, 2012

Outras de caráter metropolitano também devem influenciar diretamente a dinâmica da cidade e sua forma urbana. Com extensão de $211 \mathrm{Km}$ de trilhos, a proposta do Ferroanel coordenado pelo governo estadual em parceria com a estatal MRS Logística S.A., possibilitará a conexão das regiões metropolitanas num sistema integrado, promovendo a intermodalidade no transporte de cargas no Estado e, com isso, reduzindo custos logísticos. "Outro benefício é a redução no congestionamento rodoviário nos acessos à Região Metropolitana" (DIÁRIO DE SUZANO 2011).

O Trecho Sul, onde estão inseridas as obras em Suzano e cidades vizinhas (Poá, Itaquaquecetuba), as intervenções já estão em andamento desde 2011 e configura-se na segregação das linhas de cargas e passageiros. Esta intervenção em si provoca pouco impacto sobre o desenho da cidade, por outro lado suas obras se justificam em reduzir o número de caminhões que passam pela cidade a caminho do porto Seco (distrito de palmeiras) e Santos. 


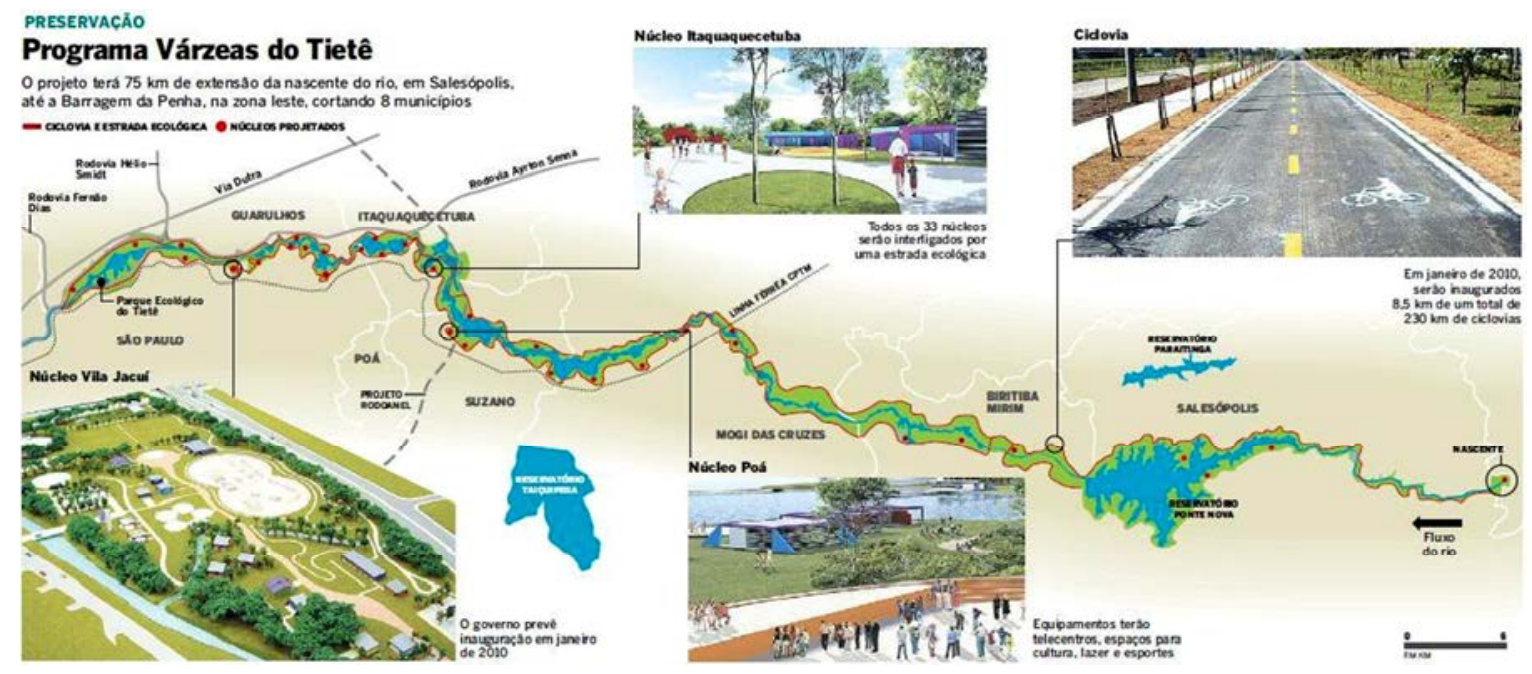

Figura 154.Parque Várzeas do Tietê com $107 \mathrm{~km}^{2}$ de área verde e 33 núcleos com equipamentos de lazer, cultura, arte e esporte

Fonte: Governo do Estado de São Paulo, 2009

Figura 155. Obras previstas para a Copa 2014, entre elas a Perimetral da Copa | Trecho Suzano Fonte: DPP | SMPU | PMS, 2012

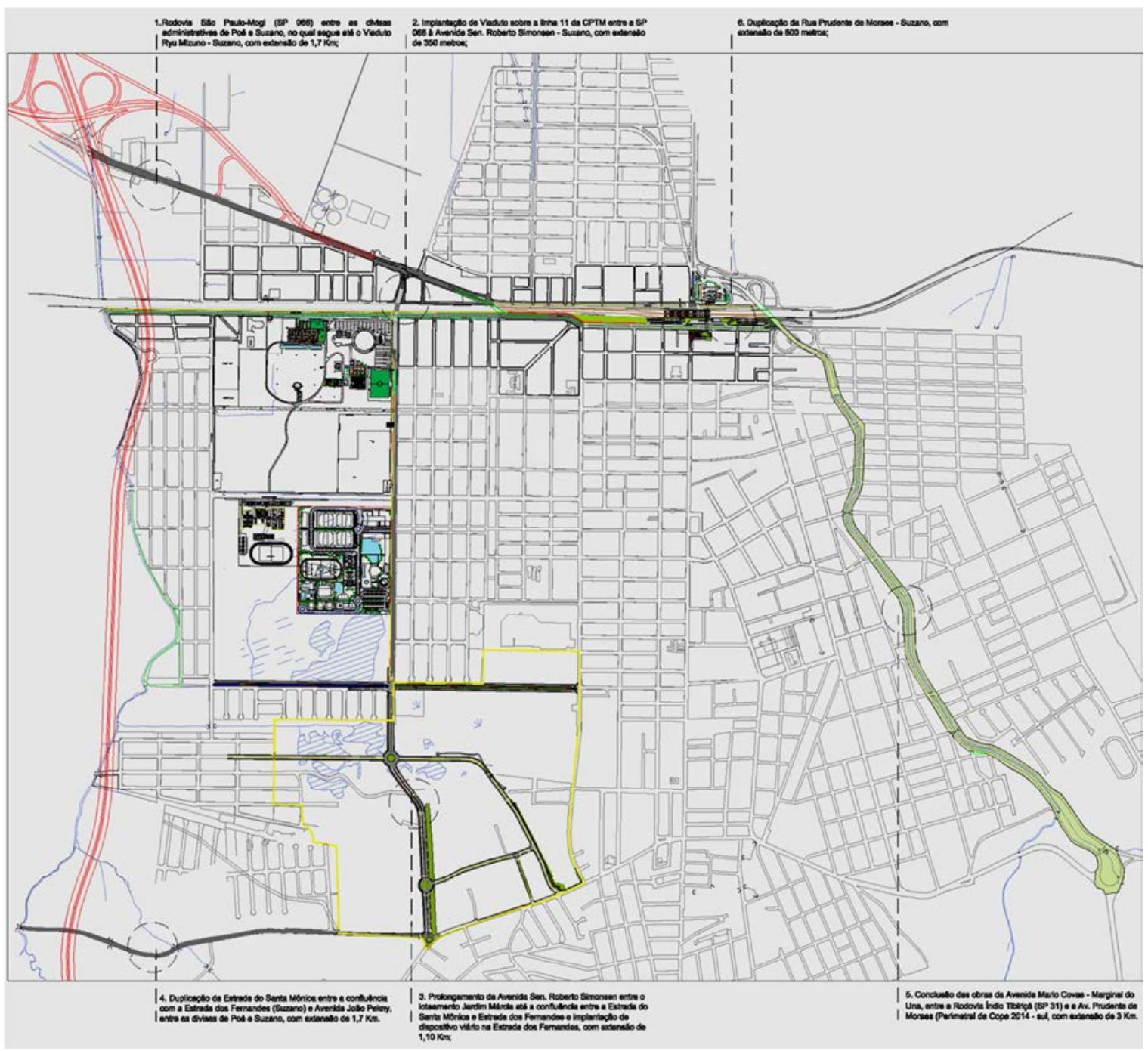


Proposta de mesma envergadura, o Hidroanel tem como objetivo possibilitar o transporte fluvial urbano, em especial os de cargas públicas sobre os rios e canais existentes. Proposto pelo Governo do Estado e coordenado pela FAUUSP - LABPROJ as intervenções se concluiriam em 31 anos (2011-2042) garantindo a "redução da frota de caminhões transportadores de cargas públicas urbanas, além do controle das águas para evitar enchentes e a diminuição do trânsito $e$ de emissões de gases poluentes"(FAUUSP e GOVERNO DE SÃO PAULO 2012).

Em Suzano (Trecho São Miguel-Taiaçupeba), as intervenções mais significativas estão junto a represa, no qual se propõe o Lago Navegável e a Cidade Canal BillingsTaiçupeba, com significativas alterações sobre o tecido urbano e o desenho dos bairros adjacentes. Apesar de ainda ser tomada como proposta, principalmente em Suzano, é valida sua aplicabilidade a médio e longo prazo como grande contribuição para os meios de transportes entre a cidade e as Regiões do Alto Tietê e Metropolitano de São Paulo.

Ainda contíguo ao Rio Tietê, a proposta do arquiteto Ruy Ohtake para o Parque Várzeas do Tietê, iniciado na década de 70 e agora sendo atualizado e adaptado às novas condições e situações das margens do rio, voltou a ser desde 2009 pelo Governo do Estado (DAEE) objeto de discussão e proposta de solução para a requalificação ambiental de um dos rios mais importantes do país.

"O rio é alargado em vários pontos, formando lagos, facilitando o escoamento da água, favorecendo a paisagem e beneficiando a população com equipamentos e atividades culturais e recreativas"(OHTAKE 2009).

Considerado o maior parque linear do mundo com $75 \mathrm{Km}$ de extensão, sua implementação esta dividida em três etapas, sendo a primeira com investimentos de US\$ 199,8 milhões, sendo 42\% do Estado de São Paulo, equivalente a US\$ 84,1 milhões e $58 \%$ financiados pelo Banco Interamericano de Desenvolvimento (BID), US\$ 115,7 milhões (DIÁRIO DE SUZANO 2011). O trecho de Suzano está previsto na $2^{a}$ etapa do projeto, com a implantação de equipamentos e núcleos de cultura e educação ambiental (OHTAKE 2009). A implantação deste parque, para a cidade, além de restabelecer a função das várzeas para o amortecimento das cheias, deve agir como "barreiras ambientais" protegendo o Tietê das ocupações antrópicas nas margens do rio.

Mais recentemente, o tema da Copa do Mundo em 2014 abriu novas discussões sobre o tema das mobilidades entre as cidades do Alto Tietê e a capital paulista. Estudos coordenados pela Agência de Desenvolvimento Regional do Alto Tietê (Adrat) e o Consórcio de Desenvolvimento dos Municípios do Alto Tietê (Condemat) estão em desenvolvimento desde 2010 com o intuito de implementar um conjunto de obras e equipamentos capaz de ampliar a capacidade das cidades do Alto Tietê em abrigar atividades correlacionadas ao evento mundial esportivo.

Visando a cidade como uma das subsedes da Copa de 2014, a municipalidade iniciou um conjunto de ações e melhorias em seus equipamentos esportivos como contrapartida aos de investimentos privados na rede hoteleira da cidade.

"Apesar de ser uma questão que depende de interesse comercial e privado, a Prefeitura pode criar condições para que empreendimentos deste setor (hotelaria) sejam implantados"(CANDIDO in DORO 2011, grifo nosso ). 


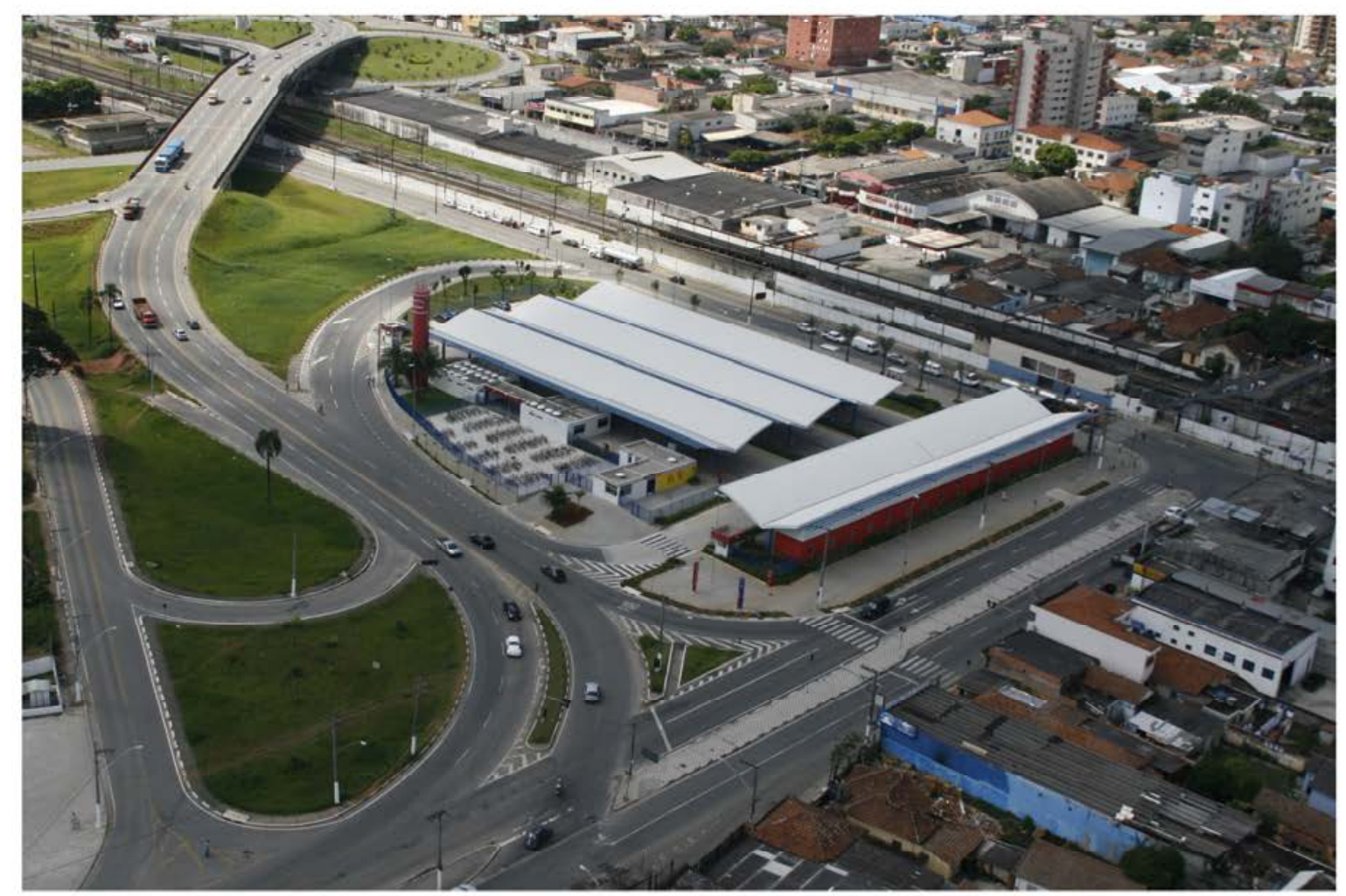

Figura 156. Terminal Urbano Ver. José Diniz, projeto do arquiteto João Valente, 2005

Foto: Wanderley Costa, 2006

Figura 157. Praça Cidade das Flores, projeto do arquiteto Marcos Boldarini e equipe, 2005 Foto: Wanderley Costa, 2006

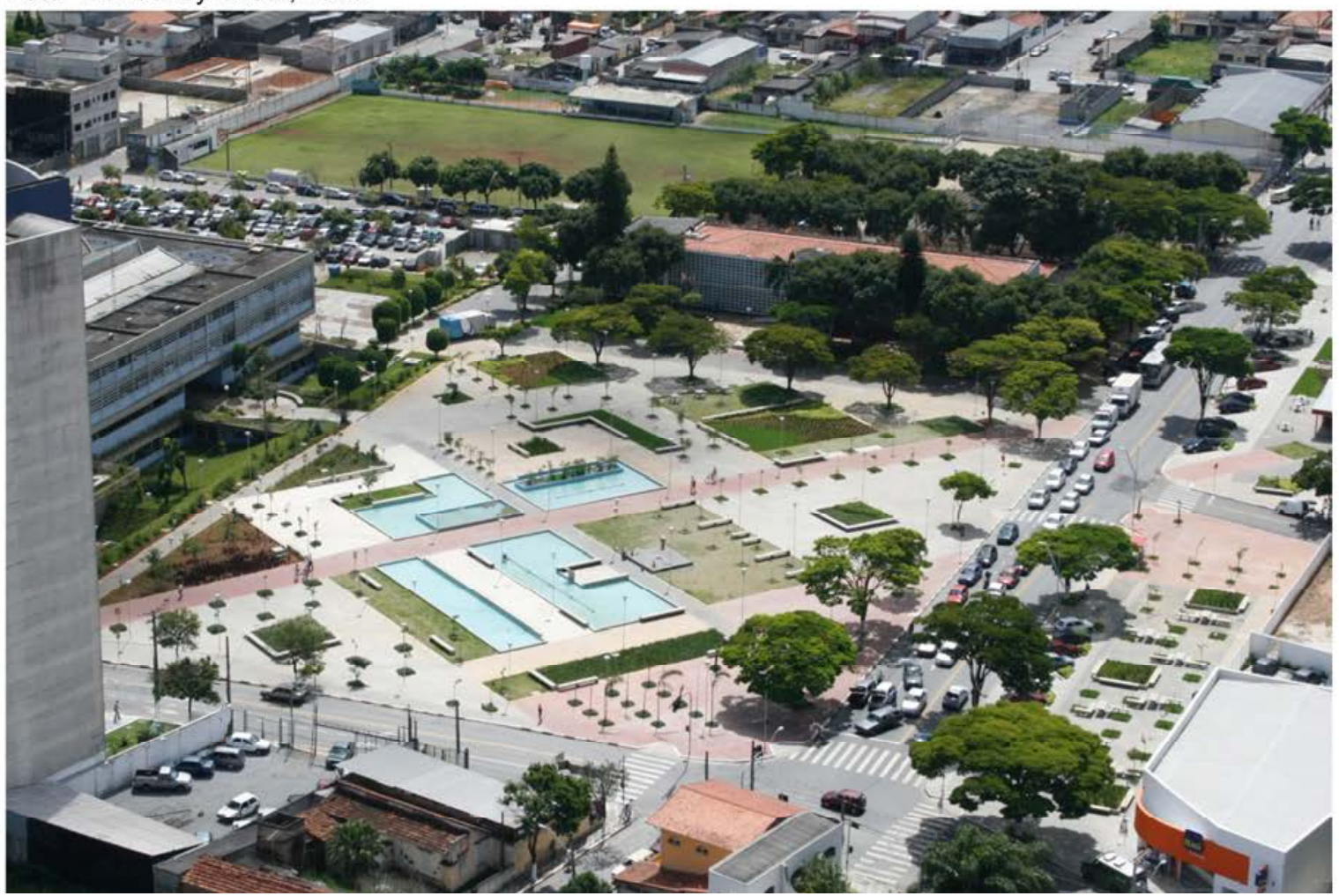


Para o então prefeito de Suzano, Marcelo de Souza Candido, a escolha da cidade como subsede da Copa de 2014 poderá beneficiar a cidade com a construção de novos equipamentos de esporte, como por exemplo, o Centro de Treinamento proposto junto ao Estádio Municipal que deve passar por adequações as Normas da FIFA, assim como ampliar seu parque hoteleiro, hoje muito singelo e insuficiente ao seu potencial. ${ }^{209}$

Outra obra de grande relevância para as cidades do Alto Tietê está numa nova via perimetral de ligação de Mogi das Cruzes à divisa de Ferraz de Vasconcelos com São Paulo, conectando a Radial Leste (bairro de Guaianazes - Zona Leste de São Paulo) com importantes vias do Alto Tietê como SP 66, acesso à Rodovia Ayrton Senna e Rodoanel Trecho Leste em Suzano, e Mogi-Dutra e Mogi-Bertioga em Mogi das Cruzes. Desenvolvido num Consórcio entre os quatro municípios atingidos pela intervenção (Mogi das Cruzes, Suzano, Poá, Ferraz de Vasconcelos), a Perimetral da Copa, com extensão de $15 \mathrm{Km}$ e orçamento previsto em $R \$ 90$ milhões ( PMS, 2012), com obras previstas entre 2013 e 2014 (ARAÚJO 2012), pretende possibilitar novas conexões viárias entre as cidades do Alto Tietê e São Paulo, em especial com o Estádio do Corinthians (Itaquerão) que sediará os Jogos da Copa de 2014.

Para Suzano, esta obra traz grandes benefícios e melhorias na malha viária do centro da cidade. Não somente pelas já previstas no sistema viário da região, como as em andamento como a segregação da linha de cargas (MRS Logística S.A.) e a construção da Nova Estação Ferroviária de passageiros, atendendo aos Planos de Expansão e Modernização da Rede Ferroviária (CPTM - linha 12 Coral). Como afirma o então prefeito da cidade:

"A cidade tem uma característica que distingue dos demais municípios, que é a proximidade com toda essa rede de infraestrutura viária. Isso permeia toda a história de Suzano que se deslocou para o Centro por causa da linha de trem. Essas obras vão modificar bastante Suzano. Não vejo a cidade nos próximos dez anos como hoje é vista. Será muito favorecida por essa nova fase" (Marcelo Candido inDiário de Suzano, 2012).

Diante deste cenário a municipalidade decide desenvolver um conjunto de Planos e Projetos Urbanos para a cidade que visavam a reestruturação física e ambiental de diversas áreas da cidade, adequando-as aos novos requisitos de infraestrutura e desenvolvimento urbano. Num primeiro momento os Planos e Projetos eram necessários para os devidos "ajustes" no desenvolvimento urbano da cidade interrompido durante as décadas de 80 e 90, da mesma forma com que deveriam ser entendidos como instrumentos urbanísticos aplicados a médio e longo prazo a fim de "garantir a sustentabilidade da cidade para as próximas gerações"(PMS 2005), trabalhando de forma integrada entre as ações estratégicas e os "projetos pontuais" necessários para atender as demandas e objetivos à curto prazo previstos no Plano Diretor Participativo.

209. Deve-se observar que a cidade recebe anualmente um número significativo de empresários nacionais e internacionais por conta de seu parque industrial, porém a estrutura com que dispõem seus hotéis são inferiores ao seu potencial tanto como locais de hospedagem como eventos e convenções das indústrias instaladas na cidade. 
Figura 158. Mapa das três regiões de Suzano: Boa Vista (norte), Centro e Palmeiras (sul) Fonte: DPP | SMPU | PMS, 2010

Organização: Thaís Fróes, 2012

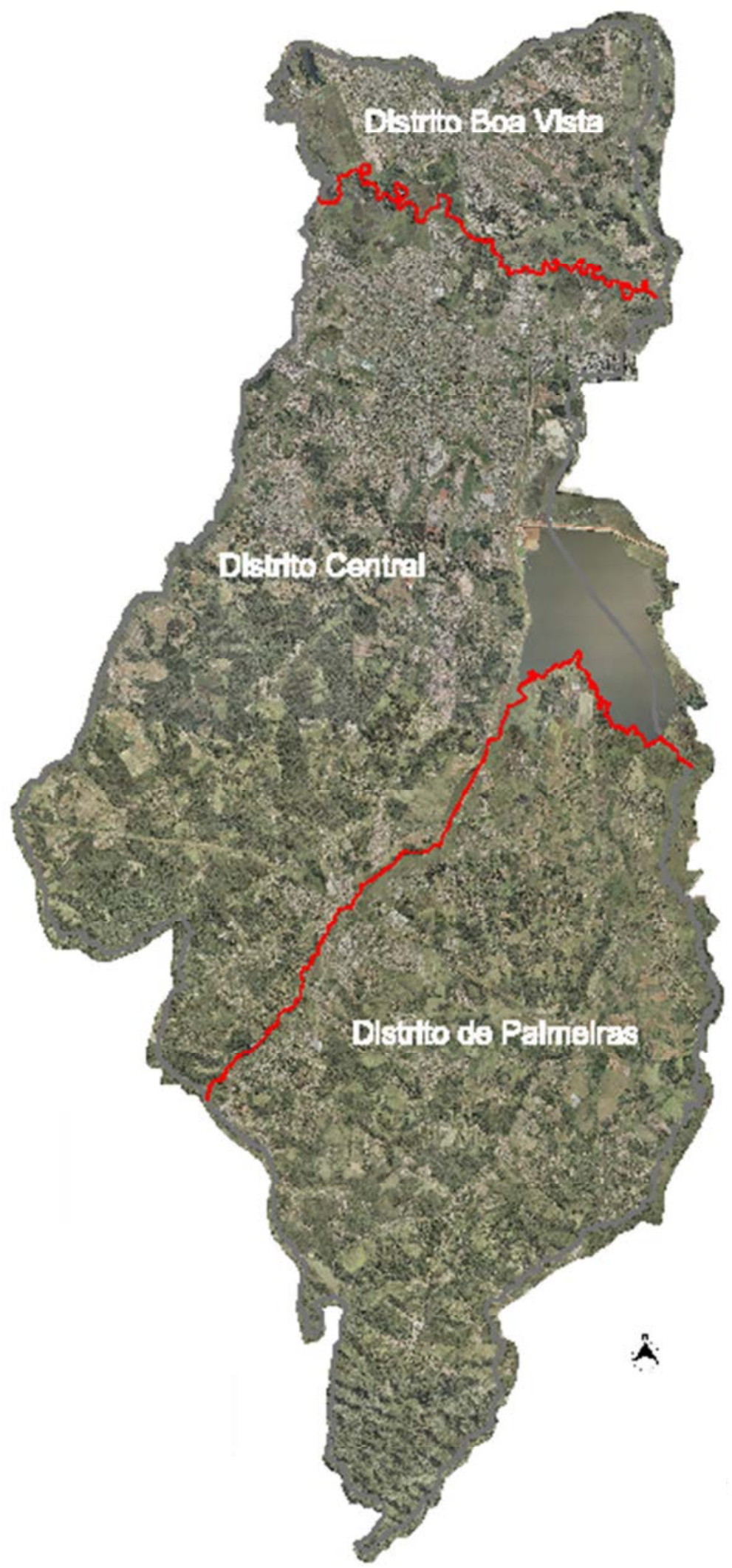


Administrativamente a cidade foi dividida em três distritos: Boa Vista à norte, Palmeiras de São Paulo a sul e Região Central, onde cada uma possui suas características e particularidades ligadas às suas relações sociais e econômicas, refletindo diretamente sobre o desenho e sua forma urbana. Da mesma forma, cada distrito também vai apresentar problemas diversos e específicos a sua região e configuração urbana, requerendo ações pontuais e à longo prazo diretamente relacionados a sua problemática e realidade.

O Distrito Central, assim como as outras regiões da cidade, tornaram-se alvo de vários planos e obras de requalificação do espaço urbano com vistas a melhorar a qualidade de vida de seus habitantes. Em diferentes fases de desenvolvimento e execução, as iniciativas sob competência do poder público que articula, por vezes, parcerias públicoprivadas tem como objetivo colocar em prática intervenções urbanas sobre o tecido degradado e desarticulados entre si e, consequentemente, redirecionar o crescimento urbano da cidade de forma sustentável e igualitária.

"A essência da arquitetura é sempre para elevar o horizonte do futuro, pois deve sonhar e ao mesmo tempo, ser realista, isto é, deve conhecer as perguntas a ser respondido, estar ciente dos efeitos que podem resultar nessa realidade $e$, por sua vez, como esta mesma vai transformar o projeto e, ao mesmo tempo, imaginar"(MONTANER e MUXÍ 2011, p 15). ${ }^{210}$

As considerações colocadas por Montaner e Muxí se enquadram aos conceitos apresentados nos Planos e Projetos Urbanos para a cidade naquele momento. Enquanto que algumas propostas tinham caráter de atender as necessidades e resolver os problemas imediatos, outros tinham como "linha de raciocínio" sua aplicabilidade a médio e longo prazo, porém de forma sustentável.

O Programa "Cidade das Flores", lançado em 2005, tinha como objetivo "colocar em prática, um conjunto de obras, ações e serviços que melhorem a vida das pessoas em Suzano" (PMS 2005), englobando intervenções em equipamentos de educação, saúde, esportes e cultura, como de ordem urbanística requalificando trechos da cidade e retomando obras de infraestruturas urbanas paralisadas por mais de meia década.

Ainda segundo as propostas da prefeitura naquele momento, o Programa "é resultado de um amplo trabalho de planejamento coletivo e estudo dos problemas do município realizado nos primeiros meses desta administração"(PMS 2005), explicitando a organização e raciocínio do poder público em responder rapidamente aos problemas urbanos enfrentados.

Dentre as mais de 60 obras previstas, podemos apontar duas como referência ao tema tratado nesta tese: a reforma e modernização do Terminal Rodoviário Norte "Vereador Diniz José dos Santos Faria", projeto de autoria do arquiteto João Valente, que redesenha um equipamento urbano com qualidade e traz novas alternativas de integração entre os sistemas de mobilidade existentes, além de ajustar uma quadra urbana até então indefinida e desconectada da malha urbana; e a construção da Praça "Cidade das Flores", de autoria do arquiteto Marcos Boldarini e equipe, convertendo uma extensa área junto a Prefeitura Municipal, até então sem uso definido, num espaço de lazer no centro da cidade, reajustando o tecido urbano desarticulado e integrando os

210. Tradução do autor, 2012

La esencia de la arquitectura es siempre plantear el horizonte de futuro; para ello debe soñar y, al mismo tiempo, ser realista, es decir, debe conocer bien las preguntas a las que dar respuesta, debe ser consciente de los efectos que pueden ocasionarse en dicha realidad y, a su vez, de cómo esta misma va a transformar el proyecto y, al mismo tiempo, debe imaginar. 
três poderes (executivo, legislativo e judiciário), tornando-se uma importante referência urbana na cidade e região.

Tais intervenções funcionariam como "Acupuntura Urbana" ${ }^{211}$ sobre todo o território da cidade, atuando pontualmente sobre o problema encontrado e refletindo em seu entorno imediato. Este processo foi confirmado com a transformação do desenho e sua forma urbana nas quadras próximas à Praça "Cidade das Flores", onde a intervenção provocou a "movimentação" do comércio e serviço para esta região do centro urbano e a valorização do solo, com o interesse da iniciativa privada em investir em novos empreendimentos residenciais e serviços.

Estes "Projetos Pontuais", assim denominados pela Prefeitura Municipal de Suzano (2005), deveriam ser integrados e acompanhados a partir de ferramentas de gestão e desenvolvimento urbano capaz de garantir não somente sua integridade $e$ aplicabilidade, mas em certos momentos, funcionarem como "projetos âncoras" aos Grandes Projetos Urbanos pensados a médio e longo prazo para a cidade. Neste sentido, vários projetos colocados em prática desde 2005 são compreendidos e defendido por Solà-Morales, como "cosas urbanas", responsáveis por restabelecer a ordem do desenho urbano e regenerar o tecido degradado como elemento integrador do Projeto Urbano (SOLÀ-MORALES 2008).

Desta forma, os Grandes Projetos Urbanos elaborados e em execução desde 2005, foram pensados como ferramentas de desenvolvimento urbano capaz de transformar e regenerar o tecido e sua forma degradada, "com a inserção de um novo repertório arquitetônico e construção de novos cenários urbanos de forma sustentável"(VIEIRA $2010)^{212}$.

Em resumo, nos últimos oito anos, podemos apontar cinco Grandes Projetos Urbanos em desenvolvimento e/ou em aplicação na cidade. Observamos também que a maioria destes projetos, quatro especificamente, está situada na Região Central da cidade, que apesar de sua localização privilegiada, com toda infraestrutura urbana instalada (ainda assim desatualizada) e rede de transporte público (municipal, regional e metropolitano), seu tecido, assim como sua forma urbana, não acompanharam o desenvolvimento tecnológico tão pouco da sociedade, resultando em um centro urbano degradado urbano, paisagístico e economicamente.

Assim, atualmente, a cidade tem nestes Grandes Projetos a oportunidade de transformar seu tecido de forma igualitária e em consonância as novas exigências do mercado e necessidades urbanas de seus habitantes e usuários, onde se aplicam:

1. Planos de Bairro: ao longo dos anos dois distritos foram se consolidando como referência urbana na cidade. O Distrito de Boa Vista (norte) e Palmeiras de São Paulo (sul) se configuram num conjunto de loteamentos e bairros residenciais com certa autonomia econômica do distrito central. As altas densidades, em especial o de Boa Vista, impulsionou a chegada e consolidação de um centro comercial que atendesse as necessidades dos habitantes daquelas regiões. Por outro lado, sua gradual formação, não foi planejada como um "organismo urbano" desenvolvido ou gerenciado como tal, resultando em espaços

211. A expressão Acupuntura Urbana, defendida por Oriol Bohigas em Barcelona nas intervenções para os Jogos Olímpicos de 1992, e Jaime Leiner em Curitiba, foi utilizada por Elvis Vieira e Ricardo Lú em 2010, em palestra proferida na Pontificia Universidad Católica de Quito (PUCE), no I Seminario de Rehabilitación Urbana - Quito - Equador, intitulada "Arquitectura Institucional como Instrumento de 'New Urban Settings': Corto Ensayo sobre la Acupunctura Urbana", sobre os projetos desenvolvidos na região central de Suzano - Brasil.

212 . Tradução do autor, 2010

Con la inserción de un nuevo conjunto de arquitectura y construcción de nuevos paisajes urbanos de una manera sostenible. 
desarticulados e com uma baixa qualidade urbana e ambiental. As propostas para os Planos de Bairro se configuram a partir da confirmação destes núcleos comerciais como "Novas Centralidades" responsáveis pela dinâmica urbana, econômica e social destas regiões, em que os Projetos Urbanos Especiais (PUE) deveriam cumprir a função de potencializar as atividades comerciais e atrair novas atividades econômicas nas áreas, incorporar e potencializar as atividades de lazer e cultura dos bairros, reordenar os espaços e equipamentos públicos de forma igualitária e, qualificar ambiental e urbanisticamente o perímetro de intervenção. Ainda que nos últimos 8 anos a administração pública não avançou significativamente na transformação da forma urbana, as intervenções pontuais ajustadas nos PUEs conformaram de forma significativa num "novo conceito pautado sobre o redesenho o espaço público e a transformação da qualidade ambiental destes lugares"( PMS, 2005);

2. Plano de Requalificação Urbana: formulado para compor uma "nova configuração econômico-territorial de todo Centro Comercial do Município", o Plano de Requalificação do Centro envolve projetos específicos de desenho urbano, reconfiguração dos edifícios públicos e a ampliação de espaços públicos de qualidade e mobilidade urbana. Sua área de atuação esta inserida sobre o "Quadrilátero Central" que ao longo dos anos se caracterizou pelo uso comercial e serviços, com habitações verticalizadas em seu núcleo, totalizando 210 hectares de intervenção direta. Como estratégia de atuação sobre esta área degradada, o conceito de "Acupuntura Urbana" foi aplicado no perímetro como forma de regenerar seu tecido e possibilitar a mutação tipológica dos espaços construídos. Devido à consolidação deste perímetro como o centro comercial e serviços da cidade e região, a área é utilizada diariamente por um número considerável de usuários da cidade e região, resultando numa alta densidade flutuante que se destinam em busca de mercadorias e prestação de serviços na grande diversidade de lojas, bancos e escritórios localizados nesta região da cidade, por outro lado, os espaços públicos não correspondem a demanda e potencial com que este centro comercial atende, as calçadas são de baixa qualidade e sem acessibilidade, o número de mobiliário urbano é insuficiente a densidade diária assim como as infraestruturas urbanas está defasadas ou subdimensionadas. Para tanto, o Plano de Requalificação do Centro tem como ação direta do poder público a implantação e reestruturação de novos equipamentos (saúde, cultura, educação), mobiliário urbano (lixeira, bancas de jornal, bancos e acentos) e o redesenho do espaço público ampliando a qualidade de vida do morador do centro e seus usuários;

3. Plano de Expansão Urbana do Centro: com uma área de aproximadamente 70 hectares, a extensa parcela de solo ainda pouco ocupada e sem infraestrutura urbana a sul do Shopping Center da cidade (inaugurado em 2001) e contínua ao centro urbano de Suzano, vem atraindo os interesses da iniciativa privada para o atendimento da população da classe média. Até os anos 2000, este setor do centro urbano (sudoeste) se caracterizava pela vasta porção de terras produtivas agrícolas, que apesar de sua proximidade direta com o centro comercial (ruas Gal. Francisco Glicério e Benjamin Constant), se manteve "intacta" em seu uso homogêneo. Após a inauguração do primeiro grande centro de compras da cidade, este equipamento provocou o redirecionamento do crescimento e eixo comercial da cidade, resultando na transformação das então construções residenciais em prestadores de serviços, especialmente laboratórios e clínicas particulares. No entanto, poucas áreas não construídas estavam disponíveis entre o centro comercial consolidado e o novo eixo de serviços, resultando na implantação de poucos edifícios residenciais, provocando a procura por novas áreas passíveis de atender a demanda e crescimento do mercado imobiliário que 
se instalava naquele momento (início dos anos 2000). Entre os anos 2000 a 2004 a região a sul do Shopping Center da cidade pouco se alterou, apenas algumas pequenas porções nas "bordas" e com conexão direta com o sistema viário existente foram alvo da implantação de empreendimentos residenciais, no entanto, a produção agrícola foi aos poucos ficando cada vez mais rarefeita denunciando sua alteração nos usos ali presentes. Desta forma, o poder público aponta esta área como um território a se expandir junto ao centro consolidado, propondo o desenho urbano de um "Novo Bairro" de uso misto e diferenciação em seu modo de ocupação urbana, incentivando os edifícios multiusos e a verticalização na área. A consolidação deste projeto se deu somente no início de 2012, com a Operação Urbana Consorciada Expansão do Centro, no qual o projeto urbanístico prevê a configuração de uma Nova Centralidade Urbana com usos mistos e novas formas urbanas. Uma parceria entre a Prefeitura Municipal de Suzano, SABESP e as empresas Cury, MRV, Fili Empreendimentos, Tecnisa e Mineradora Caravelas (atuais proprietários) possibilitou o início das obras de infraestrutura como implantação de redes de água e esgoto, drenagem e nova rede viária conectando esta área a malha urbana existente, garantindo assim, a consolidação deste bairro de forma controlada e com instrumentos urbanísticos que regulem a forma urbana daquela região: "Entendemos que essa área tem grande possibilidade de passar a ser a nova centralidade,... com qualidade urbanística, ciclovia ligando com o sistema já existente, garantindo o crescimento da cidade para esse vetor de forma organizada e com qualidade urbanística", no qual ainda podemos identificar seu potencial em um bairro experimental e de usos mistos, "... com novos zoneamentos que possibilite a garantia de edificações de usos diversos,... habitação, torres de escritórios e áreas industriais para TI (tecnologia da Informação), de alta tecnologia, garantindo também que o bairro tenha sustentabilidade própria" (VIEIRA in Diário de Suzano, 2012);

4. Parque Max Feffer | Setor Educacional:uma grande reserva urbana com aproximadamente 1 milhão de metros quadrados, localizada a oeste do centro urbano da cidade, entre os bairros jardim Imperador e Monte Cristo - este último divisa administrativa de Poá, foi destinada no final dos anos 1990 à implantação do primeiro Parque Urbano da cidade. Fruto da negociação entre a Prefeitura Municipal e o Instituto Nacional do Seguro Social - INSS, a área foi repassada a municipalidade em troca de um edifício existente no centro da cidade para abrigar a sede do INSS. Os primeiros dez anos pouco avançaram sobre a implantação de obras que consolidasse o uso proposto inicialmente, apenas uma pequena pista de caminhada e um singelo playground, além da estrutura em concreto armado para a implantação de ginásio de esportes e uma piscina pública, ambos inacabados que geravam diversos transtornos de segurança no local. A área por sua vez, foi fragmentada ao meio com a extensão da Avenida Mogi das Cruzes, eixo viário de leste a oeste que conecta os bairros antes fragmentados. Como resposta, a partir de 2005, a primeira parcela da área (norte) se mantém com a destinação proposta inicialmente, mas com um Plano de Ocupação e de Obras previstos ao longo dos próximos 20 anos, com o intuito de configurar o Parque Urbano, com equipamentos de esportes, cultura e lazer, tornando-se um local de encontros, atividades esportivas, eventos e lazer da cidade e região. Já a porção sul é destinada a implantação de grandes equipamentos de educação tecnológica e de ensino superior, tendo como piloto o Centro Federal de Educação Tecnológica - CEFET - Faculdade Pública do Governo Federal e o Instituto Piaget Brasil - UniPiaget, universidade de origem portuguesa, consolidando este setor num pólo de desenvolvimento tecnológico e 
científico, ampliando e qualificando a mão de obra especializada da cidade e região; ${ }^{213}$

5. Operação Urbana Orla Ferroviária: em função da importância da questão da mobilidade urbana e da dificuldade existente na utilização do transporte público no município, foi demarcado perímetro junto à ferrovia, contígua ao centro de Suzano na intenção de qualificar esse espaço. A iniciativa, denominada Operação Urbana Orla Ferroviária, prevê a assinatura de um 'Protocolo de Intenções' entre a Prefeitura Municipal de Suzano e o Governo do Estado de São Paulo para a disponibilização de recursos públicos para a modernização da estação ferroviária, a readequação do terminal de ônibus, a norte da cidade, e a criação do terminal de ônibus a sul da estação. As melhorias e a regulação do uso do solo dentro do perímetro têm o objetivo de dinamizar a economia local aproveitando a grande circulação de pessoas pela região;

Os cinco Planos e Projetos Urbanos descritos acima são tratados como elementos geradores da transformação do espaço livre, possibilitando a transferência do valor da "requalificação urbana" para os espaços construídos e a edificação privada, que tem neste momento, a "mutação" do espaço não construído como "ferramenta pública de incentivo para a reconstrução, atualização e requalificação de todo o conjunto construído existente"(VIEIRA 2010). ${ }^{214}$

Este fenômeno já experimentado em diversas intervenções e países vem demonstrando sua eficiência em transformar espaços subutilizados e/ou degradados de forma mais ágil e eficiente, tendo como ferramenta o "trinônimo" entre o poder público, a iniciativa privada e a população.

Grandes Projetos Urbanos, utilizados aqui como "objetos de análise urbana" como Barcelona, Paris e Torino, ou outras intervenções de tamanha importância e requalificação do espaço urbano, como por exemplo, Maastrich ou Almere na Holanda, Bilbao na Espanha, ou Docklands na Inglaterra, enfrentaram seus problemas urbanísticos propondo a transformação de áreas degradadas em regiões totalmente renovadas urbanística e tecnologicamente, demonstrando a necessidade da transformação contínua das cidades e a avaliação mútua de sua vocação como ferramenta de sustentabilidade econômica, social e cultural de seu povo e sua cidade.

Neste sentido, ao longo dos últimos oito anos, os Planos assim como os Grandes Projetos Urbanos em aplicação para os dois distritos (Palmeiras e Boa Vista) e para a região central de Suzano vêm ao encontro das necessidades de renovar o tecido urbano e substituir sua forma urbana, em particular seu conjunto edificado, em função da renovação e mutação de sua "nova vocação" urbana e econômica.

213. O Centro Federal de Educação Tecnológica - CEFET, inaugurado em 2009, está implantado numa área de 72 mil metros quadrados e $8.645 \mathrm{~m}^{2}$ de construção ( $1^{\underline{a}}$ e $2^{\underline{a}}$ fases), oferecendo três cursos de nível tecnológico: Operações Comerciais, Automação Industrial e Eletroeletrônica e um de nível superior: Tecnólogo em Química, com capacidade para 1.200 alunos. Numa área de 165 mil metros quadrados e previsão de conclusão de todo o campus em 30 anos. Fruto de licitação internacional para uso por 80 anos, a Universidade UniPiaget com sedes em Portugal e África, Suzano será a primeira da América Latina, com 17 cursos superiores propostos, capacidade de 15 mil alunos e 2.000 empregos diretos previstos. Além destes dois equipamentos educacionais, a política de educação se estruturou na implantação de uma sede da ETEC - Escola Técnica Estadual, já em funcionamento e a requalificação e ampliação da rede de equipamentos de educação infantil e fundamental, além das creches gerando uma rede pública que atenda a demanda da cidade e fortalecendo o ensino da cidade.

214 . Tradução do autor, 2010

Herramienta pública y el incentivo para la reconstrucción, rehabilitación y mejora de los actuales construido todo el conjunto. 
Figura 159. Planos e Grandes Projetos Urbanos previstos para a cidade de Suzano desde 2005 Fonte: DPP | SMPU | PMS, 2005

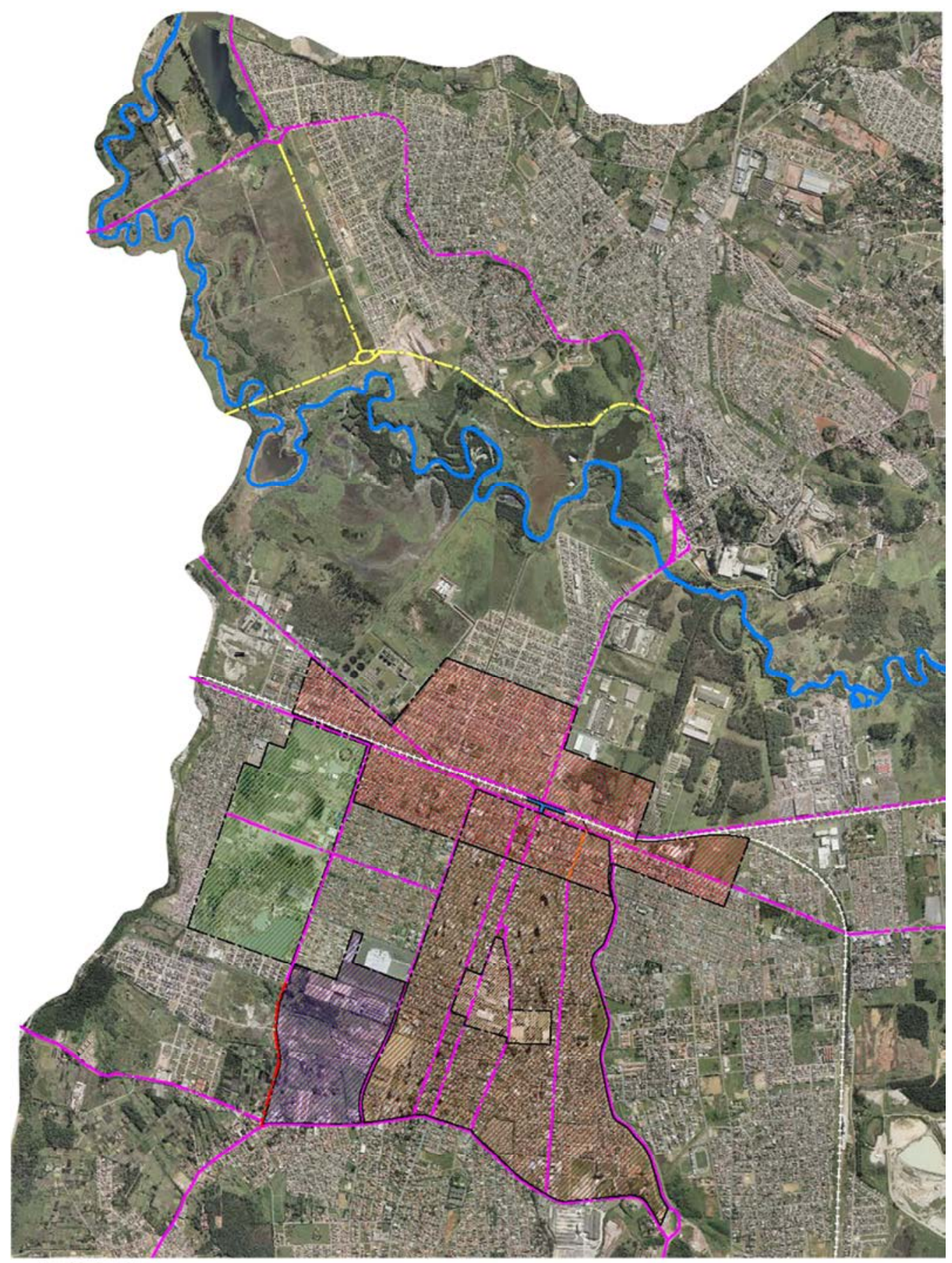

LEGENDA

11+ LINHAFÉRREA

$\sim$ RIOTIETE

-.-- PRINCIPAIS VIAS

PROPOSTA DE INTERLIGAÇÄO COM A ROD. AYRTON SENNA

---- PROLONGAMENTO DA AV. SEM. ROBERTO SIMONSEN (EM PROJETO)

PARQUE MAX FEFFER, IMPLANTAÇÃO DE UNIVERSIDADE E CEFET

Q.ZJ PLANO DE REQUALIFICAÇÃO DO CENTRO

VIJ OPERAÇÃO URBANA - ORLA FERROVIÁRIA

VIT] PLANODE EXPANSÃO URBANA

[.] SETOR ADMINISTRATIVO 
"Observamos que atualmente a cidade cumpre um papel fundamental na Região do Alto Tietê garantindo a subsistência das cidades vizinhas e atraindo um número considerável de usuários diariamente que usufruem da estrutura urbana, econômica, social e cultural de Suzano"(VIEIRA 2010). ${ }^{215}$

Os Grandes Projetos Urbanos em andamento na cidade impulsionaram a transformação da forma urbana de trechos da cidade, no qual as intervenções, sejam elas pontuais ou conjuntas, agem como "conectores urbanos" entre a cidade e a região inserida (Alto Tietê), assim como a RMSP.

Tais mudanças são visivelmente perceptíveis, apesar de sutis, as "mutações" das áreas identificadas e delimitadas dentro de cada Plano e Projeto Urbano, foram capazes de provocar um novo olhar não somente sob a ótica do poder público, mas dos empreendedores privados que se valeu da valorização de áreas a partir intervenções no espaço não construído, como apontado por Marcelo Candido, ainda no início de seu segundo mandato como prefeito da cidade:

"Suzano já vem experimentando um crescimento do ponto de vista da valorização de áreas, isso em boa parte pelas ações do poder público. A estratégia de trazer para uma área da cidade a construção de ensino superior e tecnológico é um acerto porque isso faz com que se crie um novo vetor de crescimento" (CANDIDO in PAULINO 2009).

Ainda assim, os Grandes Projetos Urbanos, como ferramenta de desenvolvimento urbano e econômico, ou ainda como instrumento gerador da transformação da forma urbana e sua tipologia, foi capaz de permitir a renovação do tecido urbano e reviver sua dinâmica econômica e social, estimulando os investimentos tanto no centro comercial, no perímetro do Plano de Requalificação do Centro (Quadrilátero Central) como nas áreas adjacentes (Plano de Expansão Urbana do Centro - Operação Urbana Consorciada Expansão do Centro).

SegundoElvis Vieira, Diretor de Projetos Públicos - SMPU - PMS, "A verticalização de Suzano tornou-se um processo natural com o decorrer dos anos", fruto dos Planos e Projetos Urbanos capaz de requalificar o tecido urbano estagnado e degradado, no qual os novos empreendimentos se adéquam aos diversos usos do centro urbano, "mantendo o comércio e a prestação de serviços com as habitações" (VIEIRA in MANGINI 2011), com isto possibilitando a transformação da cidade, a aplicação de novos projetos urbanos e a requalificação do espaço não-construído e construído, sem gerar o processo de gentrificação sobre os perímetros das intervenções urbanas e suas áreas adjacentes, possibilitando uma cidade que "tenha condições de oferecer um futuro melhor a todos" (CANDIDO 2011). 



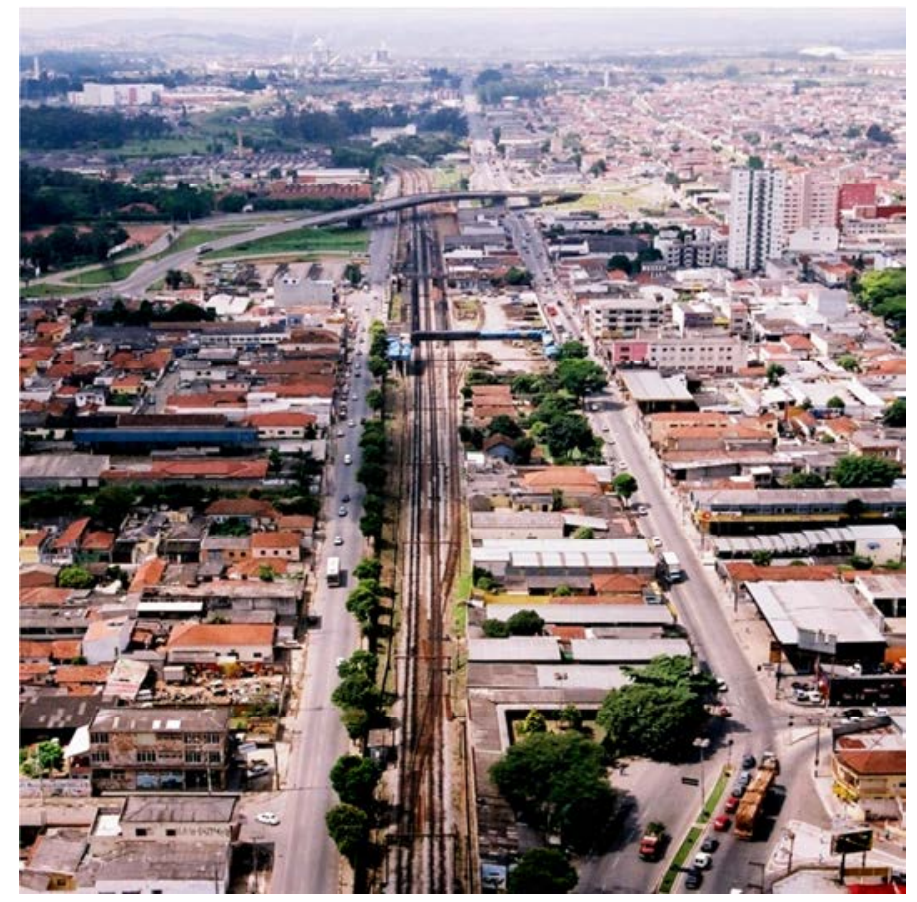

Capítulo 7

OPERAÇÃO URBANA ORLA FERROVIÁRIA: contextualização do território 



\subsection{Operação Urbana Orla Ferroviária: contextualização e estratégias urbanas}

A cidade de Suzano desde sua emancipação político-administrativa em 1949 tem se desenvolvido de forma vertiginosa atingindo status de importante articulação regional entre os demais municípios do Alto Tietê.

Ao longo dos anos, a cidade passou, e passa por diversas transformações urbanas em detrimento da "mutação" econômica gerada a partir de sua atividade econômica e/ou estratégias públicas em busca de uma cidade mais igualitária social, econômica e urbanisticamente. Desde então, a cidade passa de uma economia agrícola, a partir dos primeiros imigrantes japoneses que chegam à região, passando pela produção industrial desde a década de 70 , com importante representatividade junto à indústria química, mecânica pesada e papel e celulose e, a partir da primeira década do século XXI, com a transição de uma cidade industrial para a de serviços e educação, numa estratégia da atual gestão em busca de garantir uma cidade mais justa e com qualidade urbana, econômica e social a seus habitantes e usuários. ${ }^{216}$

Por outro lado, após a década de 1980 a cidade se desenvolveu urbanisticamente de forma descontrolada gerando bairros com pouca infraestrutura urbana e grande densidade habitacional. O centro, por sua vez, desde o início foi constituído por um desenho regular onde as quadras se desenvolviam a partir do ponto de parada da estação ferroviária. Com o passar dos anos devido à falta de políticas urbanas que garantisse o desenvolvimento deste setor da cidade e acompanhasse as atualizações tecnológicas, foi se deteriorando gradativamente, gerando espaços construídos subutilizados e desconecto do tecido urbano da malha central.

Como apontado por Carlos Leite, "a metrópole contemporânea apresenta imensas áreas desarticuladas e dispersas pelo território. São áreas dotadas de fluxos variados, em trânsito permanente, com fraturas que esgarçam o tecido urbano, estabelecendo aparente semelhança entre partes dispersas" (SOUZA 2002, p 104). No entanto, é plausível afirmar que não somente as metrópoles, mas o processo de "desarticulação e dispersão do território" não é um fenômeno apenas sofrido pelas metrópoles, mas que cidades, localizadas nas regiões metropolitanas, se beneficiaram de suas posições estratégicas para se desenvolverem, da mesma forma que sofreram com o processo de degradação de seu tecido e a desativação das áreas industriais junto ao eixo ferroviário.

Suzano, por sua vez, não é exceção deste processo, as primeiras indústrias da cidade foram ao longo dos anos migrando para os eixos rodoviários, neste caso a Rodovia Índio Tibiriçá (SP-31), por onde se deu um segundo processo de industrialização a partir da década de 1970. Consequentemente ao esvaziamento deste setor econômico, as então vilas industriais próximas ao centro urbano se desarticularam destes usos resultando ora na descaracterização de seu uso original ora na substituição por novas edificações, em sua maioria comercial ou serviço.

A região junto ao eixo ferroviário foi aos poucos, num curto período de tempo, produzindo espaços residuais e vazios urbanos gerando o desgaste de seus espaços não construídos e consequentemente os construídos. O primeiro, fruto da falta de manutenção e ingerência por parte do poder público municipal, enquanto que o segundo resulta da deterioração do conjunto edilício privado, que sem qualquer incentivo ou projeto urbano, assistiu à desvalorização imobiliária em um dos solos urbanos mais valorizados na cidade.

216. As últimas duas administrações tem por estratégia a implantação de um pólo educacional com escolas técnicas (ETEC), faculdades (FATEC e IFET) e universidades (UNIPiaget Brasil, UNISUZ, UNIP) como proposta de uma nova vocação para a cidade e possibilidade de ampliação de seu parque de serviços relacionados aos novos equipamentos educacionais. 
Figura 160. Vista da Área de Intervenção da Operação Urbana Orla Ferroviária. Em 2005 esta região da cidade se encontrava com seu conjunto edilício degradado, diversos vazios urbanos e áreas subutilizadas como o pátio de manobras e depósito de dormentes da CPTM e o terreno do "Terminal de Ônibus", área totalmente degradada urbana e fisicamente

Foto: Issamu Watanabe, 2005

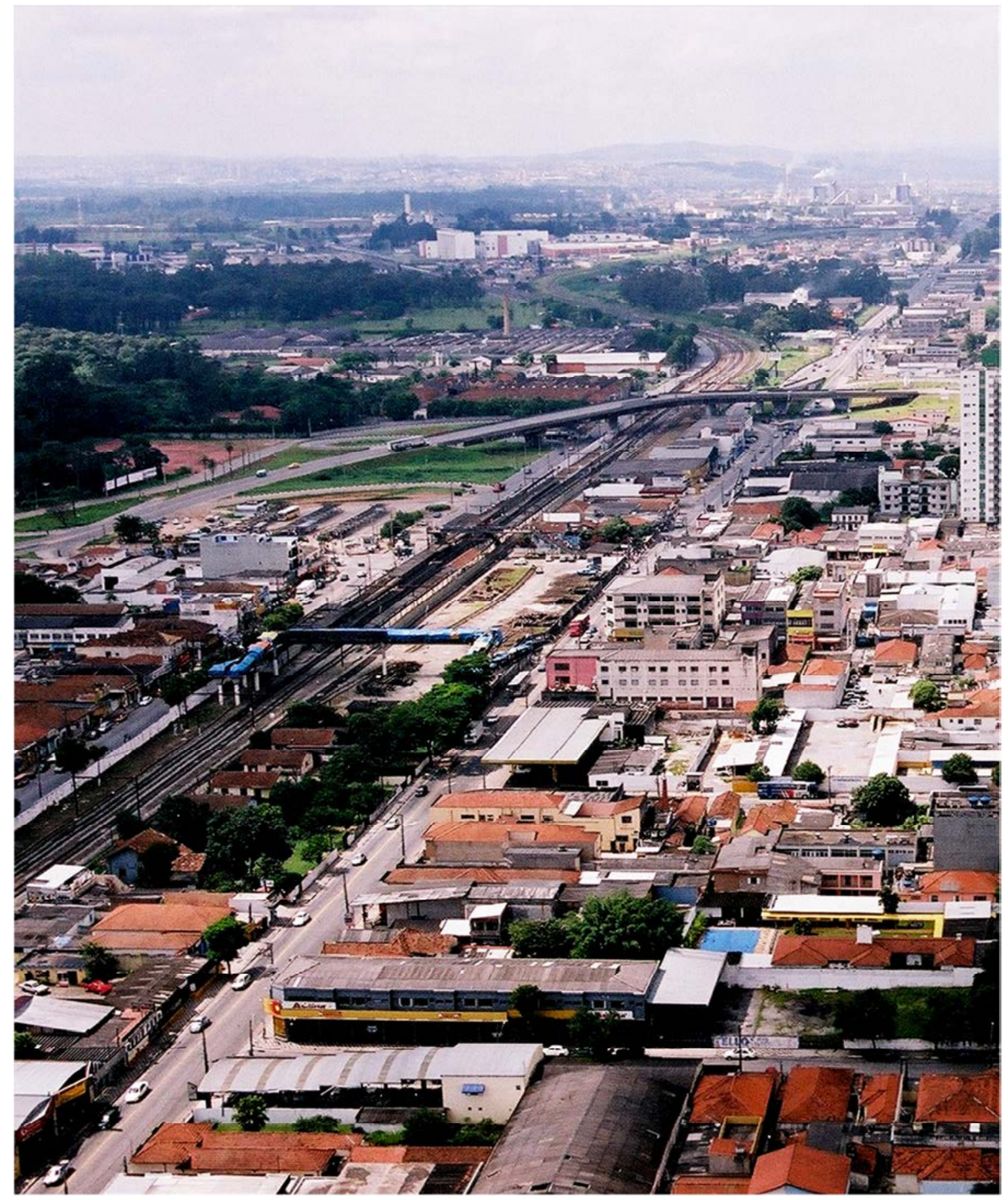


Por outro lado, estas áreas residuais podem ser consideradas como "peças urbanas" capaz de reconstruir, regenerar, renovar, regenerar e reabilitar estes espaços como novos territórios, nova vida coletiva, novos usos, uma "nova esperança de algo novo, indeterminado e promissor" (SOUZA 2002, p 113). Segundo Solà-Morales, estes espaços residuais podem se tornar privilegiados:

"as áreas de 'terrain vague' são para alguns os sítios privilegiados de identidade, de encontro entre presente e passado, ao mesmo tempo em que se oferecem como o último reduto não contaminado para o exercício da liberdade individual de pequenos grupos"(I. R. SOLÀ-MORALES 1995, p 23, grifo nosso).

A potencialidade com que estes vazios urbanos possuem para contribuir à construção de um novo território, ampliando a vida coletiva e consolidando novos usos, coloca a área hoje degradada sob uma nova condição urbana: as áreas de "terrain vague" e o tecido urbano degradado tornam-se ferramentas de transformação urbana como processo de regeneração à construção de uma nova centralidade urbana para a cidade.

Evidentemente este fato e/ou estratégia urbana não é considerada recente, tão pouco a única forma de regeneração do tecido urbano degradado. No entanto, estes vazios urbanos têm sido objeto de estudo e de intervenção urbana utilizada por diversas cidades e urbanistas, podendo aqui citar um conjunto de grandes projetos urbanos com resultados positivos, ou não necessariamente, mas que tinham como objetivo central a transformação de sua forma urbana em busca de uma nova dinâmica urbana de determinado setor da cidade e sua requalificação ou reabilitação urbana.

"Estes fenômenos foram mais presentes em cidades européias, e justiça-se devido ao grande número de ataques sofridos durante a II Guerra Mundial e a destruição do tecido urbano já consolidado"(VIEIRA 2012, p 692). Da mesma forma, áreas vazias produzidas a partir da desativação de parques industriais ou a desarticulação do sistema ferroviário, tornaram-se espaços de oportunidades e verdadeiros "laboratórios urbanos" para arquitetos e urbanistas colocarem em prática suas teses e teorias sobre o Urbanismo Contemporâneo, no qual podemos aqui citar um conjunto infinito de estudiosos que se dedicaram a propor suas teorias sobre estes trechos das cidades passíveis de transformação: Bernardo Secchi, Stefano Boeri e Vittorio Gregotti na Itália, Rem Koolhaas e MVRDV na Holanda, José Lamas em Portugal, Oriol Bohigas, Manuel de Solà-Morales e Josep Maria Montaner na Espanha, Philippe Panerai e Chistian de Portzamparc na França, entre outros que procuraram "lançar um olhar prospectivo, analítico, descritivo para a questão"(SOUZA 2002, p 113).

No caso da Operação Urbana Orla Ferroviária em Suzano, o processo de deterioração do conjunto edilício e a desativação do pátio de manobras e depósito de dormentes junto ao eixo ferroviário contribuíram para a desarticulação do tecido urbano e sua dinâmica socioeconômica, gerando espaços subutilizados, degradados e desconectados do território central da cidade, que ao longo dos anos 80 e 90 se consolidou como Centro Comercial de importante relevância para as cidades da Região do Alto Tietê.

De modo geral, sua importância econômica e geográfica entra em contradição com sua condição urbana e lógica na dinâmica do território onde se encontra. Segundo Carlos Leite: "a cidade sempre foi desenhada e construída ao longo dos tempos como expressão das inflexões socioeconômicas da lógica histórica da cidade. Não há desenho urbano aleatório, sem desprendimento histórico" (2002 p 118). 


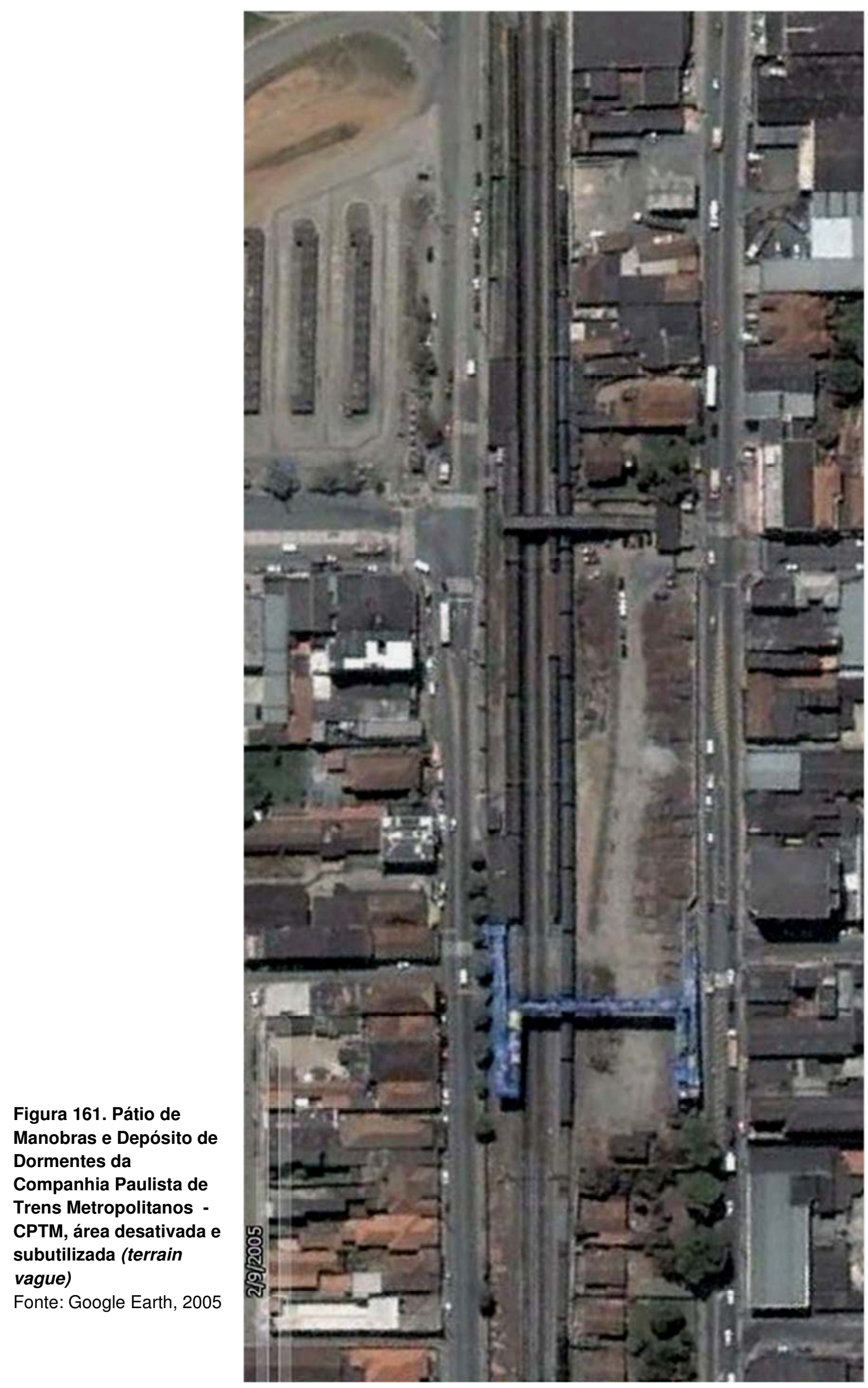


Sem dúvida, o centro comercial da cidade foi se moldando para atender ao público da região, explorando sua condição geográfica e fácil acessibilidade entre as cidades vizinhas. Por outro lado, as quadras junto à orla ferroviária se deterioram gradativamente com a substituição do comércio por prestação de serviços de baixa qualidade, quando não o abandono de seu conjunto edilício em função da migração para novos territórios eixos rodoviários) ou a degradação do espaço público.

Estes fatores levaram a repensar estes espaços subutilizados como um "território de oportunidades" numa das áreas mais beneficiadas com infraestrutura urbana em uma das regiões mais valorizadas imobiliariamente. No ano de 2005, foram iniciados estudos pela Prefeitura Municipal de Suzano para uma Operação Urbana Consorciada nos espaços envoltórios da ferrovia em sua passagem pelo centro da cidade, estudos esses que foram incorporados às propostas de um conjunto de ações e projetos urbanos já explicitados anteriormente.

A proposta de reabilitação deste trecho da cidade deveria ter por finalidade a melhoria das condições de utilização pela população do transporte público por meio da intervenção urbana na área e no entorno, buscando também o "fortalecimento das atividades de comércio e serviços, a preservação da paisagem e das edificações com valor histórico na área"( PMS, 2005). ${ }^{217}$

A substituição e/ou a construção de grandes equipamentos de transporte público de caráter local, regional e metropolitano, deveriam agir como "conectores urbanos" entre os dois lados fragmentados pela ferrovia, assim como entre a cidade e a Região do Alto Tietê, além da Região Metropolitana de São Paulo. Da mesma forma que estes equipamentos de mobilidade cumpririam a função de melhorar significativamente sua oferta de atendimento, deveriam também impulsionar a transformação dos terrenos vagos e a substituição dos usos e construções subutilizadas, gerando uma nova sinergia econômica neste trecho da cidade.

Por outro lado, é notória as dificuldades enfrentadas pelas cidades contemporâneas, em particular cidades de médio e pequeno porte, para garantir sua "sustentabilidade urbana" e articulações entre os desejos do poder público em transformar parte do tecido urbano degradado ou desatualizado tecnologicamente com as "vontades" da iniciativa privada e empreendedores imobiliários. Esta equação nem sempre resultam em espaços qualificados e que atendam a todos sem distinção, gerando um processo de gentrificação (às vezes de forma gratuita) nestes trechos que são requalificados ou regenerados. Como identificado em sua tese, Eduardo Nobre aponta os resultados dos projetos urbanos implantados em várias cidades: "esse processo de elitização, conhecido pelo termo inglês gentrification, ocorreu com frequência em várias cidades do mundo, cujos melhores exemplos são os bairros do Soho em Nova lorque, Marais em Paris e nas Docklands de Londres"(2000 p 123 - grifo nosso).

A implantação dos Grandes Projetos Urbanos nas cidades contemporâneas vem sendo cada vez mais um tema rotineiro para as administrações públicas que necessitam colocar suas cidades no circuito das "Cidades Globais" (SASSEN 2005)de forma a se tornarem atrativas aos enormes investimentos privados sobre estes territórios degradados.

217. Na ocasião foi firmado um 'Protocolo de Intenções' entre a Prefeitura Municipal de Suzano e o Governo do Estado de São Paulo prevendo a disponibilização de recursos públicos para a modernização da estação ferroviária, a readequação do terminal de ônibus Vereador Diniz José dos Santos Faria e a criação do terminal de ônibus a sul da estação. 
Figura 162. Vista aérea de Bilbao Plano Bilbao Ría

\section{0}

Fonte: Bilbao Ría, 2009

Figura 163. Vista do novo bairro 22@BCN

Fonte:22@BCN, 2009
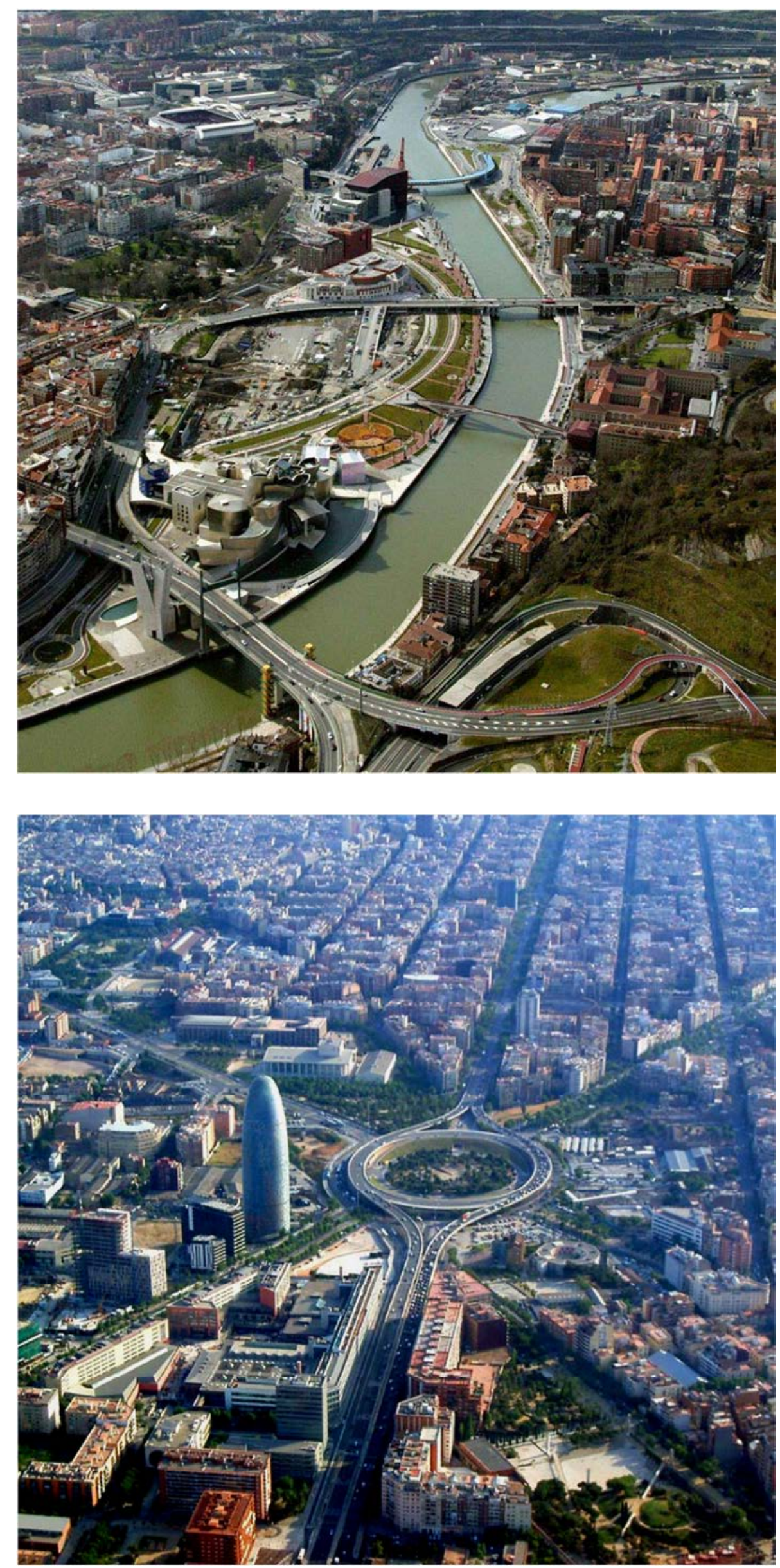
No caso dos projetos urbanos para Suzano, como já descritos no capitulo anterior, sua aplicabilidade estão condicionadas à requalificação e reabilitação de trechos da cidade e da malha urbana degradados, em especial as áreas do centro comercial e junto ao eixo ferroviário (Plano de Requalificação do Centro e Operação Urbana Orla Ferroviária). No entanto, é perceptível ao analisarmos os projetos referência desta tese, a necessidade de compartilhar as propostas entre os "desejos" do poder público com as "vontades" da iniciativa privada. Não defendemos aqui que o poder púbico renda-se à forma com que os investidores imobiliários pensam e "constroem" a cidade, tão pouco favoreça determinados grupos da iniciativa privada como solução aos problemas urbanos enfrentados na cidade contemporânea. Entendemos que os Grandes Projetos Urbanos devem apresentar soluções para os problemas urbanos que atendam a todos os agentes (habitantes, usuários, investidores) de forma equilibrada sob um objetivo claro e direto - requalificar e reabilitar o tecido urbano de determinado trecho da cidade.

Experiências colocadas em prática a partir da década de 1980, inicialmente nas cidades europeias e recentemente nos países emergentes asiáticos e americanos, comprovaram que as intervenções coordenadas pelo poder público de forma integral, e que se comprometem em "gerenciar" tantos os espaços não construídos (vias, áreas livres, parques, praças etc) como os construídos (massa edilícia) tendem a dar respostas ao tecido urbano degradado de forma mais "passível e sustentável".

Por outro lado, percebemos que a maioria dos projetos colocados em prática, em particular nas cidades europeias, teve como estratégia urbana, a implantação de um "ícone arquitetônico", em sua maioria assinado por algum "escritório de arquitetura de grife", como ferramenta de atração aos investimentos financeiros no perímetro da intervenção urbana.

Teoricamente esta "aposta" teria como objetivo potencializar o local, ou a cidade, atraindo as atenções para determinado projeto urbano, mas tendo como referência um "elemento isolado" no contexto da requalificação. Biblioteca Nacional da França em Paris - arquiteto Dominique Perrault, Torre Agbar em Barcelona - arquiteto Jean Nouvel, Museu Guggenheim em Bilbao - arquiteto Frank Gehry, ou Grand Palais, ou Congrexpo em Lille - arquiteto Rem Koolhaas, podem ser tomados como exemplos e importantes objetos de análise sobre os resultados alcançados após sua conclusão. Contudo, esta estratégia nem sempre levou a resultados satisfatórios, produzindo uma diversidade de fenômenos sobre os cenários urbanos como no caso de Barcelona e Bilbao, ou em alguns casos o de gentrificação, gerando espaços isolados de toda a dinâmica econômica e social da cidade.

É certo que os Grandes Projetos Urbanos devem ser tomados como "'laboratórios urbanos' para pesquisadores da forma urbana"(VIEIRA 2012, p 693). Desta forma, as propostas para Suzano deveriam tê-los como ferramenta de medição e averiguação que possibilitasse o monitoramento de sua aplicabilidade em conjunto com as transformações urbanas dos espaços construídos e os não construídos - públicos ou privados. Por outro lado, utilizar-se das estratégias de atrair grandes investidores, ou apostar em um grande projeto arquitetônico (arquiteto de renome internacional) não se enquadrariam aos recursos financeiros da cidade, porém a possibilidade de disponibilizar um estoque de áreas privadas, localizadas em um setor da cidade requalificado urbanisticamente, foi colocada como o "elemento de atração" para esta Operação Urbana. 


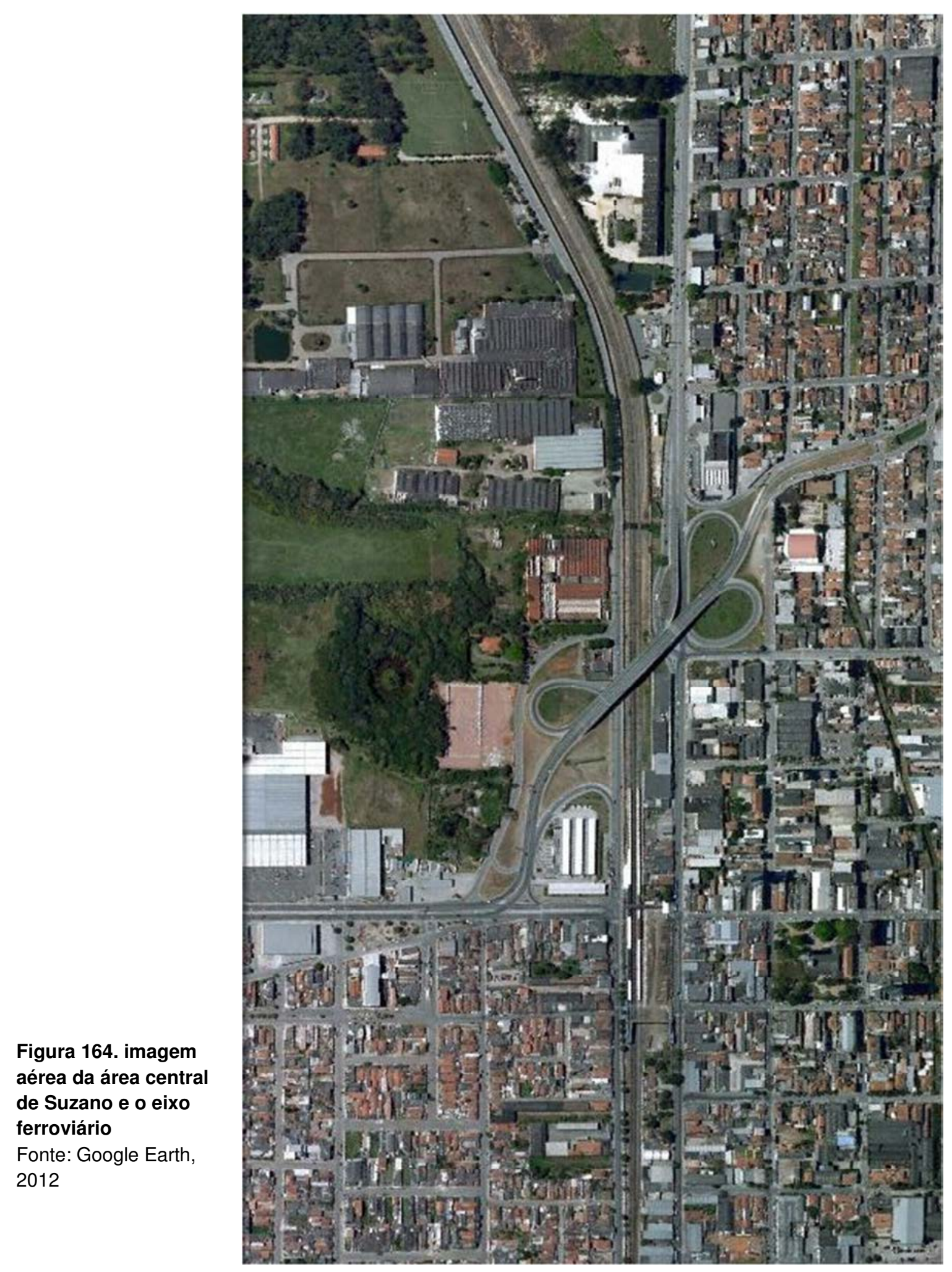




\subsection{Limites e Fronteiras: definições das Bordas Urbanas}

A ocupação urbana das cidades metropolitana paulista desenvolveu-se em função do eixo ferroviário que com sua implantação impulsionava o deslocamento ou surgimento de assentamentos em seu entorno próximo com atividades econômicas ligadas diretamente a este eixo de transporte, inicialmente de cargas e mais tarde de passageiros.

Estas ferrovias abertas pelo Estado, com apoio de investidores privados, foram capazes de não somente incorporar o maquinismo moderno, como defendido por Carlos Leite (2002), como organizar o território em seu traçado com grande atrativo para as indústrias. Neste sentido, podemos afirmar que a ferrovia serviu de instrumento de organização do espaço urbano provocando a valorização da terra, antes desprezadas por conta de sua condição topográfica (charcos e várzeas), e a definição de novas rotas diferentes das então consolidadas pelos "caminhos de tropeiros".

Contudo, a ferrovia também foi o "estimulante urbano" de um crescimento urbano desordenado provocado pela ansiedade de se estabelecer nas proximidades desta linha. No caso de Suzano, o deslocamento do núcleo existente a sul para um traçado de poucas quadras regulares nas várzeas do rio Tietê, mas conectadas diretamente à linha férrea, provocou um processo de atração a estas terras em busca de oportunidades (comércio e prestação de serviços para a ferrovia) e fixação (residências) junto ao eixo de transporte - por mais que num primeiro momento a ferrovia servisse apenas para cargas. Este mesmo progresso, que nos anos 50 e 60 atraiu um conjunto de indústrias e "subúrbios-estação" vai ser responsável pelo declínio urbanístico deste que foi o "elemento norteador" do surgimento e consolidação do que hoje entendemos como centro urbano.

Tal como notado por Michael Batty (in GAUSA 2010, p 182): "as cidades, como qualquer processo dinâmico, crescem definidas principalmente por estruturas sobrepostas $e$ processos com base em decisões locais ("de proximidade individual") que teria um impacto no seu desenvolvimento próprio e sua própria "(infra) estrutura" global, modificando seu desenvolvimento mútuo". 218

No tocante as infraestruturas urbanas da cidade, a chegada do eixo ferroviário foi o "fio condutor" para o surgimento e chegada de outras modalidades confirmando a importância daquele território como nova centralidade urbana. Assim, a ferrovia e os rios (Tietê e Guaió), foram elementos estruturadores da paisagem da cidade, impulsionando o crescimento da cidade muito além dos limites do Plano Urbano proposto no final do século XIX.

Passados mais de um século do primeiro traçado da então cidade de Suzano, observase o esvaziamento industrial e a degradação do tecido urbano e seu conjunto edilício, gerando espaços livres e construídos, em espaços obsoletos e de baixa qualidade urbana e arquitetônica. O eixo ferroviário, agora subutilizado pela modernização do sistema tecnológico, gerou ao longo dos últimos 30 anos o efeito de "terrain vague" (I. R. SOLÀ-MORALES 1995), ampliando ainda mais as "fraturas urbanas" ${ }^{219}$ entre os tecidos urbanos (norte e sul) do centro da cidade.

218 . Tradução do autor, 2012.

las ciudades, como cualquier proceso dinámico, crecerían definidas, principalmente, por estructuras y procesos superpuestos basados en decisiones locales ("de proximidad individual") que incidirían sobre su proprio desarrollo y sobre su propia"(infra) estructura" global, modificando su mutuo desarrollo.

219. O termo "fratura urbana" é utilizado por Carlos Leite em sua tese de doutorado, apresentado como fragmentação, retalhamento, desarticulação, terrenos vagos, fluidez e redes de fluxos. 
Figura 165. Mapa de Suzano com suas estruturas urbanas de ferrovias de transporte de passageiros (leste-oeste) e cargas (norte-sul) e os principais rios da cidade como Tietê (norte), Guaió (oeste) e Taiaçupeba (leste), assim como sua represa

Organização: Elvis Vieira, 2012

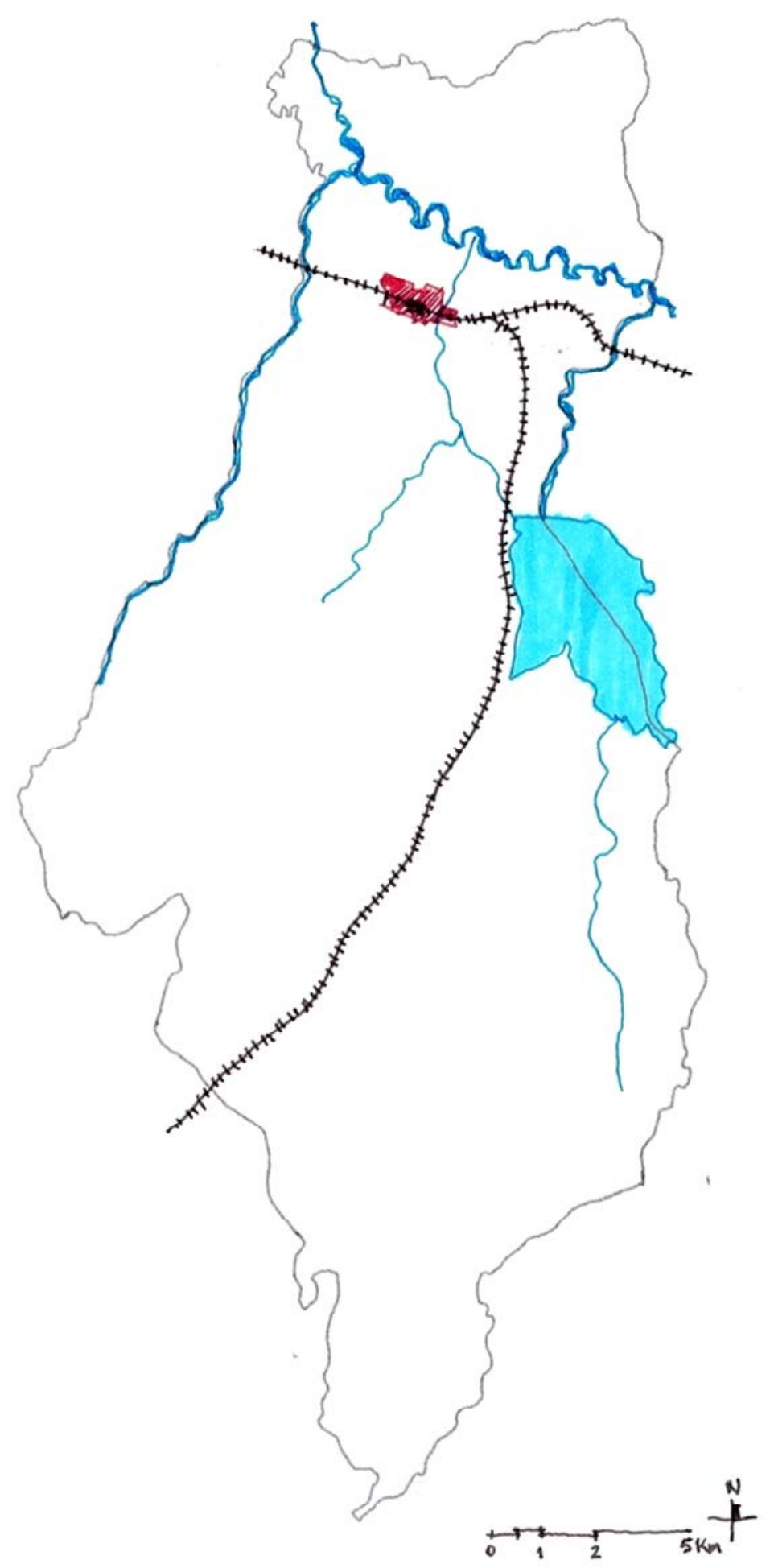


No entanto, o enfrentamento aos problemas urbanos gerados deve, a princípio, ser de competência e responsabilidade do poder público, incorporando ao discurso urbano suas divergências e soluções a necessária retomada as possíveis potencialidades com que a área de intervenção se coloca, "fazer-se presente e assumir determinados rumos que o território deve tomar, visando os interesses da coletividade, particularmente na construção de espaços públicos"(SOUZA 2002, p 170).

Da mesma forma, a delimitação de seu perímetro de ação deve levar em consideração tanto suas condicionantes físicas que se apresentam sobre o território, como os agentes urbanos e elementos arquitetônicos que possam contribuir para a requalificação do espaço. Estas decisões, e definições, devem ainda estar sobre o "olhar" do poder público, no qual deverá agir como "gerente do solo urbano" possibilitando a integração das atividades econômicas e seus usos que garantam a dinâmica do solo e eventos (econômicos, sociais) que venham a consolidar-se.

Entendemos que não se trata de tarefa fácil a definição de um perímetro ou área de intervenção que venha a responder aos problemas com que o tecido urbano se encontra, no qual estes espaços degradados ou obsoletos, normalmente com fluxos variados, em trânsito permanente, reforçam o conceito de "arquipélagos", esgarçando o tecido e estabelecendo a dispersão entre as duas partes da cidade, já reforçada pela linha férrea que se estabeleceu inicialmente.

Com isto, a cidade, neste caso o território em questão, "perde seus limites, eixos, simetria: a arquitetura perde seus símbolos, seus monumentos" (LEITE 2012, p 51).

Mas enfim, como definir os limites de uma intervenção? Como delimitar as fronteiras a serem discutidas em uma requalificação urbana desta envergadura? Como tratar as bordas urbanas e a possível fragmentação entre o território desejado (novo) e o que permanecerá (extra-área de intervenção)?

Todas estas questões colocam em pauta os limites de atuação do poder público e sua capacidade de ação e controle sobre o território degradado.

Ao analisarmos os projetos apresentados pela Prefeitura Municipal de Suzano, percebemos que o método utilizado para sua delimitação centra-se num conjunto de quadras e ambientes envoltórios à atual estação ferroviária. Conforme indicam os levantamentos, a área de atuação da Operação Urbana Orla Ferroviária perfaz aproximadamente 210 hectares, deste território, boa parcela esta delimitada a norte do eixo central, junto a espaços industriais obsoletos e o bairro Parque Maria Helena - de ocupação essencialmente residencial de baixo valor arquitetônico e urbanístico.

É possível compreender que a definição de seus limites está diretamente relacionada a determinados aspectos e situações com que se encontrava (2005) a área em discussão:

1. A área onde se encontra a estação ferroviária foi ao longo dos anos perdendo sua função de depósito de lenhas e dormentes (mais recentemente), tornando este espaço obsoleto e num grande vazio urbano (terrain vague) ampliando ainda mais a sensação de ruptura do tecido urbano. Quanto às construções existentes neste espaço, salvo algumas casas construídas para abrigar os antigos funcionários da Companhia Central do Brasil, hoje CPTM, entre elas a "Casa do Engenheiro" - construída junto à estação para moradia do engenheirochefe Joaquim Augusto Suzano Brandão, são compostas por construções sem qualquer valor arquitetônico; 


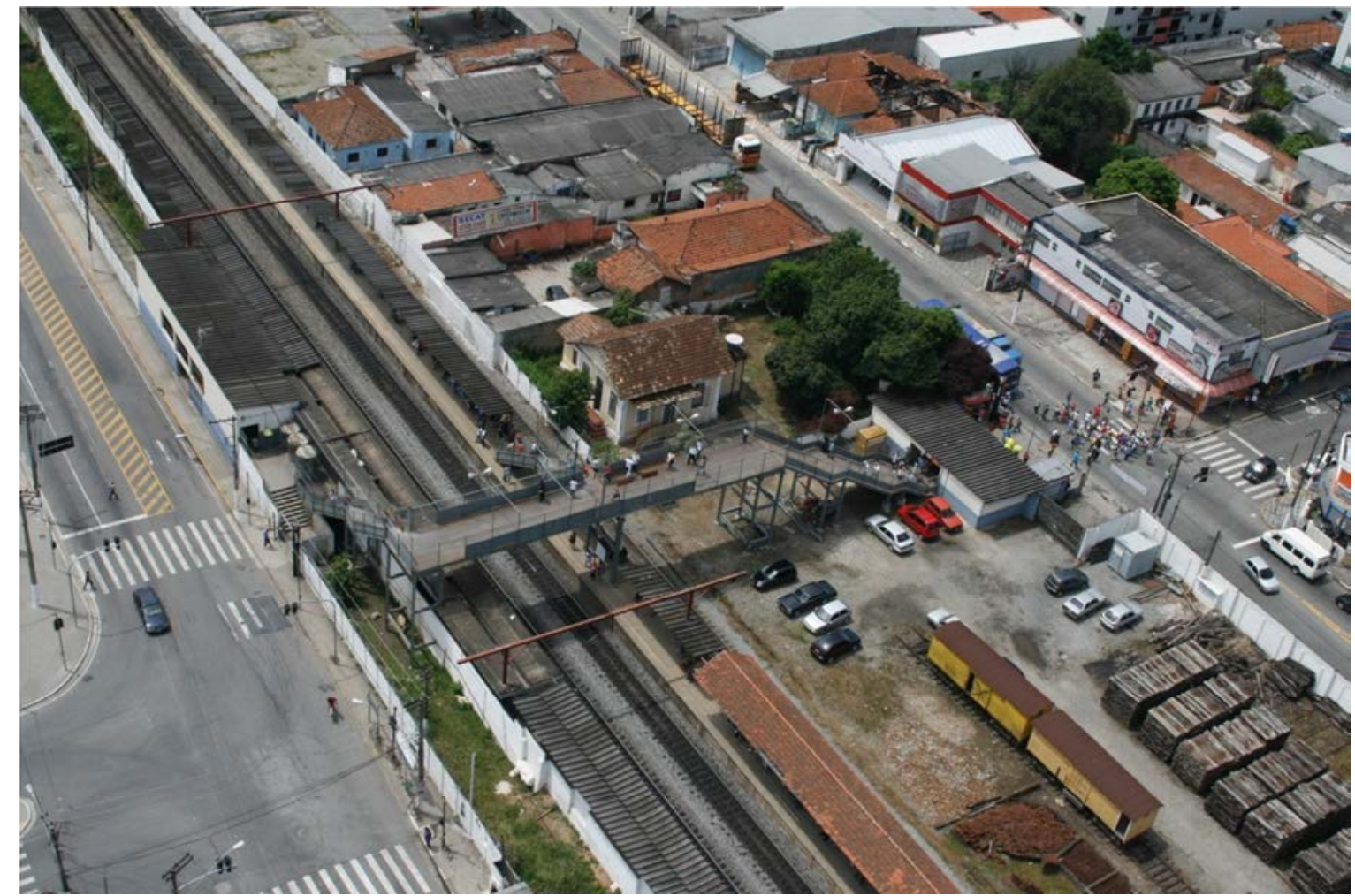

Figura 166. Casa do Engenheiro Joaquim Augusto Suzano Brandão, atualmente demolida para dar lugar a nova estação ferroviária

Foto: Wanderley Costa, 2006

Figura 167.Perímetro das intervenções urbanas da Operação Urbana Orla Ferroviária de Suzano Fonte: DPP | SMPU | PMS, 2005

Organização: Elvis Vieira, 2009

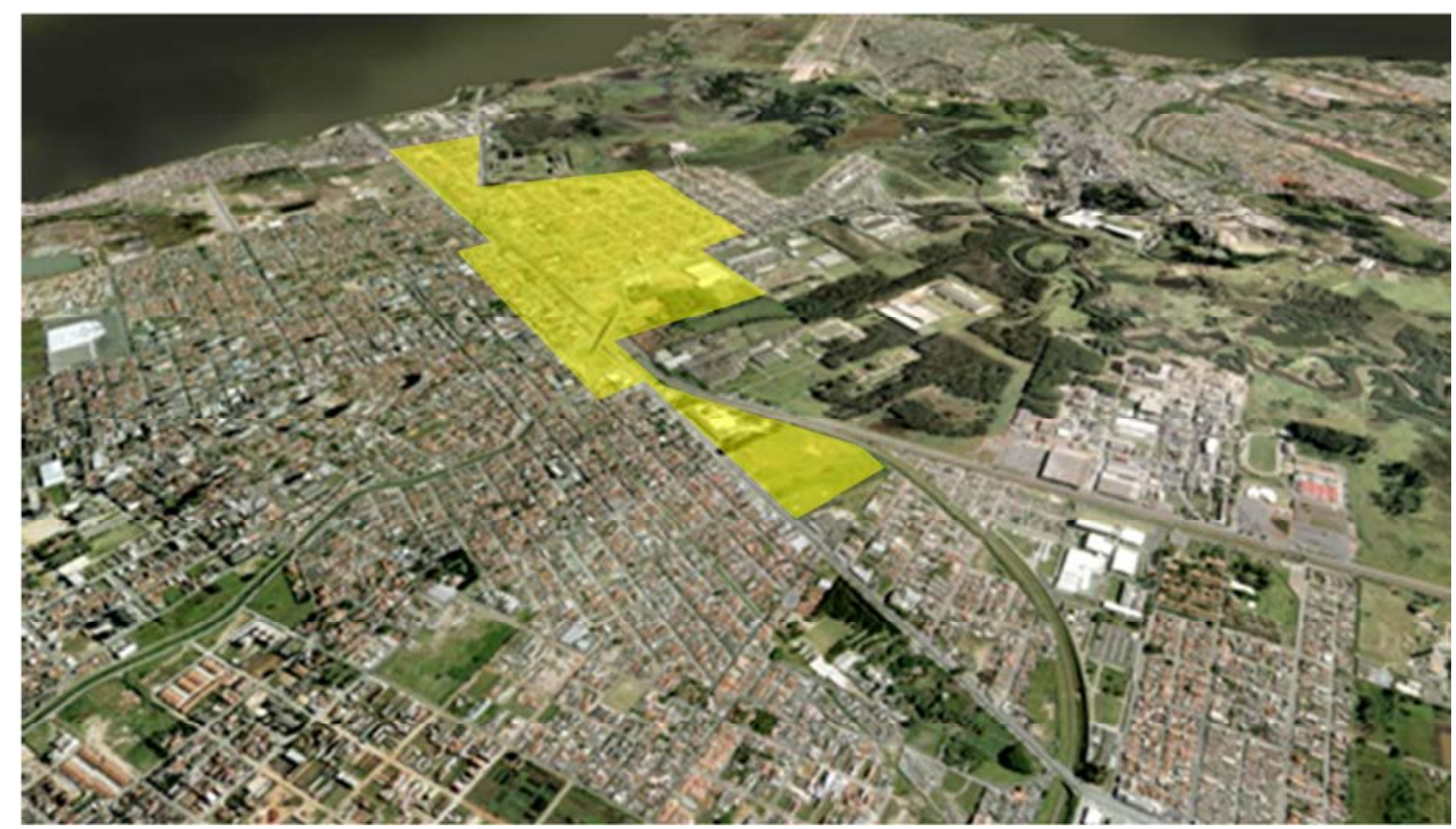


2. As quadras a sul da estação, em direção ao centro comercial da cidade, tiveram sua primeira ocupação na década de 1950 (vide Figura 138, p 254) onde ainda é possível identificar alguns exemplares daquela época, como pequenas construções comerciais ou residências unifamiliares construídas para abrigar as primeiras famílias que por ali chegaram. No entanto, grande parcela das construções foi substituída para atender as demandas com que este território se consolidava ano a ano - edifício composto por comércio no pavimento térreo e habitação em seu primeiro piso;

3. O bairro a norte da estação, apesar de sua ocupação a mais de meio século, pouco alterou sua característica habitacional composta por pequenas casas térreas unifamiliares, ao longo dos anos, as vilas industriais (vila estação) foram substituídas por edificações de uso comercial de médio e grande escala, principalmente na década de 90 , período de grande desvalorização imobiliária deste trecho da cidade;

4. As unidades industriais, e em particular a Tinturaria Romanato (vide Figura 141, p.264), primeira indústria de Suzano, estão desativadas a mais de 30 anos, ocupando um solo de grande valor imobiliário e potencial construtivo junto ao eixo ferroviário;

5. Os poucos equipamentos públicos existentes neste território, e essencialmente os de transporte urbano, encontram-se totalmente degradados e sem qualquer condição de atender ao número de usuários, culminando num problema generalizado sob os sistemas de transportes urbanos (local regional e metropolitano);

6. Os espaços livres encontravam-se degradados e com pouca atratividade paisagística, além da baixíssima relação de áreas verdes, ou áreas livres, ao número de habitantes e usuários deste território.

As condições urbanas com que se encontrava este trecho - a "Porta de Entrada da Cidade" faziam com que este território se tornasse objeto de discussão sob a ótica da requalificação urbana e o redesenho de sua forma urbana a partir dos espaços não construídos e seus equipamentos de transporte. Concomitante a este fato, os proprietários deste solo privado compreendiam a importância da "reconstrução" de todo o estoque construído. Apesar de deteriorado, seu valor imobiliário permanecia de grande montante devido a oferta de infraestrutura urbana e localização privilegiada, mas por outro lado, não eram estimulados a investir seus capitais sobre um território considerado "obsoleto". A resposta estava justamente na iniciativa do poder público em provocar a transformação da forma urbana e a elaboração de estratégias urbanas capaz de atrair novos investimentos para este setor da cidade. 
Figura 168. Vista aérea do centro comercial de Suzano. Observa-se que a única área livre verde ainda presente é a Praça João Pessoa, prevista desde 1890 pelo eng. Romariz

Foto: Wanderley Costa, 2006

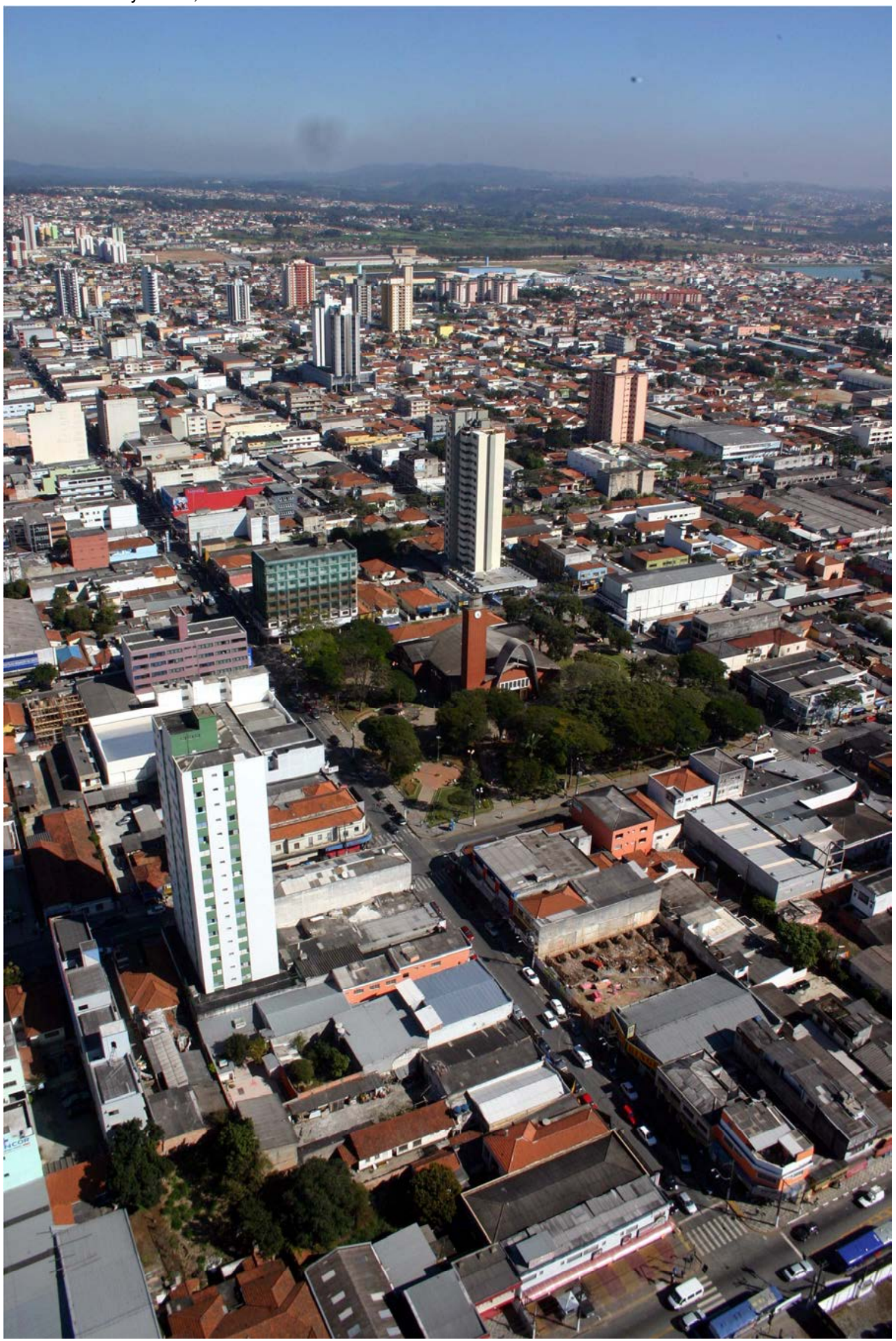




\subsection{A dinâmica do Solo Urbano}

O território da Operação Urbana por sua escala produziu acentuadas diferenciações nas formas de uso e ocupação do solo entre as duas partes da cidade dividida pela linha férrea. Isto se deu por diversos motivos que levaram esta região da cidade a comportarse como "Porta de Entrada da Cidade" e a atender as demandas dos que por ali chegavam ou passavam diariamente.

Invariavelmente os centros urbanos organizam seus espaços em função das necessidades de atendimento (social ou econômico), ou vocação em relação a sua localização geográfica ou oportunidades de transformação econômica.

Ao analisarmos os elementos que constroem a forma urbana da área de intervenção, tendo como método os "Eixos de Investigação da Forma Urbana", 220 testando e possibilitando a "leitura da cidade" e buscando compreender o "comportamento urbano" a partir da desfragmentação dos diversos elementos que a compõem, percebemos que o eixo ferroviário foi, e ainda é, a "linha divisória" não somente física, mas também da organização do espaço e seus usos relacionados ao entorno e usuários.

Podemos identificar a predominância residencial a norte da linha férrea, sendo ocupada por população de baixa renda e apresentando unidades habitacionais $e$ estabelecimentos comerciais e de prestação de serviços de gabarito baixo, entre 1 e 2 pavimentos. Esta característica de uso se mantém desde sua primeira ocupação no início do século $X X$, pois exerciam desde então uma prestação de serviços de âmbito local, voltado às necessidades cotidianas.

Por sua vez, a configuração do tecido urbano pouco se alterou desde a consolidação dos loteamentos (Parque Maria Helena, Vila Helena e Vila Maluf), mantendo a forma e dimensão das quadras traçadas a partir das chácaras ali existentes, assim como seu parcelamento, no qual percebemos mudanças muito singelas durante os últimos 50 anos, resultando consequentemente, num "congelamento" de seu conjunto edilício com pouco valor arquitetônico.

Ao sul a predominância do uso comercial e de prestação de serviços foi induzida inicialmente pela implantação do eixo ferroviário atraindo as primeiras famílias a se instalarem nesta proximidade e a prestação de serviços relacionados com esta modalidade de transportes, como lenha e carvão, além do comércio de primeira necessidade posteriormente com a alteração da modalidade de transporte de cargas para passageiros, induzindo diretamente a chegada de mais famílias para este território e a construção de edifícios comerciais e residenciais, inclusive em alguns casos, a construção de edifícios mistos com comércio no térreo e a moradia no piso superior.

Outro fator de transformação deste território se deu com a implantação do eixo rodoviário entre a capital e Mogi das Cruzes, passando junto à linha férrea e potencializando ainda mais esta região para a consolidação de um conjunto edilício de usos comerciais e de prestação de serviços, reforçando cada vez mais sua vocação de comércio de âmbito regional.

"O comércio é constituído em sua maioria por lojas de roupas de pequeno e médio porte, além dos estabelecimentos voltados à venda de materiais de construção, autopeças, postos de gasolina e outros"(PMS e FAUUBC 2006).

220 . Este método foi apresentado e estudado exaustivamente no capitulo 1: Morfologia Urbana como método de análise da cidade contemporânea. 
Figura 169. Morfologia Urbana de Suzano onde a primeira ocupação (final do século XIX) manteve-se intacta com suas quadras regulares (1 hectare). Com o passar dos anos, sua expansão se deu sem qualquer planejamento onde os bairros eram implantados sem a mesma lógica da malha regular em xadrez, resultando em uma grande diversidade de formas geometricas e dimensões

Organização: Elvis Vieira, 2012

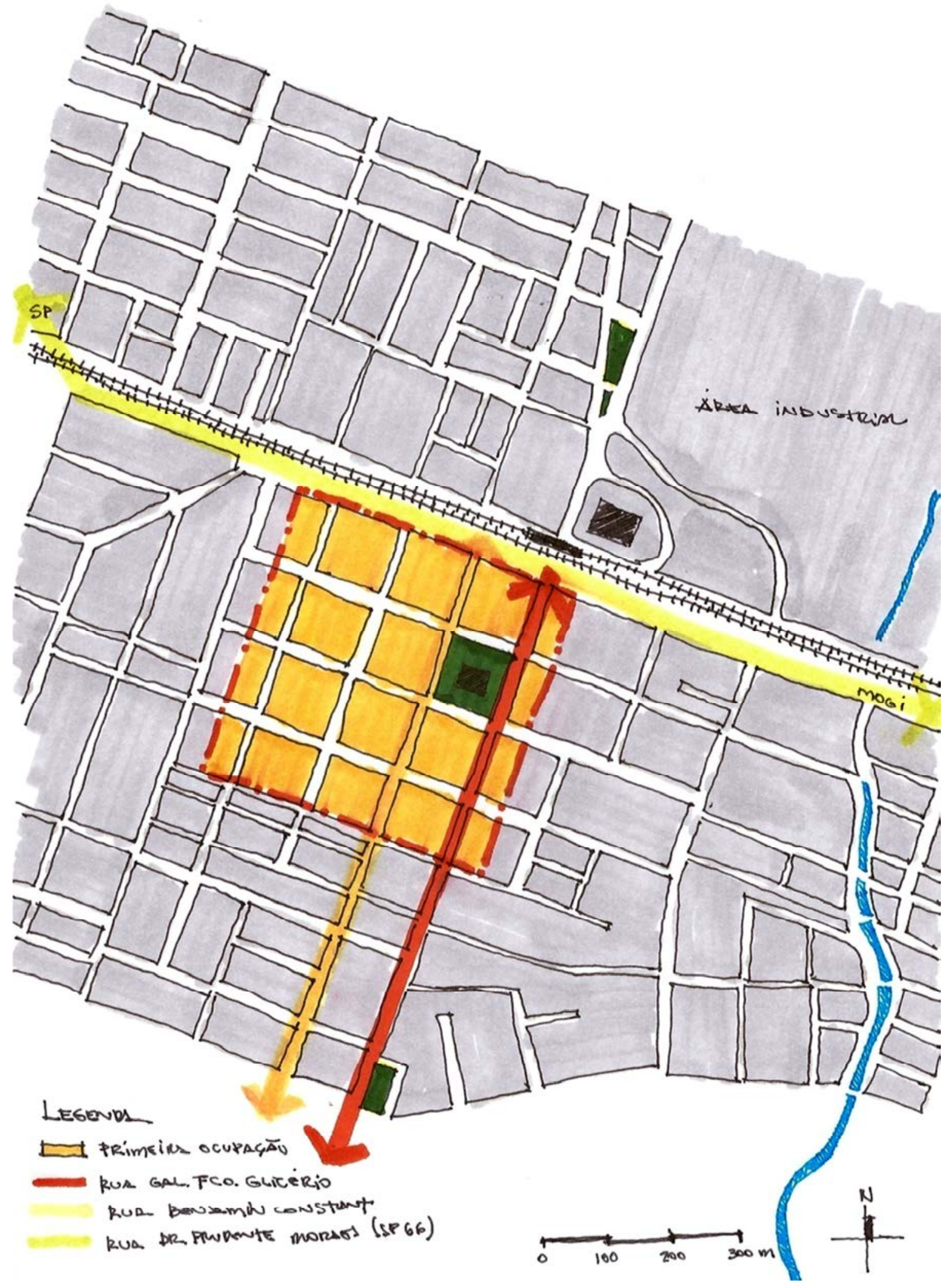


Apesar da constante mutação do cenário urbano neste setor do centro urbano da cidade, ao analisarmos as imagens das décadas de 50 e 60 e as cartografias aerofotogramétricas (GEGRAN) de 1973-74, percebemos que ao longo dos anos as construções foram sendo substituídas em função da alteração das atividades com que 0 centro foi se adequando as realidades da cidade e região. $O$ pequeno comércio, responsável por atender a linha férrea e pequena parada para abastecimento das locomotivas, foi aos poucos ampliando suas atividades e consolidando em estabelecimentos que atendessem a cidade e região. Da mesma forma, este território se torna em espaço atraente as moradias, tanto casas (térreas e assobradadas) como edifícios residenciais (a partir da década de 1980).

Já a morfologia das quadras se manteve intactas desde sua implantação, salvo as localizadas a oeste, onde inicialmente foram implantadas as quadras com $1 / 2$ hectare $e$ mais tarde foram ampliadas dobrando sua área $\left(10.000 \mathrm{~m}^{2}\right)$. No mais, a malha urbana em "xadrez" continuou organizando o tecido urbano e a tipologia das edificações ao longo dos anos.

O processo de verticalização, diferentemente de muitas cidades, não foi devastadora em consumir o solo urbano e substituir as construções históricas e/ou de interesse arquitetônico. 
Figura 170. VIsta para o centro comercial, o eixo ferroviário e os bairros a norte da linha férrea Fote: Wanderley Costa, 2006

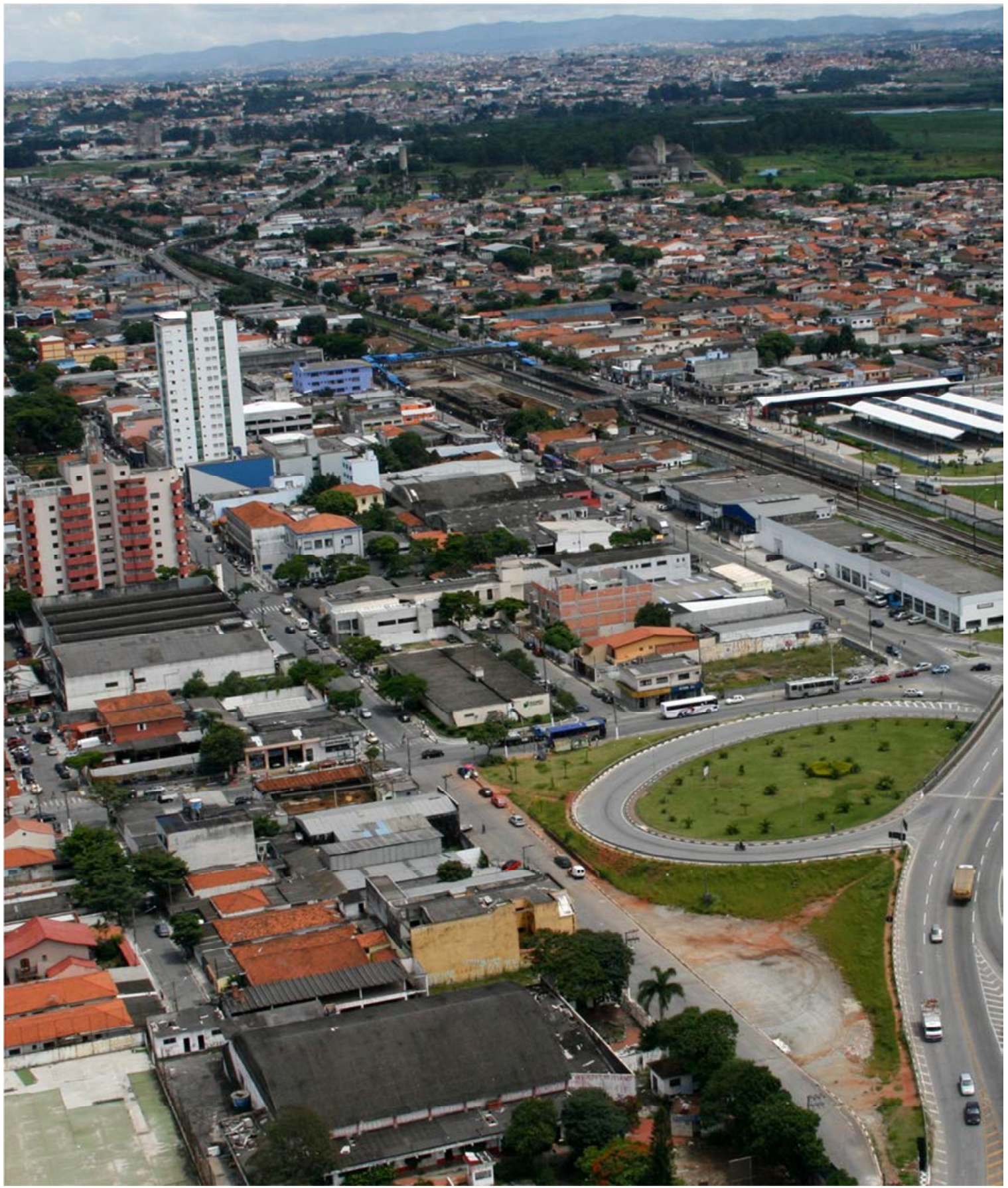




\subsection{Fluxos, Fixos e os Vazios Urbanos na Cidade}

Mover-se pela cidade além dos espaços destinados à circulação do automóvel, principal protagonista da mobilidade no Movimento Moderno, utilizar-se dos espaços limitados às pessoas como local de passagem, conexão entre dois pontos da cidade, local destinado à circulação e locação do mobiliário urbano; Explorar os espaços vazios como lugar, referência urbana e "respiro" na malha urbana podem ser considerado um dos grandes desafios para as cidades contemporâneas.

Num momento em que cada vez mais os espaços sobre as cidades são mais raros e difíceis de manterem em sua forma original, onde os espaços públicos destinados à circulação, estar e lazer devem atender ao maior número de pessoas, numa estrutura cada vez mais rígida e "congelada" e, em contrapartida, com a população e suas necessidades de circular, mover-se e recrear-se ampliando numa taxa de crescimento considerável, esta relação entre os vazios urbanos e população se torna cada vez mais difícil em atender os índices recomendados pela ONU (Organização das Nações Unidas).

Numa breve reflexão: "À medida que atingimos a marca de sete bilhões de pessoas em 2011, é hora de fazer um balanço"(NATIONAL GEOGRAPHIC 2011), ${ }^{221}$ ao mesmo tempo em que a população no planeta cresce anualmente de forma mais rápida, neste mesmo ritmo acelerado as cidades crescem e tornam-se cada vez mais "urbanas". Partindo do pressuposto que o território das cidades se torna cada vez mais escassos, a solução esta na verticalização das cidades para atender as demandas das densidades urbanas cada vez mais presentes na discussão do urbanismo contemporâneo. Por outro lado, como atender a uma porcentagem "tolerável" e ideal sobre o número de habitantes e as áreas destinadas á circulação, estar e lazer, visto que as cidades, em sua maioria, permanecem com seu território estagnado?

Para o poder público, os Grandes Projetos Urbanos são desta forma a oportunidade de reavaliar esta relação entre espaços construídos e não construídos, equilibrando de forma harmônica e atendendo as demandas necessárias aos que ali moram, trabalham ou usufruem. Como apontado por Claudio Acioly e Forbes Davidson (1998), em sua reconhecida publicação Densidade Urbana, "a densidade é um dos mais importantes indicadores e parâmetros do desenho urbano a ser utilizado no processo de planejamento e gestão dos assentamento humanos", capaz de funcionar como ferramenta urbana na concepção e controle do uso do solo, tornando-se "um referencial importante para se avaliar tecnicamente a distribuição e consumo de terra urbana, infraestrutura e serviços públicos em uma área residencial" (ACIOLY e DAVIDSON 1998, p 16).

Tal fato, no caso da área da Operação Urbana Orla Ferroviária, apesar do tecido urbano estar "congelado" desde a década de 90, a confirmação de um novo instrumento urbano capaz de regenerar o território junto ao eixo ferroviário traz a tona a discussão sobre os espaços livres e a qualidade urbana para seus moradores e usuários. Da mesma forma, os principais eixos de circulação pedonal, apesar de sua importância regional (ruas Gal. Francisco Glicério e Benjamin Constant), continuam interrompidos pela linha férrea, reforçando a potencialidade do setor sul no perímetro da área de intervenção.

221. Tradução do autor, 2012

As we reach the milestone of seven billion people in 2011, it's time to take stock. 
Figura 171. Diagramas Urbanos no perímetro da Operação Urbana Orla Ferroviária: pedonal, transporte, viário, áreas verdes

Organização: Fernanda Kano e Elvis Vieira, 2011
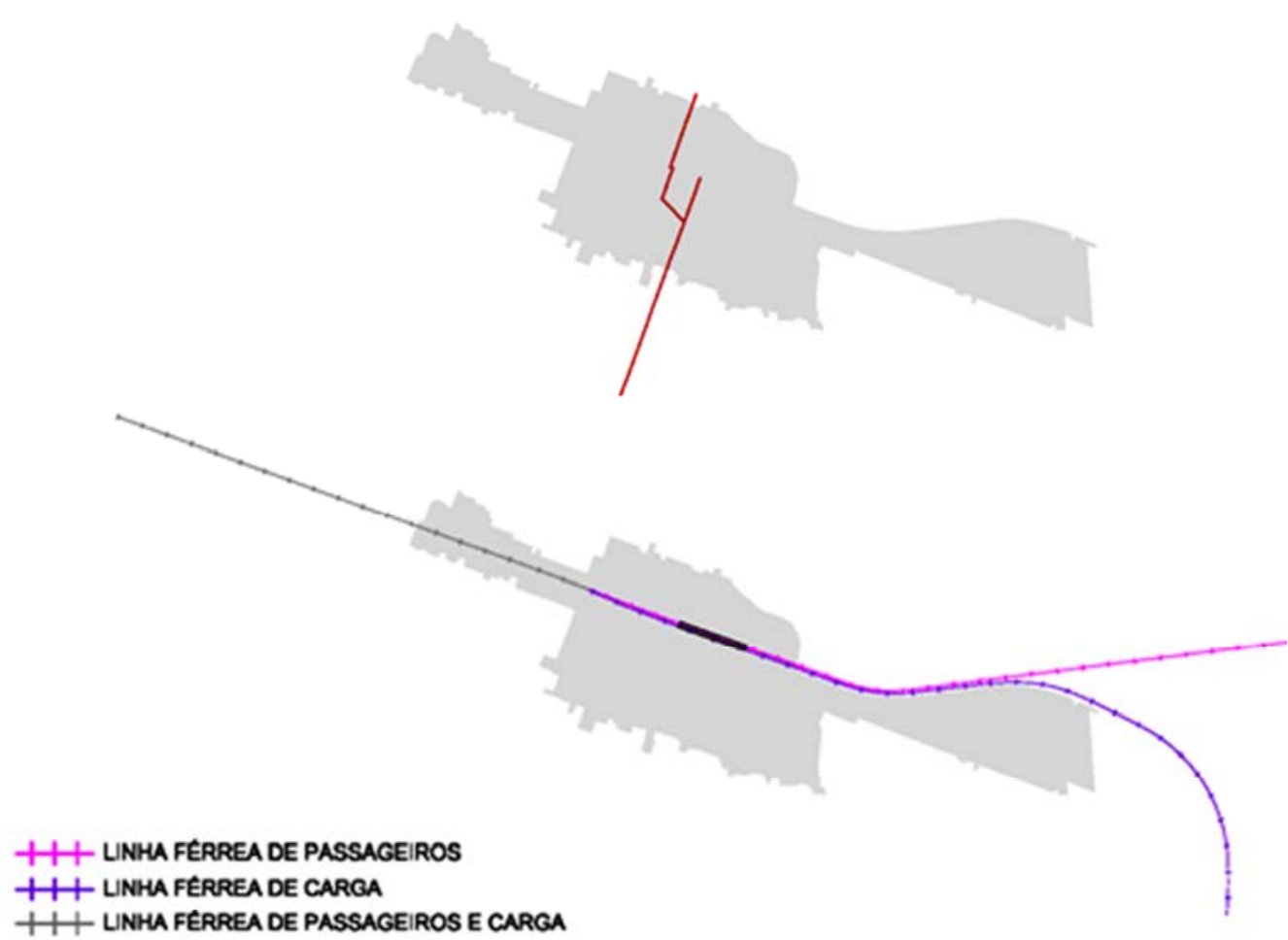

+ + LINHA FERREA DE PASSAGEIROS E CARGA

ESTACAOO FERROVARIA EXISTENTE
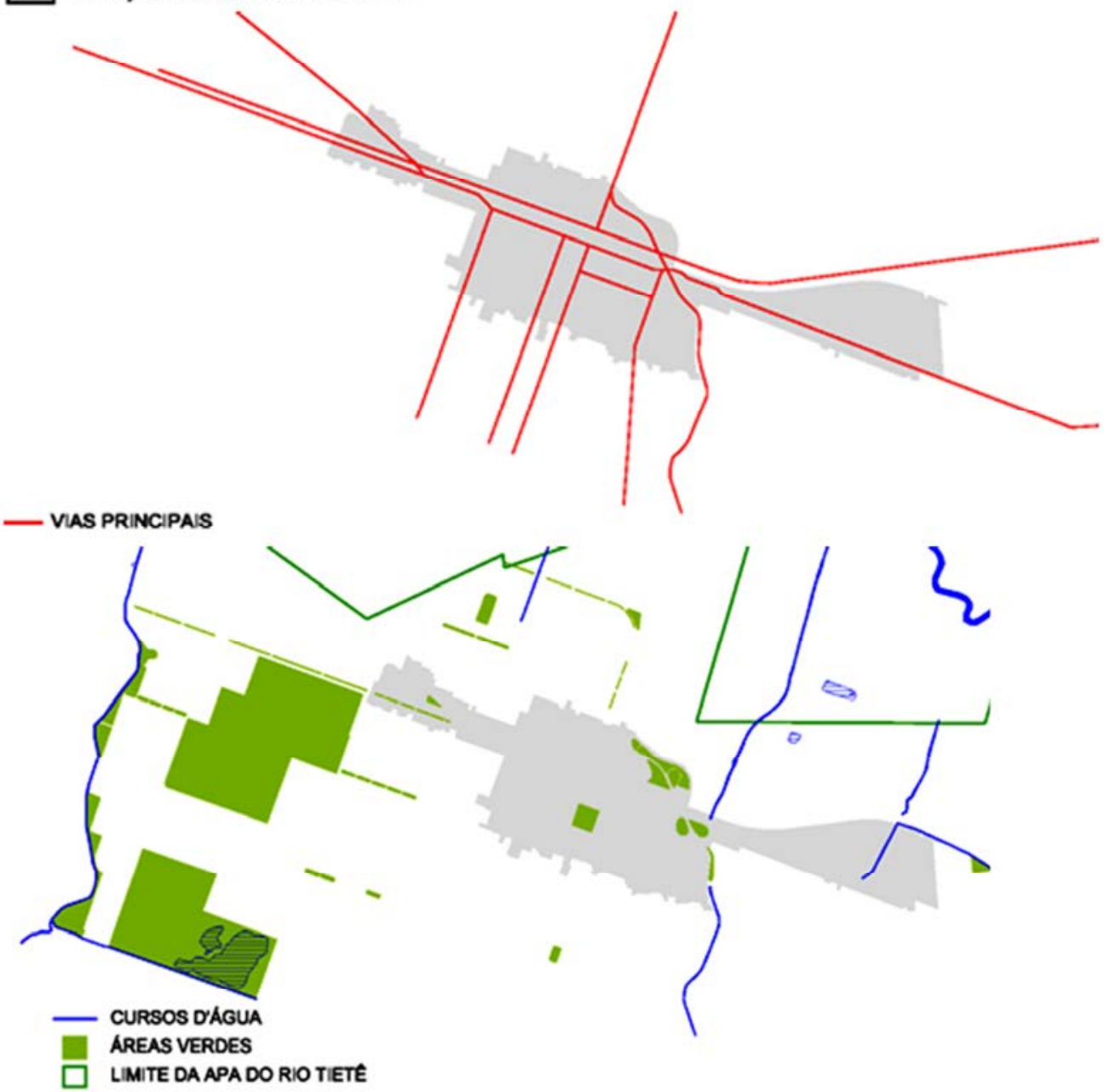
Em nossas análises, percebemos que os espaços livres (não construídos) são em sua maioria representados pelos eixos viários destinados ao automóvel, e mesmo os espaços de direito do homem (pedestre) estão atualmente destinados não somente ao caminhar, mas abrigam o mobiliário urbano (lixeiras, bancas de jornal, abrigo de ônibus) e infraestrutura urbana (postes de energia, telefonia, hidrantes, comunicação vertical de trânsito) restringindo ainda mais o espaço já saturado. Outro fato relevante esta na limitação com que os percursos são traçados; com exceção da Praça João Pessoa o pedestre circula apenas pelas bordas das quadras, por mais que identifiquemos espaços interligados por áreas não construídas, mas em uso constante (em sua maioria estacionamentos), estes percursos são limitados e bloqueados aos pedestres.

Ainda que a Cidade Contemporânea esteja ligada a uma complexa articulação de "peças urbanas" de diversas formas, voltada a uma economia terciária e a promoção de espaços individualizados; Ainda que a iniciativa privada hoje tenha um dinamismo que não tinha no passado sobre o desenho da cidade. Não podemos negar que ainda "a cidade não perdeu seu apelo em termos de vitalidade urbana, pelo contrário, aumentou com 0 alargamento das ruas animadas, a multiplicação dos locais de monumentabilidade e o enriquecimento da oferta cultural e turística" (BORJA e MUXí 2004, p 177), ${ }^{222}$ confirmando nossa tese da importância dos Grandes Projetos Urbanos como forma de redesenho da morfologia urbana e estratégia para a qualificação urbana, principalmente no que se refere aos espaços públicos e seus equipamentos urbanos.

Quanto ao volume construído, dois fatores, em função de nossas análises, provocaram o "congelamento" e desinteresse da iniciativa privada para a substituição por novos edifícios e usos na área de intervenção: a falta de investimentos e abandono do poder público, assim como políticas públicas capaz de atrair novos investimentos para este setor da cidade e, um segundo fator - de ordem morfológica, condicionado à situação fundiária e a legislação urbana municipal, no qual devido a um parcelamento composto por lotes de pequena e média dimensão e, em sua maioria estreitos, condicionam a uma massa edificatória de baixo gabarito e não explorando seu potencial construtivo. ${ }^{223}$

Tais fatores impossibilitaram uma revisão e melhor reflexão sobre os vazios urbanos da cidade, e em especial a área da Operação Urbana, no qual o único espaço em destaque nesta discussão esta ainda na Praça João Pessoa, área destinada a tal fim desde o final do século XIX. Ainda que os espaços públicos sejam raros e "ingênuos" para atender a demanda de todos habitantes e usuários deste trecho da cidade, fica evidente a necessidade de ampliar tais espaços que tenham a capacidade de integrar os espaços construídos e compor cenários urbanos mais harmoniosos, democráticos e ambientalmente ricos.

\footnotetext{
222 . Tradução do autor, 2012

La ciudad no perdió su atractivo en cuanto a vitalidad urbana, al contrario, lo aumentó por la ampliación de las calles animadas, la multiplicación de los lugares de monumentabilidad y el enriquecimiento de la oferta cultural y turística.

223 . Este fator é resultante dos índices urbanísticos aplicados nesta região da cidade. A área da OUOF está inserida sobre uma Zona de Média para Alta Densidade Demográfica - Z3, com os seguintes índices: Taxa de Ocupação - 70\%, Coeficiente de Aproveitamento - 2, Índice de elevação - 4, conforme Lei de Uso e Ocupação do Solo 025/1996. No entanto percebemos que estes índices não são atualmente tão atrativos aos investidores do mercado imobiliário, diferentemente de outras zonas na cidade que possibilitam maior aproveitamento do solo urbano. Neste sentido, os volumes edificados num primeiro momento não conseguem atingir seu potencial devido às pequenas dimensões dos lotes, da mesma forma que são pouco favoráveis à verticalização desta região.
} 



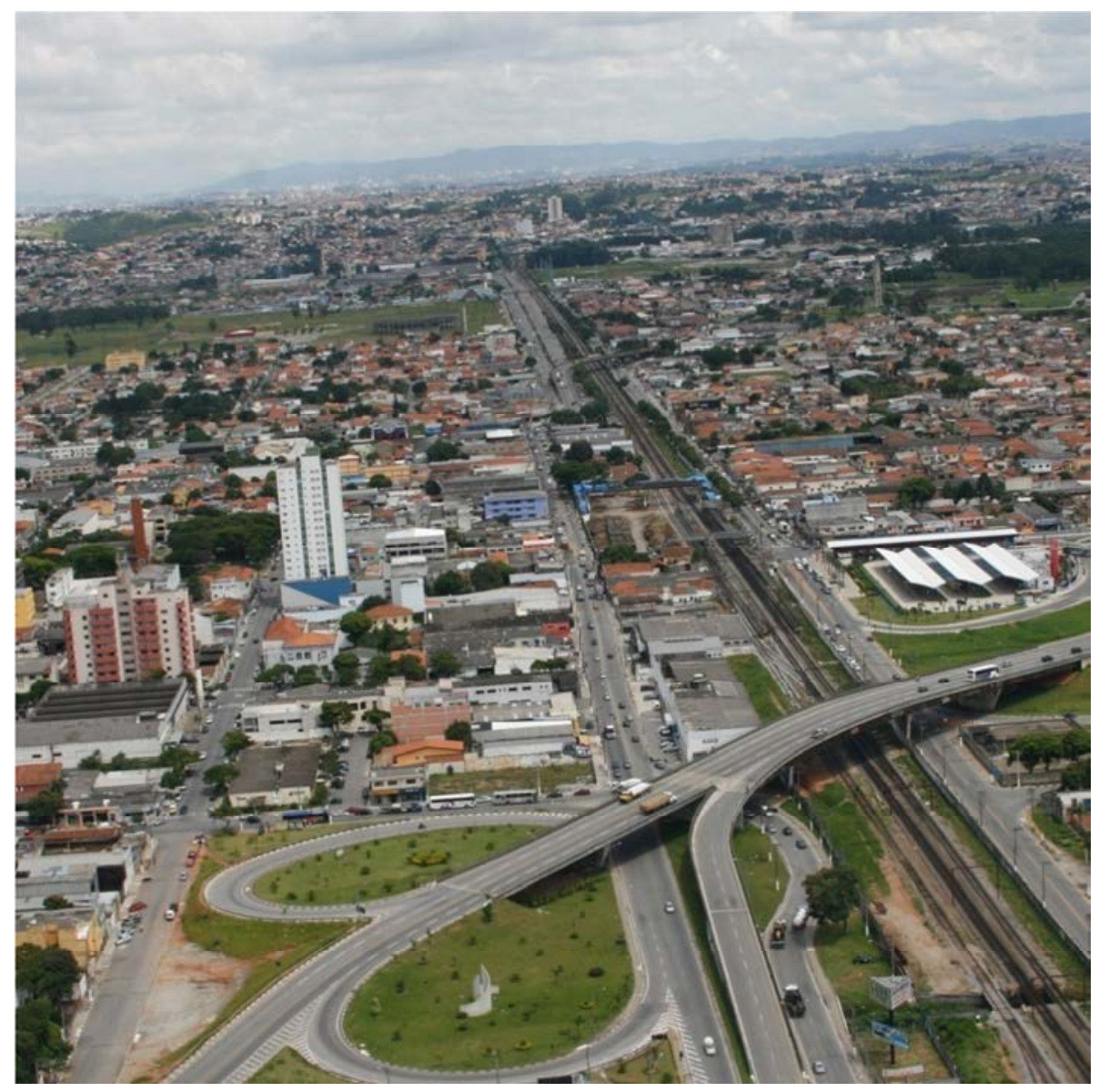

Capítulo 8 OPERAÇÃO URBANA ORLA FERROVIÁRIA: oportunidade de transformação do território urbano 



\subsection{A transformação da morfologia urbana}

As propostas para a Orla Ferroviária de Suzano devem ser vistas inicialmente como oportunidades de regeneração do tecido urbano saturado e a transformação de seu cenário, assim como a de construir em parceria com o poder privado a renovação econômica e social da área de intervenção, gerando espaços com maior vitalidade urbana.

A delimitação do perímetro de intervenção levou em consideração a necessidade de compatibilizar a estrutura urbana existente com as futuras condições de acessibilidade obtidas com os equipamentos públicos de transporte urbano, ampliação das conexões entre os "dois lados da cidade" interrompidos pelo eixo ferroviário e a abertura de novos espaços livres e áreas verdes para o centro urbano de Suzano.

Além dos investimentos públicos na área de transportes, previstos para atender a demanda municipal (dois terminais urbanos), regional (rodoviária) e metropolitana (estação ferroviária), as propostas e ações da OUOF visa orientar as ações de transformação física e funcional do setor imobiliário, de tal forma a se obter, ao longo do período de duração, "uma área com espaços e atividades qualificadas para o uso do comércio, serviços, lazer e moradia" (PMS e FAUUBC 2006).

Para os bairros lindeiros, a ferrovia, que ao longo dos anos, foi perdendo sua importância e valor imobiliário, os equipamentos de transporte urbano deverá transformar-se em importante ferramenta de articulação do tecido desfragmentado, além de gerar a melhoria dos espaços e ambientes urbanos. As intervenções deverão motivar novos investimentos nestes bairros de imponente localização geográfica e infraestrutura urbana completa, no qual o valor da terra tornou-se de grande valia, porém o imobiliário construído perdeu gradativamente seu valor, resultando em uma massa edificatória ociosa na região central da cidade.

Para melhor desempenho urbano e integração das propostas, considerando a grande escala do perímetro da Operação Urbana (210 hectares), havendo acentuadas diferenciações nas formas de uso e ocupação do solo entre as duas partes da cidade divididas pelo sistema de transporte metropolitano, como em suas extremidades com um parcelamento do solo e situação fundiária distinta (lotes pequenos e estreitos, grandes e esparsos); e com o intuito de possibilitar sua aplicabilidade por etapas e de forma gradual, foi proposta a implantação da AIU - Área de Influência Urbana, de menor escala urbana, como objeto de intervenção direta sobre as áreas destinadas a receber os principais equipamentos de transporte (estação ferroviária e terminais urbanos), com a aplicação de recursos financeiros do poder público municipal, estadual e federal visando a transformação do cenário urbano e sua morfologia de forma mais ágil, tinhase assim, a intenção de atrair investimentos privados sobre este território, agindo como "peças urbanas" capaz de influenciar as demais áreas do perímetro da Operação Urbana.

Quanto aos espaços livres ou não construídos, o Projeto Urbano prevê a revitalização das áreas já existentes como a Praça João Pessoa e suas construções (Igreja Matriz) e a implantação de novas áreas, na qual a mais significativa é o Parque da Cidade, um grande eixo verde paralelo a linha férrea em área remanescente a implantação da Nova Estação Ferroviária e que tende tornar-se o elemento natural articulador entre os bairros centrais fragmentados por este eixo desde sua implantação. Este mesmo parque deve ser o "marco zero" para a implantação do sistema de ciclovias em direção aos principais bairros da cidade, garantindo assim a "oferta de um transporte alternativo sobre um território de geografia plana e extensa"(PREFEITURA MUNICIPAL DE SUZANO 2011). 

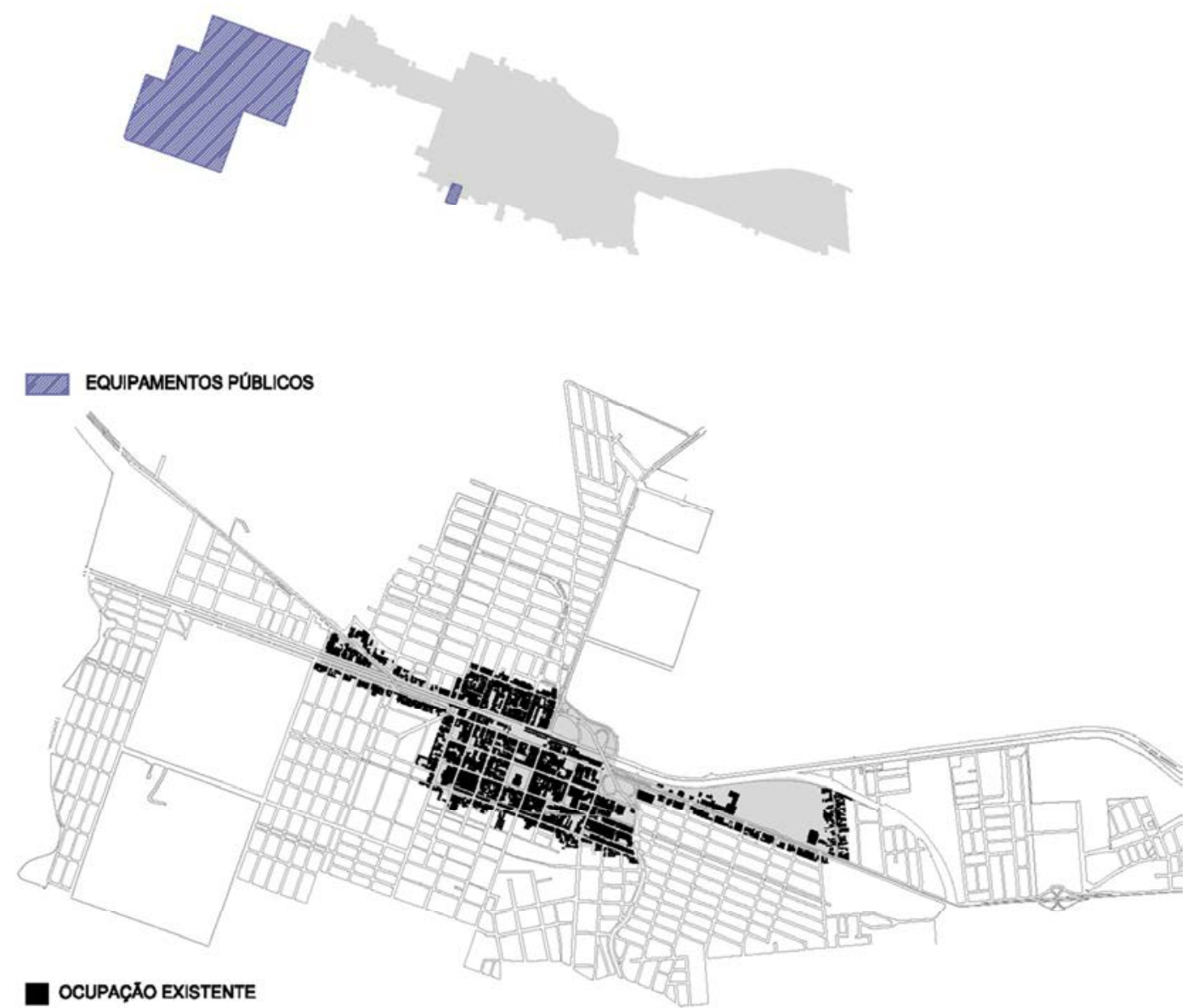

Figura 172. Digrama urbano: equipamentos públicos e espaços construídos existentes Organização: Fernanda Kano e Elvis Vieira, 2011

Figura 173. Perímetro da AIU - Área de Intervenção Urbana - Operação Urbana Orla Ferroviária Fonte: Google Earth, 2012

Organização: Elvis Vieira, 2012

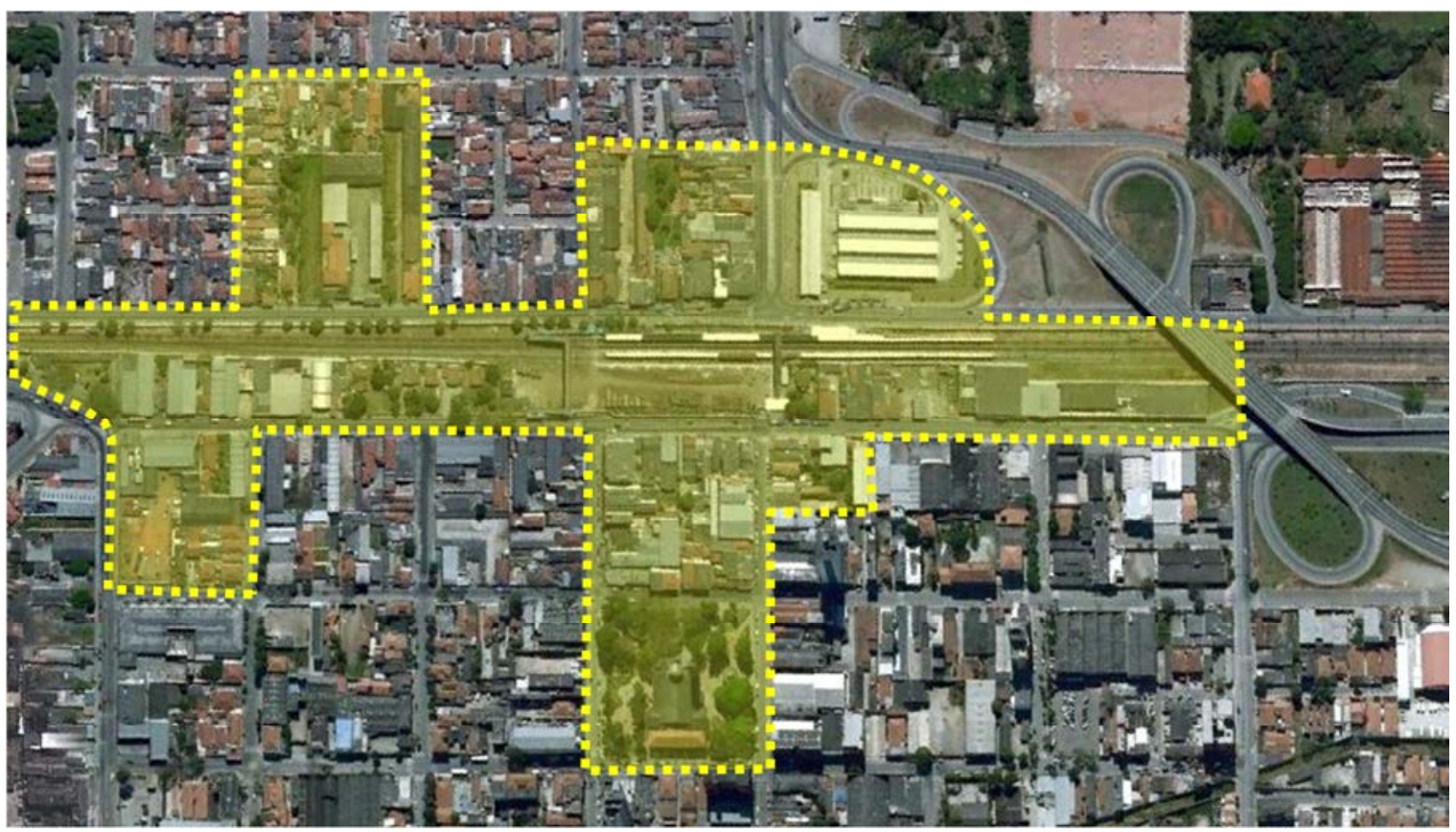


Já em relação aos espaços de mobilidade, as áreas destinadas aos passeios pedonais deveriam passar por obras de requalificação, não somente para atender às normas de acessibilidade, mas para assegurar espaços livres com qualidade urbana capaz de abrigar o mobiliário urbano, a comunicação de trânsito e visual assim como a demanda e o grande fluxo de moradores (que utilizam do centro como passagem e ligação com seus bairros) e usuários (com a intenção de compras), principalmente, sobre os dois principais eixos comerciais (rua Gal. Francisco Glicério e Benjamin Constant). Neste sentido, a primeira quadra da rua Gal. Francisco Glicério entre a Nova Estação Ferroviária e a rua Campos Sales deverá ser exclusiva para os pedestres, abrigando a Praça da Estação, local de referência urbana para o equipamento de transporte metropolitano. No que diz respeito à circulação de veículos, a proposta mais significativa está na duplicação da Avenida Dr. Prudente de Morais, principal eixo leste-oeste entre as cidades da Região do Alto Tietê e acesso ao Rodoanel Trecho Leste, com a criação de um corredor exclusivo de ônibus e novas pistas de rolamento que assegurem o fluxo constante de veículos neste trecho da cidade.

Quanto ao espaço construído (massa edificatória) é proposto um conjunto de "Novos Cenários" utilizando-se dos instrumentos previstos no Estatuto da Cidade, ${ }^{224}$ redesenhando o tecido urbano com novas tipologias e morfologia urbana, considerando a possibilidade de todo e qualquer espaço urbano que possa ser apropriado, experimentado, vivenciado. "Espaços de encontros, mas também de conflitos, espaço onde se dá a própria vida urbana" (BRAGA e JACQUES jan. 2008). Tinha-se neste momento a "pretensão", ao menos no perímetro da AIU, de experimentar novas formas de ocupação sobre as quadras para gerar o debate na cidade e as possibilidades de um urbanismo mais apropriado às novas condições e "vocação" com que o governo municipal propunha, estimulando a "verticalização para uso misto, definindo tipologias que possibilitem o aproveitamento do embasamento para uso comercial e de serviços" (PMS e FAUUBC 2006, p 32). ${ }^{225}$

Já os equipamentos urbanos, peças fundamentais de articulação e regeneração do tecido fragmentado e capaz de gerar uma nova dinâmica urbana sobre o centro da cidade, dentro das estratégias da Operação Urbana, deveriam cumprir o papel de "motores" à transformação desejada. De grande vulto financeiro estes equipamentos seriam executados com recursos públicos, cada qual com sua competência e projeto próprio sob as diretrizes apontadas nos Projetos Urbanos de cada setor da área de intervenção, no qual segundo dados da Prefeitura Municipal - Secretaria Municipal de Política Urbana - Diretoria de Projetos Públicos e Governo do Estado de São Paulo Secretaria de Transportes Metropolitanos serão:

1. Construção da Nova Estação Ferroviária, previsto no PITU 2020 (Plano Integrado de Transportes Urbanos), com cronograma de obras para 2013, sob a responsabilidade do Governo Estadual;

2. Construção de dois Terminais Urbanos - Terminal Norte (Ver. Diniz José dos Santos Faria), previsto para 2005 e Terminal Sul com cronograma de obras para 2013-2014, ambos sob a responsabilidade do Governo Municipal e que deverão estar integrados à estação ferroviária (vide pag. Figura 156. Terminal Urbano Ver. José Diniz, projeto do arquiteto João Valente, 2005);,226

224 . Estatuto da Cidade. Lei Federal no 10.257, de 10 de julho de 2001.

225 . Em 2006 a Faculdade de Arquitetura e Urbanismo - FAUUBC em convenio com a Prefeitura Municipal de Suzano SMPU - PMS realizou os estudos de viabilidade de transformação urbana da Operação Urbana Orla Ferroviária e Operação Urbana Expansão do Centro a partir dos espaços construídos.

226. O Terminal Norte construído em 2005, com projeto arquitetônico de autoria de João Valente, financiado pelo Governo Estadual (20\% da obra) e os outros $80 \%$ pela Prefeitura Municipal de Suzano. 


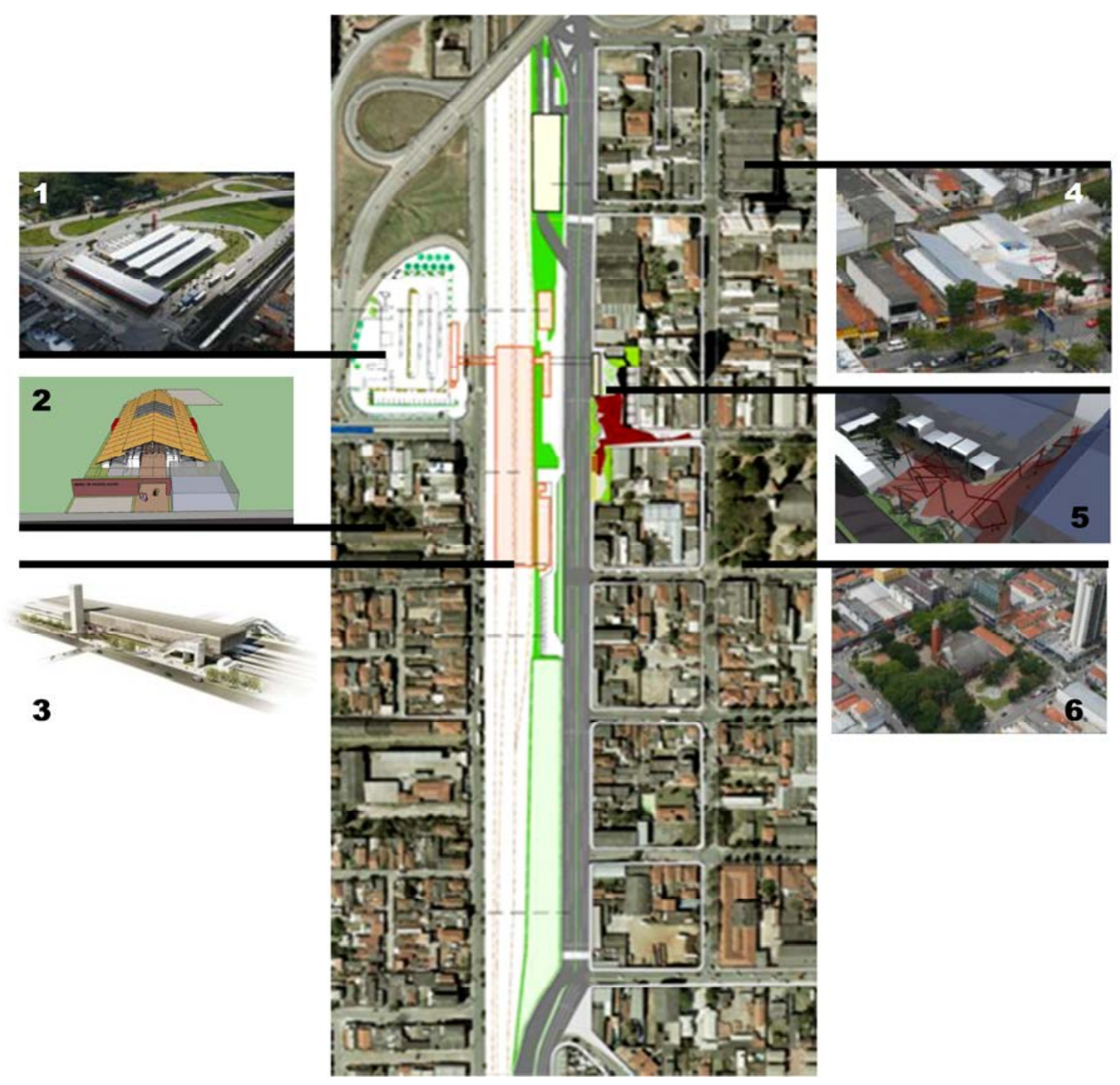

Figura 174. Projetos e obras da Operação Urbana Orla Ferroviária - AIU: 1. Terminal urbano norte, 2. Shopping Popular, 3. Nova Estação Ferroviária, 4. Restaurante Popular, 5. Nova Praça da Estação, 6. Praça João Pessoa

Fonte: DPP | SMPU | PMS, 2006

Figura 175. Nova Estação de Suzano, projeto do escritório JBMC Arquitetura e Urbanismo, 2010 Fonte: JBMC Arquitetura e Urbanismo

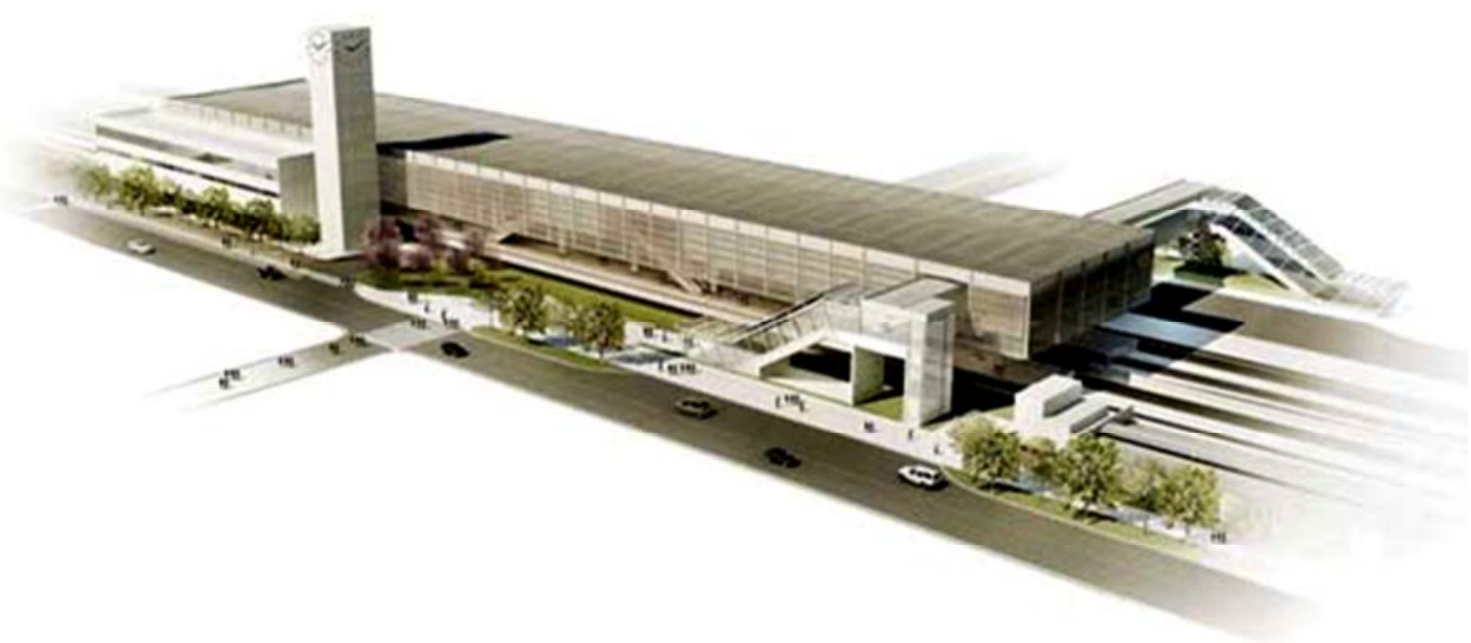


3. Construção do Mercado das Flores como forma de garantir a memória da tradicional Feira das Flores em funcionamento desde a década de 1960, sob a responsabilidade da prefeitura municipal e cronograma previsto para 2013-2014;

4. Construção da Praça da Estação, localizada na primeira quadra da rua Gal. Francisco Glicério, elemento urbano de conexão da cidade com os equipamentos de transporte e organizador dos novos fluxos propostos;

5. Implantação do Parque Central em área remanescente da "ilha urbana" dos equipamentos de transporte;

6. Construção da Rodoviária em área municipal, com cronograma previsto para 2014;

7. Implantação de equipamentos administrativos como incentivo à requalificação urbana do centro, como as Secretarias de Educação e Segurança Alimentar e Nutricional e de Agricultura e Abastecimento, assim como o Restaurante Popular (inaugurado em 2005) localizado em galpão industrial abandonado (antiga Sóvis - fábrica de vinhos) de autoria do arquiteto Marcelo Suzuki;

8. Construção do Bazar Popular e Shopping Popular, o primeiro para abrigar o comércio informal localizado nas principais vias do centro, incluindo pequenos empreendedores e artesãos (com apoio da FIESP) e em funcionamento desde 2007 sob a responsabilidade da Secretaria Municipal de Desenvolvimento Econômico, Trabalho, Negócios e Turismo. O Shopping Popular com previsão para 2013 deverá abrigar o comércio informal hoje localizado na passarela sob a linha férrea (que deverá ser demolida) incorporando os pequenos comerciantes, desde que sujeitas às regras legais, representando um avanço social dos agentes envolvidos;

9. Construção do Museu do Papel, como instrumento de afirmação ao parque industrial da cidade, a Prefeitura Municipal em parceria com a Indústria Suzano Papel e Celulose estão responsáveis por sua implantação com cronograma prevista para 2014-2015 (projeto em andamento de autoria da DPP - PMS).

Fica claro que, na sua maioria, grandes intervenções urbanas se dão ao longo de um período relativamente longo, capaz de atingir os objetivos lançados nos planos e projetos, assim como a execução dos "projetos-âncoras", por vezes, trabalham desconexos dos Grandes Projetos Urbanos, causando interferências ou atrasos no cronograma de conclusão do plano. Neste sentido, as intervenções previstas nesta Operação Urbana passam pela análise e discussão das estratégias públicas adotadas para os projetos urbanos utilizados como "estudo de casos", apesar de se tratar da discussão sobre os resultados na "nova paisagem" e a "vocação" das cidades estudadas, mas que na medida do possível contribuem para a consolidação dos objetivos iniciais desta requalificação urbana.

Entendendo que os projetos-âncoras são fundamentais para a contribuição da transformação da morfologia urbana existente, a Operação Urbana Orla Ferroviária de Suzano aponta, desde as primeiras propostas, a necessidade de se garantir a consolidação das "peças urbanas" como objetos geradores e provocadores da mutação de seu cenário urbano. Assim, os grandes equipamentos de transportes previstos deveriam possuir cronogramas de obras não muito extensos, de modo a possibilitar com sua conclusão, o impulso ao mercado imobiliário em reconstruir os espaços privados na área de intervenção. 
Figura 176. Estudos volumétricos das novas formas urbanas sobre os espaços construídos da Operação Urbana Orla Ferroviária. Propostas apresentadas pelo Grupo de Pesquisa da FAUUBC em 2006

Fonte: Projetos Urbanos para a Cidade de Suzano, 2006

Desenhos: Arq. Carlos Costa
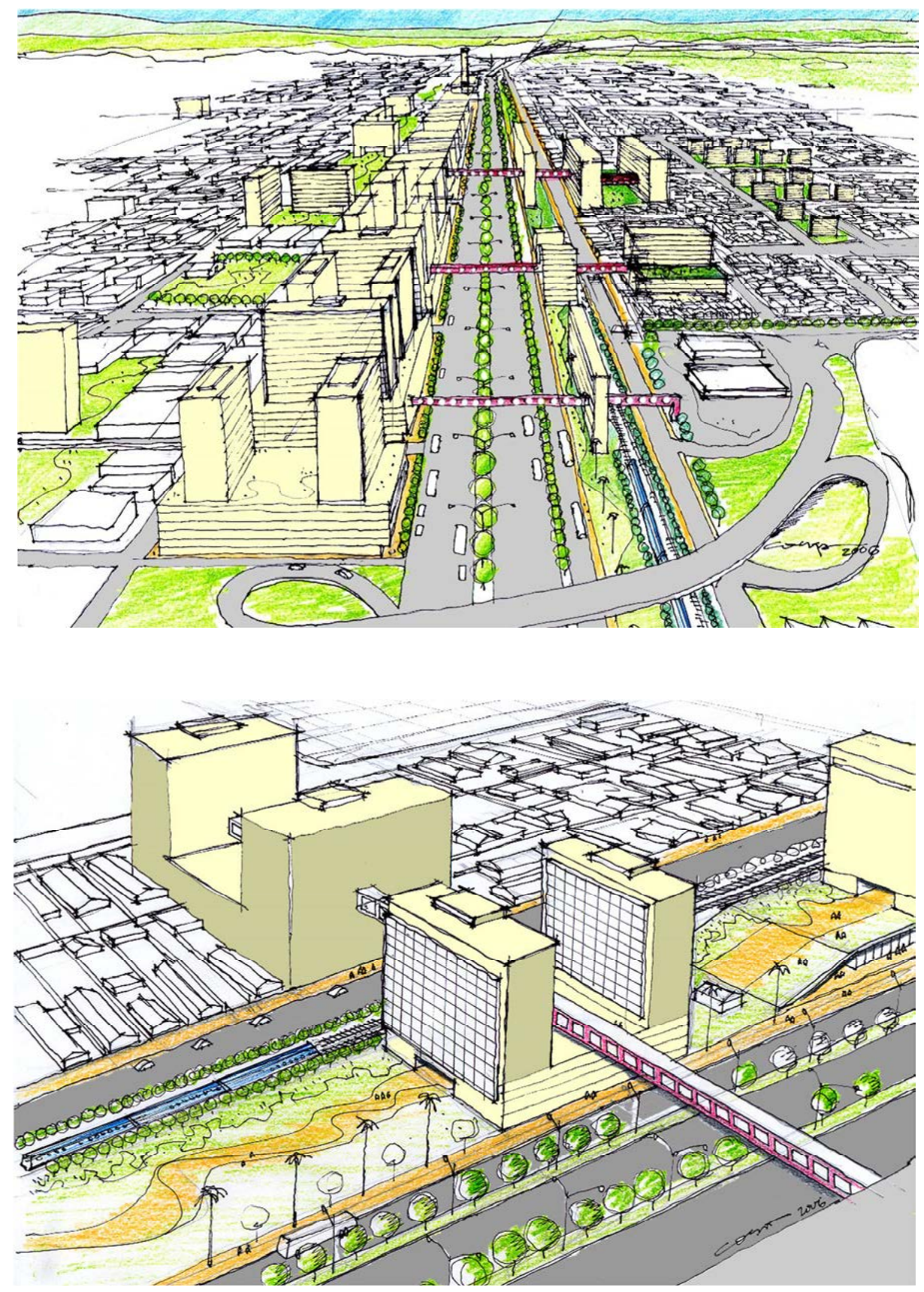
"O compromisso do poder público quanto às estratégias e os recursos financeiros dispensados se tornam necessário como mecanismo de compreender os resultados alcançados ao final das intervenções urbanas propostas"(VIEIRA 2010). ${ }^{227}$

Da mesma forma, tal engajamento do poder público torna-se necessário como incentivo aos investimentos, ou apostas, da transformação deste trecho da cidade aos "olhos da iniciativa privada", que apesar de ser detentora da maior parcela da área de intervenção e dos recursos financeiros, em sua maioria, aguardam a consolidação das obras públicas previstas como garantia a aplicabilidade de seus investimentos. Isto não é exceção em Suzano em que as raras propostas sobre solo privado irão se confirmar com a conclusão das primeiras intervenções públicas.

"O predicado econômico vem assim, espontaneamente, colocar-se ao lado do moderno conceito de espaço, a ponto de se poder afirmar que, se os urbanistas clássicos tinham do espaço um conceito geométrico, os urbanistas modernos tem um conceito econômico"(ARGAN 2001, p 86).

Isto nos faz refletir sobre o papel do arquiteto a respeito do urbanismo contemporâneo, no qual tornamos instrumentos de conexão entre os "desejos públicos", as transformações urbanas e o futuro das cidades, como apontado por Argan: "todo arquiteto urbanista é, enfim, um reformador social, do mesmo modo como os arquitetos do Renascimento foram os reformadores do pensamento cientifico de seu tempo..."(2001 p 87).

Estes fatores levaram a compreender a cidade não somente como um organismo composto por edifícios e áreas livres, geradores de espaços construídos e não construídos, organismos mutantes livres e autônomos em sua transformação "gratuita" ou descontrolada.

O que se tem visto atualmente são intervenções compostas de estratégias claras de requalificação urbana onde os elementos construídos e não construídos se integram à discussão sustentável após sua implantação e os resultados físicos a serem alcançados com a nova intervenção.

"Pensar na cidade como meio é um desafio para o homem como é para o meioambiente. O solo, com suas características, desenhou poderosamente a história material e a forma das cidades. É um dos elementos primeiros de um meio e também a continuidade pelo lado da fragmentação das grandes aglomerações contemporâneas"(BERGER 2003, p 47).

Assim, o solo apresenta recursos e obstáculos que devem ser revistos e geridos pelas intervenções contemporâneas, fazendo com que os resultados físicos encontradosse contraponham às estratégias financeiras como "revitalização dos valores de sociabilidade". ${ }^{228}$ Nisto, os meios das cidades são feitos hoje de entrelaçamentos

227 . Tradução do autor, 2012

El compromiso del gobierno acerca de las estrategias y los recursos financieros previstos se ha hecho necesario como un mecanismo para entender los resultados obtenidos al final de las intervenciones urbanas propuestas.

228 . Acreditamos que estes resultados deverão ser compreendidos como a nova paisagem construída a partir das estratégias urbanas colocadas em prática sobre a ótica dos usos da cidade contemporânea, sua multiplicidade de atividades sobre o espaço construído e a receptividade dos usuários sobre os espaços livres da cidade. 
naturais e construídos nos quais a complexidade é estendida à escala do território(BERGER 2003).

Nas últimas três décadas, assistimos a transformação de trechos de cidades em detrimento da nova economia destes organismos e pela busca por uma nova "dinâmica socioeconômica" sobre o solo urbano e seus habitantes e usuários, utilizando-se de estratégias diversas para atrair recursos financeiros capaz de executar, de forma integral e em tempo reduzido, seus planos e projetos de intervenção.

Estas intervenções demonstraram que a necessidade da realização de Grandes Projetos Urbanos sobre o tecido existente é fundamental para a garantia de uma cidade contínua e contemporânea, atendendo as necessidades tecnológicas destes últimos dois séculos.

Fica claro que as experiências colocadas em prática a partir dos anos 80 são de grande valia para a constituição de um arcabouço teórico sobre nossos conceitos, e em especial, para a compreensão das teorias e decisões do que Lamas chama de "Novo Urbanismo".Assim, as intervenções estudadas somam-se as demandas dos habitantes e usuários da área de intervenção - Operação Urbana Orla Ferroviária e coloca-se como contribuição para a construção do repertório urbano e arquitetônico na intenção de consolidar uma nova linguagem sobre a morfologia urbana proposta e sua tipologia desejada.

Face às condições existentes no perímetro compreendido pela Orla Ferroviária, e, em especial, pela AIU (Área de Intervenção Urbana), buscou-se num primeiro momento compreender as estruturas instaladas e analisar de forma mais sistemática a qualidade da paisagem e suas relações sócio-espaciais, assim como as articulações entre o espaço construído e a memória da cidade, de maneira a criar melhores condições de atratividade a investimentos, equilíbrio entre ocupação do solo e índices de aproveitamento vertical, maior oferta de espaços para habitação na área central e distribuição das atividades econômicas no espaço urbano, visando geração de renda e menores impactos de transporte e circulação.

Estes objetivos contemplavam a gradativa requalificação do espaço construído de forma mais amena, com a efetiva participação dos agentes financeiros e, principalmente, os moradores e usuários desta região da cidade, possibilitando a transformação do espaço não construído como ente articulador entre a paisagem existente, degradada e subutilizada, "num espaço dinâmico e atrativo aos investidores privados, ampliando a cada instante a revalorização dos equipamentos de transporte de massa como instrumento polarizador de negócios e serviços ao nível local, regional e metropolitano"(VIEIRA 2010). ${ }^{229}$

Junto a essa oportunidade de dinamização da área, comprovada pelos investimentos estaduais e municipais nos equipamentos de transporte, deve ser incentivada o uso habitacional para diferentes perfis de renda familiar, tais como Habitação para Mercado Popular - HMP e para a classe média-baixa, resultando dessa maneira em

229 . Tradução do autor, 2012.

En un dinámico y atractivo para los inversores privados, aumentando a cada momento la mejora de los servicios de transporte como instrumento de polarización de comunicación y servicios a las empresas a nivel local, regional y metropolitano. 
aproveitamento mais racional da infraestrutura instalada, uma vez que representa investimentos públicos vultosos e a dispersão urbana acaba por onerá-la ainda mais.

Quanto aos instrumentos urbanísticos no perímetro da Operação Urbana, considerou-se que as definições de índices, coeficientes e densidades urbanas são de grande importância para a mudança do padrão espacial existente. Os coeficientes de aproveitamento, taxas de ocupação e dimensionamento de lotes, são instrumentos consagrados em zoneamentos e códigos de edificações. Entretanto, a eles devem se somar outros dispositivos de política urbana capazes de viabilizar, em seus diversos aspectos, diretrizes que efetivamente resultem em transformações qualitativas do espaço de vida da população e seus usuários.

Assim, para assegurar os objetivos propostos pelo Projeto Urbano, os instrumentos do Estatuto da Cidade deverão dar sustentação legal e alternativas econômicas para o seu desenvolvimento urbano, possibilitando a transformação do perímetro estabelecido e salvaguardando o controle do espaço público como elemento norteador do desenho urbano.

Nisto, para a consolidação e regulação da Operação Urbana Orla Ferroviária, após o estabelecimento de seu perímetro de ação e a institucionalização do território como Área de Intervenção Urbana (AIU) estabeleceu-se os instrumentos urbanísticos passíveis de serem aplicados a esta intervenção e garantir sua aplicabilidade sobre 0 território degradado, segundo o ente institucional municipal (PMS, 2005):

- A consolidação do perímetro estabelecido como "Operação Urbana Consorciada", que garantem a transformação desta delimitação do tecido urbano, numa contribuição mútua entre os proprietários, moradores, usuários da área e poderes públicos (municipal, estadual, federal), além da possibilidade de captar recursos adquiridos de potencial construtivo, ampliando o valor da terra e otimizando as estruturas urbanas existentes; ${ }^{230}$

- Estabelecer o Direito de Preempção, no qual garanta ao poder público, neste caso somente ao executivo municipal, a preferência para aquisição de imóvel urbano objeto de alienação onerosa entre particulares. Com isto, a municipalidade poderá constituir um conjunto de reserva fundiária para a implementação de programas e projetos de interesse social sobre a área, ordenando e direcionando a transformação deste tecido de forma mais igualitária, com a implantação de equipamentos urbanos e comunitários, criação de espaços públicos de lazer e áreas verdes, de interesse paisagístico e histórico, além de ampliar as possibilidades dos espaços multiusos e a diversidade social sobre este território; ${ }^{231}$

230 . Cabe salientar que apesar das propostas de consolidação de um conjunto de índices urbanísticos e a possibilidade de venda de potencial construtivo, estes instrumentos não puderam se concretizar devido a Proposta de Revisão do Plano Diretor 2006-2016 não ser aprovado pelo poder legislativo, incapacitando legalmente ao poder executivo municipal de aprovar qualquer tipo de Operação Urbana. Ainda assim, as operações urbanas na cidade foram configuradas como importantes instrumentos de desenvolvimento urbano para a cidade.

231. Tal fato pode ser experimentado com a implantação do Restaurante Popular em 2006, com a autorização de uso sobre as antigas instalações das Fábricas Sóvis e mais recentemente em 2011, com as negociações das antigas instalações da Escola Técnica para a construção do Shopping Popular, ainda em fase de execução dos projetos executivos. 
- A implementação do Consórcio Imobiliário numa forma de viabilizar os planos urbanísticos e a substituição do conjunto edificado por meio do qual o proprietário poderá transferir ao poder público seu imóvel com a garantia de receber posteriormente, após as intervenções urbanas e obras realizadas, parcela deste imóvel como pagamento. Isto representa um ganho a todos os envolvidos, sem os prejuízos públicos que a especulação imobiliária impõe quando da valorização do solo urbano por meio da implantação de infraestrutura e demais melhoramentos. ${ }^{232}$

Uma observação importante sobre os instrumentos urbanísticos diz respeito à necessidade de estar associada às estratégias que permitam criar a mesma sinergia entre os projetos urbanos desenvolvidos no Centro Expandido da Cidade (Operação Urbana Consorciada Expansão do Centro - OUCEC), impedindo haver um direcionamento dos interesses do mercado imobiliário exclusivamente para uma área, deixando a outra em plano secundário e, ao mesmo tempo, garantindo a transformação contínua destas áreas que passam por um momento sensível de "estagnação" imobiliária e urbana.

No que se refere às condições ambientais, objetivou-se reverter os impactos já presentes na estruturação urbana, assim como evitar que o uso futuro do solo urbano acarrete consequências negativas. De maneira geral, os Projetos Urbanos buscaram a ampliação de espaços livres, públicos e privados, sob a forma de parques, áreas verdes, praças, pátios e recuos, visando proporcionar uma configuração distinta da maior parte da ocupação do vetor leste da Região Metropolitana, fundamentada na ocupação horizontal intensiva, utilização máxima dos lotes urbanos de pequenas dimensões e baixa presença de espaços livres.

A busca pela ampliação das áreas livres nesta região da Orla Ferroviária também possibilitaram a intensificação dos espaços livres, atualmente, insatisfatórios para os moradores e usuários do centro. A área é servida por apenas um praça, que abriga a Igreja Matriz, mas que não supre esta necessidade nem atende aos anseios de lazer destes moradores, além de não atender às recomendações mínimas da ONU de áreas verdes para cada habitante, ${ }^{233}$ tendo em vista que sua configuração a classifica como uso direcionado às atividades religiosas da cidade.

Cabe ressaltar que apesar da cidade de Suzano possuir apenas 63 anos de emancipação política, os resultados do desenho urbano não são diferentes das demais cidades consolidadas a partir de meados do século XX, onde os espaços livres foram conformados de forma gratuita e sem qualquer tipo de planejamento que resultasse numa paisagem urbana satisfatória ou de qualidade a seus moradores e usuários, resultando em quase todo o perímetro proposto, em sua maioria, em espaços deteriorados, mesmo possuindo uma localização privilegiada e servida de infraestrutura urbana e acessibilidade.

232. Esta estratégia tinha como finalidade garantir o conjunto de intervenções sobre a Área de Intervenção Urbana - AIU equalizando os custos de desapropriações e possibilitando a conclusão das obras de forma mais ágil e em tempo reduzido. Esta alternativa foi dada em especial para as obras de alargamento da Rua Prudente de Moraes, ciente de sua valorização imobiliária e ampliação da qualidade urbana proposta para este trecho da Operação Urbana.

233. A ONU (Organização das Nações Unidas) sugere $12,00 \mathrm{~m}^{2}$ de área verde por habitante para que haja equilíbrio entre a quantidade de oxigênio e gás carbônico. 
Neste sentido, é notória a necessária ação do poder público sobre estas áreas, identificando e consolidando novos cenários e a discussão sobre o desenho urbano contemporâneo, ajustando as necessárias transformações do espaço construído e não construído, as possibilidades de se explorar as mais avançadas tecnologias da construção e a organização da cultura urbana gerada a partir dos novos conceitos sociais, econômicos e de apropriação do espaço. 
Figura 177. Vista da área da Operação Urbana Orla Ferroviária em 2005 e proposta de intervenção urbana

Fonte: DPP | SMPU | PMS, 2006
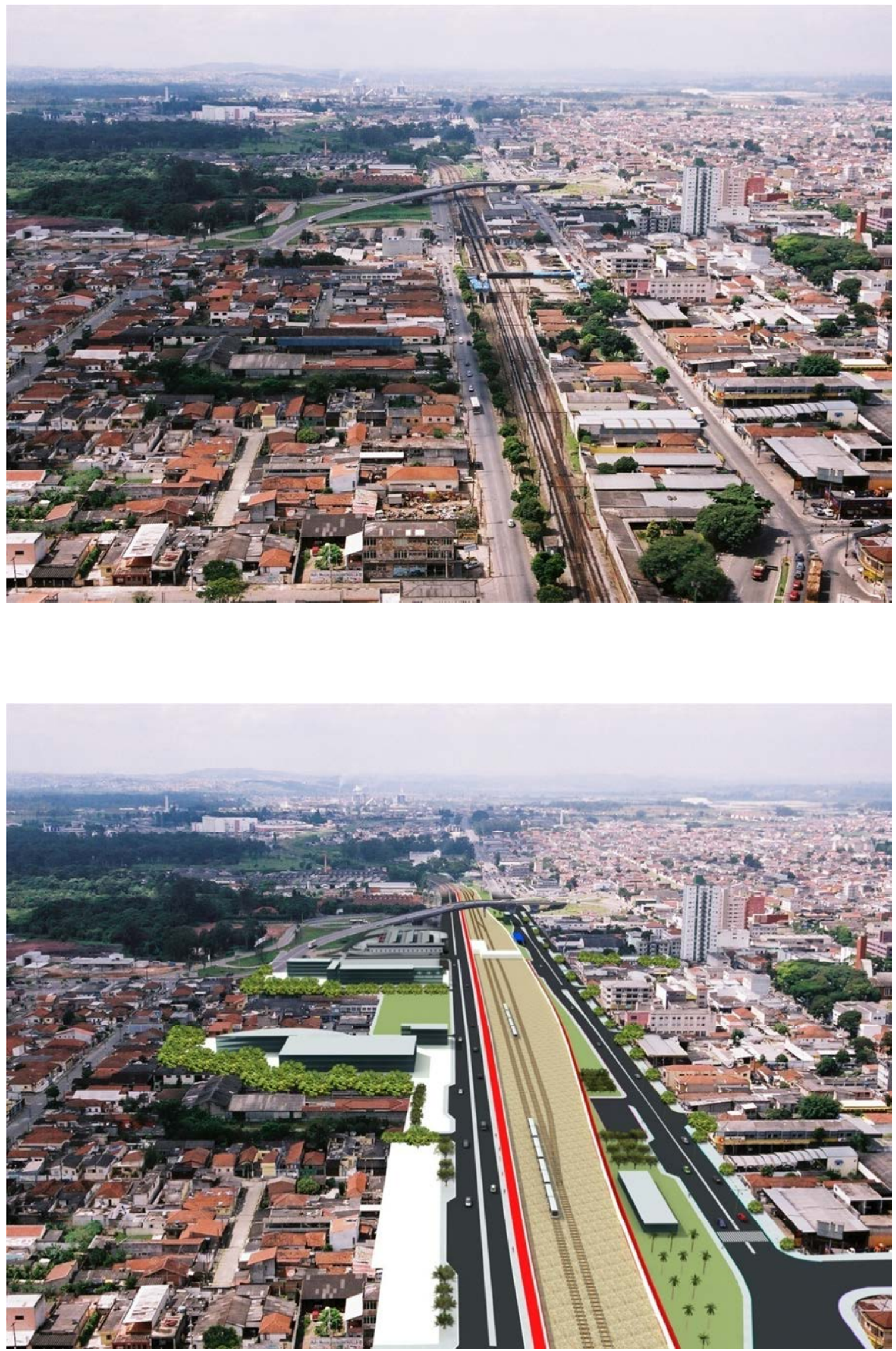


\subsection{LABORATÓRIO URBANO: mais de meia década de experiências sobre o solo}

Desde 2005, quando o poder público municipal iniciou os estudos de implantação da Operação Urbana Orla Ferroviária, o perímetro de intervenção é palco de discussões públicas, reestruturação urbana por meio de ações do poder público municipal, estadual e federal e o interesse da iniciativa privada em investir sobre este território que possui localização privilegiada em função de sua conectividade entre os equipamentos de mobilidade local, regional e metropolitana.

As primeiras ações buscaram compreender o território que deveria sofrer a intervenção cadastrando a situação fundiária, a forma com que o solo era utilizado até aquele momento, registrando as estruturas urbanas existentes e suas reais condições de funcionamento, assim como os principais equipamentos públicos e condições de atendimento, além das condições das áreas verdes e livres da área de intervenção. Neste primeiro momento, estes dados seriam fundamentais para o "mapeamento da morfologia urbana" existente e suas futuras ações a serem tomadas pela Prefeitura Municipal de Suzano.

Este território, que teve sua primeira ocupação ainda no início do século $X X$, implantado a partir da chegada da linha férrea que ligava a cidade de Mogi das Cruzes a leste com a capital do Estado - a cidade de São Paulo, aproximadamente $40 \mathrm{Km}$ deste ponto, foi se desenvolvendo a partir do primeiro traçado e implantação das quadras propostas pelo Conde Romariz, pouco se alterou em um século.

Morfologicamente as quadras a sul da linha de trem Central do Brasil (atual CPTM) se mantiveram com a mesma configuração urbana proposta, apenas a igreja foi implantada a uma quadra mais próxima à estação ferroviária, ${ }^{234}$ entretanto, o parcelamento inicialmente proposto em lotes de $2.500,00 \mathrm{~m}^{2}$ (dois mil e quinhentos metros quadrados) foi sendo subdivididos em pequenas parcelas resultando numa "colcha de retalhos" urbana, com uma diversidade grandiosa de terras divididas entre as famílias que migravam para este território.

Com uma ocupação mais tardia, as quadras a norte, mais especificamente com a chegada das primeiras indústrias na cidade, que se implantaram junto à linha férrea e provocaram o surgimento das vilas industriais como "suporte" a estes usos, tiveram sua transformação mais presente resultandoem formas urbanas "desastrosas" na construção dos cenários urbanos, no qual durante estas últimas quatro décadas, os investimentos da especulação imobiliária trataram de construir uma paisagem conturbada e desordenada urbanisticamente.

Assim sendo, a área delimitada como AIU (Área de Intervenção Urbana) se consolidou durante o século $X X$ numa região de grande diversidade em seu conjunto edilício, no entanto, com pouca atratividade paisagística, resultando num jogo de cenários urbanos com pouca atratividade a seus usuários e moradores; assim como num número

234. A quadra onde esta localizada a igreja da cidade foi construída inicialmente como uma capela particular da família Figueira, primórdios nesta região, onde mais tarde a mesma é repassada à Cúria Diocesana. 
reduzido de áreas verdes e lazer, onde a "Praça da Igreja" torna-se um dos poucos locais de lazer desta região.

Como já apontado acima, a Operação Urbana Orla Ferroviária tem por objetivo a requalificação do espaço urbano, seja ele público e/ou privado, e a ampliação das áreas livres de lazer para esta região e toda a cidade. Assim, há sete anos a Prefeitura Municipal de Suzano, através da Secretaria Municipal de Política Urbana - Diretoria de Projetos Públicos vem desenvolvendo os Planos e Projetos Urbanos sobre o perímetro estabelecido para receber as intervenções diretas do poder público, garantindo a aplicação dos mecanismos estabelecidos no Estatuto da Cidade através da aplicabilidade dos novos índices urbanísticos com o intuito de transformar os cenários urbanos existentes e consolidar uma nova vocação para esta área, onde o comércio e os serviços funcionem como elementos da dinâmica urbana do local e garanta a existência e ampliação das moradias sobre estes territórios.

O Plano Urbanístico proposto pelo poder público tinha como pressuposto a requalificação dos equipamentos de transporte existentes, como o Terminal Urbano Norte, construído em 2005, projeto do arquiteto paulista João Valente e a Estação Ferroviária, sob a responsabilidade da Companhia Paulista de Trens Urbanos - CPTM, de autoria do escritório carioca JBMC Arquitetura e Urbanismo, em construção desde 2011 e previsão de conclusão para 2013, ao qual a transformará numa estação intermodal entre o sistema de trem do Expresso Leste e a ligação da cidade de Mogi das Cruzes.

"'A arquitetura da estação respondeu a um programa bastante definido pela CPTM e a uma inserção urbana peculiar', conta Emiliano Homrich, arquiteto do escritório. Segundo ele, apesar de possibilitar o crescimento de Suzano, a criação da ferrovia separou o centro histórico ao sul e as novas áreas da cidade ao norte da linha férrea. Por isso, houve a necessidade de se criar uma nova estação, que interligasse essas duas regiões"(A. P. ROCHA 2010).

Outro importante equipamento de transporte urbano é o Terminal Urbano Sul, que se tornaránum elemento fundamental de integração entre os sistemas de transportes municipal e metropolitano, garantindo maior qualidade no transporte público da cidade e Região do Alto Tietê. Apesar dos projetos básicos estarem concluídos, a licitação das obras ainda esta condicionada à desapropriação da área proposta, colocada à EMTU (Empresa Metropolitana de Transportes Urbanos) como contrapartida aos investimentos municipais e ao compartilhamento de seu uso, no qual ainda não foi autorizado seu convênio entre as instituições públicas.

A leste do perímetro proposto, uma área privada ociosa, resultado da especulação da terra privada, foi desapropriada pelo poder público municipal para a implantação da Rodoviária da cidade e que cumprirá importante papel de "regenerador urbano" dos bairros lindeiros a este novo equipamento. Neste momento discutisse sua implantação por meio de outro mecanismo urbano previsto no Estatuto da Cidade, a Parceria Público-Privado - PPP, que possibilita a construção deste equipamento através de investimentos privados em troca de sua utilização por tempo determinado. 
Outros dois elementos também serão de suma importância para a reestruturação urbana desta região: o Shopping Popular como elemento organizador do comércio informal consolidado ao longo dos anos a partir da década de 80, e que ocuparam de forma irregular as calçadas da região central da cidade e se espraiaram ao longo dos principais eixos comerciais do centro urbano de Suzano, além da passarela sobre o eixo ferroviário que deverá ser demolida para a construção da nova estação ferroviária; e a implantação do Museu do Papel como referência as indústrias papeleiras da cidade que se implantaram durante o século $X X$, este edifício desenhado pela equipe de arquitetos da Diretoria de Projetos Públicos da Prefeitura Municipal de Suzano propõem a implantação de um conjunto edilício que abrigue não somente o acervo museológico, mas possibilite a configuração de um edifício que se relacione com o entorno de modo a requalificar o local inserido com uma diversidade de atividades relacionada ao tema proposto.

Por fim, após a década de 1970, um pequeno espaço com cerca de 2.000,00 $\mathrm{m}^{2}$ (dois mil metros quadrados) foi se configurando como a "Feira das Flores", confirmação da potencial produção de flores que a cidade adquiriu durante os anos, consolidando uma economia gerada por meio desta produção e exportação da "flor-de-natal" (nome científico Euphorbia pulcherrima). A feira das flores tornou-se referência de compra destes produtos e espaço de lazer aos finais de semana, atraindo moradores e visitantes a este espaço. A proposta do Plano Urbanístico da Operação Urbana Orla Ferroviária reforça esta dinâmica já presente na cidade e desenha o Mercado das Flores consolidando este elemento urbano e confirmando sua dinâmica como referência de turismo e lazer na cidade.

Quanto às áreas verdes do perímetro da Operação Urbana, concluímos que estas foram pouco representativas na dinâmica da área e com baixa qualidade urbana, com isto, o novo desenho urbano proposto aponta a necessidade de ampliar estes espaços e garantir mais espaços livres e lazer para o centro da cidade, além de garantir mais áreas verdes como parques e praças para Suzano.

Junto aos principais equipamentos de mobilidade urbana como a Estação Ferroviária e os dois Terminais Urbanos (Norte e Sul), uma grande faixa ocupadas por construções subutilizadas ou galpões vazios a mais de 20 anos darão lugar ao Parque Central onde estes equipamentos serão implantados sobre este "fio condutor verde" e ampliando significativamente as áreas verdes do centro urbano da cidade.

O Parque Central também cumprirá a função de "romper com a barreira visual existente entre os dois 'lados da cidade'"(VIEIRA 2010), ${ }^{235}$ o atual muro da linha férrea deverá ser substituído por um elemento de segurança "translúcido", abrindo a paisagem e rompendo com a barreira visual entre os dois setores da área de intervenção. Atualmente, estas áreas já foram desapropriadas pelo governo estadual e estão em processo de demolição para a construção da estação ferroviária, quanto à implantação do Parque Central deverá ser implantado no cronograma previsto pela OUOF.

235 . Tradução do autor, 2012

De romper la barrera visual entre los "lados de la ciudad". 


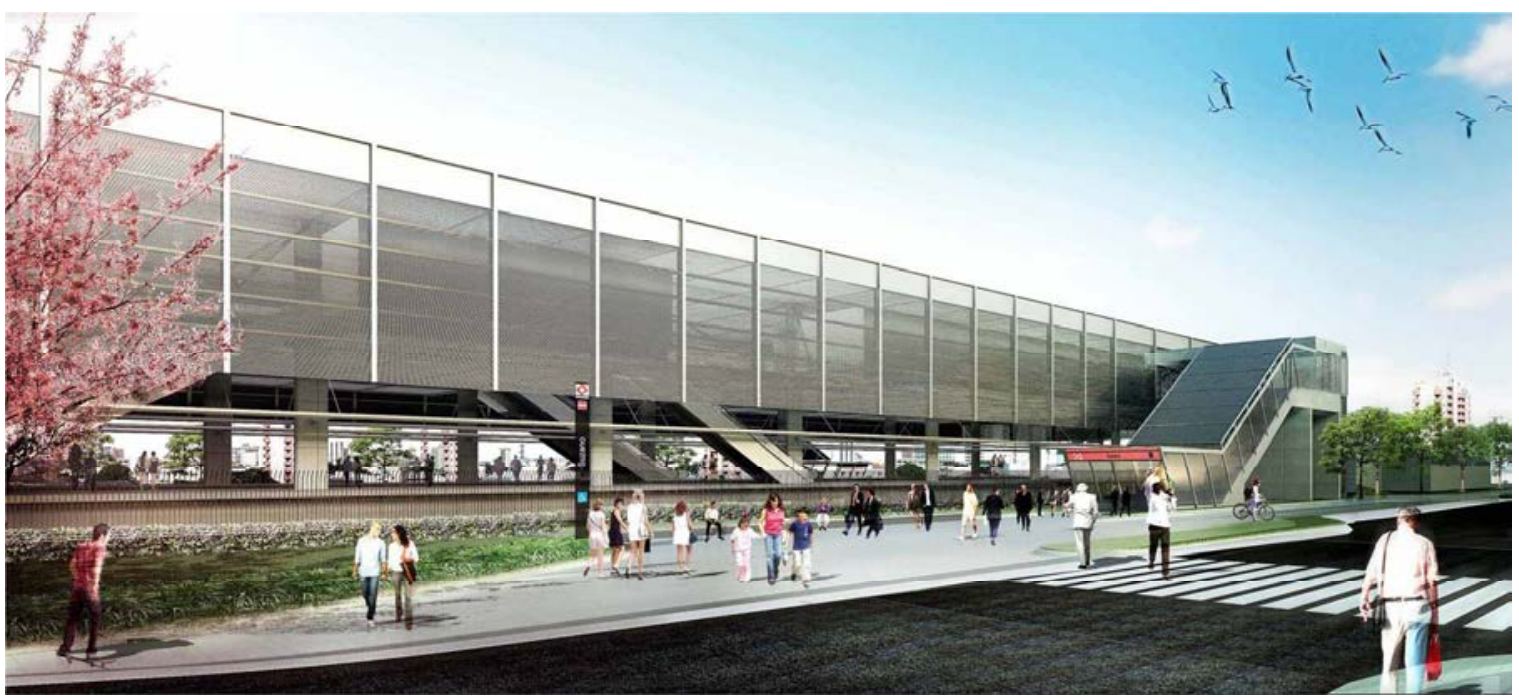

Figura 178. Nova Estação Ferroviária de Suzano, projeto do escritório JBMC Arquitetura e Urbanismo, 2010

Fonte: JBMC Arquitetura e Urbanismo

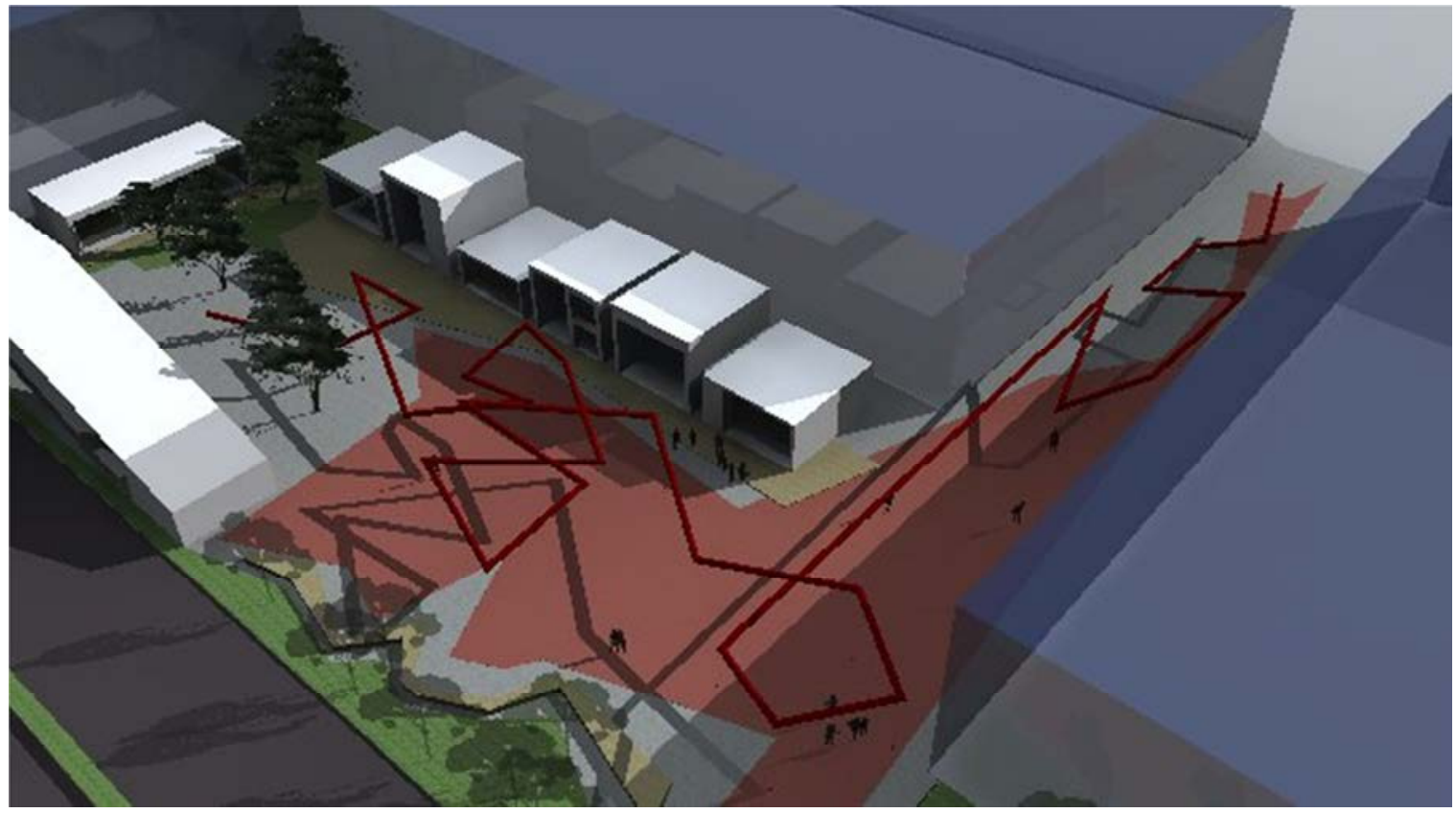

Figura 179. Projeto da Praça da Estação, de autoria da equipe técnica da PMS, 2010 Fonte: DPP | SMPU | PMS, 2010

Figura 180. Projeto do Shopping Popular, de autoria da equipe técnica da PMS, 2010

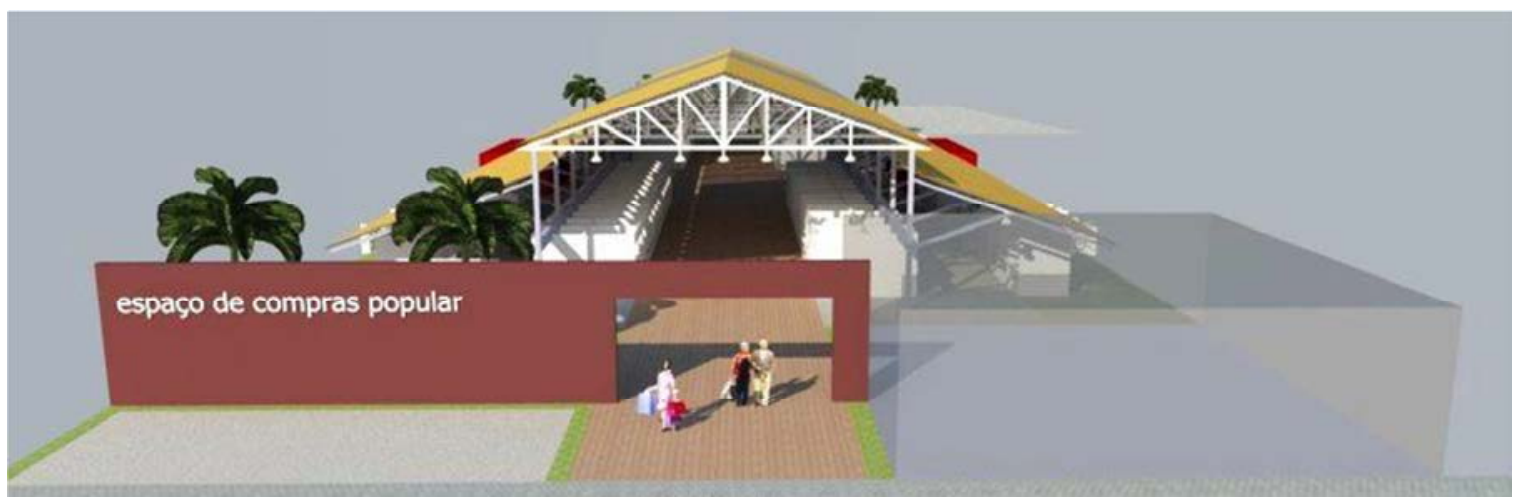


Com a proposta da nova estação ferroviária - CPTM, a Prefeitura Municipal de Suzano redesenhou as chegadas a este equipamento de transporte metropolitano onde a primeira quadra junto à estação e ao Parque Central receberá a "Praça da Estação", local de chegada e partida dos moradores e usuários desta cidade, e a implantação do "Passeio Público" como extensão dos percursos pedonais e ligação entre a Praça João Pessoa e o novo espaço urbano de referência da estação, um caminho onde o pedestre é o principal protagonista deste novo cenário redesenhado.

Por outro lado, a configuração do espaço construído deverá ser norteada pelo Plano Urbanístico de modo a reordenar a paisagem existente e criar "Novos Cenários Urbanos" no perímetro da Operação Urbana Orla Ferroviária, estimulados por uma morfologia urbana contemporânea e usos mistos, ampliando a dinâmica urbana sobre estes espaços e garantindo a maior permanência de pessoas durante o horário comercial e seu uso noturno através da implantação de um percentual em habitação verticalizada.

Para garantir a plena transformação deste perímetro, a estratégia urbana adotada considera a reformulação tipológica como ferramenta essencial e incentivo aos empreendedores imobiliários em busca de novas "formas urbanas" que justifiquem sua transformação neste setor da cidade. Para tanto, o Plano Urbanístico aponta as possibilidades do redesenho da morfologia urbana existente que venha a contribuir para a requalificação do espaço público e ampliar as possibilidades de permeabilidade sobre as quadras existentes.

Neste sentido, o estímulo à verticalização, em conjunto com a multiplicidade de usos dos edifícios, definindo tipologias que possibilitem o aproveitamento do embasamento para uso comercial e de serviços, além de possibilitar uma marquise para alargamento do passeio público e a prioridade ao pedestre em razão da "cidade humana", colocando o automóvel em segundo plano e abrindo a cidade para vislumbrar a nova paisagem recriada, tem como objetivo dar garantias de que o usuário e seus habitantes deverão ser os protagonistas das "Novas Formas Urbanas" e recriar uma "Nova Cidade", mais humana e qualitativa em seus espaços públicos e áreas verdes.

Esta Operação Urbana não tem a intenção de direcionar, ou mesmo impor, a uma tipologia estabelecida pelo poder público, mas tem como objetivo fomentar a transformação da paisagem e a regulamentação dos cenários urbanos por meio das possibilidades e "ensaios" que a equipe de arquitetos e urbanistas do poder público municipal vêm trabalhando ao longo destes oito anos e, ensaiando seus resultados como num Laboratório Urbano, a fim de garantir e acompanhar sua transformação de forma mais precisa, possibilitando medir seus resultados sobre o desenho da cidade como ferramentas de planejamento urbano integrado aos anseios dos moradores. Em primeiro plano, seus usuários que passam pela cidade diariamente em busca de uma grande diversidade de atividades (compras, serviços, lazer), e os agentes investidores do poder privado, ao qual se tornam interlocutores entre o conceito ensaiado e desejado pelo poder público e sua consolidação ao desenho da cidade. 
Figura 181. Evolução das intervenções urbanas previstass na Operação Urbana Orla Ferroviária e sua transformação da Forma Urbana: 1. situação encontrada em 2005; 2. construção do terminal urbano norte; 3. desapropriação e demolição de edifícios e espaços ociosos para a construção da nova estação ferroviária e equipamentos públicos; 4. Desapropriação de faixa edificada para a duplicação da av. dr. Prudente de Moraes; 5 . área resultante da demolição da faixa edificada; 6. construção de novos equipamentos públicos e parque central; 7. alteração da forma urbana nas quadras lindeiras num período de 10 anos; 8. alteração da forma urbana num período de $\mathbf{3 0}$ anos Fonte: DPP | SMPU | PMS, 2006
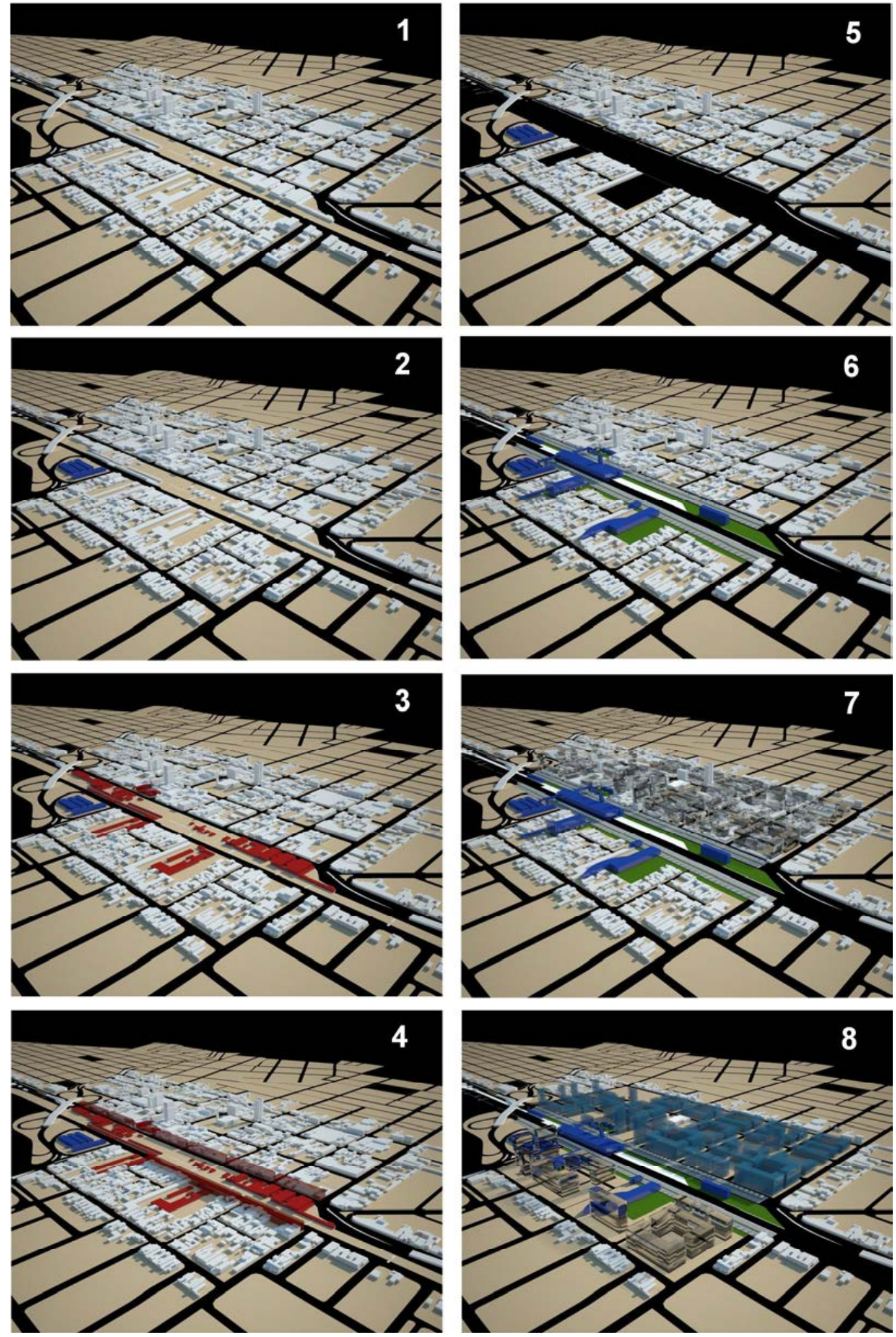
Por fim, vale ressaltar que por se tratar de uma "Operação Urbana Consorciada" ${ }^{236}$ entre os entes públicos e privados, e tendo como ator principal seus moradores e usuários, os resultados alcançados até o momento, nestes últimos anos, têm gerado um índice de satisfação de grande importância para o poder público municipal, em que foi possível confirmar que a necessária transformação deste trecho da cidade deve ser garantida em conjunto com seus atores e agentes públicos e/ou privados diretamente relacionados a este perímetro.

Apesar do curto período de aplicação dos instrumentos urbanísticos sobre o perímetro da Área de Intervenção Urbana - AIU, as dificuldades encontradas em trabalhar em conjunto com os demais órgãos públicos, em especial o Governo Estadual, que ainda permanece com o olhar direcionado aos problemas pontuais, além do retardamento da iniciativa privada em ver esta região da cidade como elemento urbano passível de transformação, entendemos que este trabalho ainda possui um longo caminho a percorrer para alcançar todos seus objetivos. No entanto, defendemos que o poder público tem por dever estimular a transformação do espaço construído e ampliar as possibilidades de novas formas urbanas para o desenho da cidade e tipologias capaz de atender a dinâmica da cidade contemporânea ao qual nos encontramos hoje.

236. A Operação Urbana não foi definida inicialmente como "Consorciada" por tratar a principio de investimentos públicos (municipal, estadual e federal) para a regeneração dos vazios urbanos a partir da implantação de grandes equipamentos de transportes públicos. Mais tarde, houve a necessidade de se discutir a reabilitação deste território a partir do espaço construído, sua tipologia e morfologia urbana desejada a partir das novas formas urbanas propostas. 



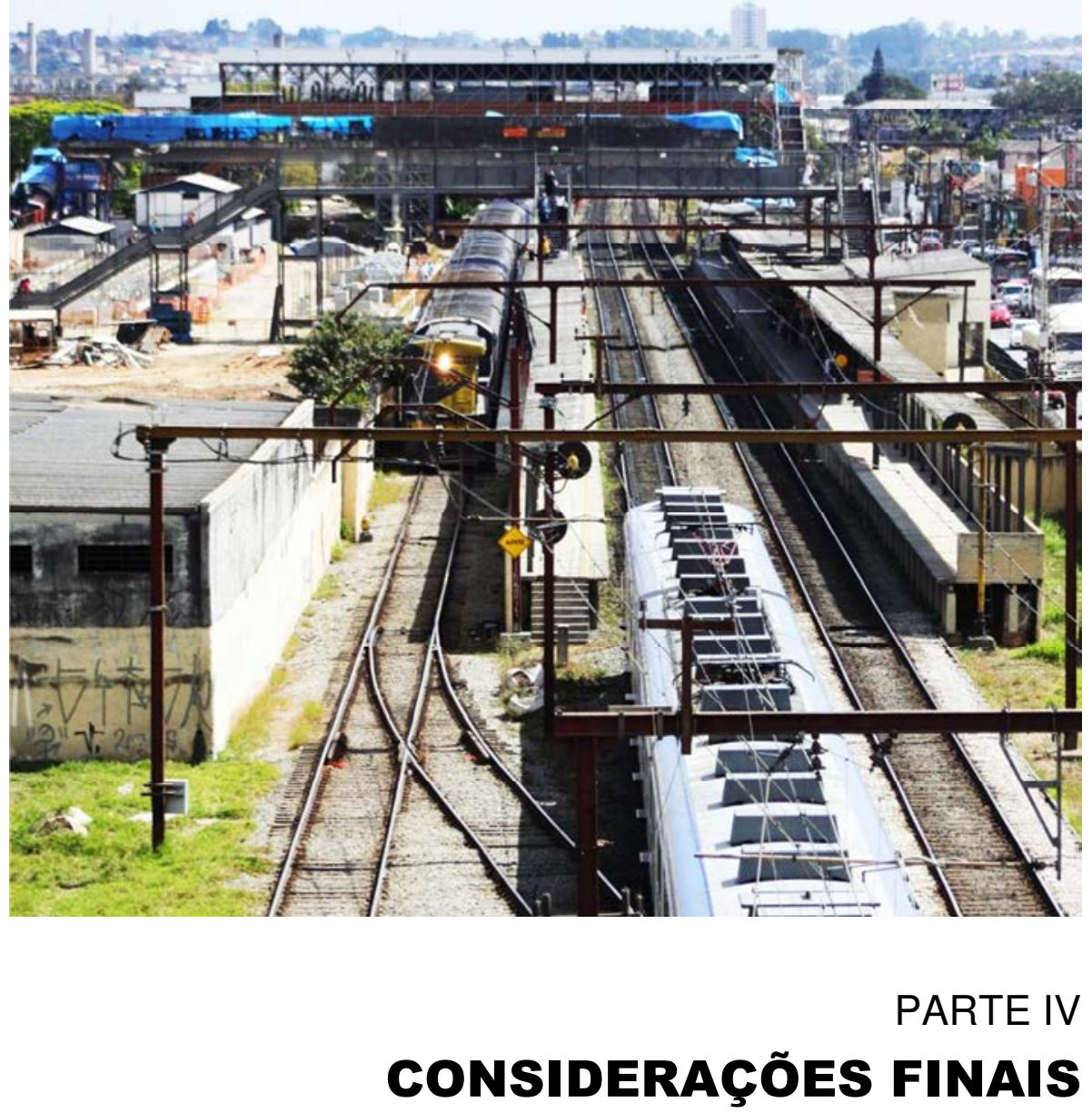





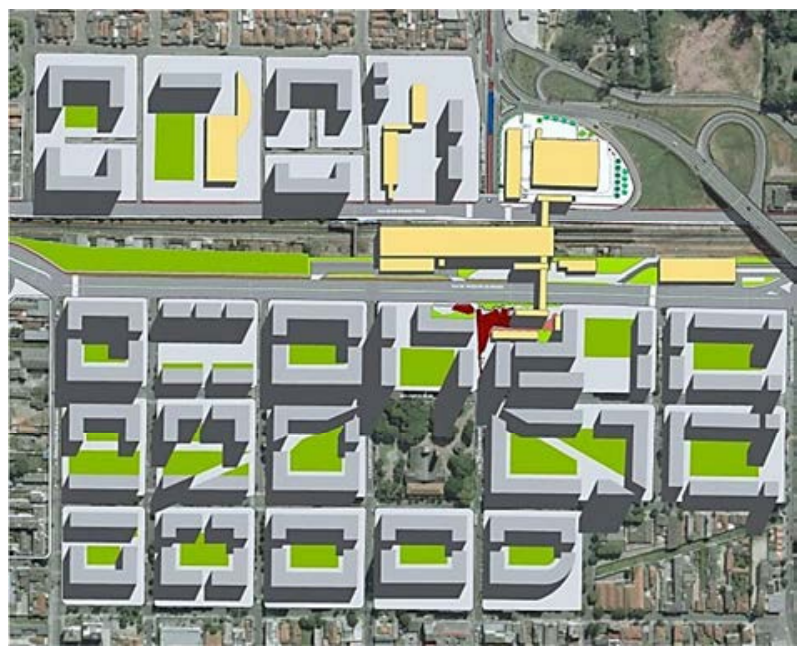

Capítulo 9

Territórios Experimentais 



\subsection{A Construção de Novas Formas Urbanas na Cidade Contemporânea}

"(...) temos que imaginar mil e um conceitos alternativos de cidade, temos que correr riscos desproporcionados, temos que nos atrever a ser profundamente acríticos, devemos aguentar a adversidade e perdoar a direita e a esquerda"

Arq. Rem Koolhass, 2002 Qué há sido del urbanismo?

Compreender a contribuição dos Grandes Projetos Urbanos Contemporâneos para a concepção de Novas Formas Urbanas sobre o tecido degradado, ocioso e desarticulado da dinâmica atual da cidade foi a motivação inicial desta pesquisa que nasceu a partir das indagações teóricas (docentes) e técnicas (profissional, como arquiteto e urbanista) que levaram a me aprofundar sobre a tese defendida em busca de respostas palpáveis sobre um objeto de estudo real, em aplicação e sobre minha responsabilidade, mesmo que parcial, dos resultados alcançados desde o início das análises, descobertas, propostas e "negociações" com os diversos agentes públicos e privados. Já os GPUs utilizados como "estudos de caso", colocados nesta pesquisa como objetos empíricos, deveriam contribuir para o aprofundamento das discussões e aplicabilidade nos Projetos Urbanos previstos na Operação Urbana Orla Ferroviária de Suzano, tendo ciência de que a simples "importação" das propostas e soluções correria o risco de desconsiderar os elementos históricos, sociais e culturais da área de estudo, mas por outro lado, entendendo que a utilização de determinadas "estratégias urbanas" seria passível de absorver de forma plausível e de grande valia para o "sucesso" das intervenções propostas pelo poder público municipal.

Ainda que o objeto de estudo fosse tratado como instrumento urbanístico denominado Operação Urbana, voltado a promover a transformação urbana em áreas lindeiras ao eixo ferroviário no trecho central da cidade de Suzano, durante o percurso de nossas pesquisas tal instrumento não se estabeleceu como Lei (específica ou complementar ao Plano Diretor), motivos determinados pelo panorama político da cidade desde a ascensão de um grupo de esquerda sobre o poder público municipal determinado a transformar a cidade num território mais justo e igualitário a todos seus habitantes e usuários, e que não cabe a esta tese (ao menos de forma direta). Entendemos que por não tratar de um instrumento urbanístico legal, deveríamos estudá-lo como Grande Projeto Urbano, com diretrizes e propostas de políticas públicas que pressupunham as transformações urbanas desejáveis - aquelas de interesse público - compreendidas principalmente na "modernização dos grandes equipamentos de transporte urbano, equipamentos de serviços públicos e de lazer e o ajuste e adequação do sistema viário existente" (PMS e FAUUBC 2006). Por outro lado, a absorção deste Projeto Urbano, de forma (in)-consciente, pelos agentes da cidade (moradores, comerciantes, usuários e visitantes), e de forma ainda mais presente pelos agentes públicos, nos leva a concluir, mesmo que de forma preliminar, que a instituição do instrumento urbanístico, neste caso, esta em segundo plano na afirmação da existência do "ente" da Operação Urbana Orla Ferroviária. Prova disto esta nas convicções e no discurso dos administradores públicos (prefeito, vice-prefeito e secretários) como nos candidatos ao cargo de chefe de 
governo municipal, em que a Operação Urbana, como demais projetos urbanos previstos para a cidade, são elucidados como estratégias de políticas urbanas para a cidade.

"O modo tradicional de pensar a cidade vinculada a uma concepção física e geográfica do espaço, reiterando raciocínios de delimitação, fixação ou permanência sobre o território hoje são substituídos por outras problemáticas como finanças, capacidade de conexão (sob diversos aspectos), nós, redes e velocidade de informações no qual caracterizam a Cidade Contemporânea de modo a atender as necessidades de um 'mundo' não somente globalizado, mas um planeta 'sem fronteiras', fruto de um acelerado avanço tecnológico em que no final do século XX e início deste novo milênio estamos passando"(VIEIRA 2011).

Em tempo, devemos estar cientes que nosso planeta esta cada vez mais "urbano". Como resposta a este fenômeno, as cidades vêm se desenvolvendo constantemente, por mais que sua estrutura urbana se mantenha "estática" durante o passar dos anos, sua forma urbana se altera por meio das edificações e a reconstrução da cidade com novos investimentos que configuram a paisagem urbana.

Marta Lagreca, em sua tese de doutorado, ao falar de suas experiências e estudos de caso sobre 22@ BCN declara:

"A prefiguração das quadras supõe uma configuração infra-estrutural precisa e uma nova subdivisão 'pública' do solo, determinada por esta configuração e pela proporcionalidade das superfícies do solo privado. Fixadas estas determinações e um padrão de implantação, cabe à arquitetura dar resposta dimensional, geométrica e construtiva em variações compositivas"(SALES 2008, p 225, grifo nosso).

Postoisto, antes de nos anteciparmos a qualquer hipótese conclusiva, a tese se centrou nos estudos sobre a Morfologia Urbana em busca de um fundamento analítico do desenho urbano contemporâneo, utilizando-se de teorias reconhecidas e principais correntes do pensamento urbanístico como Sitte, Lynch, Cullen, Aymonino entre outros que influenciaram direta ou indiretamente os estudiosos contemporâneos como Oriol Bohigas, que tem como premissa desvendar o "código genético" do lugar; Christian de Portzamparc que defende a teoria de uma reorganização urbanística através da compreensão das "Três Eras da Cidade"; Philippe Panerai que analisa a cidade a partir de dois pontos de vista - os "tecidos urbanos" e as "tipologias";as análises da forma como implicações éticas, sociais e políticas defendida por Josep Maria Montaner; SolàMorales com as análises sobre as formas de crescimento urbano a partir do conceito $\mathrm{P}+\mathrm{U}+\mathrm{E}$ (parcelamento, urbanização e edificação); as teorias de Manuel Gausa Navarro que propõem a "leitura da cidade em camadas", inicialmente de forma independentes, mas que sugerem uma leitura continua e inter-relacionadas entre elas.

As reflexões levantadas e defendidas por estes estudiosos da forma urbana ajudaram a trazer a discussão para a atualidade, na apreciação da construção das cidades, da ordem dos elementos urbanos (parcelamento, urbanização, edificação), como defendido por Solà-Morales (1997), das constantes tipologias na configuração urbana e de seu interesse como elementos de composição do espaço urbano - como "cosas" (SOLÀ- 
MORALES 2008)ou "sistemas arquitectónicos contemporáneos" (MONTANER 2008)e que, por fim, puderam contribuir para a construção de uma metodologia de análise sobre os "estudos de caso", no qual a leitura da cidade pode ser analisada sobre "Três Eixos de Investigação da Forma Urbana"(VIEIRA 2012), desvendando seus "potenciais e conflitos" em cada área de intervenção e seu território inserido na cidade.

No percurso da investigação os “estudos de caso'foram selecionados obedecendo à lógica do tema e sua relação com o objeto de estudo. Os Grandes Projetos Urbanos realizados em Barcelona (neste caso 22@ BCN e La Sagrera) elucidaram a transformação do território sob duas estratégias urbanas distintas; enquanto 22@ BCN tem sua reconversão (atividades TIC) a partir de critérios e obrigatoriedades estabelecidas pela Prefeitura garantindo a diversidade de usos além da habitação social, no entanto, a malha urbana, a configuração geométrica da quadra, permanece "intacta" garantida pelo Plano Cerdà (1859); as propostas para La Sagrera-Sant Andreu, a noroeste da cidade gótica, tem sua requalificação sobre o eixo ferroviário com a modernização do sistema de transportes (trem, metro, TAV) onde sobre este espaço nasce um grande parque linear com novos usos e a missão de "costurar o tecido urbano" por anos fragmentado; o antigo eixo de trilhos agora dá lugar ao espaço verde que amplia a qualidade urbana deste distrito. Paris Rive Gauche foi determinante para a compreensão dos instrumentos urbanísticos utilizados na França - as ZAC (Zone d'aménagement concerte - em francês) coordenadas pela SEMAPA (Société d'économie mixte d'aménagement de Paris) e sua forma de estruturar a paisagem por um modelo "negociado e controlado" pelo projeto urbano. Já o projeto urbano em si (PRG) nos garantiu uma melhor leitura e análise sobre um GPU ancorado sobre a estratégia de reconfigurar um território hostil e inseguro (13 $3^{e}$ arrondissement), hoje em um dos distritos mais qualificados na periferia de Paris e, apesar de ainda não concluso, não gerando o temeroso processo de gentrificação sobre este território. As experiências de Torino demonstraram a necessidade de reestruturar as antigas áreas industriais e vazios ferroviários obsoletos, agora sob uma nova ótica; o que antes era considerada uma "cidade industrial", busca-se agora a consolidação de uma "cidade de serviços e ensino tecnológico", o caso do GPU Spina 2 - eixo estruturador entre o centro da cidade e o aeroporto, redesenha o tecido urbano antes provocador das "fraturas urbanas", com novas estruturas urbanas e usos diversos, tendo como objeto central a nova Estação Porta Susa. Parece-me evidente o estudo destes projetos como contribuição ao objeto de estudo, mas também a realização das viagens de análise crítica sobre os estudos de caso como averiguação e confirmação a nossa tese, com isto os estudos apresentados ao longo do trabalho foram elucidativas e educativas às nossas convicções acadêmicas e profissionais.

Um dos desafios impostos aos Grandes Projetos Urbanos foi lidar com as áreas degradadas, subutilizadas ou ociosas, muitas vezes resultantes do "desmonte" das atividades econômicas central de uma cidade e em geral, responsável pela configuração espacial daquele território, como posto por Nuno Portas:

"O projeto urbano, numa primeira fase compreendida entre os anos 80/90, exercia esse papel, o de regenerar 'tecidos como alavancas para atrair novas atividades produtivas, de cultura e de lazer', entre outros fins" (PORTAS in MACHADO 2009, p 17). 
Figura 182. Transformação do tecido e sua forma urbana a partir dos Grandes Projetos Urbanos em Barcelona, Paris e Torino

Fonte: Google Earth, 2012
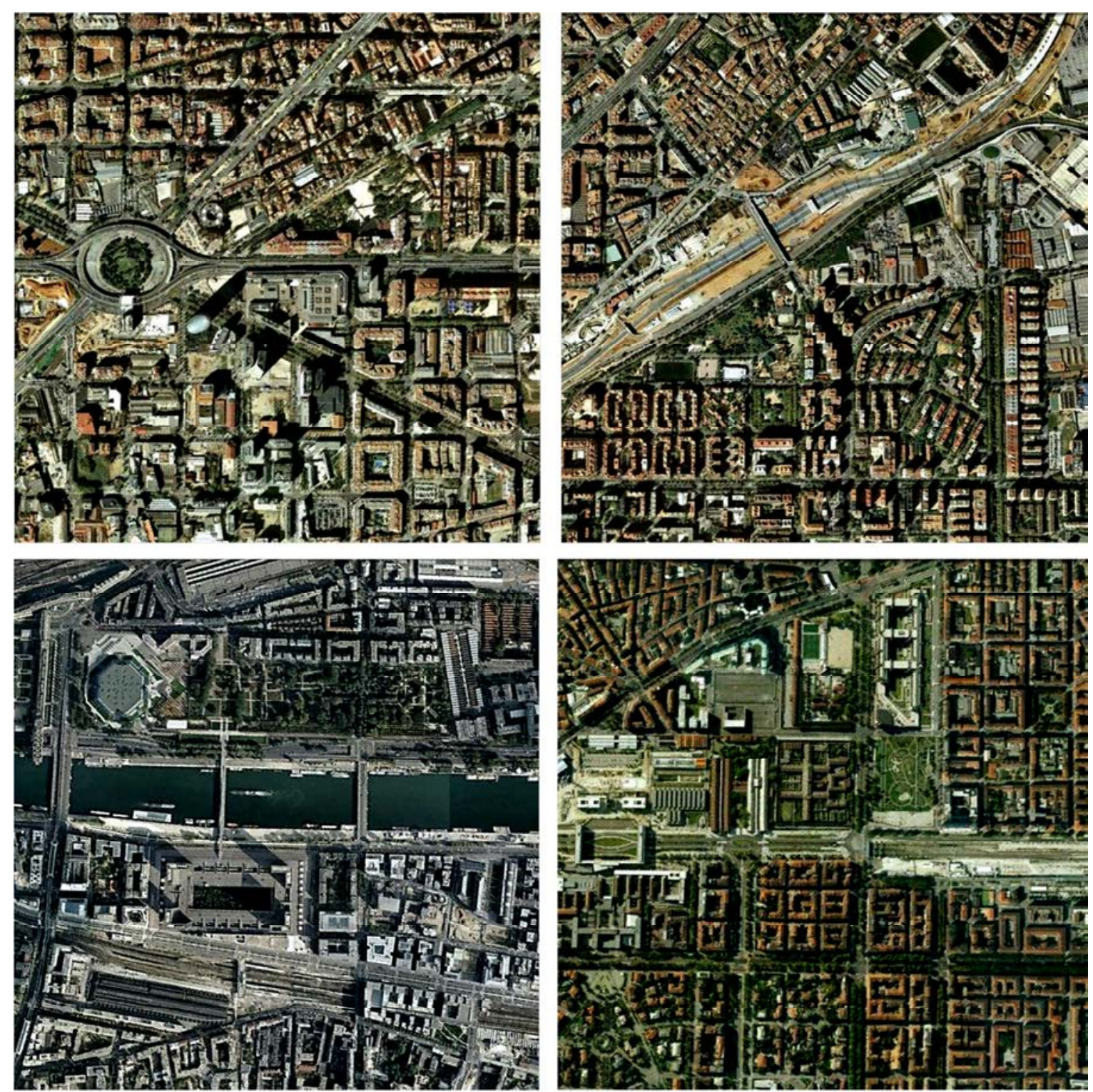
Sem dúvida, a escala e a condição da cidade contemporânea continuam questionando a forma com que os GPUs devem ser formulados e executados sobre estes territórios ociosos. A idealização destes projetos vai muito além da normatização e regulação. Muitas vezes concebidos como "alavancas" à regeneração de espaços ociosos ou a reutilização dos vazios urbanos, a ênfase das novas estruturas urbanas e suas construções está centrada em legitimar a qualidade das intervenções urbanas e do novo espaço público (vazio urbano) como um "sistema arquitectónico" (MONTANER 2008)capaz de gerar os benefícios urbanos, sociais e políticos.

Sob esta ótica, o objeto de estudo - Operação Urbana Orla Ferroviária de Suzano torna o elemento empírico deste estudo e análise da pesquisa, como objeto concreto capaz de observarmos, sentir, conduzi-lo e experimentá-lo a cada instante, no qual utilizamos dos elementos teóricos analisados no início da investigação (Morfologia Urbana) e das experiências "in loco" dos estudos de caso (GPUs) para subsidiar as indagações colocadas em nossa tese.

Neste sentido, focado na realidade de Suzano, o percurso analítico orientou-se sob duas linhas de raciocínio: a primeira de ordem teórica, ou acadêmica, no qual o objeto de estudo foi atribuído à condição de "cosa urbana" (M. d. SOLÀ-MORALES 2008)e "sistema arquitectónico" (MONTANER 2008) capaz de abstrair as estratégias e experiências estudadas na Parte II desta tese, não em sua integridade, mas na essência de seus potenciais e conflitos urbanos gerados. A segunda de ordem prática (profissional) coloca o objeto de estudo na condição de "objeto explorador da realidade", em que a investigação "propositiva" se apresenta como indutor das transformações urbanas.

Diante disto, a exploração dos conceitos teóricos e técnicos do compartilhamento equitativo da forma urbana e seus benefícios públicos e privados (especulação imobiliária) enfrentam diversas condicionantes em sua aplicabilidade plena como desejado pelo poder público municipal.

Do ponto de vista acadêmico, as indagações levadas a cabo nos cursos de Projeto de Urbanismo (FAUUBC, FAUUMC), no curso de especialização intitulado "Novas Espacialidades Urbanas na Cidade Contemporânea (FAUUBC) e nas pesquisas (Iniciação Científica) elaboradas nas duas instituições de ensino, possibilitou explorar com maior propriedade as estratégias e resultados alcançados, da mesma forma, que o "olhar acadêmico" desprendido dos preconceitos e limites, nos garantiram avançar sobre as análises e possibilidades conceituais, técnicas e operativas acerca dos Grandes Projetos Urbanos nas Cidades Contemporâneas, nos deparando com experiências diversas em suas estratégias, configuração urbana e resultado sobre o tecido urbano degradado e seu entorno existente, em suas diversas escalas. No caso da Operação Urbana Orla Ferroviária de Suzano, observamos que sua aplicabilidade esta centrada diretamente a regeneração de seus espaços públicos e privados a partir da modernização e implantação dos grandes equipamentos de transporte coletivo (local, regional, metropolitano); verificamos também que as propostas colocada pelo poder público, diferentemente de alguns projetos urbanos estudados, não possui como artifício a construção de um "projeto referência", de algum "arquiteto star", numa busca incessante da imagem publicitária, espetacular, da arquitetura e urbanismo verificado em diversos países. Em Suzano, pelo que concluímos a partir da compilação dos 
"estudos de caso", foi a configuração de novos espaços públicos (vazios urbanos) e a garantia de maior qualidade urbana para este território, fazendo disto, uma ferramenta de atração à novos investimentos privados a área de intervenção, apesar de não estabelecida legalmente este instrumento urbanístico. Percebemos ainda, que as propostas e o projeto urbano apresentado, em andamento desde 2005, tem como base os GPU elaborados e implantados a partir da década de 1980, isto deve ser visto como um elemento essencial na confirmação de "práticas bem sucedidas" e passível de ser aplicada sobre o eixo ferroviário de Suzano.

Do ponto de vista institucional e político, apesar desta pesquisa não se deter diretamente sobre este "posicionamento" entendemos sua importância nas condições de implantação do Projeto Urbano. Ainda assim, esta análise torna-se pertinente a situação com que este autor tem em relação ao objeto de estudo. Sob a ótica institucional, a garantia de sucesso deste projeto esta relacionada diretamente aos compromissos e interesses dos entes governamentais, particularmente os poderes públicos municipal e estadual, visto que a modernização e implantação dos grandes equipamentos de transportes, em sua maioria estão sobre responsabilidade do Governo Estadual, em que os interesses nem sempre são compartilhados, conflitando as estratégias de transformação urbana e no cronograma das obras. Sob a ótica política, seu principal pressuposto está na necessidade de "flexibilização" do zoneamento para o atendimento as demandas do setor imobiliário em relação às mudanças de uso e adensamento construtivo. É certo que a absorção do mercado imobiliário esta condicionado a outros dados como valor da terra e "benefícios" como a outorga onerosa ou a venda de CEPAC (Certificado de Potencial Adicional de Construção), condições estas não estabelecidas pela falta de legislação especifica sobre este tema e a "informalidade legal" da Operação Urbana Orla Ferroviária.

Do ponto de vista técnico, o Grande Projeto Urbano (Operação Urbana Orla Ferroviária) com sua aplicabilidade condicionada à "idéia-força" de transformação da forma urbana, rebatida ao território degradado e seu tecido urbano consolidado, possam se constituir como embrião da renovação urbana de todo o centro da cidade. Ainda que os esforços centrados na implantação das propostas urbanas previstas caminham em direção aos objetivos do projeto, é evidente a falta de uma legislação específica que assegure as relações de "equilíbrio" entre as atuações públicas e privadas, os coeficientes e compensações capazes de "gerenciar os bônus e ônus" da forma urbana e suas diferentes funções e atividades da cidade. Tal condição implica em compreender a área de intervenção como um "objeto único" em que os interesses (públicos e privados) não devem ser vistos como isolados e difusos, cada projeto deve ser entendido como uma "peça" que compõe todo o "conjunto urbano", baseado no critério do terreno virtual (projeto), para a realização de obras qualificadas como de interesse público. Ainda que as questões técnicas estejam vinculadas as decisões políticas e institucionais, acreditase que as medidas técnicas devem estar direcionadas à viabilização de um "Grande Projeto Urbano", formulado e implementado sob comando público, fundamental para o êxito urbanístico das transformações urbanas desejadas.

Como conclusão, cabe respondermos a última indagação desta investigação e prerrogativa de nossa hipótese levantada na tese, no qual os Grandes Projetos Urbanos possuem como prerrogativa de funcionar como elemento de "transformação e agregador" de novas formas urbanas sobre o território de intervenção direta e indireta. 
Para afirmarmos tal hipótese, espera-se que os estudos de caso (Barcelona, Paris, Torino) foram fundamentais para as análises e compreensão da transformação da morfologia urbana a partir da implantação dos GPU. A efetiva conclusão dos projetos estudados deve ser considerada como "marco zero" destas afirmações, visto que num primeiro momento, a leitura dos "estudos de caso" nem sempre apresentam as interferências e transformações além do perímetro da intervenção. Estas análises foram possíveis com as viagens de estudo e acompanhamento (sempre que possível) da implantação e consolidação destas intervenções. Dos Projetos Urbanos estudados podemos dizer que este fato defendido em nossa hipótese esta ligado diretamente as estratégias e leituras do território degradado. No caso de Barcelona, a proposta para 22@ BCN apesar de seu "sucesso" econômico é notória a desconexão da dinâmica e do tecido urbano em seu entorno, já na área de La Sagrera, o eixo ferroviário, renovado e reabilitado para o uso de lazer, serviços e habitação tem por pressuposto a costura do tecido degradado, apesar de não apontar pela possibilidade de transformação de seu entorno, visto que o eixo por si só, já garantirá a transformação da paisagem deste trecho da cidade. No caso de Paris, a ZAC PRG se responsabilizou em transformar significativamente a imagem deste distrito; colocado como uma experiência urbana bem sucedida sob vários aspectos (urbano, social e econômico); nas visitas de estudos à área de intervenção (2006 e 2012) percebe-se não somente a qualidade urbana neste trecho como também em seu entorno próximo, onde os espaços de lazer são continuamente utilizados (Parque Citroen) como o grande número de moradores da área e seu entorno que absorveram as novas formas urbanas propostas pelos arquitetos e urbanistas responsáveis. No caso de Torino, a proposta de intervenção para Spina 2 e a construção da nova estação ferroviária Porta Susa, impulsionou a iniciativa privada em conjunto com o poder público, em redesenhar todo o trecho urbano como os vazios urbanos e espaços ociosos, resultando em formas urbanas consistentes e adequadas as novas condições urbanas e econômicas da cidade (agora de caráter terciário e educacional) e consolidando uma nova centralidade sobre esta região da cidade.

Quanto ao objeto de estudo - Operação Urbana Orla Ferroviária de Suzano - apesar de sua aplicabilidade não estar condicionada à legislação específica e, ainda estar em implantação, principalmente dos elementos urbanos defendidos como "impulsionadores" da transformação urbana, entendemos que as propostas de requalificação urbana tendem a transformar a forma urbana em seu entorno direto, ainda que tais fatores estejam ligados aos espaços privados, e sob a responsabilidade de empreendedores imobiliários, cabe aos agentes organizadores do desenho urbano repensar a cidade em sua plenitude, não somente os espaços públicos (vazios urbanos) como os de caráter privado - os espaços construídos, a exemplo das experiências na França com as ZACs que compartilham as responsabilidades de desenhar as novas formas urbanas, em que os Grandes Projetos Urbanos são responsáveis em delinear o futuro de trechos da cidade como estratégia de desenho, ocupação, uso e conectividade com o tecido urbano existente. 
Figura 183. Situação atual da área de intervenção da Operação Urbana Orla Ferroviária Fotos: Elvis Vieira, 2012
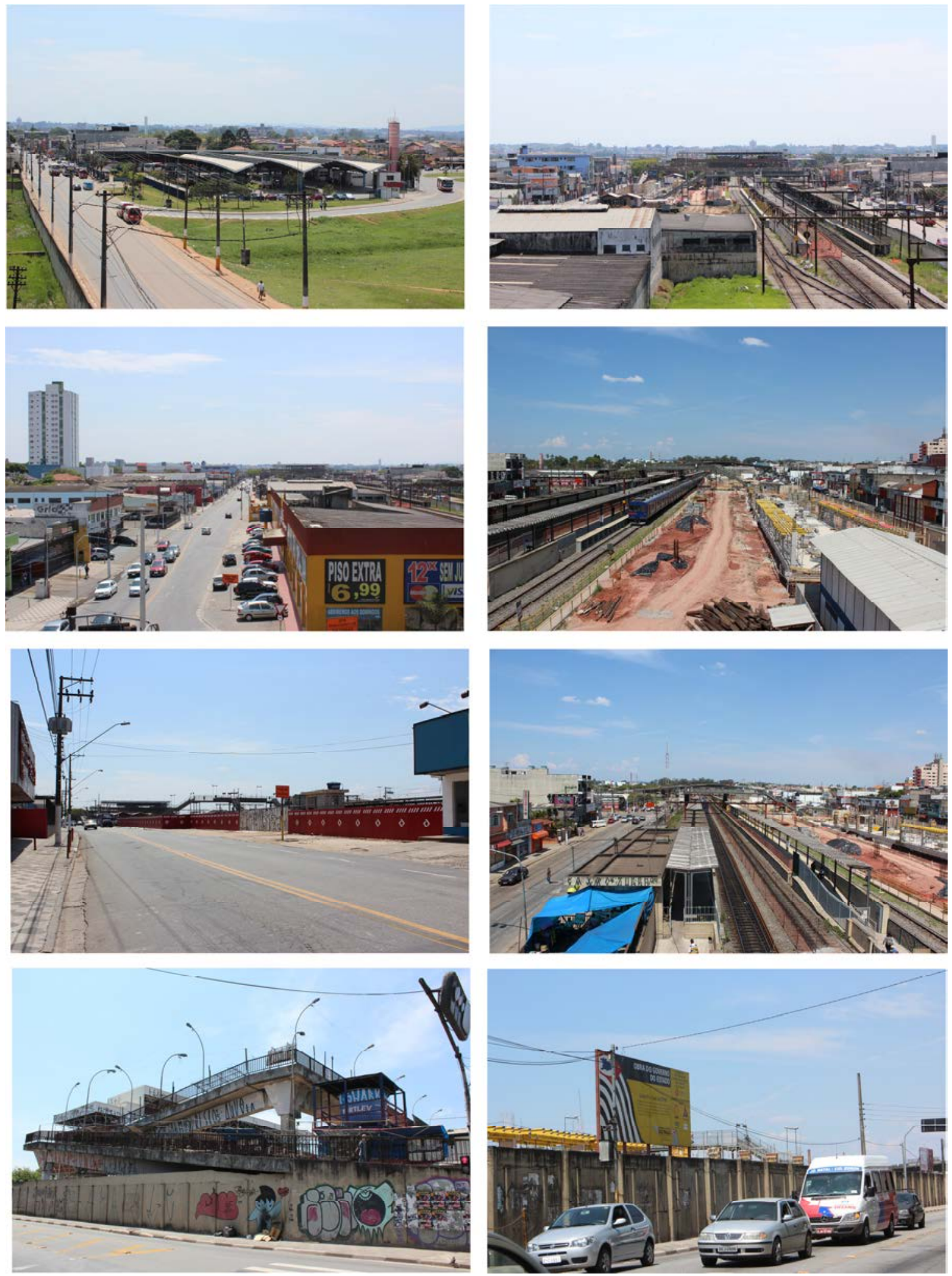
Esses são os desafios enfrentados aos Grandes Projetos Urbanos nas Cidades Contemporâneas, como comando e gestão destas Novas Formas Urbanas e organismos que sempre estarão em mutação.

"Como não vamos abandonar este lugar para fundar uma nova cidade, torna-se interessante à recomposição e a sobreposição da cidade".

Paulo Mendes da Rocha, 2012

Entrevista para a TV GNT, programa Casa Brasileira 
Figura 184. Vista do canteiro de obras da construção da Nova Estação Ferroviária de Suzano, 2012 Foto: Elvis Vieira, 2012

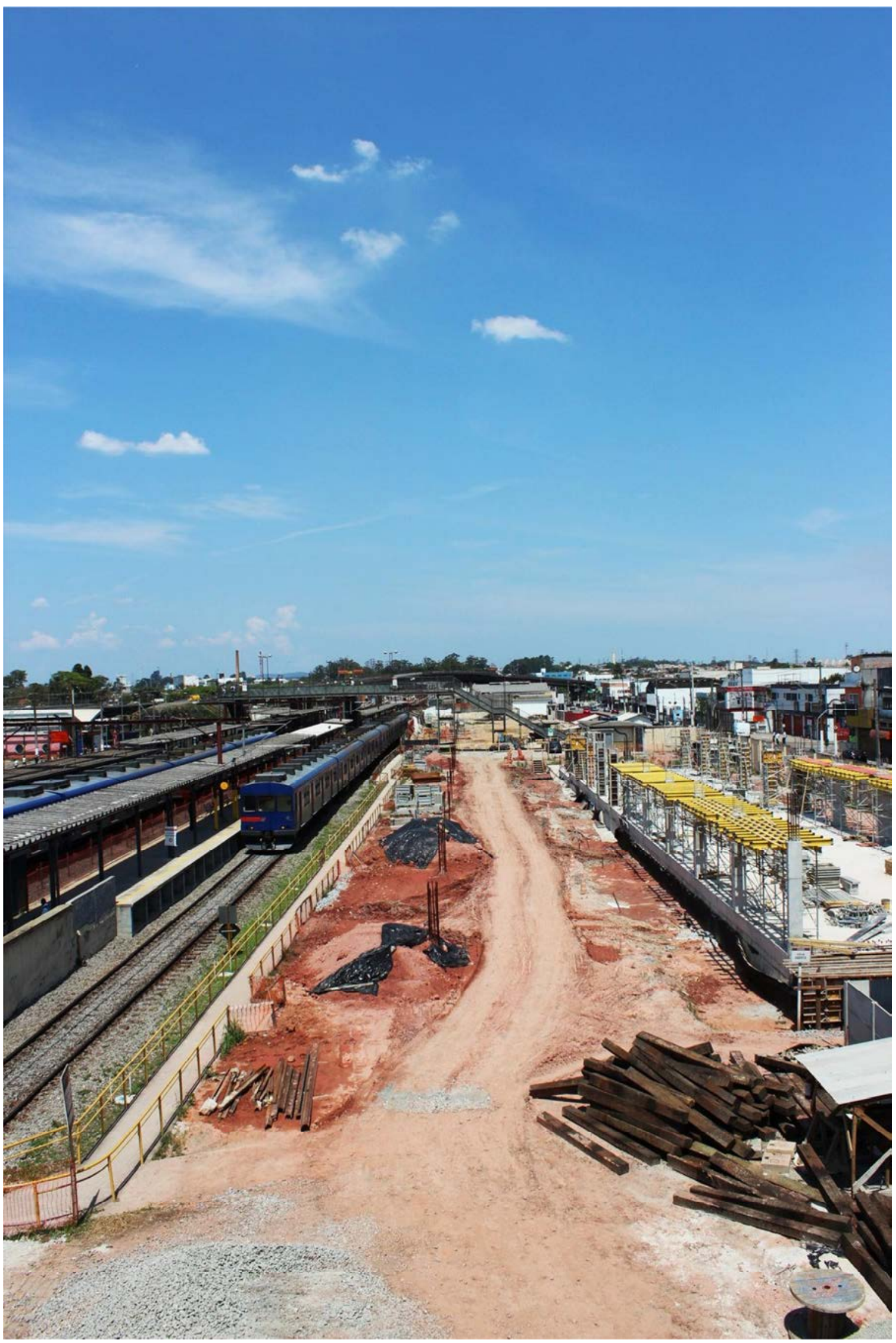




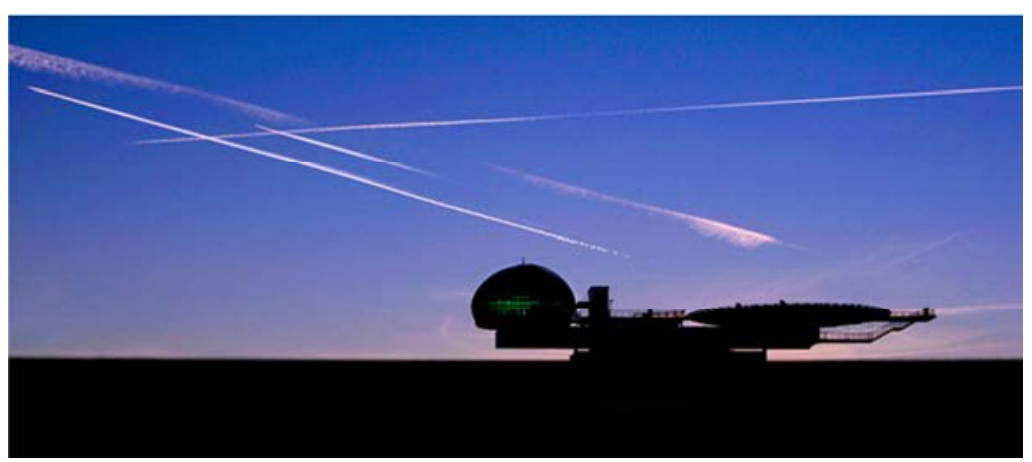

BIBLIOGRAFIA 

ACIOLY, Claudio, e Forbes DAVIDSON. Densidade Urbana: um instrumento de planejamento e gestão urbana. Tradução: Clauido ACIOLY. Rio de Janeiro: Mauad, 1998.

ADAM, Roberto Sabatella. "Analisando o conceito de paisagem urbana de Gordon Cullen." da Vinci 5, n. 1 (2008): 61-68.

AGENZIA TORINO 2006. Agenzia Torino 2006.2 s.d. http://www.agenziatorino2006.it/index.htm (acesso em 12 de fevereiro de 2012).

ALLEMANDI \& C., Umbero. TORINO Atlante dell' Architettura 1984-2008.Torino: Urban Center Metropolitano, 2008.

ANTONUCCI, Denise. "Morfologia Urbana e Legislação Urbanística: estudo de setores de bairros na cidade de São Paulo no período de 1972/2002." Tese de Doutorado, Faculdade de Arquitetura e Urbanismo, Universidade de São Paulo, São Paulo, 2005.

ARAGÃO, Solange. "O estudo dos tipos-interfaces entre tipologia e morfologia urbana e contribuições para o entendimento da paisagem." Geosul 21, n. 42 (jul./dez. 2006): 2943.

ARAÚJO, Natachy. "Obras da Perimetral da Copa começam em 2013." Diário de Suzano - Caderno Região, 20 de maio de 2012: 3.

ARGAN, Giulio Carlo. Projeto e destino.1를 Edição. Tradução: Marcos Bagno. São Paulo: Ática, 2001.

ARQUBACANA arquitetura, design, paisagismo, urbanismo e arquitetura corporativa. s.d. www.arqbacana.com.br (acesso em 18 de março de 2009).

ARTESP. Agência de Transporte do Estado de São Paulo. 2011. http://www.artesp.sp.gov.br/ (acesso em 23 de maio de 2012).

ASSOCIACIÓN BILBAO METROPOLI-30. La Estrategia. Bilbao: Bilbao 2010, 2009.

ASSOCIAZIONE TORINO INTERNAZIONALE. Piano strategico della città. Piano, Torino: Associazione Torino Internazionale, 2000.

ASSOCIAZIONE TORINO INTERNAZIONALE. "Torino Internazionale: Piano Strategico per la promozione della Città." The strategic plan of Torino 2000-2010, Torino, s/d.

AYMONINO, Carlo. El significado de las ciudades.Madrid: Herman Blume Ediciones, 1981.

—. L'Abbitazione Razionale: Atti dei Congressi CIAM 1929-30.Padua: Editora Mesilio, 1973. 
AZEVEdo, Suami Paula de. Retratos de Suzano - Canto Meu Recanto. Suzano, São Paulo: Oriom Editora, 2004.

-. Suzano - Estrada Real. Roteiro Emocionado da Minha Cidade.Suzano, SP: Alto Tietê, 1994.

BARCELONA, AJUNTAMENT DE. "22@Barcelona: el district de la innovació." Estat d'execució, Barcelona, 2008.

BARCELONA, AJUNTAMENT DE. PAD - Programa d'Atuació del Distrite de Sant Andreu 2008-2011. Proposta de Programa d'atuació del distrite informat favorablement pel consell plenari del distrite, Barcelona: Ajuntament de Barcelona, s/d.

BARCELONA, AJUNTAMENT DE, e 22@BCN. Pla Especial de Reforma Interior del Sector del Campus Audiovisual de la MPGM per a la Renovació de les Àrees Industrials del Poblenou - districte d'activitats 22@bcn. Aprovació Definitiva, Barcelona: Ajuntament de Barcelona , 2001.

BARCELONA, AJUNTAMNET DE. "Barcelona Sagrera Alta Velocitat." www.barcelonasagrera.com. 2010. www.barcelonasagrera.com (acesso em 10 de abril de 2011).

BENFATTI, Denio Munia. "Portzamparc e o urbanismo contemporâneo." Óculum, $n^{\circ}$ 9, Campinas, FAUPUC, 1997: 13-33.

BENSAID, Sylvie, e Thomas LE JEANNIC. "Des villes-marches aux villes nouvelles: 1789-1989." Resgards surl'île-de-France, novembro 1989: 13-20.

BERGER, Patrick. "Revisar o solo." In: $5^{a}$ BIA SP metrópole - Fórum de Debates, 47. São Paulo: Fundação Bienal de São Paulo, IAB, Centro Cultural Banco do Brasil , 2003.

BERTUGLIA, Cristoforo Sergio, Silvia Prodan TICH, e Andréa STANGHELLINI. Formazione di un'identitá urbana: il caso delle villes nouvelles. Milão: Franco-Angeli, 2004.

BILBAO RíA 2000. Bilbao Ría. s.d. www.bilbaoria2000.org (acesso em 2009 de abril de 29).

BOESIGER, Willy, e Hans GIRSBERGER. Le Corbusier: 1910-1965. Barcelona: Gustavo Gili, 1971.

BORGATTA, Vincenzo. "Riordinamento delle Stazioni Ferroviarie di Torino." Atti della Società degli Ingegneri e degli Architetti in Torino, Torino, 1906, 37-43.

BORJA, Jordi, e Zaida MUXÍ. Urbanismo en el siglo XXI: una visión crítica.Edição: Jordi BORJA, \& Zaida MUXÍ. Barcelona: Edicions UPC, 2004.

BRAGA, Milton Liebentrintt de Almeida. "Infra-estrutura e Projeto Urbano." Tese de Doutorado, Faculdade de Arquitetura e Urbanismo, Universidade São Paulo, São Paulo, 2006. 
BRAGA, Milton, e Paola Berenstein (entrevista) JACQUES. "Contra-ponto: Espaço público." NOZ Revista de Estudantes de Arquitetura da PUC-RIO, jan. 2008: 24-29.

BRESCIANI, Maria Stella. Leituras da cidade: a formação de um saber e de uma disciplina, o urbanismo. Campinas, 1998.

BRUSAROSCO, Carolina. "Suzano vai criar anel viário no Centro." Diário de Suzano, 26 de março de 2012: 6.

BUSQUETS, Joan. Barcelona: the urban evolution of a compact city.Rovereto: Nicolodi editore, 2005.

CARMANNINI, Stefano, e Alessandro CECCARELLI. "Grandi eventi e rilancio della città: il caso di torino." Macramè (Firenze University Press), n. 1 (2007): 33-39.

CASTILLOS, Andrés del. "La Sagrera culmina el ambicioso proyecto catalán de alta velocidad." El Periódico, julio 2010: 3.

CHALINE, Claude. Les villes nouvelles dans le monde.Paris: Presses universitaires de France, 1985.

CHOAY, Françoise. A regra e o modelo.São Paulo: Editora Perspectiva, 1985.

CITTÀ DI TORINO. Città di Torino: servizio telematico pubblico.19 de setembro de 1997. http://www.comune.torino.it/ (acesso em 12 de fevereiro de 2012).

CITTÁ DI TORINO. "Torino Work in progress: Towards 2001.” CD-rom, Torino, 2008.

CNM. Confederação Nacional dos Municipios . s.d. http://www.cnm.org.br/ (acesso em 04 de maio de 2012).

COMUNE DI BOLOGNA. s.d. www.comune.bologna.it (acesso em 16 de julho de 2011).

COMUNE DI TORINO. Cittá de Torino: servizio telematico pubblico. s.d. http://www.comune.torino.it/ (acesso em 17 de janeiro de 2012).

COMUNE DI TORINO. I/ Piano Regolatore Generale di Torino. Piano, Torino: Comune di Torino, 1995.

COMUNE DI TORINO. Piano Regolatore Generale di Torino. Piano, Torino: Comune di Torino, 1995.

CPTM. Companhia Paulista de Trens Metropolitanos . 2011. http://www.cptm.sp.gov.br (acesso em 08 de maio de 2012).

CULLEN, Gordon. Paisagem Urbana. São Paulo: Martins Fontes, 1983.

CURTI, Ilda. "La rigenerazione urbana a Torino." Rigenerazione urbana. s.d. http://www.comune.torino.it (acesso em 17 de janeiro de 2012). 
DAEE. Departamento de Águas e Energia Elétrica. s.d. http://www.daee.sp.gov.br/ (acesso em 12 de junho de 2012).

DAN, Su. "Urbanização e desurbanização." In: Fórum de Debates: 5ª Bienal Internacional de Arquitetura e Design de São Paulo, por Fundação Bienal de São Paulo, 22-33. São Paulo: Romano Guerra, 2003.

DANSERO, Egidio, Francesca GOVERNA, e Cesare EMANUEL. I patrimoni industriali. Una geografia per lo sviluppo locale. Milano: Franco Angeli, 2003.

D'ASCIA, Silvio. "Torino Porta Susa, PEC SPINA 2: Stazione Ferroviaria e Torre Servizi." Trimestrale del Laboratorio: Territorio Mobilità e Ambiente - TeMALab (Laboratorio Territorio Mobilità e Ambiente - TeMALab) 3 (dicembre 2010): 71-82.

DEBRASSI, Teresinha Maria Fortes Bustamantes. "Paradigmas e Teorias da Cidade: das reformas urbanas ao urbanismo contemporâneo - o caso de Barcelona. Dissertação de Mestrado." Campinas: FAU, Pontifícia Universidade Católica de Campinas, 2006.

del RIO, Vicente. Desenho Urbano e Revitalização na Área Portuária do Rio de Janeiro: a contribuição do estudo da percepção ambiental. Tese de Doutorado, São Paulo: FAUUSP, 1999.

—. Introdução ao Desenho Urbano no processo de planejamento. São Paulo: Pini, 1990.

DIÁRIO DE SUZANO. "Convênio com o BID garante verba para o maior parque linear do mundo." Caderno Região, 14 de julho de 2011: 2.

—. "Estado investirá R\$ 3,6 bi em Ferroanel." Caderno região, 23 de agosto de 2011: 2.

- "Suzano será muito favorecida com intervenção, diz Candido." Diário de Suzano Caderno Especial , 28 de agosto de 2011: 2.

—. "Ampliação da represa de Taiaçupeba vai beneficiar quatro cidades de SP." Diário de Suzano, caderno Cidades, 01 de setembro de 2010: 5.

DORO, Gabriele. "Suzano tem áreas para implantação de rede hoteleira para a Copa 2014." Diário de Suzano, 28 de janeiro de 2011: 3.

DUPUY, Gabriel. L'Urbanisme des réseaux: théories et méthodes. Paris: Ed. Armand Cohn, 1995.

El Centro Georges Pompidou de Paris. Jordi Garcés (apresentació i comentaris). DVD volume 2 (Arte Video) Editrama. Produção: Richard COPANS. 2005.

EMPLASA. Empresa Paulista de Planejamento Metropolitano. s.d. http://www.emplasa.sp.gov.br (acesso em 05 de maio de 2012).

EMTU. Emnpresa Metropolitana de Transportes Urbanos de São Paulo S.A. s.d. http://www.emtu.sp.gov.br (acesso em 08 de maio de 2012). 
FAUUSP e GOVERNO DE SÃO PAULO. Articulação arquitetônica e urbanística dos estudos de pré-viabilidade técnica, econômica e ambiental do Hidroanel Metropolitano de São Paulo. Estudo de Pré-viablidade, LABPROJ Grupo de Pesquisa Metrópole Fluvial | Secretraia Estadual de Logística e Transportes - Departamento Hidroviário, Universidade de São Paulo, Faculdade de Arquitetura e Urbanismo | Governo de São Paulo, São Paulo: FAUUSP, 2012.

FEI, Silvano. Nascita e sviluppo di Firenze città borghese. Firenze: G \& G Editrice, 1971. FERREIRA, Olavo Leonel. História do Brasil. São Paulo: Ática, 1995.

FERRO, Camilo Salazar. "Lectura de la Ciudad durante la Segunda Mitad del Siglo XX: el análisis urbano y la arquitectura." Maestría en Historia, Arte, Arquitectura y Ciudad, Departamento de Urbanismo y Ordenación del Territorio, Escuela Técnica Superior de Arquitectura de Barcelona - UPC, Barcelona, 2010.

FIGUEROA, Mario. Habitação Coletiva e Espaço Urbano 1938-1972. Tese de Doutorado. São Paulo: FAU - Universidade de São Paulo, 2006.

FRAMPTON, Kenneth. História Crítica da Arquitetura Moderna. São Paulo: Martins Fontes, 1997.

GAUSA, Manuel. OPEN Espacio Tiempo Información: arquitectura, vivienda y ciudad contemporanea. Teoria e Historia de un Cambio. Barcelona: Actar, 2010.

GRINBERG, Isaac. Mogi das Cruzes de 1601 a 1640. São Paulo: I. Grinberg, 1981.

GRINBERG, Isaac, 1922. Gaspar Vaz: fundador de Mogi das Cruzes.São Paulo, 1979.

GTT - GRUPPO TORINESE TRASPORTI. "Concorso di Idee Internazionale per La progettazione delle coperture degli accessi della Metropolitana Automatica di Torino Linea 1." Bando di Concorso di Progettazione, Torino, 2008.

HALL, Peter. Ciudades del mañana: historia del urbanismo en el siglo XX. Barcelona: Ediciones del Sebal, 1996.

HEREU, Jordi. "Nueva Centralidad Urbana." El Periódico, julio 2010: 6.

IBGE . Instituto Brasileiro de Geografia e Estatística. s.d. http://www.ibge.gov.br (acesso em 2012).

ISTAT - Istituto Nazionale di Statistica. ISTAT. 2011. www.istat.it (acesso em 16 de janeiro de 2011).

JEUDY, Henri Pierre. Espelho das Cidades. $1^{\underline{a}}$ edição. São Paulo: Casa da Palavra, 2005.

KOHLSDORF, Maria Elaine. "A Presença de Camillo Sitte." XI Encontro Nacional ANPUR, Salvador, 2005.

KOPP, Anatole. Quando o moderno não era um estilo e sim uma causa. São Paulo: Nobel, Universidade de São Paulo, 1990. 
LAMAS, José M. Ressano Garcia. Morfologia Urbana e Desenho da Cidade. Lisboa: Fundação Calouste Gulbenkian, Junta Nacional de Investigação Científica e Tecnologica, 1992.

LANGENBUCH, Juergen Richard. "A Estruturação da Grande São Paulo - estudo de geografia urbana. Tese (Doutorado)." FFCL, Universidade de Campinas, Rio de Janeiro: Fundação IBGE, 1971.

LEITE, Carlos. "Cidades 2010 + 25." AU - Arquitetura e Urbanismo, n. 197 (agosto 2010).

—. Cidades sustentáveis, cidades inteligentes. Porto Alegre: Bookman, 2012.

LEONE, Simone [et al.], e [prefácio de Suami Paula de Azevedo]. Memórias de Suzano: histórias e fotos de todos os tempos, do vilarejo à cidade grande. 1. Ed. Suzano, SP: Diário do Alto Tietê, 2009, il.

LORENZO, Herrera Macarena. "El gran 'nido' del AVE en Barcelona." Revista Ministerio de Fomento, maio de 2010: 12-18.

LYNCH, Kevin. A Imagem da Cidade. São Paulo: WMF Martins Fontes, 2010.

MACHADO, Denise Pinheiro (org). Tipologias e projetos urbanos na cidade contemporânea. Vols. II, Coleção Arquitetura Urbana Brasileira. Porto Alegre: Marcavisual, 2009.

MALERONKA, Camila. "Projeto e gestão na metrópole contemporânea: um estudo sobre as potencialidades do instrumento 'operação urbana consorciada' à luz da experiência paulista." Tese de Doutorado, Arquitetura e Urbanismo , Universidade São Paulo, São Paulo, 2010.

MANGINI, Marcilene. "Região norte de Suzano torna-se alvo da verticalização imobiliária." Diário de Suzano, 17 de julho de 2011: 3.

MIANA, Ana Chistina. Adensamento e Forma Urbana: inserção de parâmetros ambientais no processo de projeto. Tese de Doutorado. São Paulo: FAU - Universidade de São Paulo, 2010.

MONTANARI, Guido. "Torino 1995-2006: trasformazioni urbane o grande 'sacco'?" metropolis - Rivista Online. s.d. http://www.Ismetropolis.org/ (acesso em 18 de janeiro de 2012).

MONTANER, Josep Maria. Depois do Movimento Moderno: Arquitetura da Segunda Metade do Século XX. Barcelona: Gustavo Gili, 2007.

—. Sistemas arquitectónicos contemporáneos. Barcelona: Gustavo Gili, 2008.

MONTANER, Josep Maria, e Zaida MUXÍ. Arquitectura y Política: ensayos para mundos alternativos. Barcelona: Gustavo Gili, 2011. 
MORANDI, Maurizio. "Progetto urbano e progetto urbanistico:." Macramè (Firenze University Press), n. 3 (2009): 85-88.

MORRIS, A.E.J. Historia de la Forma Urbana: desde sus origenes hasta la revolucion industrial. 5ª Edição. Barcelona: Gustavo Gili, 1995.

MOUDON, Anne Vernez. "Urban morphology as an emerging interdisciplinary field." International Seminar on Urban Form. 1997. http://www.urbanform.org (acesso em 26 de agosto de 2011).

NATIONAL GEOGRAPHIC. National Geographic. 2011. http://www.nationalgeographic.com/ (acesso em 2012 de agosto de 2012).

NOBRE, Eduardo Alberto Cusce. Reestruturação Econômica e Território: expansão recente do terciário na marginal do rio Pinheiros. Tese de Doutorado, Faculdade de Arquitetura e Urbanismo, Universidade de São Paulo, São Paulo: Universidade de São Paulo, 2000.

OHTAKE, Ruy. Ruy Ohtake Arquiteto.2009. http://www.ruyohtake.com.br (acesso em 26 de maio de 2012).

ONU. United Nations. s.d. http://www.un.org (acesso em 19 de agosto de 2012).

PANERAI, Philippe. Análise Urbana. Tradução: Francisco Leitão, \& revisão técnica de Sylvia Ficher. Brasília: Universidade de Brasília, 2006.

PANERAI, Philippe, Jean-Charles DEPAULE, e Marcelle DEMORGON. Analyse Urbaine. Marselle: Collection Eupalino, Éditions parenthèses, 1999.

PARIS RIVE GAUCHE (PRG). Paris Rive Gauche.2008. www.parisrivegauche.com (acesso em 23 de maio de 2011).

PAULINO, Sandra. "Marcelo Candido faz balanço do ano e destaca projetos para 2010 ." Diário de Suzano, 23 de Dezembro de 2009: 5.

PENNA, José Osvaldo de Meira. Quando mudam as capitais. Rio de Janeiro: IBGE, 1958.

PMMC. PREFEITURA MUNICIPAL DE MOGI DAS CRUZES. s.d. www.mogidascruzes.sp.gov.br (acesso em 11 de março de 2010).

PMS | FUPAM. Projeto de Lei Complementar no 015-07/08 / Plano Diretor Participativo. Relatório Final, Suzano: Prefeitura Municipal de Suzano e Fundação para a Pesquisa em Arquitetura e Ambinete, 2007.

PMS. Prefeitura Municipal de Suzano. s.d. www.suzano.sp.gov.br (acesso em 27 de janeiro de 2010).

PMS. Programa Cidade das Flores. Encarte, Suzano: Prefeitura Municipal de Suzano | Secretraia de Comunicação Social, 2005. 
—. Suzano: Cidade das Flores. Suzano: Prefeitura Municpal de Suzano, 2006.

PMS, e FAUUBC. Projetos Urbanos para a Cidade de Suzano. Edição: Decio AMADIO. Mogi das Cruzes: Universidade de Braz Cubas -, 2006.

PORTOGHESI, Paolo. Depois da Arquitetura Moderna. São Paulo: Martins Fontes, 2002.

PORTZAMPARC, Christian de. "A terceira era da cidade." Óculum, no 9, Campinas, FAUPUC, 1997: 35-49.

PORTZAMPARC, Christian de. "L'îlot ouvert laisse passer la lumière et permet la diversité des architectures." TreizeUrbain: Le Magazine de la SEMAPA, n. 4 (Juillet Septembre 2010): 8-9.

PREFEITURA MUNICIPAL DE SUZANO. Plano Cicloviário de Suzano. Suzano: Secretaria Municipal de Política Urbana - Diretoria de Projetos Públicos, 2011.

PREFEITURA MUNICIPAL DE SUZANO. Suzano Cidade das Flores: Cultura. Catálogo de Projeto apresentado no I Fórum de Cooperação Descentralizada Franco-brasileira (Marseille-Farnça), Suzano: Prefeitura Municipal de Suzano, Secretaria Municipal de Comunicação, 2006.

REIS FILHO, Nestor Goulart. Quadro da Arquitetura no Brasil. 11ª Edição. São Paulo: Perspectiva, 2006.

REIS, Almir Francisco. Permanências e Transformações no Espaço Costeiro: formas e processos de crescimento Urbano-turístico na Ilha de Santa Catarina. Dissertação de Mestrado, São Paulo: FAUUSP, 2002.

RENZO PIANO . Renzo Piano Building Workshop. s.d. http://www.rpbw.com/ (acesso em 04 de março de 2012).

ROCHA, Ana Paula. "JBMC projeta nova estação da CPTM em Suzano." PINIWEB. 10 de maio de 2010. http://www.piniweb.com.br (acesso em 19 de setembro de 2010).

ROSSI, Aldo. A arquitetura da cidade. $2^{2}$ Edição. São Paulo: WMF Martins Fontes, 2001.

SALES, Marta Maria Lagreca de. Projeto Urbano: Opção Metodológica e Algumas Práticas. Dissertação de Mestrado, São Paulo: FAUUSP, 1999.

SALES, Marta Maria Lagreca de. Territórios de Intermediação: uma hipótese para a análise e o projeto da cidade contemporânea. Tese de Doutorado, São Paulo: FAU, Universidade de São Paulo, 2008.

SALES, Pedro Manuel Rivaben de. Santos: a relação entre o porto e a cidade e sua (re)valorização no território macrometropolitano de São Paulo. Tese de Doutorado, São Paulo: FAU - Universidade de São Paulo, 1999.

SASSEN, Sashia. "Urban Economies and fading distances." Megacities. 2005. http://www.megacities.nl (acesso em julho de 2012). 
SASSEN, Saskia. "As diferentes especializações das Cidades Globais." Vitruvius. s.d. www.vitruvius.com.br/arquitextos (acesso em 2009 de fevereiro de 09).

SEADE. Fundação Sistema Estadual de Análise de Dados. 2010. http://www.seade.gov.br (acesso em 08 de maio de 2012).

SEMAPA . Rapport Annuel, Paris, 2007.

SEMAPA. "PARCOURS Paris Rive Gauche: À la découverte d'un nouveau quartier." Paris: Semapa Direction de la communication, setembro de 2008.

SICCA, Paolo. Historia del urbanismo - el siglo XIX. Madrid: Edición Española, Instituto de Estudios de Administración Local, 1981.

SIMÕES JUNIOR, José Geraldo. "O Ideário Haussmanniano e sua Difusão no Brasil: os Projetos Urbanos para as Capitais Brasileiras no início da República." XIII Encontro da Associação Nacional de Pós-Graduação e Pesquisa em Planejamento Urbano e Regional. Florianópolis, 25 a 29 de maio de 2009.

SITTE, Camillo. A Construção das Cidades segundo seus Princípios Artísticos. São Paulo: Ática, 1992.

SOLÀ-MORALES i RUBIÓ, Manuel de. Las formas de crecimiento urbano. Barcelona: Edicions de la Universitat Politècnica de Catalunya, SL, 1997.

SOLÀ-MORALES, Ignaci Rubió. "Terrain Vague.” Anyplace, 1995: 118-123.

SOLÀ-MORALES, Manuel de. De cosas urbanas . Barcelona: Gustavo Gili, 2008.

SOMECKH, Nadia, e Juliana Di Cesare Margini MARQUES. "Reconversão Industrial e Projetos Urbanos: a Experiência Internacional e o caso da Área do Brás, em São Paulo." III Fórum de Pesquisa FAU. Mackenzie. São Paulo, 2007.

SOMEKH, Nadia, e Candido Malta CAMPOS NETO. "Desenvolvimento local e projetos urbanos." vitruvius. abril 2005. http://www.vitruvius.com.br/revistas/read/arquitextos/05.059/470 (acesso em 29 de maio de 2011).

SORIA Y PUIG, Arturo. Cerdà. As cinco bases de la teoría de la urbanización.Barcelona: Electa, 1996.

SOUZA, Carlos Leite de. "Fraturas Urbanas e a Possibilidade de Construção de Novas Territorialidades Metropolitanas: a Orla Ferroviária Paulista." Tese de Doutorado, Faculdade de Arquitetura e Urbanismo, Universidade São Paulo, São Paulo, 2002.

STUDIO AREP. AREP Group. 2004. www.arep.fr (acesso em 10 de março de 2012).

TALARICO, Antonio. Gli studi di fattibilità nella valutazione dei grandi progetti. II caso dello stabilimento Fiat-Lingotto a Torino. Tesi di Laurea, Torino: Politecnico di Torino Facoltà di Architettura, 2003. 
TARALLI, Cibele Haddad. Ambiente construído e Legislação: o visível e o imprevisível. Tese de Doutorado, São Paulo: FAUUSP, 1993.

TAUNAY, Affonso de E. História das Bandeiras Paulistas. São Paulo: Melhoramentos, 1961 (3 tomos).

TERÁN, Fernando de. Planeamiento urbano en la España contemporánea.Barcelona: Editorial Gustavo Gili, 1978.

TOLEDO, Benedito Lima de. São Paulo: três cidades em um século. 3 ed. ver. e ampl. São Paulo: Cosac \& Naify, Duas Cidades, 2004.

TREVISAN, Ricardo. "Cidades Novas (Tese de Doutorado)." Tese de Doutorado, Programa de Pós-Graduação em Arquitetura e Urbanismo, Universidade de Brasilia, Brasilia, 2009.

ULTRAMARI, Clovis, e Denis Alcides REZENDE. "Grandes projetos urbanos: conceitos e referenciais." Ambiente Construído 7, n. 2 (abr/jun 2007): 7-14.

UNWTO. World Tourism Organization UNWTO. s.d. http://www2.unwto.org/ (acesso em 24 de maio de 2011).

VELOCITAT, BARCELONA SAGRERA ALTA. "Barcelona Sagrera Alta Velocitat." novembro de 2009. www.barcelonasagrera.com (acesso em 13 de abril de 2011).

VENTURI, Robert. Complexidade e contradição em arquitetura. Tradução: Alvaro Cabral. São Paulo: Martins Fontes, 1995.

VIEIRA, Elvis José. "A Construção de Novos Cenários Urbanos na Cidade Contemporânea." I ENANPARQ: Arquitetura, Cidade, Paisagem e Território. Rio de Janeiro, 29 de novembro,03 de dezembro de 2010.

- "Construção de Novos Cenários Urbanos na Cidade Contemporânea: o caso Projeto Nova Luz em São Paulo e as Olimpíadas de 2016 no Rio de Janeiro - Brasil." Actas da Conferência Internacional PNUM 2012 - Portuguese Network of Urban Morphology, 5-6 de julho de 2012: 691-724.

-. "Dinâmicas Urbanas que redesenham a Morfologia da Cidade: o bairro de Santa Cecília." Actas da Conferência Internacional PNUM 2012 - Portuguese Network of Urban Morphology, 5-6 de Julho de 2012: 725-761.

VIEIRA, Elvis José. "Grandes Projetos Urbanos e a Cidade Contemporânea." Edição: Gabriel VESPUCCI, \& Francis GRAEF. Revista Contemporaneu \#07 (2011): 40-51.

- "Operaciones Urbanísticas Culo Ferrocarril Suzano." IX Seminario de Investigación Urbano Regional, Bogotá: 20,21,22 de outubro de 2010.

—. "Vestígios de uma Linha Férrea ao Longo do Tempo. TFG." Mogi das Cruzes: FAU, Universidade Braz Cubas, 1998.

VILLE DE PARIS. s.d. http://www.paris.fr/ (acesso em 29 de maio de 2011). 
Ville de Paris. "Mission Paris Rive Gauche-Service Communication.” Paris, 2004.

WAKISAKA, Tânia. Zoneamento de Uso e Ocupação do Solo e Produção do Espaço Urbano em São Paulo. Dissertação de Mestrado, São Paulo: FAUUSP, 1991.

ZANETTI, Valdir Zonta. Planos e Projetos Ausentes: desafios e perspectivas da requailificação das áreas centrai de São Paulo. Tese de Doutorado, Faculdade de Arquitetura e Urbanismo, Universidade de São Paulo, São Paulo: USP, 2005. 


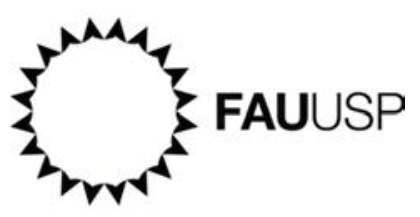

